Viviane Ceolin Dallasta Del Grossi

\title{
A defesa na cooperação jurídica internacional penal
}

Dissertação de Mestrado

Orientador: Professor Titular Dr. Paulo Borba Casella

Faculdade de Direito

Universidade de São Paulo

São Paulo

2014 
Viviane Ceolin Dallasta Del Grossi

\section{A defesa na cooperação jurídica internacional penal}

Dissertação apresentada à Banca Examinadora da Faculdade de Direito da Universidade de São Paulo como exigência parcial para obtenção do título de Mestre na área de concentração: Direitos Humanos

Orientador: Professor Titular Dr. Paulo Borba Casella

Faculdade de Direito

Universidade de São Paulo 
Autorizo a reprodução e divulgação total ou parcial deste trabalho, por qualquer meio convencional ou eletrônico, para fins de estudo e pesquisa, desde que citada a fonte.

Serviço de Biblioteca e Documentação Faculdade de Direito da Universidade de São Paulo

Grossi, Viviane Ceolin Dallasta Del

G92d A defesa na cooperação jurídica internacional penal / Viviane Ceolin Dallasta Del Grossi. -- São Paulo: USP / Faculdade de Direito, 2014.

$243 \mathrm{f}$.

Orientador: Prof. Dr. Paulo Borba Casella

Dissertação (Mestrado), Universidade de São Paulo, USP, Programa de Pós-Graduação em Direito, Direito Internacional, 2014.

Área de concentração: Direitos Humanos

1. Cooperação internacional. 2. Paridade.

3. Prova (Processo penal). 4. Acesso à justiça. 5. Defensor público. 6. Direitos humanos. I. Casella, Paulo Borba. II. Título. 
Nome: Viviane Ceolin Dallasta Del Grossi

Título: A defesa na cooperação jurídica internacional penal

Dissertação apresentada à Banca Examinadora da Faculdade de Direito da Universidade de São Paulo como exigência parcial para obtenção do título de Mestre na área de concentração: Direitos Humanos

Aprovada em de de

Banca Examinadora

Orientador: Professor Titular Dr. Paulo Borba Casella Instituição:

Professor Doutor:

Instituição:

Professor Doutor:

Instituição: 


\section{AGRADECIMENTOS}

Em primeiro lugar, gostaria de manifestar minha mais sincera gratidão ao Professor Paulo Borba Casella, meu orientador, que, ao confiar nas pretensões do meu projeto de pesquisa, proporcionou-me o ingresso no curso de pós-graduação na Faculdade de Direito da Universidade de São Paulo, tornando real um sonho de longa data. Além disso, não posso deixar de agradecer também pela oportunidade de frequentar suas aulas de Direito Internacional Público, em virtude da participação no programa de aperfeiçoamento de ensino, e com isso aprender grandes lições acerca da docência como um todo e do direito internacional que me fascina. Porém, acima de tudo, lhe sou grata pelo inestimável estímulo quando expressei minha vontade de estudar no exterior e só encontrei palavras de apoio e de incentivo. Professor, muito obrigada pelos incontáveis votos de confiança ao longo desse período de convivência e de crescimento pessoal e profissional.

À Professora Ada Pellegrini Grinover e ao Professor André de Carvalho Ramos, agradeço imensamente pelas preciosas contribuições e sugestões que recebi no exame de qualificação e, especialmente, pelo diálogo ao longo das aulas da pós-graduação que, sem sombra de dúvida, foram o gérmen do presente trabalho e contribuíram também para enriquecê-lo de uma forma que não teria sido possível sozinha.

Agradeço também à Universidade Pompeu Fabra e à Universidade Autônoma de Barcelona, pelo acolhimento durante o período de realização do curso de mestrado em criminologia e execução penal e pelas amplas oportunidades de pesquisa nas inesgotáveis bases de dados. Agradeço muito especialmente à Professora Ester Blay, Coordenadora do curso de mestrado, ao Professor Iñigo Ortiz de Urbina Gimeno, meu orientador no trabalho desenvolvido na Espanha, por toda a atenção dispensada e por dedicar parte do seu tempo para discutir ideias que, inclusive, foram aprofundadas no presente trabalho. Agradeço também ao Professor Daniel Varona pelos excelentes momentos de discussão e reflexão proporcionados em classe e por fomentar o pensamento crítico acima de tudo.

À Defensoria Pública da União, instituição a que tenho o orgulho de pertencer, meu muito obrigada por ter facilitado e viabilizado o apoio necessário para que este estudo fosse levado a efeito com êxito, e aos colegas e amigos, que de forma generosa contribuíram ao seu modo para a consecução desse trabalho.

Gostaria também de registrar meu agradecimento à gentil ajuda recebida do Departamento de Recuperação de Ativos e Cooperação Jurídica Internacional, na pessoa do Sr. Isalino Antônio Giacomet Junior, Coordenador Geral de Recuperação de Ativos, que de forma bastante solícita forneceu informações e dados estatísticos que proporcionaram ao presente trabalho relevante aferição prática do tema discutido, enriquecendo-o, assim, consideravelmente.

Não poderia deixar de externar minha gratidão à Cláudia e a Fernanda do Departamento de Direito Internacional da Faculdade de Direito da Universidade de São Paulo pelo apoio disponibilizado e sempre solícito nas questões acadêmicas e administrativas.

Às pessoas mais importantes da minha vida, agradeço simplesmente por tudo. Aos meus pais, por sempre me fazerem crer que sou capaz e por nunca medirem esforços para 
que eu realize meus sonhos. A minha mais profunda gratidão à toda minha família pela compreensão e pelo carinho que demonstram cotidianamente.

Ao Beto, que merece um agradecimento mais do que especial, por todo o entusiasmo com que recebe meus planos, por estar presente e participar incondicionalmente de todos os momentos e com um simples olhar dizer tudo que eu preciso para seguir em frente, com determinação e coragem. Agradeço-te ainda mais por compartilhar caminhos, ideais, conquistas, sonhos e até delírios e por nunca duvidar de absolutamente nada... Meu mais vibrante muito obrigada! 
¿Cuántas ideas han habido en la tierra a lo largo de la historia humana, inconcebibles incluso diez años antes de que aparecieran, pero que han surgido, de pronto, cuando ha llegado su hora misteriosa y se han difundido por la tierra toda?

FIODOR M. DOSTOIEVSKI

Los Hermanos Karamázov, 1879-1880. 


\section{RESUMO}

DEL GROSSI. Viviane Ceolin Dallasta. A defesa na cooperação jurídica internacional penal. 244 f. Dissertação (Mestrado em Direitos Humanos) - Faculdade de Direito da Universidade de São Paulo, São Paulo, 2014.

O presente estudo tem por escopo principal verificar a aplicabilidade do princípio da paridade de armas na cooperação jurídica internacional penal. Em face dessa premissa, analisam-se os regramentos nacionais e internacionais que devem ser levados em consideração pelos Estados que se intitulam Democráticos e, sobretudo, de Direito, a fim de assegurar uma persecução penal equânime, sob a ótica dos princípios do contraditório, da ampla defesa e da igualdade processual entre acusação e defesa. Para tanto, realizou-se um levantamento bibliográfico, a partir do qual se buscou elidir visão reducionista da cooperação jurídica internacional, no sentido de que não se olvide que no outro lado da missão punitiva do Estado encontra-se uma pessoa, com inúmeras garantias e direitos historicamente assegurados. No primeiro capítulo, aborda-se a cooperação jurídica internacional sob três aspectos: histórico, principiológico e analítico-descritivo. No segundo capítulo, estudam-se os princípios e garantias inerentes ao devido processo legal, os quais não podem ser suprimidos, sobretudo em âmbito internacional, por se tratar de direitos humanos consagrados. O terceiro capítulo aborda a instrumentalidade decorrente do cabedal teórico construído nos capítulos anteriores. Assim, a produção da prova em processos penais transnacionais é analisada sob o viés da cooperação jurídica internacional, passando-se pelo mecanismo do auxílio direto fundamentado em acordos bilaterais e pelas tentativas de equilibrar o sistema - dentre outras, a possibilidade de se utilizar essa modalidade na cooperação internacional penal para a produção de prova em prol da defesa -, para então se propor que a Defensoria Pública da União possa atuar a fim de promover o acesso internacional à justiça e a efetiva equalização do regime cooperacional. Por fim, reputa-se que o futuro da cooperação jurídica penal internacional está em se disponibilizar à defesa os mesmos mecanismos disponíveis à acusação, em plena e devida igualdade, haja vista não existir valor maior a ser respeitado do que a dignidade da pessoa humana.

Palavras-chave: Cooperação Jurídica Internacional Penal. Paridade de Armas. Prova (Processo Penal). Defesa. Acesso à Justiça. Defensoria Pública. 


\begin{abstract}
DEL GROSSI. Viviane Ceolin Dallasta. The defense in international legal assistance in criminal matters. $244 \mathrm{f}$. Dissertation (Master in Human Rights) - Faculty of Law of the University of São Paulo, São Paulo, 2014.

The presente work has as main scope to verify the applicability of the equality of arms in international legal assistance in criminal matters. Given this premise, it attempts to analyze international and national specific regulations that must be taken into consideration by the states that call themselves democratic and, above all, of law, in order to ensure an equitable criminal prosecution, from the perspective of the principles of adversary proceeding, full right to defense and the equality of arms. Therefore, we carried out a literature review, from which it was sought to elide reductionist view of international legal assistance, in the sense that we cannot forget that, on the other side of the punitive function of the State, there is a person with numerous safeguards and rights provided historically. The first chapter deals with the international legal assistance in three aspects: historical, applicable principles and analytical-descriptive. In the second chapter, we study the principles and guarantees inherent to the due process of law, which can not be suppressed, because it is enshrined human rights. The third chapter addresses the instrumentality derived from the theoretical leather built in previous chapters. Thus, the production of evidence in transnational criminal proceedings is examined under the bias of international legal assistance, going up by the reasoned direct assistance mechanism of bilateral agreements and by attempts to balance the system, among others, the possibility of using this modality in international criminal cooperation for the production of evidence for the defense, and then propose that the Public Defense can act to promote international access to justice and the effective equalization of cooperacional regime. Finally, it believes that the future of international legal assistance in criminal matters is to make available to the defense the same mechanisms available to the charge, in full and due equal rights, because there is no greater value to be respected than the dignity of the human person.
\end{abstract}

Keywords: International Legal Assistance in Criminal Matters. Equality of Arms. Evidence (Criminal Proceedings). Right to Defense. Access to Justice. Public Defense. 


\section{SUMÁRIO}

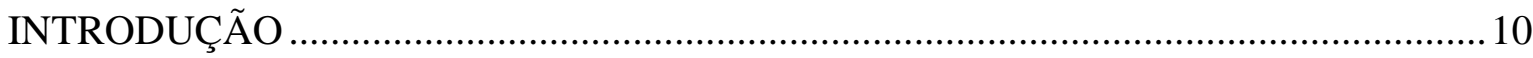

1 COOPERAÇÃO JURÍDICA INTERNACIONAL ........................................................ 16

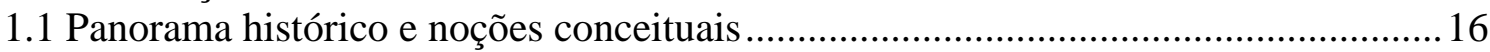

1.2 Princípios aplicáveis à cooperação jurídica internacional .............................................2

1.3 Classificação da cooperação jurídica internacional ...................................................24

1.3.1 Modalidades de cooperação jurídica internacional penal ...................................26

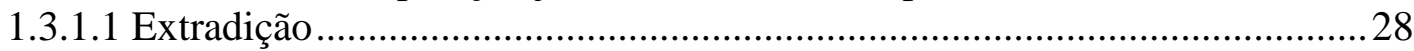

1.3.1.2 Homologação de sentença estrangeira...........................................................30

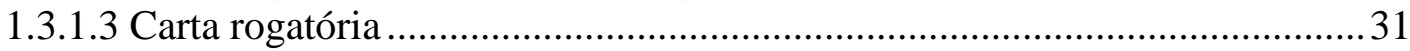

1.3.1.4 Transferência de presos e transferência de processos ou de procedimentos

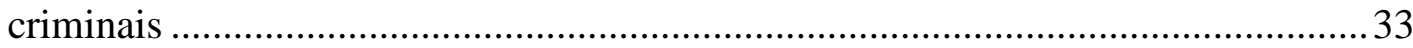

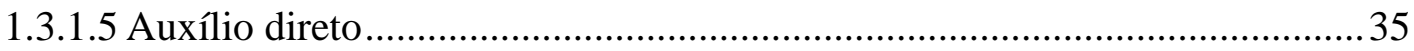

1.3.1.5.1 O papel da autoridade central ............................................................ 41

1.3.1.5.2 Hipóteses de denegação da utilização do auxílio direto pela defesa na cooperação jurídica internacional em matéria penal: análise das convenções e dos tratados bilaterais de auxílio jurídico mútuo ratificados pelo Brasil ......................47

1.3.1.5.2.1 Sistema norte-americano de produção de provas e MLAT BrasilEUA

2 A IGUALDADE DAS PARTES E OS PRINCÍPIOS E GARANTIAS ATINENTES AO

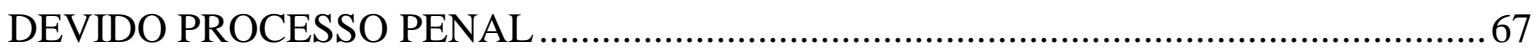

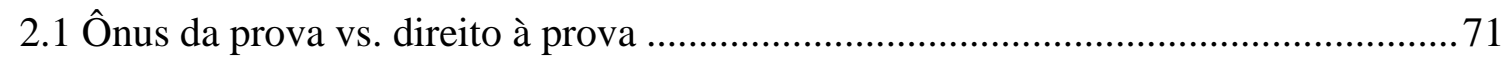

2.2 Princípio da duração razoável do processo vs. prescrição .............................................. 80

2.3 Princípios da ampla defesa e do contraditório e a paridade de armas na cooperação

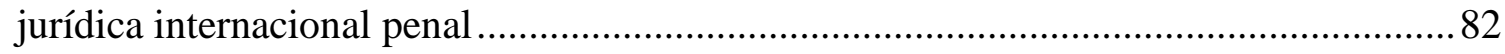

2.3.1 Instrumentalização da paridade de armas e atuação da defesa: decretação da confidencialidade da medida cooperacional e contraditório diferido .............................91

3 COOPERAÇÃO JURÍDICA INTERNACIONAL E ATUAÇÃO DA DEFESA: OFENSA AO PRINCÍPIO DA PARIDADE DE ARMAS …………………………………….....99

3.1 Common law $\mathrm{x}$ civil law e a experiência dos tribunais internacionais penais em relação ao princípio da paridade de armas. 102 3.2 Mitigação da regra do non-inquiry e críticas à (im)possibilidade de utilização do auxílio direto pela defesa . 117 3.3 Os direitos dos investigados e a paridade de armas na cooperação jurídica internacional

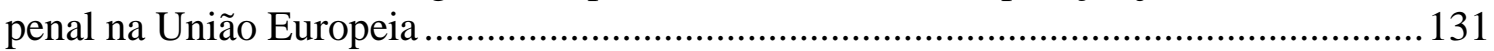

3.3.1 Tentativas e propostas com o intuito de equalizar o sistema.............................. 155 3.4 Perspectivas para a defesa no contexto jurídico nacional: o acesso internacional à justiça e a atuação da Defensoria Pública da União........................................................ 172

3.4.1 A Defensoria Pública como mecanismo de defesa social e como protagonista da cooperação jurídica internacional penal em matéria de defesa .....................................176

CONSIDERAÇÕES FINAIS: FUTURO E DESAFIOS DA COOPERAÇÃO JURÍDICA INTERNACIONAL PENAL EM MATÉRIA DE DEFESA …………………………….....190

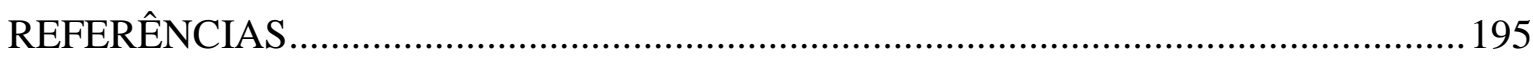

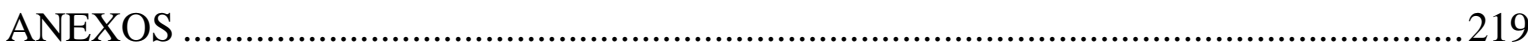

ANEXO I - Convenções internacionais .....................................................................219

ANEXO II - Quadro comparativo dos acordos bilaterais firmados pelo Brasil ............227 


\section{INTRODUÇÃO}

A criminalidade transnacional tem se expandido a diversos tipos delitivos ${ }^{1}$ e tem atingido todas as classes sociais, sem qualquer preconceito.

Vivemos em uma era de mudanças no conceito de território, em que se desmistifica o conceito do princípio de territorialidade tão conectado às características da soberania nacional, visto que agora nada está "dentro ou fora". Vivemos em uma era de globalização econômica e cultural, onde se compartilham ideias, pensamentos e, sem dúvida e por desgraça também, se compartilha a criminalidade. ${ }^{2}$

Pode-se dizer que os crimes transnacionais - crimes esses que não são de investigação simples e tampouco de fácil averiguação e solução penal, já que não se limitam às fronteiras dos Estados soberanos — se alastram com uma velocidade que desafia os órgãos investigativos e sancionatórios dos países. Como refere o protagonista Phileas Fogg, no romance de Júlio Verne, "A volta ao mundo em 80 dias": "a Terra diminuiu! Pois a percorremos agora dez vezes mais depressa do que há cem anos". ${ }^{3}$ Isso faz com que modalidades de cooperação jurídica internacional mais céleres e menos burocráticas, como o auxílio direto, ganhem destaque perante os demais mecanismos tradicionais de cooperação jurídica internacional.

A par desse contexto, o presente estudo intenta elidir visão reducionista da cooperação jurídica internacional, no sentido de que não se olvide que no outro lado da "missão punitiva" do Estado encontra-se uma pessoa, com inúmeras garantias e direitos historicamente assegurados.

Além disso, se é certo que o propalado aumento significativo nos índices da reconhecida criminalidade transnacional tem ensejado acordos de cooperação internacional em matéria criminal com fins repressivos e sob a retórica de proteção de bens jurídicos de caráter universal, certo é também que se faz imperativo reconhecer às pessoas processadas a dignidade que lhes é inerente, estabelecendo-se, em nível internacional, a equidade de

\footnotetext{
${ }^{1}$ Estes delitos recebem a qualificação de "internacional" pelo lugar em que se realizam ou pela forma em que são levados a cabo e não em razão do bem jurídico que afetam. Assim, a resposta frente a essas formas e delinquência é uma resposta político criminal que passa pela aproximação do conteúdo das legislações penais e, paralelamente, pela cooperação processual entre os Estados. (AMBOS, Kai. Temas de Derecho Penal Internacional y Europeu. Barcelona: Marcial Pons, 2006, p. 116.).

2 FARIA COSTA, J. A Globalização e o Direito Penal (ou o Tributo da Consonância ao Elogio da Incompletude). In: Globalização e Direito, STVDIA IVRIDICA, 73, colóquio 12, Coimbra Editora, p. 182 a 186.

${ }^{3}$ Essa assertiva é datada de 1872 e, para os padrões atuais, esse tempo é longo demais. Atualmente, é possível percorrer o mundo em algumas horas e, virtualmente, em alguns segundos.
} 
tratamento entre acusação e defesa.

Nesse contexto, exsurge a importância prática de se averiguar a possibilidade de cooperação jurídica internacional penal para produção e acompanhamento de prova em matéria de defesa pelas vias mais modernas.

Ao se reconhecer que a cooperação processual penal no âmbito dos acordos internacionais é uma das maneiras que os Estados encontraram para prevenir e combater crimes mais graves e, por fim, levando em conta que a vontade de que esta cooperação deva servir também para reintegrar perpetradores, não se pode esquecer que ela terá um impacto sobre uma pessoa, um cidadão e um ser humano e não sobre um inimigo, ${ }^{4}$ porque, caso contrário, se deslegitimaria qualquer processo penal nacional, regional ou internacional. ${ }^{5}$

Nesse sentido, deve-se tomar cuidado, porque muitas vezes a própria mídia abastece a animosidade em relação aos acusados, com doses de xenofobia - que se demonstra evidente na ênfase sobre as origens étnicas e costumes de supostos réus estrangeiros, quando noticia "traficantes colombianos de drogas", "terroristas palestinos", "mafiosos russos ou chineses", utilizando linguagem que torna mais fácil que as pessoas se importem menos com esses acusados. 6

Sendo assim, a colaboração jurídica entre os diversos Estados deve ter em conta a tensão existente entre os interesses de uma ação judicial que traspassa fronteiras, os da

\footnotetext{
4 "Os direitos do requerido dentro das leis do Estado são significativos, porque com base na presunção de inocência elas articulam que o réu deve ser tratado como um membro da sociedade e não como seu inimigo, pois ao acusado devem ser ofertados meios para se defender contra acusações criminais.” Tradução livre de: "The defendant's rights within a rule of law State are significant, because on the basis of the presumption of innocence they articulate that the defendant is to be treated as a member of the society and not as its enemy, therefore the accused must be supplied with means to defend himself against criminal charges." (FIJNAUT, Cyrille; OUWERKERK, Jannemieke. The Future of Police and Judicial Cooperation in the European Union. Martinus Nijhoff Publishers: Leiden/Boston, 2010, p. 391).

${ }^{5}$ VALENTE, Manuel Monteiro Guedes. La cooperación en materia procesal penal: los engaños y las ilusiones formales de los instrumentos jurídicos europeos e internacionales. Diario La Ley, $\mathrm{N}^{\circ}$ 6914, Sección Doctrina, Año XXIX, Ref. D-96, Editorial LA LEY, Mar. 2008, p. 8.

${ }^{6}$ Esses enquadramentos de notícia são conhecidos como técnica "framing". O conceito de "framing" utilizado na teoria da psicologia, sociologia e comunicação, refere-se à importância decisiva para a interpretação de um fato, o contexto ou quadro em que o evento está inserido (daí o nome "frame" palavra que significa literalmente marco ou enquadramento). O conceito é geralmente atribuído ao trabalho de Erving Goffman, em que o autor utiliza o conceito de frame para referir-se a esquemas de interpretação que permitem que indivíduos ou grupos percebam, identifiquem e rotulem os fatos, atribuindo significado e orientando as ações das pessoas. No campo da teoria da comunicação, o framing assume, assim, um passo adiante na compreensão dos efeitos que os meios de comunicação exercem na opinião pública. O framing (enquadramento noticioso) baseia-se no pressuposto de que mudanças sutis nas palavras usadas para descrever uma situação podem afetar a forma como o público interpreta a situação. Em outras palavras, o enquadramento/descrição da notícia irá influenciar a forma como o público pensa sobre as questões, não através do primeiro plano de um problema, mas invocando esquemas interpretativos que irão determinar eventual análise crítica da informação a ser recebida. (VARONA GÓMEZ, Daniel. Medios de comunicación y punitivismo. InDret 1/2011, p. 21-2). No caso, por que não destacar o estado civil da pessoa ou a idade? Fulano de tal, solteiro ou casado... Essas notícias ressaltam intencional e propositadamente a nacionalidade das pessoas.
} 
soberania nacional e os daqueles indivíduos concretos eventualmente atingidos. Não se trata de abdicar das garantias individuais ou de segmentos mais ou menos importantes da soberania em razão de um combate mais eficaz ao delito transnacional, pois o desafio consiste em aspirar que o novo Direito Penal da cooperação se estruture sobre a devida tensão das premissas de eficácia, soberania e direitos humanos, pois não é nem científica nem eticamente admissível responder à "transnacionalização do delito com uma transpersonalização do controle". ${ }^{7}$

Tudo isso num marco no qual a máxima eficiência na luta contra a criminalidade moderna se realiza sem afetar as garantias individuais e aquelas normas que, a juízo de cada Estado implicado em níveis de cooperação, integram sua ordem pública nacional e internacional. Ademais, como lembra Raúl Cervini, não se deve esquecer que tanto o Direito Penal interno de cada Estado quanto os acordos internacionais de cooperação penal devem ter o centro no homem e seus interesses. ${ }^{8}$

Não basta a mera punição daquele que se reputa culpado, faz-se imprescindível o acertamento da culpabilidade, ${ }^{9}$ pois, como no relato verniano, o suspeito pode, na verdade, estar sendo perseguido equivocadamente - o inspetor Fix permaneceu no encalço de Phileas Fogg durante toda a sua jornada por engano.

Nesse sentido, dois valores relevantes têm emergido recentemente em sede de cooperação internacional em matéria penal, os quais se afiguram até certo ponto aparentemente opostos: de um lado, a necessidade de intensificar a cooperação na luta contra o crime e, de outro, a consciência cada vez mais profunda de que os direitos fundamentais devem ser colocados como referencial nessa matéria e, consequentemente, como limites à

\footnotetext{
${ }^{7}$ CERVINI, Raúl. Princípios da Cooperação Judicial Internacional em Assuntos Penais. Doutrina - Direito Comparado. Disponível em: 〈http://www.amprs.org.br/arquivos/revista_artigo/arquivo_1283279756.pdf >. Último acesso em: 18 fev. 2014. p. 25-6, 31 e 45.

${ }^{8}$ Ibidem, p. 26.

${ }^{9}$ Como refere Díez Ripollés, a progressiva falta de receio em relação ao uso do instrumental punitivo está permitindo, em primeiro lugar, reformas impensáveis até há pouco tempo. Bastam como exemplo a paulatina generalização do monitoramento dos espaços públicos por câmeras e outros artefatos de controle visual e auditivo e a simplificação de procedimentos, facilitando a prisão preventiva. E, em segundo lugar, está prestigiando modos de operar juridicamente, nos quais o devido respeito aos direitos e liberdades individuais ficam em um segundo plano: na polícia, superado o distanciamento popular dos anos da ditadura, a eficácia e a rapidez que se exige na persecução do crime e a descoberta de culpáveis, permite desculpar facilmente atuações apressadas que incidem em alvos errados; o legislador deve mostrar clara disposição em converter em delito (criminalizar) qualquer problema social; os juízes devem ser capazes de superar os obstáculos de direito substantivo e processual que possam surgir para garantir a justiça em tempo hábil de acordo com as demandas populares; e a principal missão dos agentes de execução é garantir em todos os momentos que o suposto infrator não seja tratado com demasiada generosidade. (DÍEZ RIPOLLÉS, José L. El nuevo modelo penal de la seguridad ciudadana. Revista Electrónica de Ciencia Penal y Criminología. Núm. 06-03, 2004, p. 17).
} 
cooperação internacional em matéria penal. ${ }^{10}$

Em face dessa premissa, intenta-se analisar os regramentos nacionais e internacionais que devem ser levados em consideração pelos Estados que se intitulam Democráticos e, sobretudo, de Direito, a fim de assegurar uma persecução penal equânime, sob a ótica dos princípios do contraditório, da ampla defesa e da paridade de armas, decorrentes do princípio da isonomia, bem como do inafastável princípio da dignidade da pessoa humana. ${ }^{11}$

A visão trilateral da cooperação em matéria penal, em que avulta a figura da pessoa em relação à qual um Estado solicita cooperação a outro, encontra sólido embasamento nos esquemas processuais, quer se trate de processo jurisdicional, quer se trate de rito administrativo. ${ }^{12}$

O presente trabalho cinge-se ao chamado processo penal transnacional, o qual tem sido definido como o processo em que vários Estados estão envolvidos para a persecução de um crime, quer porque o crime tem ramificações em diferentes Estados, quer porque é necessária a cooperação jurídica internacional, a fim de levar a cabo procedimento investigativo único, a adoção de medidas cautelares ou a prisão do suspeito. ${ }^{13}$ Além disso, cumpre limitar o presente trabalho à produção da prova chamada transnacional, que é aquela cujo meio de prova encontra-se em Estado diverso ao da autoridade judicial competente. ${ }^{14}$

${ }^{10}$ GRINOVER, Ada Pellegrini. O Processo em Evolução. Rio de Janeiro: Forense Universitária, 1996, p. 156. 11 “A proteção da dignidade da pessoa humana é o primeiro desses princípios que, longe de corresponder simplesmente a uma norma programática ou simbólica, constitui fundamento do Estado democrático". (CERVINI, Raúl; TAVARES, Juarez. Princípios de cooperação judicial penal internacional no Protocolo do MERCOSUL. São Paulo: RT, 2000. p. 180).

${ }^{12}$ GRINOVER, Ada Pellegrini. O Processo em Evolução. Rio de Janeiro: Forense Universitária, 1996, p. 157.

${ }^{13}$ As definições variam, dependendo de onde se coloca maior ênfase, se no resultado final, na mútua assistência ou na proteção integral dos direitos humanos das partes envolvidas no processo. Os estudiosos que se dedicaram ao tema consideram que o processo transnacional é aquele em que os atos praticados em outro Estado tornam-se parte do processo de origem e, assim, formam um processo unitário composto de diferentes elementos. O processo penal transnacional também tem sido definido como um processo penal onde as regras de diferentes sistemas jurídicos, nacionais e/ou internacionais, restam interligadas. Para outros, o conceito de processo transnacional refere-se à ideia de que a convergência das normas de diferentes sistemas jurídicos em um único processo não deve resultar em uma diminuição dos direitos processuais das partes e, especialmente, do direito de defesa do acusado. (WINTER, Lorena Bachmaier. Transnational Criminal Proceedings, Witness Evidence and Confrontation: Lessons from the ECtHR's Case Law. In: Utrech Law Review. Volume 9, Issue 4 (September), 2013). Como visto, não há uma definição uníssona do conceito de processos transnacionais, portanto, oportuno esclarecer que dentro deste estudo, o conceito amplo de processo transnacional será utilizado - os processos em que elementos transfronteiriços convergem e que procuram alcançar um equilíbrio adequado entre eficiência e respeito pelas salvaguardas processuais. Assim, filiando-se à linha de Schünemann, para os fins do presente trabalho, no conceito de "processo penal transnacional" referido ao longo do texto não se deve incluir ou limitá-lo aos crimes que afetam diversos Estados, mas deve também abarcar processos penais criminais com demandas investigatórias ou com necessidade de medidas de restrição a direitos fundamentais em mais de um Estado. (SCHÜNEMANN, Bernd. As Bases do Processo Penal Transnacional. Traduzido por Heloisa Estellita Salomão. Revista Brasileira de Ciências Criminais. Ano 19, v. 90, mai-jun. 2011, p. 197).

${ }^{14}$ VOGEL, Joachim R. La prueba transnacional en el proceso penal: un marco para la teoría y práxis. In: FLUJA, Vicente C. Guzmán. La prueba en el espacio europeo de libertad, seguridad y justicia penal. Navarra: Thomson Aranzadi, 2006. Colección Centro de Estudios Jurídicos, p. 46. "Em outras palavras, a prova transnacional é aquela cuja fonte de prova encontra-se dentro dos limites da soberania de outro Estado, e que, 
Nesse norte, o presente trabalho tem por escopo principal explorar o tema da cooperação jurídica internacional (lato sensu), para depois focar na análise da possibilidade de se utilizar a modalidade auxílio direto na cooperação internacional penal para a produção de prova em prol da defesa, bem como analisar outras iniciativas que tiveram por objetivo incluir a defesa, ainda que na forma de cooperação vertical, como é o caso das ideias surgidas no âmbito da União Europeia.

Dito isso, no primeiro capítulo, será explanada em que consiste a figura da cooperação jurídica internacional, com a apresentação de panorama histórico e noções conceituais necessárias ao pleno entendimento dos demais elementos apresentados ao longo do trabalho, bem como os princípios aplicáveis à cooperação jurídica internacional, a sua classificação e as seguintes modalidades: extradição, homologação de sentença estrangeira, carta rogatória, transferência de presos e transferência de processos ou de procedimentos criminais e o auxílio direto. Concernente à última modalidade apresentada, será feita referência ao papel da autoridade central e as hipóteses de denegação da utilização do auxílio direto pela defesa na cooperação jurídica internacional em matéria penal, mediante a análise das convenções e dos tratados bilaterais de auxílio jurídico mútuo ratificados pelo Brasil.

No segundo capítulo, o tema será a igualdade das partes e os princípios e garantias atinentes ao devido processo penal, com a análise da contraposição atinente ao ônus da prova e ao direito à prova, o princípio da duração razoável do processo e o fenômeno da prescrição e quais são os efeitos dos princípios da ampla defesa, do contraditório e da paridade de armas na cooperação jurídica internacional penal. Além disso, tratar-se-á da atuação da defesa e da instrumentalização da paridade de armas.

No terceiro capítulo, será feita referência à experiência dos Tribunais Internacionais Penais em relação ao princípio da paridade de armas e a interação entre os sistemas do common law e do civil law, à mitigação da regra do non-inquiry e às críticas à eventual impossibilidade de utilização do auxílio direto pela defesa. Além disso, serão abordados os direitos dos investigados e a paridade de armas na cooperação jurídica internacional penal na União Europeia, com as tentativas e propostas já apresentadas com o intuito de equalizar o sistema. No contexto jurídico nacional, serão explanadas as perspectivas para a defesa, o acesso internacional à justiça e a atuação da Defensoria Pública, como mecanismo de defesa

portanto, requer a cooperação e o auxílio deste para a obtenção do dado ou elemento probatório. Em razão desta limitação funcional é que se impõe o recurso ao instrumento da cooperação jurídica internacional para a produção da prova”. (BECHARA, Fábio Ramazzini. Cooperação Jurídica Internacional em Matéria Penal: Eficácia da Prova Produzida no Exterior. São Paulo: Saraiva, 2011, pp. 37-8). 
social e como protagonista da cooperação jurídica internacional penal em matéria de defesa.

Por fim, efetuar-se-á proposta para efetiva inclusão da defesa nos mecanismos de cooperação jurídica internacional penal já existentes, levando-se em consideração as atribuições constitucionais da Defensoria Pública no Brasil, bem como as suas iniciativas de atuação na seara do acesso internacional à justiça.

Trata-se, portanto, de um trabalho doutrinário de construção teórica, com base em elementos normativos e jurisprudenciais, que utiliza o método dedutivo - parte da teoria geral da cooperação para o plano específico das considerações práticas acerca do papel da defesa na cooperação jurídica internacional penal.

Estima-se, com esta dissertação, poder contribuir para o desenvolvimento da temática da cooperação jurídica internacional em matéria penal em prol da defesa, que se encontra ainda em fase incipiente, mediante a impressão de consequências práticas a inúmeros princípios e institutos que regem a matéria, bem como a estudos doutrinários que já refletiram e se posicionaram criticamente a respeito da questão, mas que todavia não alcançaram bom termo no encontro de soluções para a polêmica questão atinente à utilização do mecanismo do auxílio direto pela defesa e a como isso poderia ser implementado.

A seguir, principia-se por um panorama geral da cooperação penal internacional, em que se aprecia o significado da cooperação internacional na atualidade, as modalidades de cooperação no âmbito penal e os fundamentos que a informam. 


\section{COOPERAÇÃO JURÍDICA INTERNACIONAL}

\subsection{Panorama histórico e noções conceituais}

A cooperação jurídica internacional não se apresenta uma novidade no cenário mundial. Há registros históricos bastante antigos sobre uma de suas principais espécies, a extradição, que remontam ao século XIV antes de Cristo. ${ }^{15}$

A referida modalidade, até há bem pouco tempo tinha relevância na doutrina e na legislação como espécie primordial da cooperação jurídica internacional em matéria penal, com esta, inclusive, confundindo-se. ${ }^{16}$ É o que se pode visualizar na definição de Haroldo Valladão, em obra de 1933, na qual conceitua a extradição como a instituição mais representativa da lei processual penal internacional, referindo a execução de sentenças estrangeiras como a instituição mais representativa do Direito Processual Civil Internacional. ${ }^{17}$

Nas últimas décadas, entretanto, o estudo da "entreajuda penal"18 vem ganhando

\footnotetext{
${ }^{15}$ Como traz André Carneiro Leão, “a depender do que se entenda por extradição, pode-se reconhecer a origem remotíssima ou ao menos vestígios do instituto na antiguidade ou apenas recentemente a partir da formação dos Estados modernos. Os que compreendem a extradição como ato de entrega por um governo soberano a outro de uma pessoa acusada do cometimento de um ato ilícito, independentemente da natureza política ou não desse ato e da nacionalidade do indivíduo transladado, identificam o primeiro registro histórico da extradição em um tratado de paz, datado aproximadamente do século XIV a.C. (para Celso Mello, mais precisamente, em 1.291 a.C.), celebrado pelo faraó egípcio Ramsés II e pelo rei dos hititas Hattusilii III". (LEÃO, André Carneiro. A Extradição no Brasil: Uma Releitura a Partir das Garantias do Devido Processo Transnacional. Monografia de Pós-Graduação. Recife, 2011). Nesse sentido também BASSIOUNI, M. Cherif. Derecho Penal Internacional: Proyecto de Código Penal Internacional. Madrid: Tecnos, 1984, p. 51.

${ }^{16}$ Como traz Helena Vasconcellos: "Veja-se que o tema da cooperação jurídica internacional em matéria penal vem adquirindo cada vez mais importância na atualidade, em razão do fenômeno da transnacionalização da criminalidade. Se nos primórdios tudo o que interessava à comunidade internacional era a extradição, uma vez que o comum era apenas a fuga do ofensor para outro país (quando muito havia o cometimento de um crime isolado, como um furto ou mesmo um homicídio, os quais normalmente eram julgados e punidos do próprio país estrangeiro), hoje a perpetração do crime já não mais respeita as fronteiras nacionais". (VASCONCELLOS, Helena. Cooperação Jurídica Internacional em Matéria Penal: Uma Análise do Mutual Legal Assistance Treaty Brasil/Estados Unidos. Dissertação apresentada ao Programa de Pós-Gradução em Direito da Faculdade de Direito da Universidade Federal do Rio Grande do Sul como requisito parcial para obtenção do grau de mestre em Direito. Orientador Prof. Dr. Tupinambá Pinto de Azevedo. Porto Alegre, 2013, p. 13).

${ }^{17}$ Em tradução livre de 'L'extradition n'est em somme que l'institution la plus representative du droit de procédure criminelle internationale, de même que l'execution des sentences étrangères est l'institution la plus representative $d u$ droit de procédure civile internationale”. (VALLADÃO, Haroldo. Da cooperação internacional nos processos criminais. São Paulo: Revista dos Tribunais, 1933, p. 10).

${ }^{18}$ Expressão cunhada por Jean-André Roux, em francês, l'entr'aide, na obra: L'entr'aide des Etats dans la lutte contre la criminalité. In Recueil des Cours de L'Academie de Droit Internacional da la Haye, Vol 36, 1931 II, Paris. Para este autor a entre-ajuda requer dupla condição: primeiro, um sentimento de cortesia existente entre as nações civilizadas e, segundo, o sentimento de que os criminosos não constituem somente um risco nacional, e sim um perigo nacional. Além disso, Cervini refere que a referida expressão foi também conhecida posteriormente entre alguns autores americanos como "extra-ajuda penal". (CERVINI, Raúl; TAVARES, Juarez. Princípios de cooperação judicial penal internacional no Protocolo do MERCOSUL. São Paulo: RT,
} 
adeptos, em função da maior preocupação dos Estados com a persecução criminal transnacional, consequência da melhoria e do avanço da tecnologia dos meios de transporte e de comunicação e até mesmo do crescimento do turismo internacional.

Atualmente, afigura-se cediço e chega a ser um truísmo afirmar que qualquer abordagem da cooperação jurídica internacional deve levar em conta os fenômenos da globalização ${ }^{19}$ em todas as suas esferas, da velocidade dos meios de transporte e da instantaneidade dos meios de comunicação. Além de ser um dever analisar criticamente o binômio "soberania nacional" e "legitimidade internacional", bem como a repressão da criminalidade e a preservação dos direitos fundamentais.

No que tange à conceituação, Nádia de Araújo define a cooperação jurídica internacional como o intercâmbio internacional para o cumprimento extraterritorial de medidas processuais do Poder Judiciário de outro Estado. ${ }^{20}$

No mesmo sentido, Raúl Cervini ${ }^{21}$ parametriza o instituto como o conjunto de atividades processuais (cuja projeção não se esgota nas simples formas), regulares (normais), concretas e de diverso nível, cumpridas por órgãos jurisdicionais (competentes) em matéria penal, pertencentes a distintos Estados soberanos, que convergem (funcional e necessariamente) em nível internacional, na realização de um mesmo fim, que não é senão o desenvolvimento (preparação e consecução) de um processo (principal) da mesma natureza (penal), dentro de um estrito marco de garantias, conforme o diverso grau e projeção intrínseca do auxílio requerido.

Ocorre que tal conceituação, na linha das classificações que serão expostas, reputase por demais restritiva, ao definir apenas a chamada cooperação judicial e ao desconsiderar a cooperação entre autoridades administrativas, a qual também se qualifica como jurídica, como aponta Ricardo Perlingeiro Mendes da Silva: “a efetividade da jurisdição, nacional ou

2000. p. 47-8). Nesta obra seminal sobre a cooperação jurídica internacional na luta contra a criminalidade, há um enfoque bastante repressivo, sem qualquer previsão de garantias ao investigado.

19 “O que os economistas denominam 'globalização' e todos repetem, dizendo-se ser contra ou a favor, sem saber a respeito do que se fala, é simplesmente, processo irreversível de mutação dos patamares da riqueza do mundo. [...] A chamada globalização é fato consumado. Não cabe questionar como veio e como se instaurou. Está presente e temos de levar em conta esse dado essencial da realidade atual. A partir da constatação da inevitabilidade desta, talvez possamos baixar as reservas mentais e ver a necessidade de atuar de modo eficiente neste mundo, de responsabilidades compartilhadas, que mudou para sempre e pode deixar para trás os saudosistas de outras eras nacionais." (ACCIOLY, Hildebrando; NASCIMENTO E SILVA, Geraldo E. e CASELLA, Paulo Borba. Manual de Direito Internacional Público. 20a ed., São Paulo: Saraiva, 2012, p. 126).

${ }^{20}$ ARAUJO, Nádia. A importância da cooperação jurídica internacional para a atuação do Estado Brasileiro no plano interno e internacional. In: MANUAL DE COOPERAÇÃO JURÍDICA INTERNACIONAL E RECUPERAÇÃ̃ DE ATIVOS. Cooperação em Matéria Penal. Brasília: Secretaria Nacional de Justiça, 2012 , p. 32.

${ }^{21}$ CERVINI, Raúl; TAVARES, Juarez. Princípios de cooperação judicial penal internacional no Protocolo do MERCOSUL. São Paulo: RT, 2000. p. 51. 
estrangeira, pode depender do intercâmbio não apenas entre órgãos judiciais, mas também entre órgãos administrativos, ou ainda, entre órgãos judiciais e administrativos, de Estados distintos." 22

Assim, entende-se mais adequado e preciso o conceito de cooperação jurídica internacional apresentado por Mueller, que a define como "a ajuda prestada por uma nação a outra como suporte a um procedimento judicial ou quase judicial que tramita no país receptor, com o intuito de evitar a frustração da política criminal em virtude das limitações territoriais da jurisdição criminal". ${ }^{23}$

Nesse sentido se coaduna o Código Modelo de Cooperação Interjurisdicional para Ibero-América, ${ }^{24,25}$ o qual, em seu artigo $1^{\circ}$, que cuida do âmbito de aplicação, refere que o

${ }^{22}$ SILVA, Ricardo Perlingeiro Mendes. Cooperação Jurídica Internacional e Auxílio Direto in BARROSO, Luis Roberto e TIBURCIO, Carmen (orgs.). O Direito Internacional Contemporâneo. Estudos em homenagem ao Professor Jacob Dolinger. Rio de Janeiro: Ed. Renovar, 2006, pp.797-809.

${ }^{23}$ Continua o autor: “A terminologia 'matéria penal' precisa ser esclarecida. Nós entendemos que o termo inclui não apenas os processos perante tribunais criminais propriamente ditos, mas também processos perante júris e juízes de instrução." Tradução livre de: “International judicial assistance, also referred to as international judicial cooperation, is defined as '[...] aid rendered by one nation to another in suport of judicial or quasijudicial proceedings in the recipient country's tribunals. [...] International judicial assistance in criminal matters is designed to counteract frustration of criminal policy by territorial limitations of criminal jurisdiction. [...] The term 'criminal matters' needs some clarification. We understand the term to include not only proceedings before criminal courts proper, but also proceedings before grand juries an United States Commissioners or before juges d'instruction'." (MUELLER, Gerhard O.W. "International Judicial Assistance in Criminal Matters" in MUELLER, Gerhard \& WISE, Edward (eds). International Criminal Law. New Jersey: Rothman Ed., 1965, p. 414).

${ }^{24}$ A proposta de um Código Modelo de Cooperação Interjurisdicional para a Iberoamérica foi elaborada pelo Instituto Ibero-americano de Direito Processual e não configura uma proposta de tratado internacional a ser ratificado, mas sim uma proposta de normas nacionais a serem incorporadas internamente pelos países Iberoamericanos e destinado à cooperação interjurisdicional, tanto na área civil como penal, com qualquer Estado, Ibero-americano ou não, por essa razão destaca-se que se trata de uma proposta de Código Modelo de Cooperação Interjurisdicional para Ibero-América e não "na Ibero-América”, de modo a não gerar uma falsa impressão de que a cooperação seria somente entre os Estados Ibero-americanos. O Código foi aprovado na Assembleia Geral do Instituto Ibero-americano de Direito Processual, ocorrida no dia 17 de outubro de 2008, por ocasião das XXI Jornadas Ibero-americanas de Derecho Procesal em Lima, Peru, observado que a proposta do Código surgiu em julho de 2005, nas Jornadas Especiais de Barcelona, o então Presidente do Instituto Iberoamericano, Jairo Parra Quijano, designou Ada Pellegrini Grinover, Angel Landoni Sosa, Ricardo Perlingeiro e Abel Augusto Zamorano para participar da Comissão destinada à elaboração do pré-projeto. Conforme descrito na Exposição de Motivos do Código, a sua finalidade reside na necessidade de compilação de princípios fundamentais e regras gerais inerentes à jurisdição transnacional que sejam passíveis de aplicação em todos os sistemas jurídicos que consagrem o Estado de Direito, ainda que não seja coercitivo. A Comissão de elaboração do projeto foi presidida pela Professora Ada Pellegrini Grinover e secretariada por Ricardo Perlingeiro. (CÓDIGO de Cooperação Interjurisdicional para Ibero-américa. Revista da SJRJ, Rio de Janeiro, n. 25, 2009, p. 429-456).

25 Iberoamérica ou Comunidade Iberoamericana de Nações é a comunidade histórica de países que compartilham uma cultura comum dentro do mundo lusoamericano e hispanoamericano. No momento, encontra-se composta por 22 Estados: Andorra, Argentina, Bolívia, Brasil, Chile, Colômbia, Costa Rica, Cuba, Equador, El Salvador, Espanha, Guatemala, Honduras, México, Nicarágua, Panamá, Paraguai, Perú, Portugal, República Dominicana, Uruguai e Venezuela. Na Cúpula Judicial Ibero-Americana também participa o Estado Livre Associado de Porto Rico. Tradução livre. No original: "Iberoamérica o la Comunidad Iberoamericana de Naciones es la comunidad histórica de países que comparten una cultura común dentro del mundo lusoamericano e hispanoamericano. Al momento presente está compuesta por 22 Estados: Andorra, Argentina, Bolivia, Brasil, Chile, Colombia, Costa Rica, Cuba, Ecuador, El Salvador, España, Guatemala, Honduras, 
Código dispõe sobre a cooperação entre tribunais e órgãos administrativos de Estados diversos, com o objetivo de assegurar a efetividade da prestação jurisdicional transnacional.

Em síntese, a cooperação jurídica internacional penal pode ser entendida como a interdependência entre os Estados, no intuito de solucionar crimes, nos seus respectivos espaços soberanos, sem a qual a conclusão da questão tornar-se-ia extremamente custosa, quando não inviável. ${ }^{26}$ Como traz Kleffens, ${ }^{27}$ a interdependência confrontou os Estados com problemas que eles não conseguiriam resolver sozinhos, ou resolveriam melhor pela cooperação - o Estado não poderia mais ser visto como o instrumento único de regulação da vida internacional, já que, no contexto de uma ordem global altamente interconectada, haveria uma série de políticas públicas que não poderiam ser implementadas sem a cooperação com outros Estados, e várias das funções públicas tradicionais dos Estados não poderiam ser cumpridas sem se recorrer a formas internacionais de colaboração.

Nesse sentido, sustenta Casella que o Direito Internacional da Cooperação prepondera desde a assinatura do Tratado de Versalhes, quando se passou do paradigma da coexistência para o paradigma da cooperação ${ }^{28}$ :

O sistema de Versalhes traz os pontos de partida do sistema presente; [...] Pode esse tratado ser marco de inauguração de nova fase do direito e das relações internacionais, porquanto, a partir deste se começa a fase de direito internacional de cooperação, que sucederia aos séculos precedentes de direito internacional de mera coexistência e mútua abstenção.

E é com esse sentido que se entende a natureza jurídica da cooperação jurídica internacional. Ainda que ela possa ser analisada sob diferentes aspectos, ${ }^{29}$ é da noção do

\footnotetext{
México, Nicaragua, Panamá, Paraguay, Perú, Portugal, República Dominicana, Uruguay y Venezuela. En la Cumbre Judicial Iberoamericana participa también el Estado Libre Asociado de Puerto Rico". (MORENO, José Miguel García. La cooperación judicial penal en el ámbito iberoamericano. Revista de Jurisprudencia, número 2, diciembre de 2013, nota 3. Disponível em: http://www.elderecho.com/tribuna/penal/cooperacion_judicial_penalambito_iberamericano_de_justicia_11_627430004.html. Acesso em: 14 ago. 2014).

${ }^{26}$ Sérgio Fernando Moro já proferiu a máxima que sintetiza a importância do instituto no cenário atual: "cooperar ou falhar!". (MORO, Sérgio Fernando. Cooperação jurídica internacional em casos criminais: considerações gerais. In: BALTAZAR Jr. José Paulo e LIMA, Luciano Flores de. Cooperação Jurídica Internacional em Matéria Penal. Porto Alegre: Verbo Jurídico, 2010, p. 16).

${ }^{27}$ KLEFFENS, E. N. Van. Sovereignty in International Law: Five Lectures. RCADI, t. 1, 1953. p. 108.

${ }^{28}$ ACCIOLY, Hildebrando; NASCIMENTO E SILVA, Geraldo E. e CASELLA, Paulo Borba. Manual de Direito Internacional Público. 20ª ed., São Paulo: Saraiva, 2012, p. 116.

${ }^{29}$ Como traz Bechara, a cooperação jurídica internacional constitui expressão do valor solidariedade pra uns, jurisdição própria ou delegada para outros e ainda seria expressão de uma interação processual-funcional internacional, cujo fundamento assentaria-se no direito internacional. (BECHARA, Fábio Ramazzini. Cooperação Jurídica Internacional em Matéria Penal: Eficácia da Prova Produzida no Exterior. São Paulo: Saraiva, 2011, pp. 43-4).
} 
paradigma da cooperação que leva em conta a relação trilateral ${ }^{30}$ entre Estado requerente, Estado requerido e pessoa afetada que se compartilha neste trabalho, segundo o ideal da solidariedade, em que os direitos humanos da pessoa sob investigação configuram reais valores a ser tutelados.

\subsection{Princípios aplicáveis à cooperação jurídica internacional}

Sempre que se inicia o estudo de um tema, afigura-se salutar apresentar os princípios que regem a matéria, de modo a facilitar o trabalho e até mesmo eventuais interpretações de regras que se façam necessárias.

De antemão, como aduz Moro, ${ }^{31}$ importa saber que o princípio básico que rege a cooperação jurídica internacional é o de que ela deve ser a mais ampla possível, obviamente dentro de limites (excepcionais) que devem ser observados. ${ }^{32}$

\footnotetext{
${ }^{30} \mathrm{Na}$ doutrina nacional, diversos autores defendem esse paradigma, tal como se pode visualizar nas seguintes passagens: “[...] Já dissemos que existe uma concepção clássica da entre-ajuda judicial penal, originada no âmbito dos jusprivatistas, a qual reivindica a exclusividade dos Estados como sujeitos dessas instâncias, desconhecendo o valor das partes substanciais da cooperação, que são tanto estes mesmos Estados quanto seus cidadãos. Graças ao aporte da moderna doutrina italiana, entre outras, hoje se reconhece o fato de que, por suas características, grande parte dos casos de assistência judicial penal internacional atinge, direta ou indiretamente, a situação daquelas pessoas concretas alcançadas pelas medidas de cooperação, provocando inúmeras vezes danos irreversíveis em sua esfera de liberdade ou em seu patrimônio." Daí advém a reconhecida legitimação ativa e a garantia da ampla defesa do concernido, ou seja, a pessoa objeto da cooperação internacional, para quem se assegura o respeito aos seus direitos individuais, na medida em que sejam atingidos por atos oriundos da cooperação [...]. "Os autores compartem de uma concepção de direito penal que tem por base a segurança jurídica dos indivíduos concretos, e com responsabilidade e brilhantismo trasladam esse mesmo critério ao âmbito da cooperação penal internacional. Esta, definitivamente, não pode ser estruturada à margem dos direitos do homem concreto, nem supostamente fortalecida mediante o sacrifício de medulares paradigmas que o direito penal substantivo e processual penal lograram consolidar após séculos de luta pela dignidade humana." (CERVINI, Raúl e TAVARES, Juarez. Princípios de cooperação judicial penal internacional no protocolo do Mercosul. São Paulo: Editora Revista dos Tribunais, 2000, p. 74, 76 e p. 9 , prólogo de Luiz Luisi); $\mathrm{Na}$ cooperação judicial internacional, a possibilidade de que a pessoa resulte prejudicada não se limita à extradição - a chamada 'medida de cooperação de terceiro grau' -, mas se estende às medidas que possam causar algum gravame a bens - as chamadas 'medidas de segundo grau' -, e até às medidas de simples assistência processual - as chamadas 'medidas de cooperação de primeiro grau' - A partir dessas considerações há que se dar legitimidade ao indivíduo para participar dos ato de cooperação judicial em matéria penal”. (GRINOVER, Ada Pellegrini. Processo Penal Transnacional: linhas evolutivas e garantias processuais. In: Revista Brasileira de Ciências Criminais, São Paulo, v. 3, n. 9, jan./mar. 1995); “[...] É preciso que as partes substanciais dos atos de cooperação, não apenas os Estados - partes formais - sejam envolvidos, pois os cidadãos são, em última análise, os destinatários dos eventuais gravames à liberdade individual [...]”. (GEMAQUE, Silvio César Arouck. A necessária influência do processo penal internacional no processo penal brasileiro. Tese de Doutorado. Universidade de São Paulo. São Paulo, 2010, p. 72); CORDANI, Dora Cavalcanti. Cooperação Jurídica Internacional em Matéria Penal no Brasil: as Cartas Rogatórias e o Auxílio Direto - Controle dos Atos pela Parte Atingida. In: VILARDI, Celso Sanchez; PEREIRA, Flávia Rahal Bresser; NETO, Theodomiro Dias. Direito Penal Econômico - Crimes Econômicos e Processo Penal. São Paulo: GVLaw e Ed. Saraiva, 2008, p.109.

${ }^{31}$ MORO, Sérgio Fernando. Cooperação jurídica internacional em casos criminais: considerações gerais. In: BALTAZAR Jr. José Paulo e LIMA, Luciano Flores de. Cooperação Jurídica Internacional em Matéria Penal. Porto Alegre: Verbo Jurídico, 2010, p. 16.

32 Para um estudo aprofundado acerca dos limites impostos à cooperação jurídica internacional em matéria
} 
No caso, difícil elencar todos os princípios informados pela doutrina, até porque não há consenso algum quanto aos princípios aplicáveis à espécie. ${ }^{33}$ Entretanto, uma sistematização básica é necessária e possível de ser efetuada a partir de um estudo mais abrangente e da análise de alguns autores de referência no tema. Raúl Cervini, ${ }^{34}$ em atenção ao anteprojeto de tratado entre Brasil e Uruguai, efetua intento de sistematização dos princípios, mencionando - meramente a título de exemplo, pois o rol é bem mais extenso — os seguintes princípios: celeridade; atendimento com preferência em solicitações urgentes; fluidez da comunicação; limitação relativa ao emprego da informação ou prova obtida; reserva de certas instâncias de investigação para efeitos de não frustar a efetividade da medida; entrega de documentos oficiais; princípio do reconhecimento da diversidade dos sistemas jurídicos nos Estados-parte; princípio do respeito à ordem pública interna e internacional do Estado requerido; princípio do respeito à lei interna substantiva e processual (formas e garantias); princípio da reserva política; princípio da responsabilidade; e - aquele que nos interessa primordialmente no presente trabalho - o princípio da proteção aos sujeitos do processo, que refere as garantias com que devem contar as pessoas envolvidas em medidas de assistência. Tais princípios, nas palavras do autor, "devem ser a ideia central de toda política de cooperação judicial penal internacional, pois o Direito Penal e, por suposto também, a cooperação penal interestática, só se justificam para servir ao homem". ${ }^{35}$ Entretanto, entende-se que os referidos princípios encontram-se abarcados nos princípios constantes no rol (mais sucinto) do Código Modelo de Cooperação

penal, remete-se a leitura dos seguintes trabalhos: TROTTA, Sandro Brescovit. Os limites da cooperação jurídica internacional em matéria penal. In: Sistema Penal \& Violência, Porto Alegre, v. 5, n. 1, p. 15-35, jan./jun. 2013. De um modo geral, o trabalho refere limites formais (solicitações por escrito, no idioma do Estado requerente etc) e materiais (que podem ser invocados como obstáculos à prestação da cooperação internacional em medidas processuais penais) e TAVARES, Juarez. Os Limites Dogmáticos da Cooperação Penal Internacional. In: CERVINI, Raúl e TAVARES, Juarez. Princípios de cooperação judicial penal internacional no protocolo do Mercosul. São Paulo: Editora Revista dos Tribunais, 2000, pp. 173-206). Nesta obra, o autor categoriza os limites em princípios penais democráticos; proteção da dignidade da pessoa humana; delimitação pelo bem jurídico; necessidade da pena; intervenção mínima; proporcionalidade e categorias lógico-objetivas.

33 Nesse sentido, ver: WADE, Marianne L. General Principles of Transnationalised Criminal Justice? Exploratory Reflections. Utrecht Law Review. Vol. 9, Issue 4 (September) 2013.

${ }^{34}$ CERVINI, Raúl. Princípios da Cooperação Judicial Internacional em Assuntos Penais. Doutrina - Direito Comparado. Disponível em:

<http://www.amprs.org.br/arquivos/revista_artigo/arquivo_1283279756.pdf>. Último acesso em: 06 ago. 2014. p. 33 a 44.

${ }^{35}$ E continua citando Zaffaroni: “Quando os Estados individualmente ou um conjunto de Estados vinculados multi ou bilateralmente em níveis de cooperação penal desconhecem o indivíduo como pessoa, se rompe uma estrutura lógico, objetiva, ficando seu acionar em mero exercício de poder que não é Direito.” (CERVINI, Raúl. Princípios da Cooperação Judicial Internacional em Assuntos Penais. Doutrina - Direito Comparado, p. 44 apud ZAFFARONI, Eugenio Raúl. Manual de Derecho Penal. Parte Geral, 4a ed. Buenos Aires: Ediar, 1985, p. 301). 
Interjurisdicional para Ibero-América, cuja principiologia apresentada no art. $2^{\circ}$ será adotada no presente trabalho, por ser bastante completa e abrangente. Como se depreende da sua própria exposição de motivos, a finalidade precípua do Código Modelo reside na necessidade de compilação de princípios fundamentais e regras gerais inerentes à jurisdição transnacional que sejam passíveis de aplicação em todos os sistemas jurídicos que consagrem o Estado de Direito, partindo de algumas preocupações de que comunga este trabalho, tal como a plenitude do acesso à Justiça transnacional com a devida preservação da soberania estatal, pois disso depende também a adequada uniformidade no tratamento das regras. ${ }^{36}$

Dito isso, os princípios gerais que regem a cooperação jurídica internacional, quer civil, quer penal, previstos no artigo $2^{\circ}$ do Código Modelo, são os seguintes:

I - Cláusula da ordem pública internacional: não será admitida a cooperação que se refira a atos contrários aos princípios fundamentais do Estado requerido ou que seja suscetível de conduzir a um resultado incompatível com esses princípios;

II - Respeito às garantias do devido processo legal no Estado requerente; III - Igualdade de tratamento entre nacionais e estrangeiros, residentes ou não, tanto no acesso aos tribunais quanto na tramitação dos processos nos Estados requerente e requerido, assegurando-se a gratuidade de justiça aos necessitados;

IV - Não dependência da reciprocidade de tratamento, salvo previsão expressa neste Código;

$\mathrm{V}$ - Publicidade processual, exceto nos casos de sigilo previstos na lei do Estado requerente ou do Estado requerido;

$\mathrm{V}$ - Tradução e forma livres para os atos e documentos necessários à prestação jurisdicional transnacional, incluindo-se os meios eletrônicos e videoconferência;

VI - Existência de uma autoridade central para a recepção e transmissão dos pedidos de cooperação, ressalvada a convalidação da recepção ou transmissão que não tenham sido perante essa autoridade;

VIII - Espontaneidade na transmissão de informações a autoridades do Estado requerente.

Os incisos $\mathrm{I}$ a $\mathrm{V}$ fazem referência aos princípios atinentes ao cabimento da cooperação e os incisos VI ao VIII referem-se ao procedimento da cooperação ativa e passiva. $^{37}$

A cláusula de ordem pública está associada à observância dos princípios fundamentais do Estado em cujo território se pretenda a eficácia de qualquer ato estrangeiro ou se pretenda praticar ato em favor da prestação jurisdicional perante tribunal estrangeiro.

\footnotetext{
${ }^{36}$ CÓDIGO de Cooperação Interjurisdicional para Ibero-américa. Revista da SJRJ, Rio de Janeiro, n. 25, 2009, pp. 429 e 445.

${ }^{37}$ Exposição de Motivos do Código de Cooperação Interjurisdicional para Ibero-américa. Revista da SJRJ, Rio de Janeiro, n. 25, 2009, p. 432.
} 
Em decorrência dessa cláusula, como é esclarecido na Exposição de Motivos, não se admite nem mesmo a prática de atos administrativos, tal como o registro de uma certidão de divórcio estrangeiro, ou a prática de atos judiciais ordinatórios que visem a uma prestação jurisdicional incompatível com os princípios fundamentais do Estado do qual se reclama tais atos.

Ademais, também como desdobramento da cláusula de ordem pública internacional, dentre os princípios apresentados, aquele que merece destaque para os propósitos do presente estudo e que será mais bem desenvolvido no capítulo 2 é o expresso no inciso II, que menciona o respeito às garantias do devido processo legal no Estado requerente, pois, "não respeitar as garantias do devido processo legal é o mesmo que negar o direito à tutela judicial efetiva e, consequentemente, ofender os princípios fundamentais de um Estado". ${ }^{38}$

A importância prática do referido princípio para os escopos do presente trabalho diz respeito à falta de oportunidade de defesa no processo judicial em curso no Estado requerente, como infringência ao princípio do devido processo legal, configurando o objeto de discussão com a apresentação de propostas de solução da questão nos próximos capítulos.

Nesse sentido, todas as garantias reconhecidas em documentos internacionais constituem o conteúdo de segurança de um processo penal justo e equitativo. Os direitos dos cidadãos, eixo central da interferência do Estado legal, também alimentam o dever ser de uma cooperação jurídica penal internacional saudável. ${ }^{39}$

Além disso, interessante destacar a não dependência da reciprocidade de tratamento, expressa no inciso IV, cujo objetivo é o de assegurar o exercício de direitos pertencentes a pessoas privadas, de modo a não sacrificá-las por culpa do Estado que se omite não oferecendo reciprocidade. Também é importante a referência a este inciso no contexto do presente trabalho, tendo em vista que mais adiante se tratará da instituição Defensoria Pública, a qual não existe em todos os países e, caso acionada em determinado caso, se restasse na dependência da reciprocidade, seria obstada a sua atuação.

Nesse sentido, a não dependência da reciprocidade deve resultar na restrição tão

\footnotetext{
${ }^{38}$ Ibidem, p. 433.

39 No original: Todas las garantías reconocidas en los documentos mencionados integran el contenido de garantía de un proceso penal justo y equitativo. También marcan el standard mínimo de exigencias aplicable a las instancias de interacción judicial penal internacional, en que los derechos humanos de los concernidos y los atributos sustantivos y adjetivos de la más Amplia Defensa, constituyen a la vez su objeto y el factor legitimante de la actuación de los Estados. Los derechos de los ciudadanos, eje central de la intromisión jurídico-estatal, también alimentan el deber ser de una sana cooperación judicial penal internacional. CERVINI, Raúl. $L a$ lectura e implementación de los Principios de la Cooperación Judicial Penal Internacional a la luz de los paradigmas inherentes al Estado Democrático de Derecho. Disponível em: www.direitocriminal.com.uy. Último acesso em: 15 jul. 2011.
} 
somente a interesses do próprio Estado inerte, sob pena de caracterizar ofensa à tutela judicial transnacional. ${ }^{40}$

Além disso, ainda que de modo genérico, importa referir que a Constituição brasileira reconheceu a realidade e a necessidade da cooperação jurídica internacional, tanto que converteu a cooperação interestatal em princípio reitor do Brasil nas suas relações internacionais. A Carta de 1988 consagrou entre os princípios norteadores da República Federativa do Brasil, em seu artigo $4^{\circ}$, inciso IX, "a cooperação entre os povos para o progresso da humanidade", diretriz na qual todos os demais princípios devem se inserir.

\subsection{Classificação da cooperação jurídica internacional}

Intentar sistematizar uma classificação da cooperação jurídica internacional afigurase importante, na medida em que se pode situar as diversas modalidades de medidas cooperacionais, de modo a melhor compreendê-las no contexto geral do instituto e, principalmente, entender melhor as medidas específicas que serão analisadas na sequência.

Os critérios classificatórios que serão objeto de apreciação são os seguintes: iniciativa da solicitação; qualidade de quem coopera, se autoridade judicial ou administrativa; e dentro da cooperação judicial, em sistema difuso e concentrado; por último, sujeito e enfoque da solicitação.

Assim, a cooperação jurídica internacional pode ser classificada em ativa ou passiva, de acordo com a iniciativa da solicitação. As medidas que um determinado Estado solicita aos demais representam a cooperação ativa — se num procedimento forem necessárias providências e diligências a serem realizadas fora do território nacional, as autoridades judiciárias ou administrativas dependerão da cooperação das autoridades estrangeiras ${ }^{41}$ ao mesmo tempo em que a cooperação passiva se realiza por meio do "intercâmbio internacional para o cumprimento extraterritorial de medidas processuais provenientes do Judiciário de outro Estado". ${ }^{42}$

Conforme Jean-André Roux, em obra datada de 1931, existem três tipos de

\footnotetext{
${ }^{40}$ EXPOSIÇÃO de Motivos do Código de Cooperação Interjurisdicional para Ibero-américa. Revista da SJRJ, Rio de Janeiro, n. 25, 2009, p. 433.

${ }^{41}$ REICHSTEINER, Beat Walter. Direito Internacional Privado, teoria e prática. 4a ed. São Paulo: Saraiva, 2000. p. 229.

42 ALMEIDA, Ricardo; ARAÚJO, Nádia; Salles, Carlos Alberto. Cooperação Interjurisdicional no Mercosul. Cartas Rogatórias, Homologação de Sentenças Estrangeiras e Laudos Arbitrais e Informação do Direito Estrangeiro. In: BASSO, Maristela (org.) Mercosul, seus efeitos jurídicos, econômicos e políticos nos Estados Membros. Porto Alegre: Livraria do Advogado, 1997, p. 494.
} 
cooperação entre Estados: a policial, a judicial e a legislativa, reconhecendo-se, contudo, atualmente apenas a cooperação administrativa (em que está inserida a policial, mas não só, conforme poderá ser conferido ao longo do trabalho, e é em que consistem algumas das propostas apresentadas ao final) e a judicial. ${ }^{43}$

Além disso, dentro da cooperação jurídica chamada judicial, pode-se classificar também o sistema de cooperação jurídica internacional em difuso ou concentrado, ${ }^{44}$ conforme classificação trazida por Carmen Tiburcio. No primeiro, as autoridades judiciárias da primeira instância têm competência tanto para julgar o cabimento quanto para conduzir a efetiva realização do pedido de cooperação enviado pelo Estado estrangeiro, enquanto que no sistema concentrado o juízo acerca do cabimento da cooperação é feito por um único órgão - geralmente o órgão de cúpula do Poder Judiciário. Neste caso, tendo sido deferida a solicitação deprecada, a realização se dará sob os auspícios de outra autoridade judiciária.

Além disso, a autora refere que, no Brasil, desde a Independência, o sistema de cooperação internacional adotado durante a maior parte do tempo, sem dúvida, foi o sistema concentrado, o qual fora inaugurado ainda no século XIX, mas só veio a alcançar status constitucional na Carta de 1934, através dos artigos 76, I, “g”, e 77, que introduziram a homologação de sentenças estrangeiras e a a concessão de exequatur às cartas rogatórias no rol das atribuições originárias do STF, situação que permaneceu durante as Constituições que lhe sucederam até o advento da Emenda Constitucional n. 45/2004, que deslocou tal competência para o Superior Tribunal de Justiça (CF, art. 105, I, “i”). Note-se, entretanto, que o Supremo Tribunal Federal continua competente para apreciação dos requerimentos de extradição (CF, art. 102, I, “g”), havendo assim uma bipartição da competência constitucional para processar o juízo de admissibilidade das modalidades clássicas de cooperação interjurisdicional. ${ }^{45}$

Já o Projeto de Código Modelo afasta-se da competência concentrada em um único tribunal do Estado requerido para o exercício do juízo de delibação. Adota-se o critério da competência difusa entre os tribunais que seriam competentes para decidir a questão de fundo, de acordo com as normas de competência em vigor no Estado requerido. Além de tornar mais célere o processamento, unificando perante o mesmo tribunal a competência para a delibação e execução da decisão estrangeira, propicia um grau de qualidade da jurisdição

\footnotetext{
${ }^{43}$ ROUX, Jean-André. L'entr'aide des Etats dans la lutte contre la criminalité. In Recueil des Cours de L’Academie de Droit Internacional da la Haye, Vol 36, 1931 - II, Paris, p. 93.

${ }^{44}$ TIBURCIO, Carmen. Temas de Direito Internacional. Rio de Janeiro: Renovar, 2006, pp. 149-151.

${ }^{45}$ Ibidem, p. 195.
} 
na medida em que entrega o feito a um tribunal especializado. ${ }^{46}$ Essa disposição é adotada no Código, em regra, para o procedimento de carta rogatória, ação e incidente de impugnação da eficácia da decisão estrangeira e medida judicial de urgência.

No Código, conforme referido em sua exposição de motivos, a exceção fica por conta da extradição, que deverá ser decidida por um único tribunal do Estado requerido, sem que haja a possibilidade de a autoridade central ou outro órgão impedir ou obstar o processamento ou execução, da mesma maneira que ocorre nas demais modalidades de cooperação (art. $2^{\circ}$, VII). ${ }^{47}$

Em relação ao enfoque e sujeitos da cooperação, há a cooperação denominada horizontal - a qual se afigura o objeto do presente trabalho —, que ocorre entre Estados soberanos, com base em consenso, ou seja, nenhum Estado encontra-se obrigado a cooperar com seus congêneres, e existe também a cooperação internacional denominada vertical, a qual ocorre entre os Estados, tribunais e organizações internacionais, de caráter obrigatório.

Em relação às modalidades de cooperação jurídica internacional em matéria penal existentes, se poderia mencioná-las nesta oportunidade, pois não deixam de configurar mecanismo classificatório; entretanto, dada a relevância e para uma apresentação pormenorizada dos procedimentos, optou-se por apresentá-las no tópico que segue.

\subsubsection{Modalidades de cooperação jurídica internacional penal}

Em relação às modalidades de Cooperação Jurídica internacional em matéria penal, apresenta-se o rol do art. 19 do Código Modelo de Cooperação Interjurisdicional para IberoAmérica, por ser documento de vanguarda com sistematização inédita da matéria e que leva em conta a experiência e as normas em vigor nos países iberoamericanos, onde se pode encontrar as seguintes modalidades de cooperação: I - citação, intimação e notificação judicial; II - realização de provas e obtenção de informações; III - investigação conjunta; IV - comparecimento temporário de pessoas; V - transferência de processo e de execução penal; VI - eficácia e execução de decisão penal estrangeira; VII - extradição; VIII - medida judicial penal de urgência.

O Código Modelo prevê procedimentos de cooperação no capítulo IV, quais sejam: auxílio mútuo, carta rogatória, ação e incidente de impugnação da eficácia de decisão

\footnotetext{
${ }^{46}$ Exposição de Motivos do Código de Cooperação Interjurisdicional para Ibero-américa. Revista da SJRJ, Rio de Janeiro, n. 25, 2009, p. 443.

${ }^{47}$ Ibidem, p. 443.
} 
estrangeira, procedimento de execução de decisão estrangeira, procedimento de medida judicial de urgência e procedimento de extradição, os quais consideram, em primeiro lugar, a natureza — administrativa ou jurisdicional — do ato objeto do intercâmbio; se reclama ou não uma medida jurisdicional perante o Estado requerido e, consequentemente, se necessita ou não de um juízo de delibação. ${ }^{48}$

Como referido acima em relação aos atos que reclamam ou não medida jurisdicional e com base nesta classificação do Código Modelo, a investigação conjunta, o comparecimento temporário de pessoas, a citação, intimação e notificação judicial e extrajudicial, a realização de provas e a obtenção de informações são modalidades de cooperação em matéria de prova que não reclamam uma medida jurisdicional do Estado requerido. Já a eficácia e execução de sentença de decisão estrangeira, a medida de urgência, a extradição, a transferência de processo e execução penal são medidas que reclamam medida jurisdicional. ${ }^{49}$

Importante observar que os mencionados procedimentos podem veicular Pedidos de Extradição, Pedidos de Assistência Jurídica, Pedidos de Homologação de Sentença Estrangeira Criminal e Transferência de Presos; em consonância com a advertência de Denise Neves Abade, ${ }^{50}$ deve-se atentar para o fato de que nem sempre um pedido será necessariamente associado a um tipo de procedimento.

Por outro lado, há pedidos que podem ser transportados por veículos diversos, tal como ocorre com a carta rogatória, que pode transportar conteúdo instrutório - citação do réu para apresentar sua defesa e produção de prova, v.g. — , cujo conteúdo também pode ser viabilizado por intermédio do pedido de auxílio direto (denominado também de pedido de assistência jurídica) ${ }^{51}$ ou de auxílio mútuo, como consta no Código Modelo de Cooperação para Iberoamérica.

De acordo com o art. 41 do Código Modelo de Cooperação Interjurisdicional para Iberoamérica, é admissível a carta rogatória nas seguintes modalidades de cooperação:

\footnotetext{
${ }^{48}$ Exposição de Motivos do Código de Cooperação Interjurisdicional para Ibero-américa. Revista da SJRJ, Rio de Janeiro, n. 25, 2009, p. 441.

${ }^{49}$ Exposição de Motivos do Código de Cooperação Interjurisdicional para Ibero-américa. Revista da SJRJ, Rio de Janeiro, n. 25, 2009, p. 434.

50 "De fato, há crescente diluição do vínculo entre determinados veículos e conteúdos, como se vê, no caso do Protocolo de Las Leñas, que permite a homologação de sentença estrangeira por meio de Carta Rogatória". (ABADE, Denise Neves. Direitos fundamentais na cooperação jurídica internacional: extradição, assistência jurídica, execução de sentença estrangeira e transferência de presos. São Paulo: Saraiva, 2013. p. 46).

51 ABADE, Denise Neves. Direitos fundamentais na cooperação jurídica internacional: extradição, assistência jurídica, execução de sentença estrangeira e transferência de presos. São Paulo: Saraiva, 2013. p. 46.
} 
I - informação sobre processo administrativo ou judicial e realização de provas que reclamam atos jurisdicionais no Estado requerido;

II - transferência temporária de pessoas;

III - transferência de processo penal e de execução penal;

IV - execução de medidas judiciais de urgência, decretadas por tribunal do

Estado requerente.

Nesse contexto, de acordo com posição trazida por Mueller, ${ }^{52}$ o melhor a ser feito é classificar a cooperação pelo seu conteúdo. Logo, o termo "cooperação jurídica internacional" deve ser concebido como "gênero", enquanto extradição, assistência jurídica mútua, homologação de sentença estrangeira, transferência de presos e transferência de processos penais delimitam as "espécies" procedimentais dessa cooperação.

Assim, antes de adentrar no estudo do procedimento de auxílio direto propriamente dito, compete mencionar, ainda que em linhas gerais, os demais mecanismos de cooperação jurídica internacional existentes, ${ }^{53}$ quais sejam, a carta rogatória, a homologação de sentença estrangeira, a extradição, a transferência de pessoas apenadas e a transferência de processos penais.

Estabelecidas as premissas iniciais e feitos os esclarecimentos necessários, serão explanados, sucintamente, em que consistem os procedimentos de cooperação jurídica internacional previstos.

\subsubsection{Extradição}

A extradição é o instituto básico da cooperação penal internacional e, como já referido, o que possui registros mais antigos. Consiste no ato jurídico pelo qual um Estado entrega um indivíduo acusado de fato delituoso ou já condenado à justiça de outro Estado, competente para julgá-lo e puni-lo. Pressupõe que o crime tenha sido cometido no território do Estado requerente ou sejam aplicáveis ao extraditando as leis penais do Estado

\footnotetext{
${ }^{52}$ MUELLER, Gerhard O.W. "International Judicial Assistance in Criminal Matters" in MUELLER, Gerhard \& WISE, Edward (eds). International Criminal Law. New Jersey: Rothman Ed., 1965. p. 441.

${ }^{53}$ Para os efeitos deste trabalho, adotou-se classificação utilizada no Brasil no artigo $1^{\circ}$ do Anteprojeto Brasileiro de Lei Geral de Cooperação Jurídica Internacional do Ministério da Justiça, que assim determina: "Esta lei dispõe sobre cooperação passiva e ativa com Estados e tribunais internacionais ou estrangeiros, em matéria civil, trabalhista, previdenciária, comercial, tributária, financeira, administrativa e penal, especialmente pelos procedimentos de: I - carta rogatória; II - ação de homologação de decisão estrangeira; III - auxílio direto; IV - transferência de processos penais; V - extradição; e VI - transferência de pessoas apenadas.". Para leitura integral do texto: SILVA, Ricardo Perlingeiro Mendes da. "Anotações sobre o anteprojeto de lei de cooperação jurídica internacional" in Revista de Processo, n. 129, 2005, p. 133-160. Interessante pontuar que o referido anteprojeto, cuja redação teve início em 2004, todavia permanece sem número e até outubro de 2014 não havia sido apresentado às Casas Legislativas.
} 
requerente, bem como exista sentença final privativa de liberdade ou prisão decretada por autoridade competente do Estado solicitante.

A Constituição Federal, no artigo $5^{\circ}$, inciso LI, veda a extradição de brasileiros natos, bem como de naturalizados, ${ }^{54}$ por crimes que sejam posteriores à naturalização, salvo no caso de comprovado envolvimento em tráfico ilícito de entorpecentes, caso em que, por exceção constitucional, o brasileiro naturalizado pode ser extraditado por crimes cometidos após a naturalização.

Entretanto, o Código Modelo para Iberoamérica, no art. $2^{\circ}$, III, rejeita qualquer diferença de tratamento entre nacionais e estrangeiros, residentes ou não residentes, inclusive quanto à possibilidade de extradição. $\mathrm{O}$ acesso à justiça deve ser efetivo e as garantias correspondentes devem estar ao alcance dos nacionais e dos estrangeiros, indistintamente.

A extradição objetiva assegurar a eficácia transnacional de decisão penal estrangeira restritiva de liberdade (art. 30, caput, do Código Modelo). A proibição da extradição de nacionais não foi acolhida pelo Projeto de Código Modelo para Iberoamérica, pois, na verdade, proibir a extradição de nacionais significa assegurar-lhes privilégio injustificável, arraigado a uma concepção nacionalista extremada. ${ }^{55}$

Ainda que o instituto permaneça regulado, em âmbito nacional, nos artigos 76 a 94 da Lei n. 6.815/1980, com as substanciais alterações processadas pela Lei n. 6.964/1981, ${ }^{56}$ o Código Modelo, no artigo 30, estabelece condições específicas para a extradição, dentre as quais se destacam as seguintes: a) estar fundada em tratado ou promessa de reciprocidade; b) ser o fato considerado crime, ainda não prescrito, no Estado requerido e no Estado requerente, e ser punível pela lei de ambos os Estados com pena privativa de liberdade de duração máxima não inferior a 12 meses ou, se a extradição tiver por finalidade o cumprimento de pena, o tempo de pena por cumprir não pode ser inferior a seis meses; c)

\footnotetext{
${ }^{54}$ A doutrina tem criticado o princípio da não extradição de nacional, não só porque viola o igualitarismo que deve prevalecer no mecanismo da extradição, mas também porque supõe uma desconfiança em relação às organizações judiciais estrangeiras, especialmente quando se lida com estados e sociedades com nível jurídico e cultural semelhante. De qualquer forma, não se deve esquecer que a sua aplicação determina uma diminuição significativa na eficácia na persecução do delito. (DELGADO MARTÍN, Joaquín. La Orden de Detención Europea y los Procedimientos de Entrega entre los Estados Mimebros de La Unión Europea. In: PECO, Ángel Galgo (Director). Derecho Penal Supranancional y Cooperación Jurídica Internacional. Cuadernos de Derecho Judicial, XIII. Madrid: Consejo General del Poder Judicial - Centro de documentación Judicial, 2003, p. 330). Tradução livre.

${ }^{55}$ Como assevera ainda a exposição de motivos: "Se a razão de preocupação reside em não submeter o nacional a um tribunal parcial ou a um tribunal que não assegure as garantais do devido processo, tal preocupação deveria se estender a todos, nacionais ou estrangeiros, mas somente em função daquelas circunstâncias de não observância das garantias do devido processo legal". (Exposição de Motivos do Código de Cooperação Interjurisdicional para Ibero-américa. Revista da SJRJ, Rio de Janeiro, n. 25, 2009, p. 440).

56 WEBER, Patrícia Núñez. A Cooperação Jurídica Internacional em Medidas Processuais Penais. Porto Alegre: Verbo Jurídico, 2011, p. 33.
} 
não se revestir o processo ou a condenação no Estado requerente de caráter político ou não ser consequência de considerações racistas, de religião, nacionalidade, ou outra espécie de discriminação, nem existirem razões sérias para supor que o pedido foi efetuado por alguma dessas razões ou que a satisfação do pedido provocaria um prejuízo à pessoa requisitada por qualquer dessas razões; d) não ser o litígio de competência do tribunal do Estado requerido, salvo se, na extradição consentida, verificar-se em relação ao Estado requerente uma das condições estabelecidas no art. 25.

A autoridade nacional competente para o processamento dos pedidos de extradição continua sendo o Supremo Tribunal Federal, mesmo após o advento da Emenda Constitucional n. 45/2004.

\subsubsection{Homologação de sentença estrangeira}

A homologação de sentença estrangeira, a seu turno, é uma pretensão destinada a conceder eficácia extraterritorial às sentenças prolatadas por autoridades competentes de outro país.

No Brasil, a matéria é regulada pelo artigo $9^{\circ}$ do Código Penal, com a redação que lhe deu a Lei n. 7.209/1984. O ordenamento pátrio não admite a homologação de sentença penal estrangeira para fins de privação da liberdade, mas para obrigar o condenado à reparação do dano, a restituições e a outros efeitos civis, inclusive confisco, e para sujeitálo a medida de segurança (o Código de Processo Penal regula a matéria nos artigos 787 a 790). ${ }^{57}$

O Código Modelo de Cooperação Interjurisdicional para Ibero-América, a seu turno e de forma diversa, não se refere a "reconhecimento" de decisão estrangeira ou "homologação"; o Código utiliza a expressão "impugnação da eficácia da decisão", por intermédio da "ação e incidente de impugnação da eficácia da decisão estrangeira", prevista em seus artigos 42 a 47. Nesse sentido, conforme esclarecido na própria exposição de motivos do Código, parte-se da premissa de que as decisões estrangeiras surtem efeito automático no território de outro Estado e não dependem de reconhecimento prévio. Assim, o que será discutido judicialmente é a impugnação dos efeitos automáticos da decisão estrangeira, constituindo oportunidade para discutir sobre coisa julgada estrangeira (art. 46) e litispendência internacional (art. 47). ${ }^{58}$

\footnotetext{
${ }^{57}$ Ibidem, p. 34.

${ }^{58}$ Exposição de Motivos do Código de Cooperação Interjurisdicional para Ibero-américa. Revista da SJRJ, Rio
} 
Para que as disposições do Código Modelo tivessem eficácia no território nacional seria necessária adequação legislativa nesse sentido, observado que a legislação vigente parametriza apenas a homologação de sentença estrangeira referida acima.

\title{
1.3.1.3 Carta rogatória
}

A Carta Rogatória é um instrumento processual utilizado por um Estado destinado à solicitação do cumprimento de uma medida no âmbito territorial de outro, que seja útil à instrução de um feito no primeiro.

Como bem elucida Valentini:

\begin{abstract}
A carta rogatória é um pedido entre autoridades estrangeiras, ou seja, entre as autoridades que operam no âmbito de um processo que visa a investigação de um crime. Entretanto, o pedido de assistência, a que se propõe a resolver uma carta rogatória internacional não pode vir de qualquer cidadão, mas apenas e exclusivamente por indivíduos identificáveis, na acepção do Estado do assistido, como autoridade competente para tomar medidas sobre o nível das relações inter-estatais e contexto do processo penal. ${ }^{59}$
\end{abstract}

Há a reconhecida inadmissibilidade de uma relação de assistência interestatal iniciada por particulares.

Com base no Manual para Cooperação Internacional em Matéria Criminal Relacionada ao Terrorismo elaborado pelo Escritório das Nações Unidas sobre Drogas e

de Janeiro, n. 25, 2009, p. 443.

${ }^{59}$ Continua o autor: "O circunlóquio se refere, em primeiro lugar, a comumente reconhecida inadmissibilidade de uma relação de assistência inter-estatal iniciada por particulares. Ressalta-se, ao contrário, como sendo o ato de cooperação entre os atores internacionais (ou entre essas autoridades que são, neste caso, tituladas para representá-los) - resulta inadimissível pedido de assistência formulado por pessoas que apenas a ordem interna do país habilitasse para determinadas medidas processuais. Sujeitos do gênero não pertencem a estrutura administrativa estatal e, portanto, não são legítimos para atuar como seus representantes". Tradução livre de: "La rogatoria si presenta come una richiesta intercorrente fra autorità straniere; nel caso di specie, fra autorità attive nel contesto di un procedimento finalizzato all'accertamento di un reato. La breve definizione appena fornita esige già qualche chiarimento. La richiesta di assistenza, in cui si risolve una rogatoria internazionale, non può provenire da qualunque cittadino, ma solo ed esclusivamente da soggetti identificabili, ai sensi dell'ordinamento interno dello Stato assistito, come autorità competenti ad attivarsi sul piano dei rapporti interstatuali e nel contesto del procedimento penale. La circonlocuzione allude, in primis, alia comunemente riconosciuta inammissibilità di un rapporto di assistenza interstatuale avviato da privati cittadini. Si sottolinea, anzi, come essendo la cooperazione atto intercorrente fra soggetti internazionali (ovvero fra quelle autorità che siano, nel caso specifico, titolate a rappresentarli) - risulta inammissibile anche la richiesta d'assistenza inoltrata da persone che il singolo ordinamento interno abilitasse d'ordinario ali'adozione di certe misure procedimentali. Soggetti dei genere non appartengono, infatti, alia struttura organizzatoria statale e, pertanto, non sono idonei ad agire quali suoi rappresentanti." (VALENTINI, Cristiana. L'Acquisizione della prova tra limiti territoriali e cooperazione com autorità straniere. Padova: CEDAM, 1998, p. 31-33). 
Crime (United Nations Office on Drugs and Crime - UNODC), ${ }^{60}$ as cartas rogatórias podem ser definidas como um pedido formal de um tribunal de um país para as autoridades judiciais competentes em outro país com requisições para tomada de depoimentos ou provas documentais ou ainda para outras evidências a serviço do processo.

Em relação ao direito positivado, as cartas rogatórias encontram previsão expressa na Constituição Federal (artigo 105, I, “i”), na Lei de Introdução às Normas do Direito Brasileiro (artigo 12, § 2º ), no Código de Processo Civil (artigos 202 a 212) e no Código de Processo Penal (artigos 783 a 786).

Entende-se que a carta rogatória é um mecanismo que viabiliza a cooperação com qualquer país estrangeiro, visto que sua previsão é irrestrita, atendidos seus pressupostos formais e materiais. Interessante pontuar, entretanto, que os Estados Unidos não aceitam pedido de cooperação no âmbito penal via carta rogatória remetida ao judiciário daquele país, sob a alegação de que o pedido deve sempre ser encaminhado à autoridade central, em função dos tratados bilaterais em vigor para essa finalidade. ${ }^{61}$

Nesse ponto, já cumpre apresentar crítica interessante de Cristiana Valentini ${ }^{62}$ ao sistema das rogatórias em relação à equidade de tratamento entre acusação e defesa e às suas consequências no processo penal: o defensor que está na necessidade de recolher provas localizadas no exterior deverá instar o tribunal competente com urgência na fase processual em que se encontra (juiz de investigações preliminares ou do julgamento), de modo a que se incline pela carta rogatória. Assim, supérfluo observar que tal situação dá origem a uma diferença significativa no tratamento entre os litigantes, um dos quais (o Ministério Público) será dotado da capacidade de avaliar a seu critério a oportunidade e a utilidade das cartas rogatórias, enquanto a outra parte (a Defesa) encontra-se obrigada a entregar nas mãos do juiz essa decisão.

\footnotetext{
${ }^{60}$ No original: "A letter rogatory is a formal request from a court in one country to the appropriate judicial authorities in another country requesting taking of testimony or documentary or other evidence or service of process". Disponível em:<http://www.unodc.org/documents/terrorism/Publications/Manual_Int_Coop_Criminal_Matters/English.p

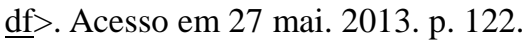

${ }^{61}$ SILVA, Ricardo Perlingeiro Mendes da. Anotações sobre o anteprojeto de lei de cooperação jurídica internacional In Revista de Processo, $\mathrm{n}^{\circ}$ 129, ano 30, nov. 2005, p. 156.

${ }^{62}$ No original: "Ovvia la conseguenza sul piano processuale penale: il difensore che si trovi nella necessità di raccogliere materiale probatorio situato all'estero, dovrà instare presso il giudice competente nella fase procedimentale in atto (giudice per le indagini preliminari o del dibattimento), affinché si attivi per la rogatoria. Superfluo dire che una situazione del genere dà luogo ad una notevole disparità di trattamento fra parti processuali, delle quali una (il pubblico ministero) e in grado di valutare discrezionalmente I'opportunità e utilità della rogatoria, mentre I'altra (il difensore) e costretta a cedere nelle mani del giudice questa decisione". (VALENTINI, Cristiana. L'Acquisizione della prova tra limiti territoriali e cooperazione com autorità straniere. Padova: CEDAM, 1998, p. 82).
} 
Reputou-se interessante introduzir esse tema já neste momento, pois diz respeito às preocupações elementares que motivaram o presente trabalho e que são também compartilhadas por parte respeitável da doutrina em outros países.

\subsubsection{Transferência de presos e transferência de processos ou de procedimentos criminais}

A transferência de presos está prevista na Convenção da ONU sobre Crime Organizado Transnacional (art. 21), no art. $8^{\circ}$ da Convenção Europeia sobre Transferência de Processos em Matéria Penal (European Convention on the Transfer of Proceedings in Criminal Matters), que foi assinada em 15 de maio de 1972 e entrou em vigor em 30 de março de 1978, bem como na Convenção Interamericana sobre o Cumprimento de Sentenças Penais no Exterior, ou Convenção de Manágua, de 1993, promulgada no Brasil pelo Decreto n. 5.919, de 3 de outubro de 2006 (Inter-American Convention on Serving Criminal Sentences Abroad - OEA). Como não há previsão desse instrumento na legislação interna brasileira, a transferência depende de tratados internacionais bilaterais ou multilaterais ${ }^{63} \mathrm{e}$ da promessa de reciprocidade. ${ }^{64}$

Como já assentado na jurisprudência do Supremo Tribunal Federal, a transferência de presos tem caráter humanitário.

O Código Modelo para Iberoamérica, de forma bastante vanguardista, disciplina a

\footnotetext{
${ }^{63}$ Atualmente, o Brasil possui 11 (onze) Tratados bilaterais de Transferência de Pessoas Condenadas, em vigor, e 2 (dois) multilaterais: Argentina: Celebrado em 11.09.1998 e promulgado pelo Decreto $\mathrm{n}^{\mathrm{o}} 3.875$, de 23.07.2001; Bolívia: Celebrado em 26.07.2007 e promulgado pelo Decreto nº 6.128, de 20.06.2007; Canadá: Celebrado em 15.07.1992 e promulgado pelo Decreto ${ }^{\circ}$ 2.547, de 14.04.1998; Chile: Celebrado em 29.04.1998 e promulgado pelo Decreto $\mathrm{n}^{\circ}$ 3.002, de 26.03.1999; Convenção Interamericana sobre o Cumprimento de Sentenças Penais no Exterior: Celebrado em 26.07.2007 e promulgado pelo Decreto n ${ }^{\circ}$ 6.128, de 20.06.2007. Países signatários: Arábia Saudita, Belize, Brasil, Canadá, Chile, Costa Rica, El salvador, Equador, Estados Unidos, Guatemala, México, Nicarágua, Panamá, Paraguai, República Tcheca, Uruguai e Venezuela; Convenção sobre a Transferência de Pessoas Condenadas entre os Estados Membros da Comunidade dos Países de Língua Portuguesa (CPLP): Celebrado em 23..11.2005 e promulgado pelo Decreto n ${ }^{\circ}$ 8.049, de 11.07.2013. Países: Angola, Brasil, Cabo Verde, Guiné Bissau, Moçambique, Portugal, São Tomé e Príncipe, Timor Leste; Espanha: Celebrado em 04.05.1998 e promulgado pelo Decreto n 2.576, de 30.04.1998; Panamá: Celebrado em 10.08.2007 e promulgado pelo Decreto $\mathrm{n}^{\mathrm{o}}$ 8.050, de 11.07.2013; Paraguai: Celebrado em 29.10.2002 e promulgado pelo Decreto $\mathrm{n}^{\circ}$ 4.443, de 28.10.2002; Peru: Celebrado em 25.08.2003 e promulgado pelo Decreto $\mathrm{n}^{\circ}$ 5.931, de 13.10.2006; Portugal: Celebrado em 25.08.2007 e promulgado pelo Decreto $\mathrm{n}^{\circ}$ 5.767, de 02.05.2006; Reino dos Países Baixos: Celebrado em 23.01.2009 e promulgado pelo Decreto $\mathrm{n}^{\mathrm{o}} 7.906$ de 04.02.2013; Reino Unido da Grã-Bretanha e Irlanda do Norte: Celebrado em 29.01.2002 e promulgado pelo Decreto $\mathrm{n}^{\mathrm{o}}$ 4.107, de 28.01.2002. (Disponível em: http://www.justica.gov.br/seusdireitos/estrangeiros/cooperacao-internacional/transferencia-de-pessoas-condenadas. Último acesso em: 03 out. 2014.

${ }^{64}$ A título elucidativo, possível verificar os argumentos apresentados no seguinte precedente: STF, Pleno, HC 84.078, Relator Min. Eros Grau, julgado em 05.02.2009.
} 
transferência de processo e de execução penal, procedimentos de que tratam a presente seção.

Assim, nos termos do artigo 25 do Código, a competência penal para o processo de conhecimento e para o processo de execução, havendo consentimento do acusado ou do condenado, pode ser transferida a outro Estado, considerado requerido, se observada uma das seguintes condições:

I - possuir o acusado ou condenado residência no Estado requerido ou neste concentrar suas atividades econômicas;

II - haver aumento das possibilidades de reintegração social do acusado ou do condenado, com a transferência para o Estado requerido;

III - encontrar-se a pessoa a cumprir, no Estado requerido, outra pena privativa de liberdade por fato distinto do estabelecido na sentença cuja execução é ou poderá ser pedida;

IV - sendo o Estado requerido o de origem do acusado ou condenado e terse declarado disposto a encarregar-se da execução;

$\mathrm{V}$ - não estar o Estado requerente em condições de executar a sanção, mesmo com recurso à extradição, possuindo-as, entretanto, o Estado requerido.

Parágrafo único. Ainda que se verifique uma das condições previstas nos incisos I, III, IV e V, não haverá lugar à transferência para o Estado requerido se houver razões para crer que a mesma não favorece a reintegração social do acusado ou condenado.

A transferência de processos ou de procedimentos criminais também encontra previsão nas Convenções de Viena contra o Tráfico Ilícito de Entorpecentes e Substâncias Psicotrópicas e na Convenção de Palermo contra o Crime Organizado Transnacional. Dispõe o art. 21 da Convenção de Palermo:

Transferência de processos penais. Os Estados Partes considerarão a possibilidade de transferirem mutuamente os processos relativos a uma infração prevista na presente Convenção, nos casos em que esta transferência seja considerada necessária no interesse da boa administração da justiça e, em especial, quando estejam envolvidas várias jurisdições, a fim de centralizar a instrução dos processos.

Embora relativamente pouco utilizada na praxe internacional e ausente na praxe nacional até o momento, diz-se que a transferência de processos (transfer of proceedings), consiste numa opção interessante quando o suspeito (ou acusado) é domiciliado no Estado requerido, ou quando este é o Estado de nacionalidade do acusado, ${ }^{65}$ criando possíveis

\footnotetext{
${ }^{65}$ VERGUEIRO, Luiz Fabrício Thaumaturgo. Implementação da Cooperação Jurídica Internacional Vertical.
} Tese de Doutorado apresentada à Faculdade de Direito da Universidade de São Paulo. São Paulo: 2012, p. 51. 
dificuldades a um pedido de extradição. ${ }^{66}$

Desse modo, a transmissão de processos penais consiste no envio de um processo penal de um Estado a outro, renunciando, o Estado emissor, à persecução do delito, de modo a que sejam os órgãos judiciais do Estado receptor que o investiguem, julguem e executem eventual sentença condenatória. Do ponto de vista de fontes legais internacionais, na Europa, destaca-se a Convenção Europeia sobre Transmissão de Processos em matéria penal, assinada em Estrasburgo em 15 de maio de $1972 .{ }^{67}$

Nesse sentido e como já descrito, bastante interessantes as disposições do Código Modelo, as quais poderiam ser seguidas em eventual regulação da matéria em âmbito nacional.

\subsubsection{Auxílio direto}

Por fim, o auxílio direto é a cooperação prestada pela autoridade nacional apta a atender a demanda externa, no uso de suas atribuições legais, como se um procedimento nacional fosse, embora oriundo de solicitação do Estado estrangeiro encaminhada por intermédio da autoridade central brasileira. ${ }^{68}$

\footnotetext{
${ }^{66}$ Conforme traz Delgado Martín, são muitos os convênios e ordenamentos jurídicos que acolheram o princípio da não-extradição de nacionais, citando como exemplo a expressa proibição constitucional existente em países como Alemanha, Chipre ou Croácia, a proibição legislativa encontrada na Suécia e na Espanha e a proibição encontrada em Declarações, como a do Art. $6^{\circ}$ do Convênio Europeu de Extradição, a que aderem França, Portugal, Grécia e Hungria, por exemplo. Assim, quando a extradição não é possível, de acordo com a famosa fórmula de Grocio: "aut dedere, aut punire" - entregar ou julgar -, se a entrega não é possível, o Estado de nacionalidade do reclamado deverá proceder ao seu julgamento pelo delito pelo qual é perseguido no outro país. Assim, os principais instrumentos internacionais destinados a evitar a mencionada situação de impunidade são a transmissão da execução e a transmissão dos procedimentos penais. Mediante a transferência da execução, um estado que emitiu uma sentença condenatória solicita ao Estado em que se encontra o condenado que execute a sentença. Os dois principais convênios no âmbito europeu são o Convênio Europeu no 70 , de 28 de maio de 1970, relativo à validez internacional das sentenças penais e os arts. 67 a 69 do Convênio de Aplicação do Acordo de Schengen de 1990. (DELGADO MARTín, Joaquín. La Orden de Detención Europea y los Procedimientos de Entrega entre los Estados Mimebros de La Unión Europea. In: PECO, Ángel Galgo (Director). Derecho Penal Supranancional y Cooperación Jurídica Internacional. Cuadernos de Derecho Judicial, XIII. Madrid: Consejo General del Poder Judicial - Centro de documentación Judicial, 2003, p. 329$333)$.

${ }^{67}$ DELGADO MARTÍN, Joaquín. La Orden de Detención Europea y los Procedimientos de Entrega entre los Estados Mimebros de La Unión Europea. In: PECO, Ángel Galgo (Director). Derecho Penal Supranancional y Cooperación Jurídica Internacional. Cuadernos de Derecho Judicial, XIII. Madrid: Consejo General del Poder Judicial - Centro de documentación Judicial, 2003, p. 330.

${ }^{68}$ Essa modalidade de cooperação, objeto do presente trabalho, começou a ser utilizada no Brasil quando o STF não admitia cartas rogatórias de cunho executório. Fundamenta-se na Constituição Federal, a qual estabelece ser um dos princípios fundamentais nas relações internacionais da República Federativa a cooperação entre os povos. (GIACOMOLLI, Nereu José; SANTOS, Laura Rodrigues dos. Cooperação Jurídica Internacional em Matéria Criminal: autoridades centrais, das rogatórias ao auxílio direto. In: Revista de Estudos Criminais, ano X, ${ }^{\circ}$ 46, jul./set. 2012, p. 110, nota 30). Ademais, importa observar que no código Modelo de Cooperação Interjurisdicional para Iberoamérica o auxílio mútuo tanto pode se dar de forma direta entre os órgãos interessados quanto com a utilização da intermediação de uma autoridade central, é o que se pode
} 
O pedido de auxílio direto não possui previsão constitucional no Brasil, mas encontra pleno respaldo legal, observando-se que o Estado já ratificou inúmeros tratados internacionais e acordos bilaterais (Mutual Legal Assistance Treaties - MLATs) com previsão expressa dessa modalidade de cooperação. ${ }^{69}$

De antemão, cumpre referir com Bruce Zagaris que o MLAT possui claras vantagens sobre os demais mecanismos de mútua assistência, em especial sobre as cartas rogatórias, além de sua compulsoriedade (enquanto as demais formas de assistência se dão em razão de uma simples cortesia internacional, o pedido de assistência via MLAT só pode ser denegado nos exatos e exíguos limites do tratado). O MLAT é mais célere, não exige a dupla incriminação para a sua aplicação, a prova colhida através dele tem muito mais chances de ser considerada como válida no país requerente (já que observa estritos parâmetros para a sua obtenção). ${ }^{70}$

Cumpre esclarecer que, no Código Modelo para Iberoamérica, o auxílio direto foi chamado de auxílio mútuo (arts. 32 a 36) e sua natureza jurídica será voluntária (não contenciosa), ao não reclamar jurisdição ou delibação no Estado requerido, conforme considerações da própria exposição de motivos do Código. Entre tribunais será um procedimento judicial de jurisdição voluntária. Nos demais casos, um procedimento administrativo, de acordo com a legislação administrativa do Estado requerido. Trata-se do auxílio mútuo judicial e do auxílio mútuo administrativo (art. 34). ${ }^{71}$

Afigura-se admissível o auxílio-mútuo nas seguintes modalidades de cooperação (art. 35 do Código Modelo):

I - citação, intimação e notificação judicial e extrajudicial, quando não for possível ou recomendável a utilização do correio;

II - informação sobre direito estrangeiro;

III - informação sobre processo administrativo ou judicial em curso no Estado requerido, salvo no caso de sigilo;

IV - investigação conjunta entre autoridades policiais e órgãos de persecução penal, salvo se a medida reclamar jurisdição no Estado

verificar em seu artigo 33: “A solicitação de auxílio mútuo poderá ser encaminhada, pelo órgão ou tribunal interessado, diretamente àquele que for responsável pelo seu atendimento, competindo-lhe, ainda, assegurar sua autenticidade e compreensão, no Estado requerido e no Estado requerente. Parágrafo único. São facultados o registro e o encaminhamento da solicitação ao órgão ou tribunal competente do Estado requerido por uma autoridade central". O Parágrafo Único do art. 33 também se aplica ao procedimento de carta rogatória (art. 38, parágrafo $1^{\circ}$ ).

${ }^{69}$ BECHARA, Fábio Ramazzini. Cooperação Jurídica Internacional em Matéria Penal. Eficácia da prova produzida no exterior. São Paulo: Saraiva, 2011, p. 55.

${ }^{70}$ ZAGARIS, Bruce. U.S. - Brazil and International Evidence Gathering: The Need for Better Procedural Due Process. Revista Brasileira de Ciências Criminais. RBCCrim. Ano 20, vol. 99, nov.-dez./2012, p. 250-1.

${ }^{71}$ Exposição de Motivos do Código de Cooperação Interjurisdicional para Ibero-américa. Revista da SJRJ, Rio de Janeiro, n. 25, 2009, p. 441. 
requerido, a qual deverá ser objeto de medida judicial de urgência; $\mathrm{V}-$ realização de provas.

Em solo pátrio, a carta rogatória e o auxílio direto são empregados para propiciar a cooperação internacional, havendo sutil diferença entre ambos. $O$ que distingue, basicamente, a carta rogatória do auxílio direto é o seu caráter ex officio. A carta rogatória compreende a "informação sobre processo administrativo ou judicial" e a "realização de provas" que reclamem atos jurisdicionais no Estado requerido, a "transferência temporária de pessoas", a "transferência de processo penal e de execução penal", e a "execução de medidas judiciais de urgência". ${ }^{72}$ Em suma, por meio da carta rogatória solicita-se a execução no Brasil de ato proferido por autoridade judiciária estrangeira, não cabendo às autoridades brasileiras exercer cognição de mérito sobre o que é solicitado. Já nos pedidos de auxílio direto, as autoridades brasileiras conhecem dos fatos narrados pela autoridade requerente para daí proferir uma decisão nacional. ${ }^{73}$

Em muitos países, a instrumentalização do auxílio direto, por intermédio das autoridades centrais, substituiu o uso das tradicionais cartas rogatórias. ${ }^{74}$

Exigindo-se jurisdição ou delibação do Estado requerido, os procedimentos necessariamente contenciosos de cognição exauriente — consideram a quem compete a iniciativa pela cooperação jurídica. Quando se cuida de iniciativa direta dos Tribunais, adotase a carta rogatória; porém, quando for a cooperação de iniciativa e responsabilidade das partes, os procedimentos variam de acordo com a pretensão a ser deduzida no Estado requerido (medida de urgência, ação e incidente de impugnação de decisão estrangeira, execução de decisão estrangeira, extradição).

No Brasil, a questão já foi mais tormentosa, em decorrência de haver previsão constitucional sobre a competência do Superior Tribunal de Justiça (STJ) para a concessão

\footnotetext{
${ }^{72}$ Art. 41 e Exposição de Motivos do Código de Cooperação Interjurisdicional para Ibero-américa. Revista da SJRJ, Rio de Janeiro, n. 25, 2009, p. 442.

${ }^{73}$ Cartilha Cooperação Jurídica Internacional em Matéria Penal. Ministério da Justiça, Secretaria Nacional de Justiça e Departamento de Recuperação de Ativos e Cooperação Jurídica Internacional, 2013, p. 23. Disponível em: $\quad$ http://www.justica.gov.br/sua-protecao/cooperacao-internacional/cooperacao-juridicainternacional/arquivos/cartilha_coop_penal.pdf/view>. Último acesso em: 03 out. 2014.

${ }^{74}$ Por oportuno e de modo a corroborar a afirmação ("em muitos países", mas não em todos...), observa-se que no Código Modelo de Cooperação Interjurisdicional para Iberoamérica o auxílio mútuo tanto pode se dar de forma direta entre os órgãos interessados quanto com a utilização da intermediação de uma autoridade central, é o que se pode verificar em seu artigo 33: a solicitação de auxílio mútuo poderá ser encaminhada, pelo órgão ou tribunal interessado, diretamente àquele que for responsável pelo seu atendimento, competindo-lhe, ainda, assegurar sua autenticidade e compreensão, no Estado requerido e no Estado requerente. Parágrafo único. São facultados o registro e o encaminhamento da solicitação ao órgão ou tribunal competente do Estado requerido por uma autoridade central. O Parágrafo Único do art. 33 também se aplica ao procedimento de carta rogatória (art. $\left.38, \S 1^{\circ}\right)$.
} 
de exequatur às rogatórias, no que a utilização do mecanismo de auxílio direto configuraria usurpação da competência do STJ para tanto, já tendo sido inclusive declarada a sua inconstitucionalidade. ${ }^{75}$ Entretanto, atualmente, ao que tudo indica, como Fênix, o instituto ressurgiu das cinzas e segue se fortalecendo no cenário nacional.

A fim de regulamentar o instituto, o Superior Tribunal de Justiça elucidou a questão na Resolução n. ${ }^{\circ}$, de 04 de maio de 2005. No parágrafo único do artigo $7^{\circ},{ }^{76}$ a Presidência da Corte Superior estabeleceu que os pedidos de cooperação judiciária "stricto sensu" "77 não serão cumpridos pelo Superior Tribunal de Justiça, devendo ser levados, quando impliquem a necessária intervenção do Poder Judiciário, ao conhecimento do primeiro grau de jurisdição. Para disciplinar a parte final dessa disposição foi editada a Portaria Conjunta n. 1, de 27 de outubro de 2005, que dispõe sobre a "Tramitação de pedidos de cooperação jurídica internacional em matéria penal entre o Ministério da Justiça, o Ministério Público Federal e a Advocacia Geral da União". ${ }^{78}$

Importa referir, ademais, que o auxílio direto constitui-se no modo mais recente de cooperação, o qual emergiu do incremento dos índices de migração, do aumento do comércio global, do avanço tecnológico dos meios de comunicação e de locomoção e, em especial, da disseminação dos crimes em nível internacional. ${ }^{79}$

Sobre o tema, cabe apresentar definição doutrinária de Ricardo Perlingeiro Mendes da Silva ${ }^{80}$ :

\footnotetext{
${ }^{75}$ Ver CR 10.711/STF, CR 10.920/STF, CR 11.154/STF, HC 85.588/STF, CR 706/STJ, CR 1.969/STJ. Pela análise dos julgados, é possível verificar que mesmo após o pronunciamento do Supremo Tribunal Federal no HC 85.588, que preconiza a necessidade de carta rogatória, o Superior Tribunal de Justiça manteve entendimento pela concessão do auxílio direto, referindo, inclusive, a jurisprudência anterior daquela Corte como no julgamento das Cartas Rogatórias mencionadas. Contudo, na CR 2484/STJ não foi deferida a realização de diligências por meio de auxílio direto, tendo como fundamento o HC 85.588.

${ }^{76} \mathrm{Art} .7^{\circ} \mathrm{As}$ cartas rogatórias podem ter por objeto atos decisórios ou não decisórios.

Parágrafo único. Os pedidos de cooperação jurídica internacional que tiverem por objeto atos que não ensejem juízo de delibação pelo Superior Tribunal de Justiça, ainda que denominados como carta rogatória, serão encaminhados ou devolvidos ao Ministério da Justiça para as providências necessárias ao cumprimento por auxílio direto.

${ }^{77}$ A modalidade auxílio direto também é conhecida pela terminologia "pedido de cooperação judiciária stricto sensu" ou "auxílio mútuo".

${ }^{78}$ No âmbito cível, o auxílio direto está previsto na Convenção de Nova Iorque sobre Prestação de Alimentos no Estrangeiro (Decreto n ${ }^{\circ}$ 56.826, de 02.09.1965) e na Convenção de Haia sobre Aspectos Civis do Sequestro Internacional de Crianças (Decreto ${ }^{\circ} 3.413$, de 14.04.2000). Nesta esfera, a capacidade postulatória é da Advocacia-Geral da União. Já no âmbito penal, a capacidade postulatória perante o Juízo Federal de 1a instância incumbe ao Ministério Público Federal.

79 “[.... A assistência direta começou nos países de Common Law e nestes ela não difere muito da carta rogatória. Este procedimento começou a ser utilizado no Brasil para resolver o impasse criado pela jurisprudência do STF sobre cartas rogatórias executórias. [...]" (LOULA, Maria Rosa Guimarães. Auxílio Direto - Novo Instrumento de Cooperação Jurídica Internacional Civil. Belo Horizonte: Forum, 2010, p. 66).

${ }^{80}$ SILVA, Ricardo Perlingeiro Mendes da. "Cooperação Jurídica Internacional e Auxílio Direto" in BARROSO, Luis Roberto e TIBURCIO, Carmen (orgs.). O Direito Internacional Contemporâneo. Estudos em homenagem ao Professor Jacob Dolinger. Rio de Janeiro: Ed. Renovar, 2006, p. 807.
} 
O auxílio direto, no direito brasileiro, é o procedimento destinado ao intercâmbio entre órgãos judiciais e administrativos de estados diversos, independentemente de carta rogatória ou homologação de sentença estrangeira, sempre que reclamar de autoridades nacionais atos com conteúdo jurisdicional.

Como se vê, o auxílio direto pode ser definido como a cooperação realizada entre autoridades centrais dos Estados-parte para dar cumprimento às convenções internacionais que preveem esse mecanismo de assistência mútua, ou ainda a acordos bilaterais que tratam especificamente do tema. ${ }^{81}$ Em relação aos últimos, cumpre mencionar que os tratados bilaterais em que o Brasil figura como parte serão analisados no capítulo seguinte.

Ainda no que concerne à definição do instituto, o Manual para Cooperação Internacional em Matéria Criminal Relacionada ao Terrorismo, elaborado pelo Escritório das Nações Unidas sobre Drogas e Crime (UNODC), ${ }^{82}$ conceitua o auxílio judiciário mútuo em matéria penal como o procedimento pelo qual os Estados procuram prestar assistência na aquisição de provas para uso em investigações e processos penais. Acerca do seu conteúdo, elucida que um pedido de auxílio judiciário mútuo é muitas vezes determinado por acordos multilaterais, regionais ou bilaterais ou pelo direito nacional.

Importante referir que a modalidade de cooperação correspondente ao auxílio direto não se particulariza somente pelo fato de que o seu processamento apresenta-se gerenciado pelas autoridades centrais. O que o singulariza, na verdade, é o fato de o Estado estrangeiro não se apresentar na condição de juiz, mas sim de administrador, porquanto não encaminha um pedido judicial de assistência, mas sim uma solicitação para que a autoridade de outro Estado tome as providências e as medidas requeridas no âmbito nacional. ${ }^{83}$

Os pedidos de auxílio direto são, em regra, alicerçados em tratados ou acordos bilaterais (os chamados Mutual Legal Assistance Treaties ou MLATs). Inexistindo ajuste expresso entre os dois Estados, a assistência poderá ser realizada baseando-se na garantia de

\footnotetext{
${ }^{81}$ ARAÚJO, Nádia de; SALLES, Carlos Alberto de; ALMEIDA, Ricardo Ramalho. Medidas de Cooperação interjurisdicional no MERCOSUL. Revista de Processo, São Paulo: RT, v. 30, n. 123, mai. 2005, p. 45.

${ }^{82}$ No original: "Mutual assistance in criminal matters is a process by which States seek and provide assistance in gathering evidence for use in criminal investigations and proceedings"; "The content of a request for mutual legal assistance is often determined by multilateral, regional or bilateral treaties or by national law". Disponível em: 〈http://www.unodc.org/documents/terrorism/Publications/Manual_Int_Coop_Criminal_Matters/English.pdf > . Acesso em 27 mai. 2013. pp. 83 e 121.

${ }^{83}$ DIPP, Gilson Langaro. Carta rogatória e cooperação internacional. In MANUAL DE COOPERAÇÃO JURÍDICA INTERNACIONAL E RECUPERAÇÃO DE ATIVOS. Cooperação em Matéria Penal. Brasília: Secretaria Nacional de Justiça, 2008, p. 32.
} 
reciprocidade do requerente. É possível cooperar nos mais diversos temas, como tributário, trabalhista e previdenciário. No entanto, os tratados mais frequentes no cenário internacional versam sobre matéria penal e civil stricto sensu. ${ }^{84}$

O auxílio direto de caráter penal é utilizado, em regra, quando um Estado, a fim de subsidiar procedimento em trâmite em seu próprio território, necessita de providência judicial a ser obtida em outra jurisdição. Crimes de lavagem de dinheiro e tráfico ilícito de entorpecentes, por exemplo, frequentemente, ao serem processados e julgados em um país, precisam de produção de provas testemunhais ou documentais em outros países. Assim, em virtude da natureza muitas vezes fluida da prova, a rapidez em sua obtenção é indispensável, o que faz com que o auxílio direto seja o instituto mais adequado para a veiculação desses pedidos.

O procedimento do auxílio direto é bem descrito no voto do Ministro Teori Albino Zavascki, prolatado na Reclamação n. 2.645-SP:

As diligências passíveis de solicitação mútua entre os Estados Partes, em regime de cooperação internacional (indicadas, v.g, no art. 18.3 da Convenção de Palermo, no art. 46.3 da Convenção de Mérida e no art. 2 do Protocolo de Assistência Jurídica Mútua em Assuntos Penais Mercosul, consistem, em grande número, de providências que, no âmbito do direito interno, não têm natureza necessariamente jurisdicional, ou seja, podem ser produzidas sem prévia autorização do Poder Judiciário. Todavia, nos casos em que o direito interno exige tal autorização, o Estado Parte requerido fica comprometido e autorizado a requerer essa medida junto aos órgãos jurisdicionais nacionais, atuação que representa uma importante modalidade de cooperação jurídica. Pode-se dizer que, nessas circunstâncias, o Estado requerido atua em regime semelhante ao da substituição processual: requer em nome próprio para atender solicitação de outro Estado. Nesse sentido, tem significativa importância, no âmbito do direito brasileiro, o papel do Ministério Público Federal e da Advocacia Geral da União, órgãos com capacidade postulatória para requerer, em nome do Estado brasileiro, perante o Judiciário, as medidas de cooperação internacional que, no âmbito interno, estão sujeitas a controle judicial (v.g.: quebra de sigilo). Foi justamente para disciplinar sua atuação que esses órgãos, juntamente com o Ministério da Justiça, editaram a Portaria Conjunta n. 1, de 27.10.2005 ("Dispõe sobre a tramitação de pedidos de cooperação jurídica internacional em matéria penal entre o Ministério da Justiça, o Ministério Público Federal e a Advocacia Geral da União").

A figura da autoridade central consiste em um órgão designado pelo Estado para efetuar o trâmite dos pedidos de auxílio direto, ${ }^{85}$ tanto na modalidade ativa quanto na passiva.

${ }^{84}$ MANUAL DE COOPERAÇÃO JURÍDICA INTERNACIONAL E RECUPERAÇÃO DE ATIVOS. Cooperação em Matéria Penal. Brasília: Secretaria Nacional de Justiça, 2008, p. 26.

${ }^{85}$ E eventualmente de carta rogatória também - vide nota 54. 
Desse modo, caberá à referida autoridade central encaminhar os casos às autoridades competentes para pleitear as medidas cabíveis perante o juízo de primeiro grau, quando não identificada a natureza administrativa do pedido, hipótese em que poderá a própria Autoridade Central atender prontamente à solicitação, cumprindo de imediato o pedido de cooperação do Estado requerente. É o que será visto adiante.

\subsection{O papel da autoridade central}

A autoridade central é um órgão técnico especializado, em regra não jurisdicional, que se encarrega da interlocução internacional no tocante à cooperação jurídica em matéria civil e penal.

Na hipótese de pedido de auxílio direto passivo, em que o Brasil é o Estado requerido, a função da autoridade central consiste em encaminhar a solicitação para a autoridade brasileira competente, seja ela judicial ou administrativa, para que tome as providências cabíveis.

Importa mencionar que há convenções que preveem várias formas de cooperação direta, como as investigações conjuntas. ${ }^{86} \mathrm{Em}$ geral, as cooperações policiais, aduaneiras e das unidades de investigação financeira são diretas e só passam pela autoridade central quando vão ser usadas como prova no processo penal. Nada impede que policiais, promotores e juízes mantenham contato direto. O importante é que a autoridade central seja sempre informada, pois os relatórios da Conferência das Partes das Convenções de Palermo e de Mérida se baseiam sempre nas informações fornecidas pelas autoridades centrais sobre as atividades desenvolvidas nos seus próprios países para a efetiva implementação dos artigos concernentes à cooperação internacional. A Conferência das Partes foi o mecanismo encontrado pela comunidade internacional para melhorar a capacidade dos Estados Partes e monitorar a implementação das convenções. ${ }^{87}$

Em regra, a autoridade central integra a estrutura do Poder Executivo, no Ministério da Justiça ou equivalente. Sua missão precípua, como ponto de contato, é facilitar e acelerar a tramitação dos pedidos de auxílio entre Estados, eliminando a intermediação dos Ministérios de Relações Exteriores. ${ }^{88}$

\footnotetext{
${ }^{86}$ Modalidade também prevista no art. 19, III, do Código Modelo de Cooperação Interjurisdicional para Iberoamérica.

${ }^{87}$ VALLE, Sandra. Prefácio da obra “Cooperação Jurídica Internacional em Matéria Penal”. BALTAZAR Jr. José Paulo e LIMA, Luciano Flores de Lima. Porto Alegre, Verbo Jurídico, 2010, p. 10-11.

88 ARAS, Vladimir. O papel da autoridade central nos acordos de cooperação penal internacional. In:
} 
Uma das principais características desse tipo de órgão centralizado é justamente a capacidade de interlocução direta com seus congêneres no exterior, independentemente da intermediação das respectivas chancelarias.

A tramitação de informações e provas por meio de autoridades centrais dispensa a legalização consular. Assim, basta que os documentos obtidos no exterior tenham sido repassados de uma autoridade central a outra para que sejam considerados formalmente válidos no Estado requerente. A chancela da autoridade central substitui o selo diplomático.

A respeito da autoridade central, conforme trazido no Código Modelo de Cooperação Interjurisdicional para Iberoamérica, é consenso que deva servir à cooperação internacional, na medida em que facilite a sua realização, ${ }^{89}$ configurando, inclusive, como já referido em capítulo anterior, princípio da cooperação jurídica internacional previsto no art. $2^{\circ}$, VII, do Código: "existência de uma autoridade central para a recepção e transmissão dos pedidos de cooperação, ressalvada a convalidação da recepção ou transmissão que não tenham sido perante essa autoridade".

O país poderá ter mais de uma autoridade central, para distintos tratados. Normalmente, para cada tratado haverá uma só autoridade central. Contudo, devido à existência de sistemas jurídicos específicos em regiões e territórios de certas nações, poderá haver autoridades centrais diferentes, num mesmo Estado, encarregadas da execução de um só tratado, havendo especialização de acordo com os sistemas jurídicos vigentes naquele país. Também se admite a existência de autoridades centrais diversas nos Estados, por exemplo: no Tratado bilateral com o Uruguai, onde a autoridade central designada é o Ministério da Educação e Cultura e, no Brasil, a autoridade central prevista é a ProcuradoriaGeral da República $;^{90}$ e com Honduras, onde consta como autoridade central designada no Brasil o Ministério da Justiça e, em Honduras, o Ministério Público. ${ }^{91}$ Reconhecendo a diversidade de organização política de dezenas de nações, as Convenções de Palermo e de Mérida toleram essa duplicidade ou multiplicidade de órgãos centrais. ${ }^{92}$

A importância do instituto, assim como sua base normativa são assim estabelecidas

BALTAZAR Jr. José Paulo e LIMA, Luciano Flores de Lima. Porto Alegre, Verbo Jurídico, 2010, p. 59-94.

${ }^{89}$ Exposição de Motivos do Código de Cooperação Interjurisdicional para Ibero-américa. Revista da SJRJ, Rio de Janeiro, n. 25, 2009, p. 445.

${ }^{90}$ Art. 3 do Acordo de Assistência Jurídica Mútua em Assuntos Penais entre a República Federativa do Brasil e a República Oriental do Uruguai. Disponível em:

<http://dai-mre.serpro.gov.br/atos-internacionais/bilaterais/1992/b_55 2011-10-14-15-30-23/>. Acesso em: 12 ago. 2014.

${ }^{91}$ Art. 21, itens 2 e 3 do Decreto n. 8.046/13.

92 Previsão contida no art. 18, item 13, da Convenção de Palermo e no art. 46, item 13, da Convenção de Mérida. 
no Manual para Cooperação Internacional em Matéria Criminal Relacionada ao Terrorismo elaborado pela UNODC $^{93}$ : a nomeação de uma autoridade central para efeitos do auxílio judiciário mútuo implica a criação de um organismo que irá centralizar todas as solicitações recebidas para esse propósito. Tal organismo assegurará a coordenação e acompanhamento dos pedidos recebidos e transmitidos. O papel essencial da autoridade central é reconhecido nos instrumentos de assistência jurídica mútua, ambos os tratados bilaterais e convenções multilaterais, bem como no âmbito das observações e recomendações formuladas pelas autoridades ou reuniões de peritos internacionais em matéria de auxílio judiciário mútuo.

A implementação da figura da autoridade central, em atenção às previsões contidas em tratados internacionais, propiciou considerável avanço na cooperação penal internacional, pois esta tem como função permitir um intercâmbio mais efetivo e célere entre os Estados, agregando conhecimento à matéria.

A primeira menção a autoridades centrais em tratados internacionais remonta à Convenção da Haia de 1965, relativa à Citação e à Notificação no Estrangeiro de Atos Judiciais e Extrajudiciais em Matéria Civil e Comercial, à qual se seguiu a Convenção da Haia de 1970 sobre Rogatórias e Recepção de Provas no Estrangeiro.

Na esfera criminal, foi a Convenção Contra o Tráfico Ilícito de Entorpecentes e Substâncias Psicotrópicas (Convenção de Viena) que estabeleceu o paradigma de autoridades centrais. Em seu art. $7^{\circ}, \S 8^{\circ}$, podem-se visualizar as funções das autoridades centrais.

No espaço jurídico da Organização dos Estados Americanos - OEA, foi o artigo $4^{\circ}$ da Convenção Interamericana sobre Rogatórias, assinada no Panamá em 1975, que introduziu o instituto da autoridade central, ao passo que no Mercosul isto se deu com o artigo $2^{\circ}$ do Protocolo de Cooperação e Assistência Jurisdicional em Matéria Civil, Comercial, Trabalhista e Administrativa, de 1992 - Protocolo de Las Leñas. ${ }^{94}$

Em suma, pode haver uma ou mais autoridades centrais em cada país, que lidarão com pedidos de auxílio direto baseados em tratados bilaterais (MLAT) e, em alguns casos,

\footnotetext{
93 No original: "The appointment of a central authority for purposes of mutual legal assistance entails the establishment of an organism that will centralize all the requests received for mutual legal assistance. Such an organism will ensure the coordination of and follow-up to the requests received and transmitted. The essential role of the central authority is recognized in the instruments on mutual legal assistance, both bilateral treaties and multilateral conventions, as well as in the framework of the observations and recommendations formulated by international authorities or expert meetings on matters of mutual legal assistance. Disponível em: <http://www.unodc.org/documents/terrorism/Publications/Manual_Int_Coop_Criminal_Matters/English.pdf > . Acesso em 27 mai. 2013, p. 79.

94 ARAS, Vladimir. O papel da autoridade central nos acordos de cooperação penal internacional. In: BALTAZAR Jr. José Paulo e LIMA, Luciano Flores de Lima. Porto Alegre, Verbo Jurídico, 2010, pp. 59-94.
} 
como já referido, com as rogatórias.

Compete-lhes receber os pedidos de assistência mútua e atendê-los se tiverem competência legal (execução direta dos pedidos), ou receber e remeter tais solicitações às autoridades competentes para seu atendimento (execução indireta).

As autoridades centrais devem comunicar-se diretamente umas com as outras, no interesse da cooperação internacional. Está também em suas atribuições manter contato com os órgãos de persecução nacionais, para obter informações sobre o cumprimento das solicitações de assistência passiva. Não existe previamente, no Direito Internacional, a indicação de um padrão para determinação das autoridades centrais no Direito interno. Cada Estado tem a liberdade de escolher o órgão que, segundo seu Direito interno, tenha condição de atuar com mais eficiência na coordenação das atividades de cooperação. ${ }^{95}$

Atualmente, para a maior parte dos tratados de assistência jurídica em matéria penal firmados pelo Brasil, o papel de autoridade central é desempenhado pelo Departamento de Recuperação de Ativos e Cooperação Jurídica Internacional (DRCI), ${ }^{96}$ órgão da Secretaria Nacional de Justiça, do Ministério da Justiça, o qual possui quatro principais áreas de

95 “O sistema é construído em torno do eixo de uma 'autoridade central', criada em cada Estado contratante para centralizar no Estado requerido as diferentes solicitações de notificação ou traslado provenientes do estrangeiro. O convênio estabelece uma série de premissas acerca do estatuto jurídico desta estrutura: é da responsabilidade de cada Estado Contratante designar a autoridade central e notificar essa designação para o Ministério dos Assuntos Estrangeiros dos Países Baixos, quer no momento do depósito do seu instrumento de ratificação ou adesão, ou posteriormente. $\mathrm{O}$ acordo não prevê a obrigação dos Estados de criar um corpo ex novo, mas o papel da autoridade central pode cair em qualquer uma das autoridades existentes em seu direito interno, e sua organização é da responsabilidade do Estado que a designa. [...] Na Convenção de 1965 se possibilita aos Estados designar junto à autoridade central outras autoridades (subsidiárias ou adicionais), e já se leva em consideração o problema dos estados com organizações jurídicas complexas, estabelecendo como precedente a possibilidade de designação de várias autoridades centrais". Tradução livre de: "El sistema se construye en torno al eje de una 'autoridad central', creada en cada Estado contratante con el fin de centralizar en el Estado requerido las distintas solicitudes de notificación o traslado provenientes del extranjero. El convenio asienta una serie de premisas sobre el régimen jurídico de esta estructura: es competencia de cada Estado contratante designar su autoridad central, y notificar dicha designación al Ministerio de Asuntos Exteriores de los Países Bajos, bien en el momento del depósito de su instrumento de ratificación o adhesión, bien posteriormente. El convenio no impone la obligación a los Estados de crear un organismo ex novo, sino que el papel de la autoridad central puede recaer en cualquiera de las autoridades ya existentes en su derecho interno, y su organización es competencia del Estado que la designa. [...] En el convenio de 1965 se posibilita a los Estados contratantes designar junto a la autoridad central otras autoridades (subsidiarias o adicionales), y ya se toma en consideración el problema de los Estados con organizaciones jurídicas complejas, asentado como precedente la posibilidad de designación de varias Autoridades Centrales”. (GARCÍA CANO, Sandra. Evolución de las Técnicas de Cooperación Internacional entre Autoridades en el Derecho Internacional Privado. Boletín Mexicano de Derecho Comparado, n. 112, p. 3, disponível em: <https://vpn.upf.edu+CSCO+00756767633A2F2F6A6A6A2E776865767176706E662E68616E7A2E7A6B+ + /publica/rev/boletin/cont/112/art/art2.htm>. Acesso em: 01 abr. 2014.

${ }^{96}$ Criado pelo Decreto n. 4.991, de 18 de fevereiro de 2004. Atualmente, suas atividades estão descritas no Decreto n. 6.061, de 15 de março de 2007.

Vide: http://portal.mj.gov.br/cooperacao/data/Pages/MJDFBD6D24PTBRNN.htm 
atuação ${ }^{97}:$ 1) Autoridade central brasileira para cooperação jurídica internacional em matérias penal e civil e recuperação de ativos; 2) Articulação institucional voltada para o combate à lavagem de dinheiro e à corrupção; 3) Implementação e Gerenciamento dos Laboratórios de Tecnologia em Combate à Lavagem de Dinheiro (LAB-LD); e 4) Representação do país nos foros nacionais e internacionais relacionados à cooperação jurídica internacional e combate à lavagem de dinheiro.

No que se refere à cooperação ativa, incumbe aos analistas da coordenação verificar as solicitações a serem enviadas ao exterior e sugerir às autoridades brasileiras eventuais modificações para melhor adequação do pedido aos requisitos do Estado requerido. Essa análise prévia é realizada com base nas peculiaridades do país destinatário, bem como no tratado ou acordo que fundamenta o pedido, e tende a acelerar e melhorar a qualidade dos resultados da cooperação.

Já na cooperação passiva, a Coordenação-Geral de Recuperação de Ativos (CGRA) recebe os pedidos estrangeiros; na sequência, realiza análise prévia da sua adequação à legislação brasileira e o encaminha ao órgão nacional competente para sua execução. $\mathrm{O}$ cumprimento do pedido no país é igualmente acompanhado pelos técnicos da área, que constantemente mantêm atualizadas as autoridades solicitantes. ${ }^{98}$

Em 2010, conforme dados apresentados por Bezerra e Saad, tramitaram pela CGRA mais de 8.000 (oito mil) solicitações ativas e passivas, visando medidas que variavam desde a comunicação de atos processuais e oitiva de testemunhas até o compartilhamento de provas, quebra de sigilo bancário, bloqueio, perdimento e repatriação de ativos de origem ilícita. $^{99}$

Em apenas três casos, no tratado bilateral em matéria penal entre Brasil e Portugal (Decreto n. 1.320/1994), no MLAT entre Brasil e Canadá (Decreto n. 6.747/2009) e no Acordo de Assistência Jurídica Mútua em Assuntos Penais entre a República Federativa do

\footnotetext{
${ }^{97}$ BEZERRA, Camila Colares. SAADI, Ricardo Andrade. Papel da Autoridade Central Brasileira para Cooperação Jurídica: DRCI. In: Revista Criminal - Ensaios sobre a atividade policial. Ano 04. Vol. 10. Jan./Abr. 2010, p. 160-1.

${ }^{98}$ BEZERRA, Camila Colares. SAADI, Ricardo Andrade. Papel da Autoridade Central Brasileira para Cooperação Jurídica: DRCI. In: Revista Criminal - Ensaios sobre a atividade policial. Ano 04. Vol. 10. Jan./Abr. 2010, p. 162-3.

Importante observar que o Brasil ainda não possui uma lei de cooperação jurídica que regule seus procedimentos internamente. Há, na verdade, alguns dispositivos esparsos que embasam de forma limitada os trâmites que devem ser seguidos na execução de um pedido estrangeiro. Não há, portanto, uma normativa clara quanto ao tratamento que deve ser dado aos pedidos de cooperação jurídica estrangeiros que buscam cumprimento de medidas no Brasil.

${ }^{99}$ BEZERRA, Camila Colares. SAADI, Ricardo Andrade. Papel da Autoridade Central Brasileira para Cooperação Jurídica: DRCI. In: Revista Criminal - Ensaios sobre a atividade policial. Ano 04. Vol. 10. Jan./Abr. 2010, p. 163.
} 
Brasil e a República Oriental do Uruguai ${ }^{100}$ a autoridade central é o Ministério Público Federal, por intermédio da Assessoria de Cooperação Jurídica Internacional (ASCJI), órgão da Procuradoria-Geral da República. ${ }^{101}$

Bezerra e Saad ${ }^{102}$ criticam a vinculação de autoridades centrais dentro dos órgãos aos quais elas devem prestar serviço, pois, para os autores, isso certamente estimularia a tendência de que as demandas originárias desses mesmos órgãos fossem atendidas de maneira privilegiada. Com o tempo, essa e outras disfunções ensejariam um contexto de monopólio, em que apenas uma ou poucas entidades investigativas e persecutórias teriam acesso aos instrumentos da cooperação jurídica internacional.

Explanam os autores, ainda, que vincular a autoridade central a um órgão investigativo ou persecutório transformaria a cooperação em um instrumento exclusivo da acusação, sendo bem sabido que, atualmente, o acesso da defesa à cooperação jurídica internacional ainda é bastante limitado. De toda forma, já se discutiria amplamente em foros nacionais e internacionais maneiras de mitigar referida limitação, conferindo alcance igualitário aos instrumentos da cooperação à defesa. Nesse viés, esclarecem que eventual vinculação da autoridade central a uma entidade ligada à acusação soaria contraditório não somente à referida tendência, mas também aos preceitos constitucionais que preconizam o amplo direito à defesa e à igualdade das partes na relação processual. ${ }^{103}$

Sob esta perspectiva, em capítulo próprio, será efetuado estudo acerca do contexto principiológico da defesa no processo penal, com análise de instrumentos nacionais e internacionais que determinam a possibilidade de produção de prova em prol da parte ré, por meio do auxílio direto, no cenário da cooperação jurídica internacional.

Tal estudo se faz necessário e é nesse sentido que se justifica a relevância do presente trabalho, pois em alguns países é vedada a utilização do auxílio direto para produção de prova em matéria de defesa no processo penal ${ }^{104} \mathrm{e}$, não bastasse isso, verifica-se que em muitos ordenamentos a ausência de acompanhamento da produção da prova por defesa técnica pode ensejar, inclusive, arguições de nulidade da prova produzida e sua inutilização

\footnotetext{
100 Observado que no acordo bilateral entre Brasil e Uruguai as autoridades centrais são distintas nos dois países.

${ }^{101}$ Vide http://ccji.pgr.mpf.gov.br.

102 BEZERRA, Camila Colares. SAADI, Ricardo Andrade. Papel da Autoridade Central Brasileira para Cooperação Jurídica: DRCI. In: Revista Criminal - Ensaios sobre a atividade policial. Ano 04. Vol. 10. Jan./Abr. 2010, p. 161.

103 BEZERRA, Camila Colares. SAADI, Ricardo Andrade. Papel da Autoridade Central Brasileira para Cooperação Jurídica: DRCI. In: Revista Criminal - Ensaios sobre a atividade policial. Ano 04. Vol. 10. Jan./Abr. 2010, p. 162.

${ }^{104}$ Países capitaneados pelos Estados Unidos, como será visto no capítulo subsequente.
} 
pelo Estado requerente.

A seguir, iniciar-se-á a análise propriamente dita dos instrumentos multilaterais e bilaterais ratificados pelo Brasil que dispõem sobre a cooperação jurídica internacional por meio do auxílio direto, com olhos à análise da possibilidade de sua utilização para a produção de prova pela defesa, ou melhor, intentando verificar a existência ou não de vedação nesse sentido, além de apurar o estado da arte dessa questão.

\subsection{Hipóteses de denegação da utilização do auxílio direto pela defesa na cooperação jurídica internacional em matéria penal: análise das convenções e dos tratados bilaterais de auxílio jurídico mútuo ratificados pelo Brasil}

Nesta seção, pretende-se efetuar análise acerca das hipóteses de denegação de cooperação jurídica internacional constantes nas Convenções ratificadas pelo Brasil, bem como nos tratados bilaterais firmados com os seguintes países: Canadá, China, Colômbia, Coreia do Sul, Cuba, Espanha, EUA, França, Honduras, Itália, México, Nigéria, Panamá, Peru, Portugal, Reino Unido, Suíça, Suriname e Ucrânia.

Nesse sentido, serão analisados o alcance e o objeto dos tratados, com a transcrição parcial dos artigos pertinentes nos Anexos I e II do trabalho - foram grifados os trechos interessantes ao estudo, onde se deve efetuar leitura crítica mais atenta —, com a finalidade de se verificar eventual previsão expressa de denegação de cooperação penal para a defesa.

Principia-se com a análise das Convenções e, após, passa-se ao estudo dos acordos bilaterais ou na sigla em inglês MLATs (Mutual Legal Assistance Treaties).

Sendo assim, a Convenção das Nações Unidas Contra o Crime Organizado Transnacional, conhecida como Convenção de Palermo, a qual foi promulgada pelo Decreto n. 5.015/2004, de 12 de março de 2004, que explicita, em seu artigo 18, a extensão do que denomina de "assistência judiciária recíproca", e que para os propósitos do presente trabalho, apesar da nomenclatura diversa, nada mais é que o auxílio-direto, delinea que será prestada toda a cooperação judiciária possível, tanto quanto o permitam as leis, tratados, acordos e protocolos pertinentes do Estado-Parte requerido, no âmbito de investigações, processos e outros atos judiciais relativos a infrações pelas quais possa ser considerada responsável uma pessoa no Estado-Parte requerente.

Ademais, a cooperação judiciária prestada pode ser solicitada para recolher testemunhos ou depoimentos; notificar atos judiciais; efetuar buscas, apreensões e embargos; examinar objetos e locais; fornecer informações, elementos de prova e pareceres de peritos; 
fornecer originais ou cópias certificadas de documentos e processos pertinentes, incluindo documentos administrativos, bancários, financeiros ou comerciais e documentos de empresas; identificar ou localizar os produtos do crime, bens, instrumentos ou outros elementos para fins probatórios; facilitar o comparecimento voluntário de pessoas no EstadoParte requerente; prestar qualquer outro tipo de assistência compatível com o direito interno do Estado-Parte requerido.

Além disso, a Convenção é expressa, em seu artigo 23, que qualquer recusa de cooperação deverá ser fundamentada e, dentre as hipóteses em que poderá ser recusada, destacam-se os casos em que o Estado-Parte requerido venha a considerar que a execução do pedido pode afetar sua soberania, sua segurança, sua ordem pública ou outros interesses essenciais ou o caso em que a aceitação do pedido possa contrariar o sistema jurídico do Estado-Parte requerido no que se refere à cooperação judiciária. ${ }^{105}$

Em um panorama geral, ${ }^{106}$ não se verifica qualquer restrição explícita à possibilidade de a defesa se utilizar da presente Convenção para a produção de prova nos seus moldes, tampouco foram previstas restrições nos seus protocolos adicionais, quais sejam: a) Protocolo Adicional à Convenção das Nações Unidas Contra o Crime Organizado Transnacional relativo ao Combate ao Tráfico de Migrantes por Via Terrestre, Marítima e Aérea, que foi promulgado pelo Decreto n. 5.016, de 12 de março de 2004, e tem como objetivo prevenir e combater o tráfico de migrantes, bem como promover a cooperação entre os Estados-Partes com esse fim, protegendo ao mesmo tempo os direitos dos migrantes objeto desse tráfico (artigo $2^{\circ}$ do Protocolo); b) Protocolo Adicional à Convenção das Nações Unidas Contra o Crime Organizado Transnacional relativo à Prevenção, Repressão e Punição do Tráfico de Pessoas, em Especial Mulheres e Crianças, o qual foi promulgado pelo Decreto n. 5.017, de 12 de março de 2004, que objetiva prevenir e combater o tráfico de pessoas, prestando atenção especial às mulheres e crianças; proteger e ajudar as vítimas desse tráfico, respeitando plenamente os seus direitos humanos, com a promoção da cooperação entre os Estados-Partes de forma a atingir esses objetivos (artigo $2^{\circ}$ do Protocolo); c) Protocolo Adicional à Convenção das Nações Unidas Contra o Crime Organizado Transnacional Contra a Fabricação e o Tráfico Ilícito de Armas de Fogo, suas Peças, Componentes e Munições, promulgado pelo Decreto n. 5.941, de 26 de outubro de 2006, com a finalidade de promover, facilitar e fortalecer a cooperação entre os Estados-Partes a fim de prevenir, combater e erradicar a fabricação e o tráfico ilícitos de armas de fogo, suas peças,

\footnotetext{
105 Previsão existente em termos semelhantes em todas as Convenções analisadas.

${ }^{106}$ Para uma melhor averiguação e compreensão do tema, remete-se o leitor à análise do Anexo I.
} 
componentes e munições (artigo $2^{\circ}$ do Protocolo).

Não bastasse isso, verifica-se, inclusive, o direito à demonstração da inocência, como se pode observar no artigo 18, item 5:

[...] As autoridades competentes que recebam estas informações deverão satisfazer qualquer pedido no sentido de manter confidenciais as referidas informações, mesmo se apenas temporariamente, ou de restringir a sua utilização. Todavia, tal não impedirá o Estado Parte que receba as informações de revelar, no decurso do processo judicial, informações que inocentem um arguido. [...]

Previsão semelhante consta também no artigo 46.5 da Convenção da ONU Contra a Corrupção, a qual será abordada a seguir.

Convenção das Nações Unidas Contra a Corrupção, conhecida como Convenção de Mérida, foi promulgada pelo Decreto n. 5.687, de 31 de janeiro de 2006, e prevê, em seu artigo 46, questões atinentes à assistência judicial recíproca, ${ }^{107}$ bem como aduz as hipóteses de denegação de cooperação, estipulando que os Estados-Partes prestar-se-ão a mais ampla assistência judicial recíproca, no maior grau possível, relativa a investigações, processos e ações judiciais relacionados com os delitos compreendidos na Convenção, que consistam em: a) receber testemunhos ou tomar declaração de pessoas; b) apresentar documentos judiciais; c) efetuar inspeções, incautações e/ou embargos preventivos; d) examinar objetos e lugares; e) proporcionar informação, elementos de prova e avaliações de peritos; f) entregar originais ou cópias certificadas dos documentos e expedientes pertinentes, incluída a documentação pública, bancária e financeira, assim como a documentação social ou comercial de sociedades mercantis; g) identificar ou localizar o produto de delito, os bens, os instrumentos e outros elementos para fins probatórios; h) facilitar o comparecimento voluntário de pessoas ao Estado-Parte requerente; i) prestar qualquer outro tipo de assistência autorizada pela legislação interna do Estado-Parte requerido; j) identificar, embargar com caráter preventivo e localizar o produto de delito, em conformidade com as disposições do Capítulo V da presente Convenção; 1) recuperar ativos em conformidade com as disposições do Capítulo V da presente Convenção.

Além disso, como anteriormente referido, há previsão expressa ao direito de demonstração da inocência no artigo 46, item $5,{ }^{108}$ assim como ocorre na Convenção das

\footnotetext{
107 Aqui, do mesmo modo como referido na Convenção das Nações Unidas Contra o Crime Organizado Transnacional, entende-se a expressão como "auxílio-direto".

108 “[...] As autoridades competentes que recebem a informação deverão aquiescer a toda solicitação de que se respeite seu caráter confidencial, inclusive temporariamente, ou de que se imponham restrições a sua utilização.
} 
Nações Unidas Contra o Crime Organizado Transnacional. E mais, a revelação de dados aptos a ensejar a prolação de um Juízo absolutório impõe-se mesmo diante do princípio da especificidade.

Isto significa que, excepcionalmente, quando provas, documentos e determinadas medidas forem necessárias para prolação de juízo absolutório, eles poderão ser usados em relação a fatos e/ou procedimentos distintos daqueles que fundamentaram o pleito ao Estado requerido.

É o que se depreende do artigo 46, item 19, da presente Convenção:

O Estado Parte requerente não transmitirá nem utilizará, sem prévio consentimento do Estado Parte requerido, a informação ou as provas proporcionadas por este para investigações, processos ou ações judiciais distintas daquelas indicadas na solicitação. Nada do disposto no presente parágrafo impedirá que o Estado Parte requerente revele, em suas ações, informação ou provas que sejam fatores de absolvição de uma pessoa acusada. Neste último caso, o Estado Parte requerente notificará o Estado Parte requerido antes de revelar a informação ou as provas e, se assim solicitado, consultará o Estado Parte requerido. Se, em um caso excepcional, não for possível notificar este com antecipação, o Estado Parte requerente informará sem demora o Estado Parte requerido da mencionada revelação.

Nesse contexto, observa-se que a cooperação jurídica internacional, se devidamente instrumentalizada, é um fator decisivo de aprimoramento da justiça e do devido processo legal, no que se inclui o princípio da paridade de armas entre acusação e defesa, pois o modelo do devido processo exige procedimentos contraditórios de averiguação, tribunais imparciais, com a possibilidade real de o acusado desacreditar as provas produzidas contra ele.

Este modelo, ao contrário do modelo de controle do crime, ${ }^{109}$ defende a noção de igualdade a todos, segundo o qual ambas as partes devem ser colocadas na mesma posição com relação aos recursos à disposição para a coleta de provas no processo penal. ${ }^{110}$

\footnotetext{
Sem embargo, ele não obstará para que o Estado Parte receptor revele, em suas ações, informação que seja fator de absolvição de uma pessoa acusada [...]".

${ }^{109} \mathrm{O}$ referencial teórico mais conhecido para o processo criminal no sistema do common law foi desenvolvido por Herbert Packer na década de 1960. Na revisão de Packer, as tendências na justiça criminal poderão ser avaliadas no quadro normativo de dois modelos: o modelo de controle do crime e o modelo do devido processo. "Esse sistema de valores destaca que o modelo de Controle do Crime é baseado na proposição de que a repressão da conduta criminosa é de longe a mais importante função a ser realizada pelo processo penal”. (PACKER, Herbert. The Limits of the Criminal Sanction. California, USA: Stanford University Press, 1968, p. 158-9).

110 "O modelo do devido processo exige que o modelo adversarial constate os fatos em audiência pública do caso realizada por um tribunal imparcial e sua avaliação só depois de o arguido ter tido a possibilidade de desacreditar as provas produzidas contra si. Este modelo defende a idéia de igualdade, de acordo com a qual
} 
A próxima convenção a ser analisada é a Convenção Contra o Tráfico Ilícito de Entorpecentes e Substâncias Psicotrópicas, chamada de Convenção de Viena.

Esta Convenção foi promulgada pelo Decreto n. 154, de 26 de junho de 1991, e prevê no artigo $7^{\circ}$ os assuntos pertinentes à assistência jurídica recíproca, no qual se destaca que as partes poderão prestar qualquer outra forma de assistência judicial recíproca autorizada pelo Direito interno da parte requerida. ${ }^{111} \mathrm{E}$, nos mesmos termos das Convenções analisadas anteriormente, prevê que a assistência solicitada poderá ser denegada, primordialmente, quando a parte requerida considerar que o cumprimento da solicitação possa prejudicar sua soberania, sua segurança, sua ordem pública ou outros interesses fundamentais; quando o Direito interno da parte requerida proibir suas autoridades de atender à solicitação formulada com respeito a delito análogo, se este tiver sido objeto de investigação, processo ou procedimento no exercício da própria competência e no caso de a solicitação contrariar a ordem jurídica da parte requerida.

De igual modo, aqui também não se visualiza qualquer restrição à possibilidade de a defesa se utilizar da presente Convenção para a produção de prova.

A Convenção Interamericana sobre Assistência Mútua em Matéria Penal, Convenção de Nassau, a seu turno, foi promulgada pelo Decreto n. 6.340, de 03 de janeiro de 2008, com previsão das recusas de assistência, no artigo $9^{\circ}$, quando o pedido de assistência for usado com o objetivo de julgar uma pessoa por um delito pelo qual essa pessoa já tiver sido previamente condenada ou absolvida num processo no Estado requerente ou requerido; a investigação for iniciada com o objetivo de processar, punir ou discriminar de alguma maneira uma pessoa ou grupo de pessoas, por motivo de sexo, raça, condição social, nacionalidade, religião ou ideologia; o pedido se referir a delito político ou relacionado com delito político, ou a delito comum que estiver sendo processado por motivos políticos; se tratar de pedido de assistência emanado de um tribunal de exceção ou de um tribunal ad hoc; for afetada a ordem pública, soberania, segurança ou interesses públicos fundamentais; e o pedido se referir a um delito fiscal.

todos devem ser colocados na mesma posição em relação aos recursos à sua disposição para a realização da defesa no processo criminal". Tradução livre de: "The due process model requires the adversarial fact findings processes, a public hearing of the case by an impartial tribunal and its evaluation only after the accused has had the possibility to discredit the evidence against him. This model upholds the idea of equality according wich everyone should be placed in the same position with regards to the resources at their disposal for conducting defence in the criminal process". (WASEK-WIADEREK, Malgorzata. The principle of "equality of arms" in criminal procedure under Article 6 of the European Convention on Human Rights and its functions in criminal justice of selected European countries - A comparative view. Belgium: Leuven University Press, 2000, p. 11).

${ }^{111}$ Art. $7^{\circ}$, item 3 . 
De igual modo, sob a égide da presente Convenção, também não se verifica qualquer restrição à possibilidade de a defesa utilizá-la para a produção de prova nos seus termos, verificado que as recusas dizem respeito a questões procedimentais que, em regra, nada tem a ver com a qualidade do sujeito solicitante. ${ }^{112}$

Todas as convenções supramencionadas são denominadas por Bruce Zagaris de "mini-MLATs", 113 ou seja, Convenções Criminais Internacionais que, ao conter dispositivos específicos que determinam a necessidade de assistência entre as nações, não vedam a sua utilização pela defesa ou, nos termos de outros instrumentos, a sua utilização "por particular", ao contrário dos MLATs propriamente ditos, que impedem o seu uso pela defesa ou por terceiros interessados, como será visto mais adiante.

Nesse passo, cabe registrar que o Protocolo de Assistência Jurídica Mútua em Assuntos Penais do Mercosul, ou Protocolo de San Luis, que foi promulgado pelo Decreto n. 3.468, de 17 de maio de 2000, apesar de não prever, em seu artigo 5º hipóteses de denegação de assistência que restringiriam a possibilidade de a defesa utilizá-lo para a produção de provas, dispõe, no artigo $1^{\circ}$, item 2 , que "não se conferem direitos aos particulares para obtenção, supressão ou exclusão de provas, ou para se oporem ao cumprimento de uma solicitação de assistência." Assim, tanto na cooperação ativa como passiva, não podem, os particulares, solicitar assistência.

Solange Mendes de Souza, ${ }^{114}$ ao tratar da situação jurídica dos particulares, entende que "aos particulares não é conferida legitimidade ativa, não podendo solicitar assistência, nada impedindo, contudo, que requeiram à autoridade competente a realização de determinada prova. Também não lhes é conferida legitimidade passiva, não lhes sendo possível intervir no pedido de assistência, opondo-se à pretensão deduzida."

Márcio Anselmo, ao discorrer sobre a anatomia do Pacto de San Luis, explicita que apenas as autoridades judiciais e os membros do Ministério Público podem ser partes nos

\footnotetext{
${ }^{112}$ Há Convenção mais antiga no âmbito interamericano - Convenção Interamericana sobre Prova e Informação Acerca do Direito Estrangeiro, promulgada pelo Decreto n. 1.925 de 10 de junho de 1996 - que tem por objeto Esta Convenção tem por objeto estabelecer normas sobre a cooperação internacional entre os Estados Partes para a obtenção de elementos de prova e informação a respeito do direito de cada um deles (art. $1^{\circ}$ ), cujo artigo $4^{\circ}$ estende a possibilidade de solicitar as medidas a outras autoridades: "As autoridades jurisdicionais dos Estados Partes nesta Convenção poderão solicitar as informações a que se refere a alínea c do artigo $3^{\circ}$. Os Estados Partes poderão estender a aplicação desta Convenção aos pedidos de informações de outras autoridades. Sem prejuízo do acima estipulado, poder-se-á atender as solicitações de outras autoridades que se refiram aos elementos de prova indicados nas alíneas a e b do artigo 3".

${ }^{113}$ ZAGARIS, Bruce. U.S. - Brazil and International Evidence Gathering: The Need for Better Procedural Due Process. Revista Brasileira de Ciências Criminais. RBCCrim. Ano 20, vol. 99, nov.-dez./2012, pp. 269-270. 114 SOUZA, Solange Mendes de. Cooperação Jurídica Penal no Mercosul: Novas Possibilidades. Rio de Janeiro: Renovar, 2001, p. 200.
} 
pedidos de cooperação:

O protocolo tem por objetivo a assistência jurídica mútua em assuntos penais, entre as autoridades competentes dos Estados Parte, abrangendo a investigação de delitos ou a cooperação penal em procedimentos relacionados com assuntos penais.

De acordo com o item 1 do Acordo, ele "tem por finalidade a assistência jurídica mútua em assuntos penais entre as autoridades competentes dos Estados partes". Como autoridades competentes, o Protocolo menciona as autoridades judiciais e o Ministério Público, cujo assunto será discutido posteriormente.

Os particulares, por sua vez, ficam excluídos do direito a obtenção, supressão, exclusão de provas ou, ainda, não podem se opor ao cumprimento de um pedido de assistência. Em homenagem ao princípio da ampla defesa, resta como alternativa, em caso de diligência requerida pela defesa, que a mesma seja reputada como necessária pela autoridade judicial ou, ainda, que a parte, caso possível, realize a diligência diretamente no exterior, como por exemplo, a obtenção de documento, que pode ser devidamente consularizado perante as autoridades consulares brasileiras com atribuição no local onde coletada a prova. ${ }^{115}$

A segunda sugestão proposta no trecho supracitado, por óbvio, encontra óbice nos altos custos envolvidos na contratação de advogado no exterior e nas despesas com viagens e demais custos que se fariam necessários, estando longe de ser uma solução democrática e acessível a todos os réus, como determina o princípio do acesso à Justiça. ${ }^{116}$

Além disso, em relação à possibilidade de iniciativa do Ministério Público em prol da defesa, Bruce Zagaris recorda alguns problemas advindos dessa sugestão. Por exemplo, o autor menciona que, nos Estados Unidos, o Escritório de Assuntos Internacionais - que trabalha em estreita colaboração com os procuradores e é composto por advogados com experiência na acusação - não se sentiria confortável ao trabalhar tão proximamente com os advogados de defesa. ${ }^{117}$

Situação idêntica é o que se pode verificar em outros tratados de assistência jurídica, a exemplo do MLAT entre Brasil e EUA, que contêm cláusula que limita o escopo do acordo bilateral. O artigo I, item 5, do referido MLAT prevê que o Acordo destina-se apenas à

115 ANSELMO, Márcio Adriano. Cooperação Internacional em Matéria Penal no Âmbito do Mercosul Anatomia do Protocolo de San Luis. In: BALTAZAR Jr. José Paulo e LIMA, Luciano Flores de Lima. Cooperação Jurídica Internacional em Matéria Penal. Porto Alegre, Verbo Jurídico, 2010, pp. 228-9.

${ }^{116}$ VASCONCELLOS, Helena. Cooperação Jurídica Internacional em Matéria Penal: Uma Análise do Mutual Legal Assistance Treaty Brasil/Estados Unidos. Dissertação apresentada ao Programa de Pós-Gradução em Direito da Faculdade de Direito da Universidade Federal do Rio Grande do Sul como requisito parcial para obtenção do grau de mestre em Direito. Orientador Prof. Dr. Tupinambá Pinto de Azevedo. Porto Alegre, 2013, p. 181 .

${ }^{117}$ ZAGARIS, Bruce. U.S. - Brazil and International Evidence Gathering: The Need for Better Procedural Due Process. Revista Brasileira de Ciências Criminais. RBCCrim. Ano 20, vol. 99, nov.-dez./2012, p. 258. 
assistência judiciária mútua entre as Partes. Seus dispositivos não dão direito a qualquer indivíduo de obter, suprimir ou excluir qualquer prova ou impedir que uma solicitação seja atendida.

A discussão acerca da vedação à defesa da possibilidade de lançar mão do instituto para a obtenção de provas exclusivas em seu favor no estrangeiro fez com, em estudo atinente ao tratado bilateral Brasil-EUA, Helena Vasconcellos se manifestasse no seguinte sentido:

a par do viés filosófico que essa discussão poderia adquirir — o inevitável questionamento quanto aos limites da soberania, quando contrastada com o princípio da cooperação que deve nortear as relações internacionais -, são inúmeras as questões decorrentes deste único dispositivo, violador, a um só tempo, de preceitos constitucionais basilares, bem como de inúmeros tratados internacionais. ${ }^{118}$

Raúl Cervini e Juarez Tavares criticam essas disposições referindo que constituem "resquício de concepções obsoletas que sacrificam as garantias em prol de pretendida eficácia na assistência”, com ênfase no fato de que

normas desse caráter cerceiam radicalmente o direito de ampla defesa consagrado no plano interno, a partir da própria Constituição, de cada um dos Estados membros do Mercosul e em Tratados internacionais de Direitos Humanos ratificados pelos mesmos Estados-parte, que, por sua especificidade, prevaleceriam sobre estas normas convencionais restritivas de garantias. ${ }^{119}$

Assim, em relação ao alcance dos demais acordos bilaterais ratificados pelo Brasil, que passarão a ser estudados a partir deste momento, bem como em relação à previsão das hipóteses de denegação ou limites à cooperação, apresenta-se no Anexo II pormenorizado quadro em que se podem visualizar as datas de ratificação de cada tratado, bem como comparar suas disposições, com a consequente constatação de que os documentos seguem paradigma semelhante quanto à terminologia e estrutura.

Esclarece-se que tal similitude se deve ao fato de que os tratados foram elaborados

\footnotetext{
118 VASCONCELLOS, Helena. Cooperação Jurídica Internacional em Matéria Penal: Uma Análise do Mutual Legal Assistance Treaty Brasil/Estados Unidos. Dissertação apresentada ao Programa de Pós-Gradução em Direito da Faculdade de Direito da Universidade Federal do Rio Grande do Sul como requisito parcial para obtenção do grau de mestre em Direito. Orientador Prof. Dr. Tupinambá Pinto de Azevedo. Porto Alegre, 2013, p. 13.

${ }^{119}$ CERVINI, Raúl e TAVARES, Juarez. Princípios de cooperação judicial penal internacional no protocolo do Mercosul. São Paulo: Editora Revista dos Tribunais, 2000, pp. 77-8.
} 
segundo o Tratado Modelo sobre Assistência Mútua em Matéria Penal ("Model Treaty on Mutual Assistance in Criminal Matters"), adotado pela Assembleia Geral da ONU como Resolução n. 45/117, segundo a recomendação do VIII Congresso sobre a Prevenção do Crime e o Tratamento dos Delinquentes, realizado em dezembro de 1990, o qual configura uma espécie de guia para negociações de tratados bilaterais e multilaterais na matéria.

Sobreleva anotar que aguardam assinatura, promulgação, ou se encontram em negociação, acordos com vários outros países, tais como Alemanha, Mônaco, Bahamas, África do Sul, Rússia, Japão, Ilhas Cayman, Luxemburgo e Liechtenstein. ${ }^{120}$

O quadro comparativo foi apresentado em ordem cronológica, tendo em vista as datas de ratificação. Entretanto, isso não autoriza concluir, de antemão, que houve evolução no tratamento do tema, tendo em vista, como já dito, que há um padrão na confecção dos tratados, ${ }^{121}$ os quais não se alteram substancialmente, exceto quanto à possibilidade de utilização da via do auxílio direto em procedimentos preliminares à judicialização, como se verifica os acordos com Portugal, EUA, Peru, Coreia do Sul, Ucrânia, China, Cuba, Espanha, Canadá, Suriname, Suíça, Nigéria, México e Panamá, enquanto outros são expressos em prescrever a possibilidade apenas quando o procedimento já estiver a cargo de uma autoridade judicial, nos tratados com Itália, França e Colômbia. No restante, mantêm, praticamente, a mesma estrutura e previsões uniformes.

Por oportuno, neste momento, cumpre tecer alguns comentários quanto à terminologia utilizada nos tratados em análise.

Em determinados tratados, verifica-se o termo "cooperação", já em outros - como é o caso dos tratados bilaterais com os EUA, Suriname, Colômbia, Canadá, Nigéria, Peru, China, Coreia do Sul, Ucrânia Honduras e Reino Unido - , observa-se o termo "assistência"; e, em outros - tratados bilaterais com Panamá, Portugal e Espanha - utiliza-se o termo

\footnotetext{
${ }^{120}$ Conforme dados atualizados em agosto de 2014, encontram-se em vigor acordos bilaterais em matéria penal com Canadá, China, Colômbia, Coréia do Sul, Cuba, Espanha, Estados Unidos da América, França, Honduras, Itália, México, Nigéria, Panamá, Peru, Portugal, Reino Unido, Suíça, Suriname e Ucrânia. Aguardam promulgação acordos firmados com Angola e Líbano. Também foram assinados acordos com Bélgica, El Salvador e Jordânia. Foram negociados, ainda, acordos com Alemanha, Argélia, Bahamas, Hong Kong, Marrocos, Nicarágua, Romênia, Síria e Turquia. E, finalmente, se encontram em processo de negociação acordos com África do Sul, Albânia, Camarões, Costa Rica, Egito, Emirados Árabes Unidos, Equador, Grécia, Ilhas Cayman, Ilhas Virgens Britânicas, Índia, Irã, Israel, Japão, Liechtenstein, Lituânia, Luxemburgo, Mônaco, Noruega, Polônia e Rússia. Disponível em:

〈http://www.gafisud.info/pdf/BRASIL_5.pdf>. Acesso em: 13 ago. 2014 e

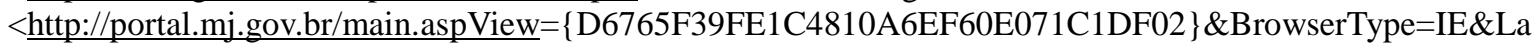
ngID=pt-br\&params=itemID\%3D\%7B2D47B89B-61AF-4149-8B54-

471D880805DD\%7D\%3B\&UIPartUID=\%7B2868BA3C-1C72-4347-BE11A26F70F4CB26\%7D>. Acesso em 14 ago. 2014.

${ }^{121}$ Pelo fato de utilizarem a normativa do Tratado Modelo das Nações Unidas sobre Cooperação Jurídica Internacional em Matéria Penal, como mencionado.
} 
"auxílio". Ainda que seja facilmente inteligível que os termos são utilizados e compreendidos como sinônimos, sem maiores implicações jurídicas, em atenção ao caráter técnico-científico do presente trabalho, importa trazer a lição de Adriana Beltrame, ${ }^{122}$ que entende ser o termo "cooperação" o mais tecnicamente apropriado:

Entre os termos "assistência" e "cooperação" verifica-se ser este último o
mais apropriado. De acordo com o Novo Dicionário Aurélio da Língua
Portuguesa, assistência significa "4. Proteção, amparo, arrimo; 5 . Auxílio,
ajuda", ao passo que cooperação significa "ato ou efeito de cooperar".
Cooperar significa "1. Operar, ou obrar, simultaneamente; colaborar; 2 .
Prestar colaboração, serviços, trabalhar em comum; colaborar". 22 Assim,
é possível compreender que o termo "assistência" tem uma conotação de
ajuda, de auxílio financeiro, como foi utilizado no âmbito das relaçães
internacionais no período do pós-guerra para socorrer aqueles Estados
sensibilizados pela guerra. O termo "cooperação", por outro lado, traz a
conotação de colaboração, de trabalho em comum, mais apropriado para o
presente contexto.

De igual modo, o Código Modelo de Cooperação Interjurisdicional para Iberoamérica, de acordo com os argumentos expressos na exposição de motivos, reputou o termo "cooperação" como o mais adequado à tutela judicial transnacional, pois os litígios transnacionais são aqueles que possuem elementos conectados em mais de um Estado. Nesses casos, a efetividade da jurisdição depende, sempre, da atuação conjunta de Estados soberanos. $^{123}$

Nessa linha, outra importante distinção diz respeito aos termos "judicial", “jurisdicional” e "jurídico". "Judicial” é o ato praticado por um juiz (estatal) dentro das atribuições que lhe são conferidas no exercício do seu cargo. "Jurisdicional" é um termo mais amplo que engloba tanto o ato praticado por juiz como o ato praticado por árbitro. Já o termo "jurídico" abrange essas duas situações bem como todo e qualquer ato praticado por autoridades administrativas (polícia, por exemplo). ${ }^{124}$

O Código Modelo de Cooperação Interjurisdicional para Iberoamérica, a seu turno, como o próprio nome indica, reputou a expressão "cooperação interjurisdicional" como a mais adequada, pois, de acordo com a sua exposição de motivos, não se trataria propriamente de uma “cooperação internacional”, já que esta expressão seria mais apropriada às relações

${ }^{122}$ BELTRAME, Adriana. Cooperação Jurídica Internacional. In: Revista de Processo, vol. 162, Ago. 2008, p. 5 .

${ }^{123}$ Exposição de Motivos do Código de Cooperação Interjurisdicional para Ibero-américa. Revista da SJRJ, Rio de Janeiro, n. 25, 2009, p. 432.

${ }^{124}$ BELTRAME, Adriana. Cooperação Jurídica Internacional. In: Revista de Processo, vol. 162, Ago. 2008, p. 5 . 
de Direito Internacional Público e, portanto, à tutela judicial perante tribunais internacionais. $^{125}$

Entretanto, não se pode deixar de lado o fato de que, ao se pensar em cooperação internacional dentro do Direito, deve-se ter em mente não somente a evolução humana, como também a do próprio Direito. Assim, comunga-se das ideias de Adriana Beltrame, quando menciona que hoje em dia afigura-se comum a procura de novas formas de solução de conflitos, que passam ao largo da jurisdição estatal, como é o caso da arbitragem, da negociação, da conciliação e da mediação. Logo, não seria possível pensar em uma cooperação entre Estados soberanos que não permitisse que uma decisão oriunda de uma arbitragem ou, ainda, de uma autocomposição, pudesse ser cumprida em um Estado estrangeiro através do fenômeno de cooperação.

Além do mais, o termo "interjurisdicional” parece inapropriado dentro desta análise, uma vez que, além de ser mais restritivo (em relação a "jurídico"), não implica necessariamente em uma cooperação internacional, pois pode se referir também à cooperação entre jurisdições diversas de um mesmo Estado (o que não é incomum). Falar em cooperação entre Estados soberanos também implica falar em um ato internacional. A ideia de uma cooperação jurídica internacional nos dias de hoje não pode ser vista apenas sob a ótica de um Estado-nacionalista, em que se observam apenas interesses internos. Como o momento atual é de mudança, de transformação em que a relação entre os Estados estreitase a cada dia, a linguagem a ser utilizada tem que ser universal no sentido de abranger as possibilidades de cada individualidade para ser entendida como um todo. ${ }^{126}$

Acompanhando este raciocínio, o presente trabalho se posiciona no sentido de que a expressão que melhor se adequa a esta realidade é "cooperação jurídica internacional”, assim como se afigura ser a posição governamental, externada pelo Ministério da Justiça, mais especificamente, pelo Departamento de Recuperação de Ativos e Cooperação Jurídica Internacional - DRCI.

Nesse sentido, Ricardo Perlingeiro Mendes da Silva explicita ainda que a preferência pela expressão "cooperação jurídica internacional" decorre da ideia de que a efetividade da jurisdição, nacional ou estrangeira, pode depender do intercâmbio não apenas entre órgãos judiciais, mas também entre órgãos administrativos, ou, ainda, entre órgãos judiciais e

\footnotetext{
${ }^{125}$ Exposição de Motivos do Código de Cooperação Interjurisdicional para Ibero-américa. Revista da SJRJ, Rio de Janeiro, n. 25, 2009, p. 432.

${ }^{126}$ BELTRAME, Adriana. Cooperação Jurídica Internacional. In: Revista de Processo, vol. 162, Ago. 2008, p. 5 .
} 
administrativos de Estados distintos. ${ }^{127}$ A qualificação da cooperação como jurídica está muito mais associada aos efeitos que dessa podem advir do que propriamente à natureza do objeto da cooperação ou a qualidade de quem coopera. ${ }^{128}$

Além disso, importa ressaltar que o termo deriva da locução alemã "internationale Rechtshilfe" — literalmente "cooperação jurídica internacional” —, cunhada pelos juristas alemães Von Martizt e Von Liszt. ${ }^{129}$

Feito este "parêntese" em relação à terminologia, passa-se à análise substancial dos termos dos tratados bilaterais em relação à eventual vedação de produção de prova pela defesa.

De plano, já é possível identificar que em onze dos dezenove acordos analisados há disposições que permitem interpretar o seu conteúdo como vedações à produção de prova em favor da defesa. Entretanto, conforme consulta feita ao DRCI, em abril de 2013, por meio de trocas de mensagens eletrônicas, a China também não aceita pedidos de cooperação em prol de particulares.

Constata-se, portanto, que a maioria dos países com quem o Brasil mantém relações bilaterais denega pedidos provenientes de particular, mediante o entendimento de que não seria possível tramitar pela via do auxílio direto pedidos de interesse exclusivo da defesa. Nos demais casos, os tratados são silentes gerando ampla margem para discussão.

Nos acordos com os EUA (MLAT Brasil/EUA, artigo I, item 5), com a Colômbia (artigo I, item 4, alínea “c"), com o Peru (artigo 4", item 3, alínea “c”), com a Espanha (artigo $1^{\circ}$, item 4, alínea “c”), com a Ucrânia (artigo I, item 4) e com o Suriname (artigo $1^{\circ}$, item 6) há previsão em igual sentido: "O presente Acordo destina-se tão-somente à assistência judiciária mútua entre as Partes. Seus dispositivos não darão direito a qualquer indivíduo de obter, suprimir ou excluir qualquer prova ou impedir que uma solicitação seja atendida".

Os tratados com a Nigéria (artigo $1^{\circ}$, item 3), com o México (artigo $1^{\circ}$, item 5), com Honduras (artigo $1^{\circ}$, item 4) e com o Reino Unido (artigo $1^{\circ}$, item 3 ), que são os mais recentes, excluem expressa e diretamente a defesa nos seguintes termos: "Para os propósitos deste Tratado, as autoridades competentes para enviar solicitação de auxílio jurídico mútuo a sua Autoridade Central são aquelas responsáveis por conduzir investigações, ações penais

127 SILVA, Ricardo Perlingeiro Mendes da. Cooperação Jurídica Internacional e Auxílio Direto. In: Revista CEJ, Brasília, n. 32, p. 75-79, jan./mar. 2006, p. 76.

${ }^{128}$ BECHARA, Fábio Ramazzini. Cooperação Jurídica Internacional em Matéria Penal: Eficácia da Prova Produzida no Exterior. São Paulo: Saraiva, 2011, p. 43.

${ }^{129}$ LASZLOCZKY, Paolo. La cooperazione internazionale negli atti d'istruzione penale. Padova: CEDAM, 1980, p. 25. 
ou processos judiciais, conforme definido na lei interna da Parte Requerente."

No que tange, ainda, ao tratado com o Estado Mexicano, interessante observar a disposição do artigo $4^{\circ}$, item 2 , a qual parece ser até redundante levando-se em conta o dispositivo supramencionado: “As disposições do presente Tratado não outorgam direito algum a favor de pessoas físicas ou jurídicas na obtenção, eliminação ou exclusão de provas, ou para impedir o cumprimento de pedido de cooperação jurídica internacional."

Por último, a previsão do tratado com o Panamá, nos moldes das previsões acima referidas (artigo $1^{\circ}$, item 6 ):

Para os propósitos deste Tratado, as autoridades competentes para enviar solicitações de auxílio jurídico mútuo à sua autoridade central são aquelas responsáveis ou com poder para atuar em procedimentos administrativos ou judiciais relacionados à prática de um delito, conforme definido na lei interna da Parte requerente.

Assim, verificam-se vedações expressas acerca da possibilidade de se prestar assistência a particulares, ou seja, para a defesa.

Traçando um paralelo com as Convenções analisadas no início do capítulo, verificase que disposição restritiva semelhante encontra-se no artigo $1^{\circ}$, item 2, do Protocolo de San Luis, que regula a cooperação penal no Mercosul.

Dentre os exemplos de países que denegam a assistência jurídica em prol da defesa destacam-se os Estados Unidos, pelo volume de pedidos, ${ }^{130}$ motivo pelo qual seu sistema merecerá atenção especial no presente trabalho, inclusive com a intenção de se entender as razões das denegações dos pedidos da defesa.

\footnotetext{
${ }^{130} \mathrm{Na}$ consulta feita ao DRCI, em abril de 2013, por meio de trocas de mensagens eletrônicas com o Coordenador-Geral de Recuperação de Ativos e Cooperação Jurídica Internacional, foi recebida a seguinte informação: "A respeito do resultado quantitativo, ao total de 60 pedidos, 45 foram dirigidos aos Estados Unidos da América e baseados no Acordo Bilateral. Desde o fim de 2012, após diversas conversas com os órgãos envolvidos, esse Departamento agora encaminha os pedidos da defesa pela via diplomática, sem ainda termos notícias acerca do resultado do trâmite adotado. Ainda do total de casos identificados, 6 foram embasados na Convenção das Nações Unidas contra o Crime Organizado Transnacional Convenção de Palermo." Além disso, conforme estatísticas divulgadas oficialmente, os Estados Unidos é o país com o qual o Brasil mantém relação cooperacional mais intensa, figurando em primeiro lugar (como destinatário ou remetente) dos pedidos de cooperação em matéria penal, no período de 2004 a 2012, com 16,3\% dos pedidos. (Cartilha Cooperação Jurídica Internacional em Matéria Penal. Ministério da Justiça ,Secretaria Nacional de Justiça e Departamento de Recuperação de Ativos e Cooperação Jurídica Internacional, 2013 , p. 23. Disponível em: 〈http://www.justica.gov.br/sua-protecao/cooperacao-internacional/cooperacao-juridica internacional/arquivos/cartilha_coop_penal.pdf/view>. Último acesso em: 03 out. 2014.)
} 


\subsection{Sistema norte-americano de produção de provas e MLAT Brasil-EUA}

No common law, e com particular intensidade nos Estados Unidos, ${ }^{131}$ nessa verificação das características da tradição angloamericana será feita especial referência ao sistema processual federal dos Estados Unidos, porque, a partir da perspectiva do processualista continental, este sistema oferece uma concepção sobre a prova particularmente alheia à mantida no civil law, como será mais bem analisado em capítulo próprio. Com efeito, o ordenamento processual dos EUA constitui o máximo expoente das características diferenciadas do common law e se encontra no epicentro dos infindáveis desencontros verificados nos casos de cooperação jurídica internacional.

Nesse norte, verifica-se que os princípios norteadores do common law, adotado nos Estados Unidos, estabelecem que procedimentos de colheita de provas para a instrução de um processo devem ocorrer de acordo com um procedimento intitulado "discovery", 132 que configura essencialmente um procedimento para preservar o contraditório, de modo que a outra parte tenha imediato conhecimento das provas produzidas. "Especialmente para o acusado, a audiência pode ser a oportunidade de obter informações úteis para preparar o julgamento". ${ }^{133}$ Como traz Petrus, o emprego do discovery pelas partes e o recurso à crossexamination (submissão das provas ao confronto) são instrumentos processuais que

${ }^{131}$ PETRUS, Christian Herrera. La obtención internacional de pruebas, asistencia jurisdiccional en Europa. Real Colegio de España: Bolonia, 2005, pp. 72-3.

${ }^{132}$ As principais formas de colheita de provas dentro de um procedimento de discovery são:

a) Interrogatórios escritos (interrogatories), por meio dos quais a parte solicita diretamente à testemunha a apresentação de respostas escritas às perguntas;

b) Oitiva de testemunhas (depositions), por meio da qual a parte realiza diretamente a oitiva de uma testemunha, com a presença da outra parte, mas sem a participação de um juiz ou envolvimento de um tribunal. Os custos e esforços relacionados à oitiva de testemunhas dentro do Common Law são arcados integralmente pelas partes; c) Solicitações de produção de provas (requests for discovery), onde uma parte solicita que a outra apresente provas que estão sujeitas ao processo de discovery, também sem a participação de um juiz ou envolvimento de um tribunal. (MANUAL DE COOPERAÇÃO JURÍDICA INTERNACIONAL E RECUPERAÇÃO DE ATIVOS. Cooperação em Matéria Penal. Brasília: Secretaria Nacional de Justiça, 2012, p. 167).

Além disso, no modelo adversary desenvolvido na Inglaterra, e depois transplantado para suas colônias americanas, a iniciativa da atividade probatória incumbe preponderantemente aos próprios litigantes, que devem obter, selecionar e apresentar o material probatório ao júri [...]; disso decorre o papel de mero moderador atribuído ao juiz que preside o julgamento, que raramente utiliza sua faculdade de convocar e interrogar testemunhas (GOMES FILHO, Antonio Magalhães. Direito à Prova no Processo Penal. São Paulo: Editora Revista dos Tribunais, 1997, p. 59).

${ }^{133}$ No original: "L'importanza del preliminary hearing non risiede solo nell'accertamento della probable cause, ma anche nell'opportunità per l'accusa e la difesa di conoscere le prove in possesso della controparte (c.d. discovery). Sopratutto per l'imputato, tale udienza può essere l'occasione per ottenere informazioni utili per preparare il dibattimento". Tradução livre: "A importância da audiência preliminar não reside apenas em determinar as prováveis causas, mas também na oportunidade para a acusação e a defesa ver as provas na posse da outra parte. Especialmente para o acusado, a audiência pode ser a oportunidade de obter informações úteis para preparar o julgamento". (AMODIO, Ennio; BASSIOUNI, M. Cherif. Il Processo Penale negli Stati Uniti D’America. Milano: Giuffrè Editore, 1988, p. 66). 
otimizam a qualidade do debate processual e contribuem para assegurar a obtenção da verossimilhança a que deve aceder o sistema jurisdicional. "O procedimento deve estar ordenado a criar as condições para um encontro dialético revelador". ${ }^{134}$

Assim sendo, a produção das provas nessa modalidade é efetuada diretamente pelas partes, sendo que só haverá o envolvimento de um juiz caso haja algum desentendimento entre elas acerca do que deve ou não ser produzido, ou da forma de produção.

Assim, os gastos e esforços relacionados à colheita de provas no país são arcados integralmente pelas partes. O Estado estadunidense só arcará com os custos relacionados à colheita de provas da acusação, e os custos da colheita de provas da defesa serão arcados pela defesa, o que será feito por representação privada ou por meio de defensor público ou dativo.

Nesse contexto, necessário lembrar que, sendo a justiça criminal nos EUA muito onerosa, muito fazem as partes para evitar a produção de provas em Juízo.

Assim, é comum que os escritórios, quer sejam dos promotores, quer sejam dos advogados de defesa, produzam as provas fora da sala de audiências e apenas introduzam essas provas, na forma documental, para a discussão durante o julgamento. As promotorias e os maiores escritórios de advocacia possuem, inclusive, notários que auxiliam na produção de depoimentos pré-processuais. A produção desses depoimentos pode ser acompanhada pelos advogados da parte contrária ou pelos promotores. ${ }^{135}$

Desse modo, o governo norte-americano não concorda em utilizar bens e esforços públicos para custear a oitiva de testemunhas arroladas pela defesa, a não ser que exista, concomitantemente, interesse específico por parte do juiz ou da acusação nesta diligência. ${ }^{136}$

Com base nisso, com os Estados Unidos, a vedação ocorre com fulcro no artigo I, item 5, do Tratado Bilateral firmado com o Brasil (Decreto n. 3.810/2001): “O presente Acordo destina-se tão-somente à assistência judiciária mútua entre as partes. Seus dispositivos não darão direito a qualquer indivíduo de obter, suprimir ou excluir qualquer prova ou impedir que uma solicitação seja atendida."

Há críticas bastante severas em relação ao dispositivo acima transcrito, como as efetuadas por Bruce Zagaris, em artigo concernente à coleta de provas nos Estados Unidos,

\footnotetext{
${ }^{134}$ PETRUS, Christian Herrera. La obtención internacional de pruebas, asistencia jurisdiccional en Europa. Real Colegio de España: Bolonia, 2005, p. 84.

${ }^{135}$ RAMOS, João Gualberto Garcez. Curso de Processo Penal Norte-americano. São Paulo: Revista dos Tribunais, 2006, p. 190-1.

${ }^{136}$ MANUAL DE COOPERAÇÃO JURÍDICA INTERNACIONAL E RECUPERAÇÃO DE ATIVOS. Cooperação em Matéria Penal. Brasília: Secretaria Nacional de Justiça, 2008, p. 32.
} 
no Brasil e a prova transnacional, mediante a necessidade de um melhor procedimento no devido processo legal. ${ }^{137} \mathrm{O}$ ensaio trata, especificamente, do acordo de Assistência Jurídica em Matéria Penal - MLAT e os problemas que réus e terceiros, que fazem parte do processo, podem ter além de uma desvantagem substancial com relação ao acesso às evidências do processo criminal. $\mathrm{O}$ autor destaca ainda que os réus precisam lidar com longos períodos de atraso e ficam essencialmente à mercê do juiz ou órgão do governo, pois o MLAT exclui expressamente a possibilidade de réus e terceiros utilizarem o MLAT para obtenção de provas ou a tentativa de excluí-las. Além disso, refere no texto que outras opções de se obter provas, tais como as cartas rogatórias, estão fora de uso e apresentam problemas, pois pode demorar anos para que sejam integralmente processadas. Nesse contexto, a proposta do artigo consiste na detalhada abordagem desses obstáculos, com a apresentação de soluções que possam auxiliar os réus nessas situações "até que os países comecem a retificar essas questões por conta própria”.

Em relação ao mencionado dispositivo constante no MLAT, Helena Vasconcellos ${ }^{138}$ assevera ser a maior desvantagem materializada no tratado, tendo em vista que não há consenso acerca da interpretação do dispositivo - enquanto os EUA entendem que a disposição proíbe integralmente a utilização do MLAT pela defesa, o STJ vem entendendo que a defesa poderia sim se utilizar do instituto, desde que o pedido de mútua assistência seja feito por meio da acusação ou do Juízo. ${ }^{139}$. Em realidade, sequer há consenso no território nacional, já que o STJ considera não haver qualquer violação constitucional no dispositivo, posição diametralmente oposta à da doutrina, que entende ser flagrante a violação dos princípios constitucionais da isonomia, da paridade de armas e, em última análise, do devido processo legal.

Além disso, Bruce Zagaris refere que o dispositivo vai contra a tendência de cada vez mais tratar os indivíduos como sujeitos e não como objetos dos tratados e, a menos que os governos desenvolvam MLATs e outros mecanismos de mútua assistência que sejam equilibrados, há um grande risco de os Estados perderem o apoio e a legitimidade em face da sociedade civil, enfraquecendo com isso a própria sustentabilidade dos referidos tratados

\footnotetext{
${ }^{137}$ ZAGARIS, Bruce. U.S. - Brazil and International Evidence Gathering: The Need for Better Procedural Due Process. Revista Brasileira de Ciências Criminais. RBCCrim. Ano 20, vol. 99, nov.-dez./2012.

${ }^{138}$ VASCONCELLOS, Helena. Cooperação Jurídica Internacional em Matéria Penal: Uma Análise do Mutual Legal Assistance Treaty Brasil/Estados Unidos. Dissertação apresentada ao Programa de Pós-Gradução em Direito da Faculdade de Direito da Universidade Federal do Rio Grande do Sul como requisito parcial para obtenção do grau de mestre em Direito. Orientador Prof. Dr. Tupinambá Pinto de Azevedo. Porto Alegre, 2013, p. 187.

${ }^{139}$ Nesse sentido: STJ, HC n. 147.375/RJ, Quinta Turma, Rel. Min. Jorge Mussi, julgado em 22/11/2011, DJE $19 / 12 / 2011$.
} 
e mesmo de seus regimes políticos. ${ }^{140}$

Bruce Zagaris narra um único caso, em que atuou como perito, inclusive, em que foi admitido o uso do MLAT em prol da defesa. O caso diz respeito a um navio holandês que derramou óleo no Alasca, tendo o Juiz distrital dos Estados Unidos decidido que a tripulaçãoré e outros trabalhadores do navio de cruzeiro não poderiam receber um julgamento justo a menos que tivessem acesso aos mecanismos do MLAT que lhes permitiria, por exemplo, prestar depoimentos. Mesmo diante da apresentação pelo governo dos EUA das disposições do MLAT EUA-Holanda, que restringe o seu uso à acusação, o Juiz disse, no caso, que, apesar das expressas disposições do MLAT, naquele tribunal os direitos presentes na Constituição dos EUA ao devido processo legal e a igualdade de armas deveriam prevalecer. O Juiz concedeu à Promotoria uma escolha: ou permitir aos arguidos o direito de utilizar os mecanismos do MLAT ou ele iria arquivar o caso imediatamente. Confrontada com essa escolha, a acusação relutantemente concordou em permitir aos réus o uso do MLAT. Infelizmente, no caso, o autor narra que o Juiz não emitiu um "memorando de ordem" e a única evidência da determinação são as transcrições da decisão. Como consequência disso, poucos advogados conhecem esse precedente, não se prestando como um marco jurisprudencial. O autor menciona, por fim, que não tem conhecimento de outros precedentes que foram capazes de estabelecer direitos para os réus e terceiros, e que o acesso a MLATs em tribunais dos Estados Unidos continua a ser uma meta difícil de alcançar. ${ }^{141}$

\footnotetext{
140 "Infelizmente, os recentes acordos bilaterais negam os direitos dos arguidos de utilizar os acordos e de invocar o Tratado para excluir provas, impedir a execução de um pedido, e/ou de obter depoimentos, documentos e assistência em seu próprio nome. Estas disposições vão contra a tendência recente de entender os indivíduos como sujeitos e não meros objetos dos tratados. Ela muda o equilíbrio de poder desnecessariamente a favor da aplicação da lei e põe em perigo a justiça no funcionamento do sistema penal internacional. [...] Em última instância, a menos que os governos reconheçam e desenvolvam tratados bilaterais e regimes de execução de acordos que sejam equilibrados, correm o risco de perder o apoio da sociedade civil e de minar a sustentabilidade de tais acordos e regimes". Tradução livre de: "Unfortunately, the recent MLATs deny rights of defendants and tafgets to use the MLAT and to invoke the treaty to exclude evidence, impede the execution of a request, and/or to obtain testimony, documents, and assistance on their own behalf. These provisions go against the recent trend to make individuals subjects and not just objects of treaties. It shifts the balance of power unnecessarily in favor of law enforcement and imperils the justice in the operation of the criminal system internationally. [...]Ultimately, unless governments recognize and develop MLATs and other enforcement agreements and regimes that are balanced, they risk losing the support of civil society and undermining the sustainability of such agreements and regimes.” (ZAGARIS, Bruce. U.S. - Brazil and International Evidence Gathering: The Need for Better Procedural Due Process. Revista Brasileira de Ciências Criminais. RBCCrim. Ano 20, vol. 99, nov.-dez./2012, p. 253 e 273).

${ }^{141}$ No original: "A U.S. District Judge, presiding over a prosecution of a Dutch ship that spilled oil off the Alaskan court, decided that the defendant crew and other workers on the cruise liner, could not receive a fair trial unless they had access to the mechanisms in the MLAT that would allow them, for instance, to take depositions. Even though the the U.S government recited the provisions of the U.S.-Dutch MLAT that restricts the use of the MLAT to the prosecution, in this court the U.S. Constitution's right to due process and equality of arms took priority. He gave the prosecution a choice: either afford the defendants the right to use the mechanisms of the MLAT or he would dismiss the case immediately. Faced with that choice, the prosecution reluctantly agreed to allow the defendant the use of the MLAT. [...] Unfortunately, the judge not prepare a
} 
De certa forma, as razões originárias para a relutância dos norte-americanos em cooperar juridicamente em algumas questões restam posicionadas, de forma contundente, por Mueller e Wise, que descrevem as Cortes norte-americanas como "isolacionistas, ignorantes em relação ao Direito Penal e Processo Penal estrangeiro, e não familiarizadas com os poderes explícitos e implícitos do Julgador para conceder assistência". ${ }^{142}$

Não bastasse isso, outro problema detectado por Bruce Zagaris está na possibilidade que o MLAT abre para que a prova seja utilizada, pelo Estado requerido, para instaurar uma nova investigação contra o mesmo indivíduo. Para o autor, ainda que o verdadeiro propósito do MLAT seja auxiliar os Estados estrangeiros em seus casos criminais, o MLAT não proíbe expressamente o Estado requerido de usar a informação obtida a pedido do país estrangeiro para dar início à sua própria investigação criminal. Tal circunstância seria facilitada em razão de o investigado não ser detentor de quaisquer direitos segundo o MLAT. ${ }^{143}$

Nesse contexto, revela-se alarmante e temerário o fato de a defesa, todavia, não estar abarcada nesses mecanismos e tampouco estar imbuída de quaisquer direitos nessa modalidade de cooperação.

De acordo com informações obtidas do Departamento de Recuperação de Ativos e Cooperação Jurídica Internacional da Secretaria Nacional de Justiça, por meio de consulta efetuada informalmente em abril de 2013, ainda que todas as hipóteses passíveis de denegação da produção de prova pela defesa - como visto acima, doze dos dezessete países com quem o Brasil mantém tratados bilaterais possuem previsões que, em tese, seriam passíveis de vedar a utilização do mecanismo pela defesa - não se tenham verificado na prática, certo é que:

Pelos registros do Departamento, tramitam ou tramitaram 60 pedidos de cooperação com o objeto de ouvir testemunhas de defesa.

Identificamos que os seguintes países não cumpriram tais pedidos: China,

memorandum order and the only evidence of his ruling is the transcript of the ruling. As a result, few lawyers know about it and does not serve as a jurisprudential landmark. I am not aware of many others precedentes, so establishing rights for defendants and third parties to have access to MLATs in U.S. courts remains a difficult goal to achieve through litigation." (ZAGARIS, Bruce. U.S. - Brazil and International Evidence Gathering: The Need for Better Procedural Due Process. Revista Brasileira de Ciências Criminais. RBCCrim. Ano 20, vol. 99, nov.-dez./2012, p. 269).

${ }^{142}$ MUELLER, Gerhard O.W. "International Judicial Assistance in Criminal Matters" in MUELLER, Gerhard \& WISE, Edward (eds). International Criminal Law. New Jersey: Rothman Ed., 1965. p. 415.

${ }^{143}$ No original: "Although the purpose of the MLAT is to assist a foreign government's criminal case, the MLAT does not expressly prohibit the requested case from using the same information it necessarily it obtains for the foreign government from starting its own criminal investigation. The use by a requested state of the very evidence it obtains for a foreign partner is facilitated because the defendant has no rights under the MLAT." (ZAGARIS, Bruce. U.S. - Brazil and International Evidence Gathering: The Need for Better Procedural Due Process. Revista Brasileira de Ciências Criminais. RBCCrim. Ano 20, vol. 99, nov.-dez./2012, p. 260). 
Estados Unidos da América, Canadá e México.

Por exclusão, consideramos que os demais países poderiam cumprir pedidos veiculados por meio de auxílio direto que almejam a oitiva de testemunhas da defesa, a exemplo de Alemanha, Uruguai e Rússia - que diligenciaram plenamente as requisições.

Para os países: Bolívia, Inglaterra, Noruega, Israel, Gibraltar, Ilhas Virgens Britânicas, os pedidos ainda seguem em trâmite e, até o momento, não identificamos qualquer sinalização de que não serão cumpridos. ${ }^{144}$

Em relação às razões de denegação da assistência, os países basicamente se referem ao fato de que os pedidos de cooperação na seara penal somente compreendem pedidos feitos em nome do Estado requerente, ou seja, em nome de autoridades estatais devidamente constituídas para atuar em investigações de processos criminais, não contemplando pedido em nome de particulares, no caso, os investigados ou réus. Para isso, alegam dispositivos contidos nos próprios Acordos bilaterais ou no Direito interno.

Assim, levando em conta as razões informadas pelo DRCI acerca dos motivos do não cumprimento, entende-se que questão prejudicial se apresenta quando a Defensoria Pública patrocina a defesa, pois a parte assistida, ${ }^{145}$ notadamente, não terá condições de arcar com o custo da produção da prova, bem como não seria apenas um particular stricto sensu a ter interesse na causa como polo passivo, mas sim o próprio Estado, por meio dos seus agentes.

Marco Bruno Miranda Clementino, ao escrever sobre a cooperação jurídica internacional em matéria penal e as dificuldades enfrentadas no Direito brasileiro, destaca o fato de que "somente autoridades públicas podem recorrer à cooperação, sendo vedado seu manejo por particulares, mesmo que com o objetivo de municiar a defesa". ${ }^{146}$

Entretanto, tal argumento restaria de pronto rechaçado quando o pedido fosse proveniente da Defensoria Pública, por se enquadrar na definição de autoridade pública, conforme exigido nos acordos bilaterais, ademais configurando instituição pública e qualificada de defesa.

Desse modo, informa-se que, em face desta constatação, o propósito primordial do presente trabalho afigura-se a apresentação de propostas para a solução desse impasse. Como traz Cervini, no caso da Convenção Interamericana para assistência mútua em matéria

\footnotetext{
144 Consulta informal efetuada em abril de 2013 junto ao Departamento de Recuperação de Ativos e Cooperação Jurídica Internacional da Secretaria Nacional de Justiça.

145 Importante lembrar, todavia, que a atuação da Defensoria Pública na defesa criminal é ampla, independentemente da renda do acusado, em atuação atípica, e ocorre sempre que este não constituir advogado particular - art. $5^{\circ}, \mathrm{LV}$, da CF e do art. $4^{\circ}$, XIV, da LC 80/94.

${ }^{146}$ CLEMENTINO, Marco Bruno Miranda. A Cooperação Jurídica Internacional em Matéria Penal e as Dificuldades Enfrentadas no Direito Brasileiro. In: Direito Federal - Revista da Associação dos Juízes Federais do Brasil, v. 25, n. 92, jan./jun, 2012, p. 229.
} 
criminal, não se outorga direito aos particulares para obter ou excluir provas, ou para impedir a execução de qualquer solicitação de assistência; caracteriza-se assim a Convenção como "acordo entre Estados", ainda que, em "nenhum caso", a juízo do referido autor se poderia desprezar o direito à defesa, nem os legítimos direitos e interesses dos terceiros. ${ }^{147}$

No capítulo seguinte, serão abordadas as garantias e os princípios norteadores do que se convencionou chamar de "devido processo penal", relacionados à preservação da igualdade das partes e da paridade de armas, os quais são invocados para justificar a necessidade de que à defesa também seja possibilitado o acesso a mecanismos céleres e mais eficazes de cooperação jurídica internacional, pois se revela imperativa a necessidade de se encontrar meios para sanar a atual sistemática dos países que denegam a assistência.

${ }^{147}$ CERVINI, Raúl. Princípios da Cooperação Judicial Internacional em Assuntos Penais. Doutrina - Direito Comparado. Disponível em: 〈http://www.amprs.org.br/arquivos/revista_artigo/arquivo_1283279756.pdf $>$. Último acesso em: 18 fev. 2014. p. 29. 


\section{A IGUALDADE DAS PARTES E OS PRINCÍPIOS E GARANTIAS ATINENTES AO DEVIDO PROCESSO PENAL}

Após todo o panorama apresentado, importante não perder de vista que o combate desenfreado à criminalidade transnacional não pode suprimir as garantias previstas na Constituição Federal e em tratados e declarações internacionais atinentes aos direitos humanos.

Ainda que para parte da doutrina a efetiva realização da justiça penal constitua um importante interesse do Estado, em determinadas circunstâncias poder-se-ia justificar o sacrifício dos direitos individuais, reputando-se, assim, legítima a derrogação de certas regras de exclusão de prova ditadas pelo interesse de proteção ao indivíduo, em nome da prevenção e repressão das formas mais graves de criminalidade. ${ }^{148}$

Felizmente, tal posição não configura doutrina majoritária, sendo bastante veementes as críticas daqueles que consideram intolerável uma compreensão dos direitos fundamentais relativizada pela repressão de determinados delitos, pois isso significaria admitir uma banalização dos referidos direitos, cuja eficácia, na matéria examinada, ficaria limitada aos agentes de delitos menos graves, enquanto nas situações de criminalidade mais grave haveria sempre uma frustração da tutela dos direitos fundamentais.

A esses argumentos, cuja legitimidade nos parece induvidosa, pode-se acrescentar que essa disparidade de tratamento conduziria a uma sistemática violação da presunção de inocência dos acusados de infrações mais graves, pois à simples imputação já se seguiriam efeitos negativos, não só no âmbito do processo, mas, igualmente, no campo dos direitos constitucionais protegidos pelas proibições de prova, por exemplo. Ademais, a qualificação dos fatos, como mais ou menos graves, no limiar das investigações, acabaria fatalmente por abrir um espaço incontrolável à discricionariedade (senão ao arbítrio) dos agentes policiais. Além disso, não interessa a punição do inocente, assegurando-se a impunidade do verdadeiro culpado. $^{149}$

Eduardo Araujo da Silva também admite que haveria uma inegável tendência de restrição de certos direitos fundamentais dos investigados e acusados, no plano processual penal, na busca da maior eficiência penal, como consequência do crime organizado. ${ }^{150}$

\footnotetext{
${ }^{148}$ GOMES FILHO, Antonio Magalhães. Direito à Prova no Processo Penal. São Paulo: Editora Revista dos Tribunais, 1997, p. 105, nota 41.

${ }^{149}$ Ibidem, p. $105-7$ e nota 42.

${ }^{150}$ SILVA, Eduardo Araujo da. Crime Organizado: procedimento probatório. São Paulo: Atlas, 2003. p. 47.
} 
Moraes, de outro modo, de forma bastante pragmática, intitula essa questão de "pseudo dilema", pois, em suas palavras, na área processual penal, uma nova política criminal somente poderá ser efetivamente discutida se estivermos maduros para superar um falso dilema de que pseudoideologias teórico-academicistas insistem em construir, qual seja, uma inconciliável dicotomia entre eficiência e garantismo. "Por ignorância ou má-fé, insistese em difundir a ideia de que sistemas garantistas são ineficientes, pois dificultariam o rápido julgamento do culpado". 151

O conflito entre o devido processo penal e o eficaz controle da criminalidade não deve necessariamente existir, ou seja, as garantias processuais não devem ser colocadas de forma antagônica à eficiência do processo, visto como instrumento de defesa social.

Nesse sentido, Mário Chiavario, de forma irretocável, afirma que processo eficiente é mais do que aquele voltado à absolvição dos inocentes e condenação dos culpados; a verdadeira eficiência processual incorpora também a eficiência no reconhecimento e desenvolvimento das garantias processuais. A eficiência processual não é aquela que requer maior repressão: é a eficiência de um processo que deverá permitir a obtenção de resultados credíveis também no sentido da oportunidade e eficácia das sanções, permitindo que tais resultados sejam alcançados de um modo "justo" também no plano do percurso seguido. ${ }^{152}$

Como lembra Denise Neves Abade, “a noção de maior eficiência processual, antes de excluir o conceito das garantias do devido processo penal, as pressupõe". ${ }^{153} \mathrm{E}$ a autora prossegue afirmando que as garantias constitucionais do processo penal, assim, devem ser voltadas aos fins da Justiça Penal: proteção de bens jurídicos, restabelecimento da paz, realização da Justiça no caso concreto, manutenção da confiança da sociedade em sua própria eficácia, sem olvidar das garantias individuais do acusado. Dessa forma, os valores imputados e os interesses do acusado podem e devem conviver com novas metas de política criminal, que preservem a consciência dos valores ético-sociais, não apenas na direção da pena, mas também do próprio procedimento de punir e do próprio processo penal. ${ }^{154}$

\footnotetext{
${ }^{151}$ MORAES, Maurício Zanoide de. Política Criminal, Constituição e Processo Penal: Razões da Caminhada Brasileira para a Institucionalização do Caos. In: MARTINS, Ives Gandra da Silva; JOBIM, Eduardo (Coord.). O Processo na Constituição. São Paulo: Quartier Latin, 2008. p. 862-3.

${ }_{152}$ Tradução livre. No original: "la vera efficienza processuale è tale solo se ingloba anche l'efficienza nel riconoscimento e nello sviluppo delle garanzie processuali. L'efficienza processuale no è quella di un processo purchessia in funzione di una maggiore repressione: è efficienza di un processo che deve sì consentire di raggiungere dei risultati credibili anche nel senso della tempestività e dell'efficacia delle sanzioni, ma deve consentire di raggiungerli in modo 'giusto'anche sul piano delle modalità di percorso". (CHIAVARIO, Mario. Garanzie individuali ed efficienza del processo in Il giusto processo. Milano: Giuffrè Ed., 1998, p. 54).

${ }^{153}$ ABADE, Denise Neves. Garantias do Processo Penal Acusatório: o novo papel do Ministério Público no processo penal de partes. Rio de Janeiro: Renovar, 2005, p. 119.

${ }^{154}$ Ibidem, p. 120-1.
} 
Portanto, conclui-se que o processo de internacionalização e constitucionalização dos direitos humanos estende-se às garantias processuais. Segundo André de Carvalho Ramos, ${ }^{155}$ o Direito Internacional dos Direitos Humanos é um sistema de princípios e de normas que regulam a cooperação internacional dos Estados, cujo objetivo é a promoção do respeito aos direitos humanos e liberdades fundamentais universalmente reconhecidos, assim como o estabelecimento de mecanismos de garantia e proteção de tais direitos.

Nesse contexto, insta salientar que o trabalho está norteado pela ótica garantista. ${ }^{156}$ Logo, adota-se a ideia de que o garantismo no processo penal representa a efetivação do devido processo legal, nos prismas subjetivo e objetivo: como garantias das partes, essencialmente do acusado, e como garantias do justo processo. ${ }^{157,158}$

${ }^{155}$ RAMOS, André de Carvalho. Teoria Geral dos direitos humanos na ordem internacional. 3a ed. São Paulo: Saraiva, 2013, pp. 51 e ss.

${ }^{156} \mathrm{O}$ uso da terminologia "garantismo", no direito penal e processual penal, encontra-se revestido de diversas acepções. Desse modo, cumpre esclarecer que, no presente trabalho, segue-se o modelo estruturado no pensamento de Luigi Ferrajoli, desenvolvido na obra "Direito e Razão: teoria do garantismo penal". A obra de Ferrajoli se sustenta na definição do que se chama de "sistema garantista" integrado por um conjunto de garantias penais e processuais. O próprio autor reconhece que o modelo máximo do sistema garantista é uma utopia, um modelo repleto de aporias lógicas e teóricas, nas próprias palavras do autor, "um modelo ideal e em grande parte ideológico". Entretanto, se algumas dessas limitações são irredutíveis outras não o são, de forma que o modelo engendrado pelo sistema garantista converte-se em um modelo "tendencial", no sentido de que os esforços legislativos devem buscar maximizar sua eficácia, eliminando, na medida do possível, as limitações que possam existir. No que se refere à garantia processual, a identifica com o chamado "princípio da estrita jurisdição". Em essência, este princípio assegura as garantias processuais dentro do modelo garantista e um dos seus principais componentes reside em atingir a possibilidade de verificação ou de refutação das hipóteses acusatorias em função do seu caráter assertivo (não valorativo) e sua prova empírica, em virtude de procedimentos que permitam tanto a verificação como a refutação. Nesse contexto, Luigi Ferrajoli utiliza dez axiomas, ou princípios fundamentais, para definir o modelo garantista, o qual, como já referido, é um modelo apenas tendencialmente e jamais perfeitamente concretizável. Esses axiomas expressam proposições prescritivas, ou seja, o que um sistema penal deve ser em adesão aos seus princípios normativos internos e a parâmetros de justificação externa, ou seja, valores ético-políticos normativamente por eles tutelados, sendo os primeiros atinentes ao sistema penal e os quatro últimos às garantias processuais penais. São eles: Al Nulla poena sine crimine - princípio da retributividade ou da conseqüencialidade da pena em relação ao delito; $A 2$ Nullum crimen sine lege - princípio da legalidade, no sentido lato ou no sentido estrito; A3 Nulla lex (poenalis) sine necessitate - princípio da necessidade ou da economia do direito penal; A4 Nulla necessitas sine iniuria princípio da lesividade ou da ofensividade do evento; $A 5$ Nulla injuria sine actione - princípio da materialidade ou da exterioridade da ação; A6 Nulla actio sine culpa - princípio da culpabilidade ou da responsabilidade pessoal; A7 Nulla culpa sine juditio - princípio da jurisdicionariedade, também no sentido lato ou no sentido estrito; A8 Nullum judicium sine accusatione - princípio acusatório ou da separação entre juiz e acusação; $A 9$ Nulla accusatio sine probatione - princípio do ônus da prova ou da verificação; A10 Nulla probatio sine defensione - princípio do contraditório ou da ampla defesa. Na concepção de Ferrajoli, estes dez princípios, ordenados e conectados sistematicamente, definem o modelo garantista de direito ou de responsabilidade penal, ou seja, as fundamentais regras do jogo do direito penal. (FERRAJOLI, Luigi. Derecho y razón - Teoría del garantismo penal. 10a ed., Madrid: Editorial Trotta, 2011, p. 33-38, 93 e 851-855).

${ }^{157}$ FERNANDES, Antonio Sacarance. Reflexões sobre as noções de eficiência e de garantismo no processo penal. In: FERNANDES, Antonio Sacarance; ALMEIDA, José Raul Gavião de; MORAES, Maurício Zanoide de. Sigilo no processo penal: eficiência e garantismo. São Paulo: Revista dos Tribunais, 2008, p. 10.

${ }^{158}$ Díez Ripollés em artigo de 2004 critica a inadequação do modelo garantista para enfrentar à realidade normativa e político-criminal atual, em especial, em relação ao uso do princípio da legalidade, o qual limitaria o trabalho do jurista a realizar interpretações forçadas da lei vigente ("Aprisionados no princípio da legalidade, somente nos resta questioná-lo, com o que minamos o edifício dogmático laboriosamente construído, ou esperamos por tempos melhores limitando-nos a fazer uma pequena força de trabalho de pá por interpretações 


\section{De acordo com Cervini:}

Os poderes da defesa vinculam-se medularmente com o modelo garantista sustentado por Ferrajoli, em sua dupla função, cognitiva e de proteção das liberdades. O modelo garantista, desde o ponto de vista cognitivo, expressa o parâmtero para a atividade probatória, configura o método mais adequado para a apreensão da realidade. Já do ponto de vista das liberdades, o garantismo está associado à proteção do indivíduo no processo, assegurando, por exemplo, a participação das partes, o direito ao silêncio e, fundamentalmente, o direito à defesa técnica. Nesse sentido, o magistério da defesa representa muito a expressão de um processo justo, de natureza garantista. Como reconheceu a Corte Interamericana de Direitos Humanos, significa, na realidade, o padrão de exigência mínima das adequadas garantias de um processo qualificado como democrático. ${ }^{159}$

forçadas da lei”. Tradução livre de: “[...] atrapados en el principio de legalidad sólo nos queda, bien cuestionar a éste, con lo que minamos el edificio dogmático laboriosamente construido, bien esperar a tiempos mejores limitándonos a realizar una insignificante labor de zapa de la ley vigente mediante interpretaciones forzadas de ella"). Para este jurista, o debate social e jurídico sobre a política criminal contemporânea não oscila entre os pólos de mais ou menos garantismo, mas nos modelos mais eficazes de prevenção da criminalidade. Nesse sentido, a alternativa ao modelo de segurança pública não seria o modelo garantista, mas sim um modelo penal de bem-estar social, que anteponha uma aproximação social a uma aproximação repressiva contra a delincuência. (DÍEZ RIPOLLÉS, José L. El nuevo modelo penal de la seguridad ciudadana. Revista Electrónica de Ciencia Penal y Criminología. Núm. 06-03, 2004, p. 22 e 31). Nesse sentido, compartilha-se da opinião deste jurista quando refere que o garantismo não deve ser entendido como um modelo global de intervenção penal, pois sua função não é a de elaborar programas de atuação político-criminais, senão o de constituir-se em um baluarte frente aos possíveis abusos dos poderes públicos ao desenvolver tais programas. Ademais, deve existir o dever de fazer crível à sociedade que tais abusos existem que podem aumentar. Somente quando suficientes setores sociais compreendam os riscos que implica o desmantelamento do sistema de garantias se estará em condições de reverter o fenômeno social no qual se está disposto a substituir garantias por efetividade na persecução do delito. ("O que faremos com o sistema de garantias tão laboriosamente construído? Mantê-lo, ou melhor dito, convencer a sociedade de que não pode prescindir dele. Para tanto, temos de assegurar, em primeiro lugar, que o garantismo deixe de ser entendido como um modelo global de intervenção penal. Esta caracterização, que em grande parte viemos lhe atribuindo por defeito, condicionados pela ausência de autênticos projetos político-criminais, não corresponde a sua natureza. Pois sua função não é a de elaborar programas de atuação político-criminais, mas sim constituir-se em um baluarte, uma trincheira, contra eventuais abusos de autoridades públicas no desenvolvimento de tais programas. Feitos os devidos esclarecimentos, e em segundo lugar, deve ser credível à sociedade a existência de tais abusos, e que esses abusos ainda podem se agravar. Somente quando suficientes setores sociais compreendam os riscos que implica o desmantelamento do sistema de garantias, se estará em condições de reverter o fenômeno social acima referido, pelo qual se está disposto a substituir garantias pela efetividade na persecução de crimes. Mais uma vez, seria desejável que descêssemos dos princípios e das abstrações para casos concretos, mediante a descrição de abusos efetivos sobre potenciais e reais delinquentes”. Tradução libre de: "¿Y qué hacemos con el sistema de garantías tan trabajosamente construido? Mantenerlo o, mejor dicho, convencer a la sociedad de que no puede prescindir de él. Para ello hay que procurar, en primer lugar, que el garantismo deje de ser entendido como un modelo global de intervención penal. Esta caracterización, que en buena parte le hemos venido atribuyendo por defecto, condicionados por la ausencia de auténticos proyectos políticocriminales, no responde a su naturaleza. Pues su función no es elaborar programas de actuación políticocriminales, sino constituirse en un baluarte, una trinchera, frente al posible abuso de los poderes públicos al desarrollar tales programas. Aclarado esto, y en segundo lugar, hay que hacer creíble a la sociedad que estos abusos existen, y que se pueden incrementar. Sólo cuando suficientes sectores sociales comprendan los riesgos que implica el desmantelamiento del sistema de garantías se estará en condiciones de revertir el fenómeno social antes aludido, por el que se está dispuesto a sustituir garantías por efectividad en la persecución del delito. De nuevo convendría que descendiéramos de los principios y las abstracciones a casos concretos, a la descripción de abusos efectivos sobre potenciales y reales delincuentes."). Ibidem, pp. 32-3.

159 Tradução libre de: "Las facultades de la Defensa, se vinculan medularmente con el modelo garantista sustentado por Luigi Ferrajoli, en su doble función; cognitiva y de protección de las libertades. El modelo 
O modelo garantista, na tutela das liberdades individuais, assegura o direito à prova, assim compreendido o direito a buscar e postular a produção de provas, a participar da formação da prova, a produzir a contraprova e também o direito à valoração da prova produzida.

Em suma, um verdadeiro modelo cognitivo de justiça penal pressupõe não apenas que a acusação seja confirmada por provas (nulla accusatio sine probatione), mas também o reconhecimento de poderes à defesa do acusado no procedimento probatório, especificamente o de produzir provas contrárias às da acusação (nulla probatio sine defensioni). ${ }^{160}$

Nesse norte, cumpre tecer alguns comentários, ainda que preliminares, sobre o ônus da prova no processo penal.

\section{1 Ônus da prova vs. direito à prova}

O ônus da prova ${ }^{161}$ é um estímulo às partes. O risco de uma decisão desfavorável, pela não observância do ônus da prova, exerce uma pressão psicológica, instigando as partes a provar os fatos necessários para a obtenção de uma decisão favorável. Essa função estimuladora liga-se ao conceito subjetivo ou formal do ônus da prova. ${ }^{162}$

\footnotetext{
garantista, desde el punto de vista cognitivo expresa el parámetro para la actividad de producción de pruebas, en tanto es el método más adecuado para la aprehensión de una realidad. Desde el punto de vista de las libertades, el modelo garantista está asociado a la protección del indivíduo en el proceso, asegurando por ejemplo, la participación de las partes, el derecho al silencio y fundamentalmente el derecho a la defensa técnica. En ese sentido, el magisterio de la defensa, representa mucho que la expresión de un proceso justo, de naturaleza garantista. Como ha reconocido la Corte Interamericana de Derechos Humanos, significa, en realidad, el padrón de exigencia mínima de las adecuadas garantías en un proceso calificado como democrático." (CERVINI, Raúl. Principio de Confidencialidad y Magisterio de la Defensa en la Cooperación Judicial Penal Internacional. Revista de la Facultad de Derecho, nº 31, Montevideo, julio-diciembre 2011, p. 107).

${ }^{160}$ GOMES FILHO, Antonio Magalhães. Direito à Prova no Processo Penal. São Paulo: Editora Revista dos Tribunais, 1997, p. 55.

${ }^{161} \mathrm{O}$ ônus é uma faculdade cujo exercício é necessário para a obtenção de um interesse, de acordo com concepção de Carnelutti trazida por Badaró (BADARÓ, Gustavo Henrique Righi Ivahy. Ônus da Prova no Processo Penal. São Paulo: Editora Revista dos Tribunais, 2003, p. 171). Além disso, os ônus são um imperativo do próprio interesse que se manifestam sob a ameaça de um prejuízo. Assim, o desincumbir-se de um ônus pode resultar não só em uma vantagem, como também em evitar consequências desfavoráveis (BADARÓ, Gustavo Henrique Righi Ivahy. Ônus da Prova no Processo Penal. São Paulo: Editora Revista dos Tribunais, 2003, p. 172, notas 72 e 73). Pode-se falar em ônus da prova objetivo e subjetivo, aquele destinado ao Juiz, como estipulação de regras de julgamento, e este consiste no ônus de subministrar a prova. O ônus subjetivo trata-se de aspecto voltado para as partes, consiste em saber qual delas há de suportar o risco da prova frustada, logo, são "regras de conduta" da parte. (BADARÓ, Gustavo Henrique Righi Ivahy. Ônus da Prova no Processo Penal. São Paulo: Editora Revista dos Tribunais, 2003, p. 183).

${ }^{162}$ BADARÓ, Gustavo Henrique Righi Ivahy. Ônus da Prova no Processo Penal. São Paulo: Editora Revista dos Tribunais, 2003, p. 194.
} 
Assim, com relação à defesa, não há um verdadeiro dever de se defender. O Estado não pode impor ao acusado o dever de provar sua inocência. Entretanto, não se concebe que um acusado possa estar no processo penal sem a assistência de um defensor. Trata-se, contudo, de regra que se volta menos ao acusado e muito mais ao próprio Estado, impondolhe a obrigação de ofertar um defensor para todo e qualquer cidadão que, por qualquer motivo, não esteja amparado por profissional com habilitação técnica. Não há, porém, em relação ao acusado, um dever de apresentar defesa técnica. ${ }^{163}$

Nesse sentido, como lembra Badaró, ${ }^{164}$ sendo o ônus um imperativo do próprio interesse, muitas vezes o interesse do acusado pode ser, justamente, não fornecer qualquer versão dos fatos para a polícia ou ao juiz, pois se trata de mera faculdade.

Com relação à prova testemunhal, o ônus subjetivo da prova seria algo mais claro, ante a possibilidade de operar-se a preclusão caso as testemunhas não sejam arroladas no momento do oferecimento da defesa prévia. ${ }^{165}$

Sendo assim, em tese, seria possível admitir que entre as posições jurídicas do acusado no processo penal existem ônus processuais. Seria possível aceitar um ônus subjetivo da prova, ainda que fosse um ônus imperfeito ou relativo. Contudo, Badaró já rechaça essa possibilidade ao concluir que, levando em consideração o princípio do in dubio pro reo, há empecilho intransponível para que se imponha ao acusado qualquer ônus probatório na ação penal condenatória, mesmo em relação às excludentes de ilicitude e de culpabilidade. ${ }^{166}$

Em síntese, tanto no Direito comparado ${ }^{167}$ quanto no ordenamento jurídico nacional, mesmo no combate ao crime organizado, em suas diversas formas de manifestação, não há qualquer previsão, expressa ou implícita, de inversão do ônus da prova, para fins de julgamento do mérito da ação penal. ${ }^{168}$ Aliás, qualquer dispositivo nesse sentido seria

\footnotetext{
${ }^{163}$ BADARÓ, Gustavo Henrique Righi Ivahy. Ônus da Prova no Processo Penal. São Paulo: Editora Revista dos Tribunais, 2003, p. 230.

164 Ibidem, p. 231.

165 Ibidem, p. 232.

166 Ibidem, p. 233.

167 “[...] A presunção de inocência constitui um elemento integrante do Estado de Direito. O ônus da prova recai sobre a parte acusadora” (Sección III, Revue Internationale de Droit Pénal 70/929, juin.-de. 1999). 168 Ainda que haja doutrina que defenda que também o acusado possui ônus de provar. Tratar-se-ia de ônus imperfeito ou impróprio, visto que a produção da prova pelo acusado não seria condição necessária e inafastável para a obtenção da vantagem consistente na absolvição (MONNERAT, Carlos Fonseca. Inversão do ônus da Prova no Processo Penal Brasileiro. Santos, SP: Comunnicar, 2006, pp. 103-4). Entretanto, o mesmo autor, ainda que efetue construção no sentido de ser aprovada alteração constitucional para ensejar a possibilidade de inversão do ônus da prova, admite que "na atual fase da dogmática penal, não é possível regra de julgamento que permita a inversão do ônus da prova no processo penal, em virtude da existência de regra de julgamento própria de natureza constitucional". (Ibidem, p. 136).
} 
declarado inconstitucional, por ser incompatível com a garantia constitucional da presunção de inocência ${ }^{169}$.

Para Badaró, ${ }^{170}$ inverter o ônus da prova no processo penal equivaleria a aplicar a regra in dubio pro societate ou a regra in dubio contra reum, observado ser a presunção de inocência cláusula pétrea.

Entretanto, o estudo sobre a prova revelou que, embora na União Europeia o ônus de provar a culpabilidade do arguido incumba normalmente à acusação, por vezes e em casos excepcionais, como nas infrações de carácter documental ou as contravenções, uma vez que a acusação tenha provado a existência de uma obrigação, ocorre a inversão do ônus da prova e o arguido tem de demonstrar que cumpriu essa obrigação. Em certos casos o investigado também teve de invocar um meio de defesa (por exemplo, a legítima defesa, a incapacidade mental ou um álibi) antes de a acusação ter de refutá-lo. ${ }^{171}$

Ademais, ainda que no Brasil, felizmente, a presunção de inocência seja cláusula pétrea, como já referido, tal entendimento não prevalece em outros países. No âmbito processual penal na União Europeia, por exemplo, a questão já foi abordada pela Corte Europeia de Direitos Humanos, em razão das garantias processuais do acusado previstas no art. $6^{\circ}$ da Convenção, tendo havido decisões que admitiram a inversão do ônus da prova para comprovação da inocência.

Nesse sentido, o caso Salabiaku vs. França, ${ }^{172}$ em que a Corte Europeia decidiu pela ausência de violação da Convenção pela simples existência de presunção de culpa no caso em concreto, houve a inversão do ônus da prova em caso de tráfico de drogas com base no Código aduaneiro francês. Na decisão, firmou a Corte, em suma, que

todo sistema legal conhece de presunções de fato ou de direito. Logo, a Convenção não estabeleceria, em princípio, obstáculos a esse reconhecimento, mas em matéria penal os Estados contratantes são obrigados a não ultrapassar limites razoáveis, tendo em conta a gravidade da questão, preservando os direitos da defesa. ${ }^{173}$

\footnotetext{
${ }^{169}$ Isso não quer dizer que não se possam adotar regras diversas, quando se trate de processo penal no qual não se aplique a presunção de inocência, assim como ocorre na revisão criminal, em que não vigora o in dubio pro reo. (nota 441, BADARÓ, Ibidem, p. 366).

170 BADARÓ, Gustavo Henrique Righi Ivahy. Ônus da Prova no Processo Penal. São Paulo: Editora Revista dos Tribunais, 2003, p. 362.

${ }^{171}$ Vide Livro Verde da Comissão sobre a presunção de inocência, p. 22. Disponível em: <http://eurlex.europa.eu/LexUriServ/site/pt/com/2006/com2006_0174pt01.pdf >. Acesso em: 20 jun. 2013.

${ }^{172}$ Série A, $n^{\circ} 141$, n. 28, sentença de 07.10.88. Ver também caso Pham Hoang - Série A, n. 243, sentença de 25.09.92.

173 Tradução livre. No original: "Tout système juridique connait des presomptions de fait ou de droit; la Convention n'y met pas obstacle em principe, mais em matière pénale elle oblige les Etats contractants à nes pas dépasser des limites raisonnables, prenant em compte la gravité de l'enjeu et préserver les droits de la
} 
Ademais, Petrus ${ }^{174}$ assinala o quão é óbvio que um sistema de assistência jurídica insatisfatório interfere de forma direta no direito fundamental à prova, previsto nos ordenamentos constitucionais da maioria dos Estados modernos e reconhecido como patrimônio do cidadão nos instrumentos internacionais e na jurisprudência em matéria de direitos humanos.

Por isso é que se reputa oportuna a discussão do presente tópico no trabalho, tendo em vista que o objetivo maior do estudo consiste em defender a possibilidade de a defesa se utilizar do mecanismo do auxílio direto na cooperação jurídica internacional para produção de prova no exterior, também com o devido acompanhamento da prova a ser produzida no exterior ou em território nacional. Caso restasse constatado que a defesa não detém, sob nenhuma hipótese, a necessidade de produzir prova, certamente parte significativa da importância e proposta do estudo se desqualificaria. Entretanto, como se pôde ver e se continuará a verificar na sequência, este não se afigura o caso.

Não bastasse isso, há previsão da inversão do ônus da prova quanto à origem lícita dos bens apreendidos na Convenção de Viena sobre o Tráfico Ilícito de Entorpecentes e de Substâncias Psicotrópicas (art. $5^{\circ}$, item $7^{175}$ ), na Convenção de Palermo contra o Crime Organizado Transnacional (art. 12, item $7^{176}$ ) e na Convenção de Varsóvia sobre Lavagem de Dinheiro e Financiamento do Terrorismo (art. $3^{\circ}$, item 4$)^{177}$.

Aponta Scarance Fernandes ${ }^{178}$ a existência de três entendimentos em relação à

défense." (PETTITI, L.E., DECAUX, E., IMBERT, Pierre-henri (org.) La convention européene des droits de l'homme. Paris, Economica, 1995, p. 272, nota 355 apud ABADE, Denise Neves. Garantias do Processo Penal Acusatório: o Novo Papel do Ministério Público no Processo Penal de Partes. Rio de Janeiro: Renovar, 2005, p. 222).

${ }^{174}$ PETRUS, Christian Herrera. La obtención internacional de pruebas, asistencia jurisdiccional en Europa. Real Colegio de España: Bolonia, 2005, p. 108-9.

175 "Cada Parte considerará a possibilidade de inverter o ônus da prova com respeito à origem lícita do suposto produto ou outros bens sujeitos a confisco, na medida em que isto seja compatível com os princípios de direito interno e com a natureza de seus procedimentos jurídicos e de outros procedimentos."

176 “Os Estados Partes poderão considerar a possibilidade de exigir que o autor de uma infração demonstre a proveniência lícita do presumido produto do crime ou de outros bens que possam ser objeto de confisco, na medida em que esta exigência esteja em conformidade com os princípios do seu direito interno e com a natureza do processo ou outros procedimentos judiciais."

${ }^{177}$ A recuperação de ativos junto do arguido ou de um terceiro pode implicar uma inversão do ônus da prova no caso de os ativos serem produto de uma atividade criminosa, o que o proprietário desses ativos deverá refutar, ou uma redução do nível de exigência da prova, em que a acusação é autorizada a provar a culpabilidade em função das probabilidades, em vez de prová-la para além de toda a dúvida razoável, como é normalmente o caso. Qualquer recuperação de ativos deve poder ser susceptível de recurso, ser razoável e proporcional. Obviamente, esta análise também se aplica à recuperação de ativos transfronteiras. As reclamações de terceiros de boa fé devem ser devidamente tomadas em conta em caso de violação do seu direito de propriedade e os Estados devem assegurar a existência de mecanismos para os proteger. (vide: < $\underline{\text { http://eur- }}$ lex.europa.eu/LexUriServ/site/pt/com/2006/com2006_0174pt01.pdf >, p. 22).

${ }^{178}$ FERNANDES, Antonio Scarance; ALMEIDA, José Raul Gavião de; MORAES, Maurício Zanoide de 
interpretação quanto ao alcance da inversão desse ônus da prova: o primeiro entendimento reflete que o princípio constitucional da presunção de inocência impede a inversão do ônus da prova para qualquer fim, cabendo ao Ministério Público o ônus de provar também a origem ilícita dos bens; o segundo entendimento preconiza a perda dos bens do acusado caso ele não comprove sua origem lícita; e o terceiro entendimento (intermediário, ao qual se filia o autor), que admite a inversão do ônus da prova para a restituição dos bens durante o processo, mas condiciona a sua perda a que o Ministério Público prove a origem ilícita destes.

Ademais, nessa linha de argumentação, para João Gualberto Garcez Ramos, como regra geral, a defesa do imputado tem uma pauta mínima: a de provar a existência de uma dúvida razoável. Não cabe à defesa provar a inocorrência do fato, ou provar que não tomou parte dele, ainda que o tenha afirmado. Tem ela o ônus mínimo de provar que o acusador não se desincumbiu de seu ônus adequadamente, isto é, que não provou o fato além de uma dúvida razoável. Por isso é que se diria que a distribuição do ônus processual é desigual; enquanto ao acusador cabe provar o fato, ao imputado cabe provar a existência de uma dúvida sobre a ocorrência do fato ou sobre sua participação nele, mas ainda assim a defesa detém grau de responsabilidade nessa fase. A mera dúvida resolve o processo em favor do acusado. $^{179}$

Enfim, como restou verificado, e como regra geral, ponderando a questão da inversão do ônus da prova em determinados casos e, como se trata de cooperação jurídica internacional, em outros países também não há ônus, mas há direito à prova. ${ }^{180} \mathrm{Na}$ doutrina de Magalhães Gomes Filho, o direito à prova possui a mesma natureza e o mesmo fundamento dos próprios direitos de ação e de defesa em juízo, pois se trata de um direito público subjetivo, cujos titulares são as partes no processo, em igualdade de condições e cujo sujeito passivo é, fundamentalmente, o Estado, representado pelo órgão jurisdicional, ao qual

(Coords.). Crime Organizado - aspectos processuais. São Paulo: Revista dos Tribunais, 2009, p. 21.

179 RAMOS, João Gualberto Garcez. Curso de Processo Penal Norte-americano. São Paulo: Revista dos Tribunais, 2006, p. 190.

${ }^{180}$ No direito processual-penal brasileiro, o reconhecimento do direito à prova é uma decorrência, em primeiro lugar, do próprio sistema de garantias constitucionais, especialmente das cláusulas que asseguram o devido processo legal, o contraditório, a ampla defesa e a presunção de inocência (art. $5^{\circ}$, inc. LIV, LV e LVII, CF); além disso, com a incorporação ao nosso ordenamento jurídico em nível constitucional (art. $5 .^{\circ}, \S 2 .^{\circ}, \mathrm{CF}$ ), dos textos do Pacto Internacional sobre Direitos Civis e Políticos e da Convenção Americana sobre Direitos Humanos, é expressamente reconhecido a toda pessoa acusada de delito o direito de inquirir as testemunhas de acusação, bem como o de obter o comparecimento de testemunhas de defesa, em igualdade de condições. (GOMES FILHO, Antonio Magalhães. Direito à Prova no Processo Penal. São Paulo: Editora Revista dos Tribunais, 1997, p. 172). 
incumbe tornar efetivas as postulações legítimas em relação às atividades probatórias. ${ }^{181}$

A importância do reconhecimento de um direito à prova, no quadro das garantias mínimas inerentes a um processo justo, também pode ser facilmente verificada por sua constante referência nos textos internacionais sobre direitos humanos.

Assim, dentre os direitos fundamentais proclamados nos vários textos internacionais, merecem destaque os relacionados à proteção dos acusados em processo penal, pois esta sempre foi uma área particularmente propícia às mais brutais violações contra a liberdade, a integridade física e a dignidade do ser humano. ${ }^{182}$

Assim, embora sem referência expressa à garantia do direito à prova, a Declaração Universal de 1948 proclamou, em seu artigo 11.1, a presunção de inocência, com a asseguração de todas as garantias necessárias à defesa.

Já o Pacto Internacional de Direitos Civis e Políticos é mais explícito, com a seguinte previsão entre as garantias mínimas estabelecidas em favor do acusado: "inquirir ou fazer inquirir as testemunhas de defesa, nas mesmas condições que as de acusação" (art. 14, item 3, letra "e").

De igual modo apresenta-se a Convenção Europeia de 1950, que estatui em seu artigo $6^{\circ}, 3$, letra "d", que todo acusado tem o direito de "inquirir ou fazer inquirir as testemunhas de defesa, nas mesmas condições que as de acusação". Na mesma linha, a Convenção Americana sobre Direitos Humanos, que assegura também à defesa o direito de "inquirir as testemunhas presentes no Tribunal e de obter o comparecimento, como testemunhas ou peritos, de outras pessoas que possam lançar luz sobre os fatos" (art. $8^{\circ}$, item 2 , letra “f”).

A esse respeito, quanto à garantia do direito à prova, como componente essencial e inafastável da noção de justo processo, a jurisprudência da Corte Europeia tem sido bastante significativa.

Na sentença de 22 de abril de 1992, sobre o caso Vidal vs. Bélgica, a Corte entendeu ter havido violação dos parágrafos $1^{\circ}$ e 3$]$, "d", do art. $6^{\circ}$ da Convenção, pois a Corte de Apelação de Bruxelas condenou o acusado sem ouvir quatro testemunhas de defesa que haviam sido indicadas no recurso. ${ }^{183}$ A Corte Europeia concluiu, nesse caso, que o silêncio

181 GOMES FILHO, Antonio Magalhães. Direito à Prova no Processo Penal. São Paulo: Editora Revista dos Tribunais, 1997, p. 172.

182 Ibidem, p. 73.

${ }^{183}$ Julgamento de 22 de abril de 1992, serie A, No. 235-B. Tratava-se de um guarda penitenciário ao qual havia sido atribuído o fato de haver entregado uma arma a um detento, para frustada tentativa de fuga; depois de uma absolvição por um tribunal de primeiro grau, essa primeira decisão foi reformada em grau de apelação, para condená-lo a três anos de reclusão; tendo obtido sucesso em seu recurso de cassação, Vidal solicitou à Corte de Bruxelas, competente para o novo julgamento, a inquirição das referidas testemunhas, mas esse pedido não chegou nem mesmo a ser considerado pelo Tribunal, que simplesmente proferiu uma nova condenação a quatro 
quanto ao pedido de prova testemunhal era incompatível com a ideia de um processo justo.

Analisadas em conjunto, essas disposições evidenciam que o direito à prova constitui um dos componentes essenciais e constantes do "modelo internacional de processo justo" a que se refere Comoglio, ${ }^{184}$ e garantem ao acusado não só o direito de obter o comparecimento de testemunhas de defesa (right of attendance), mas também o de participar, em contraditório, da inquirição das testemunhas de acusação (right of confrontation). ${ }^{185}$

A Corte Europeia de Direitos Humanos também tem enfatizado que a utilização de prova produzida fora do contraditório caracteriza ofensa ao direito à prova, com violação do artigo $6^{\circ}, 3$, “d”, da Convenção. ${ }^{186}$

No próprio Direito Penal norte-americano, um dos pilares é a cláusula do direito à confrontação presente na Sexta Emenda, a qual prevê que "em todas as persecuções criminais, o acusado terá direito [...] de ser confrontado com as testemunhas de acusação".

Esse princípio da confrontação estabelece ser um direito do imputado o de confrontar ou ser confrontado com as testemunhas arroladas pela acusação. Evidente que não se trata de um direito de conteúdo meramente formal, mas garante ao imputado o direito de contestar a real condição da testemunha, sua identidade, seus motivos, suas versões. ${ }^{187}$

E mais, na opinião da Suprema Corte, redigida pelo Juiz Associado Black, em Illinois

anos. (GOMES FILHO, Antonio Magalhães. Direito à Prova no Processo Penal. São Paulo: Editora Revista dos Tribunais, 1997, p. 76).

${ }^{184}$ COMOGLIO, Luigi Paolo. I modelli di garanzia costituzionale del processo, in Studi in onore di Vittorio Denti, Padova, Cedam, 1994, v. I, p. 315-7 apud GOMES FILHO, Antonio Magalhães. Direito à Prova no Processo Penal. São Paulo: Editora Revista dos Tribunais, 1997, p. 74, nota 38.

185 GOMES FILHO, Antonio Magalhães. Direito à Prova no Processo Penal. São Paulo: Editora Revista dos Tribunais, 1997, p. 74. O autor adverte, ainda, que "sobre o âmbito de aplicação dessas disposições, cumpre salientar que a referência dos textos unicamente a testemunhas (salvo a menção da Convenção Americana a peritos) não deve levar a entender-se excluída a garantia em relação aos demais meios de prova, pois as redações adotadas estão certamente influenciadas pela tradição anglo-americana, em que há predominância da via testemunhal para introdução de elementos informativos no processo; ademais, tratando-se, como visto, de atributo essencial à noção de justo processo, é induvidosamente aplicável a qualquer tipo de prova" (Ibidem). 186 Vide casos Kostovski (julgamento de 20/11/1989, Serie A, n. 166), Windisch (julgamento de 27/09/1990, Serie A, n. 186), Lüdi (julgamento de 15/06/1992, Serie A, n. 238) e Saïdi (julgamento de 20/09/1993, Serie A, n. 261-C) . Em todos esses casos foi tratada a questão das testemunhas e informantes anônimos. A Corte tem uma jurisprudência consistente e bem desenvolvida acerca do tema e, considerando especialmente o raciocínio da Corte no caso Kostovski, chega-se a constatação de que as seguintes condições devem ser preenchidas, a fim de disponibilizar um julgamento justo ao acusado nesses casos: 1) a testemunha anônima deve ser examinada na presença do acusado ou do seu advogado (deve-se ressaltar que a Convenção não impede a identificação do acusado com seu defensor para determinados atos processuais); 2) o exame será conduzido pelo juiz de instrução, e não pela polícia; 3) o juiz da instrução deve estar ciente da identidade das testemunhas; e 4) a condenação do acusado não deve ser baseada unicamente ou mesmo em grande medida (em extensão decisiva) nas declarações prestadas de forma anônima. (WASEK-WIADEREK, Malgorzata. The principle of "equality of arms" in criminal procedure under Article 6 of the European Convention on Human Rights and its functions in criminal justice of selected European countries - A comparative view. Belgium: Leuven University Press, 2000, p. 40).

${ }^{187}$ Cf. john G. Douglass, Beyond admissibility: real confrontation, virtual cross-examination, and the right to confronthearsay, Geo.Wash.L.Rcv., 11. 67, 1998-1999, p. 191-272 apud RAMOS, João Gualberto Garcez. Curso de Processo Penal Norte-americano. São Paulo: Revista dos Tribunais, 2006, p. 147. 
vs. Allen, 397 US337 (1970), “um dos mais básicos direitos contidos na cláusula de confrontação é o do acusado estar presente na sala durante cada um dos momentos processuais de seu julgamento", ${ }^{188}$ restringindo-se tal direito em hipóteses rigorosamente necessárias - como nos casos em que o acusado possa, com sua atitude, intimidar as testemunhas, ou quando protagonizar um comportamento desordeiro, destrutivo ou desrespeitoso para com o juiz ou para com outro participante, hipóteses em que esse direito poder-lhe-á ser negado. ${ }^{189}$

Desenvolvendo essa ideia de que a defesa, além de produzir a prova, teria interesse no acompanhamento da prova a ser produzida, a Professora Ada Pellegrini Grinover lembra ainda o posicionamento preocupado com os direitos da pessoa, pela qual o Estado requerido é tão responsável quanto o Estado requerente pela rigorosa observância dos direitos fundamentais e das garantias processuais na cooperação internacional em matéria penal. ${ }^{190}$

Em decisão do Tribunal de Alçada Criminal de São Paulo, que corrobora e elucida os argumentos expostos, houve anulação do processo por violação à ampla defesa, a partir do despacho judicial do juiz de primeiro grau que indeferiu a oitiva de testemunhas residentes fora do país, com o intuito de evitar eventual prescrição. Destaca-se a seguinte ponderação: "Nada no processo pode ser mais importante que assegurar às partes o contraditório e ao réu o direito de ampla defesa. Aliás, trata-se de norma constitucional (CF, art. $\left.5^{\circ}, \mathrm{LV}\right)$ ". 191

188 Hugo L. Black. Opinião, in lllinois v. Allen, 397US337,338 (1970). Disponível em: <www. findlaw.com/casecode/supreme.html>. Acesso em: 09 mai. 2013.

189 RAMOS, João Gualberto Garcez. Curso de Processo Penal Norte-americano. São Paulo: Revista dos Tribunais, 2006, p. 148.

${ }^{190}$ GRINOVER, Ada Pellegrini. O Processo em Evolução. Rio de Janeiro: Forense Universitária, 1996, p. 1945. Tal aspecto será melhor desenvolvido no capítulo dedicado ao estudo da flexibilização da regra do noninquiry.

${ }^{191}$ Acórdão da $2^{\text {a }}$ Câmara do TACRIMSP na Apelação n ${ }^{\circ}$ 767.321-8, da Comarca de Ribeirão Preto, Relator Juiz Oliveira Passos, publicado pelo Boletim AASP, no 1.849, de 1 a 8 jun. 1994, p. 175. Entretanto, esta não se afigura a regra, como se pode visualizar no seguinte julgado recente proveniente do Tribunal Regional Federal da 3a Região: PROCESSO PENAL. HABEAS CORPUS. TESTEMUNHA DE DEFESA. OITIVA NO EXTERIOR (EUA). ACORDO DE ASSISTÊNCIA JURÍDICA EM MATÉRIA PENAL ENTRE BRASIL E ESTADOS UNIDOS - APLICABILIDADE AOS ENTES ESTATAIS. INDEFERIMENTO DE EXPEDIÇÃO DE CARTA ROGATÓRIA - AUSÊNCIA DE ILEGALIDADE. CERCEAMENTO DE DEFESA. INOCORRÊNCIA. ORDEM DENEGADA. I - O Acordo de Assistência Judiciária em Matéria Penal (MLAT) firmado entre os Governos do Brasil e o dos Estados Unidos da América, promulgado pelo Decreto ${ }^{\circ} 3.810 / 01$, não abrange as diligências requeridas pela defesa nas ações penais. II - Referido acordo, dispõe seu preâmbulo, visa facilitar a execução das tarefas das autoridades responsáveis pelo cumprimento da lei de ambos os países, no que se refere às atividades de investigação, inquérito, ação penal e prevenção do crime, através de cooperação e assistência judiciária mútua em matéria penal. E, ainda, não se aplica às pessoas naturais, mas apenas aos entes estatais (artigo I, item 5, do acordo). III - O Acordo de Assistência Judiciária em Matéria Penal (MLAT) não padece de inconstitucionalidade, vez que não afronta os princípios da isonomia processual, contraditório e ampla defesa. O que ocorre, na verdade, é uma recusa do Estado americano em proceder à oitiva de testemunhas arroladas pela defesa, fundamentando tal negativa nos princípios norteadores do sistema de Common Law, adotado por aquele país, segundo o qual referidas diligências são realizadas às custas da defesa, 
Além disso, em razão da disposição do art. $5^{\circ}, \S 2^{\circ}$, da Lei Maior, que incorpora ao rol de direitos e garantias aquelas adotadas nos tratados em que a República Federativa do Brasil seja parte e em face da adesão do Brasil à Convenção Americana sobre Direitos Humanos (Pacto de São José da Costa Rica), cujo integral cumprimento foi determinado pelo Decreto n. 678, de 6 de novembro de 1992, também configura garantia inerente ao sistema processual pátrio a prevista no art. $8^{\circ}, \S 2^{\circ}$, letra “f”, do referido texto internacional:

Toda pessoa acusada de delito tem direito a que se presuma sua inocência enquanto não se comprove legalmente sua culpa. Durante o processo, toda pessoa tem direito, em plena igualdade, às seguintes garantias mínimas:

[...]

f) direito da defesa de inquirir as testemunhas presentes no tribunal e obter o comparecimento, como testemunhas ou peritos, de outras pessoas que possam lançar luz sobre os fatos.

Por tudo isso é que se refere que os mecanismos de garantias e proteção dos direitos efetivam-se no pressuposto do devido processo legal, ${ }^{192}$ no âmbito formal e material. Nos dizeres da doutrina mais contemporânea, um processo penal constitucional. ${ }^{193} \mathrm{Na}$ sequência, discorrer-se-á sobre outros consectários do princípio do devido processo legal correlacionados ao tema.

pouco importando se os réus são americanos ou estrangeiros. IV - É certo que o princípio do devido processo legal deverá proporcionar ao acusado todas as formas possíveis de defesa, porém, dentro dos limites do território nacional, pois as regras constitucionais e processuais pátrias não podem ser compelidas a outro Estado soberano. V - Não há ilegalidade na negativa de expedição de carta rogatória aos EUA, uma vez que o juízo a quo fundamentou sua decisão no entendimento de que a diligência não seria cumprida pela Justiça norte-americana, visto que não há acordo entre ambos os países aptos a autorizar a oitiva de testemunhas arroladas pela defesa nos tribunais americanos. Trata-se da discricionariedade do juiz, ao qual é facultado indeferir diligência, em decisão fundamentada, que considere irrelevante, impertinente ou protelatória, sendo que, no caso, pelo fato de o ato não ser cumprido por aquele país, se tornaria meramente procrastinatório. VI - Resta afastada, também, a hipótese de cerceamento da defesa, pois há outros meios possíveis para a defesa realizar a sua produção probatória. VII - Ademais, caso a defesa considere imprescindível, ficou autorizado o comparecimento pessoal das testemunhas arroladas pela defesa, residentes nos EUA, ao Juízo, a fim de que sejam ouvidas, não havendo qualquer óbice ou impedimento para a realização do ato. VIII - Ordem denegada. (HC - HABEAS CORPUS - 44625; Processo: 000488382.2011.4.03.0000; UF: SP; Órgão Julgador: SEGUNDA TURMA; Data do Julgamento: 12/04/2011; Fonte: e-DJF3; Relator: DESEMBARGADOR FEDERAL COTRIM GUIMARÃES).

192 Esse conjunto de garantias pode ser sintetizado nas denominações devido processo legal, adotada nas Emendas $5^{\mathrm{a}}$ e $14^{\mathrm{a}}$ da Constituição americana, ou processo justo, constante da Convenção Europeia de Direitos Humanos e do recém reformado artigo 111 da Constituição italiana. Na Constituição brasileira, esse processo humanizado e garantístico encontra suporte principalmente nos incisos XXXV, LIV e LV do artigo $5^{\circ}$, que consagram as garantias da inafastabilidade da tutela jurisdicional, do devido processo legal, do contraditório e da ampla defesa.

193 A esse respeito, recomenda-se a leitura da obra de FERNANDES, Antônio Scarance. Processo Penal Constitucional. $4^{\mathrm{a}}$ Ed. São Paulo: Revista dos Tribunais, 2005. 


\subsection{Princípio da duração razoável do processo vs. prescrição}

Tendo em vista que um dos principais, senão o principal, mote do presente estudo consubstancia-se na possibilidade de utilização pela defesa dos mecanismos cooperacionais mais ágeis, este tópico será dedicado à discussão do argumento de que a defesa não teria interesse na utilização de mecanismos céleres de cooperação tendo em vista a eventualidade de beneficiar-se do instituto da prescrição.

Dito isso, em primeiro lugar, cumpre lembrar que o processo penal moderno deve ser regido pelo princípio da eficiência. Para Jean Pradel, o princípio da eficiência é um protetor da sociedade e contém dois princípios: o da busca da verdade e o da celeridade. ${ }^{194}$ Desse modo, tanto a acusação quanto à defesa devem primar pela observância desse valor sem dilações indevidas, pois interessa também ao acusado o julgamento rápido, fazendo cessar o constrangimento decorrente do processo. ${ }^{195}$

Nesse sentido, Ada Pellegrini Grinover já pontuou que o garantismo é visto "tanto no prisma subjetivo dos direitos públicos das partes, e sobretudo da defesa, como no enfoque objetivo de tutela do justo processo e do correto exercício da função jurisdicional". ${ }^{196}$ Desse modo, não se poderia argumentar que a demora processual interessaria, ou mais, configuraria em objetivo da defesa ou mesmo que a defesa não visa à celeridade, pois, com norte no garantismo penal, a eficiência, com todos os seus supedâneos, afigura-se um dos objetivos mais desejados.

Imperativo lembrar, também, a garantia da duração razoável do processo assegurada tanto pela Constituição quanto por Convenções internacionais. ${ }^{197}$ Nesse sentido, todo

\footnotetext{
${ }^{194}$ PRADEL, Jean. Procédure pénale. 10. Ed. Paris: Cuja, 2000, p. 300 apud FERNANDES, Antonio Scarance. Reflexões sobre as noções de eficiência e de garantismo no processo penal. In: FERNANDES, Antonio Scarance; ALMEIDA, José Raul Gavião de; MORAES, Maurício Zanoide de. Sigilo no processo penal: eficiência e garantismo. São Paulo: Revista dos Tribunais, 2008. p. 10. Ada Pellegrini Grinover já acentuou que não vê incompatibilidade entre essas duas tendências (garantismo e eficiência), destacando-os como sendo os valores fundamentais do novo processo penal latino-americano ( $I n$ : Lineamentos gerais do novo processo penal na América Latina. RePro, São Paulo, v. 15, n. 58, p.134, 1990).

${ }^{195}$ FERNANDES, Antonio Scarance. O Tempo e o Movimento no Processo Penal: A Eficiência e o Garantismo em uma Visão Equilibrada do Processo Penal. In LIMA, Marcellus Polastri; SANTIAGO, Nestor Eduardo Araruna - Coords - A Renovação Processual Penal após a Constituição de 1988: Estudos em Homenagem ao Professor José Barcelos de Souza. Rio de Janeiro: Lumen Juris, 2009, p. 33.

${ }^{196}$ Ibidem, p. 134.

${ }^{197}$ A Convenção Europeia assegura a todo imputado o direito de ser julgado “dentro de um prazo razoável”. O Pacto Internacional sobre Direitos Civis e Políticos contempla a mesma garantia ao afirmar que o acusado tem direito de ser julgado "sem injustificado atraso" (art. 14). Idêntica previsão foi inserida na Convenção Americana sobre Direitos Humanos de San José da Costa Rica, no art. $8^{\circ}$, I: "Toda pessoa tem direito de ser ouvida com as devidas garantias e dentro de um prazo razoável por um juiz ou Tribunal competente, independente e imparcial, estabelecido por lei anterior, na defesa de qualquer acusação penal contra ela formulada[...]. Entre nós, a Constituição no art. 5 , LXXVIII, incluído pela emenda 45/2004, consagrou a garantia enfocada ao dispor que "a todos, no âmbito judicial e administrativo, são asseguradas a razoável
} 
imputado tem o direito de "obter um pronunciamento que ponha termo, de modo mais rápido possível, à situação de incerteza e de inegável restrição da liberdade que comporta o processo penal". 198

Analisando o tema, afirma André de Carvalho Ramos que, se no caso Genie Lacayo a Corte sustentou que a acusação tem direito a um processo de duração razoável, condenando o Estado da Nicarágua por violação à Convenção Americana de Direitos Humanos, no caso Suárez Rosero a Corte fez o inverso e também observou que o réu tem direito a um processo de duração razoável, condenando, então, o Estado equatoriano. ${ }^{199}$ Ainda que o caso Suárez Rosero diga respeito a réu preso, situação que não está sendo discriminada no presente trabalho, entende-se que pode ser utilizado como precedente para discussão também em situações em que o réu/investigado encontra-se em liberdade, pois ainda que seja óbvio que a restrição à liberdade é a máxima expressão de um processo penal, não se pode negar que a pessoa sobre a qual recai um processo, ou até mesmo um inquérito policial, também se vê sob o pálio de restrições de outras naturezas, mas que também lhe são indubitavelmente prejudiciais.

Realmente, tendo-se na devida conta as graves consequências psicológicas (no plano subjetivo), sociais (no plano objetivo), processuais, e até mesmo pecuniárias, resultantes da persecução penal para o indivíduo nela envolvido, imperiosa torna-se a agilização do respectivo procedimento, a fim de que elas, tanto quanto possível, se minimizem, pela conclusão do processo em prazo razoável. ${ }^{200}$

Como traz Ada Pellegrini Grinover, ${ }^{201}$ o critério do fair trial tem envolvido o controle da duração razoável do processo, da imparcialidade, do respeito aos direitos de defesa e ao princípio da igualdade de armas, reconhecendo-se, entre outros, o direito à defesa técnica e à autodefesa; finalmente, com relação ao contraditório, garantiu-se também o direito à prova, com a faculdade de produzi-las. É o que será mais detalhadamente aferido na próxima seção.

duração do processo e os meios que garantam a celeridade de sua tramitação". (FERNANDES, Antonio Scarance. O Tempo e o Movimento no Processo Penal: A Eficiência e o Garantismo em uma Visão Equilibrada do Processo Penal. In LIMA, Marcellus Polastri; SANTIAGO, Nestor Eduardo Araruna (Coords.). A Renovação Processual Penal após a Constituição de 1988: Estudos em Homenagem ao Professor José Barcelos de Souza. Rio de Janeiro: Lumen Juris, 2009, p. 32).

${ }^{198}$ BADARÓ, Gustavo; LOPES JR, Aury. Direito ao processo penal no prazo razoável: Rio de Janeiro: Lumen Juris, 2006, p. 18-9.

${ }^{199}$ RAMOS, André de Carvalho. Direitos Humanos em Juízo. São Paulo: Max Limonad, 2001, p. 250.

200 TUCCI, Rogério Lauria. Direitos e Garantias Individuais no Processo Penal Brasileiro. 3a ed. Rev., atual. e ampl. São Paulo: Editora Revista dos Tribunais, 2009, p. 210.

${ }^{201}$ GRINOVER, Ada Pellegrini. O Processo em Evolução. Rio de Janeiro: Forense Universitária, 1996, p. 193. 


\subsection{Princípios da ampla defesa e do contraditório e a paridade de armas na cooperação jurídica internacional penal}

Quando se pretende atingir a discussão em relação à paridade de armas no processo penal e, no caso específico, na cooperação jurídica internacional penal, torna-se imperativo perpassar pelos princípios do contraditório e da ampla defesa, aliados à ponderação da coexistência dos princípios da prevalência da dignidade da pessoa humana e do Estado Democrático de Direito.

Em âmbito nacional, os princípios da ampla defesa e do contraditório encontram previsão no art. $5^{\circ}$, inciso LV, ${ }^{202}$ da Constituição Federal de 1988. Tais princípios têm origem na Declaração Universal dos Direitos do Homem, de 1948, ${ }^{203}$ e no Pacto de São José da Costa Rica, de 1969. ${ }^{204}$

Há uma íntima e intrínseca relação entre o princípio da ampla defesa e do contraditório, que não poderia ter sido mais bem retratada que na seguinte passagem:

defesa e contraditório estão indissoluvelmente ligados, porquanto é do contraditório (visto em seu primeiro momento, da informação) que brota o exercício da defesa; mas é essa - como poder correlato ao de ação —, que garante o contraditório. A defesa, assim, garante o contraditório, mas também por este se manifesta e é garantida. Eis a íntima relação e interação da defesa e do contraditório. ${ }^{205}$

Referidos princípios possuem relação intrínseca com o Estado Democrático de Direito, pois se afiguram mecanismos eficientes na implementação de inúmeros direitos fundamentais. ${ }^{206}$ Assim, nas palavras de Gómes de la Serna: "nenhum direito é mais natural, nenhum é mais sagrado do que a defesa". ${ }^{207}$

202 "Aos litigantes, em processo judicial ou administrativo, e aos acusados em geral são assegurados o contraditório e ampla defesa, com os meios e recursos a ela inerentes".

203 a)Art. $7^{\circ}$ : garantia à igualdade das parte; b) Arts. $9^{\circ}$ e 10: garantia ao devido processo legal; c) Art. 11.1: garantia à ampla defesa.

204 a) Art. $8^{\circ} .1$ : garantia ao acesso à justiça; b) Arts. $8^{\circ} .2$, alíneas “a”, "b", "c", "d", "e", "f” e "g": garantia do contraditório e da ampla defesa; c) Art. $8^{\circ} .2$, alíneas de "a" a "h": garantia do devido processo legal.

${ }^{205}$ GRINOVER, Ada Pellegrini; FERNANDES, Antônio Scarance; GOMES FILHO, Antônio Magalhães. As Nulidades no Processo Penal. 3a ed. São Paulo: Malheiros, 1994, p. 44.

206 "Por vezes, um direito é ao mesmo tempo garantia de proteção de outros direitos. Assim é para o direito de defesa, em si mesmo declaratório, mas concomitantemente garantia para a efetivação de outros direitos. Realmente, o direito de defesa pode viabilizar o direito ao processo, pode garantir o direito ao contraditório, pode tutelar até o direito de ir e vir, ou seja, a liberdade pessoal. Por sua vez, o direito de defesa tem suas garantias." (GRINOVER, Ada Pellegrini. O Princípio da Ampla Defesa. Revista da Procuradoria Geral do Estado de São Paulo, n. 19, dez./81-dez./82, 1982, p. 9).

${ }^{207}$ LA SERNA, Gómes de. La Defensa en el Proceso Penal. Madri: Civitas, 1982, p. 22 apud MOURA, Maria Thereza Rocha de Assis; BASTOS, Cleunice A. Valentim. Defesa Penal: Direito ou Garantia. Revista Brasileira de Ciências Criminais. Ano 1, n. 4, out.-dez. 1993, p. 113. 
Foram a constitucionalização e a internacionalização dos direitos fundamentais, particularmente desenvolvidas na jurisprudência dos tribunais constitucionais e das instâncias supranacionais de Direitos Humanos, como a Corte Europeia de Direitos Humanos, que revelaram o conteúdo da tutela jurisdicional efetiva como direito fundamental, minudenciado em uma série de regras mínimas a que se convencionou chamar de garantias fundamentais do processo, universalmente acolhidas em todos os países que instituem a dignidade da pessoa humana como um dos pilares do Estado Democrático de Direito. $^{208}$

Nesse sentido, deve-se tentar conciliar a ambição estatal em punir acusados de praticar crimes de âmbito transnacional, praticados em organização criminosa ou não, sem violar direitos e garantias individuais, quando necessária a utilização da cooperação jurídica internacional.

Vale lembrar que o processo penal e as garantias que o regem não são dirigidos aos criminosos, podendo ser alterados conforme o grau de perversidade destes. A tutela se dirige à sociedade como um todo e a cada indivíduo em particular, que pode, a qualquer momento, se transformar em suspeito ou acusado, ficando sujeito a abusos injustificáveis e a injustiças irreparáveis, se não cercado das garantias constitucionais que lhe asseguram um devido processo legal.

A gravidade do crime em investigação ou em julgamento não pode autorizar a adoção de meios repressivos que repugnam a consciência de países democráticos, violando a dignidade da pessoa humana, reduzindo o valor da liberdade e da igualdade, e levando o Estado à imoral competição com os criminosos na prática da violência, em atos de desumanidade. ${ }^{209}$

Assim sendo, o princípio da paridade de armas recomenda que os meios postos à disposição do Ministério Público sejam igualmente deferidos à defesa. ${ }^{210}$

Ademais, concorda-se que o princípio da igualdade de armas é um dos elementos significativos da noção de "julgamento justo". A Comissão Europeia, no relatório dos casos

\footnotetext{
${ }^{208}$ Mauro Cappelletti e Denis Tallon, Les garanties fondamentales des parties dans le procès civil, Giuffrè, Milano, 1973, págs.661/774; Luigi Paolo Comoglio, "Garanzie costituzionali e 'giusto processo' (modelli a confronto)", in Revista de Processo, ed. Revista dos Tribunais, São Paulo, ano 23, abril-junho de 1998, n. 90, pp.. 95-150.

${ }^{209}$ Conforme Valiante, Il nuovo Processo penale; processo per l'uomo, Milão, 1975, p. 45 In: TUCCI, Rogério Lauria. Direitos e Garantias Individuais no Processo Penal Brasileiro. 3a ed. Rev., atual. e ampl. São Paulo: Editora Revista dos Tribunais, 2009, p. 64.

${ }^{210}$ ECtHR 12 February 2009, Samokhvalov v Russia, appl. no. 3891/03, Para. 46; also see ECtHR 6 September 2005, Salov v Ukraine, appl. n. 65518/01, Para. 87; ECtHR 8 April 2010, Sabayev v Russia, appl. no. 11994/03, Para. 35 .
} 
Dunshirn e Pataki vs. Austria, apontou que a

a igualdade de armas é a igualdade processual do acusado com o Ministério Público, configura elemento inerente ao "julgamento justo", com base legal no parágrafo $3^{\circ}$, mediante a interpretação das alíneas (b) e (c). Desse modo, a Comissão não precisa expressar uma opinião definitiva sobre esta questão, uma vez que, em qualquer caso, não há dúvida de que a disponibilização de um julgamento justo mais amplo e geral, contida no parágrafo $1^{\circ}$ do artigo $6^{\circ}$ incorpora a noção de "igualdade de armas". ${ }^{211}$

Além disso, o elemento significativo do conceito de igualdade de armas está conectado com as provas e especialmente com as provas orais produzidas. A ideia de um julgamento contraditório resulta na suposição de que o acusado tem o direito de examinar e a oportunidade de refutar as alegações da testemunha que depõe em seu desfavor. ${ }^{212}$

Correto está Ferrajoli ao afirmar que o conceito de "processo contraditório" expressa os valores democráticos de igualdade entre as partes, respeito à pessoa do imputado e necessidade prática de refutação da pretensão punitiva. ${ }^{213}$ Segundo o jurista italiano, para que o litígio se desenvolva lealmente e com igualdade de armas, é necessária a perfeita igualdade das partes. ${ }^{214}$

Teleologicamente, as partes devem ser tratadas com igualdade, de tal modo que desfrutem concretamente das mesmas oportunidades de sucesso final, em face das circunstâncias da causa.

No dizer de Scarance Fernandes, ${ }^{215}$ por decorrência dos princípios da igualdade e do contraditório, exige-se que as normas procedimentais garantam a ambas as partes tratamento isonômico e lhes assegurem a ciência dos atos da parte contrária e a oportunidade de contrariá-los. Quanto ao primeiro, liga-se a outro princípio, o do favor rei, o qual, para equilibrar a situação do acusado à posição naturalmente privilegiada do Ministério Público, órgão de Estado, permite regras que o favoreçam. Ao levar em conta o contraditório no encadeamento dos atos procedimentais, a defesa deve ser posta sempre em condições de

\footnotetext{
${ }^{211}$ WASEK-WIADEREK, Malgorzata. The principle of "equality of arms" in criminal procedure under Article 6 of the european Convention on Human Rights and its functions in criminal justice of selected European countries - A comparative view. Belgium: Leuven University Press, 2000, p. 23.

212 WASEK-WIADEREK, Malgorzata. The principle of "equality of arms" in criminal procedure under Article 6 of the european Convention on Human Rights and its functions in criminal justice of selected European countries - A comparative view. Belgium: Leuven University Press, 2000, p. 27.

${ }^{213}$ FERRAJOLI, Luigi. Derecho y razón - Teoría del garantismo penal. 10a ed., Madrid: Editorial Trotta, 2011, p. 613-614.

214 Ibidem.

215 FERNANDES, Antonio Sacarance. Reflexões sobre as noções de eficiência e de garantismo no processo penal. In: FERNANDES, Antonio Sacarance; ALMEIDA, José Raul Gavião de; MORAES, Maurício Zanoide de. Sigilo no processo penal: eficiência e garantismo. São Paulo: Revista dos Tribunais, 2008. p. 14-5.
} 
reagir à acusação.

Sendo assim, o autor enuncia, em linhas gerais, as seguintes diretrizes paradigmáticas para a estruturação de um procedimento processual penal justo, "eficiente e afinado com as garantias do devido processo penal"216.

a) o ato inicial do procedimento deve consubstanciar acusação oferecida por sujeito distinto do juiz, incumbindo-lhe delimitar o fato que constitui o objeto do processo e do julgamento;

b) os atos do procedimento devem ser desenvolvidos de modo a proporcionarem a atuação imparcial do juiz e a participação contraditória $e$ igualitária das partes; na ordem procedimental, devem ser proporcionadas à defesa meios eficazes para reagir à acusação formulada e aos atos praticados pelo órgão acusatório;

c) durante o procedimento, devem ser reservadas fases especiais para que a acusação e a defesa possam provar as suas alegações; o julgamento só pode ser proferido após a produção de prova pelas partes e depois que essas se tenham manifestado a respeito da prova realizada.

Dessa forma é que se entende que os acordos bilaterais referidos em capítulo precedente, quando impossibilitam a produção de prova pela defesa, ferem a paridade de armas prevista na Constituição Federal da República Federativa do Brasil, e mais, ferem previsão insculpida no Pacto Interamericano de Direitos Humanos ${ }^{217}$ — Pacto de São José

${ }^{216}$ FERNANDES, Antonio Sacarance. Reflexões sobre as noções de eficiência e de garantismo no processo penal. In: FERNANDES, Antonio Sacarance; ALMEIDA, José Raul Gavião de; MORAES, Maurício Zanoide de. Sigilo no processo penal: eficiência e garantismo. São Paulo: Revista dos Tribunais, 2008, p. 15. De igual modo manifesta-se Tucci: [...] c) asseguração, no processo, de paridade de armas entre as partes que o integram como seus sujeitos parciais, visando à consecução de igualdade substancial: esta somente será atingida quando, ao equilíbrio de situação, preconizado abstratamente pelo legislador, corresponder a realidade processual. Nesse derradeiro enfoque, como adverte TARZIA, não há como prover à iniciativa procedimental com exclusiva vantagem de uma das partes, sem a correlata atribuição de poder de reação à outra: o processo legitimamente instituído e regularmente desenvolvido reclama, [...] "um contraditório não somente formal, mas substancial, no qual as partes sejam cientificadas da iniciativa judicial e postas em condições de cumprir determinações tidas pelo órgão jurisdicional como necessárias". (TUCCI, Rogério Lauria. Direitos e Garantias Individuais no Processo Penal Brasileiro. 3a ed. Rev., atual. e ampl. São Paulo: Editora Revista dos Tribunais, 2009, pp. 58-9).

${ }^{217}$ A Constituição Federal inscreveu a prevalência dos Direitos Humanos como um dos princípios a reger o Brasil nas suas relações internacionais e o Decreto n ${ }^{\circ}$ 678, de 6 de novembro de 1992, promulgou a Convenção Americana sobre Direitos Humanos, conhecido como Pacto de São José da Costa Rica, que notadamente no seu art. $8^{\circ}$ dispôs sobre as garantias judiciais determinando:

"1. Toda pessoa tem direito a ser ouvida, com as devidas garantias e dentro de um prazo razoável, por um juiz ou tribunal competente, independente e imparcial, estabelecido anteriormente por lei, na apuração de qualquer acusação penal formulada contra ela, ou para que se determinem seus direitos ou obrigações de natureza civil, trabalhista, fiscal ou de qualquer outra natureza. 2. Toda pessoa acusada de delito tem direito a que se presuma sua inocência enquanto não se comprove legalmente sua culpa. Durante o processo, toda pessoa tem direito, em plena igualdade, às seguintes garantias mínimas, dentre outras: direito do acusado de defender-se pessoalmente ou de ser assistido por um defensor de sua escolha e de comunicar-se, livremente e em particular, com seu defensor; direito irrenunciável de ser assistido por um defensor proporcionado pelo Estado, remunerado ou não, segundo a legislação interna, se o acusado não se defender ele próprio nem nomear defensor dentro do prazo estabelecido pela lei; direito de não ser obrigado a depor contra si mesma, nem a declarar-se culpada. 3. A confissão do acusado só é válida se feita sem coação de nenhuma natureza. 4. O 
da Costa Rica - e, sobretudo, violam o devido processo legal, ${ }^{218}$ conforme analisado linhas acimas, com sua previsão em diversos tratados internacionais, circunstâncias que serão pormenorizadamente discutidas em momento oportuno na sequência do trabalho.

Nesse sentido, não se deve jamais olvidar que o processo penal acusatório deve ser equilibrado para ambas as partes, quer para crimes nacionais, quer para crimes de alcance global.

Ademais, segundo jurisprudência do Tribunal Europeu de Direitos Humanos, o princípio fundamental e estrutural do processo com todas as garantias é o da igualdade de armas, segundo o qual tanto a acusação quanto a defesa e o acusado devem contar com igualdade de possibilidades. ${ }^{219}$

acusado absolvido por sentença passada em julgado não poderá ser submetido a novo processo pelos mesmos fatos".

${ }^{218}$ Também denominado pela moderna processualística de "devido processo penal", assim concebido nas seguintes garantias: a) de acesso à Justiça Penal; b) do juiz natural em matéria penal; c) de tratamento paritário dos sujeitos parciais do processo penal; d) da plenitude de defesa do indiciado, acusado, ou condenado, com todos os meios e recursos a ela inerentes; e) da publicidade dos atos processuais penais; f) da motivação dos atos decisórios penais; g) da fixação de prazo razoável de duração do processo penal; h) da legalidade da execução penal. (TUCCI, Rogério Lauria. Direitos e Garantias Individuais no Processo Penal Brasileiro. 3a ed. Rev., atual. e ampl. São Paulo: Editora Revista dos Tribunais, 2009, p. 61).

219 "Em geral, pode-se dizer que o princípio fundamental e estrutural do processo com todas as garantias (para usar as palavras do art. 24.2 da Constituição Espanhola) na jurisprudência da Corte Europeia de Direitos Humanos é a igualdade de armas, segundo a qual tanto o Ministério Público quanto a defesa e os acusados devem contar com igualdade de oportunidades, de modo que o acusado não seja prejudicado em relação ao Ministério Público, especialmente no que diz respeito à intimação de testemunhas ou peritos, no oferecimento de provas e na inquirição das testemunhas da acusação ou da defesa. [...] Entretanto, não há como negar que no processo penal moderno o princípio da igualdade de armas opera reduzidamente, toda vez que se limita praticamente a possibilidade de oferecer provas e de inquirir a testemunhas. Na doutrina, tem sido salientado, com razão, que na praxis atual o julgamento resta decidido, em grande parte, durante o inquérito, onde provavelmente vigora a "desigualdade de armas". Tradução libre de: "En general es posible afirmar que el principio fundamental y estructural del proceso con todas las garantías (para emplear las palabras del art. 24.2 CE) en la jurisprudencia del TEDH es el de la igualdad de armas, según el cual tanto la acusación como la defensa y el acusado deben contar con igualdad de posibilidades, de tal manera que el acusado no sea perjudicado en relación a la acusación, sobre todo en lo concerniente a la citación de testigos o peritos, al ofrecimiento de prueba y al interrogatorio de los testigos de cargo o de descargo. [...] Pero no es posible negar que no obstante esta jurisprudencia, en el proceso penal moderno el principio de igualdad de armas opera reducidamente, toda vez que se limita prácticamente a la posibilidad de ofrecer pruebas y de interrogar a los testigos. En la doctrina se ha señalado con razón que en la praxis actual el juicio queda decidido, en gran parte, durante la instrucción donde probablemente rige la 'desigualdad de armas'." (BACIGALUPO, Enrique. Justicia Penal y derechos fundamentales. Madrid: Marcial Pons Ediciones Jurídicas y Sociales, 2002. p. 136-7). E continua: “[...] vale dizer, na expressão de Héctor Fix Zamudio, deve ser propiciado o direito de defesa, na sua maior amplitude, em que se traduz, convergentemente, a igualdade das partes no processo. A isonomia processual, por sua vez, reclama que aos sujeitos parciais sejam concedidas as mesmas armas, a fim de que, paritariamente tratadas, tenham idênticas chances de reconhecimento, satisfação ou asseguração do direito que constitui o objeto material do processo. Todavia, não se podendo, como antes aventado, cogitar de igualdade absoluta, no seio da coletividade, tem-se que o regramento ora examinado deve ser concebido como tal genericamente, podendo, contudo, deixar de ser invocado, quando e onde a própria Constituição Federal, quer explícita, quer implicitamente, permita a desigualdade. Consequentemente, e tendo-se, ainda, presente que esse alvitre é restrito às 'distinções de fato', e não às 'de direito' [...]." (TUCCI, Rogério Lauria. Direitos e Garantias Individuais no Processo Penal Brasileiro. 3a ed. Rev., atual. e ampl. São Paulo: Editora Revista dos Tribunais, 2009, p. 123). A propósito o julgamento do Agravo de Instrumento 11.380-0 pela Câmara Especial do Tribunal de Justiça de São Paulo que assinalou: "Segundo a 
A igualdade processual decorre do princípio da isonomia, inscrito no inciso I do art. $5^{\circ}$, transformado-a no princípio dinâmico da par condicio ou da igualdade de armas, mediante o equilíbrio dos litigantes no processo civil, e da acusação e defesa, no processo penal. $^{220}$

Entende-se, modernamente, por par condicio ou paridade de armas, o princípio de equilíbrio das situações, não iguais mas recíprocas, como o são, no processo penal, as dos ofícios da acusação e da defesa. ${ }^{221} \mathrm{O}$ equilíbrio das situações é que garante a verdadeira contraposição dialética das partes. Visto assim, o contraditório identifica-se com a par condicio e não com a igualdade formal, saindo, ele também, do plano estático para se inserir no dinâmico. ${ }^{222}$

Mas não é só. A Constituição de 1988 foi além, preocupando-se em delinear mais claramente um processo penal de modelo acusatório — um processo penal de partes —, em que a acusação e a defesa devem necessariamente ocupar posições paritéticas e simétricas, conforme ensinamentos da Professora Ada Pellegrini Grinover. A Constituição de 1988 o fez de maneira expressa, ao considerar acusação e defesa como funções essenciais à justiça (Cap. IV do Título IV da Constituição), regulando minuciosamente o Ministério Público (arts. 127-130), a Advocacia e a Defensoria Pública (art. 133-135), instituições às quais assegurou, até onde possível, garantias simétricas. ${ }^{223}$

lição do saudoso Professor Hely Lopes Meirelles, que se lê em Estudos e Pareceres de Direito Público, 1983, vol. VII/195: 'Quando se afirma o princípio da igualdade, é evidente que não se desconhece a existência de desigualdades reais entre indivíduos, resultantes de suas condições pessoais, habilidade, inteligência, trabalho, oportunidade etc. $O$ que se afirma é a proibição de diferenças artificiais, decorrentes de uma legislação discriminatória' (v. RJTJESP 132/279 in TUCCI, Rogério Lauria. Direitos e Garantias Individuais no Processo Penal Brasileiro. 3a ed. Rev., atual. e ampl. São Paulo: Editora Revista dos Tribunais, 2009, p. 124). Além disso, deve ser anotado que uma das consequências do desejável equilíbrio entre as situações das partes no processo penal "relaciona-se à tutela diferenciada que deve ser dada ao direito de defesa do acusado no confronto com as prerrogativas conferidas à acusação. $E$ isso, com a inafastável adição de que o tratamento privilegiado de quem se defende, longe de consistir numa violação ao postulado da igualdade, atende não apenas a um princípio geral, que impõe maior consideração à posição daquele que poderá vir a ter sacrificado o seu direito à liberdade, mas igualmente resulta da constatação histórica de que na generalidade dos casos a acusação criminal recai sobre sujeitos já desfavorecidos no plano social e econômico". TUCCI, Rogério Lauria. Direitos e Garantias Individuais no Processo Penal Brasileiro. 3a ed. Rev., atual. e ampl. São Paulo: Editora Revista dos Tribunais, 2009, p. 149, citando Antonio Magalhães Gomes filho. A motivação das decisões penais, p. 42-43).

${ }^{220}$ GRINOVER, Ada Pellegrini. Princípios e Garantias Constitucionais. In: LIMA, Marcellus Polastri; SANTIAGO, Nestor Eduardo Araruna - Coords - A Renovação Processual Penal após a Constituição de 1988: Estudos em Homenagem ao Professor José Barcelos de Souza. Rio de Janeiro: Lumen Juris, 2009, p. 5.

221 "A quem age ou se defende em juízo devem ser asseguradas as mesmas possibilidades de obter a tutela de suas razões [...]. O princípio da igualdade processual garante contraposição dialógica real entre as partes, estimulada pelo juiz, a quem cabe disciplinar o contraditório, sem que isso signifique perda de imparcialidade" (GRINOVER, Ada Pellegrini. Novas tendências do direito processual. Rio de Janeiro: Forense, 1990, p. 7, 11 e 12).

${ }^{222}$ GRINOVER, Ada Pellegrini. O Processo em Evolução. Rio de Janeiro: Forense Universitária, 1996, p. 315.

${ }^{223}$ Ibidem. 
No dizer do professor Antônio Scarance Fernandes, ${ }^{224}$ autor e réu deverão ter os mesmos direitos, os mesmos ônus e os mesmos deveres. Dentro das necessidades técnicas do processo, deve a lei propiciar ao autor e ao réu uma atuação processual em plano de igualdade no processo, deve dar a ambas as partes análogas possibilidades de alegação e prova, ou seja, deve equilibrar as posições das partes, sem dar predominância a qualquer delas, procurando compensar eventuais desigualdades naturais ou jurídicas entre elas.

Enfim, o princípio da igualdade de armas visa, sobretudo, assegurar às partes a igualdade jurídica, não somente sob o aspecto formal, mas principalmente material, a partir da previsão de instrumentos e mecanismos que permitam a manutenção de uma relação de equilíbrio. É esse o sentido que se extrai da Declaração Universal dos Direitos Humanos e dos demais tratados internacionais pertinentes à matéria. 225

Ademais, observe-se que o presente estudo trata de um dos aspectos significativos da justiça em casos criminais: o conceito de igualdade de armas. Este conceito, embora não explicitamente formulado como tal, está incluído no direito geral a um julgamento justo, 226 previsto no artigo $6^{\circ}$ da Convenção Europeia dos Direitos Humanos. ${ }^{227}$

Isso tem muito a ver com o enfoque tridimensional que se deve adotar acerca da cooperação internacional e com seu embasamento processual, do qual decorre a rigorosa observância do contraditório e das demais garantias do devido processo legal, ${ }^{228}$ pois não se afigura possível falar de "justiça” se a pessoa é punida de forma proporcional e com razão, mas não "de forma justa", ou seja, sem lhe permitir o direito de apresentar o seu caso, defender-se e obter apoio judiciário suficiente para angariar provas. ${ }^{229}$

${ }^{224}$ FERNANDES, Antônio Scarance. Processo Penal Constitucional. $4^{\mathrm{a}}$ Ed. São Paulo: Editora Revista dos Tribunais, 2005, p. 52 e 256.

${ }^{225}$ BECHARA, Fábio Ramazzini. Cooperação Jurídica Internacional em Matéria Penal: Eficácia da Prova Produzida no Exterior. São Paulo: Saraiva, 2011, p. 105.

${ }^{226} \mathrm{Na}$ França, o processo justo intitula-se processo équitable. Por meio da Lei $\mathrm{n}^{\circ} 516$, de junho de 2000, foram delineadas as garantias que, no seu conjunto, asseguram o processo équitable. A idéia é de equilíbrio entre um sistema eficiente e, ao mesmo tempo, respeitoso ao princípio da igualdade das partes (Il nuovo article préliminaire del Codice di Procedura Penale francese. Rivista di Diritto Processuale, Padova: Cedam, p. 9911.009, out.-dez. 2000 apud FERNANDES, Antonio Sacarance. Reflexões sobre as noções de eficiência e de garantismo no processo penal. In: FERNANDES, Antonio Sacarance; ALMEIDA, José Raul Gavião de; MORAES, Maurício Zanoide de. Sigilo no processo penal: eficiência e garantismo. São Paulo: Revista dos Tribunais, 2008. p. 12.

${ }^{227}$ WASEK-WIADEREK, Malgorzata. The principle of "equality of arms" in criminal procedure under Article 6 of the European Convention on Human Rights and its functions in criminal justice of selected European countries - A comparative view. Belgium: Leuven University Press, 2000, p. 7.

${ }^{228}$ GRINOVER, Ada Pellegrini. O Processo em Evolução. Rio de Janeiro: Forense Universitária, 1996, p. 165. ${ }^{229} \mathrm{O}$ conceito de justiça processual foi criado por N. Luhman. Em sua opinião, a finalidade do processo penal não é o mero estabelecimento da verdade e a realização da justiça, mas a eficiência do processo em si, bem como a persuasão dos participantes do processo penal, a fim de alcançar a verdade e a justiça do processo, contando com o máximo esforço das partes. (WASEK-WIADEREK, Malgorzata. The principle of "equality of arms" in criminal procedure under Article 6 of the european Convention on Human Rights and its functions in 
O indiciado, acusado ou condenado necessitado não podem sofrer, de que modo seja, limitação em sua atividade probatória. ${ }^{230} \mathrm{O}$ direito de defesa deve ser constituído por um conjunto de garantias, direitos e faculdades suficientes para uma oposição efetiva à pretensão penal.

No Código de Processo Penal vigente, a iniciativa probatória também é expressamente reconhecida às partes. Os arts. 41 e 395 facultam à acusação e à defesa a indicação de testemunhas; o art. 399 possibilita a ambas o requerimento de diligências; o art. 400 também permite às partes o oferecimento de documentos em qualquer fase do processo; o art. 499 estabelece nova oportunidade de requerimento de diligência ao final da instrução, no procedimento ordinário; os arts. $417, \S 2^{\circ}$, e 421 , parágrafo único, tratam dessas faculdades no procedimento do Júri, dentre outras disposições pertinentes.

Caracteriza-se assim, como já mencionado, um verdadeiro direito subjetivo à introdução do material probatório no processo, bem como de participação em todas as fases do procedimento respectivo. ${ }^{231}$

O reconhecimento de um verdadeiro direito subjetivo à prova, cujos titulares são as partes no processo, supõe considerar que as mesmas devem estar em condições de influir ativamente em todas as operações desenvolvidas para a constituição do material probatório que irá servir de base à decisão. Nessa visão, a prova, acima de tudo, deve ser atividade aberta à iniciativa, participação e controle dos interessados no provimento jurisdicional. ${ }^{232}$ É o chamado direito de defender-se provando. ${ }^{233}$

Na Itália, as investigações defensivas denominam-se "investigazioni difensive" ou "indagini difensive" e encontram respaldo constitucional nos artigos 2 24 e 111 da

criminal justice of selected European countries - A comparative view. Belgium: Leuven University Press, 2000, p. 9 e nota 1$)$.

${ }^{230}$ TUCCI, Rogério Lauria. Direitos e Garantias Individuais no Processo Penal Brasileiro. 3a ed. Rev., atual. e ampl. São Paulo: Editora Revista dos Tribunais, 2009, p. 165.

${ }^{231}$ Direito subjetivo que possui a mesma natureza constitucional e o mesmo fundamento dos direitos de ação e de defesa: o direito de ser ouvido em Juízo não significa apenas poder apresentar ao órgão jurisdicional as próprias pretensões, mas também inclui a garantia do exercício de todos os poderes para influir positivamente sobre o convencimento do juiz. (GOMES FILHO, Antonio Magalhães. Direito à Prova no Processo Penal. São Paulo: Editora Revista dos Tribunais, 1997, p. 84).

${ }^{232}$ GOMES FILHO, Antonio Magalhães. Direito à Prova no Processo Penal. São Paulo: Editora Revista dos Tribunais, 1997, p. 85. A concepção moderna da garantia de ampla defesa reclama, a saber: [...] c) o direito à prova legitimamente obtida ou produzida (comprovação da inculpabilidade) (TUCCI, Rogério Lauria. Direitos e Garantias Individuais no Processo Penal Brasileiro. 3a ed. Rev., atual. e ampl. São Paulo: Editora Revista dos Tribunais, 2009, p. 148-9).

${ }^{233}$ [...] "Na Itália, através da exegese do art. 24 da Constituição de 1948, que assegura a inviolabilidade do direito de defesa, chegou-se à compreensão de que a regra constitucional não se limita a garantir às partes o direito a um defensor ou de simplesmente expor as próprias razões ao juiz, mas implica o diritto di difendersi provando, ou seja, o direito de não ver diminuída a possibilidade de defesa através de uma restrição arbitrária dos meios de prova oferecidos ao juiz ou do objeto da prova proposta." (GRINOVER, Ada Pellegrini. $O$ Processo em Evolução. Rio de Janeiro: Forense Universitária, 1996, p. 324). 
Constituição da República. Os artigos referem-se, genericamente, ao direito de defesa, embora haja previsão de que o sujeito passivo deva dispor do tempo e das condições necessárias para preparar a defesa e poder angariar qualquer meio de prova a seu favor. ${ }^{234}$

Podem-se destacar alguns objetivos da investigação criminal defensiva, tais $\operatorname{como}^{235}$ : (i) comprovação do álibi ou de outras razões demonstrativas da inocência do imputado; (ii) desresponsabilização do imputado em virtude da ação de terceiros; (iii) exploração de fatos que revelam a ocorrência de causas excludentes de ilicitude ou de culpabilidade; (iv) eliminação de possíveis erros de raciocínio a que possam induzir determinados fatos; (v) revelação da vulnerabilidade técnica ou material de determinadas diligências realizadas na investigação pública; (vi) exame do local e a reconstituição do crime para demonstrar a impropriedade das teses acusatórias; (vii) identificação e localização de possíveis peritos e testemunhas.

Além disso, no caso da prova produzida no exterior, o respeito à paridade de armas implica assegurar a iniciativa em recorrer a mecanismos de cooperação jurídica internacional mais céleres e eficazes tanto à acusação quanto à defesa. Nesse sentido, já na produção da prova, a igualdade de armas compreende a igualdade de oportunidades, de intenção de justiça, ${ }^{236}$ observado ser a investigação defensiva uma das formas de concreção do princípio da paridade de armas no processo penal nacional e transnacional, como incentivo à busca da verossimilhança processual.

Por tudo isso é que exsurge a importância de se conferirem meios de acesso à cooperação jurídica internacional, via auxílio direto, também à defesa e, em especial, meios específicos à Defensoria Pública, propiciando a sua interação com o sistema, pois, embora enfáticas na proclamação dos direitos humanos, como referido acima, as convenções internacionais esbarram em enormes dificuldades quando se trata de conferir-lhes efetividade.

Como lembra Gomes Filho, procura-se assegurar à defesa, em paridade com o Ministério Público, a possibilidade de utilizar determinadas fontes de prova. Entretanto, como é fácil imaginar, inúmeros obstáculos se apresentam a uma efetiva concretização desse direito e, consequentemente, ao próprio direito à prova. Ademais, basta lembrar a

\footnotetext{
${ }^{234}$ Le investigazioni preventive dei difensore. Milano: Giuffré, 2003, p. 15-20 apud MACHADO, André Augusto Mendes. A Investigação Criminal Defensiva. Dissertação de Mestrado apresentada na Faculdade de Direito da Universidade de São Paulo. São Paulo, 2009, p.112.

235 MACHADO, André Augusto Mendes. A Investigação Criminal Defensiva. Dissertação de Mestrado apresentada na Faculdade de Direito da Universidade de São Paulo. São Paulo, 2009, p. 132.

${ }^{236}$ BARRETO, Irineo Cabral. A Convenção Europeia dos Direitos do homem anotada. 3 ed. Coimbra: Coimbra Editora, 2005, p. 136.
} 
necessidade de regulamentação dessas atividades, que acabam por gerar uma relação de dependência entre os investigadores particulares e os órgãos estatais incumbidos das mesmas tarefas, assim como a acentuação da desigualdade entre ricos e pobres. ${ }^{237}$

Poder-se-ia argumentar, inclusive, que a investigação defensiva, apesar de concebível no plano teórico, seria impraticável no Brasil, em virtude da precária situação econômica da maioria dos imputados, que não podem custear defensor particular. Em contraponto, entretanto, é exatamente neste contexto que incumbe ao Estado suprir a deficiência econômica do acusado, por intermédio da atuação da Defensoria Pública. ${ }^{238}$

O imputado tem, de fato, o direito fundamental de defesa, do qual se extraem os direitos à prova e à investigação. $\mathrm{O}$ direito de defesa é essencial para garantir a regularidade da própria persecução penal.

\subsubsection{Instrumentalização da paridade de armas e atuação da defesa: decretação da confidencialidade da medida cooperacional e contraditório diferido}

Às partes, como já amplamente referido no capítulo anterior, devem ser oferecidas as mesmas oportunidades e os mesmos instrumentos para intervir no processo, uma vez que, conforme ensina Alessandro Malinverni, a relação entre o direito ao contraditório e o direito do acusado à contestação da prática criminosa revela uma característica do processo: a de desenvolver-se em forma dialética. ${ }^{239}$

Fechando o círculo e filiando-se às palavras de Cervini, ${ }^{240}$ pode-se dizer que existe uma inseparável simbiose entre o contraditório e o magistério da defesa. O direito a ter uma defesa técnica implica o direito a estar assistido por um defensor legalmente habilitado ou nomeado de ofício pelo Juiz. No que se refere à prova produzida no exterior, a observância do direito de defesa se manifesta, fundamentalmente, na oportunidade de acompanhamento do ato a ser implementado no Estado requerido, como também por intermédio do direito do acusado de ser assistido por um profissional. Assim, o autor prossegue referindo que, assim

\footnotetext{
237 GOMES FILHO, Antonio Magalhães. Direito à Prova no Processo Penal. São Paulo: Editora Revista dos Tribunais, 1997 , p. 87 e nota 81.

${ }^{238}$ Se o imputado não tiver condições de suportar os custos de um advogado, incumbe ao Estado prover assistência jurídica integral e gratuita, nos termos do referido artigo $5^{\circ}$, LXXIV, da Constituição da República, e do artigo $8^{\circ}, 2$, "e", da Convenção Americana sobre Direitos Humanos.

${ }^{239}$ MALINVERNI, Alessandro. Principi del Processo Penale. Milano: Torim Giapichelli, 1972, pp. 11-12 citado por ABADE, Denise Neves. Garantias do Processo Penal Acusatório: o Novo Papel do Ministério Público no Processo Penal de Partes. Rio de Janeiro: Renovar, 2005, p. 218.

${ }^{240}$ CERVINI, Raul. Principio de Confidencialidad y Magisterio de la Defensa en la Cooperación Judicial Penal Internacional. Revista de la Facultad de Derecho, n 31, Montevideo, julio-diciembre 2011, pp. 108-9.
} 
como o acusado tem direito a uma defesa efetiva, também tem o direito a um controle técnico da regularidade dos atos realizados no exterior por parte de seu representante legal, incumbindo às autoridades competentes o dever de atuar de modo a assegurar ao interessado o gozo efetivo desse direito. ${ }^{241}$

Em determinados casos, o desconhecimento por parte do sujeito afetado de uma medida de cooperação internacional a ser adotada é legítimo. A regra da imediata comunicação da existência e do conteúdo de uma imputação ao sujeito imputado pode ser flexibilizada, caso seja imprescindível ao sucesso da medida. Perderia o sentido, por exemplo, avisar o sujeito de que interceptações telefônicas estão sendo realizadas, tal como informar que o sigilo epistolar será quebrado no interesse de investigação em curso.

Assim, para tratar desse assunto, será feita referência ao Protocolo de Assistência Jurídica Mútua em assuntos Penais do Mercosul, conhecido como Protocolo de San Luis, o qual dispõe no artigo 10 sobre o caráter confidencial da solicitação:

A pedido do Estado requerente, será mantido o caráter confidencial da solicitação e de sua tramitação. Se a solicitação não puder ser cumprida sem infringir esse caráter confidencial, o Estado requerido informará esse fato ao Estado requerente que decidirá se insiste na solicitação.

Deve-se ter em mente que essa previsão deve ser tratada como exceção, pois, sob a perspectiva do Estado de Direito e de suas garantias, a atuação da defesa técnica constitui nos casos de interação processual penal internacional um imperativo inafastável de legitimidade. ${ }^{242}$ Sendo assim, deve-se ter muito cuidado acerca da imposição desse caráter confidencial em determinadas medidas. Como adverte Cervini, tratam-se de medidas de assistência consistentes em quebra de sigilo bancário, bloqueio de bens, inspeções, violação de domicílio, interceptação de correspondências e sequestro de bens, por exemplo, por configurarem medidas bastante gravosas ao sujeito afetado por elas, o qual se encontra, na prática, em muitos casos, desprovido de defesa e de amparo legal, o que é de todo inadmissível, sob pena de se derrogarem as garantias constitucionais e legais que possui todo cidadão, bem como anular a função primordial do direito, que é a de atuar de forma preventiva às possíveis lesões subjetivas aos direitos do sujeito afetado. ${ }^{243}$

\footnotetext{
${ }^{241}$ BARRETO, Irineo Cabral: A Convenção Europeia dos Direitos do Homen Anotada, 3 ed. Coimbra Editora Coimbra, 2005, p. 171.

242 DELMAS-MARTY, Mireille. Os crimes internacionais podem contribuir para o debate entre universalismo e relativismo de valores? In: CASSESE, Antonio; DELMAS-MARTY, Mireille. Existe um conflito insuperável entre soberania dos Estados e Justiça Penal Internacional? São Paulo: Manole, 2004, p. 105.

243 CERVINI, Raúl. Principio de Confidencialidad y Magisterio de la Defensa en la Cooperación Judicial
} 
Nesse sentido, o princípio de confidencialidade ${ }^{244}$ procura impedir o prévio conhecimento da existência da medida cooperacional penal internacional solicitada e o conhecimento prévio da sua data de realização, meios e procedimentos com os quais se levará a cabo a execução da medida sigilosa; porém, como refere Cervini, de forma alguma se pode cercear a possibilidade de controle precautório concomitante e posterior à execução da medida intrusiva de direitos e suas consequências por parte do advogado do investigado. ${ }^{245}$ Para Solange Mendes de Souza, “evidente que o sigilo, opondo-se à regra de publicidade, deve ter emprego criterioso, justificado por princípio constitucional que permita, no caso concreto, aferir sua indispensabilidade". 246

Na própria Resolução n. 9/2005 do STJ, o parágrafo único do art. $8^{\circ}$ excepciona a regra contida no caput - o qual estabelece, em homenagem ao princípio do contraditório, que a parte interessada será citada para, no prazo de 15 (quinze) dias, contestar o pedido de homologação de sentença estrangeira ou intimada para impugnar a carta rogatória —, referindo que "a medida solicitada por carta rogatória poderá ser realizada sem ouvir a parte interessada quando sua intimação prévia puder resultar na ineficácia da cooperação internacional".

Interessante pontuar que, na seara doméstica, só há regulamentação da questão do contraditório - ainda que "diferido, retardado ou postergado", conforme já se manifestou o $\mathrm{STF}^{247}$ — para as cartas rogatórias. Como lembra Dora Cavalcanti Cordani, 248 "ao contrário do que ocorre nas rogatórias passivas, a parte interessada no pedido de auxílio direto deparase com um verdadeiro deserto normativo". Para a autora, na realidade, a insegurança jurídica imposta ao atingido pelo auxílio direto tem início já no que toca aos critérios que o

Penal Internacional. Revista de la Facultad de Derecho, Montevideo, julio-deciembre, 2011, p. 106.

${ }^{244}$ Como citado, no marco da cooperação jurídica internacional penal, o Juiz exortante pode utilizar a faculdade prevista, entre outras Convenções e acordos bilaterais, no art. 10 do Protocolo de San Luis - atinente à cooperação penal no âmbito do Merscosul - que expressa o seguinte: “A pedido do Estado requerente, será mantido o caráter confidencial da solicitação e de sua tramitação. Se a solicitação não puder ser cumprida sem infringir esse caráter confidencial, o Estado requerido informará esse fato ao Estado requerente que decidirá se insiste na solicitação".

${ }^{245}$ CERVINI, Raúl. Principio de Confidencialidad y Magisterio de la Defensa en la Cooperación Judicial Penal Internacional. Revista de la Facultad de Derecho, n 31, Montevideo, julio-diciembre 2011, p. 112.

${ }^{246}$ SOUZA, Solange Mendes de. Cooperação Jurídica Penal no Mercosul: Novas Possibilidades. Rio de Janeiro: Renovar, 2001, p. 215.

${ }^{247}$ HC 89.651, 2a Turma do STF, julgado em 10/04/2007, e HC 89.555, 89.651 e 90.485, todos voltados contra o exequatur concedido na Carta Rogatória n. 1.621, que foram denegados por unanimidade pela 2a Turma do STF, que reconheceu cuidar-se de "caso de contraditório diferido, retardado ou postergado" plenamente aceitável.

${ }^{248}$ CORDANI, Dora Cavalcanti. Cooperação Jurídica Internacional em Matéria Penal no Brasil: as Cartas Rogatórias e o Auxílio Direto - Controle dos Atos pela Parte Atingida. In: VILARDI, Celso Sanchez; PEREIRA, Flávia Rahal Bresser; NETO, Theodomiro Dias. Direito Penal Econômico - Crimes Econômicos e Processo Penal. São Paulo: GVLaw e Ed. Saraiva, 2008, pp.119-122. 
distinguem da rogatória em sentido estrito, o que geraria um "sem-número" de dúvidas, por exemplo: o juiz de primeiro grau, competente para decidir sobre os atos atinentes ao auxílio direto de acordo com a Portaria Conjunta n. 1, deverá cientificar a parte interessada sobre a existência do pedido de assistência? Será a ela assegurado, por analogia, o direito de impugnar o pleito da Justiça Rogante, podendo inclusive recorrer da determinação de cumprimento da diligência solicitada? Poderá a parte valer-se de embargos dirigidos à Presidência do STJ, nos moldes previstos em relação aos atos praticados pelo tribunal ou juiz que estiver dando cumprimento à carta rogatória? É por essas e outras razões que se entende imprescindível a inclusão da defesa no procedimento atinente ao auxílio direto, de acordo com a proposta do presente trabalho. ${ }^{249}$

Categoricamente, destaca o jurista Carlos Ramos Rubio que, ainda que tenha sido solicitada a confidencialidade da medida cooperacional requerida, as declarações e as diligências probatórias efetuadas ante organismos jurisdicionais estrangeiros vulneram as garantias processuais se durante a sua efetiva realização não estão presentes os processados nem suas defesas. Naturalmente, não basta a mera presença física do advogado, ele deve estar munido de poderes para agir e estar protegido para fazê-lo eficazmente. O caráter sigiloso da medida não deve servir de excusa para impedir o controle simultâneo e posterior da sua execução pelo defensor técnico, sob pena de violação do princípio da igualdade de armas, as garantias da defesa e o próprio princípio de presunção de inocência. ${ }^{250}$

A esse respeito, deve-se ter em conta que, como um dos pilares de um processo de garantias, a presunção de inocência se manifesta na regra do in dubio pro reo, que se expressa em dois aspectos complementares: como garantia política e como regra de tratamento do investigado.

Como garantia política, impõe que a quebra do estado geral de inocência seja precedida, necessariamente, pela observância do devido processo legal e, simultaneamente,

\footnotetext{
${ }^{249}$ Nesse sentido, Dora Cavalcanti Cordani é enfática ao afirmar que "ao menos por ora, graças aos precedentes judiciais, o vazio normativo parece superado pela não aplicação da regra alusiva ao auxílio direto, o que de modo algum recomenda permaneça esta modalidade de cooperação carente da devida regulamentação." (Ibidem, p. 122).

${ }^{250}$ Em livre tradução. No original: "las declaraciones y las diligencias probatorias efectuadas ante organismos jurisdiccionales extranjeros, aún mediando la solicitud de confidencialidad, vulneran las garantías procesales si durante su efectiva realización no están presentes ni los procesados ni sus defensas. Naturalmente con la simple presencia física del abogado no alcanza, éste debe estar facultado para actuar y protegido para hacerlo eficazmente. Como otros publicistas contemporáneos reconoce que el carácter sigiloso de la medida no sirve de excusa para impedir el control simultáneo y posterior de la ejecución de la medida por parte del defensor técnico, ello violaría el principio de "igualdad de armas", las garantías de la defensa y el propio principio de presunción de inocencia". (RUBIO, Carlos Ramos. Comisiones Rogatorias para la obtención de pruebas Problemas de validez de las pruebas obtenidas en el extranjero: análisis de la jurisprudencia del Tribunal Supremo Español. Estudios Jurídicos No. 3, Ministerio Fiscal, Madrid, 2003, p. 357).
} 
como regra de tratamento do acusado ao longo do processo, encarna, a seu turno, a exigência da mais ampla defesa com o consequente acompanhamento da assistência técnica em todo trâmite processual suscetível de causar gravame irreparável aos direitos do acusado. ${ }^{251}$

Em relação às soluções existentes no plano interno para não infringir essas garantias, Marcelo Caetano Guenzelli Peruchin sintetiza a questão e menciona o instituto do contraditório diferido, referindo que, pelo imperativo do art. $5^{\circ}, \mathrm{LV}$, da Constituição Federal, afigura-se obrigatória a presença ativa do defensor em qualquer interrogatório policial, em qualquer ato de obtenção de prova judicial e também no caso de medidas de cooperação jurídica internacional - ou seja, imperiosa a presença do defensor controlando e fiscalizando os aspectos formais de todos os atos cooperacionais solicitados ao Juiz comissionado. No caso excepcional de decretação de sigilo ou confidencialidade da medida, corresponderá igualmente a presença e atuação técnica do defensor, "a partir do momento que inicia a execução da medida de cooperação decretada preventivamente como sigilosa". O controle e a fiscalização do advogado terão por objeto a regularidade referida à execução ou implementação da medida. Nesse caso, prevê-se para tais hipóteses o exercício pleno de um contraditório diferido acerca do mérito para um momento posterior à realização da medida sigilosa, de acordo com jurisprudência consolidada do Supremo Tribunal Federal nesse sentido. ${ }^{252}$

${ }^{251}$ BADARÓ, Gustavo Henrique Righi Ivahy. Ônus da Prova no Processo Penal. São Paulo: Editora Revista dos Tribunais, 2003, p. 286.

${ }^{252}$ PERUCHIN, Marcelo Caetano Guazzelli. Legitimação ativa e direito a ampla defesa e ao contraditório pelo cidadão envolvido na Cooperação Judicial Penal Internacional. Dissertação de mestrado. Pontifícia Universidade Católica Do Rio Grande Do Sul, Porto Alegre, agosto 2000, p. 80. Em tese de doutorado sobre o tema, o mesmo autor aprofunda a questão, especificamente, em relação às cartas rogatórias, no seguinte sentido: "Infelizmente, na história das deliberações acerca de cartas rogatórias passivas examinadas tanto pelo STF, como pelo STJ (a título de ilustração, veja-se: BRASIL. Superior Tribunal de Justiça. EDcl na CR 438/BE, Rel. Ministro LUIZ FUX, CORTE ESPECIAL, julgado em 01/08/2008, DJe 20/10/2008. Disponível em: <http://www.stj.jus.br>. Acesso em: 05 jan. 2013; BRASIL. Supremo Tribunal Federal. HC 90485, Relator(a): Min. CEZAR PELUSO, Segunda Turma, julgado em 10/04/2007, DJe-032 DIVULG 06-06-2007 PUBLIC 0806-2007 DJ 08-06-2007 PP-00048 EMENT VOL-02279-04 PP-00685. Disponível em: <http://www.stf.jus.br>. Acesso em: 10 fev. 2013; BRASIL. Supremo Tribunal Federal. HC 89171, Relator(a): Min. MARCO AURÉLIO, Relator(a) p/ Acórdão: Min. MENEZES DIREITO, Primeira Turma, julgado em 24/03/2009, DJe-084 DIVULG 07-05-2009 PUBLIC 08-05-2009 EMENT VOL-02359-03 PP-00426 RTJ VOL-00210-01 PP-00274 RT v. 98, n. 886, 2009, p. 479-487 LEXSTF v. 31, n. 365 , 2009, p. 333-348. Disponível em: <http://www.stf.jus.br>. Acesso em: 08 out. 2012) - antes e após a entrada em vigor das alterações trazidas pela EC 45/2004, portanto -, em algumas ocasiões o contraditório foi postergado ou diferido, sem que se tenha exigido qualquer motivação do Estado requerente acerca do cabimento da medida inaudita altera parte, ou seja, sem que o país rogante tenha demonstrado os requisitos para a concessão válida do pedido veiculado na carta rogatória ainda antes da citação da pessoa alvo da medida, para que tivesse a oportunidade de oferecer a sua impugnação, vinculada aos aspectos formais. $O$ fundamento utilizado nessas decisões para a consideração do cabimento e da legalidade da postergação do contraditório (deixá-lo para ser exercido após a concessão da medida inaudita altera parte) foi o risco de frustração da cooperação judicial internacional, o que se nos apresenta como fundamento insuficiente e descabido. (PERUCHIN, Marcelo Caetano Guazzelli. Cooperação judicial internacional: a invalidade do art. $8^{\circ}$, parágrafo único, da Resolução $n^{\circ} 09$, do Superior Tribunal de Justiça, de 2005. Tese Doutorado - Programa de Pós-Graduação em Direito - Faculdade de Direito, 
Nesses termos, a atividade de controlador técnico desempenhada pela defesa deverá ser tutelada pelo magistrado responsável direto pela condução e implementação da medida qualificada como confidencial. ${ }^{253}$

Atualmente, a parte atingida pelo pedido de assistência ativo pode submeter ao DRCI pedido de acompanhamento dos atos por ele praticados, desde que comprove ter obtido autorização para este fim do juiz presidente da causa no seio da qual dito pedido foi expedido. Por essa razão, é de extrema importância que a formulação dos pedidos de assistência seja noticiada nos autos principais - seja da ação penal, seja de procedimento investigativo - e não à margem do conhecimento do acusado. ${ }^{254}$ Para Dora Cavalcanti Cordani, em suma, "de raiz constitucional incontestável, o direito do cidadão brasileiro a exercer a ampla defesa, com todos os meios e recursos a ela inerentes, também nos processos de cooperação internacional ativa que tenham o condão de afetar seus interesses individuais, não pode seguir sendo ignorado". ${ }^{255}$

Ademais, o Professor italiano Polimeni dá a palavra final na matéria, esclarecendo que

a regra geral em um processo penal democrático é a publicidade dos atos. Isso alcança, inclusive, as instâncias de cooperação jurídica internacional penal. Logo, a cláusula de confidencialidade não autoriza obstaculizar o devido controle por parte da defesa, em relação à execução de medidas de cooperação jurídica internacional, particularmente, daquelas mais gravosas e passíveis de fracionamento (casos de busca e apreensão de bens e documentos), sob o pueril pretexto de evitar sua frustração ou obstáculos à sua boa e fluida execução. Realmente em tais casos o que se frustra é o próprio exercício do direito, já que não é admissível face ao mesmo (direito), uma "execução fluida" de tais medidas sem o devido controle do advogado. É natural e inerente ao exercício das garantias da cooperação

Pontifícia Universidade Católica do Rio Grande do Sul, 2012, p. 276).

${ }^{253}$ CERVINI, Raul. Principio de Confidencialidad y Magisterio de la Defensa en la Cooperación Judicial Penal Internacional. Revista de la Facultad de Derecho, no 31, Montevideo, julio-diciembre 2011, p. 110.

254 "Mesmo na hipótese de envolver a rogatória ativa ou o auxílio direto ativo medida cautelar que implique, aos olhos da autoridade requerente, em postergação do contraditório para momento posterior à efetivação da diligência requerida, é insofismável que, uma vez colhida a prova, deve ser esta juntada aos autos acompanhada das cartas ofícios, ou e-mails trocados entre os países com o fim de obtê-la. De rigor salientar que apenas a medida de urgência que comportar o contraditório diferido é que pode, em tese, ser mantida à margem do conhecimento da parte atingida enquanto estiver pendente de cumprimento, não porém outros pedidos que porventura integrem o mesmo pedido de assistência. [...] Isto porque, muito embora nas hipóteses de pedidos de assistência ativos o contraditório e a ampla defesa possam ser exercidos perante o Estado estrangeiro, o livre acesso aos termos do pedido formulado, assim como aos documentos que o instruíram, é imprescindível ao efetivo exercício das garantias individuais de índole processual penal tanto aqui quanto lá". (CORDANI, Dora Cavalcanti. Cooperação Jurídica Internacional em Matéria Penal no Brasil: as Cartas Rogatórias e o Auxílio Direto - Controle dos Atos pela Parte Atingida. In: VILARDI, Celso Sanchez; PEREIRA, Flávia Rahal Bresser; NETO, Theodomiro Dias. Direito Penal Econômico - Crimes Econômicos e Processo Penal. São Paulo: GVLaw e Ed. Saraiva, 2008, pp. 123-4).

${ }^{255}$ Ibidem, p. 126. 
jurídica internacional penal a atuação de controle jurídico-formal do advogado in loco, durante a implementação das medidas cooperacionais. Isso tudo ainda em relação às medidas pré-qualificadas como sigilosas, que no caso somente o serão quanto ao mérito, estratégia e oportunidade (com base em que direito, como e quando executá-las). Superado este nicho de justificado sigilo, uma vez iniciada sua implementação, já haverá desaparecido todo risco de desvirtuar tal categoria de medida reservada e os atributos da defesa plasmados no controle integral da execução material recobrarão sua inerente gravitação constitucional e toda sua força vigilante para o devido resguardo de suas sequelas formais. ${ }^{256}$

Em suma, comunga-se da noção de que o exercício do chamado contraditório diferido, postergado ou retardado, acatado pela jurisprudência pátria na cooperação jurídica internacional, deve ser levado a efeito somente em relação ao mérito da questão qualificada como sigilosa ou, no caso das rogatórias em que é concedido o exequatur de medida cautelar inaudiatur et altera pars (sem a oitiva da parte afetada), observado que a partir do momento em que se iniciam os atos executórios da medida a defesa deve fazer valer o seu direito de controlador, ao menos, da regularidade formal.

De acordo com tal entendimento, ao qual se filia o presente trabalho, as medidas de assistência penal internacional qualificadas como confidenciais devem ser analisadas, necessariamente, de maneira fracionada. Sendo assim, a parte confidencial da medida tem toda sua vigência no campo da determinação ao como e quando da medida; entretanto, uma vez iniciada sua execução, afigura-se indiscutível que se deve facilitar a presença e o controle por parte do advogado de defesa.

A título de exemplo, Dora Cavalcanti Cordani ${ }^{257}$ menciona a troca de informações entre Brasil e Estados Unidos no caso da "Força-Tarefa CC5" e sua atuação no Caso Banestado, em que ainda há discussão acerca da licitude das medidas cooperacionais adotadas no caso, referindo ser ainda cedo para avaliar como estas questões formais serão

\footnotetext{
${ }^{256}$ POLIMENI, Gioacchino. La assisttenza in materia penale, Milan, Turccio, 1990, p. 19 apud CERVINI, Raúl. Principio de Confidencialidad y Magisterio de la Defensa en la Cooperación Judicial Penal Internacional. Revista de la Facultad de Derecho, no 31, Montevideo, julio-diciembre 2011, p. 110. Também dentro da doutrina cooperacionista italiana Gianluca DIANESE sustenta: "As medidas de assistência penal internacional qualificadas pelo magistrado exortante com a prerrogativa da confidencialidade, devem ser analisadas necessariamente fracionadas. $\mathrm{O}$ segredo exaure toda sus vigência no plano da determinação relativa ao como e quando da medida. Entretanto, uma vez iniciada sua execução, indiscutível que a sede comissionada deve facilitar a presença e controle, pelo advogado da parte afetada pela medida". (DIANESE, Gianluca. Le rogatorie internazionali in materia penale. Edizioni Giuridiche Simone, Arzano, 1998, p. 58. No mesmo sentido: RAMAJOLI, Sandro. Rogatoria all"estero e garanzie difensive, en Giustizia Penale III, pp. 338 e ss. apud CERVINI, Raúl. Principio de Confidencialidad y Magisterio de la Defensa en la Cooperación Judicial Penal Internacional. Revista de la Facultad de Derecho, $n^{\circ}$ 31, Montevideo, julio-diciembre 2011, p. 110).

${ }^{257}$ CORDANI, Dora Cavalcanti. Cooperação Jurídica Internacional em Matéria Penal no Brasil: as Cartas Rogatórias e o Auxílio Direto - Controle dos Atos pela Parte Atingida. In: VILARDI, Celso Sanchez; PEREIRA, Flávia Rahal Bresser; NETO, Theodomiro Dias. Direito Penal Econômico - Crimes Econômicos e Processo Penal. São Paulo: GVLaw e Ed. Saraiva, 2008, pp. 129-131.
} 
apreciadas pelos tribunais nacionais. De todo modo, nas palavras da autora, esse caso demonstra ser imprescindível a participação da parte interessada no pedido de auxílio direto, compreendendo não só o conhecimento de seu conteúdo como também os termos em que cumprida e devolvida a solicitação pelo Estado requerido. ${ }^{258}$

A par de todo esse aparato teórico e principiológico, a seguir serão apresentados os meios atualmente disponíveis à atuação da defesa no cenário da cooperação jurídica internacional.

258 Um balanço geral do caso e informações aprofundadas sobre o caso podem ser obtidas em: <http://noticias.pgr.mpf.mp.br/noticias/noticias-do-site/copy of criminal/mpf-pr-balanco-sobre-o-casobanestado>. Último acesso em: 03 out. 2014. 


\section{COOPERAÇÃO JURÍDICA INTERNACIONAL E ATUAÇÃO DA DEFESA: OFENSA AO PRINCÍPIO DA PARIDADE DE ARMAS}

Em primeiro lugar, cumpre referir que se deve primar pela possibilidade de utilização dos mecanismos de cooperação internacional da forma mais abrangente possível.

Como já referido, o princípio básico que rege a cooperação jurídica internacional é o de que ela deve ser a mais ampla possível. ${ }^{259}$

Regra geral, o particular pode efetuar a produção de prova diretamente no exterior, na medida em que o investigado, o acusado ou seu defensor podem obter documentos fora do país e legalizá-los perante as autoridades consulares nacionais. Tal prática consiste na cooperação com “consularização" ou legalização consular. ${ }^{260}$

Como assinalado, a prova poderá ser produzida diretamente pela parte no exterior e submetida a legalização consular, ou, ainda, pode-se utilizar o mecanismo das cartas rogatórias, ${ }^{261}$ que não encontra os mesmos empecilhos dos pedidos de auxílio direto.

Ocorre que, hoje em dia, a via diplomática é cada vez menos utilizada para a obtenção

${ }^{259}$ MORO, Sérgio Fernando. Cooperação jurídica internacional em casos criminais: considerações gerais. In: BALTAZAR Jr. José Paulo e LIMA, Luciano Flores de. Cooperação Jurídica Internacional em Matéria Penal. Porto Alegre: Verbo Jurídico, 2010, p. 16. Obviamente, há determinados limites que devem ser observados. Entretanto, tais limites constituem a exceção e não a regra, como já se anotou na nota 32 acima.

${ }^{260}$ ARAS, Vladimir; LIMA, Luciano Flores de. Cooperação Internacional Direta pela Polícia ou Ministério Público. In: BALTAZAR Jr. José Paulo e LIMA, Luciano Flores de Lima. Porto Alegre, Verbo Jurídico, 2010, p. 140.

261 Entretanto, cumpre referir que as cartas rogatórias ativas para realização de diligências (oitiva de testemunhas, peritos etc.) só serão expedidas se demonstrada previamente a sua imprescindibilidade, arcando a parte requerente com os custos de envio (art. 222-A do CPP). Nesse ponto, interessante lembrar que no caso da Ação Penal 470 - conhecido "Caso do Mensalão" julgado pelo STF - o custo para que fossem feitas oitivas de testemunhas no exterior ultrapassaram a cifra de dezenove milhões de reais - “O ministro calculou que seriam gastos mais de $\mathbf{R} \$ 19$ milhões para a tradução de três cartas rogatórias — já que as de Portugal não precisam ser traduzidas - porque 'o acesso ao inteiro teor dos autos deve ser garantido, para permitir a melhor colheita das provas, sob o crivo do contraditório'. Barbosa deu, então, prazo de cinco dias para que os réus demonstrassem a necessidade de ouvir as testemunhas apontadas, a colaboração que poderão prestar e a disposição em pagar as passagens de ida e volta para elas. Na petição protocolada nesta segunda-feira (16/2) no Supremo, os ex-funcionários do Banco Rural descrevem qual é a importância de cada uma das quatro testemunhas para sua defesa. Apesar de justificar os motivos do arrolamento, a defesa afirma que a regra que exige isso é 'evidentemente afrontosa ao constitucional direito à ampla defesa'. E diz que a oitiva é imprescindível, sob pena de cerceamento de defesa. [...] Sobre a possibilidade de a parte pagar as despesas com passagens e estadia, os ex-diretores afirmam que 'impor à testemunha o deslocamento entre países constituiria ônus pessoal injustificável e constrangedor a quem deverá servir aos interesses da Justiça"". Disponível em: <http://www.conjur.com.br/2009-fev-16/reusmensalao-insistem-oitivas-testemunhas-exterior $>$. Acesso em: 21 jun. 2013. A esse respeito, Denise Neves Abade se pronuncia de modo bastante coerente: “[...] Ora, se o Poder Judiciário entende que o requerimento de expedição de Carta Rogatória Ativa é manobra protelatória [...] deve indeferi-las. Porém, soa contraditório e ofensivo ao princípio da igualdade de armas e ao devido processo legal exigir que a Defesa custeie antecipadamente a produção probatória imprescindível ao justo processamento da lide penal." (ABADE, Denise Neves. Direitos fundamentais na cooperação jurídica internacional: extradição, assistência jurídica, execução de sentença estrangeira e transferência de presos. São Paulo: Saraiva, 2013, p. 331). 
de provas criminais, sendo empregada quando não existem tratados de assistência jurídica mútua, servindo para as hipóteses de formalização de compromissos de reciprocidade, ou para as situações em que a lei nacional ou o próprio tratado de cooperação vigente exigem a utilização de rogatórias.

Como visto em capítulo precedente, na maioria dos tratados bilaterais há vedação explícita à utilização do auxílio direto para a produção de prova pela defesa. ${ }^{262}$ Pertinente citar a posição defendida por David McClean no sentido da obrigação de assistência mútua, "a qual, na medida do possível implica que, dentro do contexto do pedido, todas as ações possíveis relacionadas com a investigação e acusação de criminosos podem, em princípio, ser requeridas" e que os "pedidos relacionados a formas de assistência não explicitamente descritas nas convenções podem também ser respeitados". Na visão do autor:

haveria espaço para a utilização dos novos métodos de investigação. Assim, as convenções sobre assistência mútua seriam instrumentos flexíveis, cuja aplicação poderia ser ajustada de acordo com as necessidades dos tempos e sem fazer uma mudança formal no texto da convenção. ${ }^{263}$

Como averiguado, entretanto, não é exatamente isso que se verifica na prática internacional e nos tratados bilaterais em que o Brasil é parte.

Desse modo, pode-se esquematizar a questão do atendimento aos pedidos de cooperação pela via do auxílio direto para produção de prova em matéria de defesa da seguinte forma: 1) países que não apresentam qualquer oposição em cumprir pedidos de cooperação por esse mecanismo ou que até o momento permanecem silentes quanto ao assunto $^{264}$ e 2) países que denegam a cooperação, quando os pedidos são veiculados por esse

\footnotetext{
${ }^{262}$ Quando há, no texto dos tratados, menção à proibição aos particulares stricto sensu.

263 Tradução livre de: "The obligation to grant mutual assistance to the maximum possible extent implies that, within the context of the request, all possible actions related to the investigation and prosecution of criminals can, in principie, be asked for". E prossegue o autor: "In that sense, requests related to forms of assistance not explicitly described in the Convention may also be complied with. This leaves room for the use of new methods of investigation as well as for laying certain emphasis which would, for instance be stressed by the European Union. Thus, the conventions on mutual assistane are flexible instruments, the application of which can be adjusted depending on the needs of the times and without making a formal change to the text of the convention." (MCCLEAN, David. International Co-operation in Civil and Criminal Matters, Oxford 2002, p .173).

${ }^{264}$ Como já referido, mas que compete reiterar nesse momento, em consulta feita ao Departamento de Recuperação de Ativos e Cooperação Jurídica Internacional restou esclarecido o seguinte: "Pelos registros do nosso Departamento, tramitam ou tramitaram 60 pedidos de cooperação com o objeto de ouvir testemunhas de defesa. Identificamos que os seguintes países não cumprem tais pedidos: China, Estados Unidos da América, Canadá e México. Tais Estados transmitiram documentos formais, nos quais restam esclarecidas as razões de direito interno para a não execução da referida diligência.

Por exclusão, consideramos que os demais países poderiam cumprir instrumento rogatório que almeja a oitiva de testemunhas, a exemplo de Alemanha, Uruguai e Rússia - que diligenciaram plenamente as requisições. Para os países: Bolívia, Inglaterra, Noruega, Israel, Gibraltar, Ilhas Virgens Britânicas, os pedidos ainda seguem
} 
meio (auxílio direto) e com esse intuito (defesa). ${ }^{265}$

O presente trabalho, por óbvio, concentrará sua atenção no segundo grupo, entretanto, também pretende incrementar os mecanismos de cooperação quando realizados com países pertencentes ao primeiro grupo, tendo em vista que a atuação da defesa não resta prejudicada apenas quando a prova é negada, mas também quando a prova é produzida sem respeito aos direitos fundamentais do acusado.

Ainda que a sistemática da denegação dos pedidos de auxílio direto para a defesa, com fulcro nos tratados bilaterais em vigor, seja criticável por sua evidente limitação à ampla defesa, a eliminação de tal óbice dependeria do aperfeiçoamento da negociação de tratados internacionais do gênero, e não pode ser resolvida mediante imposição unilateral de qualquer dos Estados-partes. ${ }^{266}$

Paula Bajer Fernandes da $\operatorname{Costa}^{267}$ enfatiza que os agentes públicos dispõem dos

em trâmite e, até o momento, não identificamos qualquer sinalização de que não serão cumpridos. Além disso, observar tratados citados no capítulo 1.

${ }^{265}$ Países como os Estados Unidos, a China, a Colômbia dentre outros e, mesmo no âmbito do Mercosul, entendem pela impossibilidade de aplicação do instituto para a defesa de particulares. Conforme Vladimir Aras, a utilização da via baseada em tratados de assistência jurídica mútua em matéria penal (MLAT) não tem sido facultada à defesa. $\mathrm{O}$ atendimento de solicitações no interesse exclusivo do investigado ou denunciado tem sido rechaçado nesses tratados e na práxis cooperativa estatal. De igual modo, informações prestadas pelo DRCI dão conta da existência concreta de tal espécie de denegação.

${ }^{266}$ Ainda que haja quem refira que a cortesia internacional seria suficiente para solucionar a questão, como se extrai do seguinte trecho: "As seguintes duas situações excepcionais, com respeito ao pedido de assistência internacional apenas baseadas na cortesia internacional, são: o pedido pode contribuir para a melhoria da situação pessoal do réu ou condenado ou à sua reinserção social e pode servir para esclarecer a situação judicial de um cidadão romeno (ou semelhante), no sentido de que se concentre na pessoa e não no ato criminoso em si. Toda vez que a situação de uma pessoa acusada ou condenada possa ser melhorada, a sua reintegração social possa ser mais fácil de ser concretizada ou a situação pessoal de um romeno possam ser esclarecidas, o princípio da reciprocidade não é mais necessário, sendo a cortesia internacional suficiente. Consideramos que para regulamentar estas situações excepcionais, o legislador romeno levou em consideração o lado social e humanitário da persecução, com as suas duas funções, a sanção e a prevenção." Tradução livre de: "The following two exceptional situations, respective the request for international assistance only based on international courtesy in the cases where: 'it or it may contribute to the improvement of the defendant's or convicted person's situation or to its social reintegration' and 'it may serve to clarify the judicial situation of a Romanian citizen'are somewhat similar, in the sense that they focus on the person and not on the criminal act. Every time a defendant's or a convicted person's situation may be improved at a certain moment, its social reintegration may be easier to realize or the personal situation of a Romanian citizen may be clarified, the principle of reciprocity is no longer needed, the international courtesy being sufficient. We find that in regulating these exceptional situations the Romanian legislator has taken into consideration the social, humanitarian side of the prosecution, with its two functions, respective the sanction and the prevention." (POP, Oana Mihaela. The Principles and General Rules of the International judicial Cooperation in Criminal Matters. In: 2008 AGORA Int 1 J. Jurid. Sci. 209 2008. Disponível $\mathrm{em}:<$ https://www.copyright.com/ccc/basicSearch.do\&operation=go\&searchType=0\&lastSearch=simple\&all= on\&titleOrStdNo=1843-570X >. Acesso em 03 set. 2012. p. 212), essa não é reputada a solução mais eficiente e eficaz para solucionar eventual impasse no pedido de produção de provas pela defesa. Seguindo linha de raciocínio de Aras, também se espera que o sistema de MLA evolua e não seja mais prerrogativa da acusação. (ARAS, Vladimir; LIMA, Luciano Flores de. Cooperação Internacional Direta pela Polícia ou Ministério Público. In: BALTAZAR Jr. José Paulo e LIMA, Luciano Flores de Lima. Porto Alegre, Verbo Jurídico, 2010). ${ }^{267}$ COSTA, Paula Bajer Fernandes Martins da. Igualdade no Direito Processual Penal Brasileiro. São Paulo: Editora Revista dos Tribunais, 2001, p. 10. 
instrumentos do Estado para a investigação e repressão, enquanto que os indiciados e acusados dispõem dos próprios meios para encontrar e demonstrar a verdade. Por outro lado, sendo público o processo, interessando a todos a verossimilhança processual, também deveriam ser postos à disposição dos acusados e interessados os meios oficiais de procura da verdade.

Desse modo, a impossibilidade de utilização do mecanismo de auxílio direto fundado em determinados acordos bilaterais por si só já atua em prejuízo da defesa, a qual deverá utilizar a morosa e burocrática via diplomática ou solicitar a expedição de cartas rogatórias pelo Juízo, observado que a parte adversa tem mecanismos mais céleres e eficientes para obter ou produzir a prova.

\subsection{Common law $\mathbf{x}$ civil law e a experiência dos tribunais internacionais penais em relação ao princípio da paridade de armas}

Uma das fontes de incessantes problemas para a efetividade da coleta internacional de provas consiste nas diversas concepções que se tem sobre a atividade probatória nos ordenamentos pertencentes ao common law e nos que conformam o civil law. ${ }^{268}$

A referida diversidade se manifesta em uma pluralidade de aspectos, cuja análise em profundidade, como traz Christian Petrus, é imensamente complexa e necessariamente genérica. Entretanto, para realçar essa questão na prática probatória transfronteiriça, basta verificar os principais aspectos distintivos de ambas as tradições jurídicas. ${ }^{269}$

No common law, a prova é concebida como um fenômeno de natureza predominantemente privada, que não se relaciona diretamente com a função pública dos Estados nem compromete o princípio de soberania do Direito Internacional Público. Como resultado, não se verificam problemas na aplicação extraterritorial das regras internas de procedimento de prova, ou, em geral, na obtenção de provas no território de um Estado estrangeiro, sem a ajuda de suas autoridades.

Em contrapartida, a concepção continental enfatiza o caráter soberano da atividade jurisdicional. A obtenção de provas costuma ser contemplada como uma função pública exclusiva das próprias autoridades estatais, inclusive quando se realiza em prol de um

${ }^{268}$ PETRUS, Christian Herrera. La obtención internacional de pruebas, asistencia jurisdiccional en Europa. Real Colegio de España: Bolonia, 2005, p. 71.

${ }^{269}$ Ibidem, p. 72. 
procedimento estrangeiro, no qual as provas surtirão toda a sua eficácia. ${ }^{270}$

Nesse sentido, com o intuito de aferir as possíveis razões para a denegação dos pedidos de cooperação para produção de prova em prol da defesa, sobressai a questão das diferenças intrínsecas aos sistemas do common law e do civil law, como referido, tendo em mente que a cooperação jurídica internacional envolve a solicitação de medidas cooperacionais entre países de distintas tradições jurídicas, e que as principais dificuldades na obtenção internacional de prova estão associadas a esse fator. ${ }^{271}$

Sendo assim, reputou-se interessante mencionar a experiência dos tribunais internacionais penais na matéria, pois ainda que no caso dos tribunais internacionais penais se verifique a jurisdição supranacional, que a natureza dos crimes julgados seja diversa, bem como que haja a cooperação chamada vertical, em contraposição à cooperação horizontal que ocorre entre países soberanos e em jurisdição reconhecida como transnacional, os atos praticados não deixam de se tratar de ações no âmbito da cooperação internacional com países das mais diversas raízes jurídicas, motivo pelo qual se poderia aproveitar a experiência angariada nesses casos para a seara da cooperação jurídica internacional entre os países, na tentativa de aprimorar o sistema, tornando, assim, plenamente efetiva toda a principiologia vigente na matéria, em especial a paridade de armas.

De acordo com Christian Herrera Petrus, ${ }^{272}$ os traços característicos do common law, como expressão por excelência do sistema processual acusatório (adversarial), são a ampla margem de atuação concedida às partes na produção da prova, especialmente durante a fase prévia à judicialização, e as limitadas faculdades do juiz, que atuaria como mero árbitro neutro, intervindo apenas para garantir uma correta confrontação litigiosa e equitativa, porém mantendo atitude passiva em relação ao desenvolvimento e ao resultado final do processo.

Michail Wladimiroff, ${ }^{273}$ explica que, para a perspectiva da defesa, os sistemas do common law e do civil law ${ }^{274}$ têm impactos totalmente diferentes e, ao que tudo indica, a

${ }^{270}$ PETRUS, Christian Herrera. La obtención internacional de pruebas, asistencia jurisdiccional en Europa. Real Colegio de España: Bolonia, 2005, p. 73.

${ }^{271}$ BECHARA, Fábio Ramazzini. Cooperação Jurídica Internacional em Matéria Penal: Eficácia da Prova Produzida no Exterior. São Paulo: Saraiva, 2011, p. 81.

${ }^{272}$ PETRUS, Christian Herrera. La obtención internacional de pruebas, asistencia jurisdiccional en Europa. Real Colegio de España: Bolonia, 2005, p. 74.

${ }^{273}$ WLADIMIROFF, Michail. Cooperation on Criminal Matters: a Defence Lawyer's Perspective. In: R. Yepes-Enríquez and L. Tabassi (eds.), Treaty Enforcement and International Cooperation in Criminal Matters, 2002, pp. 243-244.

${ }^{274}$ Como o Brasil ratificou os tratados bilaterais concernentes ao tema, sem qualquer reserva em relação às tradições jurídicas dos países, as conclusões extraídas são aplicáveis também ao contexto nacional. In verbis: "Na prática, a partir da perspectiva de um advogado de defesa, toda essa rede de convenções e tratados deve 
rede de Convenções e Tratados existentes é orientada pelo sistema continental europeu do civil law, em que a participação da defesa técnica tem papel marginal e secundário, observado que o referido problema se agrava quando a defesa precisa da cooperação de outro Estado em procedimentos prévios à judicialização.

Além disso, o autor invoca que o pressuposto em todos os julgamentos, onde quer e a que nível sejam realizados, é o de que devem ser justos. Porém, isso levanta uma questão: "o que se pretende dizer com 'julgamento justo'?”

A imparcialidade do julgamento é medida no contexto do sistema em que está sendo conduzida. O que seria considerado “justo” em uma jurisdição de common law pode, e deve, ser diferente do que em uma jurisdição norteada pelo civil law. Por exemplo, os direitos de defesa em uma jurisdição de common law não podem funcionar como uma base diretamente traduzida para avaliar os direitos "apropriados" da defesa em uma jurisdição de civil law, pois as justificativas para os processos dos dois sistemas não são compatíveis. Deixando de lado a questão do significado exato de "justiça”, concorda-se, em princípio, que o julgamento

ser vista em conjunto com os dois sistemas jurídicos da Europa em que os instrumentos são impostos: o common law e o direito europeu continental. A posição dos advogados de defesa ao lidar com pedidos em cada uma das convenções é totalmente diferente nestes sistemas. No common law - "sistema acusatório"-, o réu é parte no julgamento, e o sistema impõe à acusação e à defesa as tarefas do desenvolvimento do caso, enquanto as funções do juiz cingim-se às de um árbitro da lei. A tradição continental do civil law, no entanto, utiliza o "sistema inquisitorial": o juiz governa o julgamento tanto como um árbitro da lei quanto como um investigador no desenvolvimento pleno da prova dos fatos. O papel do Ministério Público, portanto, também é diferente. Julgamentos em jurisdições do common law podem ser caracterizados como "horizontais", com as duas partes abordando igualmente a causa, enquanto que no civil law há uma "verticalização" dos julgamentos e, assim, a acusação resta, na verdade, muito perto do juiz e o réu torna-se a matéria do julgamento em vez de um participante neste. Um exame dos mecanismos estabelecidos nas convenções de assistência mútua revela que os pedidos de cooperação entre Estado operam de forma a ter uma conformação orientadad pelo civil law sistema europeu continental. Estas convenções dão espaço muito reduzido para uma participação efetiva do advogado de defesa, quer através da possibilidade de efetuar solicitações, que ao conferir cumprimento aos pedidos, pois a defesa tem um papel bastante marginal no sistema vertical. Este problema se agrava ainda mais quando os advogados de defesa precisam da cooperação do Estado perante um tribunal internacional." Tradução livre de: “In practice, from a defence lawyer's perspective, this whole network of conventions and treaties must be viewed in conjunction with the two legal systems in Europe under which the instruments are enforced: the common law, and the continental European civil law. The position of defence lawyers dealingwith a request under one of the conventions is totally different in these systems. In the common law “adversarial system", the defendant is a party in the trial, and the system tasks the prosecution and defence with fact development while the judge functions principally as an arbiter of the law. The continental civil law tradition, however, utilises the "inquisitorial system": the judge governs the trial as both an arbiter dealing with the law and an investigator fully developing the dossier of facts. The role of the prosecution is also accordingly different. Trials in common law jurisdictions can be characterised as "horizontal", with the two parties equally addressing the cause, while in a civil law "top down trial" the prosecution is actually very close to the bench and the defendant becomes the subject of the trial rather than a participant in it. An examination of the mechanisms established in the mutual assistance conventions reveals that requests for State cooperation operate in a manner fitting a continental European civil law orientation. These conventions give very littie room for effective defence lawyer participation, through either making or complying with requests, because the defence has such a marginal role in the top down system. This problem comes into even sharper focus when defence lawyers need State cooperation in proceedings before an international tribunal. 
deve ser justo. A justiça pode, então, servir como critério para examinar as ferramentas garantidas à defesa em um sistema jurídico. Pode um advogado de defesa, utilizando essas ferramentas, garantir um julgamento justo, fazendo o seu trabalho corretamente? Se forem verificados os instrumentos jurídicos que regem os dois tribunais ad hoc e o Tribunal Penal Internacional (TPI), observa-se que os julgamentos estão sendo realizados de forma semelhante aos julgamentos do sistema de common law e se nota que a defesa não está dotada de ferramentas comparáveis às fornecidas ao Ministério Público. ${ }^{275}$

Ademais, a diferença no papel desempenhado pela defesa pode ser aferida com base na predominância do procedimento contraditório ou inquisitivo. Na Europa, atualmente, todos os procedimentos criminais podem ser descritos como "mistos", pois contêm traços e elementos de diferentes tradições processuais; entretanto, as raízes históricas do processo penal continuam a ser importantes para a compreensão contemporânea dos valores processuais que regem os modelos de ambos os sistemas. ${ }^{276}$ Delmas-Marty, por exemplo, a respeito da bipartição entre common law e o Direito continental, conclui que, "na verdade, a oposição se enfraqueceu consideravelmente, a ponto de tornar possível a proposta de um modelo unificado". 277

De todo modo, ao se traçar um paralelo entre a equidade de tratamento na cooperação com órgãos internacionais ou supranacionais, tais como os Tribunais ad hoc para a Iugoslávia e para Ruanda e o Tribunal Penal Internacional, os quais lidam com países cujo Direito tem origem civilista e origem consuetudinária, e a equidade de tratamento na cooperação jurídica entre os países, as conclusões, como dito, poderiam levar à compreensão das razões pelas quais a cooperação é denegada em determinados casos. ${ }^{278}$

\footnotetext{
${ }^{275}$ No original: In my perception, the fairness of the trial is measured in the context of the system in which it is being conducted. What would be considered "fair" in a common law jurisdiction could, and should, be different than in a civil law jurisdiction. For example, the rights of the defence in a common law jurisdiction cannot function as a directly translated basis for evaluating the "proper" rights of the defence in a civil law jurisdiction because the rationale for the two systems' proceedings are not comparable. Setting aside the question of the exact meaning of "fairness," let's agree in principle that a trial should be fair. Fairness can then serve as a criterion for examining the tools given to the defence by a legal system. Can a defence lawyer, utilising these tools, guarantee a fair trial by doing his or her job properly? If one looks at the legal instruments governing the two ad hoc tribunals and the International Criminal Court (ICC), and observes that the trials are being conducted on a basis similar to common law system trials, one notes that the drafters failed to provide the defence with tools comparable to those provided to the prosecution.

276 HODGSON, Jacqueline S. Safeguarding Suspects' Rights in Europe: a Comparative Perspective. New Criminal Law Review, vol. 14, n. 04, 2011, p. 636. No mesmo sentido: PETRUS, Christian Herrera. La obtención internacional de pruebas, asistencia jurisdiccional en Europa. Real Colegio de España: Bolonia, 2005, p. 76, que menciona que, na realidade, atualmente nenhum ordenamento se ajusta exatamente ao modelo teórico do sistema acusatório ou do sistema inquisitivo. Todos são, em alguma medida, mistos.

277 DELMAS-MARTY, Mireille. Trois défis pour un droit mondial. Paris: Éditions du Seuil, 1998, p. 116.

${ }^{278}$ Os tribunais internacionais penais foram escolhidos por julgar indivíduos e não Estados, além de terem como objeto matéria criminal, em situação análoga aos tribunais nacionais. Além disso, os Estatutos desses Tribunais formulam a normativa de cooperação com os Estados em moldes semelhantes aos que regem
} 
Nesse sentido, Michail Wladimiroff esclarece que, quando solicitada a cooperação do Estado perante um órgão judicial supranacional, como acontecia com o Tribunal Penal Internacional para a ex-Iugoslávia (TPIJ) ou com o Tribunal Penal Internacional para Ruanda (TPIR), por exemplo, o papel do advogado poderia ser bem mais efetivo do que era.

A título de exemplo, o autor narra a seguinte situação:

Imagine que você é um advogado de defesa em um processo perante o TPIJ. Você quer entrevistar alguém que é militar, ou é um policial, e o Estado não está disposto a cooperar com você, porque eles dizem: "Quem é você? Você é um indivíduo, não um órgão do Tribunal. Nós não estamos falando com você, qualquer de seus pedidos será totalmente irrelevante para nós." Você pode relatar a questão a uma câmara de julgamento? O que a câmara de julgamento fará - será que ordenará ao Estado cooperar com a defesa? Pode ser que sim, mas agora imagine o que acontece se você está à procura de testemunhas, no meio de um conflito em curso. Você tem que voltar para a Haia, para pedir uma ordem judicial, esperá-la, pegá-la e, em seguida, retornar com a ordem. E quem é que vai cumprir a ordem judicial? $\mathrm{O}$ Estado? E se o Estado não é um Estado-membro da ONU, mas um fantoche ou um Estado rebelde? Quem é que vai cumprir a ordem, se é um advogado-indivíduo que entrega em mãos? Mais uma vez, você não é um órgão do Tribunal. Você é, politicamente falando, ninguém. Você é apenas um advogado de defesa comum, agindo em nome de um réu sem qualquer posição. ${ }^{279}$

Em igual sentido, Kai Ambos ${ }^{280}$ enfatiza que a experiência dos Tribunais ad hoc

genericamente a cooperação interestatal em matéria penal.

${ }^{279}$ Ibidem, p. 244-246. In verbis: Against this background, imagine you are a defence attorney in a proceeding before the ICTY. You want to interview someone who is in the military, or is a policeman, and the State is not willing to cooperate with you because they say, "Who are you? You are an individual, not an organ of the Tribunal. We are not talking to you; any of your requests are totally irrelevant to us." Can you report that response to a trial chamber? What will the trial chamber do - will they order the State to cooperate with the defence? It may, but now imagine what happens if you are looking for witnesses in the middle of an ongoing conflict. You have to come back to The Hague, ask for a court order, wait for it, get it, and then go back with the court order. And who is going to comply with the court order? The State? What if the State is not a UN member State, but a puppet or a rebel State? Who is going to comply with the order if it is an individual lawyer who hands it over? Again, you are not an organ of the Tribunal. You are, politically speaking, no one. You are just an ordinary defence lawyer, acting on behalf of a defendant without any standing.

${ }^{280}$ No original: "La experiencia de los tribunales ad hoc demuestran que la defensa - sin considerar la circunstancia que entra al caso en una etapa (de antejuicio) muy tardía - nunca tiene iguales, ni similares, posibilidades que la Fiscalía para preparar la causa. Eso se debe en parte a la falta de recursos humanos, lo que hace imposible enviar a personas a los lugares de los crímenes para realmente 'investigar' el caso; mayor importancia tiene, sim embargo, la dependencia respecto de la cooperación estatal em la reunión de pruebas. Mientras resulta difícil para la Fiscalía entrar en el territorio de un Estado en particular con fines investigadores, esto resulta generalmente imposible de todo para la defensa, si el Estado se niega a cooperar. Hay varias causas en que a abogados de la defensa les fue denegado el permiso de ingreso a la República de Bosnia-Herzegovina o de Ruanda. En un caso como el de Milosevic, en el que la Fiscalía depiende fuertemente de información de inteligencia, alguién creería seriamente que la CIA u otro servicio secreto cooperaría voluntariamente com abogados privados de la defensa? De esto modo, la única posibilidad de la defensa para obtener la información necesaria para la preparación de su caso, es que la Fiscalía investigue en ambas direcciones y revele su información a la defensa. [...] Este punto fue destacado durante las negociaciones del Comité Preparatorio antes de la Conferencia de Roma" (AMBOS, Kai. Temas de Derecho 
demonstra que a defesa nunca tem iguais, nem similares possibilidades às que o Ministério Público tem para preparar a causa. Isso se deve em parte à falta de recursos humanos, o que torna impossível enviar profissionais aos locais dos crimes para realmente investigar o caso; maior importância tem, entretanto, a dependência em relação à cooperação estatal na reunião de provas. Enquanto resulta difícil para a Procuradoria ingressar no território de um Estado, em particular com finalidade investigativa, resulta absolutamente impossível para a defesa, se o Estado se nega a cooperar. Existem várias causas em que aos advogados da defesa foi negada permissão para entrar na Bósnia-Herzegovina ou em Ruanda. Em casos como o de Milosevic, nos quais a Procuradoria depende fortemente de informações da inteligência, alguém acreditaria realmente que a CIA ou outro serviço secreto cooperaria voluntariamente com advogados privados da defesa? Deste modo, a única possibilidade de a defesa obter a informação necessária para a preparação do seu caso seria que a Procuradoria investigasse em ambas as direções e revelasse suas informações à defesa. ${ }^{281}$

O presente trabalho não coaduna com essa possibilidade, tendo em vista que, na prática, afigura-se deveras ilusória. A problemática e as dificuldades práticas de sua implementação parecem ser bastante cristalinas. Apenas para reflexão preliminar acerca da flagrante inviabilidade da proposta: como se teria certeza de que todas as vertentes investigativas foram esgotadas pelo órgão responsável por acusar o indiciado?

Desse modo, como mencionado, tanto Michail Wladimiroff quanto Kai Ambos referem a abismal desvantagem em que se encontra a defesa para instruir a causa, levando em conta a experiência dos tribunais internacionais penais.

Nesse sentido, cumpre mencionar que o princípio da igualdade de armas já foi expressamente levado à apreciação dos Tribunais ad hoc para a antiga Iugoslávia e para Ruanda, na primeira decisão relevante acerca da questão, ${ }^{282}$ proferida pelo TPIR, em maio de 1997 - Prosecutor vs. Kayishema/Ruzindana. A alegação da iniquidade entre acusação e defesa foi rechaçada pelos julgadores, com base, principalmente, no argumento de que não se deveriam confundir os direitos do acusado e a igualdade entre as partes com a igualdade

Penal Internacional y Europeu. Barcelona: Marcial Pons, 2006. p. 412-413).

${ }^{281}$ Este ponto foi destacado durante as negociações do Comitê Preparatório para a Conferencia de Roma.

282 "The first relevant decision is the ICTR's May 5, 1997 order in Prosecutor v. Kayishema/Ruzindana. This order was rendered in response to a request by the defense to the ICTR judges to order the prosecution, based on the principle of equality of arms, "to divulge and limit its number of lawyers, consultants, assistants and investigators working on the case," and to explain "the time spent and resources available to the Prosecution, since the opening of the Kayishema file." (AMSTERDAM, Robert R. KNOOPS, Geert-Jan Alexander. THE DUALITY OF STATE COOPERATION WITHIN INTERNATIONAL AND NATIONAL CRIMINAL CASES. In: Fordham University School of Law, Fordham International Law Journal, Jan. 2007, pp. 3-4). 
de meios e recursos. ${ }^{283}$

De igual modo, no primeiro caso julgado pelo TPIJ, em novembro de 1996 Prosecutor vs. Dusko Tadic —, também foi levantado o princípio da igualdade de armas em relação à cooperação estatal. ${ }^{284} \mathrm{O}$ primeiro argumento levantado pela defesa, na apelação, foi o seguinte: "o direito do recorrente a um julgamento justo foi prejudicado, pois não houve igualdade de armas entre o Procurador e a Defesa devido às condições prevalecentes no qual o julgamento foi conduzido”. A defesa arguiu que uma defesa efetiva restou frustrada como resultado da ausência de cooperação estatal. Novamente a alegação foi rechaçada pela Câmara de Apelação, em razão de ter adotado o entendimento de que a igualdade de armas envolve somente a igualdade no sentido procedimental e não em um sentido substantivo, o que incluiria a cooperação dos Estados com a defesa, antes da instauração do procedimento perante o TPIJ. $^{285}$

283 “Os juízes do Tribunal Internacional Penal para Ruanda rejeitaram este pedido, sustentando que os direitos do acusado e da igualdade entre as partes não devem ser confundidos com a igualdade de meios e recursos; [...] Os direitos do arguido, tal como previsto no artigo 20 e, em especial, (2) e (4) (b) do Estatuto não deve, em caso algum, ser interpretado no sentido de que a defesa tem o direito de [o] mesmo meios e recursos como [são] à disposição do Ministério Público; [...] o advogado de defesa não demonstrou qualquer violação dos direitos do arguido, tal como previsto no artigo 20 (2) e (4) (b). A Câmara de Julgamento acrescentou que a diretiva relativa à cessão de defesa explica amplamente os meios financeiros disponíveis para a defesa, e o reu, neste caso, não foi capaz de mostrar que estes meios financeiros não foram fornecidos.” Tradução livre de: The ICTR judges rejected this request, holding that The rights of the accused and equality between the parties should not be confused with the equality of means and resources; [...] the rights of the accused as laid down in Article 20 and in particular (2) and (4)(b) of the Statute shall in no way be interpreted to mean that the Defence is entitled to [the] same means and resources as [are] available to the Prosecution;[...]the Defence Counsel has not proved to [this Tribunal's] satisfaction any violation of the rights of the accused as laid down in Article 20(2) and (4)(b). The Trial Chamber added that the Directive on the Assignment of Defense Counsel explains extensively which financial means are available to the defense, and the suspect in this case was unable to show that these financial means were not provided.

${ }^{284}$ AMSTERDAM, Robert R; KNOOPS, Geert-Jan Alexander. THE DUALITY OF STATE COOPERATION WITHIN INTERNATIONAL AND NATIONAL CRIMINAL CASES. In: Fordham University School of Law, Fordham International Law Journal, Jan. 2007, pp. 15-16.

285 "O primeiro caso do Tribunal Internacional Penal para a antiga Iugoslávia, caso Tadic, fornece enfoques sobre a questão de como o referido Tribunal aplicou o princípio da igualdade de armas no que diz respeito à cooperação para o Estado. No recurso do caso Tadic, o primeiro fundamento foi que: "o direito da recorrente a um julgamento justo foi prejudicado, pois não houve igualdade de armas entre o Procurador e a Defesa devido às circunstâncias que prevaleceram no modo como o julgamento foi conduzido. Mais especificamente, a defesa argumentou que uma defesa eficaz foi frustrada como resultado da falta de cooperação do Estado, e até mesmo obstrução, no decurso do processo por parte da República Sérvia, (ou seja, as autoridades sérvias locais em Prijedor). A Câmara de Apelações rejeitou este argumento e aceito o raciocínio do promotor de que a igualdade de armas envolve igualdade apenas em sentido processual e não em um sentido substantivo, inclusive quando estão em causa a cooperação dos Estados com a defesa pelo Tribunal Penal Internacional. De importância é o fato de que, a este respeito, a Câmara de Apelações do ICTY baseou principalmente sua decisão na jurisprudência da $\mathrm{CEDH}$, afirmando que "não há nada na jurisprudência do TEDH que sugere que o princípio é aplicável a condições, fora do controle do um tribunal, que impediu a parte de garantir a presença de algumas testemunhas. Todos os casos considerados referem que o órgão judicial tinha o poder de conceder". [...] Tendo em conta o contexto jurídico-político particular em que ocorrem os processos penais perante tribunais internacionais e as relações políticas e geo-políticas complexas em jogo para o Estado envolvido, o princípio da igualdade de armas em relação à cooperação do Estado deveria ter um significado específico. [...] Igualdade de armas deve, portanto, assegurar que a defesa tem meios adequados para preparar e apresentar o seu caso. Estes meios devem ser pelo menos iguais aos disponíveis para o Ministério Público, que geralmente tem todas 
$\mathrm{Na}$ segunda decisão paradigma ${ }^{286}$ acerca da questão, proferida pelo TPIJ, em fevereiro de 1998 - Prosecutor vs. Delalic — , destacou-se voto em separado do Juiz Lal C. Vohrah, proferido no primeiro caso levado ao Tribunal ad hoc para a ex-Iugoslávia, citado acima, em que explanou que o princípio da igualdade de armas afigura-se primária e fundamentalmente destinado a trabalhar em favor dos direitos processuais do suspeito e de sua defesa. ${ }^{287}$

Entretanto, apesar de considerar inicialmente plausíveis os argumentos do voto em separado na decisão anterior, o TPIJ rejeitou a interpretação do Juiz Vohrah, no julgamento de Delalic, por entender que a opinião do Juiz inclinava-se a favor da defesa, o que equivaleria a uma desigualdade processual contra o Ministério Público, que resultaria em

as vantagens e apoios do aparato Estatal." Tradução livre de: "The first case of the ICTY, the Tadic case, provides insight into the question of how the ICTY applied the principle of equality of arms with respect to State cooperation. In the Tadic appeal case, the first appeal ground was the argument that: "The appellant's right to a fair trial was prejudiced as there was no equality of arms between the Prosecutor and the Defense due to the prevailing circumstances in which the trial was conducted.". More specifically, the defense argued that an effective defense was thwarted as a result of lack of State cooperation, and even obstruction, during the proceedings by the Republic Srpska, (i.e., the local Serbian authorities in Prijedor).

The Appeals Chamber rejected this argument and accepted the prosecutor's reasoning that equality of arms involves equality only in a procedural sense and not in a substantive sense, including when concerning the cooperation of States with the defense before the ICTY. Of importance is the fact that, in this regard, the ICTY Appeals Chamber primarily based its decision on jurisprudence of the ECHR, stating that "there is nothing in the ECHR case law that suggests that the principle is applicable to conditions, outside the control of a court, that prevented a party from securing the attendance of certain witnesses. All the cases considered applications that the judicial body had the power to grant." [...] In view of the particular legal-political context in which criminal cases before international tribunals occur and the complex political and geo-political relations at stake for the State involved, the principle of equality of arms in relation to State cooperation ought to have a specific meaning. [...] Equality of arms should therefore ensure that the defense has adequate means to prepare and present its case. These means should at least be equal to those available to the prosecutor, who usually has all the advantages of a supportive State apparatus.

286 “A segunda decisão relevante neste contexto é a decisão de 04 de fevereiro de 1998 no caso Procurador v. Delalic. Antes desta decisão, o juiz Lal C. Vohrah proferiu voto dissidente em 27 de novembro de 1996, no primeiro caso do TPIJ, o caso contra Dusko Tadic.

A terceira decisão relevante é a decisão da Câmara de Apelações do TPIJ, de 16 de fevereiro de 1999, no caso Procurador v. Aleksovki. Nesta decisão, o TPIJ decidiu que o princípio da igualdade de armas deve ser aplicado em favor de ambas as partes de um processo e não apenas em favor do réu." Tradução livre de: "The second decision relevant in this respect is the ICTY February 4, 1998 decision in the case of Prosecutor v. Delalic. Prior to this decision, Judge Lal C. Vohrah rendered a so-called separate opinion on November 27, 1996 in the first ICTY case, the case against Dusko Tadic.

The third relevant decision is the ICTY Appeals Chamber decision of February 16, 1999 in the case of Prosecutor v. Aleksovki. In this decision, the ICTY held that the principle of equality of arms should be explained in favor of both parties in the procedure and not merely in favor of the defendant." (AMSTERDAM, Robert R; KNOOPS, Geert-Jan Alexander. THE DUALITY OF STATE COOPERATION WITHIN INTERNATIONAL AND NATIONAL CRIMINAL CASES. In: Fordham University School of Law, Fordham International Law Journal, Jan. 2007, pp. 3-4).

287 "Parece-me das autoridades acima que a aplicação do princípio da igualdade de armas, especialmente no processo penal, deve ser inclinado em favor da Defesa para aquisição de paridade com o Ministério Público na apresentação do caso perante o Tribunal para evitar qualquer injustiça contra o acusado." Traduçaõ livre de: "It seems to me from the above authorities that the application of the equality of arms principle especially in criminal proceedings should be inclined in favour of the Defence acquiring parity with the Prosecution in the presentation of the Defence case before the Court to preclude any injustice against the accused." 
desigualdade de armas. Com base nesta consideração, a Câmara de Julgamento ordenou que a defesa fornecesse ao Ministério Público uma lista com as testemunhas indicadas, a fim de que fosse solicitada sua oitiva. ${ }^{288}$ Não obstante isso, na fase recursal do caso Tadic, em 1999, os juízes da Câmara de Recurso do TPIJ atentaram para uma aplicação extensiva da igualdade de armas também em relação à cooperação do Estado em favor da defesa. Entretanto, esse precedente configurou um caso isolado, não representando, como verificado, a prática efetiva de tribunais penais internacionais.

Assim, entende-se que tal disparidade não deveria ser reiterada no trato da cooperação interestatal. Logo, o presente trabalho foi pensado com o intuito de aprimorar o sistema, de modo a ensejar reflexão sobre a atual sistemática que se instaura nos tratados bilaterais, sob pena de se incorrer no que Amsterdam e Knoops denominam de "Dual State", situações sujeitas a manipulações e a duplos standards, ${ }^{289}$ em que a desvantagem consiste

288 "Em suma, pode-se argumentar que o TPIJ e o TPIR veem o princípio da igualdade de armas como uma noção a favor de ambas as partes. A questão de saber se esta interpretação se justifica à luz das experiências dos advogado de defesa que atuaram perante esses tribunais penais internacionais. Lá, a defesa claramente opera em posição de desvantagem em termos processuais. Em consonância com isso, pode-se argumentar que a visão do juiz Vohrah parece mais justa. No entanto, em Delalic, o juízo de instrução do TPIJ rejeitou a interpretação do juiz Vohrah pelo seguinte motivo: não há dúvida de que a igualdade processual significa o que diz, a igualdade entre o Ministério Público e a Defesa. Para sugerir, como tem sido feito na citação acima, uma inclinação a favor da Defesa equivale a uma desigualdade processual em favor da defesa e contra o Ministério Público, e resultará em desigualdade de armas. Esta seria incompatível com a garantia mínima prevista no artigo 21, par. 4 (e), do Estatuto. Nas circunstâncias do tribunal internacional, o Procurador e o Defensor contam com a cooperação dos Estados para sua investigação, por isso, à primeira vista, não se verifica qualquer fundamento para o argumento da desigualdade. Com base nesta análise, a câmara de julgamento ordenou que a defesa fornecesse uma lista de testemunhas de defesa para a acusação antes do julgamento." Tradução livre de: In sum, it could be argued that the ICTY and the ICTR see the principle of equality of arms as a notion in favor of both parties. The question arises as to whether this interpretation is justified in light of current experiences of defense counsel acting before these international criminal tribunals. There, the defense clearly operates from a procedurally disadvantaged position. In line with this, one could argue that Judge Vohrah's vision appears more fair. However, in Delalic, the ICTY Trial Chamber rejected Judge Vohrah's interpretation for the following reason: There is no doubt that procedural equality means what it says, equality between the Prosecution and the Defence. To suggest, as has been done in the above quotation, an inclination in favour of the Defence is tantamount to a procedural inequality in favour of the Defence and against the Prosecution, and will result in inequality of arms. This will be inconsistent with the minimum guarantee provided for in Article 21 para. 4(e) of the Statute. In the circumstances of the International tribunal, the Prosecutor and the Defence rely on State cooperation for their investigation, so prima facie, the basis for the inequality argument does not arise.

Based on this consideration, the trial chamber ordered the defense to provide the prosecutors with a list of defense witnesses prior to the trial."

289 “".... No entanto, a desvantagem é que o Ministério Público tem de fato mais benefícios do que a defesa como resultado do desequilíbrio de recursos financeiros e poderes políticos. Consequentemente, a cooperação entre Estados em casos penais internacionais não pode ser invocado com base no equilíbrio processual. Não obstante a observação de que, no caso Tadic, em 1999, os juízes da Câmara de Recursos do TPIJ atentaram para uma aplicação extensiva da igualdade de armas, também em relação à cooperação de Estado a favor da defesa, uma aplicação extensiva de tal diretriz não é efetuada na prática internacional e internacionalizada dos tribunais penais. [...] A cooperação Estatal se torna um instrumento do Estado Dual, potencialmente colocando em risco princípios fundamentais de justiça, incluindo o princípio da igualdade de armas. Os riscos inerentes a esse fenômeno são claras. Os objetivos da justiça penal internacional podem ser frustrados enquanto a cooperação do Estado esteja sujeita a manipulações impulsionadas pela prerrogativa de um Estado ambíguo." Traduçaõ livre de: [...] However, the downside is that the prosecution de facto benefits more than the defense 
no fato de a acusação dispor de mais beneplácitos que a defesa, como resultado do desequilíbrio de recursos financeiros e de poder político.

Já no que tange aos procedimentos perante o Tribunal Penal Internacional (TPI), instituído pelo Estatuto de Roma, ${ }^{290}$ aprovado no dia 17 de julho de 1998, pela Conferência Diplomática de Plenipotenciários das Nações Unidas, importa referir que o TPI atua de forma complementar aos sistemas jurídicos nacionais, só intervindo quando o Estado com jurisdição sobre o caso não estiver em condições de processar o acusado ou não revelar disposição de fazê-lo, em respeito ao princípio da complementaridade, previsto no art. 17.

No Estatuto de Roma, estão expressamente consagrados os princípios da legalidade dos delitos (art. 22) e das penas (art. 23), da irretroatividade, com exceção da lei mais benigna ao réu (art. 24), da responsabilidade penal subjetiva (art. 30), da presunção de inocência (art. 66), ampla defesa, paridade de armas e direito à prova (art. 67) e outras disposições com mesma índole garantista, demonstrando a evolução do sistema rumo a um procedimento penal norteado pelos direitos humanos. Com esse intuito, refere-se que ${ }^{291}$ : ao princípio da

as a result of the imbalance of financial resources and political powers. Consequently, State cooperation in international criminal cases cannot be invoked on the basis of procedural equity. Notwithstanding the observation that in the 1999 Tadic case, the ICTY Appeal Chamber judges strove for an extensive application of equality of arms also in relation to State cooperation in favor of the defense, such an extensive application is not effectuated in the practice of international and internationalized criminal tribunals. [...] State cooperation becomes an instrument of the Dual State, potentially endangering bedrock principles of justice, including the principle of equality of arms. The risks attendant to this phenomenon are clear. The goals of international criminal justice may be thwarted as long as State cooperation is subject to manipulations driven by the prerogative of a Dual State. (AMSTERDAM, Robert R. KNOOPS, Geert-Jan Alexander. THE DUALITY OF STATE COOPERATION WITHIN INTERNATIONAL AND NATIONAL CRIMINAL CASES. In: Fordham University School of Law, Fordham International Law Journal, Jan. 2007. p. 15).

${ }^{290}$ O Estatuto de Roma entrou em vigor no dia 02 de julho de 2002, primeiro dia do mês seguinte ao sexagésimo dia a partir da data em que ocorreu o depósito do sexagésimo instrumento de ratificação, aceitação, aprovação ou adesão junto ao secretário-geral das Nações Unidas, em Nova York (artigo 11 do Estatuto).

${ }^{291}$ No original: "Under the Statute of the International Tribunal, the principle of equality of arms must be given a more liberal interpretation than that normally upheld with regard to proceedings before domestic courts. This principle means that the Prosecution and the Defence must be equal before the Trial Chamber. It follows that the Chamber shall provide every practicable facility it is capable of granting under the Rules and Statute when faced with a request by a party for assistance in presenting its case." (AMSTERDAM, Robert R. KNOOPS, Geert-Jan Alexander. THE DUALITY OF STATE COOPERATION WITHIN INTERNATIONAL AND NATIONAL CRIMINAL CASES. In: Fordham University School of Law, Fordham International Law Journal, Jan. 2007, p. 5). Como contra argumento à situação da defesa antes do início efetivo da demanda perante os tribunais internacionais, há doutrina que refere que, antes da instauração de qualquer procedimento jurisdicional, a acusação e a defesa estariam em paridade de armas e partiriam do mesmo marco inicial. Entretanto, para Amsterdam e Knoops tal afirmação não se revela minimamente convincente, pois a defesa não detem os mecanismos jurídico-políticos postos à disposição do Ministério Público, in verbis: “O contra-argumento, que o Ministério Público perante tribunais internacionais, assim como a defesa, tem que contar com a cooperação dos Estados para a investigação e a ação penal e, portanto, passam pelos mesmos problemas da defesa, não parece convincente. Afinal de contas, o Ministério Público não só tem mais meios financeiros à sua disposição para instaurar um processo no Estado em causa, mas eles também podem recorrer a um mandato jurídico-político de apoio à investigação para persuadir ou mesmo recorrer a medidas de execução para garantir que um Estado ceda os documentos comprobatórios. Um exemplo disso são as sanções econômicas impostas pela Organização das Nações Unidas sobre a Sérvia e Montenegro, que foram iniciadas pelo Procurador-Geral do TPIJ e excluíram a possibilidade de o Estado se tornar um membro da União 
igualdade de armas deve ser conferida interpretação mais liberal do que a normalmente mantida no que diz respeito ao processo perante os tribunais nacionais. Este princípio significa que a acusação e a defesa devem ser iguais perante a Câmara de Julgamento. Conclui-se que a Câmara deve conceder todas as facilidades práticas de que é capaz para garantir o apoio, nos termos do Estatuto e dos regulamentos do Tribunal, quando confrontada com um pedido de uma das partes para assistência na apresentação do seu caso.

Reputa-se relevante o estudo histórico desses julgados provenientes dos Tribunais Internacionais Penais ad hoc ${ }^{292}$ e do TPI, pois configuram indicativo do que virá a ocorrer na seara doméstica, em caso de violação de princípios constitucionais e internacionais em matéria penal, em especial às críticas quanto à legitimidade do sistema, quando as alegações de nulidade poderão se tornar corriqueiras, sem contar as prováveis responsabilizações internacionais dos países pelas cortes internacionais de direitos humanos. ${ }^{293}$

Salienta-se que tais advertências em relação às prováveis alegações de nulidade e de responsabilização internacional dos Estados não consistem exercício de futurologia, pois tais circunstâncias já vêm sendo aferidas na prática. A título de exemplo, em relação à responsabilização internacional dos Estados, a Corte Europeia de Direitos Humanos, no caso P.V. vs. FRG, ${ }^{294}$ em que P.V. apresentou reclamação contra o Tribunal Alemão por ter feito

Europeia. Tais mecanismos jurídico-políticos não estão à disposição da defesa perante estes tipos de tribunais." Tradução livre de. "The counterargument, that prosecutors before international tribunals, just like the defense, have to rely on the cooperation of States for investigation and prosecution and therefore meet the same problems as the defense, seems unconvincing. After all, the prosecutors not only have more financial means at their disposal to pursue an inquiry in the State concerned, but they can also resort to a legal-political mandate in support of the investigation to persuade or even rely on enforcement measures to ensure that a State hands over evidentiary documents. An example of this is the economic sanctions imposed by the United Nations ("U.N.") on Serbia and Montenegro, which were initiated by the Chief Prosecutor of the ICTY and precluded that State from becoming a European Union member. Such legal-political mechanisms are not at the disposal of the defense before these types of tribunals.

${ }^{292}$ Tendo em vista as críticas quanto ao fato de serem tribunais especialmente criados para julgamento de crimes já ocorridos, assim como os Tribunais de Nuremberg e de Tóquio, com a flagrante ofensa ao princípio do juiz natural e da proibição de tribunais de exceção, houve maior pressão para que os países envidassem esforços para a criação de um tribunal penal internacional de caráter permanente, o TPI.

${ }^{293}$ É nesta linha que se filia à posição de Denise Neves Abade quando expõe o modelo de engajamento que estimula o diálogo e a fertilização cruzada, estimulando os Tribunais a utilizarem os paradigmas de outros Tribunais Constitucionais e Tribunais Internacionais para chegar à definição sobre a forma de incidência dos direitos fundamentais na cooperação. Com este modelo, abrir-se-ia uma janela para, no futuro, uma eventual adoção da incidência de direitos fundamentais que leve em consideração a concepção geral dos direitos fundamentais no direito globalizado, o que se aproximaria dos defensores da teoria da incidência imediata dos direitos mínimos de matriz internacional. (ABADE, Denise Neves. Direitos fundamentais na cooperação jurídica internacional: extradição, assistência jurídica, execução de sentença estrangeira e transferência de presos. São Paulo: Saraiva, 2013, p. 119-121, 125-129, 222 e p. 380).

${ }^{294}$ P.V v. FRG, no. 11853/85, ECHR Admissibility decision 13 July 1987. Extraído de: VAN HOEK, Aukje A.H.; LUCHTMAN, Michiel J.J.P. Transnational cooperation in criminal mattters and the safeguarding of human rights. Utrecht Law Review, Volume 1, Issue, 2005, p. 19. Entretanto o autor pondera: Isso não significa, porém, que atualmente a proteção dos direitos da Convenção é suficientemente garantida em casos transnacionais. Vários casos mostram que a proteção efetiva pode ser frustrada pela falta de informações por parte do reclamante. Fatos são necessários, não só para fundamentar a alegação de que se perpetrou uma 
uso de provas obtidas por carta rogatória na Turquia, sem que lhe tenha sido viabilizada a oportunidade de contrainterrogar a testemunha. No caso, a Corte pontuou que "as autoridades alemãs não podem ser responsabilizadas pela não observância das previsões da lei turca por um tribunal turco”. Entretanto, salientou que tal circunstância não excluiria a responsabilidade dos Tribunais alemães nos termos do artigo $6^{\circ}$, ou seja, "apesar de o tribunal alemão não ser responsável pela análise da atividade de outro tribunal em exercício, é, em princípio, possível que o uso da evidência obtida afronte os artigos 6(3)(d)". Isso significa que um tribunal que permite a introdução de provas obtidas no estrangeiro tem um dever independente nos termos do artigo $6^{\circ}$, que diz respeito à maneira pela qual a evidência foi obtida.

Se a informação estrangeira é usada como prova em um processo penal, as responsabilidades do Estado de julgamento receptor são de natureza diversa. Este Estado é responsável pela justiça do processo como garantido no artigo $6^{\circ}$ da Convenção Europeia de Direitos Humanos. Isso significa que noções essenciais de justiça no julgamento, tais como a igualdade de armas e o caráter contraditório do processo, terão de ser garantidos. $\mathrm{O}$ uso da informação externa é uma parte intrínseca do julgamento. Quando a origem da informação não é contabilizada, não pode ser testada - nem pela defesa, nem pelo tribunal - e, portanto, não deve ser usada como prova. Isto parece ser a consequência simples e direta da responsabilidade do Estado receptor, de acordo com o artigo $6^{\mathbf{o}} .^{295}$

Em que pese o Tribunal Europeu de Direitos Humanos ainda não ter desenvolvido doutrina específica de igualdade de armas no plano criminal transnacional, a jurisprudência da TEDH discute particularmente a entrega de pessoas para a custódia de outros Estados.

No emblemático caso Soering, Estrasburgo realizou um julgamento histórico, no sentido de ampliar a responsabilidade do Estado requerido em relação ao cumprimento das regras de um julgamento justo no Estado requerente e, inclusive, ser responsabilizado por eventual inobservância.

No caso, o demandante, Jens Soering, de nacionalidade alemã, foi detido em 1986, na Inglaterra, pelo delito de estelionato, junto com sua companheira de nacionalidade canadense. Em junho desse mesmo ano, o Grand Jury do Condado de Bedford, Virgínia (EUA), acusou o casal de haver assassinado os pais dela em março de 1985, de modo que o

violação aos direitos da Convenção, mas também para identificar o Estado responsável. Especialmente em casos de assistência mútua em matéria penal, pode se revelar difícil traçar a fonte da informação, o que, por sua vez torna difícil poder afirmar a violação dos direitos nos termos do artigo $6^{\circ}$ e artigo $8^{\circ}$ (Ibidem, p. 20).

${ }^{295}$ VAN HOEK, Aukje A.H.; LUCHTMAN, Michiel J.J.P. Transnational cooperation in criminal mattters and the safeguarding of human rights. Utrecht Law Review, Volume 1, Issue, 2005, p. 24. 
governo dos Estados Unidos solicitou a extradição de ambos em agosto de 1986, mediante a aplicação do Tratado Anglo-Americano sobre extradição de 1972.

Em março de 1987, a República Federal da Alemanha solicitou igualmente a extradição do recorrente, com fundamento em um tratado celebrado com o Reino Unido em 1872. Em 11 de agosto de 1988, o Presidente da Comissão Europeia de Direitos Humanos sinalizou ao governo Britânico que seria desejável, pelo interesse das partes e para o bom desenvolvimento do processo, que o demandante não fosse extraditado aos Estados Unidos até que a Comissão houvesse tido a possibilidade de examinar o assunto. Tal pedido foi renovado várias vezes até que o Tribunal Europeu conheceu do caso.

Nas palavras do Tribunal, o art. $1^{\circ}$ não consagra um princípio geral segundo o qual um Estado-parte deveria denegar a extradição de um indivíduo até se assegurar que as condições as condições do país de destino não vulneram nenhuma das garantias previstas pelo Convênio, entretanto, toda interpretação dos direitos e liberdades enumerados no documento devem ser conciliados com seu espírito geral: a promoção e a salvaguarda dos ideais e valores de toda sociedade democrática. Um desses valores é a proibição absoluta da tortura e dos tratos desumanos e degradantes. ${ }^{296}$

Nesse caso, a Corte abordou diretamente o caso da extradição, deportação ou entrega de indivíduos a Estados não signatários da Convenção Europeia de Direitos Humanos, ainda não estabelecendo doutrina aplicável a outros casos de cooperação.

Entretanto, entre os Estados-membros da CEDH, o Tribunal abriu recentemente uma nova porta para a responsabilidade em casos que envolvam assistência jurídica mútua em matéria penal. No caso França e Bélgica contra Stojkovic, autoridades francesas solicitaram mediante cartas rogatórias que o Sr. Stojkovic, que se encontrava detido na Bélgica, fosse interrogado (na presença de um advogado) acerca de sua alegada participação em um assalto a mão armada, na França. Ocorre que o Sr. Stojkovic foi interrogado por policiais belgas na presença do juiz de instrução francês e de um promotor público, mas sem a presença de qualquer advogado, apesar de haver sido requerida a assistência deste profissional. Nesse caso, o Tribunal de Estrasburgo não declarou explicitamente as obrigações dos Estados na seara dos direitos humanos na cooperação, mas deixou claro que aos réus devem ser assegurados os direitos previstos no artigo $6^{\circ}$ (3) da $\mathrm{CEDH}$ também nos casos de

\footnotetext{
296 "Em suma, a decisão de um Estado contratante de extraditar um fugitivo pode suscitar problemas em conformidade com o art. $3^{\circ} \mathrm{e}$, por isso, comprometer a responsabilidade do Estado de acordo com o Convênio, em casos em que se verifiquem razões substanciais para crer que a pessoa a ser extraditada enfrentaria um risco real de ser submetida a tortura ou penas e tratos desumanos ou degradantes no Estado solicitante" (parágrafo 91 da decisão).
} 
investigação transfronteiriça. ${ }^{297}$

De igual modo, no recente caso Süzer vs. Turquia, o solicitante - Mehmet Ugur Süzer, nacional turco, nascido em 04 de outubro 1987 - se encontrava preso em Gaziantep (Turquia). Um estudante secundário e um menor de idade foram acusados de roubo com agravantes cometido em novembro de 2003 e afirmaram que Süzer simplesmente havia sido pego em uma disputa entre seus amigos e outro jovem. Com fundamento no art. $6^{\circ}, \S 1$ y $\S 3$ (c) (direito a um julgamento justo e direito a ser assistido por um advogado), o solicitante alegou que lhe haviam sido negados esses direitos e que o seu direito de defesa havia sido vulnerado, pois foi obrigado a assinar vários documentos sem ter tido acesso à ajuda adequada. No caso, a Corte declarou que, efetivamente, foram violados os preceitos referidos, em razão da ausência de imparcialidade dos procedimentos contra o demandante derivados da restrição do seu direito de defesa. ${ }^{298}$

Muito embora, no caso da assistência jurídica mútua com Estados não signatários da Convenção para a coleta de provas, as partes contratantes arriscam ser responsabilizadas pela CEDH apenas se os fatos satisfizerem o rigoroso teste da "negação flagrante de justiça", ${ }^{299}$ pois, como exposto no caso Soering, a Corte modera a expansão das obrigações de direitos humanos na cooperação transfonteiriça: a Convenção Europeia não pode "governar as ações dos Estados que não aderiram à Convenção, nem pretende ser um meio de exigir que os Estados-partes imponham as normas da Convenção para outros Estados". 300

Interessante salientar que, além da ênfase no princípio da responsabilidade individual do Estado derivado da aplicação territorial da Convenção, a Corte Europeia de Direitos Humanos tem afirmado repetidamente que os direitos concedidos pela Convenção devem, em princípio e principalmente, serem práticos e eficazes. Tendo esse parâmetro em mente, no campo da assistência mútua tem-se que as violações aos diretos previstos na Convenção

297 GLESS, Sabine. Transnational Cooperation in Criminal Matters and the Guarantee of a Fair Trial: Approaches to a General Principle. Utrech Law Review. Vol. 9, Issue 4, Set. 2013, p. 93-4.

${ }^{298}$ CEDH, Süzer vs. Turquia, aplic. n. 13885/05, 23 de abril de 2013.

299 "Uma negação flagrante de justiça ocorre se um processo for manifestamente contrário ao disposto no artigo $6^{\circ}$ ou aos princípios aí fixados, por exemplo, quando um julgamento é conduzido com total desrespeito pelos direitos da defesa ou ocorre uma recusa deliberada e sistemática de acesso a um advogado." (CEDH, 17 janeiro 2012, Othman (Abu Qatada) vs. UK, appl. no. 8139/09, Para. 259; CEDH 1 março 2006, Sejdovic vs Italy, appl. no. 56581/00, Para. 84; CEDH 27 outubro 2011, Stojkovic vs França e Bélgica, appl. no. 25303/08, Para. 56; CEDH 26 junho 1992, Drozd e Janousek vs França e Espanha, appl. no. 12747/87, Para. 110). Nesse contexto, a questão remanescente é se a doutrina da "negação flagrante" e o disposto no caso Soering tem o potencial de serem utilizados de forma mais ampla para equalizar a posição do Ministério Público e da defesa na seara transnacional. (GLESS, Sabine. Transnational Cooperation in Criminal Matters and the Guarantee of a Fair Trial: Approaches to a General Principle. Utrech Law Review. Vol. 9, Issue 4, Set. 2013, p. 102).

300 GLESS, Sabine. Transnational Cooperation in Criminal Matters and the Guarantee of a Fair Trial: Approaches to a General Principle. Utrech Law Review. Vol. 9, Issue 4, set. 2013, p. 93. 
devem, em primeiro lugar, ser impedidos e, em segundo lugar, remediados. A partir desse ponto de partida, Van Hoek e Luchtman ${ }^{301}$ estabelecem um conjunto de propostas que pode servir como auxílio para evitar/minimizar violações aos direitos dos acusados:

1) A flexibilização da regra do non-inquiry, que será abordada no capítulo seguinte, o que significa que um teste ex officio dos fatos do caso deve ser sempre realizado, a fim de evitar violações flagrantes dos direitos da Convenção e que uma investigação mais detalhada sempre deve ser levada a efeito no caso de uma violação ser demonstrada.

2) Deve haver o dever entre os Estados de compartilhar informações adicionais, caso sejam solicitadas. Dentro do contexto da União Europeia, por exemplo, tal disposição poderia fluir a partir do dever de lealdade na cooperação, pois os Estados-membros devem ajudar uns aos outros com o intuito de evitar violações aos direitos humanos.

3) Deve haver a possibilidade, ou melhor, o dever de recusar a cooperação no caso em que o pedido de informações descrito acima seja recusado ou permaneça sem efeito, por exemplo, quando a origem da informação é indetectável.

No que concerne à alegação de nulidades, ainda que os tribunais superiores não tenham tido a oportunidade de se pronunciar sobre o tema, já que se trata de fenômeno recente, insta sublinhar que a Defensoria Pública da União, em memoriais apresentados no Processo n. 2001.61.81.004937-0, que tramitou perante a $7^{\text {a }}$ Vara Federal Criminal de São Paulo-SP, requereu a nulidade da citação e do interrogatório realizados nos Estados Unidos, sob o "compromisso de dizer a verdade" e sem o acompanhamento de defesa técnica. Nesse caso, a ré ingressou com determinada quantidade de bens destinados ao comércio, sem comprovar a legalidade da importação. Em razão de a ré residir nos EUA, o Juízo solicitou assistência daquele país para proceder a citação e o interrogatório da acusada, os quais, sob a ótica da defesa, encontravam-se eivados de nulidade. Ao final, não houve pronunciamento do Juízo acerca das alegações aventadas, tendo em vista a extinção da punibilidade da acusada pela prescrição.

${ }^{301}$ VAN HOEK, Aukje A.H.; LUCHTMAN, Michiel J.J.P. Transnational cooperation in criminal mattters and the safeguarding of human rights. Utrecht Law Review, Volume 1, Issue, 2005, p. 37, em tradução livre. 


\subsection{Mitigação da regra do non-inquiry e críticas à (im)possibilidade de utilização do auxílio direto pela defesa}

Em contraposição à linha de pensamento clássica, segundo a qual "ao Estado requerido não é dado interferir ou exercer o controle do que se passou ou vai se passar no processo do Estado requerente", de modo que o princípio do non-inquiry, por razões diversas, deveria ser "respeitado religiosamente", 302 conforme o denominado "export-ban argument", pelo qual o sistema legal estrangeiro não poderia ser medido na base do sistema do Estado requerido. ${ }^{303}$

De antemão, entretanto, cumpre esclarecer em que consiste a regra do chamado "noninquiry". Com base na lição de Van Hoek e Luchtman, ${ }^{304}$ de acordo com essa regra, permitese que os tribunais de um país abstenham-se de averiguar questões econômicas, jurídicas ou sociais de outro país, a fim de cumprir ou não a cooperação solicitada. A regra tem seu fundamento nos acordos de extradição, mas agora também é utilizada em outras formas de cooperação internacional.

As justificativas para a aplicação da regra são várias. Nos Estados Unidos, ela é concebida como uma consequência direta da divisão de poderes entre o Executivo e o Judiciário, de forma que a cooperação jurídica internacional penal, constituindo uma parte da política externa, deveria ser tratada exclusivamente pelo Executivo. Portanto, em regra, os tribunais não deveriam se ater a questões relativas à legitimidade dos atos de autoridades estrangeiras.

Contudo, Van Hoek e Luchtman esclarecem que, no âmbito da União Europeia, com uma concepção totalmente diversa, a criação de uma área legal, de um espaço de segurança e justiça, indica que os atos de cooperação jurídica internacional penal não representam mais do domínio exclusivo dos negócios estrangeiros, mas sim do Judiciário. Tal aspecto também foi sublinhado pelo Tribunal de Justiça da União Europeia nos casos Brügge e Gözotük, nos quais a regra do non-inquiry foi reduzida em seu escopo, dado que outros Estados devem fornecer todas as informações necessárias a fim de permitir a aferição, por exemplo, do critério da proporcionalidade, conforme exigido pelo artigo $8^{\circ}$ da Convenção Europeia de Direitos Humanos. Além disso, tendo em vista que o dever de detectar ofensas aos direitos

\footnotetext{
${ }^{302}$ GRINOVER, Ada Pellegrini. O Processo em Evolução. Rio de Janeiro: Forense Universitária, 1996, p. 195. ${ }^{303}$ Ibidem, p. 195.

${ }^{304}$ VAN HOEK, Aukje A.H.; LUCHTMAN, Michiel J.J.P. Transnational cooperation in criminal mattters and the safeguarding of human rights. Utrecht Law Review, Volume 1, Issue, 2005, pp. 2 e 22.
} 
humanos no sistema do país requerente deriva do dever de cooperação leal, os EstadosMembros devem ajudar uns aos outros, não só na obtenção transnacional das provas, mas também na defesa das normas da Convenção. ${ }^{305}$

Além disso, Winter refere que, no âmbito da União Europeia, em suma, a CEDH já declarou que uma negação flagrante dos direitos estabelecidos na Convenção poderia implicar responsabilidade por parte do Estado-Membro que executa um pedido de cooperação, bem como do Estado solicitante que utiliza material probatório obtido mediante flagrante violação dos direitos consagrados na Convenção. Logo, apesar de o Estado requerente não ser responsável pelo desrespeito à Convenção por parte das autoridades requeridas, ele é responsável pela utilização do material como prova, não sendo admissível "branquear" uma evidência. ${ }^{306}$

Caso contrário, segundo a autora, os princípios do reconhecimento mútuo e do noninquiry prejudicariam a proteção dos direitos de defesa e, consequentemente, da eficiência,

305 “A regra do non-inquiry (não arguição) permite que os tribunais de um país abstenham-se de investigações sobre questões jurídicas, econômicas e/ou sociais de outro país. Ela tem sua base na lei de extradição, mas agora também é usada em outras formas de cooperação internacional. As justificativas da regra são várias. Nos Estados Unidos, muitas vezes é concebida como uma consequência directa da divisão de poderes entre o Executivo e o Judiciário. A Cooperação penal internacional, sendo uma parte da política externa, é uma questão que tem de ser tratada pelo executivo (o Presidente ou o Secretário de Estado em seu nome). Portanto, os tribunais não devem - em regra - entreter questões relativas à legitimidade dos atos de autoridades estrangeiras. Isso não significa, porém, que esses tipos de questões não são tratadas em sua íntegra. Elas são, pelo contrário, conduzidas pelo podere executivo, que se considera estar melhor equipados para este tipo de investigação. [...] Apesar de tudo, a criação de um espaço jurídico indica que este tipo de cooperação não é mais do domínio dos negócios estrangeiros, mas sim do Judiciário. Isto também foi enfatizado pelo Tribunal de Justiça, nos casos Bruges e Gözotük. Em segundo lugar, onde a regra da não-investigação é reduzido em escopo, outros Estados devem fornecer todas as informações necessárias a fim de permitir a realização de, por exemplo, o critério da proporcionalidade, conforme exigido pelo artigo 8o. Esta obrigação pode ser derivada do dever de cooperação leal, que foi recentemente estabelecido no âmbito do terceiro pilar da estrutura da UE. Os Estados-membro devem ajudar-se mutuamente, não só na coligação transnacional de provas, mas também na defesa das normas da Convenção." Tradução livre de: "The rule of non-inquiry allows the courts in one country to refrain from investigations into legal, economic and/or social matters of another country. It has its basis in extradition law, but is now also used in other forms of international cooperation. The rationales of the rule are several. In the United States it is often conceived as a direct consequence of the division of powers between the executive and the judiciary. International criminal cooperation, being a part of foreign policy, is a matter that has to be dealt with by the executive (the President or the Secretary of State on his behalf). Therefore, the courts should not as a rule - entertain questions concerning the legitimacy of the acts of foreign authorities. This does not mean, however, that such types of questions are not dealt with at all. They are on the contrary conducted by the executive powers, which are considered to be better equipped for these kinds of investigation. [...] After all, the creation of a legal area indicates that this kind of cooperation is no longer the domain of foreign affairs, but rather that of the judiciary. This was also emphasized by the Court of Justice in the Brügge and Gözotük cases. Second, where the rule of non-inquiry is reduced in scope, other states should provide all the necessary information in order to enable the carrying out of, for instance, the proportionality test as required by Article 8. Such a duty might be derived from the duty of loyal cooperation that was recently established in the Third Pillar of the EU structure. States should assist each other not only in the transnational gathering of evidence, but also in upholding Convention standards". (VAN HOEK, Aukje A.H.; LUCHTMAN, Michiel J.J.P. Transnational cooperation in criminal mattters and the safeguarding of human rights. Utrecht Law Review, Volume 1, Issue, 2005, pp. 2 e 22).

306 WINTER, Lorena Bachmaier. Transnational Criminal Proceedings, Witness Evidence and Confrontation: Lessons from the ECtHR's Case Law. In: Utrech Law Review. Volume 9, Issue 4 (September), 2013. 
pois esta não deve ser alcançada à custa da supressão daqueles direitos. Os Estados-Membros têm de garantir que nenhuma evidência que tenha sido obtida com violação dos direitos humanos, tal como definido pela $\mathrm{CEDH}$, seja admitida no julgamento.

Nesse contexto, em relação à necessidade de mitigação da regra do non-inquiry, revelam-se irretocáveis as considerações da Professora Ada Pellegrini Grinover, ${ }^{307}$ as quais não puderam ser resumidas, sob o risco de serem pioradas:

\begin{abstract}
Observou-se que, dado que no momento da extradição - e o mesmo vale para outras formas de cooperação judicial - o indivíduo está submetido à jurisdição do Estado requerido, este se torna responsável pelo tratamento processual e/ou substancial reservado ao indivíduo pelo Estado requerente, ainda que a violação vá ocorrer ou tenha ocorrido fora de sua esfera territorial. Trata-se de extrair do sistema internacional de cooperação judiciária, um conceito de jurisdição desligado da esfera territorial de cada Estado envolvido, juntamente com a conceituação de uma responsabilidade direta e imediata do Estado requerido pelas violações, ainda que potenciais, aos direitos humanos por quaisquer das partes ( $\mathrm{com}$ palavras mais duras, o Relatório nacional do Egito apresentado ao XV Congresso da AIDP, de autoria de Iskandar Ghattas, fala em cumplicidade intolerável do Estado requerido que se abstenha de examinar as garantias processuais dispensadas pelo Estado requerente).

[...] as maiores cautelas deverão ser tomadas quando se tratar de países não signatários das Convenções sobre direitos humanos, como já deixaram assentados os órgãos internacionais de garantia.

Sobretudo nesses casos, o controle do juiz do Estado requerido estende-se às normas processuais (e materiais) do Estado requerente, assim como às modalidade de sua aplicação. Fica assim superada a dificuldade, acusada pela jurisprudência da Europa continental, de resolver o conflito entre a ideia de soberania do Estado requerente e a exigência de recusar a cooperação judiciária com relação a um país em que não seja assegurado o standard mínimo de garantias. E fica também superada a rule of noninquiry imposta ao juiz norte-americano, de quem se retirava o controle sobre os motivos pelos quais a cooperação era solicitada, e sobretudo sobre o tratamento processual reservado à pessoa do Estado requerente.
\end{abstract}

Naturalmente, essa visão opõe-se radicalmente ao entendimento antigo que advogava a proibição de um Estado imiscuir-se nos assuntos internos e processos de outro. Entretanto, a denominada prohibition of exporting (direito nacional ou regional) sobre os direitos humanos não existe, em face da responsabilidade que o Estado tem perante sua própria Constituição. ${ }^{308}$

Dito isso, flagrante que a limitação da utilização da via do auxílio direto ofende o princípio da ampla defesa, no que diz respeito ao acesso aos meios e recursos a ela inerentes

\footnotetext{
${ }^{307}$ GRINOVER, Ada Pellegrini. O Processo em Evolução. Rio de Janeiro: Forense Universitária, 1996, p. 195.
}

${ }^{308}$ Ibidem, p. 194. 
(Artigo $5^{\circ}$, inciso LV, da Constituição), ferindo o sistema de contraditório e paridade de armas como estatuído no ordenamento jurídico pátrio. Logo, qualquer tratado que assim disponha poderia ser submetido a controle de constitucionalidade para interpretação conforme $^{309}$ declaração de inconstitucionalidade, ou melhor, ao controle de convencionalidade ${ }^{310}$ tendo em vista a flagrante ofensa às Convenções Internacionais de Direitos Humanos que dispõem sobre o tema. ${ }^{311}$

No mesmo sentido afirma Bruce Zagaris, para quem certamente as previsões do MLAT serão desafiadas sob a perspectiva constitucional e à luz dos tratados internacionais de direitos humanos, por se tratarem de dispositivos injustos, que privam os réus de proteção igualitária perante a lei, ao mesmo tempo em que impedem a efetiva assistência por parte das defesas, dentre outros obstáculos. ${ }^{312}$

Referidas soluções restringem-se à inaplicabilidade do MLAT no território nacional, porém nada disso garante a aplicação da decisão em território americano. Em suma: de nada adianta considerar o instrumento inconstitucional ou incompatível com as convenções internacionais se os Estados Unidos não concordarem com esse entendimento e insistirem

309 ARAS, Vladimir. O papel da autoridade central nos acordos de cooperação penal internacional. In: BALTAZAR Jr., José Paulo; LIMA, Luciano Flores de. Cooperação Jurídica Internacional em Matéria Penal. Porto Alegre: Verbo Jurídico, 2010, pp. 83-4.

310 Segundo lição de André de Carvalho Ramos, o controle de convencionalidade consiste na análise da compatibilidade dos atos internos (comissivos ou omissivos) em face das normas internacionais. [...] O controle de convencionalidade de matriz internacional, também denominado de autêntico ou definitivo, é atribuído a órgãos internacionais. [...] $\mathrm{Na}$ seara dos direitos humanos, exercitam o controle de convencionalidade internacional os tribunais internacionais de direitos humanos (Corte Europeia, Interamericana e Africana), os comitês onusianos, entre outros. (RAMOS, André de Carvalho. Teoria Geral dos direitos humanos na ordem internacional. 3a ed. São Paulo: Saraiva, 2013, p. 280).

${ }^{311}$ Neste sentido, observe-se também o art. $8^{\circ}$ do Pacto de San José da Costa Rica: “Art. $8^{\circ}$. Toda pessoa tem direito a ser ouvida com as devidas garantias e dentro de um prazo razoável, por um juiz ou Tribunal competente, independente e imparcial, estabelecido com anterioridade pela lei, na tramitação de qualquer acusação penal formulada contra ela, ou para a determinação de seus direitos e obrigações de ordem civil, laboral, fiscal ou de qualquer outro caráter.”. Logo, a aplicação do texto constitucional, como também do referido art. $8^{\circ}$ do Pacto de San José, não pode levar a outra solução senão aquela que afaste a aplicação do art. 1.2 da Convenção de Assistência Mútua em matéria penal no âmbito do "Mercosul", v.g, que prevee que as disposições dos referidos textos de cooperação bilateral e multilateral "não conferem direitos aos particulares para obtenção, supressão ou exclusão de provas, ou para se oporem ao cumprimento de uma solicitação de assistência". Sem dúvida, trata-se de exemplo de influência garantista do direito interno brasileiro na solução de questões de índole internacional. Raul Cervini cunhou essa influência garantista, que na realidade é bifronte ou bifocal, como "princípio da continuidade jurídica na proteção das garantias", em que sustenta que a norma penal e processual interna deve adequar-se, por via ab-rogatória, aos textos internacionais incorporados ao direito interno e também deve ser alcançada por normas garantistas de direito interno ou externo todas as situações onde sua vigência, por logicidade, tenha que ser aplicada. (CERVINI, Raúl. Os processos de descriminalização. 2a ed. São Paulo: RT, 1995, p. 113).

${ }^{312}$ No original: "Undoubtedly, these provisions will be challenged constitutionally and under international human rights treaties as being unfair, depriving defendants of equal protection under the law, deprivation of effective assistance of counsel, and so forth." (ZAGARIS, Bruce. U.S. - Brazil and International Evidence Gathering: The Need for Better Procedural Due Process. Revista Brasileira de Ciências Criminais. RBCCrim. Ano 20, vol. 99, nov.-dez./2012, p. 254). 
em negar assistência à defesa nos processos de cooperação, com base na literalidade do artigo I, item 5, do MLAT. ${ }^{313}$

Portanto, a autoridade central brasileira não poderá recusar a tramitação de pedidos da defesa provenientes de outros países (cooperação passiva). Contudo, certo é que, em muitos casos, os Estados estrangeiros manifestarão recusa a solicitações dessa ordem, ${ }^{314} \mathrm{em}$ razão de os instrumentos de assistência recíproca serem considerados prerrogativas dos órgãos estatais de persecução e julgamento da criminalidade transnacional. ${ }^{315}$

Assim, a não ser que haja permissão expressa no texto do tratado bilateral ou que a praxe entre as nações cooperantes o admita, não terão seguimento no exterior os pedidos de exclusivo interesse e iniciativa da defesa para a utilização em ações penais em curso no Brasil. $^{316}$

Nesse ínterim, Vladimir Aras apresenta solução, na tentativa de equilibrar o sistema, que consistiria na chancela do pedido da defesa pelo Judiciário ou pelo Ministério Público 317 :

Basta que a solicitação de MLA de interesse da defesa seja submetida à autoridade central brasileira por intermédio da autoridade legitimada no texto do acordo, isto é, pelo juiz, pelo membro do Ministério Público ou pela autoridade policial. Deste modo, ficará claro que a prova indicada pela defesa é de interesse da investigação criminal ou da instrução criminal, resguardando-se os princípios da verdade real, da comunhão da prova, da ampla defesa e do contraditório.

\footnotetext{
${ }^{313}$ VASCONCELLOS, Helena. Cooperação Jurídica Internacional em Matéria Penal: Uma Análise do Mutual Legal Assistance Treaty Brasil/Estados Unidos. Dissertação apresentada ao Programa de Pós-Gradução em Direito da Faculdade de Direito da Universidade Federal do Rio Grande do Sul como requisito parcial para obtenção do grau de mestre em Direito. Orientador Prof. Dr. Tupinambá Pinto de Azevedo. Porto Alegre, 2013, p. 182.

${ }^{314}$ De acordo com informações trazidas por Ricardo Perlingeiro Mendes da Silva provenientes das observações apresentadas em reunião científica promovida pelo Mnistério da Justiça, em 31 de março de 2005, naquela época, verificou-se que no campo da extradição, por exemplo, enquanto o Brasil havia atendido a $90 \%$ dos pedidos formulados por autoridades estrangeiras nos três anos anteriores, as autoridades brasileiras haviam sido atendidas em apenas $16 \%$ dos pedidos que haviam formulado ao exterior. Nas solicitações de outras medidas, estudo realizado pelo Conselho da Justiça Federal mostrou que $70 \%$ das catas rogatórias expedidas por autoridades brasileiras simplesmente não são atendidas. Nos poucos casos em que a carta rogatória é atendida, o procedimento tem se mostrado inadequado e absolutamente ineficiente para a obtenção da medida solicitada. (SILVA, Ricardo Perlingeiro Mendes da. Anotações sobre o anteprojeto de lei de cooperação jurídica internacional In Revista de Processo, no 129, ano 30, nov. 2005, pp. 134-5).

315 Ainda que se trouxesse o argumento de que as normas protetivas dos direitos humanos estariam abarcadas pela ideia de jus cogens, tal argumento parece não fazer diferença nas negativas de cooperação: “[...] E isso, por considerações de ordem interna, mas também por considerações de ordem internacional, ora baseadas na ideia do jus cogens, pelo que os direitos fundamentais reconhecidos em nível internacional representariam regras peremptórias no campo das relações internacionais, ora em face dos arts. 55 e 103 da Carta das Nações Unidas." (GRINOVER, Ada Pellegrini. O Processo em Evolução. Rio de Janeiro: Forense Universitária, 1996, p. 163).

316 Por exemplo, a defesa pode requerer a produção de prova com o intuito de comprovar alguma das excludentes de tipo, ilicitude ou culpabilidade previstas no código penal.

317 ARAS, Vladimir. O papel da autoridade central nos acordos de cooperação penal internacional. In: BALTAZAR Jr. José Paulo e LIMA, Luciano Flores de Lima. Porto Alegre, Verbo Jurídico, 2010, p. 84.
} 


\begin{abstract}
Ainda que assim não seja, a defesa de um acusado no Brasil não estará definitivamente prejudicada pela recusa do Estado estrangeiro em cooperar por MLA, tendo em vista que resta o caminho da legalização consular. A prova poderá ser obtida no exterior por qualquer meio e apresentada à representação consular brasileira no país de origem, para autenticação e regularização documental. Neste caso, não haverá a participação da autoridade central na produção probatória.
\end{abstract}

Sobre essa solução propugnada, Michail Wladimiroff já se manifestou, esclarecendo que esta revela-se ineficaz, exemplificando com atuação concreta perante o Tribunal ad hoc para a antiga Iugoslávia, ${ }^{318}$ em que estava discutindo um caso e necessitava localizar possíveis testemunhas que se encontravam refugiadas na Alemanha. Então, ao abordar as autoridades alemãs, pedindo-lhes que o (a defesa) ajudassem a localizar as possíveis testemunhas, a resposta foi: “Não. Quem é você?” Depois de esclarecidos alguns pontos e o seu status de defensor, disseram: "Bem, não há nenhuma disposição de Direito alemão que

318 "Para um exemplo muito simples, eu estava discutindo uma vez um caso no Tribunal Penal Internacional e queria localizar possíveis testemunhas que estavam entre os refugiados localizados na Alemanha. Eu abordei as autoridades alemães, perguntando-lhes se eles seriam capazes de ajudar a defesa a localizar essas possíveis testemunhas, e sua resposta foi simplesmente: "Não. Quem é você?". Foi o seu primeiro caso pelo Tribunal Penal Internacional e talvez estes eram problemas para iniciantes. Mas uma vez que eles foram capazes de compreender e identificar o meu status, sua resposta foi: "Bem, não há nenhuma disposição de direito alemão, então por que devemos responder a seu pedido?" Minha solução naqueles dias foi muito simples: eu pedi a acusação que o fizesse. Eles têm as respostas certas, e eles passaram as respostas para mim. Minha solução não é, no entanto, a rotina no common law, é uma solução mais ou menos orientada pelo civil law. Aplicando o sistema do TPIJ num Estado pertencente ao common law torna a defesa totalmente dependente do Ministério Público, porque os advogados de defesa só podem obter certos tipos de informação, através da promotoria. Este sistema não funciona. Se eu quiser documentos na França, por exemplo, e quiser inspecioná-los, porque eu tenho razões para acreditar que eles são relevantes para a defesa, eu não posso ir a um tribunal francês e pedir uma liminar que obrigue o Estado francês a entregar esses documentos para inspeção da defesa. O Ministério Público pode fazê-lo, mas o direito nacional francês não dá pé para os advogados de defesa nessas questões. Enfrentam-se os mesmos problemas no âmbito das convenções e tratados que lidam com a assistência mútua em matéria penal europeus, porque eles são baseados no sistema inquisitorial do civil law." Tradução livre de: "For a very simple example, I was once arguing a case before the ICTY and wanted to locate possible witnesses who were among the refugees then located in Germany. I addressed the German authonties, asking them whether they would be able to assist the defence in locating these possible witnesses, and their answer was essentially: "No. Who are you?" Nowit was their first case before the ICTY and maybe these were beginner's problems. But once they were able to understand and identify my status, their answer was, "well, there is no provision under German law, so why should we answer your request?" My solution in those days was very simple: I asked the prosecution to do it. They got the right answers, and they passed the answers to me. My solution is not, however, the normal common law routine; it's more or less a civil law orientated solution, and while it worked, it cannot be relied upon. Applying the ICTY system in a common law State renders the defence totally dependent on the prosecution, because defence attorneys can only get certain types of information through the prosecution. This system doesn't work. If I want documents in France, for example, and I want to inspect them because I have reason to believe that they are relevant to the defence, I cannot go to a French court and ask for an injunction ordering the French State to produce these documents for defence inspection. The prosecution may do so, but French national law gives no standing to defence lawyers in these matters. One faces the same problems under the European Conventions and treaties dealing with mutual assistance in criminal matters, because they are based on the civil law inquisitorial system." (WLADIMIROFF, Michail. Cooperation on Criminal Matters: a Defence Lawyer's Perspective. In: R. Yepes-Enríquez and L. Tabassi (eds.), Treaty Enforcement and International Cooperation in Criminal Matters, 2002, p. 248). 
preveja essa possibilidade, então por que deveríamos responder ao seu pedido?”

Nesse contexto, o autor revela que a solução encontrada naquela época foi bastante simples: pediu ao Ministério Público para que o fizesse. Entretanto, refere que essa solução não é a rotina-padrão no sistema de common law e, em qualquer sistema que seja adotado, torna a defesa totalmente dependente do Ministério Público. Além do mais, sem mencionar que os advogados de defesa só conseguirão obter determinados tipos de informação através da acusação, ou seja, resta claro que esse sistema não funciona. Se o advogado quiser documentos na França, por exemplo, para inspecioná-los, porque tem razões plausíveis para acreditar que eles são relevantes para a defesa, ele não pode ir a um tribunal francês e pedir uma liminar ordenando o Estado francês a produzir esses documentos em prol da defesa. Ao revés, o Ministério Público poderá fazê-lo, mas nenhuma lei nacional francesa dá guarida para os advogados de defesa nesses assuntos. Nesse panorama, enfrentam-se os mesmos problemas no âmbito das convenções e tratados europeus de auxílio judiciário mútuo em matéria penal.

A título de conclusão do raciocínio apresentado e seguindo a linha de pensamento de Michail Wladimiroff, importa apresentar as conclusões finais do seu trabalho ${ }^{319}$ : a lei necessária para atender claramente às normas de um julgamento justo - aquele no qual ambas as partes são capazes de apresentar suficientemente o seu caso - não está presente nos documentos legais em vigor. Essa é uma questão de Direito Internacional, mas também de Direito nacional, porque os Estados cumprem as obrigações internacionais através de estatutos internos. A prática na implementação dessas obrigações em jurisdições regidas pelo common law é totalmente diferente da implementação em jurisdições do civil law, e os legisladores têm ignorado as consequências dessas diferenças sobre os poderes e habilidades da defesa. Ao elaborar tratados, protocolos, convenções ou estatutos em matéria de cooperação do Estado com organismos internacionais ou supranacionais, sejam eles órgãos

\footnotetext{
${ }^{319}$ No original: "The law needed to clearly meet the standards of a fair trial - one in which both parties are able to sufficiently present their case - is not present in current legal documents. This is an issue of international law, but it is also an issue of national law, because states comply with international obligations through domestic statutes. The practice of implementing these obligations in common law jurisdictions is totally different from the implementation in civil law jurisdictions, and legislators have overlooked the consequences of these differences on the powers and abilities of the defence. [...] When drafting treaties, protocols, conventions or statutes regarding state cooperation with international or supranational bodies, be they judicial bodies or not, the drafters must always remember that there are always at least two parties, and those parties should have, or at least be able to achieve, equal rights. [...] Do not seek procedures for guaranteeing the ideal trial; there are no ideal trials, for either the prosecution or the defence. But they do seek laws establishing a procedural standard that adequately fulfils the demands of fair trial in tribunal proceedings. And after a survey of the ICTY, the ICTR, the European conventions and treaties, and the Statute of the ICC, I am not yet satisfied”.(Ibidem, p. 248-250).
} 
judiciais ou não, os redatores devem lembrar que há sempre pelo menos duas partes, e as partes devem ter ou, pelo menos, ser capazes de alcançar direitos iguais. Não se devem buscar procedimentos para garantir o julgamento ideal; não existem julgamentos ideais, quer para a acusação quer para defesa. Porém se devem buscar leis que estabeleçam um padrão de procedimentos que cumpram adequadamente as demandas de um julgamento justo em procedimentos judiciais. E, depois de uma pesquisa com o TPIJ, o TPIR, as convenções e tratados europeus e o Estatuto do TPI, o autor revela ainda não estar satisfeito.

Ademais, como traz Gless, para os efeitos da cooperação transfronteiriça em matéria de igualdade de armas nos casos criminais transnacionais, os aspectos mais problemáticos dizem respeito ao fato de a defesa não ter acesso ao benefício da cooperação transfronteiriça pela forma de cooperação jurídica mútua ou por meio de redes. Para a autora, poderia ser encontrada uma solução pragmática em uma base caso a caso, mas essa possibilidade incrementa uma estrutura de enfraquecimento da posição do réu, que deve, por sua vez, encontrar um caminho através de uma situação transfronteiriça complexa. ${ }^{320}$

De igual modo, na jurisdição doméstica, também já se verificou que a solução apresentada por muitos autores nacionais - acima ilustrada pelo pensamento de Vladimir Aras — consiste na adoção da prova solicitada pela defesa como causa própria do Juízo ou do Ministério Público, com base, fundamentalmente, no princípio da comunhão das provas e da verdade real, ${ }^{321}$ que, como explicitado, tampouco resolve o problema, observado que ficar ao alvedrio do entendimento subjetivo de outros sujeitos da relação processual não se afigura salutar, como se pode avaliar pela leitura do seguinte julgado:

PROCESSO PENAL. HABEAS CORPUS. TESTEMUNHA DE DEFESA. OITIVA NO EXTERIOR (EUA). ACORDO DE ASSISTÊNCIA JURÍDICA EM MATÉRIA PENAL ENTRE BRASIL E ESTADOS UNIDOS - APLICABILIDADE AOS ENTES ESTATAIS. INDEFERIMENTO DE EXPEDIÇÃO DE CARTA ROGATÓRIA: AUSÊNCIA DE ILEGALIDADE. CERCEAMENTO DE DEFESA:

\footnotetext{
320 GLESS, Sabine. Transnational Cooperation in Criminal Matters and the Guarantee of a Fair Trial: Approaches to a General Principle. Utrech Law Review. Vol. 9, Issue 4, Set. 2013, p. 101.

${ }^{321}$ A distinção entre verdade formal e verdade material ou real encontra-se superada, entretanto, segue sendo utilizada por alguns autores, como é o caso do autor cujo trecho foi citado, entretanto, cumpre referir que dita distinção encontra-se superada no plano jurídico. Com efeito, atualmente se pode considerar não só desvanecida a crença de que no processo se poderia atingir a verdade material, como também a crença de que seria possível alcançar qualquer tipo de verdade no processo. Nesse sentido, os argumentos para a refutação da distinção entre verdade formal e verdade material foram proporcionados por Carnelutti, no início do século, ao afirmar que o processo não está direcionado à busca da verdade no caso concreto, pois de acordo com Carnelutti o processo não é um sistema de busca e conhecimento da verdade dos fatos, senão que um sistema para a fixação ou determinação dos próprios fatos, que pode coincidir ou não com a verdade daqueles e que permanece completamente independente deles. (GUZMÁN FLUJA, Vicente C. Anticipación y Preconstitución de la Prueba en el Proceso Penal. Valencia: Tirant lo Blanch, 2006, p. 69-70).
} 
INOCORRÊNCIA. ORDEM DENEGADA.

I - O Acordo de Assistência Judiciária em Matéria Penal (MLAT) firmado entre os Governos do Brasil e o dos Estados Unidos da América, promulgado pelo Decreto $n^{o} 3.810 / 01$, não abrange as diligências requeridas pela defesa nas ações penais.

II - Referido acordo, dispõe seu preâmbulo, visa facilitar a execução das tarefas das autoridades responsáveis pelo cumprimento da lei de ambos os países, no que se refere às atividades de investigação, inquérito, ação penal e prevenção do crime, através de cooperação e assistência judiciária mútua em matéria penal. E, ainda, não se aplica às pessoas naturais, mas apenas aos entes estatais (artigo I, item 5, do Acordo).

III - Assim, ao contrário do sustentado na impetração, o Acordo de Assistência Judiciária em Matéria Penal (MLAT) citado não padece de inconstitucionalidade por afrontar aos princípios da isonomia processual, contraditório e ampla defesa. O que ocorre, na verdade, é uma recusa do Estado americano em proceder à oitiva de testemunhas arroladas pela defesa, fundamentando tal negativa nos princípios norteadores do sistema de Common Law, adotado por aquele país, segundo o qual referidas diligências são realizadas às custas da defesa, pouco importando se os réus são americanos ou estrangeiros.

IV - De fato, o princípio constitucionalmente garantido do devido processo legal deverá proporcionar ao acusado todos as formas possíveis de defesa, porém dentro dos limites do território nacional, pois as regras constitucionais e processuais pátrias não podem ser compelidas a outro Estado soberano.

V - Ademais, não há ilegalidade na negativa de expedição de carta rogatória aos EUA, uma vez que o juízo a quo fundamentou sua decisão no entendimento de que a diligência não seria cumprida pela Justiça norteamericana, visto que não há acordo entre ambos os países aptos a autorizar a oitiva de testemunhas arroladas pela defesa nos tribunais americanos. Trata-se da discricionariedade do juiz, ao qual é facultado indeferir diligência, através de decisão fundamentada, que considere irrelevante, impertinente ou protelatória, sendo que, no caso, pelo fato de o ato não ser cumprido por aquele país, se tornaria meramente procrastinatório.

VI - Resta afastada, além disso, a hipótese levantada pelos impetrantes no sentido de que houve o cerceamento da defesa, tendo em vista que, segundo as informações constantes da mensagem eletrônica enviada pelo Ministério da Justiça, há outros meios possíveis para a defesa realizar a sua produção probatória.

VII - Destaco, também que, conforme os esclarecimentos prestados pela autoridade coatora, nos autos da ação penal originária do presente mandamus ainda não foram ouvidas as testemunhas de acusação e de defesa, logo, no momento processual em que se encontram os autos não é possível determinar-se a oitiva da testemunha arrolada pela defesa do paciente, residente nos EUA, na qualidade de testemunha do juízo.

VIII - E, por fim, esclareceu o juízo impetrado que, caso a defesa considere imprescindivel, está autorizado o comparecimento pessoal das testemunhas arroladas pela defesa, residentes nos EUA, ao Juízo da $4^{a}$ Vara Criminal Federal de São Paulo/SP, ora autoridade coatora, a fim de que seja realizada sua oitiva, não havendo qualquer óbice ou impedimento para a realização do ato.

IX - Ordem denegada. (TRF-3 ${ }^{a}$ Região, HC n ${ }^{\circ}$ 2010.03.00.030380-2. Rel. Desembargador Federal Cotrim Guimarães, Segunda Turma, julgado em 15 mar. 2011). Grifo nosso. 
O julgado transcrito é bastante elucidativo, em especial com a leitura das partes grifadas em negrito, em relação à denegação de prova requerida pela defesa, quando se nega a aplicação do princípio da comunhão das provas, com solução bastante cínica em relação ao voluntário comparecimento da parte que reside nos Estados Unidos ao Juízo localizado em São Paulo.

Nesse sentido, de modo a superar as inconsistências referidas, o que se pretende como solução efetiva e concreta da quaestio juris é a de não ser mais necessário restar na dependência de o Judiciário ou o Ministério Público compreenderem e chancelarem as razões do pedido da defesa, transformando-o em causa própria do Juízo, inclusive, sendo possibilitado à defesa o acompanhamento das provas produzidas no exterior, de modo a não se falar em nulidades processuais posteriormente, o que sim favoreceria a prescrição dos crimes.

No Reino Unido, essa discussão já foi posta em pauta há mais de duas décadas, desde a edição do International Co-operation Act de 1990, como traz Murray em interessante estudo que aborda a perspectiva da defesa nas solicitações de assistência jurídica internacional, em razão do incremento dos crimes transnacionais. ${ }^{322}$ A proposta do estudo realizado consistiu em examinar os mecanismos para a obtenção de provas em favor dos réus em procedimentos transnacionais e até que ponto havia igualdade de oportunidades e de armas entre a acusação e a defesa na obtenção de evidências no exterior em procedimentos do Reino Unido. O artigo também explorou os novos problemas que começaram a emergir quando a referida paridade foi atacada. Para tanto, o autor estudou o mecanismo que rege a assistência mútua no Reino Unido, qual seja, o International Co-operation Act de 1990.

$\mathrm{O}$ autor sintetiza referindo que problemas entre o Reino Unido e outras jurisdições do common law, incluindo os Estados Unidos e os membros da Commonwealth, são mais fáceis de prever e, assim também, de resolver. Na realidade, os mais problemáticos são os pedidos que envolvem jurisdições do civil law, que podem, inclusive, ameaçar os processos em trâmite no Reino Unido. Nos primeiros tempos da Lei de 1990, os pedidos em prol da defesa direcionados para jurisdições do civil law (e para outras, como as jurisdições do

\footnotetext{
${ }^{322}$ No original: The purpose of this Essay is to examine the machinery for providing evidence to defendants in foreign proceedings and the extent to which there is equality of arms and opportunity between the prosecutor and defendant when obtaining evidence from abroad in U.K. proceedings. This Essay will also identify the new problems that are starting to emerge when such equality is threatened. To do so, one must explore the mechanism by which mutual assistance is governed in the United Kingdom - the Criminal Justice (International Co-operation) Act of 1990. (MURRAY, Christopher. Defense Requests for International Judicial Assistance: The UK Perspective. In: Fordham International Law Journal. Vol. 23, Issue 5, Article 4, 1999, p. 1348).
} 
ordenamento islâmico) comumente desapareciam no éter. Uma vez tendo sido transmitidos, nunca mais se ouviu falar desses pedidos novamente.

Felizmente, as coisas mudaram rapidamente e, pelo menos, os pedidos já estão sendo respondidos. Os problemas, no entanto, não desapareceram. [...] Advogados britânicos questionaram a necessidade de tais condições e chamaram a atenção para possíveis violações do artigo $6^{\circ}$ da Convenção Europeia dos Direitos Humanos, que garante instalações adequadas para a preparação de uma defesa do acusado. ${ }^{323}$

Com ênfase na questão de que existe o perigo de se considerar a necessidade de uma maior colaboração entre os países somente para a perspectiva do Ministério Público, observa-se ser igualmente importante o reconhecimento de que uma cooperação jurídica adequada e eficiente também deve estar disponível ao acusado. ${ }^{324}$

Não bastasse isso, situação peculiar no Brasil, que não é levada em conta nos casos de denegação da produção de prova pela defesa, ocorre quando esta é patrocinada pela

\footnotetext{
323 "No campo da assistência mútua, o Reino Unido é muito mais um "dos jovens" no bloco. O Reino Unido só efetivamente chegou ao clube em 1990, e, assim, exemplos de pedidos de defesa e problemas já reconhecidos são limitadas. Problemas entre o Reino Unido e outras jurisdições do common law, incluindo os Estados Unidos e os membros da Commonwealth, serão mais fáceis de prever e, assim, também de resolver. São as solicitações que envolvem jurisdições do civil law, que já começaram a destacar problemas, alguns dos quais podem de fato ter impacto em processos que tramitam no Reino Unido, de tal forma que eles podem voltar a ser ameaçado. Nos primeiros dias da Lei de 1990, os pedidos de defesa para jurisdições de civil law (e outros, tais como jurisdições de lei islâmica) desapareceram no éter. Uma vez que eles foram transmitidos, não se ouviu mais notícias deles. Felizmente, as coisas mudaram rapidamente e, pelo menos, os pedidos já estão sendo respondidos. Os problemas, no entanto, não desapareceram. [...] Advogados britânicos questionaram a necessidade de tais condições e chamaram a atenção para possíveis violações do artigo $6^{\circ}$ da Convenção Europeia dos Direitos Humanos, que garante instalações adequadas para a preparação de uma defesa do acusado." Tradução livre de: "Within the field of mutual assistance, the United Kingdom is very much one of the "new kids on the block." The United Kingdom only effectively joined the club in 1990, and thus examples of defense requests and the problems they met are limited. Problems between the United Kingdom and other common law jurisdictions, including the United States and members of the Commonwealth, will be easier to predict and thereby to resolve. It is the requests involving civil law jurisdictions, which have already started to highlight problems, some of which may indeed impact U.K. proceedings to such an extent that they may themselves be threatened. In the early days under the 1990 Act, defense requests to civil law jurisdictions (and others, such as Islamic law jurisdictions) commonly disappeared into the ether. Once they were transmitted, nothing was heard of them again. Thankfully, things have moved apace and at least requests are now being answered. The problems, however, have not disappeared. [...] U.K. lawyers questioned the necessity for such conditions and drew attention to potential breaches of Article 6 of the European Convention on Human Rights, which guarantees adequate facilities in the preparation of an accused's defense". (Ibidem, pp. 1365-6).

324 "O crescimento do crime internacional e do reconhecimento da ameaça que representa para a sociedade civilizada, particularmente na sua forma organizada, é visto como um dos itens mais importantes na agenda política internacional atual. Existe o perigo de que esta necessidade de uma maior colaboração seja percebida apenas como uma necessidade do Ministério Público. É igualmente importante, no entanto, que os direitos do arguido sejam reconhecidos de forma semelhante. Cooperação jurídica adequada e eficiente deve estar igualmente disponível para o acusado." Tradução livre de: The growth of international crime and the recognition of the threat it poses to civilized society, particularly in its organized form, is seen as one of the most important items on the current international political agenda. There is a danger that this need for increased collaboration is perceived only to be a prosecutorial necessity. It is equally important, however, that the rights of the defendant are similarly recognized. Adequate and efficient judicial cooperation must be equally available to an accused. (Ibidem, p. 1.347).
} 
Defensoria Pública e, assim, ao se vislumbrar pleito de prova em outro país, não é um particular stricto sensu que o pretende, mas sim o Estado, por meio de uma instituição qualificada e legitimada a atuar em favor de réus hipossuficientes economicamente. ${ }^{325}$

Assim sendo, um paradoxo se instala. De um lado, pessoa, em regra, carente, que sequer tem condições de constituir advogado no Brasil, necessitando da assistência da Defensoria Pública da União (considerando se tratar de crime transnacional), e que tampouco poderia custear produção de prova no exterior. ${ }^{326}$ De outro, um Estado instado a cooperar, mas que denega tal cooperação, sob o fundamento da impossibilidade da sua utilização por particular.

Nesse norte, não há que se falar que a produção de provas no exterior diz respeito apenas a crimes de grande monta, em que estão envolvidos criminosos com grande poderio econômico, pois, como lembra Murray, ${ }^{327}$ não é só em casos complexos e em que há grandes somas de dinheiro envolvidas que a cooperação se faz necessária. Até mesmo casos aparentemente mais simples, que envolvem, por exemplo, um acidente de trânsito de menor importância, podem envolver testemunhas ou acusados de outra jurisdição que não aquela em que ocorreu o acidente. Em casos mais complexos, nos quais, por exemplo, existe a

\footnotetext{
${ }^{325}$ Importante referir que em atuação atípica, na esfera criminal, não há análise acerca da hipossuficiência econômica para que a Defensoria seja designada para atuar na defesa do réu, basta que o réu não constitua advogado para sua defesa.

${ }^{326}$ Como refere Díez Ripollés, em nossos tempos tem-se a impressão de que os poderosos, com assessoria técnica só acessível às pessoas com seu status econômico ou endosso político, têm sido capazes de explorar os garantes do direito procedimental penal, conseguindo um processo criminal que em grande parte elude a condenação ou a imposição de sanções. (DÍEZ RIPOLLÉS, José L. El nuevo modelo penal de la seguridad ciudadana. Revista Electrónica de Ciencia Penal y Criminología. Núm. 06-03, 2004, p. 6).

327 "A cooperação internacional em investigações criminais tornou-se cada vez mais importante para os profissionais, tanto para os procuradores quanto para os advogados de defesa. Não é apenas em casos complexos que existe uma necessidade de uma cooperação eficaz. Mesmo o caso aparentemente mais simples que envolve, por exemplo, um acidente de trânsito de menor importância, pode envolver testemunhas ou acusados de outra jurisdição que não aquele em que ocorreu o acidente. Testemunhas do exterior podem ter de ser convocadas para o tribunal, documentos oficiais terão de ser apresentados, as provas relativas a testemunhas precisam ser obtidas. Em casos mais complexos, onde, por exemplo, existe a necessidade de desvendar uma trilha complexa de transações financeiras em muitos países e, talvez, vários continentes, um sistema eficaz de assistência jurídica mútua é essencial para a investigação rápida e eficaz e repressão de casos. Em todos esses casos, a defesa também pode querer obter provas de outra jurisdição, a fim de apresentar o seu caso adequadamente." Tradução livre de: "International cooperation in criminal investigations has become increasingly important for practitioners-both for prosecutors and defense lawyers. It is not just in complex cases that there is a need for effective cooperation. Even the most apparently simple case involving, for instance, a minor road traffic accident, may involve witnesses or accused persons from a jurisdiction other than the one in which the accident occurred. Witnesses from abroad may need to be summoned to court, official papers will need to be served, the evidence concerning witnesses may need to be obtained. In more complex cases, where, for example, there is a need to unravel a complex trail of financial dealings across many countries and perhaps several continents, an effective system of mutual legal assistance is essential for expeditious and effective investigation and prosecution of cases. In all such cases, the defense also may wish to obtain evidence from another jurisdiction in order to present their case properly." (MURRAY, Christopher. Defense Requests for International Judicial Assistance: The UK Perspective. In: Fordham International Law Journal. Vol. 23, Issue 5, Article 4, 1999, p. 1346).
} 
necessidade de desvendar uma trilha complexa de transações financeiras em muitos países e, talvez, vários continentes, com muitas pessoas envolvidas, um sistema eficaz de assistência jurídica mútua é essencial para a investigação rápida e eficaz e para a repressão de tais casos. Em todos eles, a defesa também pode querer e ter o direito de obter evidências em outra jurisdição, a fim de apresentar o seu caso adequadamente.

No mesmo sentido, Fijnaut e Ouwerkerk ${ }^{328}$ esclarecem que o pressuposto central do quadro legal é que as partes ampliem a assistência mútua entre si para o máximo possível, fazendo com que o âmbito de aplicação dessa forma de cooperação internacional torne-se extremamente amplo e praticamente ilimitado. Então, deve primeiro ser estabelecido que esse âmbito de aplicação não se limita a questões relacionadas com crimes mais complexos ou mais sérios, mas também abrange os procedimentos em relação aos chamados "delitos menores", como as infrações de trânsito de menor potencial ofensivo, e em relação a pessoas de classes sociais mais desfavorecidas também.

Ademais, com a divulgação do Relatório Mundial sobre Drogas da ONU, elaborado pelo Escritório das Nações Unidas sobre Drogas e Crime (UNODC), no mês de junho de 2011, em que o Brasil consta como principal rota do tráfico de cocaína para a Europa, a situação das prisões das chamadas "mulas do tráfico", nos aeroportos internacionais brasileiros, tem se agravado. Hipótese em que, em regra, a Defensoria Pública da União assiste a parte ré, observada a presença do fator insuficiência de recursos financeiros do polo passivo. Ademais, conforme notícia veiculada no jornal O Estado de São Paulo, ${ }^{329}$ em 23 de junho de 2011, o Brasil foi considerado, em 2009, entre os países das Américas, a principal rota de passagem da cocaína apreendida na Europa. O número de casos de apreensões que envolveram o Brasil como país de trânsito de cocaína subiu de 25 em 2005 (somando 339 quilos) para 260 em 2009, somando 1,5 toneladas.

Não bastasse isso, em recente entrevista também veiculada pelo jornal O Estado de São Paulo, ${ }^{330}$ Marina Dias, Advogada Criminal e ex-presidente do Instituto de Defesa dos Direitos de Defesa (IDDD), referiu expressamente que:

\footnotetext{
${ }^{328}$ No original: "The central assumption of the legal framework is that the parties extend mutual assistance to each other to the maximum possible extent, making the scope of application of this form of international cooperation extremely broad and virtually unlimited. So it must first be established that this scope of application is not limited to matters related to major or more serious criminal offences, but also covers procedures regarding the so-called 'minor offences' such as, for instance, minor traffic violations." (FIJNAUT, Cyrille; OUWERKERK, Jannemieke. The Future of Police and Judicial Cooperation in the European Union. Martinus Nijhoff Publishers: Leiden/Boston, 2010, p. 133.

${ }^{329}$ Disponível em: <http://www.estadao.com.br/noticias/nacional,brasil-e-principal-rota-de-passagem-dacocaina-rumo-a-europa-diz-relatorio,736168,0.htm>. Acesso em 30 de junho de 2011.

${ }^{330}$ O ESTADO de São Paulo. Matéria de Capa. Entrevista com Marina Dias. Domingo, 31 de agosto de 2014.
} 
no Brasil, não existe uma polícia que investiga. Existe polícia repressiva, herança da ditadura, tanto que grande parte dos processos começa com prisões em flagrante. O próprio tráfico de drogas... Quem está sendo preso? É o grande traficante? Não. É o usuário que está com um pouco mais de droga, ou o pequeno traficante.

É com esse panorama que o presente trabalho tem a (ousada) pretensão de apresentar meios para colocar a defesa em real igualdade com a acusação no cenário jurídico da cooperação internacional em matéria penal, levando em conta experiências e discussões já travadas no âmbito da União Europeia, dos Tribunais Internacionais Penais e do Tribunal Europeu de Direitos Humanos, bem como com referência a instituições já existentes no cenário nacional e comparado que poderão desempenhar papel fundamental nessa tarefa.

Com esse intuito, no capítulo seguinte, serão abordados alguns caminhos que já vêm sendo trilhados no âmbito da União Europeia (UE), além de apresentados alguns institutos específicos para a salvaguarda dos direitos dos investigados no âmbito da União, a fim de possibilitar a aferição de se as soluções aventadas no campo comunitário poderiam ser transplantadas para o âmbito jurídico nacional, com o reconhecimento de que a UE já deu um passo adiante nessa temática ao passar do paradigma da mútua assistência para o paradigma do reconhecimento mútuo das decisões judiciais.

Com a sábia advertência de Heloisa Estellita ${ }^{331}$ é que se reconhecem as limitações do presente trabalho, assim como se justifica a eleição da União Europeia para estudo:

\begin{abstract}
Nenhuma região melhor exemplifica este quadro do que a da União Europeia, na qual, de carona com o incremento da cooperação para o "combate" ao crime, levantaram-se vozes postulando que a esse incremento do esforço internacional "contra os criminosos" correspondesse, igualmente, um esforço internacional e nacional de garantia das prerrogativas processuais das pessoas "objeto" dos atos de cooperação. A igualdade não foi até hoje alcançada.
\end{abstract}

E adverte, ainda, que a Justiça criminal, na realidade, não está preparada ou ainda não está disposta a pagar o preço de combater o crime transnacional com respeito às prerrogativas dos acusados.

\footnotetext{
${ }^{331}$ ESTELLITA, Heloisa. Prerrogativas Processuais dos Acusados Estrangeiros: O Outro Lado da Moeda da
} "Luta Contra o Crime Transnacional”. Boletim IBCCRIM. Ano 18, n. 214, set. 2010, pp. 8-9. 


\subsection{Os direitos dos investigados e a paridade de armas na cooperação jurídica internacional penal na União Europeia}

$\mathrm{Na}$ área da cooperação jurídica internacional, pode-se pensar em dois possíveis cursos de ação: a mútua assistência e o reconhecimento mútuo das decisões judiciais. Ainda que os objetivos que dirigem esses dois paradigmas de atuação possam ser comuns, eles não têm a mesma base normativa, tampouco os resultados angariados são semelhantes.

O espírito teórico que impulsiona atualmente a cooperação jurídica na União Europeia é a substituição progressiva de um sistema de assistência jurídica, no sentido em que tradicionalmente tem sido entendida (com base em convenções e em tratados bilaterais entre os países), por um conjunto de normas suportado sobre o princípio do reconhecimento mútuo das decisões judiciais.

O princípio político que transparece nesse propósito é evidente: enquanto a assistência jurídica mútua em sentido clássico toma como base a existência de Estados plenamente soberanos, com sistemas penais independentes, o reconhecimento mútuo pressupõe um passo além, na medida em que as leis criminais dos diversos Estados aspiram não só o trabalho conjunto harmônico, mas também um alto nível de integração ou, ao menos, de coordenação operativa. Isso significa não só atingir um determinado padrão de compatibilidade normativa, que permita um fluxo ágil de pedidos de assistência com o devido cumprimento, mas fundamentalmente um alto grau de permeabilidade do processo desenvolvido em um Estado para alcançar eficácia em outro. As políticas comunitárias na temática estão optando pelo princípio do reconhecimento mútuo como fundamento, com a nítida intenção de reduzir ao mínimo as possibilidades de que um Estado ponha travas de qualquer natureza à assistência requerida. ${ }^{332}$

Nesse ponto, interessante observar que o art. $6^{\circ}$ do Tratado da União Europeia (UE) determina que a União respeite os direitos fundamentais tal como garantidos pela Convenção Europeia de Salvaguarda dos Direitos do Homem e das Liberdades Fundamentais e tal como resultaram das tradições constitucionais comuns dos Estados-Membros. ${ }^{333}$

\footnotetext{
332 PÉREZ GIL, Julio. El Convenio de Asistencia Judicial en Materia Penal Entre los Estados Miembros de la UE: ¿Un Instrumento Anclado en Coordenadas Superadas? Diario La Ley, Año XXVI. Número 6208, 2005, pp. 1-2.

${ }^{333}$ Artigo 6: "1. A União reconhece os direitos, as liberdades e os princípios enunciados na Carta dos Direitos Fundamentais da União Europeia, de 07 de dezembro de 2000, com as adaptações que lhe foram introduzidas em 12 de Dezembro de 2007, em Estrasburgo, e que tem o mesmo valor jurídico que os Tratados. De forma alguma o disposto na Carta pode alargar as competências da União, tal como definidas nos Tratados. Os direitos, as liberdades e os princípios consagrados na Carta devem ser interpretados de acordo com as disposições gerais constantes do Título VII da Carta que regem a sua interpretação e aplicação e tendo na
} 
Como lembra Vogel, ${ }^{334}$ certamente, o Direito Processual Penal nos Estados-Membros tem uma base jurídica europeia comum nos artigos $5^{\circ}$ e $6^{\circ}$ da Declaração Europeia dos Direitos Humanos. No entanto, é sabido que o sistema e as normas legais do processo penal variam consideravelmente entre os Estados-Membros: vários adotaram o "sistema penal acusatório”, baseado no Direito consuetudinário tradicional, cuja principal característica é que, em parte do julgamento, tanto a acusação quanto a defesa podem apresentar provas, enquanto a maioria dos Estados-Membros segue o "sistema inquisitorial", segundo o qual o juiz que preside o julgamento recolhe e investiga as evidências relevantes. Ademais, em vários Estados-Membros, é o Ministério Público que investiga e tramita os casos, enquanto, em outros, as investigações são conduzidas por um magistrado (por exemplo, o juiz de instrução francês). Nesse sentido, até mesmo dentro da UE se verificam as dificuldades de interação entre sistemas jurídicos diversos, como já tratado em capítulo precedente.

Além disso, o papel da polícia e a situação legal de um suspeito na fase de investigação policial ${ }^{335}$ variam consideravelmente a depender do Estado-Membro, e também varia consideravelmente a legislação sobre provas e a sobre prisão preventiva e suas alternativas (fiança, v.g.). É sabido que essas divergências constituem um obstáculo para a cooperação e tendem a minar a confiança mútua que constitui a base do reconhecimento mútuo. ${ }^{336}$ Portanto, inevitável fixar também algumas normas mínimas em relação aos processos penais nacionais, observada a particular urgência de se alcançar um certo grau de harmonização e aproximação na área da prisão preventiva e de outras medidas coercitivas na etapa de investigação e de coleta de provas.

Levando em conta esse panorama, Puyenbroeck e Vermeulen ${ }^{337}$ chegaram a $^{2}$

devida conta as anotações a que a Carta faz referência, que indicam as fontes dessas disposições. 2. A União adere à Convenção Europeia para a Proteção dos Direitos do Homem e das Liberdades Fundamentais. Essa adesão não altera as competências da União, tal como definidas nos Tratados.3. Do direito da União fazem parte, enquanto princípios gerais, os direitos fundamentais tal como os garante a Convenção Europeia para a Proteção dos Direitos do Homem e das Liberdades Fundamentais e tal como resultam das tradições constitucionais comuns aos Estados-Membros.”

${ }^{334}$ VOGEL, Joachim. Cooperación Penal: Cinco Tendencias. Cinco Propuestas Para Una Acción Futura. In: ROMERO, Marta Muñoz de Morales (Coord.). El Derecho Penal de la Unión Europea. Situación Actual y Perspectivas de Futuro. Cuenca: Ediciones de la Universidad de Castilla La-Mancha, 2007, p. 165.

335 “Como estender o princípio da igualdade de armas para a fase da investigação preliminar, portanto, é uma das questões mais importantes do processo penal europeu moderno em relação aos direitos garantidos pela Convenção Europeia de Direitos Humanos." Tradução libre de: "Cómo extender el principio de igualdad de armas a la fase de la investigación preliminar, por lo tanto, es una de las cuestiones más trascendentes del proceso penal europeo moderno en relación a los derechos que garantiza la CEDH”. (BACIGALUPO, Enrique. Justicia Penal y derechos fundamentales. Madrid: Marcial Pons Ediciones Jurídicas y Sociales, 2002. p. 137).

336 Princípio do "reconhecimento mútuo" significa que uma decisão judicial proferida em um Estado-Membro da UE é válida e aplicável em qualquer outro Estado.

${ }^{337}$ PUYENBROECK, Laurens Van; VERMEULEN, Gert. Towards Minimum Procedural Guarantees for the Defence in Criminal Proceedings in the EU. International and Comparative Law Quarterly, vol. 60, 2011, pp. 
desenvolver um estudo com o objetivo de examinar o estado atual dos direitos processuais dos suspeitos e arguidos em processos penais na União Europeia, cujas conclusões baseiamse nas respostas obtidas dos representantes dos Ministérios da Justiça dos Estados-Membros. A equipe do projeto salientou que não realizou nenhuma pesquisa adicional sobre a precisão dessas respostas. A análise foi estruturada em torno de três questões principais. Em primeiro lugar, qual é a importância de tais direitos na UE? Em segundo lugar, que garantias processuais atualmente existem nos Estados-Membros e estão os direitos processuais fundamentais em processos penais de acordo com o previsto na Convenção Europeia de Direitos Humanos (CEDH) e efetivamente garantidos nos sistemas de justiça penal da UE? Por fim, se as respostas para as perguntas anteriores sugerem a necessidade de uma ação da UE nesse domínio, que medidas já foram tomadas a esse respeito e o que o futuro reserva?

Por meio desse estudo, aferiu-se que, em quase todos os países onde o advogado está autorizado a estar presente, as autoridades estão obrigadas a informar o suspeito desse direito, mas existem diferenças significativas entre os Estados-Membros quanto ao momento em que surge a obrigação de informar e a maneira como a informação é prestada ao suspeito. Além disso, em vários Estados-Membros, não há possibilidade para a defesa deliberar em privado durante o interrogatório. Finalmente, o estudo mostra que a presença de um advogado no interrogatório não é considerada essencial: apenas em três Estados-Membros (Portugal, Espanha e Itália), não é permitido usar a confissão de um suspeito feita na ausência de seu advogado como prova em juízo. Não bastasse isso, o estudo demonstra ainda que, embora o direito à assistência jurídica gratuita (ainda que parcial) exista em todos os EstadosMembros (com exceção da Alemanha), há diferenças significativas na aplicação desse direito. Também preocupante é o fato de que, em alguns Estados-Membros, não há obrigação legal de informar o suspeito do seu direito à assistência jurídica de forma gratuita, ainda que parcialmente. Além disso, na maioria dos Estados-Membros, a especialização e a disponibilidade do advogado não são levadas em conta ao se decidir sobre qual profissional será nomeado para o caso. Esses resultados levantam a questão de saber se a qualidade da assistência jurídica gratuita é de fato garantida em toda a UE. ${ }^{338}$

Essas preocupações informaram o Livro $\operatorname{Verde}^{339}$ da Comissão Europeia para o

1018 e 1022.

${ }^{338}$ PUYENBROECK, Laurens Van; VERMEULEN, Gert. Towards Minimum Procedural Guarantees for the Defence in Criminal Proceedings in the EU. International and Comparative Law Quarterly, vol. 60, 2011, p. 1033-4.

${ }^{339}$ Conforme glossário do Centro de Informação Europeia Jacques Delors, os Livros Verdes são “documentos da responsabilidade da Comissão Europeia, tem por objectivo fomentar a reflexão sobre um assunto específico, a nível da UE. Convida à participação no processo de consulta e debate dos temas em consideração". 
estabelecimento de regras mínimas comuns aos Estados-Membros sobre as garantias processuais a conceder às pessoas suspeitas, arguidas, julgadas e condenadas pela prática de infrações penais, a qual configurou medida seminal nessa temática. ${ }^{340}$

O Livro Verde colocou à consideração dos interessados os seguintes pontos ${ }^{341}$ :

- Acesso dos suspeitos e arguidos à representação por defensor, tanto antes como durante o processo;

- Acesso à interpretação e a tradução;

- Comunicação aos suspeitos e arguidos dos seus direitos (Carta de Direitos);

- Garantia de proteção adequada em especial para os suspeitos e arguidos vulneráveis.

- Assistência consular aos detidos estrangeiros.

$\mathrm{Na}$ parte introdutória desse programa, deixou-se expresso que o princípio do reconhecimento mútuo das decisões penais “deverá permitir não só o reforço da cooperação entre os Estados-Membros, mas também a proteção dos direitos das pessoas".

Há críticas bastante contundentes em relação ao conteúdo desse Livro Verde, por exemplo, destaca-se a seguinte: ainda que as justificativas para edição desse documento devam ser elogiadas, no sentido de que colocaram em evidência a necessidade da discussão sobre o direito à obtenção de provas ser tratado de forma justa e igualitária, reputa-se lamentável a ausência de qualquer enfoque ou conexão com técnicas específicas de coleta de provas e ainda mais lamentável que a questão tenha sido arquivada indefinidamente. Ao se cindir o debate entre os direitos processuais e a coleta de provas, perdeu-se a oportunidade de visualizar as técnicas de aquisição de provas da perspectiva dos direitos procedimentais em oposição à perspectiva de uma acusação eficaz. Assim, novos elementos deveriam ser inseridos no debate sobre direitos procedimentais, tal como a possibilidade de estabelecer padrões mínimos, além dos tradicionais direitos a um julgamento justo. ${ }^{342}$ Além disso,

Disponível em: <http://www.eurocid.pt/pls/wsd/wsdwcot0.detalhe?p_cot_id=4797>. Acesso em: 23 jun. 2013. 340 Disponível em: <http://eur-lex.europa.eu/LexUriServ/site/pt/com/2003/com2003_0075pt01.pdf>. Acesso em: 23 jun. 2013.

${ }^{341}$ Ver: <http://eur-lex.europa.eu/LexUriServ/site/pt/com/2003/com2003_0075pt01.pdf>, p. 5.

${ }^{342}$ E esclarecem: "Em primeiro lugar, é evidente que padrões mínimos são necessários, os quais vão além da concepção dos direitos a um julgamento justo tradicional. Assim, a viabilidade destes deve ser analisada para cada domínio da cooperação judiciária. Por exemplo, no contexto da assistência jurídica mútua, poderiam ser estabelecidos padrões mínimos para uma série de técnicas de investigação. Tomando em consideração a análise de estudos anteriores que revelaram que a adoção de normas mínimas em matéria de direitos processuais para certas técnicas de investigação reduziria significativamente a percepção da necessidade dos Estados-Membros em exigir determinadas formalidades. Isso, portanto, tem o potencial de alavancar a lógica e a transparência para a interpretação do princípio de reconhecimento mútuo entre os Estados”. (BONDT, Wendy De; VERMEULEN, Gert. The Procedural Rights Debate. A Bridge Too Far or Still Not Far Enough? EUCRIM, vol. 4, 2010, p. 165). 
refere-se que um equilíbrio deve ser atingido entre debates individuais sobre os direitos processuais e debates integrados que combinam tanto direitos processuais quanto mecanismos de cooperação específicos.

Desse modo, a evolução do princípio do reconhecimento mútuo desenvolvido entre os países da União Europeia tem ensejado novas propostas de métodos mais eficazes de cooperação entre os países. Uma das mais recentes consiste na European Investigation Order (Ordem Europeia de Investigação - OEI) ${ }^{343}$ derivada da European Evidence Warrant (EEW) - Mandado Europeu de Investigação, ${ }^{344}$ o qual tem como objetivo incrementar a cooperação internacional em matéria penal, já configurando uma evolução ao instituto da assistência mútua. Após a introdução do conceito de reconhecimento mútuo na lei de extradição da UE por meio do mandado de detenção europeu (European Arrest Warrant - EAW), ${ }^{345}$ apresentase essa proposta de uma ordem de investigação no campo da assistência mútua.

O Mandado ou a Ordem de Detenção Europeia ${ }^{346}$ consiste em uma resolução judicial ditada por um Estado-Membro visando à detenção e à entrega por outro Estado-Membro de uma pessoa procurada em ações penais ou para a execução de uma pena ou medida de segurança, destinada a substituir o instituto da extradição dentro da União Europeia e

\footnotetext{
${ }^{343}$ Com base no mandado, a EIO foi projetada para simplificar e promover a coleta e transferência de evidências entre Estados-Membros da UE, mas também propõe poderes mais amplos de cooperação policial do que aqueles previstos no mandado. O projeto de diretiva EIO está atualmente em discussão, deixando o mandado em uma espécie de limbo, não implementado e descumprido, até que seja formalmente revogado.

${ }^{344}$ A decisão-quadro do Conselho relativa ao mandado europeu foi adotada em 18 de dezembro de 2008 (2008/978/JHA). Os Estados-Membros tinham até 19 de janeiro de 2011 para a implementar. No entanto, diretiva mais abrangente de ordem europeia de investigação foi proposta pelo Conselho em junho de 2010 e está atualmente em discussão. O mandado europeu de investigação, de fato, foi um natimorto. Como um instrumento pré Tratado de Lisboa, a Comissão não tem poderes de execução e assim ele não será implementado e provavelmente revogado (HODGSON, Jacqueline S. Safeguarding Suspects' Rights in Europe: a Comparative Perspective. New Criminal Law Review, vol. 14, n. 04, 2011, p. 612). De qualquer forma, como traz Van Hoek et al, o escopo da proposta do mandado de investigação foi bastante limitado (aplicava-se aos objetos, documentos ou dados obtidos em vários âmbitos processuais, incluindo a possibilidade de apreensão, de produção e de busca de provas. Entretanto, o mandado não se destina a ser utilizado para proceder ao interrogatório de suspeitos, a tomada de declarações, ou a oitiva de testemunhas e vítimas. A obtenção de amostras de DNA, por exemplo, também é excluída do âmbito de aplicação do mandado europeu. Em terceiro lugar, o mandado europeu não se destina a ser usado para iniciar as diligências de instrução que envolvam obtenção de provas em tempo real, tais como a intercepção de comunicações telefônicas e o controle de contas bancárias), oportunidade em que a Comissão Europeia tornou público que propostas semelhantes são susceptíveis de serem seguidas, como ocorreu com a proposta da European Investigation Order (EIO) derivada da EEW. Estas propostas também levam o conceito de reconhecimento mútuo como seu ponto de partida, na opinião da Comissão, o mandado é o primeiro passo em direção a um único instrumento de reconhecimento mútuo que irá substituir todo o regime de auxílio judiciário mútuo em matéria penal na UE. (VAN HOEK, Aukje A.H.; LUCHTMAN, Michiel J.J.P. Transnational cooperation in criminal mattters and the safeguarding of human rights. Utrecht Law Review, Volume 1, Issue, 2005, p. $32 \mathrm{e}$ nota 138).

345 O mandado de detenção europeu é um procedimento judicial em que os indivíduos são "entregues" em custódia, mas ainda é muitas vezes referido como extradição. Decisão-quadro do Conselho de 13/06/2002 (2002/584/JHA).

${ }^{346}$ Decisión-Marco del Consejo de 13/06/2002 (2002/584/JAI). Ha entrado en vigor en enero de 2004.
} 
fortemente focada na abolição do requisito da dupla incriminação. ${ }^{347}$

De acordo com Manuel Valente, a ordem de detenção europeia é o exemplo mais nítido de que a segurança prevalece sobre a liberdade das pessoas, não só por ser a primeira concreção do princípio de reconhecimento mútuo, como também pela desnecessidade de dupla incriminação para uma série de infrações penais. A lógica de que não interessa que delito é, mas que, configurando um delito, deve ser combatido eficazmente, não pode ser a pedra angular da construção de um espaço penal humanista assentado sob a primazia dos direitos fundamentais, por imposição do próprio art. $6^{\circ}$ do Tratado da União Europeia. $\mathrm{O}$ "salto" que a ordem de detenção europeia representa acentua a opção por uma política de segurança e não por uma política criminal de liberdade. ${ }^{348}$ A opção por iniciar a concreção do reconhecimento mútuo por meio da ordem de detenção europeia, cuja execução priva o sujeito de sua liberdade, realça a questão de se a "psicose do medo dirige o direito penal", sendo este o antídoto para os problemas vinculados à ideia de crime, o que denotaria a fraqueza das instâncias europeias que impõem aos Estados-Membros a harmonização, que seria a opção mais adequada para destruir a ideia de engano e de ilusão de tutela efetiva dos bens jurídicos por meio de sua integração. ${ }^{349}$

Nesse contexto, embora o Tribunal Europeu de Direitos Humanos disponha de garantias para um julgamento justo, há uma ampla margem de apreciação na forma como pode ser efetivado, refletindo as diferentes tradições processuais penais dos países-membros. Além disso, a conformidade com a Convenção também é de todo inconsistente, e os mecanismos de execução de suas disposições ainda são fracos. Não bastasse isso, os novéis instrumentos da UE, como o mandado de detenção europeu, o mandado de investigação e a proposta de Ordem de Investigação Europeia (OIE), demandam uma necessidade de maior proteção dos suspeitos em relação a essas medidas potencialmente abrangentes, pois os seus termos bem ilustram a preocupação da UE com medidas destinadas a ajudar nos

\footnotetext{
${ }^{347} \mathrm{Em}$ trinta e duas categorias de delitos graves, incluindo o terrorismo, a fraude, a pornografia infantil, o tráfico de armas e a lavagem de ativos, o princípio da dupla criminalidade não se aplica, ou seja, não existe a necessidade de que o delito seja reconhecido como crime tanto no país requerente quanto no país requerido que executará a detenção e a extradição dos cidadãos, sempre e quando o delito seja suficientemente grave e seja sancionado com no mínimo três anos de prisão no Estado-membro requerente (art. 2 da Decisão-Marco). A esse respeito ver: GLESS, Sabine. "Transnational Cooperation in Criminal Matters and the Guarantee of a Fair Trial: Approaches to a General Principle”. In: Utrech Law Review. Vol. 9, N. 4, Sept. 2013.

${ }^{348}$ Não por casualidade, o Tribunal Constitucional Federal Alemão declarou a ordem europeia de detenção e entrega inconstitucional, em 18 de julho de 2005 (2 BvR 2236/04).

349 VALENTE, Manuel Monteiro Guedes. La cooperación en materia procesal penal: los engaños y las ilusiones formales de los instrumentos jurídicos europeos e internacionales. Diario La Ley, $\mathrm{N}^{\circ}$ 6914, Sección Doctrina, Año XXIX, Ref. D-96, Editorial LA LEY, Mar. 2008, p. 7. Nesse sentido, também se apresentam: FIJNAUT, Cyrille; OUWERKERK, Jannemieke. The Future of Police and Judicial Cooperation in the European Union. Martinus Nijhoff Publishers: Leiden/Boston, 2010, pp. 369-70 e 382-3.
} 
julgamentos, em que pese a lamentável ausência de qualquer consideração adequada em relação ao papel da defesa e à salvaguarda dos direitos do acusado. ${ }^{350}$

Como aduz Hodgson, afigura-se, no mínimo, estranho que uma medida destinada a promover a troca de provas tenha excluído a defesa. Tampouco os termos do mandado respeitam o princípio da igualdade de armas. $\mathrm{O}$ arguido pode ser confrontado com as provas obtidas em outra jurisdição, mas não tem o poder próprio de requerer a produção de qualquer evidência que possa apoiá-lo no caso, o que não só constrange o bom exercício dos direitos de defesa, mas também priva o tribunal de provas relevantes na determinação das acusações. Como questiona a autora, "é evidência somente aquilo que é recolhido pela polícia, ministério público ou juiz? Claro que não." 351

Houve um fluxo constante de medidas de justiça penal na UE para promover o reconhecimento mútuo e a cooperação em matéria persecutória policial e do Ministério Público. No entanto, isso criou uma lacuna na proteção do acusado, que não pode ser preenchida somente pela aplicação do princípio do reconhecimento mútuo. Essa é uma das reflexões de ponta contrapostas ao predomínio das preocupações de controle da criminalidade em toda a Europa e do desrespeito pelos direitos básicos do devido processo. ${ }^{352}$ Verifica-se que os Estados tornaram-se obcecados com a busca nacional e

${ }^{350}$ HODGSON, Jacqueline S. Safeguarding Suspects' Rights in Europe: a Comparative Perspective. New Criminal Law Review, vol. 14, n. 04, 2011, p. 613 e 627.

351 "É estranho que uma medida destinada a promover a troca de provas deva excluir a defesa. Só é prova o que é recolhido pela polícia, pelo Ministério Público ou pelo juiz? Óbvio que não. Mesmo dentro de procedimentos baseados inquisitorialmente como os da França, onde a investigação é entendida como sendo a função do Juízo responsável pelo recolhimento tanto das provas de defesa, quanto das provas de acusação, o direito da defesa de produzir provas é reconhecido. Nem os termos do mandado europeu de provas respeitam o princípio da igualdade de armas. O acusado pode ser confrontado com as provas obtidas a partir de outra jurisdição, mas não tem poder de solicitar para si mesmo a produção de qualquer prova que possa apoiar o seu caso. Isto não só restringe o exercício dos direitos de defesa, mas também priva o Tribunal de elementos de prova relevantes na determinação das acusações." Tradução livre de: "It is strange that a measure designed to promote the exchange of evidence should exclude the defense. Is evidence only that which is gathered by the police, prosecutor, or judge? Clearly not. Even within more inquisitorially based procedures such as those of France, where the investigation is understood to be the function of a judicial officer responsible for collecting both exculpatory as well as incriminating evidence, the right of the defense to bring forward evidence is recognized. Neither do the terms of the EEW respect the principle of equality of arms. An accused may be confronted by evidence obtained from another jurisdiction, but she is powerless to herself request the production of any evidence that might support her case. This not only constrains the proper exercise of the rights of the defense, but also deprives the court of relevant evidence in its determination of the charges." (HODGSON, Jacqueline S. Safeguarding Suspects' Rights in Europe: a Comparative Perspective. New Criminal Law Review, vol. 14, n. 04, 2011, p. 628).

${ }^{352}$ Como refere Bernd Schünemann, Professor da Universidade de Munique, em texto que examina os principais problemas identificados nos métodos dominantes de europeização do direito penal na União Europeia à luz do Estado de Direito: o enfraquecimento das bases democráticas, a adoção preferencial de um sistema de justiça criminal mais punitivo a ser implementado por toda a UE e a ausência geral de justo equilíbrio processual, como seria possível e adequado por meio do reforço da defesa. (SCHÜNEMANN, Bernd. As Bases do Processo Penal Transnacional. Traduzido por Heloisa Estellita Salomão. Revista Brasileira de Ciências Criminais. Ano 19, v. 90, mai-jun. 2011, p. 191). 
transnacional de informações e provas e se recusam a ter qualquer dificuldade nesse aspecto, considerando como empecilho os requisitos para garantir o respeito de salvaguardas uniformes. O nível de confiança que essa cooperação requer é quase total, no entanto, esses poderes são exercidos na ausência de qualquer quadro jurídico abrangente negociado ou com responsabilidade democrática. $\mathrm{O}$ reconhecimento mútuo é incapaz de garantir proteções uniformes para suspeitos ou mesmo a confiabilidade das provas recolhidas e compartilhadas no âmbito da UE. ${ }^{353}$

A necessidade - conforme alguns - ou a conveniência - para outros - de contar com um marco de garantias homogêneas entre os Estados-Membros da União Europeia parece ligada à aposta pelo reconhecimento mútuo das decisões judiciais. Ainda que todos os Estados-Membros sejam partes da CEDH, a experiência já colocou manifesto que, por si só, isso nem sempre aporta o grau suficiente de confiança nos sistemas judiciais penais dos demais Estados-Membros, dentre outras razões, porque o grau de cumprimento dos direitos que nele se proclamam não é homogêneo. O reconhecimento mútuo das decisões judiciais em matéria penal somente pode funcionar eficazmente em um clima de confiança, em que não somente as autoridades judiciais, mas também todos os participantes no processo penal, considerem as decisões das autoridades judiciais de outros Estados-Membros equivalentes as de seu próprio Estado. O que implica não só a confiança na adequação das normas dos outros Estados-Membros, como também em que ditas normas sejam aplicadas corretamente. O reforço da confiança mútua exige uma aplicação mais coerente dos direitos e garantias estabelecidos no art. $6^{\circ}$ do $\mathrm{CEDH}^{354}$

Para reforçar essa tendência estão os recentes acórdãos da $\mathrm{CEDH}$, reafirmando a importância do aconselhamento de defesa precoce e eficaz, seja qual for o procedimento legal do país. ${ }^{355}$

Nesse ponto, interessante lembrar que existem reivindicações para que à defesa também seja possível utilizar a Ordem Europeia de Investigação, por exemplo, no Reino Unido, o Ministério do Interior assegurou à Câmara dos Lordes que este será o caso, ${ }^{356}$ mas

${ }^{353}$ HODGSON, Jacqueline S. Safeguarding Suspects' Rights in Europe: a Comparative Perspective. New Criminal Law Review, vol. 14, n. 04, 2011, p. 663.

${ }^{354}$ FANEGO, Coral Arangüena. Nuevas Directivas Sobre Derechos Procesales de Sospechosos e Imputados en el Proceso Penal. In: FANEGO, Coral Arangüena (Coord.). Cooperación Judicial Civil y Penal en el Nuevo Escenario de Lisboa. Granada: Editorial Comares, 2011, p. 270.

355 HODGSON, Jacqueline S. Safeguarding Suspects' Rights in Europe: a Comparative Perspective. New Criminal Law Review, vol. 14, n. 04, 2011, p. 664.

${ }^{356}$ Em 27 de julho de 2010, Theresa May, Secretária de Estado do Ministerio do Interior da Inglaterra e País de Gales, ao anunciar que o Reino Unido deveria optar pela proposta de diretiva, tranquilizou membros interessados do Parlamento: "Peço aos senhores deputados para lembrar o seguinte: a EIO será aplicada a ambos - promotores e advogados de defesa-, o que significa que poderá ser usada para provar a inocência de 
isso, novamente, restará a critério dos Estados-Membros, o que resultará em padrões diferenciados de aplicação e proteção inadequada da defesa mais uma vez. Também interessante pontuar que, na época, a Comissão propôs tornar o mandado disponível para a defesa, mas isso foi rejeitado. ${ }^{357}$

Em suma, o mandado de detenção, o mandado de investigação e a proposta de ordem europeia de investigação representam importantes meios de cooperação judiciária penal na investigação e repressão de crimes. Entretanto, eles também demonstram e incorporam as lacunas na proteção para aquelas pessoas que se tornam objeto de tais medidas. Logo, o acusado resta em séria desvantagem por ser impedido de solicitar a mesma evidência que está disponível para a acusação, e o tribunal, de igual modo, é privado de provas relevantes para a determinação do caso. A decisão de excluir a defesa pode ter origem no regime de assistência jurídica mútua, por meio de tratados bilaterais, em que os pedidos e as evidências são feitos e apresentados para e pela inteligência dos países, discriminação contra a defesa que sublinha as discrepâncias nos padrões probatórios.

A importância desses institutos e propostas reside no fato de que levam o conceito de reconhecimento mútuo como seu ponto de partida e, na opinião da Comissão, são os primeiros passos rumo a um único instrumento de reconhecimento mútuo que irá substituir todo o regime de auxílio judiciário mútuo na União Europeia.

A aplicação do princípio do reconhecimento mútuo das decisões penais exige, assim, que a União Europeia ofereça um nível equivalente de proteção aos suspeitos e arguidos em todos os seus Estados-Membros.

Tal escopo só será atingido através do estabelecimento de um conjunto básico de regras mínimas comuns de garantias processuais dos suspeitos e arguidos, incluindo estrangeiros.

A Comissão examinou também a necessidade de garantias relativas a um tratamento equitativo na obtenção e tratamento dos elementos de prova na UE. Os direitos decorrentes da presunção de inocência (incluindo o direito ao silêncio, o direito a não testemunhar contra si próprio e as normas que regem o ônus da prova) foram também examinados. ${ }^{358}$

A implementação de todas essas regras mínimas comuns a todos os Estados-

súditos britânicos no exterior, bem como para julgar os culpados em casa." (HODGSON, Jacqueline S. Safeguarding Suspects' Rights in Europe: a Comparative Perspective. New Criminal Law Review, vol. 14, n. 04, 2011, p. 631/32).

${ }^{357}$ HODGSON, Jacqueline S. Safeguarding Suspects' Rights in Europe: a Comparative Perspective. New Criminal Law Review, vol. 14, n. 04, 2011, p. 628.

358 Regras presentes no Livro Verde sobre a presunção de inocência, disponível em: <http://eurlex.europa.eu/LexUriServ/site/pt/com/2006/com2006 0174pt01.pdf>. Acesso em: 23 jun. 2013. 
Membros coroaria o conjunto de instrumentos que visam à efetivação da cooperação policial e judiciária.

Só assim a União Europeia poderá garantir em todos os Estados-Membros um nível equivalente de proteção dos suspeitos e arguidos nos processos penais desencadeados pela Procuradoria Europeia. ${ }^{359}$

Nessa temática, interessa referir que o artigo $6^{\circ}$, parágrafo $3(\mathrm{c})$, da Convenção Europeia de Direitos Humanos, confere três direitos ao denunciado: o direito à autodefesa, o direito a escolher defensor de confiança e o direito a contar com um defensor gratuitamente. ${ }^{360}$ Assim, nas palavras de Kai Ambos: “A falta do defensor pode levar a um desequilíbrio irreparável entre as autoridades de persecução e o acusado. [...] A participação do defensor é de interesse para a correta administração da justiça." ${ }^{361}$

No caso Airey vs. Irlanda de 1979, ${ }^{362}$ a Corte Europeia de Direitos Humanos decidiu favoravelmente à Sra. Airey, no sentido de que os Estados têm a obrigação de prover de modo ativo e efetivo a assistência de um advogado, gratuitamente, se seus cidadãos não têm condições de custeá-lo.

No mesmo sentido, o artigo $6^{\circ}$, parágrafo 3(d), da Convenção Europeia de Direitos Humanos, em essência, pretende garantir "full equality of arms" (plena igualdade de armas) e exige que o imputado, em algum momento, tenha a oportunidade adequada e apropriada de interrogar as testemunhas da acusação e de apresentar testemunhas de defesa, situação

\footnotetext{
359 Ibidem.

${ }^{360}$ Conforme dispõe o Livro Verde da Comissão sobre garantias processuais dos suspeitos e arguidos em procedimentos penais na União Europeia: "A questão fundamental é provavelmente a que diz respeito à assistência judiciária e à representação por um defensor. O suspeito ou arguido que tem um advogado está em situação incontestavelmente mais favorável no que se refere ao exercício dos seus outros direitos, em parte porque as suas oportunidades para ser informado destes direitos são maiores e, também, porque um advogado prestará a sua assistência no sentido de os seus direitos serem respeitados. Por conseguinte, será mais conveniente começar por examinar o direito à assistência judiciária e à representação por um defensor". (Disponível em: <http://eur-lex.europa.eu/LexUriServ/site/pt/com/2003/com2003_0075pt01.pdf〉,p. 22).

361 Tradução libre de: "La falta de defensor puede conducir a un desequilibrio irreparable entre las autoridades de persecución y el imputado. [...] La participación del defensor es de interés para la correcta administración de justicia.” AMBOS, Kai. Temas de Derecho Penal Internacional y Europeu. Barcelona: Marcial Pons, 2006, p. 435-6.

362 BIRGIN, Haydée; KOHEN, Beatriz (compiladoras). Acceso a la justicia como garantía de igualdadInstituciones, actores y experiencias comparadas. 1a Ed. Buenos Aires: Biblos, 2006. p. 17-8. No mesmo sentido, Kai Ambos, ao se referir ao direito penal europeu esclarece: "O acusado tem o direito, sob duas condições, a uma defesa gratuita, a saber: quando carece de recursos e a defesa pública reside no 'interesse da correta administração da justiça'. A segunda condição, cuja existência depende da gravidade da infração, a complexidade do caso e a situação pessoal do acusado." Tradução libre de: "El imputado tiene derecho, bajo dos condiciones, a uma defensa gratuita, a saber: cuando carece de medios y la defensa de oficio reside em el 'interés de la correcta administración de justicia'. La segunda condición, cuya existencia depende de la gravedad del delito, la complejidad del caso y la situación personal del imputado" (AMBOS, Kai. Temas de Derecho Penal Internacional y Europeu. Barcelona: Marcial Pons, 2006, p. 437). Sistemática, essa, que difere da adotada no Brasil.
} 
que vale desde a fase de investigação. ${ }^{363}$

A essas previsões teóricas pode-se contrapor a dificuldade em contratar profissional para acompanhar a produção de provas em outro país, ainda mais se a parte requerente não tiver condições financeiras de arcar com esse custo. ${ }^{364}$

Bastante interessante a contundente reflexão de Kai $\operatorname{Ambos}^{365}$ que revela a importância e a problemática da questão em toda a sua dimensão: certamente, em comunicação aprovada acerca do Livro Verde, a Comissão da União Europeia reconhece — junto a outros pontos críticos — uma "proteção equivalente dos direitos de defesa" como uma demanda principal decorrente da criação da Procuradoria Europeia, porém essa mera confissão normativa - já conhecida - acerca dos direitos do imputado permanece tão inefetiva como a criação, a nível europeu, de outros textos agradáveis ao ouvido sobre direitos fundamentais, se é que a organização da defesa penal não pode seguir a marcha da institucionalização e harmonização da persecução penal. Em outras palavras, a elaboração de um padrão mínimo de direitos humanos é insuficiente quando não é acompanhada por um contrapoder próprio do Estado de Direito, que possa assegurar a igualdade de armas de maneira prática e efetiva. A organização desse contrapoder é tarefa das associações europeias de defensores criminais, eventualmente apoiadas por juristas penais. Em concreto, a

\footnotetext{
${ }^{363}$ AMBOS, Kai. Temas de Derecho Penal Internacional y Europeu. Barcelona: Marcial Pons, 2006, p. 439. ${ }^{364}$ Assim, interessante a lição trazida por Fijnaut e Ouwerkerk: "Englobando só o direito à informação, o direito à assistência jurídica (incluindo a assistência jurídica gratuita) e o direito à interpretação e à tradução, fez a proposta apoiar uma causa nobre. No entanto, a construção da confiança mútua entre os Estados-membros exige mais do que uma quantidade mínima de aproximação em relação aos direitos mencionados." Tradução livre de: "Encompassing only the right to information, the right to legal assistance (including free legal assistance) and the right to interpretation and translation, made the proposal support a noble cause. However, building mutual trust between Member States requires more than a minimum amount of approximation regarding the rights mentioned". (FIJNAUT, Cyrille; OUWERKERK, Jannemieke. The Future of Police and Judicial Cooperation in the European Union. Martinus Nijhoff Publishers: Leiden/Boston, 2010, p. 251).

${ }^{365}$ No original: "Ciertamente, en la comunicación Follow-up recientemente aprobada acerca del Libro Verde, la Comisión de la UE reconoce - junto a otros puntos críticos - una "protección equivalente de los derechos de defensa" como uma demanda principal de la creación de la Fiscalía Europea, pero esta mera confesión normativa - ya conocida - acerca de los derechos del imputado permanece tan inefectiva como la creación, a nivel europeu, de otros textos agradables al oído acerca de derechos fundamentales, si es que la organización de la defensa penal no puede seguir la marcha de la institucionalización y armonización de la persecución penal. En otras palabras: la elaboración de un estándar mínimo de derechos humanos es insuficiente cuando no es acompañada por un contrapoder proprio del Estado de Derecho que pueda garantizar la igualdad de armas de manera práctica y efectiva. La organización de este contrapoder es tarea de las asociaciones europeas de defensores penales, eventualmente apoyadas por los juristas penales, [...]. em concreto, la organización e institucionalización de la defensa com alcance europeu puede ser alcanzada a través del fortalecimiento o bien de la (re)activación de iniciativas existentens en especial la European Criminal Bar Association, ECBA) o la fundación de un organismo de coordinación similar al Eurojust o de un European Defence Bar - de manera similar al International Criminal Bar fundado em junio de 2002 para la CPI. [...] Si no se logra uma organización eficiente de la defensa penal, entonces amenaza al principio de igualdade de armas el peligro de ser sepultado em el mismo lugar desde donde originariamente uma vez irradió - em mayor o menor medida exitosamente - su efecto hacia el Derecho interno: a nivel europeu." (AMBOS, Kai. Temas de Derecho Penal Internacional y Europeu. Barcelona: Marcial Pons, 2006, p. 466-7).
} 
organização e institucionalização da defesa com alcance europeu pode ser atingida através do fortalecimento, ou melhor, da reativação de iniciativas existentes, em especial, a Associação Europeia de Advogados Criminais (European Criminal Bar Association ECBA), ou da fundação de um organismo de coordenação à semelhança do Eurojust ou de uma Rede Europeia de Defesa (European Defence Bar) - similar à Rede Internacional de Defesa fundada em junho de 2002 para o TPI. Se não se logra uma organização eficiente de defesa penal, então, ameaça o princípio da paridade de armas o perigo de ser sepultado no mesmo lugar onde originariamente uma vez se irradiou — com maior ou menor êxito — seu efeito à legislação nacional: a nível europeu.

Ademais, como questiona Amann, ${ }^{366}$ como se poderia garantir que os direitos das pessoas acusadas de crimes transnacionais estão sendo honrados? O equilíbrio entre as necessidades de segurança pública e a autonomia privada deve ser restaurado. Como traz a autora, é preciso estabelecer um lobby da defesa. Há a necessidade de uma organização que tanto vai defender os interesses do acusado internacionalmente quanto treinar seus membros para representar os réus em processos transnacionais com plena habilidade. ${ }^{367}$ Já houve um bom começo com a criação da Associação Internacional dos Advogados de Defesa Criminal, fundada em Montreal, em 1997.

No mesmo sentido, mais recentemente, na doutrina europeia, já se fala em Eurodefensor $^{368}$ : como já enfatizado, o direito a uma defesa eficaz está no cerne dos direitos do réu. Os aspectos pessoais desse direito são multiplamente violados dentro do contexto da UE devido ao fato de que o réu deve enfrentar uma ou mais ordens jurídicas que são absolutamente desconhecidas para ele, em razão do princípio do reconhecimento mútuo, o que inviabiliza uma defesa efetiva. A igualdade de armas também é violada devido à longa

\footnotetext{
366 AMANN, Diane Marie. The Rights of the accused in a Global Enforcement Area. ILSA Journal of International \& Comparative Law, Vol. 6, 2000, p. 564.

367 Tais ideias também foram defendidas em seminário promovido pela Academia de Direito Europeu (ERA), a Criminal Bar Association (ECBA) e o Ilustre Colegio de Abogados de Barcelona (ICAB) a que a autora teve a oportunidade de participar, intitulado "El Derecho Penal Europeo para Abogados Penalistas", que forma parte de um projeto de formação co-financiado pela comissão Europeia, de modo a capacitar os advogados penalistas europeus sobre os instrumentos de justiça penal e de cooperação jurídica. O evento ocorreu em Barcelona, nos dia 21 e 22 de fevereiro de 2004. Os temas-chave abordados disseram respeito ao impacto da justiça penal europeia no trabalho diário relacionado com o direito de defesa nos Estados-membros. Para visualização do programa na íntegra: 〈https://www.era.int/upload/dokumente/15664.pdf〉.

${ }^{368}$ No original: As already emphasized, the right to an effective defence lies at the heart of a defendant's rights. The individual aspects of this right are multiply violated within the EU context because of the fact that a defendant must confront the regulatory provisions of one or more legal orders that are unknown to him due to the principle of mutual recognition, thus he is sometimes unable to mount an effective defence. The equality of arms is also violated due to the long and constantly increasing transnational cooperation between prosecuting authorities, aided by European institutions specifically created to accomplish this objective. (FIJNAUT, Cyrille; OUWERKERK, Jannemieke. The Future of Police and Judicial Cooperation in the European Union. Martinus Nijhoff Publishers: Leiden/Boston, 2010, p. 396.).
} 
e crescente cooperação transnacional entre as autoridades de acusação, auxiliadas por instituições europeias especificamente criadas para perpetrar esse objetivo.

Há doutrina europeia massiva referindo essa inclinação para a acusação nos atuais mecanismos de cooperação jurídica internacional, um "sesgo persecutorio", como se diz em espanhol, que em livre tradução seria um predominante viés da acusação regendo os mecanismos de cooperação jurídica internacional em matéria penal existentes, ${ }^{369}$ questão

${ }^{369}$ Veja-se, dentre outros: MURRAY, Christopher. Defense Requests for International Judicial Assistance: The UK Perspective. In: Fordham International Law Journal. Vol. 23, Issue 5, Article 4, 1999, p. 1347; M Anderson, "Law enforcement cooperation in the EU and fundamental rights protection" in M Martin (ed), Crime, rights and the EU: the future of police and judicial cooperation (Justice 2008), pp. 105-120; E Cape; J Hodgson; T Prakken e T Spronken (eds), "Suspects in Europe, procedural rights at the investigative stage of the criminal process in the European Union" (Intersentia 2007, pp 2-3). "Do exposto pode-se deduzir que o desenvolvimento do direito processual na Europa de hoje, especialmente condicionado por fenômenos criminais como o terrorismo e o crime organizado parece não avançar na direção de fortalecer a igualdade de armas. Muito pelo contrário: ela tende a reforçar a obtenção policial de provas, neutralizando determinadas garantias como o princípio "nemo tenetur se ipsum accusare", mediante instrumentos processuais como agentes encobertos, o uso de meios técnicos para ouvir no interior da residência, a submissão a observação da polícia ou certas formas de controle preventivo, mesmo afetando não suspeitos, conforme previsto na lei de lavagem de dinheiro. A eficácia de algumas destas medidas tem sido questionada. Em sua edição de 13/14 de novembro de 1999, o Süddeutsche Zeitung informou em primeira página sobre os projetos da coligação governamental na Alemanha para uma reforma total das escutas, o reforço da proteção de dados e uma reforma no regulamento da "clemência" (Kronzeugenregelung). Tais reformas levam em conta a comprovação denunciada pelo encarregado da proteção de dados acerca do aumento extraordinário do número de escutas telefônicas, que em 1998 afetou 10.000 conexões na Alemanha e cerca de meio milhão de conversas telefônicas. No que diz respeito à regulamentação da clemência, referiu o jornal que tais regras "têm sido por dez anos a injustiça personificada no direito penal alemão [...] com elas, o legislador ultrapassou os limites dos princípios mais elementares da pena". É verdade que estas medidas são geralmente limitadas essencialmente ao crime organizado e, talvez, poderia ser justificada pela necessidade. No entanto, uma regulamentação adequada deve ser acompanhada por uma interpretação rigorosa dos pressupostos do estado de necessidade e uma proibição de avaliar as provas obtidas nos casos em que tais pressupostos não foram devidamente apreciados ao dispor da medida. No entanto, esta não é a orientação da jurisprudência e legislação atualmente. Além disso, nesta área as exceções ameaçam tornar-se a regra." Traduçaõ livre de: "De todo lo anterior es posible deducir que el desarrollo del Derecho procesal en la Europa actual, especialmente condicionado por fenómenos criminales como el terrorismo y la llamada criminalidad organizada, no parece avanzar en el sentido de un fortalecimiento de la igualdad de armas. Más bien ocurre lo contrario: se tiende a potenciar la obtención policial de pruebas neutralizando ciertas garantías como el principio nemo tenetur se ipsum accusare mediante instrumentos procesales como los agentes encubiertos, el empleo de medios técnicos para escuchas dentro del domicilio, el sometimiento a observación policial o ciertas formas de control preventivo que afectan incluso a personas no sospechosas, como previstas para el blanqueo de dinero. La eficacia de algunas de estas medidas ya ha sido puesta en duda. En su edición del 13/14 de noviembre de 1999 la Süddeutsche Zeitung informaba en primera página de los proyectos de la coalición gobernante en Alemania para una reforma total de las intervenciones telefónicas, una mayor protección de datos y una modificación de la regulación de los «arrepentidos» (Kronzeugenregelung). Tales proyectos de reforma tienen en cuenta la comprobación denunciada por el Encargado de Protección de Datos sobre el extraordinario aumento del número de intervenciones telefónicas, que en 1998 afectó en Alemania a 10.000 conexiones y aproximadamente a medio millón de conversaciones telefónicas. Según la misma información, son las asociaciones de profesionales de jueces y abogados las que hace años exteriorizan sus reparos por esta situación. Con respecto a la regulación para arrepentidos en el arto el editorial de la misma fecha dice el periódico que dichas normas «han sido durante diez años la injusticia personificada en el Derecho penal alemán [...] con ellas el legislador ha sobrepasado los límites de principios elementales de la pena». Es cierto que estas medidas se suelen limitar básicamente a la criminalidad organizada y que, acaso, se podrían justificar por el estado de necesidad. No obstante, en una adecuada regulación deberían ir acompañadas de una estricta interpretación de los presupuestos del estado de necesidad y de una prohibición de valoración de la prueba obtenida en los casos en los que tales presupuestos no hayan sido correctamente apreciados al disponer la medida. Sin embargo, no 
que será melhor abordada no capítulo seguinte.

Puyenbroeck e Vermeulen, ${ }^{370}$ a título de exemplo, referem que um observador crítico não negaria que a prática política da União Europeia no campo do direito penal na década passada, desde a implementação do Programa de Tampere, em 1999, tem-se inclinado principalmente para a repressão e é repressivo-orientada. A ideia de introduzir uma série de regras mínimas comuns, garantindo o direito de defesa em um mesmo nível na União Europeia, não teve a mesma atenção concedida à introdução de instrumentos destinados a melhorar a eficácia do combate ao crime.

Ademais, como lembra Hodgson, ${ }^{371}$ embora um dos objetivos básicos da cooperação judiciária e policial seja o de que ela deve respeitar os direitos humanos e as liberdades fundamentais, a justiça penal na UE tem parecido quase exclusivamente preocupada com medidas destinadas a facilitar a investigação, o julgamento e a condenação de criminosos.

Isso tem dado lugar à generalização das críticas em relação ao desequilíbrio com que se está construindo o espaço de liberdade, segurança e justiça na Europa, no sentido de se ter avançado com celeridade nas medidas repressivas ou ligadas à segurança, porém exibindo uma manifesta incapacidade para articular um sistema paralelo de garantias dos direitos individuais. Foi adotado um grande número de instrumentos para facilitar e acelerar a investigação e a persecução de casos transfronteiriços, entretanto, até o momento não existe praticamente nenhum instrumento direcionado a incrementar a posição jurídica das pessoas envolvidas nesses casos. Em face desse panorama, é evidente a necessidade de adotar medidas que permitam alcançar um equilíbrio com a proteção dos direitos processuais das pessoas. $^{372}$

A par de todo esse contexto crítico e de modo a minimizar as negativas consequências

es ésta la orientación de las jurisprudencias y las legislaciones actualmente. Más aún, en esta materia las excepciones amenazan con convertirse en regla." (BACIGALUPO, Enrique. Justicia Penal y derechos fundamentales. Madrid: Marcial Pons Ediciones Jurídicas y Sociales, 2002. p. 138-9).

370 PUYENBROECK, Laurens Van; VERMEULEN, Gert. Towards Minimum Procedural Guarantees for the Defence in Criminal Proceedings in the EU. International and Comparative Law Quarterly, vol. 60, 2011, p. 1017.

${ }^{371}$ HODGSON, Jacqueline S. Safeguarding Suspects' Rights in Europe: a Comparative Perspective. New Criminal Law Review, vol. 14, n. 04, 2011, p. 616.

${ }^{372} \mathrm{E}$ a Professora Coral Arangüena continua: tudo isso mais além das últimas decisões marco aprovadas antes da entrada em vigor do Tratado de Lisboa: Decisão-marco 20091299/JAI do Conselho, de 26 de fevereiro de 2009 pela qual se modificam as Decisões-Marco 2002/5841JAI, 2005/2 14/JAI, 20061783/JAI, 2008/909IJAI Y2008/947/JAI, destinadas a reforçar os direitos processuais das pessoas e a propiciar a aplicação do princípio de reconhecimento mútuo das resoluções ditadas à raiz de juízos celebrados sem o comparecimento do imputado; Decisão-marco 2009/829/JAI, de 23.10.2009 relativa à aplicação do princípio de reconhecimento mútuo às resoluções sobre medidas de vigilância como substitutivas da prisão provisória. (FANEGO, Coral Arangüena. Nuevas Directivas Sobre Derechos Procesales de Sospechosos e Imputados en el Proceso Penal. In: FANEGO, Coral Arangüena (Coord.). Cooperación Judicial Civil y Penal en el Nuevo Escenario de Lisboa. Granada: Editorial Comares, 2011, p. 271-2). 
ao acusado nesse âmbito, a própria União Europeia já reconheceu que deve pôr em prática o seu próprio sistema de proteção processual para garantir uniformidade e, assim, reforçar o princípio da confiança mútua entre os países, ingrediente-chave para o sucesso da cooperação. Desse modo, para o desenvolvimento dessa confiança plena, fundamental é o tratamento dispensado a suspeitos e acusados, ${ }^{373}$ bem como a legitimidade de seus sistemas de policiamento e de acusação.

Para tanto, após várias tentativas fracassadas, ${ }^{374}$ finalmente restou acordado um programa de medidas legislativas relativas aos direitos para um julgamento justo.

Em 2009, o Conselho Europeu adotou o Programa de Estocolmo, que estabelece a estratégia da UE no domínio da liberdade, segurança e justiça para o período de 20092014. ${ }^{375}$ Uma das áreas de destaque da ação foram os direitos procedimentais — o

${ }^{373}$ Hodgson argumenta ainda que as tentativas anteriores para uniformizar os direitos processuais falharam, em grande parte, devido às diferenças na tradição processual penal, incluindo o papel apropriado do advogado, bem como o contexto de segurança em que está incluído, o qual é dominantemente orientado a uma eficiência que tende para a restrição em vez do reforço aos direitos dos suspeitos. (HODGSON, Jacqueline S. Safeguarding Suspects' Rights in Europe: a Comparative Perspective. New Criminal Law Review, vol. 14, n. 04, 2011, p. 613).

374 Ainda que a ideia não seja inovadora, pois já se apresentava nas conclusões do Conselho Europeu de Tampere de 1999 (no ponto 33 do Programa de Tampere figurava como objetivo a adoção de normas mínimas comuns no campo das garantias processuais no âmbito penal, considerando que com isso aumentaria a confiança mútua entre as autoridades judiciais dos Estados-membros, ponto de partida necessário para alcançar a consolidação do princípio de reconhecimento mútuo, pedra angular da cooperação jurídica penal na UE). Tal objetivo restou concretado em uma série de medidas a serem adotadas, reunidas em documento da Comissão e do Conselho do ano 2001 (Programa de medidas destinado a colocar em prática o princípio do reconhecimento mútuo das resoluções em matéria penal - DOC núm. 12 de 15 de janeiro de 2001), os intentos que o sucederam de levar a efeito a tarefa se cristalizaram em 2004 com a Proposta de Decisão-Marco sobre garantias processuais para suspeitos e indiciados em processos penais na União Europeia, os quais fracassaram no momento de sua adoção pelos Estados-membros - Proposta de Decisão-marco relativa a determinados direitos processuais nos processos penais em trâmite na UE - COM (2004) 328 final - apresentada pela Comissão em 28 de abril de 2004. Depois de três anos de debate no seio do Conselho da União Europeia, a proposta foi bloqueada por seis Estados-membro: Reino Unido, Irlanda, Chipre, Malta, Eslovaquia e República Tcheca, tendo sido definitivamente abandonada em junho de 2007. Dentre os motivos deste fracasso e à margem da reconhecida postura de alguns Estados tradicionalmente contraria ao trabalho de harmonização das instituições europeias, verifica-se o caráter excessivamente detalhado de algumas de suas disposições e as dificuldades para inserir as garantias contempladas no marco de sistemas processuais nacionais tão diversos (FANEGO, Coral Arangüena. Nuevas Directivas Sobre Derechos Procesales de Sospechosos e Imputados en el Proceso Penal. In: FANEGO, Coral Arangüena (Coord.). Cooperación Judicial Civil y Penal en el Nuevo Escenario de Lisboa. Granada: Editorial Comares, 2011, p. 271).

375 Deixando para trás o fracasso que significou a não nata Decisão-marco sobre garantias processuais, e admitida a impossibilidade de uma harmonização conjunta das referidas garantias em um instrumento único, a Presidência de turno da UE do segundo semestre de 2009 (Suécia) levantou uma nova estratégia menos ampla, porém mais efetiva, consistente em abordar de maneira gradual e em instrumentos normativos diversos as principais garantias dos suspeitos e acusados. Como consequência, a Presidência sueca já contava com o apoio do Reino Unido, principal opositor da frustrada Decisão-marco de 2004, apresentando ao Conselho um "roteiro" ou "proposta de plano de trabalho" que marcava as etapas a seguir e a desenvolver gradualmente com o intuito de reforçar os direitos processuais dos acusados em processos penais, programa que foi imediatamente adotado pelo Conselho Europeu que o aprovou pela Resolução de 30 de novembro de 2009 (Plano de trabalho para reforçar os direitos processuais de suspeitos ou acusados em processos penais) e que, como era de esperar, encontrou imediata acolhida no Programa de Estocolmo e posterior Plano de ação no qual o cidadão constitui o centro de atenção das políticas comunitárias; também em matéria de justiça penal (FANEGO, Coral 
programa inclui um "roteiro"376 para o fortalecimento de direitos processuais que são considerados uma prioridade da ação ${ }^{377}$ — , pois a cooperação no âmbito da UE no domínio do direito penal pressupõe a confiança mútua dos Estados-Membros. Confiança que descansa na crença de que, dentro do âmbito da União, existe uma cultura comum de respeito aos direitos e liberdades fundamentais como membros signatários do Convênio Europeu dos Direitos do Homem, que sustenta o tão desejado espaço comum de segurança, justiça e liberdade, através de três principais linhas de atuação: a harmonização das legislações, a cooperação internacional e, principalmente, o necessário reconhecimento das decisões judiciais entre todos os Estados-Membros, princípio que se chegou a denominar de "quinta liberdade comunitária". Reconhecimento esse que, em seu aprofundamento, segue de "mãos dadas" à intensificação na proteção dos direitos fundamentais. ${ }^{378}$ Assim, para que esse sistema se torne cada vez mais eficaz, faz-se necessária a construção de medidas de confiança, por exemplo, o reforço dos direitos da pessoa suspeita de um crime

Arangüena. Nuevas Directivas Sobre Derechos Procesales de Sospechosos e Imputados en el Proceso Penal. In: FANEGO, Coral Arangüena (Coord.). Cooperación Judicial Civil y Penal en el Nuevo Escenario de Lisboa. Granada: Editorial Comares, 2011, p. 272).

${ }^{376} \mathrm{O}$ roteiro prevê as medidas a serem adotadas em torno de cinco temas: 1) tradução e interpretação; 2) informações sobre os direitos e sobre as acusações; 3 ) assessoria jurídica e assistência jurídica; 4) comunicação com familiares, empregadores e Consulados; 5) salvaguardas especiais para pessoas suspeitas ou acusadas em situação de vulnerabilidade; e um Livro Verde sobre a prisão preventiva. Uma das críticas a este programa consiste em que: A direção tomada com o roteiro de 2009 sobre direitos procedimentais, como sequela da fracassada proposta de Decisão-Quadro de 2004, nitidamente, perdeu a conexão com situações transfronteiriças. O roteiro apela para o reforço de uma lista de direitos tradicionais na seara de um julgamento justo, tais como: o direito à tradução e à interpretação, o direito à informação sobre os encargos, e o direito à ajuda legal especializada. Na palavra dos autores, mesmo que não se pretendesse minimizar a importância desses direitos, considera-se a estrutura deste Roteiro "uma ponte longa demais" que não esclarece suficientemente estes direitos, tampouco os conectando com preocupações transfronteiriças em processos penais que envolvam vários Estados-membros. [...] Mesmo que as medidas constantes no Roteiro fossem limitadas, a preocupação dos autores foca-se no fato de que a interpretação do conceito de "direitos procedimentais" todavia é muito estreita. Eles acreditam seriamente que o sistema de justiça criminal na íntegra é um grande aglomerado de direitos processuais, em que os tradicionais direitos a um julgamento justo representam apenas uma pequena fração. $\mathrm{O}$ processo penal não deveria ser limitado à fase de julgamento, à parte que ocorre com um juiz a frente. Na realidade, como defendem, as incompatibilidades dos direitos processuais são muito mais significativas na fase de investigação preliminar, quando a coleta de provas está espalhada por vários Estados-Membros. (BONDT, Wendy De; VERMEULEN, Gert. The Procedural Rights Debate. A Bridge Too Far or Still Not Far Enough? EUCRIM, vol. 4, 2010, p. 164-5). No mesmo sentido: FANEGO, Coral Arangüena. Nuevas Directivas Sobre Derechos Procesales de Sospechosos e Imputados en el Proceso Penal. In: FANEGO, Coral Arangüena (Coord.). Cooperación Judicial Civil y Penal en el Nuevo Escenario de Lisboa. Granada: Editorial Comares, 2011, p. 273.

${ }^{377}$ Resolução de 30 de novembro de 2009 do Conselho da União Europeia, com roteiro para o reforço dos direitos processuais dos suspeitos ou acusados (2009/C 295/01). Disponível em: <http://eurlex.europa.eu/LexUriServ/LexUriServ.do?uri=OJ:C:2009:295:FULL:EN:PDF〉. Último acesso em: 07 fev. 2014.

378 PENÍN ALEGRE, Clara. "Cooperación Jurídica Internacional”. In: HERMIDA, Ágata M. Sanz; PRADILLO, Juan Carlos Ortiz (Coords.). Problemas Actuales de la Justicia Penal: Secreto Profesional, cooperación jurídica internacional, víctimas de delitos, criminalidad organizada, personas jurídicas, eficacia y licitud de la prueba, prueba y derechos fundamentales. Madrid: Colex, 2013, p. 52. 
transnacional. ${ }^{379}$

Além disso, importa referir que a já tão propalada "confiança" é essencial para a aceitação do princípio da base de reconhecimento mútuo. Dada essa confiança, o Estado requerido não precisa verificar a legalidade da sentença estrangeira antes de implementá-la. Essa é a principal diferença entre o sistema de auxílio jurídico mútuo e o reconhecimento mútuo. Além das formalidades — sob a assistência mútua existe uma "petição", enquanto, sob o sistema de reconhecimento mútuo, o Estado remetente envia uma "ordem" —, uma das principais diferenças entre a assistência jurídica mútua e o reconhecimento mútuo reside no procedimento de reconhecimento e os motivos de recusa do pedido. De acordo com o princípio do reconhecimento mútuo, o Estado requerido, como regra, não irá verificar, ou melhor, não está autorizado a verificar os motivos - grau de suspeita, necessidade ou proporcionalidade da medida - que provocaram o pedido, enquanto, no sistema de assistência mútua, o Estado de execução tem muito mais margem de manobra para testar os méritos da decisão estrangeira. Isso não significa que o princípio do reconhecimento mútuo seja equivalente a um reconhecimento automático cego de aplicação da medida solicitada, mas, como regra geral, os motivos de recusa são restritos ao mínimo. ${ }^{380}$

O legislador europeu, consciente de que, apesar da presença de todos os Estados da União no sistema de proteção de direitos do Conselho da Europa, o grau de cumprimento do Convênio ainda não é homogêneo, extremo que dificulta a aplicação do princípio de reconhecimento mútuo, pedra angular da cooperação jurídica penal (e civil), reputou necessário dar um passo à frente em matéria de direitos processuais e adotou um catálogo de garantias homogêneas entre os Estados-Membros. Para esse fim, empreendeu uma decidida ação na matéria, facilitada agora pelo novo cenário inaugurado por Lisboa com a supressão

${ }^{379}$ HODGSON, Jacqueline S. Safeguarding Suspects' Rights in Europe: a Comparative Perspective. New Criminal Law Review, vol. 14, n. 04, 2011, p. 651.

${ }^{380}$ No original: "La confianza es la base esencial para la aceptación del principio de reconocimiento mutuo. Dada esta confianza, el Estado requerido no tiene la necesidad de comprobar la legalidad de la resolución judicial extranjera antes de ejecutarla. Esta es la principal diferencia entre el sistema de asistencia jurídica mutua y el reconocimiento mutuo. Aparte de las formalidades - bajo la mutua asistencia existe una "petición", mientras que en el marco del sistema de reconocimiento mutuo, el Estado emisor envía una "orden" - una de las principales diferencias entre la asistencia judicial recíproca y el reconocimiento mutuo se encuentra en el procedimiento de reconocimiento y las causas de denegación de la solicitud. Bajo el principio de mutuo reconocimiento el Estado requerido, por regla general, no comprobará y no está permitido comprobar los motivos - nivel de sospecha, necesidad o proporcionalidad de la medida - que han motivado la solicitud, mientras que en el sistema de asistencia mutua, el Estado de ejecución tiene mucho más margen de maniobra para comprobar los méritos de la decisión judicial extranjera. Esto no significa que el principio de reconocimiento mutuo sea equivalente a un reconocimiento ciego y ejecución automática de la medida solicitada, pero, como regla general, los motivos de denegación están restringidas a un mínimo". (BACHMAIER WINTER, Lorena. "European investigation order for obtaining evidence in the criminal proceedings Study of the proposal for a European directive". In: Zeitschrift für Internationale Strafrechtsdogmatik. Septiembre, 2010, pp. 582 y siguientes). 
da velha estrutura de pilares e a comunitarização, portanto, da matéria de cooperação jurídica penal. Ação que já se concretizou com a adoção de diretivas em matéria de tradução e interpretação (2010/64/UE), direito à informação nos procedimentos criminais (2012/13/UE) e de assistência letrada (2013/48/UE), havendo já iniciado os trabalhos para a adoção de uma quarta diretiva em matéria de assistência jurídica gratuita. ${ }^{381}$

Como referido acima, a primeira medida resultante desse plano de trabalho, a diretiva que confere direito a um intérprete e para a tradução de documentos durante a investigação e o julgamento, foi aprovada em outubro de $2010 .{ }^{382}$ Ela é um marco, configura a primeira medida de justiça criminal a ser aprovada pelo procedimento de codecisão e a primeira a abordar as salvaguardas para o acusado, garantindo o direito à interpretação em todo o processo penal, incluindo aconselhamento jurídico, bem como a tradução de todos os documentos essenciais à causa. ${ }^{383}$ Sem embargo, infelizmente, a decisão ainda não foi implementada pelos Estados-Membros. ${ }^{384}$

Posteriormente, foi aprovada a Diretiva 2012/13/UE, de 22 de maio de 2012, relativa ao direito à informação nos procedimentos penais, que se aplica desde o momento em que as autoridades competentes de um Estado-Membro põem em conhecimento suspeitas ou acusações que recaiam sobre uma pessoa até a conclusão do processo, inclusive, em uma ordem de detenção europeia, ${ }^{385}$ levando em consideração que "o artigo $6^{\circ}$ da Carta e o artigo $5^{\circ}$ da Convenção Europeia de Direitos Humanos (CEDH) consagram o direito à liberdade e a segurança das pessoas. A limitação desse direito não pode ir além do permitido, em conformidade com o artigo $5^{\circ}$ da $\mathrm{CEDH}$, segundo se infere da jurisprudência do Tribunal Europeu de Direitos Humanos" 386 e que "o reforço da confiança mútua exige normas detalhadas sobre a proteção das garantias e os direitos processuais derivados da Carta e da

\footnotetext{
381 ARANGÜENA FANEGO, Coral. Nuevas Directivas Sobre Derechos Procesales de Sospechosos e Imputados en el Proceso Penal. In: ARANGÜENA FANEGO, Coral (Coord.). Cooperación Judicial Civil y Penal en el Nuevo Escenario de Lisboa. Granada: Editorial Comares, 2011, p. 270.

${ }^{382}$ Em outubro de 2011 a situação ainda era a seguinte, conforme estudo de Puyenbroeck e Vermeulen: "Em relação às informações sobre o direito à interpretação e à tradução. Em nove Estados-Membros, não há obrigação legal de informar o suspeito em seu direito à interpretação (Bulgária, Dinamarca, Estónia, Finlândia, França, Alemanha, Itália, Luxemburgo e Países Baixos) e em oito Estados não há obrigação de informar o suspeito em seu direito à tradução (Dinamarca, Estonia, Finlândia, Alemanha, Itália, Luxemburgo, Países Baixos e os Estados Unidos). (PUYENBROECK, Laurens Van; VERMEULEN, Gert. Towards Minimum Procedural Guarantees for the Defence in Criminal Proceedings in the EU. International and Comparative Law Quarterly, vol. 60, 2011, p. 1032).

${ }^{383}$ Viviane Reding, Vice-Presidente da Comissão e primeira Comissária para a Justiça, Direitos Fundamentais Cidadania, descreveu a medida como: "um primeiro passo importante para corrigir o desequilíbrio existente entre os direitos do Ministério Público e o incremento e fortalecimento dos direitos da defesa na Europa".

${ }^{384}$ Os Estados tinhas até julho de 2013 para implementar a medida, porém até agora nada mudou desde 2011.

${ }^{385}$ Arts. $1^{\circ}$ e $2^{\circ}$ da Diretiva.

${ }^{386}$ Parágrafo $6^{\circ}$ da Exposição de Motivos da Diretiva.
} 
CEDH".387

A mais recente diretiva aprovada foi a Diretiva n. 2013/48/UE, de 22 de outubro de 2013, relativa ao direito à assistência de advogado nos processos penais e nos procedimentos relativos à ordem de detenção europeia. Estabelece, em suma, o direito a que se informe a um terceiro no momento da privação da liberdade e o a comunicar-se com terceiros e com autoridades consulares durante a privação da liberdade. Desse modo, promove a aplicação da Carta e, em particular, de seus artigos $4^{\circ}, 6^{\circ}, 7^{\circ}, 47$ e 48 , desenvolvendo o estabelecido nos artigos $3^{\circ}, 5^{\circ}, 6^{\circ}$ e $8^{\circ}$ da CEDH, conforme interpretação do Tribunal Europeu de Direitos Humanos, que, em sua jurisprudência, estabelece com frequência normas sobre o direito à assistência de letrado. Referida jurisprudência estabelece, entre outras coisas, que a imparcialidade do processo exige que o suspeito ou acusado possa obter toda a gama de serviços que se associam especificamente com a assistência letrada. Nesse sentido, o advogado do suspeito ou acusado deve poder exercer sem restrições os aspectos fundamentais da defesa. ${ }^{388}$ Há um prazo de três anos para que essa diretiva seja implementada.

Nesse contexto, a informação dos direitos que assistem a toda pessoa suspeita da comissão de um fato punível deve ser estendida ao direito a dispor de assistência letrada, no caso, gratuita (com a devida indicação das condições para obtê-la), ${ }^{389}$ o direito à

\footnotetext{
${ }^{387}$ Parágrafo $8^{\circ}$ da Exposição de Motivos da Diretiva.

${ }^{388}$ Parágrafo 12 da Exposição de Motivos da Diretiva.

${ }^{389}$ Ainda que a Diretiva relativa à assistência letrada devesse dispor sobre a assistência jurídica gratuita, não o fez e, assim, nas palavras da Professora Coral Arangüena, "ha nacido privada de una parte fundamental" (palavras pronunciadas em Conferência sobre o tema na Universidade Pompeu Fabra, em Barcelona, em 28 de janeiro de 2014). Importa referir que em 27 de novembro de 2013, a Comissão aprovou proposta de Diretiva do Parlamento Europeu e do Conselho sobre assistência jurídica gratuita provisional aos suspeitos ou acusados privados de liberdade e a assistência jurídica gratuita no procedimento da ordem de detenção europeia (COM(2013)0824 de 27 de novembro de 2013). Na primeira parte do documento está disposto: "2. [...] O direito à assistência jurídica está intimamente ligado ao direito de acesso a um advogado, contida na Directiva 2013/48/UE do Parlamento Europeu e do Conselho, de 22 de outubro de 2013. Para as pessoas que não têm os meios financeiros necessários, somente o aconselhamento jurídico gratuito pode tornar efetivo o direito de acesso a um advogado. 3. A proposta da Comissão é um passo positivo para garantir um nível mínimo de assistência jurídica em todos os Estados-Membros. No entanto, é limitada ao direito à assistência jurídica provisória de suspeitos ou acusados que estão privados de liberdade no processo penal e direito à assistência jurídica provisória a pessoas sob quem recaiam um Mandado de Detenção Europeu. Outros aspectos do direito à assistência jurídica foram incluídos em uma Recomendação apartada da Comissão (C (2013) 8179/2). 4. A Diretiva e a Recomendação devem ser tratadas de maneira conjunta, uma vez que é difícil discutir o direito provisório de assistência jurídica sem também discutir os requisitos para se qualificar essa assistência jurídica, ou a qualidade da assistência jurídica prestada. Um dos pontos que o Parlamento deve discutir, refere-se, sem dúvida, ao alcance exato de ambos os instrumentos” Tradução libre de: “2. [...] El derecho a la asistencia jurídica está estrechamente vinculado al derecho a acceder a un letrado, recogido en la Directiva 2013/48/UE del Parlamento Europeo y del Consejo, de 22 de octubre de 2013. Para las personas que carecen de los medios financieros necesarios, sólo el asesoramiento jurídico gratuito puede hacer eficaz el derecho de acceso a un letrado. 3. La propuesta de la Comisión es un paso positivo para garantizar un nivel mínimo de asistencia jurídica en todos los Estados miembros. No obstante, se limita al derecho a la asistencia jurídica provisional para los sospechosos o acusados que se encuentran privados de libertad en los procedimientos penales, y al
} 
interpretação, à tradução e o direito a permanecer em silêncio, todos eles na forma em que são aplicados, de acordo com a legislação nacional. Dita informação deverá ser proporcionada tão logo esses direitos sejam aplicáveis durante o processo e com suficiente antecedência para permitir o seu exercício efetivo. De modo semelhante, preveem as diretivas analisadas que também o direito à informação será exigível não só em todo o processo penal em um Estado-Membro da União Europeia, como também nos procedimentos de execução de uma ordem europeia de detenção e entrega e, da mesma forma, naqueles casos de infrações menores cuja fase de recurso prossiga perante um órgão jurisdicional penal (ainda que, nesses casos, o direito à informação limite-se precisamente à fase judicial que se inicia com a apresentação do recurso). ${ }^{390}$

O próprio fato de que as medidas para um julgamento justo estão agora na agenda e que o consenso suficiente foi alcançado para iniciar o processo de sua adoção é extremamente significativo. Ademais, o direito à assistência letrada constante na diretiva mais recente da UE em relação à implementação do roteiro estabelecido no Programa de Estocolmo vai ao encontro de decisões paradigmáticas da Corte Europeia de Direitos Humanos, quais sejam os casos Salduz vs. Turkey ${ }^{391}$ e Panovits vs. Chipre, ${ }^{392}$ nos quais o

derecho a la asistencia jurídica provisional y a la asistencia jurídica a las personas buscadas que sean objeto de un procedimiento de orden de detención europea. Otros aspectos del derecho a la asistencia jurídica han sido incluidos en una Recomendación por separado de la Comisión (C(2013)8179/2). 4. La Directiva y la Recomendación se deben tratar de manera conjunta, ya que es difícil discutir sobre el derecho a la asistencia jurídica provisional, sin discutir también sobre los requisitos para tener derecho a la asistencia jurídica, o la calidad de la asistencia jurídica que se ha de prestar. Uno de los puntos que debe debatir el Parlamento Europeo se refiere, sin duda, al alcance preciso de ambos instrumentos." (DOCUMENTO DE TRABAJO relativo a la asistencia jurídica gratuita provisional a los sospechosos o acusados privados de libertad y a la asistencia jurídica gratuita en el procedimiento de la orden de detención europea. Comisión de Libertades Civiles, Justicia y Asuntos de Interior Ponente: Cornelis de Jong. Disponible en: $<$ http://www.europarl.europa.eu/sides/getDoc.do?pubRef=\%2F\%2FEP\%2F\%2FNONSGML\%2BCOMPARL \%2BPE-530.085\%2B02\%2BDOC\%2BPDF\%2BV0\%2F\%2FES>. Aceso en 30 abr. 2014). Além disso, houve uma comunicação da Comissão ao Parlamento Europeu, ao Conselho, ao Comitê Econômico e Social Europeu e ao Comitê das Regiões, para promover a agenda da União Europeia sobre as garantias processuais dos suspeitos ou acusados - fortalecimento da fundação do espaço europeu de justiça penal (COM (2013) 820/2) que introduz um pacote de cinco medidas legais para avançar na agenda dos direitos processuais e para fortalecer ainda mais as bases para o campo europeu de justiça criminal. Este pacote segue-se à recente adoção bem sucedida das três diretivas sobre direitos processuais. É composto de três propostas de diretivas sobre: (1) o fortalecimento de alguns aspectos da presunção de inocência e do direito a ser apresentado no julgamento no processo penal; (2) garantias especiais para os menores suspeitos ou acusados em processos penais, e (3) a assistência jurídica provisória aos suspeitos ou acusados privados de liberdade e de assistência jurídica nos procedimentos do mandado de detenção europeu. Dado que as medidas tomadas devem ser proporcionais aos objetivos de ação da UE, existem também duas recomendações da Comissão: (4) as garantias processuais para as pessoas vulneráveis suspeitas ou acusadas nos processos penais, e (5) o direito à assistência jurídica gratuira aos suspeitos e arguidos em processos penais. (COM (2013) 820/2, p. 3, em livre tradução).

390 ARANGÜENA FANEGO, Coral. "Nuevas Directivas Sobre Derechos Procesales de Sospechosos e Imputados en el Proceso Penal”. En: ARANGÜENA FANEGO, Coral (Coord.). Cooperación Judicial Civil y Penal en el Nuevo Escenario de Lisboa. Granada: Editorial Comares, 2011, p. 297.

${ }^{391}$ Salduz [2008] CEDH $36391 / 02$ Grande Seção (Nov. 27, 2008).

392 Panovits [2008] CEDH 4268/04 (11 de dezembro de 2008). 
Tribunal proferiu suas decisões mais emblemáticas sobre a importância da assessoria jurídica às pessoas privadas de liberdade. $\mathrm{O}$ modelo de defesa promovido nesses julgamentos evoca a participação ativa da defesa desde o início do interrogatório policial.

No caso Salduz, o requerente, um menor de dezessete anos, foi detido e interrogado por uma agência antiterrorismo, em maio 2001, por suspeita de ter participado de uma manifestação clandestina em apoio a uma organização ilegal, denominada PKK (Partido dos Trabalhadores do Curdistão), e de pendurar uma bandeira a partir de uma ponte em Bornova, em 26 de abril de 2001. Ele foi informado das acusações contra ele e de seu direito ao silêncio, mas não teve acesso à assistência jurídica. Durante o interrogatório policial, ele admitiu as acusações que lhe foram imputadas, mas se retratou perante o juiz de instrução, alegando que sua confissão foi obtida sob coação e que ele havia sido espancado e insultado pela polícia. O apelante foi condenado em dezembro de 2001, e a alegação perante o Tribunal Europeu de Direitos Humanos foi a de que a ausência de assistência jurídica no momento da detenção violou seus direitos de defesa, nos termos do artigo $6^{\circ}$, §3(c), da Convenção. No acórdão de 26 de abril de 2007, a Câmara considerou que não houve tal violação e que teria sido mantida a equidade do seu julgamento, a qual não foi prejudicada pela falta de assistência jurídica durante a custódia policial, pois o recorrente foi legalmente representado no julgamento. Além disso, a Câmara considerou que a sua confissão não foi a única base para a sua condenação e que tinha sido capaz de desafiar a acusação no julgamento em condições que não o colocaram em desvantagem substancial à acusação. A Grande Seção reverteu o acórdão, sublinhando a importância da investigação policial inicial na definição do caso, a vulnerabilidade dos suspeitos nessa fase do procedimento e, portanto, a importância da assistência de um advogado, cuja tarefa é, entre outras coisas, "garantir o respeito ao direito de um acusado não se auto incriminar" (parágrafo 54). ${ }^{393}$

Em suma, o Tribunal não considerou que o posterior acesso a aconselhamento jurídico, durante a condução do julgamento, fosse suficiente para "sanar os defeitos ocorridos durante a custódia na polícia” (parágrafo 58), especialmente tendo em conta que o recorrente era menor de idade: "embora o recorrente tenha tido a oportunidade de contestar as provas ao longo do julgamento e, posteriormente, em sede de recurso, a ausência de um

\footnotetext{
393 O Tribunal declarou que: "para que o direito a um julgamento justo permaneça suficientemente prático e eficaz [...], o Artigo $6^{\circ}$, §1, exige que, como regra, o acesso a um advogado deve ser fornecido a partir do primeiro interrogatório de um suspeito pela polícia, a não ser que se demonstre à luz das circunstâncias específicas de cada caso que há fortes razões para que esse direito seja restringido. [...] Os direitos da defesa, em princípio, são irremediavelmente prejudicado quando declarações incriminatórias feitas durante o interrogatório policial, sem acesso a um advogado, são usadas para condenação.” (parágrafo 55).
} 
advogado enquanto estava sob custódia policial afetou irremediavelmente a defesa de seus direitos" (parágrafo 62). ${ }^{394}$

O impacto do caso Salduz, que aborda a assessoria jurídica desde a custódia policial, um dos direitos mais difíceis de ser implementado pelos Estados-Membros, fornece certo otimismo para uma agenda da UE, que inclui liberdades individuais, bem como o combate ao crime transnacional.

Na linha dos casos Salduz e Panovits, a jurisprudência posterior da Corte reforçou os fundamentos desses julgamentos. Por exemplo, em Dayanan vs. Turquia, ${ }^{395}$ o Tribunal reiterou que o direito à assistência jurídica desde o início da custódia policial é um dos elementos fundamentos de um julgamento justo, direito que não pode ser suspenso, mesmo nos casos de acusação por crimes mais graves - porque o suspeito foi acusado de um crime que era da competência do tribunal de segurança do Estado, a lei turca o impediu de receber assistência jurídica. Isso é significativo, já que muitas jurisdições colocam restrições ao acesso à assessoria jurídica para os suspeitos de terrorismo e de outros crimes graves.

Nesse sentido, há estudo levado a efeito por Spronken e De Vocht, ${ }^{396}$ intitulado "Effective Defence Rights in the EU and Access to Justice: Investigating and Promoting Best

\footnotetext{
${ }^{394}$ No caso Panovits, o recorrente também tinha dezessete anos e em abril de 2000 foi interrogado por suspeita de assassinato e roubo. Seu pai o acompanhou à delegacia, mas não pode ficar junto com o filho durante o interrogatório. $\mathrm{O}$ requerente foi advertido, mas nem ele nem o seu pai foram informados do direito a aconselhamento jurídico antes do interrogatório. Panovits fez uma confissão por escrito, mas afirmou que foi involuntária, induzida através de engano psicológico, promessas, ameaças, e táticas projetadas para incutir medo, e que ele estava bêbado no momento dos fatos e assim incapaz de recordar com detalhes os acontecimentos sobre o qual ele estava sendo questionado. Em maio de 2001, o recorrente foi condenado por homicídio e roubo, e seu recurso foi rejeitado. Perante a Corte Europeia de Direitos Humanos, Panovits alegou que estes fatos constituíram violação ao artigo $6^{\circ}$ da CEDH. Em outro julgamento contundente, o Tribunal voltou a salientar a natureza crucial da assessoria jurídica na fase de privação de liberdade, afirmando: "o conceito de justiça, consagrado no artigo $6^{\circ}$ exige que ao acusado deve ser proporcionado o benefício da assistência de um advogado já nos estágios iniciais do interrogatório policial. A falta de assistência jurídica durante o interrogatório constitui restrição dos seus direitos de defesa (parágrafo 66). O Tribunal considerou que, neste caso, houve violação do artigo 6o. O requerente não tinha conhecimento do seu direito a aconselhamento jurídico e das consequências de ser interrogado sem um advogado. Na ausência de um advogado durante o interrogatório, o requerente não tem condições de compreender suficientemente a natureza dos seus direitos, como o direito de não se auto-incriminar, e tampouco houve renúncia inequívoca e de forma explícita ao direito a aconselhamento jurídico, a qual é necessária para evitar violações ao artigo $6^{\circ}$. Finalmente, tal como em Salduz, o Tribunal não considerou que esta violação na fase preliminar fosse sanada pelos procedimentos subsequentes.

395 Dayanan 7377/03, 13 outubro de 2009, parágrafos. 30-34. No mesmo sentido os seguintes casos: Pishchalnikov v. Russia (Pishchalnikov 7025/04, 24 de dezembro de 2009); Brusco v. France (Brusco 14661407, 14 de outubro de 2010); Sebalj v. Croatia (Sebalj 4429/09, 28 de junho de 2011). Essas decisões são importantes não só porque demonstram o impacto da jurisprudência da CEDH sobre a esfera doméstica, mas também porque situam a importância do aconselhamento jurídico carcerário no contexto mais amplo possível, em que a Corte situou seu raciocínio.

${ }^{396}$ SPRONKEN, Taru; VOCHT, Dorris de. EU policy to guarantee procedural rights in criminal proceedings: "step by step". Paper to be presented at the conference "The Future of the Adversarial System", University of North Carolina at Chapel Hill School of Law, April, 2011.
} 
Practice", que teve por escopo ${ }^{397}$ descrever como as garantias processuais dos suspeitos e arguidos são protegidas pela Convenção Europeia dos Direitos Humanos, bem como aferir o aumento crescente e o impacto, muitas vezes competitivo, da União Europeia nessa área. O estudo foi conduzido por uma equipe de trinta acadêmicos e profissionais provenientes dos nove países analisados. Depois de três anos de pesquisa, iniciada em setembro de 2007, foi apresentado um esboço sobre a questão do acesso a uma defesa efetiva nos processos criminais de nove jurisdições europeias que constituem exemplos das três principais tradições jurídicas da Europa: inquisitorial, adversarial (acusatório) e regime pós-socialista, quais sejam: Bélgica, Inglaterra, País de Gales, Finlândia, França, Alemanha, Hungria, Itália, Polônia e Turquia. O ponto de partida foi o art. $6^{\circ}, \S^{\circ}$, da Convenção Europeia de Direitos Humanos, o qual prevê que, na determinação de qualquer acusação criminal, todas as pessoas têm direito a uma audiência justa e pública, sendo sustentada pela presunção de inocência no parágrafo segundo, e, em seu parágrafo terceiro, o artigo estabelece uma série de direitos mínimos que devem ser concedidos a quem é acusado de um crime: como o direito do tempo e dos meios para preparar sua defesa, o acesso à representação legal, o direito de inquirir as testemunhas ou de as ter examinado e o direito à assistência gratuita de um intérprete.

Os autores argumentam que a defesa criminal eficaz é um aspecto integrante do direito à um julgamento justo e que exige não apenas o direito à assistência jurídica competente, mas também estruturas legislativas aptas a tanto. $\mathrm{O}$ fundamento baseia-se na premissa de que, ainda que a assistência jurídica seja boa e competente, por si só não garantirá um julgamento justo se os outros elementos essenciais para tanto estiverem faltando. Portanto, defesa criminal eficaz tem um significado mais amplo do que simplesmente assistência jurídica competente.

Além do mais, os autores destacam que tem que ser levado em conta que os réus são em sua maioria pobres, o que exige um sistema de assistência jurídica adequada. Por exemplo, sem interpretação e tradução é difícil imaginar como um réu que não fala a língua

\footnotetext{
397 O objetivo do projeto era duplo: primeiro, fornecer informação empírica sobre a medida em que os direitos processuais identificados como essenciais para uma defesa criminal eficaz estão previstos na prática e, segundo, contribuir para a efetiva implementação desses direitos aos suspeitos e arguidos, especialmente, para aqueles considerados "indigentes", de modo a que acedam a uma defesa real e eficaz, como parte de um processo de avanço, observância e respeito do devido processo legal e dos direitos humanos. A pesquisa, porém, não estava simplesmente preocupada apenas com a Justiça ou com um julgamento justo. $\mathbf{O}$ foco foi mais específico, ou seja, de uma defesa criminal eficaz como pré-condição para o gozo das garantias de um julgamento equânime. (SPRONKEN, Taru; VOCHT, Dorris de. EU policy to guarantee procedural rights in criminal proceedings: "step by step". Paper to be presented at the conference "The Future of the Adversarial System", University of North Carolina at Chapel Hill School of Law, April, 2011, p. 2).
} 
poderia realmente participar do processo ou se comunicar com seu advogado. $\mathrm{O}$ direito ao silêncio não tem como proteger o suspeito de fazer declarações incriminatórias quando ele não está consciente ou informado desse direito antes de um interrogatório. ${ }^{398}$

Assim, partindo dos países estudados, cinco grandes temas surgiram, mostrando deficiências nos mecanismos e nas culturas jurídicas para apoiar uma defesa criminal eficaz em praticamente todas as jurisdições incluídas no estudo. Em primeiro lugar, a assistência jurídica é problemática em muitos países, especialmente em relação ao acesso a ela, à oportunidade do acesso e à qualidade dessa assistência legal. Segundo, a assistência judiciária, intimamente ligada ao direito à assistência jurídica, muitas vezes é ineficaz devido aos métodos de aplicação lentos, pouco claros e complicados. Além disso, a disponibilidade, a qualidade e independência dos advogados de defesa criminal nos casos de assistência jurídica provaram ser inadequadas, nomeadamente, devido à baixa remuneração prevista para essa atividade. ${ }^{399}$ Ademais, os governos têm uma responsabilidade importante na criação de estruturas e recursos para garantir a prestação de assistência jurídica gratuita, assim como para garantir que a interpretação e a tradução gratuitas estejam disponíveis em tempo hábil para aqueles que não podem pagar por elas. ${ }^{400}$

Além desse interessantíssimo trabalho de pesquisa, outro estudo também foi levado a efeito por Spronken, que diz respeito a como os suspeitos nos Estados-Membros da UE são informados dos seus direitos nos procedimentos em matéria penal. Nesse estudo, desenvolveu-se um quadro normativo com base na jurisprudência da CEDH para estabelecer

\footnotetext{
398 Nesse norte, são esclarecidos os três níveis de abordagem que compõe o que consideram uma defesa criminal eficaz: 1) verificar a existência de uma estrutura legislativa e constitucional que disponibilize adequadamente os direitos de defesa seguindo a jurisprudência do Tribunal Europeu de Direitos Humanos, e se esta está estabelecida como padrão mínimo; 2) se existem regulamentos e práticas que permitam que esses direitos sejam práticos e efetivos; e 3) se existe um nível consistente de competência dos advogados de defesa, apoiada por uma cultura profissional que reconhece que essa defesa deve estar preocupada com processos eficientes, bem como com os seus resultados, e em relação às quais as percepções e experiências dos suspeitos e réus são centrais. (SPRONKEN, Taru; VOCHT, Dorris de. EU policy to guarantee procedural rights in criminal proceedings: "step by step". Paper to be presented at the conference "The Future of the Adversarial System”, University of North Carolina at Chapel Hill School of Law, April, 2011, p. 3 e 35).

${ }^{399}$ A investigação existente sobre o nível de salvaguardas no âmbito da UE mostra claramente que um número considerável de países europeus não cumprem adequadamente suas obrigações decorrentes da Convenção. $\mathrm{O}$ estudo ilustra que certos direitos básicos, tais como: o direito de permanecer em silêncio, o direito a ter acesso aos autos e para examinar testemunhas ou peritos, todos os requisitos básicos de um julgamento justo na CEDH, não estão previstos na legislação de todos os Estados membros. (SPRONKEN, Taru; VOCHT, Dorris de. EU policy to guarantee procedural rights in criminal proceedings: "step by step". Paper to be presented at the conference "The Future of the Adversarial System", University of North Carolina at Chapel Hill School of Law, April, 2011, p. 2-3, 8).

400 "National governments have an important responsibility for establishing structures and providing resources to ensure that free legal assistance as well as free interpretation and translation are available in a timely fashion to those who cannot pay for these. (SPRONKEN, Taru; VOCHT, Dorris de. EU policy to guarantee procedural rights in criminal proceedings: "step by step". Paper to be presented at the conference "The Future of the Adversarial System”, University of North Carolina at Chapel Hill School of Law, April, 2011, p. 36).
} 
padrões e uma base jurídica para as informações que devem ser prestadas aos suspeitos na fase inicial das investigações policiais. Um modelo para uma Carta de Direitos foi projetado para a UE, a ser aplicada em todos os Estados-Membros, a qual também estava destinada a funcionar como inspiração para iniciativas a nível nacional, bem como a nível da UE. ${ }^{401} \mathrm{~A}$ pesquisa foi concluída em julho de 2010 e, dentre as revelações do trabalho, tomou-se ciência de que, somente em 17 dos 27 Estados-Membros da UE, os suspeitos são informados de seus direitos através de uma Carta de Direitos ou em um formato semelhante. ${ }^{402}$ Entretanto, em detrimento da efetividade de uma Carta de Direitos aos acusados estrangeiros, verificou-se que apenas em poucos Estados a referida Carta de Direitos está disponível em diversos idiomas. Nesse sentido, Inglaterra, País de Gales, Alemanha, Suécia e Bélgica configuram notáveis exceções por disponibilizarem a Carta de Direitos traduzida em mais de quarenta línguas. ${ }^{403}$

Importa destacar que esses estudos deveriam ser replicados no âmbito interamericano, a fim de se aferir o grau de cumprimento dos direitos processuais penais dos investigados nos países que ratificaram a Convenção Americana de Direitos Humanos, bem como replicar iniciativas tais como a realização de uma Carta de Direitos a ser entregue para todos os detidos e processados nos países, sem distinção de nacionalidade.

A seguir serão analisadas as iniciativas no âmbito da União Europeia na tentativa de equilibrar o sistema em relação aos direitos da defesa.

\subsubsection{Tentativas e propostas com o intuito de equalizar o sistema}

Com a intenção de analisar as propostas já veiculadas no âmbito da União Europeia nesse tema e como o título do capítulo sugere, será utilizada a sistematização feita por Joachim Vogel ${ }^{404}$ que identifica cinco tendências principais no âmbito da cooperação

\footnotetext{
${ }^{401}$ A Comissão Europeia, ciente dos resultados da pesquisa, apresentou Diretiva sobre o direito à informação nos processos criminais em 20 de julho de 2010, na qual estava incluída modelo de Carta de Direitos inspirada no modelo desenvolvido no estudo (DIRETIVA 2012/13/UE do Parlamento Europeu e do Conselho adotada em de 22 de maio de 2012).

${ }^{402}$ Os resultados completos do trabalho foram publicados na seguinte obra: SPRONKEN, Taru. An EU-Wide Letter of Rights - Toward Best Practice. Antwerp, Cambridge, Portland: Intersentia and Metro, 2010. O projeto foi financiado pelo Ministério da Justiça da Alemanha e pela Comissão Europeia. Dentre os demais parceiros do projeto, destacam-se: o Ministério da Justiça da Áustria, o Conselho da Europa e a Associação Europeia dos Advogados Criminais. A pesquisa começou em 2009 e os resultados foram finalizados em julho de 2010.

${ }^{403}$ A esse respeito vide anexo 2 do estudo: SPRONKEN, Taru. An EU-Wide Letter of Rights - Toward Best Practice. Antwerp, Cambridge, Portland: Intersentia and Metro, 2010, pp. 189-258.

${ }^{404}$ VOGEL, Joachim. Cooperación Penal: Cinco Tendencias. Cinco Propuestas Para Una Acción Futura. In: ROMERO, Marta Muñoz de Morales (Coord.). El Derecho Penal de la Unión Europea. Situación Actual y Perspectivas de Futuro. Cuenca: Ediciones de la Universidad de Castilla La-Mancha, 2007, p. 158.
} 
europeia em matéria penal:

1) um avanço da cooperação tradicional para uma verdadeira integração;

2) mudança de soluções "horizontais" para soluções "verticais";

3) alteração do que se denomina de "protecionismo nacional" para a confiança e o reconhecimento mútuos, pelo menos na teoria e na legislação, embora ainda não reconhecidos na prática;

4) avanço de uma abordagem "repressiva" para uma abordagem "integral" (tanto repressiva quanto preventiva) que inclui ainda a cooperação entre as administrações;

5) a mudança de um "viés persecutório" rumo a um sistema que inclui alguns controles e supervisão, a fim de proteger os direitos humanos.

Para os propósitos deste trabalho, serão abordadas com mais profundidade as tendências expostas nos itens " 2 " e "5", as quais corroboram a linha de raciocínio desenvolvida no estudo.

Como explana o autor, tradicionalmente, a cooperação em matéria penal constituía um fenômeno "horizontal": o Estado requerido e suas autoridades prestavam ajuda em procedimentos penais no Estado requerente, mediante a prisão e extradição de pessoas acusadas ou condenadas ou executando outras solicitações relacionadas ao processo penal, por exemplo, os pedidos de busca e apreensão, confisco de produtos provenientes do crime, solicitações de interrogatório de suspeitos, testemunhas ou peritos, ou transferência de pessoas condenadas.

Além disso, o marco legal da cooperação exibia uma estrutura "horizontal" que consistia em tratados internacionais, bilaterais ou multilaterais, por um lado, e as legislações nacionais dos Estados implicados, por outro, sendo bem conhecidos os problemas decorrentes dessa "horizontalidade" - resulta quase impossível fazer cumprir a cooperação, pois, com certa frequência, as autoridades do Estado requerido carecem das informações necessárias para um cumprimento eficaz, e as provas obtidas segundo as leis do Estado requerido podem não corresponder aos padrões normativos do Estado requerente, podendo, portanto, ser inadmissíveis in foro. ${ }^{405}$

${ }^{405}$ VOGEL, Joachim. Cooperación Penal: Cinco Tendencias. Cinco Propuestas Para Una Acción Futura. In: ROMERO, Marta Muñoz de Morales (Coord.). El Derecho Penal de la Unión Europea. Situación Actual y Perspectivas de Futuro. Cuenca: Ediciones de la Universidad de Castilla La-Mancha, 2007, p. 159. 
Não resulta, portanto, surpreendente e é certamente útil a emergência de estruturas "verticais" no âmbito da União Europeia, tanto a nível institucional quanto legislativo. Europol (Policia Europeia), Eurojust e OLAF (Oficina Europeia de Luta contra a Fraude), ${ }^{406}$ no momento, são as estruturas institucionais "verticais" mais importantes. O próximo passo para essa verticalização já foi incluído no artigo III-175 do Projeto de Tratado que estabelece uma Constituição para a Europa: a já conhecida e muito debatida Procuradoria Europeia ("Fiscalía Europea"), responsável pela investigação, interposição e processamento dos suspeitos de crimes graves que afetam a mais de um Estado-Membro e de delitos contra os interesses financeiros da União. ${ }^{407}$

Acerca da quinta tendência trazida pelo autor, cumpre referir que, tradicionalmente, a lei sobre a cooperação em matéria penal tem sido uma área bastante relevante, principalmente para especialistas dos Ministérios de Justiça ou de Interior nacionais, para o Poder Judiciário e, sobretudo, muito importante para as forças policiais nacionais.

Os acadêmicos, advogados de defesa e ativistas de direitos humanos não estavam interessados e tampouco detinham qualquer influência sobre os instrumentos jurídicos no campo da cooperação. A consequência disso foi o que Vogel denominou de "viés ou mote persecutório", dada a avassaladora influência da acusação sobre a lei e a prática nesse campo. As reformas legislativas levadas a cabo sempre foram claramente destinadas a facilitar a cooperação mediante o estabelecimento de unidades e de oportunidades inter e transnacionais de investigação e acusação, com a redução de qualquer controle e/ou supervisão dos organismos envolvidos. ${ }^{408}$

Entretanto, recentemente, verifica-se que esse contexto tem se alterado. As rápidas e significativas reformas dos últimos anos provocaram atenção generalizada no público e também nos advogados de defesa, grupos de defesa e outras ONGs de direitos humanos,

\footnotetext{
${ }^{406}$ A OLAF investiga fraudes ao orçamento da UE, a corrupção e as faltas graves às instituições europeias e elabora a política de luta contra a fraude para a Comissão Europeia. Disponível em: $<$ http://ec.europa.eu/anti_fraud/index_es.htm〉. Último acesso em: 26 out. 2014.

407 VOGEL, Joachim. Cooperación Penal: Cinco Tendencias. Cinco Propuestas Para Una Acción Futura. In: ROMERO, Marta Muñoz de Morales (Coord.). El Derecho Penal de la Unión Europea. Situación Actual y Perspectivas de Futuro. Cuenca: Ediciones de la Universidad de Castilla La-Mancha, 2007, p. 160.

${ }^{408} \mathrm{~A}$ evolução na Europa não constituiu exceção à regra: resulta muito significativo que o parágrafo 2o do artigo 31 da Decisão-Quadro relativa à Orden Europeia de Detenção e Entrega estabeleça que os Estados membros continuem a aplicar os acordos e alcançarão novos acordos, na medida em que "contribuam para simplificar ou facilitar ainda mais os processos de entrega de pessoas que são objeto de uma ordem europeia de detenção", em particular estabelecendo prazos reduzidos para execução ou limitando ainda mais os motivos para sua rejeição. (VOGEL, Joachim. Cooperación Penal: Cinco Tendencias. Cinco Propuestas Para Una Acción Futura. In: ROMERO, Marta Muñoz de Morales (Coord.). El Derecho Penal de la Unión Europea. Situación Actual y Perspectivas de Futuro. Cuenca: Ediciones de la Universidad de Castilla La-Mancha, 2007, p. 162).
} 
como a Fair Trial Abroad ou a State Watch. Como traz Vogel, ${ }^{409}$ grupos de vozes críticas têm manifestado preocupações sobre as salvaguardas dos suspeitos e acusados nos processos penais inter ou transnacionais e sobre o respeito aos seus direitos nas diligências requeridas. Nesse sentido, tem-se invocado a ideia de métodos de controle e supervisão para limitar a cooperação em matéria penal, ou melhor, incluir de vez a defesa nessa temática.

Vogel conclui referindo que as críticas deveriam ser levadas a sério, pois são dotadas de pleno fundamento ao exigir um justo equilíbrio entre uma cooperação internacional cada vez mais eficaz, por um lado, e, por outro, dever ter em conta os interesses das pessoas afetadas.

Nesse panorama, depois de apresentar as cinco tendências antes referidas, o autor preocupa-se em apresentar propostas de ação futura para a cooperação em matéria penal no âmbito da União Europeia, em que se destaca a seguinte: “A União deve estabelecer garantias processuais em todo o seu território para os processos penais transnacionais", especialmente, a fim de melhorar a situação dos suspeitos, acusados ou condenados que não sejam nacionais do Estado acusador, em particular, a União deveria criar um marco legal para uma "Eurodefensa" 410 em casos transnacionais.

É por isso que, na opinião de Fijnaut e Ouwerkerk, ${ }^{411}$ afigura-se absolutamente

${ }^{409}$ VOGEL, Joachim. Cooperación Penal: Cinco Tendencias. Cinco Propuestas Para Una Acción Futura. In: ROMERO, Marta Muñoz de Morales (Coord.). El Derecho Penal de la Unión Europea. Situación Actual y Perspectivas de Futuro. Cuenca: Ediciones de la Universidad de Castilla La-Mancha, 2007, p. 162.

${ }^{410}$ A legislação em matéria de cooperação em matéria penal tem deixado de lado os direitos de defesa. Neste momento, um grupo de professores de direito penal alemão está elaborando uma proposta de alteração ao projeto de Tratado que estabelece uma Constituição para a Europa, a qual iria introduzir um "Eurodefensor" como equivalente ao Ministério Público Europeu. Para Vogel, a idéia de uma "Eurodefensor", como a instituição da UE é incompatível com o princípio de livre defesa, mas imagina um quadro jurídico para a "Eurodefensa", o qual incluiria pelo menos os itens indicados a seguir: a) as Associações de Advogados nos Estados-Membros devem estabelecer uma rede de "Advogados Defensores Europeus" com conhecimentos especiais e experiência no campo dos processos penais transnacionais; b) Devem-se notificar as pessoas afetadas pelas medidas de cooperação em materia Penal quanto ao seu direito a aconselhamento jurídico, no momento apropriado, também sobre a existência da rede de advogados de defesa". c) Pessoas que não têm os meios financeiros para a obtenção de serviços de um "advogado de defesa" devem ter direito a aconselhamento jurídico gratuito (pago pelo Estado-Membro que faz a denúncia) e d) os advogados de defesa europeia teriam direito a todos os registros relevantes de todas as instituições envolvidas, ou seja, do Estado-Membro acusador, do Estado-Membro executor e, conforme o caso, da Europol, Eurojust ou OLAF. O acesso deve ser ilimitado após o final das investigações e, durante estas, deve-se conceder acesso em um grau razoável, especialmente se a pessoa acusada foi presa. (VOGEL, Joachim. Cooperación Penal: Cinco Tendencias. Cinco Propuestas Para Una Acción Futura. In: ROMERO, Marta Muñoz de Morales (Coord.). El Derecho Penal de la Unión Europea. Situación Actual y Perspectivas de Futuro. Cuenca: Ediciones de la Universidad de Castilla LaMancha, 2007, p. 165).

411 "É por isso que, na minha opinião, é absolutamente imperativo que uma instituição europeia seja fundada para os casos de controle do crime transnacional, como já foi proposto por um relevante programa da União Europeia. O chamado Eurodefensor iria apoiar e fortalecer a defesa do indivíduo acusado." Tradução livre de: "That is why, in my opinion, it is absolutely imperative that a European institution be founded for cases of transnational crime control, as already proposed by a relevant European programme. The so-called Eurodefensor would support and strengthen the defence of the accused individual." (FIJNAUT, Cyrille; OUWERKERK, Jannemieke. The Future of Police and Judicial Cooperation in the European Union. Martinus 
imperativa a criação de uma instituição de defesa, nos moldes do Procurador Europeu, o chamado "Eurodefensor", que iria apoiar e fortalecer a defesa dos acusados individualmente.

Assim, o Eurodefensor iria incorporar a função adicional, além de simplesmente apoiar a defesa, de comandar um departamento para a proteção legal e o monitoramento do cumprimento dos direitos do réu. Além disso, o Eurodefensor poderia ser chamado se as investigações na fase pré-processual ${ }^{412}$ forem conduzidas de forma encoberta ou em casos de crime transnacional. Nesses dois casos, não só o Eurodefensor deve ser notificado acerca das medidas de investigação e sobre eventuais violações de grau mais elevado dos seus direitos básicos, mas também deve comparecer às diligências, a fim de assegurar o cumprimento dos direitos do réu, se este ou seu conselheiro não são informados ou não são convocados para as atividades de investigação. "É evidente que tais deveres não devem, de modo algum, afetar os direitos do réu." ${ }^{413}$

Além do Eurodefensor, há doutrina que trata ainda da criação de um "Defensor del Pueblo" europeu em matéria penal, ao estilo do ombudsman norte-americano. ${ }^{414}$ Assim

Nijhoff Publishers: Leiden/Boston, 2010, p. 396).

${ }^{412}$ Como traz Schünemann, os Estados envolvidos em medidas cooperacionais penais investigativas deveriam agir "em consulta com o Eurojust e especialmente com o Eurodefensor, de forma que uma das instituições representativas dos direitos da defesa possa identificar possíveis problemas de parcialidade já desde o princípio." SCHÜNEMANN, Bernd. As Bases do Processo Penal Transnacional. Traduzido por Heloisa Estellita Salomão. Revista Brasileira de Ciências Criminais. Ano 19, v. 90, mai-jun. 2011, p. 204.

413 "Em terceiro lugar, seria incorporar uma função adicional além de simplesmente apoiar a defesa, com um departamento de proteção jurídica dos direitos do réu”, para qualquer futura disposição regulamentar no domínio das jurisdições penais simultâneas de vários Estados em casos transnacionais e na hipótese de um processo penal exclusivamente por um único Estado. Nesse caso, o Eurodefensor poderia salvaguardar os interesses do réu quanto à determinação do Estado exclusivamente autorizado a realizar o processo criminal. Além disso, o Eurodefensor poderia ser chamado se as investigações em fase pré julgamento forem realizados de forma encoberta, ou em casos de processos penais transnacionais "qualificados". Nesses dois casos, o Eurodefensor não deve apenas ser notificado das diligências de investigação que são violações de maior grau de direitos fundamentais, mas também deve comparecer à manutenção dos direitos do requerido se o réu ou seu conselheiro não são informados ou não são convocados para atividades de investigação. É evidente que estes direitos não devem, em circunstância alguma, afetar os direitos do réu." Tradução livre de: "Thirdly, it would embody an aditional function besides simply supporting the defence, with a department for legal protection of the defendant's rights', for any future regulatory provision in the field of concurrent criminal jurisdictions of more States in transnational cases and the assumption of the criminal procedure exclusively by a single State. In such a case, the Eurodefensor could safeguard the defendant's interests regarding the determination of the State exclusively authorised to carry out the criminal process. Moreover, the Eurodefensor could be called upon if investigations in the pre-trial phase are conducted covertly, or in cases of 'qualified' transnational criminal procedures. In those two cases, the Eurodefensor should not only be notified of investigatory measures being higher degree violations of fundamental rights, but should also attend to the safeguarding of the defendant's rights if the defendant or his counsellor is not informed of or is not summoned to the investigative activities. It is self-evident that these duties should not under any circumstances affect the defendant's rights." (FIJNAUT, Cyrille; OUWERKERK, Jannemieke. The Future of Police and Judicial Cooperation in the European Union. Martinus Nijhoff Publishers: Leiden/Boston, 2010. p. 396-397).

414 Assim apresenta Morales Romero: “As linhas com que inicio compõe o parágrafo $5^{\circ}$ da proposta do Conselho dos Advogados Europeus (a seguir CCBE), onde, sob o nome de Defensor da População em matéria penal (direito penal europeu Ombudsman - ECLO) destina-se a restabelecer o princípio da igualdade de armas em processos transfronteiriços de natureza penal que ocorrem dentro da União Europeia (Conseil des barreaux 
como se criou em seu momento, primeiro, a Europol para fortalecer a cooperação policial entre os Estados-Membros e, em segundo lugar, a Eurojust sob o lema de aprimorar a cooperação judicial, o Defensor del Pueblo europeu, em matéria penal, nasce com objetivo similar ao dos anteriores: coordenar, facilitar, melhorar a cooperação. Ainda que o que se coordene, se melhore ou se facilite não seja nem a cooperação judicial - que ocorre entre autoridades judiciais - nem a policial, senão a cooperação entre advogados defensores de sujeitos imersos em processos de natureza transnacional, garantindo assim seus direitos de defesa básicos. ${ }^{415}$

As preocupações gerais que nortearam essa proposta ${ }^{416}$ podem ser transplantadas ao

européens/Conselho das Ordens dos Advogados da União Europeia. Criado em 1960, o Conselho de Advogados Europeus (CCBE) é a organização representativa e oficialmente reconhecida na União Europeia (UE) e do Espaço Econômico Europeu (EEE), na profissão de advogado. o CCBE é constituído como uma associação internacional sem fins lucrativos de direito belga e é o elo de ligação entre o Conselho da Ordem dos Advogados dos Estados-Membros da União Europeia. Ele representa o conjunto desses Conselhos em face das Instituições Europeias e, através deles, mais de 1 milhão de advogados) e que foi objeto de estudo no seminário sobre "O Defensor do Povo Europeu em matéria penal", realizado em Trier (Alemanha), no dia 7 de abril de 2006." Tradução libre de: "Las líneas con las que empiezo componen el párrafo na 5 de la Propuesta del Consejo de la Abogacía Europea (en adelante CCBE) en la que bajo la denominación de Defensor del Pueblo Europeo en materia de Derecho penal (European Criminal Law Ombudsman - ECLO) se pretende restablecer el principio de igualdad de armas en los procesos penales de naturaleza transfronteriza que tienen lugar en el seno de la Unión Europea (Conseil des barreaux européens/Council of Bars and Law Societies of Europe. Creado en 1960, el Consejo de la Abogacía Europea (CCBE), es la organización representativa y oficialmente reconocida en la Unión Europea (UE) y el Espacio Económico Europeo (EEE), de la profesión de abogado. El CCBE está constituido como asociación internacional sin ánimo de lucro de derecho belga yes el organismo de enlace entre los Consejos de los colegios de abogados de los Estados miembros de la Unión Europea. Representa al conjunto de estos Consejos ante las Instituciones Europeas y a través de éstos más de 1 millón de abogados) y que ha sido objeto de estudio en el Seminario sobre "The European Criminal Law Ombudsman" celebrado en Trier (Alemania) el día 7 de abril de 2006." (MORAleS ROMERO, Marta M. La Propuesta de un Defensor del Pueblo Europeo en Materia Penal (ECLO). In: ROMERO, Marta Muñoz de Morales (Coord.). El Derecho Penal de la Unión Europea. Situación Actual y Perspectivas de Futuro. Cuenca: Ediciones de la Universidad de Castilla La-Mancha, 2007, p. 263).

${ }^{415}$ No original: “Al igual que se creó en su momento, primero, Europol para fortalecer la cooperación policial entre los Estados miembros y, en segundo lugar, Eurojust bajo el lema de mejorar la cooperación judicial, el Defensor del Pueblo Europeo en materia penal nace con un objetivo similar al de los anteriores: coordinar, facilitar, mejorar la cooperación. Si bien, lo que se coordina, se mejora o se facilita no es ni la cooperación judicial -se entiende entre autoridades judiciales-, ni la policial, sino la cooperación entre abogados defensores de sujetos inmersos en procesos de naturaleza transnacional, garantizando así sus derechos de defensa básicos." (MORALES ROMERO, Marta M. La Propuesta de un Defensor del Pueblo Europeo en Materia Penal (ECLO). In: ROMERO, Marta Muñoz de Morales (Coord.). El Derecho Penal de la Unión Europea. Situación Actual y Perspectivas de Futuro. Cuenca: Ediciones de la Universidad de Castilla LaMancha, 2007, p. 263).

416 “As razões que levaram às associações europeias de advogados, em especial o CCBE (há outra associação europeia que se pronunciou em sentido positivo sobre a criação do Defensor do Povo Europeu em matéria penal, a Criminal Bar Association - relativamente aos seus objetivos ver seu website em http://www.ecba.org/cms/), se preocupar com esta questão gira em torno das questões apresentadas na fase preliminar do processo, bem como as dificuldades de índole prática típicas de qualquer processo transnacional: a existência de dois ou mais sistemas jurídicos diferentes em conjunto; o desconforto em trabalhar em vários idiomas quando o seu conhecimento é escasso ou inexistente; barreiras, às vezes intransponíveis, para iniciar e manter o contato entre autoridades judiciais, policiais e advogados de acusação e de defesa de diferentes países e assim por diante. Estas dificuldades e os problemas não são resolvidos (nem poderiam ser resolvidos por razões óbvias) estabelecendo mecanismos internos. Primeiro, porque as autoridades nacionais não se preocupam com tais casos, ou seja, elas não têm entre as suas prioridades eliminar os obstáculos que aparecem 
presente trabalho, pois se afiguram extremamente elucidativas para a conscientização acerca da relevância do tema e da plausibilidade dos argumentos.

A proposta do Conselho de Advocacia Europeu apresentada ao Conselho e ao Parlamento Europeu em 26 de julho de 2000, relativa ao reconhecimento mútuo das decisões finais em matéria penal (COM (2000) 495, final, 29.7.2000), afirmou que "é preciso, pois, assegurar que o tratamento dos suspeitos e os direitos da defesa não só não iriam sofrer com a aplicação do princípio [de mútuo reconhecimento], mas que as salvaguardas iriam, inclusive, ser incrementadas ao longo do processo". Entretanto, a experiência do Conselho de Advocacia consiste em verificar que os suspeitos e os direitos da defesa estão "sofrendo" e que não existem, ou as salvaguardas não são suficientes, para os casos criminais transfronteiriços, em que os cidadãos da UE se veem envolvidos em processos penais em Estados-Membros diferentes do seu.

quando um advogado tem de lidar com o processo transfronteiriço (autoridades internas cuidam d formação de seus juízes, promotores, policiais, etc., mas não conseguem estabelecer mecanismos específicos para os advogados). Ainda que fosse uma de suas prioridades melhorar as condições de defesa, nestes casos, a realidade é que seus recursos são limitados e as suas chances de sucesso, bem como os seus triunfos, se é que existe algum, seriam sempre setoriais. Quando uma violação dos direitos de defesa dentro de um procedimento transfronteiriço ocorre não existe uma autoridade supranacional prévia a CEDH (os partidários da ECLO argumentam que o remédio à CEDH é tardio demais e é conveniente a criação de uma instituição anterior a partir do início dos trabalhos em qualquer Estado-Membro que tenha acesso a todas as informações relativas aos direitos fundamentais de defesa do acusado), capaz de lidar com esses problemas e, portanto, o CCBE recomenda a criação de um Euroadvogado capaz de organizar uma "defesa dupla" em dois ou mais países envolvidos, de modo a assegurar que os direitos de defesa do acusado sejam respeitados." Tradução libre de: "Las razones que han llevado a las asociaciones europeas de abogados, en particular a la CCBE (existe otra asociación europea que se ha pronunciado en sentido positivo acerca de la instauración del Defensor Europeo en materia penal, me refiero a la European Criminal Bar Association. Respecto a sus objetivos como asociación véase su portal web en http://www.ecba.org/cms/), a preocuparse por esta cuestión giran en torno a los problemas que se presentan en la fase prejudicial del procedimiento así como en las dificultades de índole práctica típicas de cualquier proceso transnacional: la existencia de dos o más sistemas jurídicos distintos entre sí; la incomodidad de trabajar en varios idiomas cuando su conocimiento es escaso o nulo; las barreras, a veces infranqueables, para iniciar y mantener contactos entre autoridades judiciales, policiales y abogados de la acusación y de la defensa procedentes de distintos países, etcétera. Estas dificultades y problemas no se resuelven (ni tampoco pueden ser resueltos por razones obvias) mediante la instauración de mecanismos internos. En primer lugar, porque las autoridades nacionales no se preocupan por este tipo de casos, es decir, no tienen entre sus prioridades, remover los obstáculos que se presentan cuandores, do un abogado tiene que hacer frente a un proceso transfronterizo (Las autoridades internas se preocupan por la fornlación de sus jueces, fiscales, policías, etcétera, pero no llegan a establecer mecanismos específicos para los abogados). Pero es más, aunque fuese una de sus prioridades mejorar las condiciones de defensa en estos supuestos, la realidad es que sus recursos son limitados y sus posibilidades de éxito también, ya que sus triunfos -si es que los hubiera- siempre serían sectoriales. Y es que cuando se produce una violación de los derechos de defensa en el seno de un procedimiento transfronterizo no existe ninguna autoridad supranacional, previa al TEDH (Los partidarios de ECLO sostienen que la vía de recurso al TEDH es demasiado tardía y por ello es conveniente crear una institución previa que desde el inicio del procedimiento en un Estado miembro tenga acceso a toda la información concerniente a los derechos de defensa básicos del imputado), capaz de tratar este tipo de problemas y por ello, la CCBE recomienda la instauración de un Euro-abogado capaz de organizar una "doble defensa" en los dos o más países implicados asegurando así que se respetan los derechos de defensa del acusado. (MORALES ROMERO, Marta M. La Propuesta de un Defensor del Pueblo Europeo en Materia Penal (ECLO). In: ROMERO, Marta Muñoz de Morales (Coord.). El Derecho Penal de la Unión Europea. Situación Actual y Perspectivas de Futuro. Cuenca: Ediciones de la Universidad de Castilla La-Mancha, 2007, pp. 265-6). 
Na parte que concerne às justificativas da proposta, ${ }^{417}$ esclarece-se que, no âmbito da União Europeia, a Europol e a Eurojust atuam através das fronteiras, com amplo respaldo legal, mas há uma necessidade urgente de uma nova forma de "proteção transfronteiriça" dos direitos de defesa para contrabalançar essa situação, pois, na visão do Conselho, há muitas iniciativas sobre "segurança" e "lei e ordem", mas muito pouco sobre os direitos fundamentais e da justiça, o que resulta em que esses importantes elementos sejam insuficientemente abordados nos trabalhos da Comissão. O Conselho de Advocacia Europeu acredita que esse desequilíbrio só poderia ser remediado com a criação de um órgão independente para salvaguardar os direitos da defesa.

Na visão do Conselho de Advogados são os seguintes problemas que vêm sendo enfrentados:

1) Enquanto o sistema de Estrasburgo e da jurisprudência estiver equipado para lidar com processos somente quando estiverem finalizados, será ineficaz para lidar com problemas que ocorrem no início de um processo. ${ }^{418}$ Observado que não existe

\footnotetext{
${ }^{417}$ Para visualizar a proposta na íntegra vide: PROPOSAL BY THE CCBE FOR THE ESTABLISHMENT OF A EUROPEAN CRIMINAL LAW OMBUDSMAN. Dezembro, 2004. Disponível em: 〈http://www.ccbe.eu/fileadmin/user_upload/NTCdocument/criminal_law_ombudsm1_1183714563.pdf > Último acesso em: 19 fev. 2014.

418 Acredita-se que no âmbito da União Europeia tal problema encontra-se sanado, tendo em vista o procedimento prejudicial do Tribunal de Justiça da União Europeia previsto no artigo 267 do Tratado de Funcionamento da UE, in verbis: "O Tribunal de Justiça da União Europeia é competente para decidir, a título prejudicial:
}

a) Sobre a interpretação dos Tratados;

b) Sobre a validade e a interpretação dos actos adoptados pelas instituições, órgãos ou organismos da União. Sempre que uma questão desta natureza seja suscitada perante qualquer órgão jurisdicional de um dos Estados-Membros, esse órgão pode, se considerar que uma decisão sobre essa questão é necessária ao julgamento da causa, pedir ao Tribunal que sobre ela se pronuncie.

Sempre que uma questão desta natureza seja suscitada em processo pendente perante um órgão jurisdicional nacional cujas decisões não sejam susceptíveis de recurso judicial previsto no direito interno, esse órgão é obrigado a submeter a questão ao Tribunal.

Se uma questão desta natureza for suscitada em processo pendente perante um órgão jurisdicional nacional relativamente a uma pessoa que se encontre detida, o Tribunal pronunciar-se-á com a maior brevidade possivel."

Desse modo, não se exige que determinado ato de um tribunal nacional esteja albergado sob o manto de uma sentença final irrecorrível nos tribunais nacionais para que este Tribunal supranacional seja acionado. De acordo com Clara Penín Alegre, está se abrindo um novo corpo jurisprudencial, a parte dos direitos constitucionais nacionais e da jurisprudência do Tribunal Europeu de Direitos Humanos. O Tribunal de Justiça da União Europeia começou a emitir decisões interpretativas sobre cooperação penal das várias decisõesquadro e convenções de assistência mútua, nomeadamente o acordo Schengen, com força vinculante aos juízes da Comunidade Europeia, a partir do conhecido julgamento "Maria Pupino", que introduziu a necessidade de interpretação conforme, para que a normativa interna dos Estados pudesse atingir os objetivos de determinada decisão-marco. (PENÍN ALEGRE, Clara. Cooperación Jurídica Internacional. In: HERMIDA, Ágata M. Sanz; PRADILlO, Juan Carlos Ortiz (Coords.). Problemas Actuales de la Justicia Penal: Secreto Profesional, cooperación jurídica interancional, víctimas de delitos, criminalidad organizada, personas jurídicas, eficacia y licitud de la prueba, prueba y derechos fundamentales. Madrid: Colex, 2013, p. 45). 
nenhuma instituição para lidar com a violação dos direitos, quando muitos problemas surgem, tampouco para supervisionar o início do processo.

2) Casos transfronteiriços criam dificuldades especiais. Há dois Estados envolvidos, muitas vezes com sistemas substancialmente distintos, procedimentos legais e idiomas diferentes. As comunicações entre as autoridades de diferentes países, entre os tribunais e diferentes advogados de acusação e de defesa tornam-se complexas e difíceis. O cidadão em seu país de origem não terá acesso a aconselhamento jurídico competente do outro Estado. Esses "empecilhos" transnacionais levaram, em nossa experiência, à quebra do princípio da "igualdade de armas", gerando grandes dificuldades para os arguidos em processos penais que necessitam de um sistema mais eficiente.

3) Em regra, os órgãos jurisdicionais nacionais só se preocupam com a sua legislação nacional, e não estão aptos a fornecer nenhum remédio quando um problema transfronteiriço surge. Quem pode acudir a um advogado de defesa uma vez que a violação dos direitos ocorre em outro país em um caso transfronteiriço? Não existe uma autoridade supranacional para lidar com isso.

4) Na ausência de assistência jurídica, como é que o advogado de defesa no país de origem obterá acesso aos arquivos e obterá a devida divulgação, organizando uma “defesa dupla” (em ambos países) e lidando com a disponibilização de intérpretes?

Nesse contexto, a solução apresentada pelo Conselho da Advocacia Europeia parte do pressuposto de que, no âmbito da UE, o Espaço de Liberdade, Segurança e Justiça é construído sobre um sistema de reconhecimento mútuo e que o reconhecimento mútuo baseia-se na confiança mútua, então, o Conselho acredita que deve haver um mecanismo confiável para salvaguardar os direitos dos suspeitos e, para que possa ser bem-sucedido, deve ser independente. O Conselho propõe, portanto, que deveria ser criada uma OuvidoriaGeral concernente à Defesa Criminal (Criminal Law Ombudsman), cujo Ouvidor seria um advogado de defesa criminal com independência funcional. Esse Defensor atuará como presidente de um colégio de advogados de defesa criminal provenientes de cada EstadoMembro. O mandato desse "Defensor-Presidente" deve ser limitado e deve haver rotatividade entre os advogados de diferentes Estados-Membros da UE. O seu dever se constituiria em coletar informações sobre casos de advogados e clientes que tenham sido reportados para ele.

O Conselho de Advocacia Europeu acredita, ainda, que essa instituição independente 
configurará um avanço notável em lidar com o atual desequilíbrio entre os direitos da acusação e os direitos da defesa e ficaria satisfeito em cooperar na elaboração de disposições mais concretas para a implementação dessa proposta. Só então haverá um mecanismo realmente adequado para salvaguardar os direitos dos suspeitos, réus e aqueles sob investigação em casos transfronteiriços.

Nesse contexto, apresentam-se as seguintes funções do Defensor-Ouvidor (European Criminal Law Ombudsman - ECLO): a principal preocupação do ECLO é proteger e salvaguardar os direitos dos suspeitos, réus, e aqueles sob investigação em litígios transfronteiriços. Além disso, necessitará:

a) lidar com problemas e reclamações em relação ao mandado de detenção europeu, o mandado europeu de investigação e legislação similar;

b) reagir rapidamente a problemas encontrados nas fases iniciais do processo, a fim de buscar ajuda para fornecer soluções;

c) ser capaz de abordar a Comissão e as autoridades nacionais de informação ou assistência, bem como o Poder Judiciário nacional;

d) ser capaz de aproximar os órgãos competentes no Parlamento Europeu e informar ao público o que está acontecendo;

e) coordenar a ação e fornecer ajuda para a construção de uma equipe de defesa, tanto a emissão e a execução no Estado, de modo que uma defesa eficaz possa ser apresentada em ambos os países;

f) prestar apoio na localização de assistência jurídica ou de financiamento, quando necessário;

g) suprir a falta de "igualdade de armas", onde ela surgir.

Sabine Gless, professora de direito penal e processo penal na Universidade de Basel, na Suíça, pondera, entretanto, que serviços de defesa institucionalizados, tais como o Eurodefensor ou o Defensor del Pueblo europeu, ainda não foram estabelecidos. Em todo caso, admite que seria duvidoso que tal agência de defesa centralizada fosse resolver todos os problemas, pois, atualmente, os advogados de defesa não têm acesso a uma organização que lhes permita intercambiar informações relevantes ou até mesmo recursos e financiamento para uma coordenação transfronteiriça de defesa criminal. De lege lata, refere que o quadro está longe de ser aquele que os advogados de defesa entendem como padrão mínimo ideal para a defesa criminal, que coincidiria com o desenvolvimento da cooperação 
transfronteiriça no processo penal. ${ }^{419}$

O Tribunal Europeu de Direitos Humanos (TEDH), com decisões como as dos casos Soering e Stojkevic, já mencionados, oferece os blocos de construção para uma abordagem básica, assegurando firmemente que os Estados devem sempre cumprir o seu compromisso com os direitos humanos, o que implica que eles têm responsabilidades para o cumprimento dos direitos humanos em casos de auxílio judiciário mútuo na cooperação transfronteiriça. O TEDH, no entanto, ainda não construiu uma ponte para uma abordagem mais ampla: o projeto é estabelecer o direito a um julgamento justo e, em particular, o direito à igualdade de armas como um princípio geral que seria válido em todos os casos criminais transnacionais (europeus) e, portanto, ofereceria a "cura" para as deficiências atuais, especialmente para os casos criminais transnacionais. Marco com essa finalidade pode ser o desenvolvimento de um quadro de evidências transfronteiriças reunidas sem cortes de direitos para a defesa ou uma proposta clara sobre trocas de informações transfronteiriças através de redes que incrementem os direitos de defesa e suas implicações para o julgamento justo. Para chegar lá, o estabelecimento de um "princípio geral de julgamento justo”, ou melhor, a "igualdade de armas" é necessária. 420 "Caso contrário, o réu e a defesa se tornarão cada vez mais solitários na terra de ninguém entre fronteiras", ${ }^{421}$ esse princípio geral, na visão da autora, deveria ser confirmado como "regras do jogo". 422

419 Tradução livre. No original: "Institutionalised defence services, such as Eurodefensor or the European Criminal Law Ombudsman, have not yet been established. In any case, it is doubtful that such a centralised European defence agency would solve all the problems. To this day, defence lawyers do not have access to an organization that allows them to exchange relevant information or to resources financing the coordination of crossborder criminal defence. De lege lata the framework is far from what defence lawyers claim must be the minimum standard for a criminal defence that matches the development of cross-border cooperation in criminal prosecution." (GLESS, Sabine. Transnational Cooperation in Criminal Matters and the Guarantee of a Fair Trial: Approaches to a General Principle. Utrech Law Review. Vol. 9, Issue 4, Set. 2013, p. 106).

${ }^{420}$ Tradução livre. No original: "The ECtHR, with decisions such as Soering and Stojkevic, offers the building blocks for a basic approach, holding firmly that states must always fulfil their commitment to human rights and implying that they do have responsibilities for human rights compliance in cases of mutual legal assistance or crossborder cooperation. The ECtHR, however, has not yet built a bridge to a broader approach: the project is to establish the fair trial right and, particularly, the right to equality of arms as a general principle that is valid in all (European) transnational criminal cases, and thus offers a 'cure' to current shortfalls, especially for transnational criminal cases. Milestones could be the development of a framework for transborder evidence gathering without curtailments of defence rights or a clear proposition on crossborder information exchange over networks affecting defence rights and its implications for fair trial. To get there, establishing a 'general principle of fair trial' or, rather, 'equality of arms' is necessary." (GLESS, Sabine. Transnational Cooperation in Criminal Matters and the Guarantee of a Fair Trial: Approaches to a General Principle. Utrech Law Review. Vol. 9, Issue 4, Set. 2013, p. 106).

421 "Otherwise the defendant and the defence will become ever lonelier in the no man's land between borders." (GLESS, Sabine. Transnational Cooperation in Criminal Matters and the Guarantee of a Fair Trial: Approaches to a General Principle. Utrech Law Review. Vol. 9, Issue 4, Set. 2013, p. 108).

422 "O direito a um julgamento justo, incluindo a igualdade de armas, deve ser estabelecido como um princípio geral, com implicações para o nosso entendimento das investigações criminais e processos judiciais não se limitando aos sistemas nacionais de justiça penal. No entanto, apesar dos vários compromissos, da introdução de novos instrumentos eficiente-orientados na cooperação e discutir, em casos particulares, que suas promessas 
Em suma, qualitativamente, como traz Bassiouni, ${ }^{423}$ as Convenções Europeias em matéria de cooperação interestatal estão se movendo para o estágio de segunda geração, enquanto a OEA e a ONU ainda estão na fase de sistema operacional de primeira geração. No entanto, como refere: "estamos agora em um momento em que precisamos de uma terceira geração de instrumentos internacionais". E, como recomendação, sugere o desenvolvimento de novas modalidades de cooperação interestatal, com a aplicação de mecanismos similares aos já existentes, ${ }^{424}$ sendo particularmente importante compreender que a proteção dos direitos humanos individuais não é e não deve ser colocada em uma relação conflituosa com a eficácia do processo. ${ }^{425}$

Nesse panorama, é que se reputa plenamente pertinente e executável o transplante das soluções acima propugnadas para o âmbito das redes de cooperação das quais o Brasil já faz parte, ${ }^{426}$ tendo em vista que, em nosso país e em vários outros da América Latina, por

não se aplicam em ambientes cooperativos. Estes argumentos não fazem nada para mudar nossa visão de que a igualdade de armas é indispensável em qualquer processo penal equitativo e que a igualdade de armas em casos criminais transnacionais pode ser utilizada apenas se o princípio geral é confirmado como a regra do jogo." Tradução livre de: "The right to a fair trial, including equality of arms, must be established as a general principle with implications for our understanding of criminal investigations and prosecutions not limited to national criminal justice systems. However, despite various commitments, states introduce new, efficiencyoriented instruments on cooperation and argue, in particular cases, that their pledges do not bind them in cooperative settings. These arguments do nothing to change our view that equality of arms is indispensable in any fair criminal trial and that equality of arms in transnational criminal cases can be resorted to only if the general principle is upheld as the rule of the game." (Ibidem, p. 108)

${ }^{423}$ No original: Qualitatively, the European Conventions on Inter-State Cooperation are moving into the stage of second generation, whereas the OAS and UN are still at the stage os first generation. However, we are now at a time when we need a third generation of international instruments. (BASSIOUNI, M. Cherif. Policy Considerations on Inter-State Cooperation in Criminal Matters. Pace Y.B. International Law. Vol. 4, Issue 123, 1992, p. 139).

${ }^{424}$ Ibidem, p. 141.

${ }^{425}$ É necessária uma nova abordagem em que as modalidades de cooperação inter-estatal são considerados como um processo judicial internacional objetiva e politicamente neutra que preserva os padrões internacionais da legalidade e proteção dos direitos humanos em seu funcionamento judicial e administrativo. (Ibidem, p. 144$5)$.

${ }^{426} \mathrm{O}$ Brasil faz parte, atualmente, de diversas redes de cooperação jurídica internacional, dentre as quais se destaca a IberRed - Rede Ibero-americana de Cooperação Judicial, instituída em 2004, em Cartagena das Índias na Colômbia, composta por representantes dos 23 Estados que participam das Cúpulas Iberoamericanas de Chefes de Estado e de Governo (Argentina, Bolívia, Brasil, Chile, Colômbia, Costa Rica, Cuba, El Salvador, Equador, Espanha, Guatemala, Guiné Equatorial, Honduras, México, Nicarágua, Panamá, Paraguai, Peru, Portugal, Porto Rico, República Dominicana, Uruguai e Venezuela). "A Rede Ibero-Americana de Cooperação Jurídica Internacional, IberRed é uma estrutura formada por autoridades centrais e pontos de contato dos Ministérios da Justiça, do Ministério Público e magistrados do Ministério Público e Judiciário dos países que compõem a Comunidade Sul-Americana de Nações, e pelo Supremo Tribunal de Puerto Rico. Destina-se a otimizar os instrumentos de assistência jurídica civil e penal, bem como o reforço dos laços de cooperação entre os nossos países. Constitui, assim, um passo fundamental para a criação de uma Área Judicial Iberoamericana, entendida como um cenário específico onde a atividade está sujeita a cooperação jurídica reforçada, dinâmica e com ferramentas para simplificar e acelerar a realização dos mecanismos de tutela jurisdicional efetiva." Tradução livre de: "La Red Iberoamericana de Cooperación Jurídica Internacional, IberRed, es una estructura formada por Autoridades Centrales y por puntos de contacto procedentes de los Ministerios de Justicia, Fiscalías y Ministerios Públicos, y Poderes Judiciales de los países que componen la Comunidad Iberoamericana de Naciones, así como por el Tribunal Supremo de Puerto Rico. Está orientada a la optimización de los instrumentos de asistencia judicial civil y penal, y al reforzamiento de los lazos de 
exemplo, já existe uma “defesa institucionalizada” — a Defensoria Pública (o que, de plano, já solucionaria o problema apontado por Gless, linhas acima, consistente na ausência de uma instituição de defesa oficial apta a intercambiar informações no âmbito da União Europeia). Desse modo, pontualmente, seria interessante a análise de tratativas, no intuito de serem firmados acordos bilaterais para a produção de prova em matéria de defesa penal, nos moldes dos MLATs já existentes e que foram analisados nos capítulos precedentes, nos quais a autoridade central, no Brasil, poderia ser a Defensoria Pública da União, e, ainda que não houvesse instituição congênere em outro país, isso não configuraria qualquer óbice, tendo em vista que, como visto no capítulo que cuidou do papel da autoridade central, nem sempre é a mesma instituição que detém essa função nos países.

Tudo isso também com o respaldo de estudos realizados em âmbito nacional, como se revela a proposta de lei infraconstitucional em matéria de cooperação idealizada por Fábio Ramazzini Bechara em sua obra, cuja orientação deve se pautar pelo padrão normativo universal dos direitos humanos, que abrange o marco de garantias incidente sobre a atividade probatória, com a previsão expressa do direito à prova, presunção de inocência, contraditório (compreendida a participação das partes na formação da prova testemunhal), igualdade de armas (compreendida a iniciativa da cooperação tanto pela acusação como pela defesa), exercício do direito de defesa (compreendida a necessidade de nomeação de defensor na

cooperación entre nuestros países. Constituye así un paso fundamental en la conformación de un Espacio Judicial Iberoamericano, entendido como un escenario específico donde la actividad de cooperación jurídica sea objeto de mecanismos reforzados, dinámicas e instrumentos de simplificación y agilización en la consecución de un tutela judicial efectiva." - Disponível em: 〈https://www.iberred.org/>, acesso em 23 mai. 2013. O referido sítio contém todas as informações e objetivos da Rede; a Rede Judiciária da CPLP Cooperação Jurídica e Judiciária Internacional dos Países de Língua Portuguesa, criada em novembro de 2005 (Instituída durante a X Conferência de Ministros da Justiça dos Países de Língua Portuguesa, composta por oito países: Angola, Brasil, Cabo Verde, Guiné-Bissau, Moçambique, Portugal, São Tomé e Príncipe e Timor Leste); a Rede Hemisférica de Intercâmbio de Informações para o Auxílio Jurídico Mútuo em Matéria Penal e de Extradição, criada no âmbito da Organização dos Estados Americanos (OEA), na V Reunião de Ministros da Justiça daquela Organização, realizada no ano de 2004, em Washington, da qual fazem parte 34 países (Antígua e Barbuda, Argentina, Bahamas, Barbados, Belize, Bolívia, Brasil, Canadá, Chile, Colômbia, Costa Rica, Dominica, Equador, El Salvador, Estados Unidos, Granada, Guatemala.; Guiana, Haiti, Honduras, Jamaica, México, Nicarágua, Panamá, Paraguai, Peru, República Dominicana e Venezuela). Para mais informações sobre as redes de cooperação acessar: <http://ascji.pgr.mpf.gov.br/atuacao-da-ccji/redes-decooperacao-juridica>, último aceso em 23 mai. 2013). Ainda no âmbito da OEA, existe a Rede de Cooperação Jurídica Hemisférica em Matéria de Família e Infância (esta rede teve origem na VII Reunião de Ministros de Justiça ou Outros Ministros ou Procuradores-Gerais das Américas - REMJA VII, realizada em Washington, em 2008), a Rede de Recuperação de Ativos do GAFISUD - RRAG, que conta com doze países membros do GAFISUD: Argentina, Bolívia, Brasil, Chile, Colômbia, Costa Rica, Equador, México, Panamá, Paraguai, Peru e Uruguai (seus documentos constitutivos permitem que países que não fazem parte do GAFISUD se tornem parte da RRAG. Para mais informações ver: Manual de Cooperação Jurídica Internacional e Recuperação de Ativos do Ministério da Justiça, 2012, pp. 74-75) e, por fim, a Plataforma Pontos Focais de Recuperação de Ativos STAR-INTERPOL (a Plataforma foi estabelecida pela iniciativa da INTERPOL em parceria com o Banco Mundial e o Escritório das Nações Unidas sobre Drogas e Crimes como forma de prestar apoio ao esforço de combate à corrupção em paraísos fiscais). 
atividade probatória desenvolvida no exterior), duração razoável do processo, nomeação gratuita de intérprete, exigência de provisão legal e controle judicial nas medidas restritivas à intimidade e à vida privada (entende-se por atendida a exigência do controle judicial, tanto a análise prévia como a revisão judicial posterior). ${ }^{427}$

Nesse contexto, a Assessoria Internacional da Defensoria Pública da União, estabelecida pela Portaria n. 198, de 27 de março de 2012, tem entre suas funções a de assistir a Defensoria Pública da União em assuntos de caráter internacional, notadamente para: desenvolver, estabelecer e manter as relações da Defensoria Pública da União com outras instituições, nacionais ou estrangeiras, em assuntos internacionais, visando à cooperação e ao intercâmbio, e coordenar a assistência jurídica em âmbito internacional prestada às pessoas em condição de vulnerabilidade socioeconômica, brasileiros ou estrangeiros, em conformidade com legislação nacional, além dos tratados e acordos assinados pelo Brasil. ${ }^{428}$

Além disso, outra solução que poderia ser de aplicabilidade imediata seria a utilização das redes já existentes de cooperação entre Defensorias, tais como a REDPO, a RIPAJ e a AIDEF, para ampliação de suas funções e acompanhamento de casos de criminalidade transfronteiriça, quando houvesse a necessidade de acompanhamento ou produção de prova em outros países.

A Reunião Especializada de Defensores Públicos Oficiais do Mercosul (REDPO) foi criada em 20 de fevereiro de 2004, por meio da Resolução Mercosul/GMC/RES n. 12/04, tendo em vista que a integração dos países do Mercosul abrange as mais diversas vertentes, incluindo uma instituição que está presente em todos os Estados Parte do bloco: a Defensoria Pública, cuja missão é prestar assistência jurídica integral e gratuita aos que comprovarem insuficiência de recursos.

A REDPO tem como objetivos a coordenação e cooperação das Defensorias Públicas Oficiais dos Estados Partes do Mercosul; o auxílio na defesa das garantias reconhecidas à sociedade civil do bloco nas constituições nacionais, nas normas do Mercosul, nos tratados e nas legislações dos Estados Parte; a garantia da vigência e eficácia dos direitos; a criação de um sistema de coordenação e cooperação entre as Defensorias Públicas Oficiais do Mercosul; ${ }^{429}$ e, por fim, o estímulo ao fortalecimento institucional e à autonomia financeira das Defensorias Públicas dos Estados Parte, tudo para alcançar a plenitude e a excelência do

\footnotetext{
${ }^{427}$ BECHARA, Fábio Ramazzini. Cooperação Jurídica Internacional em Matéria Penal: Eficácia da Prova Produzida no Exterior. São Paulo: Saraiva, 2011, pp. 189-190.

${ }^{428}$ Disponível em: 〈http://www.dpu.gov.br/internacional/index.php/en/inst〉. Acesso em: 08 set. 2014.

429 Disponível em <http://dpu.jusbrasil.com.br/noticias/2495052/redpo-quer-agilizar-mecanismos-decooperacao-internacional>. Acesso em: 08 set. 2014.
} 
direito de defesa. ${ }^{430}$

Visando a intensificar os laços de cooperação entre os países de língua portuguesa, a Defensoria Pública da União lançou a ideia da criação de foro que reunisse as instituições públicas de papel análogo ao da DPU nos países lusófonos, o qual firmaria a cooperação mútua entre tais instituições. Dessa ideia se desenvolveu o projeto da I Reunião das Instituições Públicas de Assistência Jurídica dos Países de Língua Portuguesa (RIPAJ), ${ }^{431}$ com o compromisso de reforçar os laços de solidariedade e de cooperação que os unem, conjugando iniciativas para a promoção do desenvolvimento econômico e social dos seus povos.

Os elementos fundamentais de tal iniciativa estão bem-descritos na Declaração Constitutiva da RIPAJ, ${ }^{432}$ a saber: a necessidade de defender a plena vigência e eficácia, no âmbito de competência da defesa pública, dos direitos humanos e das garantias fundamentais reconhecidas pelos acordos, os tratados internacionais, as Constituições e as leis internas vigentes nos Estados-Membros da Comunidade dos Países de Língua Portuguesa (CPLP); a conveniência de criar um sistema estável de coordenação, cooperação e intercâmbio entre instituições públicas e outras entidades vocacionadas à prestação de assistência jurídica dos países de língua portuguesa; a importância de prover, em cada país que adota o português como o idioma oficial, a necessária assistência jurídica e judiciária das pessoas necessitadas, que permitam uma ampla defesa e o mais amplo acesso à justiça, com a devida qualidade $\mathrm{e}$ excelência, toda vez que tal direito for pleiteado em face do Estado; o alargamento da cooperação entre os seus países na área da concertação político-diplomática, particularmente no âmbito das organizações internacionais, por forma a dar expressão crescente aos interesses e necessidades comuns no seio da comunidade internacional; a promoção de ações de cooperação entre si e de coordenação no âmbito multilateral para assegurar o respeito pelos direitos humanos nos respectivos países e em todo o mundo.

A Associação Interamericana de Defensorias Públicas (AIDEF) foi criada em 18 de outubro de 2003, na cidade do Rio de Janeiro, por ocasião do II Congresso Interamericano de Defensorias Públicas. Ela é formada por representantes das instituições oficiais de Defensorias Públicas e das associações de defensores dos países da América. Participam da

\footnotetext{
${ }^{430}$ Disponível em: 〈http://www.dpu.gov.br/internacional/index.php/cooperacao-internacional/redpo $>$. Acesso em: 05 set. 2014.

${ }^{431}$ Disponível em: 〈http://www.dpu.gov.br/internacional/index.php/cooperacao-internacional/ripaj〉. Acesso em: 05 set. 2014.

${ }^{432}$ Disponível em:

$\langle$ http://www.dpu.gov.br/internacional/images/PDF/declaracao_constitutiva_cplp.pdf $>$. Acesso em: 08 set. 2014.
} 
assinatura da ata constitutiva representantes dos seguintes países: Antigua e Barbuda, Argentina, Brasil, Colômbia, Costa Rica, Chile, Equador, El Salvador, Honduras, México, Nicarágua, Paraguai, Porto Rico, República Dominicana, Uruguai e Venezuela. Posteriormente, se incorporaram Bahamas, Bolívia, Estados Unidos, Guatemala, Jamaica, Panamá, Peru e Trinindade e Tobago.

A iniciativa teve por fundamentos: defender a plena vigência e eficácia dos direitos humanos e as garantias reconhecidas na Declaração Americana dos Direitos e Deveres do Homem, na Declaração Universal dos Direitos Humanos, no Pacto Internacional dos Direitos Civis e Políticos e na Convenção Americana sobre Direitos Humanos; estabelecer um sistema permanente de coordenação e cooperação interinstitucional das Defensorias Públicas e das Associações das Américas e do Caribe; prover a necessária assistência e representação das pessoas e dos direitos dos necessitados, garantindo a ampla defesa e o acesso à justiça com a devida qualidade e excelência toda vez que requerida; proporcionar a independência e autonomia funcional das Defensorias Públicas para assegurar o pleno exercício do direito de defesa das pessoas; apoiar o fortalecimento institucional das Defensorias Públicas em equilíbrio com aqueles que exercem as funções acusatórias do Estado.

Ao longo dos anos, a AIDEF foi sendo reconhecida, angariando protagonismo no continente, e, mais recentemente, aproximou-se da Organização dos Estados Americanos (OEA) e da Corte Interamericana de Direitos Humanos.

Em relação à OEA, em 2011, a AIDEF foi aceita no Registro de Organização da Sociedade Civil da OEA, o que aprimora seu posicionamento institucional ante a organização, permitindo-lhe participar de diversos foros de discussão e desenvolver mecanismos de cooperação mútua.

Já frutos dessa aproximação foram as aprovações de quatro resoluções nas Assembleias Gerais da OEA de 2011, 2012, 2013 e 2014. ${ }^{433}$ Nessas resoluções, a OEA, por unanimidade, destaca, "o trabalho realizado pelos defensores públicos oficiais, em diversos países do Hemisfério, na defesa dos direitos fundamentais dos indivíduos, especificamente,

\footnotetext{
433 A OEA já avançou muito na matéria com a edição destas Resoluções. Jurisprudencialmente, o Tribunal Europeu de Direitos Humanos avança no mesmo sentido, tal como se pode verificar em recente decisão que sustentou que a obrigação do Estado em proporcionar assistência jurídica gratuita não se cumpre simplesmente mediante a designação de advogados financiados com fundos públicos (TEDH, Pavlenko vs. Rusia, 42371/02, sentença de 04 de outubro de 2010, parágrafo 99). Deve-se assegurar que a assistência prestada seja prática e eficaz. Para este fim, a Recomendação emitida pede aos Estados-membros que estabeleçam mecanismos para garantir serviços de assistência legal de alta qualidade, com formação profissional contínua. A aplicação da Recomendação melhorará a qualidade e eficácia dos serviços de assistência jurídica e aumentará a confiança mútua em outros Estados-membros.
} 
os serviços de assistência jurídica gratuita que possibilitam o fácil e oportuno acesso de todas as pessoas à justiça". Afirma que "o acesso à justiça, como direito humano fundamental, é, ao mesmo tempo, o meio que possibilita que se restabeleça o exercício dos direitos que tenham sido ignorados ou violados" e apoia "o trabalho que vêm desenvolvendo os defensores públicos oficiais dos Estados do Hemisfério, que constitui um aspecto essencial para o fortalecimento do acesso à justiça e a consolidação da democracia”.

Essas resoluções também incentivam os Estados-Membros que não têm Defensorias Públicas a criarem-nas e os que as têm a adotarem medidas que garantam independência e autonomia funcional, destacando a

importância da independência, autonomia funcional, financeira e/ou orçamentária da Defensoria Pública Oficial, como parte dos esforços dos Estados-Membros para garantir um serviço público eficiente, livre de ingerências e controles indevidos por parte de outros poderes do Estado. ${ }^{434}$

Além dessas redes, em matéria de cooperação e outros temas afetos ao acesso à justiça para pessoas vulneráveis, foram editadas as "100 Regras de Brasília” sobre acesso à justiça das pessoas em condição de vulnerabilidade. ${ }^{435} \mathrm{O}$ texto foi elaborado com o apoio do Projeto Eurosocial Justiça, por um Grupo de Trabalho constituído no seio da Conferência Judicial Ibero-americana, da qual também participaram a Associação Ibero-americana de Ministérios Públicos (AIAMP), a Associação Interamericana de Defensores Públicos (AIDEF), a Federação Ibero-americana de Ombudsman (FIO) e a União Iberoamericana de Colégios e Agrupamentos de Advogados (UIBA). O documento foi aprovado na XIV Conferência Judicial Ibero-americana, em Brasília, que ocorreu nos dias 4 a 6 de março de 2008 .

Nas regras "3" e "4" do documento, pode-se visualizar o conceito das pessoas em situação de vulnerabilidade:

(3) Consideram-se em condição de vulnerabilidade aquelas pessoas que, por razão da sua idade, gênero, estado físico ou mental, ou por circunstâncias sociais, econômicas, étnicas e/ou culturais, encontram especiais dificuldades em exercitar com plenitude perante o sistema de justiça os direitos reconhecidos pelo ordenamento jurídico.

(4) Poderão constituir causas de vulnerabilidade, entre outras, as seguintes:

\footnotetext{
${ }^{434}$ LEITE, Antonio José Maffezoli. A Atuação da Defensoria Pública na Promoção e Defesa dos Direitos Humanos, inclusive perante o Sistema Interamericano de Direitos Humanos. In: RÉ, Aluísio Lunes Monti Ruggeri; REIS, Gustavo Augusto Soares dos. Temas Aprofundados de Defensoria Pública. Vol. 2, Salvador: Ed. Juspodivm, 2014, pp. 581-83.

435 http://www.anadep.org.br/wtksite/100-Regras-de-Brasilia-versao-reduzida.pdf
} 
a idade, a incapacidade, a pertença a comunidades indígenas ou a minorias, vitimização, a migração e o deslocamento interno, a pobreza, o gênero e a privação de liberdade. A concreta determinação das pessoas em condição de vulnerabilidade em cada país dependerá das suas características específicas, ou inclusive do seu nível de desenvolvimento social e econômico.

As regras "30" e "31", a seu turno, versam sobre a questão da assistência de qualidade, especializada e gratuita:

(30) Ressalta-se a necessidade de garantir uma assistência técnico-jurídica de qualidade e especializada. Para esse fim, promover-se-ão instrumentos destinados ao controle da qualidade da assistência.

(31) Promover-se-ão ações destinadas a garantir a gratuidade da assistência técnico-jurídica de qualidade àquelas pessoas que se encontram na impossibilidade de enfrentar os gastos com os seus próprios recursos e condições.

E, por fim, as regras “90" e "91" versam sobre cooperação internacional:

(90) Promover-se-á a criação de espaços que permitam o intercâmbio de experiências nesta matéria entre os diferentes países, analisando as causas do êxito ou do fracasso em cada uma delas ou, inclusivamente, fixando boas práticas. Estes espaços de participação podem ser setoriais. Nestes espaços poderão participar representantes das instâncias permanentes que se possam criar em cada um dos Estados.

(91) Instam-se as Organizações Internacionais e Agências de Cooperação para que: continuem a brindar a sua assistência técnica e econômica no fortalecimento e melhoria do acesso à justiça; tenham em conta o conteúdo destas Regras nas suas atividades, e o incorporem, de forma transversal, nos distintos programas e projetos de modernização do sistema judicial em que participem, impulsionem e colaborem no desenvolvimento dos mencionados espaços de participação.

A seguir serão esmiuçadas as ideias apresentadas no presente capítulo, com o aprofundamento das propostas.

\subsection{Perspectivas para a defesa no contexto jurídico nacional: o acesso internacional à justiça e a atuação da Defensoria Pública da União}

Muito se pode discutir acerca da possibilidade de se firmarem tratados bilaterais em prol da defesa ou de se ampliar o papel das redes de cooperação existentes entre as Defensorias Públicas na América Latina, por exemplo.

Em primeiro lugar, sobre a natureza jurídica dessa novel função a ser desempenhada 
em casos de criminalidade transnacional, se stricto sensu, deveria haver uma instituição coordenadora (ainda que com mandato fixo e rotatividade entre os países na função), nos moldes da proposta do "Eurodefensor" ou do "Defensor del Pueblo". Como esclarecido linhas acima, deveria se tratar, portanto, de espécie de cooperação vertical. Ou, tratando-se de acordos bilaterais entre as defesas ou mero incremento das funções das redes existentes de cooperação entre as Defensorias, o enfoque seria, então, horizontal à sua implementação e desenvolvimento.

De igual modo, suas funções também não estão nada definidas. Não se discutiu ainda (e essa discussão desborda a proposta do presente trabalho, ainda que deva ser suscitada para desenvolvimento em estudos futuros) sobre se a instituição deve dispor de funções de recompilação, controle da informação e elaboração de informes, v.g., atuando mais como autoridade moral ou social ou se, pelo contrário, deveria se tratar de uma instituição forte, com poderes para intervir mediante a adoção de decisões vinculantes em procedimentos que estejam tramitando sob a jurisdição de outro Estado cooperante.

Por exemplo, poderia receber e analisar os problemas e as queixas ligados à denegação de justiça, reagindo rapidamente aos problemas que se originam no início do procedimento, em atuação verdadeiramente preventiva, tendo em vista que, em nosso sistema atual, uma questão só pode ser levada aos tribunais internacionais de direitos humanos quando já houve o esgotamento das vias internas, ou seja, uma questão hipotética de flagrante denegação de justiça só poderia ser levada à Corte Interamericana de Direitos Humanos quando já houvesse produzido dano irreversível à eventual pessoa afetada, com o trânsito em julgado em âmbito interno, por exemplo.

Outra função plenamente factível e legítima seria a de coordenar as ações e proporcionar assistência com a finalidade de constituir uma equipe de defensores com conhecimentos específicos e qualificados em matéria penal transnacional no Estado de emissão e também no Estado de execução da medida transnacional, para assim assegurar uma defesa real e efetiva nos territórios dos países implicados. Em suma, avaliar o grau de "igualdade de armas" em cada caso concreto. ${ }^{436}$

Além disso, ou melhor, antes disso e de forma imediata, seria possível empoderar a Defensoria Pública com a prerrogativa de ser intimada nos procedimentos de cooperação

\footnotetext{
${ }^{436}$ Questões suscitadas no âmbito europeu por Morales Romero e que foram adaptadas para discussão em âmbito nacional e regional, como referido. Para mais detalhes ver: MORALES ROMERO, Marta M. La Propuesta de un Defensor del Pueblo Europeo en Materia Penal (ECLO). In: ROMERO, Marta Muñoz de Morales (Coord.). El Derecho Penal de la Unión Europea. Situación Actual y Perspectivas de Futuro. Cuenca: Ediciones de la Universidad de Castilla La-Mancha, 2007, pp. 265 a 273.
} 
jurídica internacional em matéria penal, com o intuito de aferir se as prerrogativas e os direitos do investigado e/ou réu estão sendo observados. A Defensoria Pública poderia, inclusive, iniciar contatos com as suas congêneres no exterior, no sentido de que, quando um procedimento de cooperação penal fosse solicitado por autoridades brasileiras, as respectivas Defensorias dos países solicitados fossem instadas a comparecer nos procedimentos, como forma de certificar que os direitos do acusado sejam respeitados, ao longo dos interrogatórios e da produção da prova, assim como prescrito na legislação do país requerente. ${ }^{437}$ Logo, o defensor deve estar habilitado a desempenhar um papel de defesa plena e efetiva, verificando a detenção, averiguando provas e organizando a defesa.

De modo bastante pragmático, a Defensoria Pública da União poderia ser inserida no âmbito da Portaria Conjunta n. 01, ${ }^{438}$ a fim de que tal intento fosse levado a efeito. Assim, quando o pedido se referisse à matéria de defesa, a Defensoria Pública da União seria instada a comparecer e acompanhar a produção da prova (além de poder acionar as suas congêneres no exterior, na hipótese de se tratar de cooperação ativa, de modo que também protagonizassem essa tarefa nos pedidos oriundos do Brasil), bem como a provocar o Judiciário de $1^{\circ}$ grau, quando necessário.

${ }^{437}$ Como traz Bechara: "No que se refere à prova produzida no exterior, a observância do direito de defesa manifesta-se fundamentalmente pela oportunidade de acompanhamento do ato a ser realizado no Estado requerido, como também pelo direito do acusado ver-se assistido por um profissional habilitado, constituído ou nomeado oficialmente para o ato. $\mathrm{O}$ acusado tem direito a uma defesa efetiva, incumbindo às autoridades competentes o dever de atuar de modo a assegurar ao interessado o gozo efetivo desse direito". (BECHARA, Fábio Ramazzini. Cooperação Jurídica Internacional em Matéria Penal: Eficácia da Prova Produzida no Exterior. São Paulo: Saraiva, 2011, p. 106). Nesse sentido, Carlos Ramos Rubio afirma: 'las declaraciones y diligencias efectuadas ante organismos jurisdiccionales extranjeros vulneram las garantías procesales si no están presentes ni los procesados ni sus defensas, tanto más si después no pudieron ser interrogados, o careados, debido a su ausencia em el juicio oral, y vulneran la presunción de inocencia [...]"' (RUBIO, Carlos Ramos. Comisiones Rogatorias para la obtención de pruebas. Problemas de validez de las pruebas obtenidas em el extranjero: análisis de la jurisprudencia del Triunal Supremo Español. Estudios Jurídicos, Madrid: Ministerio Fiscal, n. 3, 2003, p. 357). Além disso, na apresentação das propostas de lege ferenda, em sua obra, Fábio Ramazzini Bechara expõe como ideias centrais, em futura lei infraconstitucional em matéria de cooperação jurídica internacional penal, a necessidade de: [...] 4) igualdade de armas, compreendida a iniciativa da cooperação tanto pela acusação como pela defesa; 5) exercício do direito de defesa, compreendida a necessidade de nomeação de defensor na atividade probatória desenvolvida no exterior." (BECHARA, Fábio Ramazzini. Cooperação Jurídica Internacional em Matéria Penal: Eficácia da Prova Produzida no Exterior. São Paulo: Saraiva, 2011, p. 190)

438 A Portaria Conjunta $\mathrm{n}^{\circ} 1-\mathrm{MJ} / \mathrm{PGR} / \mathrm{AGU}$, de 27.10.2005, dispõe sobre a tramitação de pedidos de cooperação jurídica internacional em matéria penal entre o Ministério da Justiça, o Ministério Público Federal e a Advocacia Geral da União. Antes disso, no âmbito do Ministério Público Federal, foi editada a Portaria n. 23 de 03.02.2005, que criou o Centro de Cooperação Jurídica Internacional (CGJI), pelo então ProcuradorGeral da República Cláudio Fontelles. Entretanto, nas palavras de Dora Cavalcanti Cordani, “falta, contudo, um aprimoramento de mecanismos que confiram transparência às atividades desenvolvidas pelo DRCI (MJ), de modo a permitir à parte atingida o exercício pleno das garantias constitucionais que lhe são asseguradas no processo penal brasileiro". (CORDANI, Dora Cavalcanti. Cooperação Jurídica Internacional em Matéria Penal no Brasil: as Cartas Rogatórias e o Auxílio Direto - Controle dos Atos pela Parte Atingida. In: VILARDI, Celso Sanchez; PEREIRA, Flávia Rahal Bresser; NETO, Theodomiro Dias. Direito Penal Econômico - Crimes Econômicos e Processo Penal. São Paulo: GVLaw e Ed. Saraiva, 2008, p.108). 
Tal escopo está em consonância com o que refere Weber: em solicitações referentes a provas diversas, como colheita de testemunhos, realização de perícias, identificação de bens, obtenção de documentos, a regra é a participação do afetado no ato. Para tanto, no pedido de cooperação, poderão constar eventuais dados da pessoa implicada e/ou advogado a ser intimado no Estado requerido. Caso contrário, deverá ser designado Defensor Público. ${ }^{439}$

Em um contexto mais amplo, deve-se levar em conta que, se o Estado já está arcando com os custos da assistência jurídico-processual da parte, ao utilizar os recursos humanos da Defensoria Pública, também deveria admitir a possibilidade de ser firmado acordo de cooperação jurídica internacional para a produção de prova pela defesa, sob pena de agravar o ônus estatal, aniquilando o princípio da igualdade entre acusação e defesa.

Isso tudo pensado para não se ter mera igualdade perante a lei, genérica e abstrata, pois, no início do século XXI e, em face de uma Constituição como a de 1988, seriamente preocupada com os direitos fundamentais, isso não se afigura mais admissível. ${ }^{440}$

Como em todas as áreas, o Direito sempre busca a evolução e o aprimoramento e, em uma era iniciada pela guerra ao terror e pelo direito penal do inimigo, não se devem perder de vista as palavras do Professor José Faria Costa ${ }^{441}$ contra um discurso de endurecimento penal:

o direito penal desta contemporaneidade é infinitamente melhor do que se exercia, o que se aplicava, no mundo antigo ou medieval. Daí o que é preciso é ousar, é ousar pensar em transformar qualitativamente o direito penal em qualquer coisa de melhor. O que é que isso fosse não nos disse Radbruch. O que isso seja ninguém é capaz, sequer, de o prognosticar. É uma meta, é uma utopia, por isso vale o que vale. No entanto, mesmo que não consigamos chegar a esse lugar, que é o lugar dos não-lugares, mesmo que, como nós, se ache que o crime é uma manifestação onto-antropológica do modo-de-ser da humanidade e como tal inarredável, urge que não nos deixemos seduzir pela via fácil do endurecimento do direito penal.

\footnotetext{
${ }^{439}$ WEBER, Patrícia Núñez. A Cooperação Jurídica Internacional em Medidas Processuais Penais. Porto Alegre: Verbo Jurídico, 2011. p. 145.

440 Como afirma Canotilho, "[...] Reduzir, porém, o princípio da igualdade a uma refração do princípio da legalidade (com minimização da dimensão subjetiva do direito à igualdade) e a um mecanismo de aplicação igual do direito, significa encobrir o problema fundamental da igualdade: aplicação igual do direito igual. A primeira dimensão (aplicação igual do direito) seria e será suficiente quando a lei contém direito igual; a segunda dimensão (criação de direito igual) ganha particular acuidade quando não há direito igual e a lei tem de o criar. No último caso, a igualdade é direito à igualdade através da lei. Em termos clássicos: por igualdade entende-se igualdade em sentido formal e igualdade em sentido material" (CANOTILHO, José Joaquim Gomes. Constituição dirigente e vinculação do legislador: contributo para a compreensão das normas constitucionais programáticas. Coimbra: Coimbra Ed., 1994, p. 380-81).

${ }^{441}$ COSTA, José Faria. A Criminalidade em um mundo globalizado: ou plaidoyer por um direito penal não securitário, in Revista Legislação e Jurisprudência, Coimbra, Coimbra Editora, Ano 135, n. 3934, Set-Out 2005, pp. 26-7.
} 
Situada a questão, no capítulo seguinte, pretende-se apresentar a instituição Defensoria Pública e, especificamente, a atuação e as potencialidades da Defensoria Pública da União. Em especial, no que tange ao que se convencionou chamar de "acesso internacional à justiça”, tendo em vista que, nas causas que atinem ao direito internacional, crimes transnacionais e atribuição federal de um modo geral ${ }^{442}$, é esta a instituição competente para cuidar da matéria.

\subsubsection{A Defensoria Pública como mecanismo de defesa social e como protagonista da cooperação jurídica internacional penal em matéria de defesa}

Neste tópico, em primeiro lugar, cumpre delinear o sentido da existência da instituição Defensoria Pública, referindo relevantes manifestações teóricas do pensamento liberal e iluminista ainda pouco difundidas. ${ }^{443}$

Existe passagem na obra "De l'organisation judiciaire et de la codification", de Jeremy Bentham, a qual foi escrita há mais de dois séculos, em 1791, e que, trazida por Ferrajoli, merece ser aqui citada integralmente, ${ }^{444}$ na medida em que já naquele tempo tratava com assombrosa atualidade de aspectos atinentes à figura do defensor público, à legitimidade judicial, à desconfiança da opinião pública em relação à justiça, à necessidade de igualdade entre defesa e acusação, como forma de preservar a imparcialidade judicial, sob pena de se retroceder à época de barbárie:

O papel do defensor público, se perguntava Bentham, será talvez inútil? É
talvez menos necessário do que o do Ministério Público? A sociedade tem,
talvez, menos interesse na segurança dos inocentes do que na persecução
do crime? Se necessita empregar meios e provisóes para a acusação e não
para a defesa? E acrescentou, com otimismo típico da cultura iluminista,
que a falta deste fundamental instituto de garantia, o defensor público, se
identificava com a sobrevivência em tempos de barbárie, que devia ser
eliminada: para além de algumas honrosas exceções, a administração da
justiça sempre foi gerida com uma frieza e uma dureza que refletia a
barbárie geral dos tempos antigos. A acusação, mais do que ser o objetivo

${ }^{442}$ De acordo com o artigo 109 da Constituição Federal de 1988.

${ }^{443}$ Nesse assunto, recomenda-se a leitura do irretocável texto do Prof. Luigi Ferrajoli: "Garantismo y Defensa Penal - o sobre la defensa pública". (FERRAJOLI, Luigi. Garantismo y Defensa Penal - o sobre la defensa pública. In: REVISTA DAS DEFENSORIAS PÚBLICAS DO MERCOSUL (REDPO). Defensoria Pública da União. n. 1 (out./2010). Brasília: DPU, 2010, 247 p.)

${ }^{444}$ BENTHAM, Jeremy. De l'organisation judiciaire et de la codification. ch. XIX, en Oeuvres, vol III, (1791) p. 35 apud FERRAJOLI, Luigi. Garantismo y Defensa Penal - o sobre la defensa pública. In: REVISTA DAS DEFENSORIAS PÚBLICAS DO MERCOSUL (REDPO). Defensoria Pública da União. n. 1 (out./2010). Brasília: DPU, 2010, p. 10-11. 
principal foi o único propósito de governantes, que esgotava completamente o seu ponto de vista e projetava o horizonte de despotismo. Era, de fato, do interesse do rei ou barão que o culpado fosse punido, uma vez que o confisco e multas inchava o seu tesouro, enquanto que os inocentes não produziam qualquer lucro e apenas eles próprios estavam preocupados com a sua salvação. Consequentemente, Bentham acrescentou com palavras mais atuais hoje do que nunca, que isso gerou um profundo descrédito da jurisdição, sob a acusação de "despotismo" dirigida a juízes e total desconfiança da opinião pública para com a justiça. A desconfiança "pouco importa se ou não fundada", concluiu Bentham, que é o sintoma mais evidente da falha da função jurisdicional, pois, e novamente suas palavras, desperta temor a instituição que deve inspirar confiança, tanto que se as pessoas estão alarmadas pela justiça, isso significa que há certamente falhas na lei ou no tribunal. Por tudo isso, é essencial colocar visivelmente ao lado do magistrado que persegue o crime, um magistrado que vele pela sorte dos inocentes, que não permita à acusação vantagem alguma que não seja compartilhada com o defensor, e que estes duas funções estejam separadas da do juiz, de tal forma que ele possa assegurar integralmente a imparcialidade. ${ }^{445}$

Antes ainda de Bentham, a proposta de instituição de um defensor público foi enunciada por Gaetano Filangieri, em "La institución de un magistrado defensor", na obra "Scienza della legislazione", de 1787. ${ }^{446}$ Nas palavras do autor, a função do magistrado-

445 Tradução livre de: “La función del defensor público se preguntaba Bentham Es quizá inútil?, Es quizá menos necesaria que la del Ministerio Público Fiscal? Tiene acaso la sociedad menos interés en la seguridad del inocente que en la persecución del crimen? Se necesita emplear medios y tomar previsiones en la acusación y no en la defensa? Y agregaba, con el optimismo típico de la cultura iluminista, que la falta de este fundamental instituto de garantía, el defensor público, se identificába como una sobrevivencia de épocas de barbarie, que debía ser eliminada: prescindiendo de algunas honorables excepciones, la administración de justicia ha sido siempre gestionada con una insensibilidad y una dureza que reflejaba la barbarie general de los tiempos antiguos. La acusación, mucho más que ser el principal objetivo, era el único fin de los gobernantes, que agotaba completamente su punto de vista y diseñaba el horizonte del despotismo. Era, de hecho, el interés del rey o del barón que el culpable fuera penado, puesto que confiscaciones y multas venían a engrosar su tesoro, mientras los inocentes no producían ninguna ganancia y solamente ellos mismos estaban interesados en su propia salvación. En consecuencia, agregaba Bentham con palabras hoy más actuales que nunca, se generaba un profundo descrédito de la jurisdicción, la acusación de "despotismo" dirigida a los jueces, la total desconfianza de la opinión pública hacia la justicia. Una desconfianza "poco importa si fundada o no", concluía Bentham, que es el síntoma más evidente del fracaso de la función judicial: puesto que, y de nuevo sus palabras, suscita pavor la institución que debería inspirar confianza, tan es así, que si la gente está alarmada por la justicia, ello quiere decir que seguramente existen vícios en las leyes o en los tribunales. Por todo ello, es esencial colocar de manera visible, al lado del magistrado que persigne el crimen, un magistrado que vele por la suerte dei inocente, que no le permita a la acusación ventaja alguna que no esté compartida con el defensor, y que estas dos funciones estén separadas de la del juez, de tal suerte que éste pueda garantizar integramente la imparcialidad." (sem grifos no original).

${ }^{446}$ No original: "Sería por lo tanto necesaria. Cada província deberia tener uno o más, proporcionalmente a su población. La función de este magistrado no debería ser solamente aquella de defender a los imputados, que por su pobreza no pueden ser defendidos por otros, sino también de asistir a todos frente a los juicios capitales, toda vez que el imputado no tuviese su ministerio. De esta figura de magistrado Filangieri diseña a la vez, los lineamientos deontológicos: "la persona encargada de una función asi noble", y afirma, "debería ser respetado cuanto su cargo... Un profundo conocimiento de las leyes y una asegurada probidad deberian ser sus requisitos; una facilidad de ordenar las propias ideas y de comunicarias a otros debería ser su talento y una sensibilidad de corazón, unida a la tolerancia a la fatiga, deberían indicar su carácter moral". FILANGIERI, Gaetano, La scienza della legislazione. Libro III, cap. XX, (1787) p. 484 apud FERRAJOLI, 
defensor não deveria ser apenas a de defender o acusado que por sua pobreza não poderia contratar advogado, mas assistir a todos os julgamentos que enfrentam juízos capitais. Para essa figura, Filangieri reúne algumas diretrizes deontológicas: a pessoa encarregada de tão nobre função deve ser respeitada pelo encargo de que está imbuída, possuindo conhecimento profundo das leis, facilidade de organizar as próprias ideias e talento para comunicá-las aos demais. A sensibilidade de coração ligada à tolerância à fadiga deveriam indicar o seu caráter moral.

Importante referir, ainda, a lúcida argumentação de Luigi Lucchini, também trazida por Ferrajoli, ${ }^{447}$ que defende "L'ufficio dei difensore", mencionando no parágrafo 195 de seu "Elementi di procedura penale", de 1895, o seguinte: "É de natureza pública, tanto quanto é o ofício do promotor. A defesa é também uma necessidade urgente de lógica jurídica, o que não pode alcançar a descoberta da verdade, senão graças à luta incessante das duas forças paralelas: a acusação e a defesa." ${ }^{448}$

Feitas essas importantes considerações históricas, toma-se a liberdade de transcrever abaixo passagens do capítulo de trabalho apresentado por Luigi Ferrajoli449 ${ }^{44 e}$ trata do rol garantista da Defensoria Pública, indispensável ao entendimento de em que consiste a referida instituição:

Em suma, a defesa pública é uma instituição de garantia que tem vários fundamentos axiológicos e responde a várias instâncias garantistas.

[...] Embora a verificação garantida da hipótese do Ministério Público, como é garantido tanto a sua "confrontabilidade" com a defesa. A confrontabilidade de fato, não só ao nível da política.

Assegura, em segundo, as liberdades fundamentais das pessoas contra os poderes arbitrários terríveis - na sua ausência e sem seu controle - que são o requisitorio poder, seja da polícia ou do Ministério Público, ou o pode mesmo do juiz.

[...] Efetiva o princípio da paridade entre acusação e defesa, e aqueles conexos ao contraditório; a um e outro violados, na ausência de defesa daqueles que não têm condições de pagar um advogado de confiança. E

Luigi. Garantismo y Defensa Penal - o sobre la defensa pública. In: REVISTA DAS DEFENSORIAS PÚBLICAS DO MERCOSUL (REDPO). Defensoria Pública da União. n. 1 (out./2010). Brasília: DPU, 2010, p. 11.

${ }^{447}$ LUCCHINI, Luigi. Elementi di procedura penale. Barbèra Editor Firenze, 1895, 195, pp. 218-219. Reenvío, sobre la propuesta de institución de un Ministerio Público de la Defensa, a Diritto e ragione, Laterza, RomaBari, (1989), p. 597 apud FERRAJOLI, Luigi. Garantismo y Defensa Penal - o sobre la defensa pública. In: REVISTA DAS DEFENSORIAS PÚBLICAS DO MERCOSUL (REDPO). Defensoria Pública da União. n. 1 (out./2010). Brasília: DPU, 2010, p. 12.

448 Tradução livre de: "Es de carácter público tanto como lo es el oficio del acusador. La defensa es también una urgente exigencia de la lógica judicial, que no puede lograr el descubrimiento de la verdad, si no es merced a la lucha incesante de las dos fuerzas paralelas: la de la acusación y la de la defensa".

449 FERRAJOLI, Luigi. Garantismo y Defensa Penal - o sobre la defensa pública. In: REVISTA DAS DEFENSORIAS PÚBLICAS DO MERCOSUL (REDPO). Defensoria Pública da União. n. 1 (out./2010). Brasília: DPU, 2010, pp. 12-13. 
representa, a este respeito, uma condição indispensável do modelo acusatório.

Satisfaz o princípio da igualdade das pessoas perante a lei, não deixando sem defesa substancial aqueles que, por razões econômicas, não podem aceder a um advogado de confiança. ${ }^{450}$

No âmbito normativo interno, por oportuno, vale citar as seguintes previsões legais, abaixo transcritas, em que se estabelece a Defensoria Pública como órgão essencial à função jurisdicional do Estado, conforme artigo 134 da Constituição Federal, bem como o artigo $1^{\circ}$ da Lei Complementar n. 80 de 1994, ${ }^{451}$ como forma de delinear também o fundamento jurídico da institucionalização de uma defesa apta a atuar em nível transnacional, in verbis:

Art. $1^{\circ}$ A Defensoria Pública é instituição permanente, essencial à função jurisdicional do Estado, incumbindo-lhe, como expressão e instrumento do regime democrático, fundamentalmente, a orientação jurídica, a promoção dos direitos humanos e a defesa, em todos os graus, judicial e extrajudicial, dos direitos individuais e coletivos, de forma integral e gratuita, aos necessitados, assim considerados na forma do inciso LXXIV do art. $5^{\circ}$ da Constituição Federal.

Com os seguintes objetivos institucionais (art. $3^{\circ}$-A da LC 80/1994):

I - a primazia da dignidade da pessoa humana e a redução das desigualdades sociais;

II - a afirmação do Estado Democrático de Direito;

III - a prevalência e efetividade dos direitos humanos; e

IV - a garantia dos princípios constitucionais da ampla defesa e do contraditório.

E as seguintes funções pertinentes à temática em análise (art. $4^{\circ}$ da LC 80/1994):

\footnotetext{
450 Tradução livre de: "En suma, la defensa pública es una institución de garantia que tiene múltiples fundamentos axiológicos y que responde a diversas instancias garantistas.

[...] en tanto es garantizada la verificación de las hipótesis de la acusación, en cuanto sea a la vez garantizada su "confrontabilidad" por parte de la defensa. Una confrontabilidad de hecho, y no solamente en el plano normativo.

Garantiza, en segundo lugar, las libertades fundamentales de las personas contra aquellos tremendos poderes arbitrarios - en su ausencia y sin su control - que son el poder requisitorio, sea policial o dei ministerio fiscal, y el poder mismo del juez.

[...] Realiza el principio de la paridad entre acusación y defensa y aquel conexo de un efectivo contradictorio; el uno y el otro violados, ante la falta de defensa de quienes no están en posibilidades de pagar un defensor de confianza. Y representa por ella y, bajo este aspecto, una condición indispensable del modelo acusatorio.

Satisface el principio de igualdad de las personas frente a la ley, no dejando sin defensa sustancial, a quienes por razones económicas, no pueden acceder a un defensor de confianza." (sem grifos no original)

${ }^{451}$ Organiza a Defensoria Pública da União, do Distrito Federal e dos Territórios e prescreve normas gerais para sua organização nos Estados, e dá outras providências.
} 
I - prestar orientação jurídica e exercer a defesa dos necessitados, em todos os graus;

[...]

III - promover a difusão e a conscientização dos direitos humanos, da cidadania e do ordenamento jurídico;

$[\ldots]$

$\mathrm{V}$ - exercer, mediante o recebimento dos autos com vista, a ampla defesa e o contraditório em favor de pessoas naturais e jurídicas, em processos administrativos e judiciais, perante todos os órgãos e em todas as instâncias, ordinários ou extraordinários, utilizando todas as medidas capazes de propiciar a adequada e efetiva defesa de seus interesses;

VI - representar aos sistemas internacionais de proteção dos direitos humanos, postulando perante seus órgãos;

[...]

$\mathrm{X}$ - promover a mais ampla defesa dos direitos fundamentais dos necessitados, abrangendo seus direitos individuais, coletivos, sociais, econômicos, culturais e ambientais, sendo admissíveis todas as espécies de ações capazes de propiciar sua adequada e efetiva tutela;

Estabelecem, por sua vez, os arts. 32 e 263 do CPP, respectivamente, que: "Nos crimes de ação privada, o juiz, a requerimento da parte que comprovar a sua pobreza, nomeará advogado para promover a ação penal"; e "Se o acusado não o tiver, ser-lhe-á nomeado defensor pelo juiz, ressalvado o seu direito de, a todo tempo, nomear outro de sua confiança, ou a si mesmo defender-se, caso tenha habilitação".

O ideal seria, induvidosamente, que se cumprisse, com total exação, de sorte a concretizar-se vigorosamente o salutar alvitre do legislador constituinte, o preceituado no art. 134 e seus dois parágrafos, tendo em conta que é instituição tipicamente social, de “advocacia do povo"; ${ }^{452}$ a Defensoria Pública é a instituição própria para a garantia do acesso à justiça. ${ }^{453}$

A Defensoria Pública é um instrumento de efetivação do acesso à justiça e de manutenção de uma ordem jurídica justa, ${ }^{454}$ sendo que, no processo penal, passa a ocupar um lugar de destaque ao garantir aos seus assistidos e aos acusados em geral um provimento

${ }^{452}$ CALAMANDREI, Piero. Istituzioni di diritto processuale civile, vol. IV, p. 505 apud TUCCI, Rogério Lauria. Direitos e Garantias Individuais no Processo Penal Brasileiro. 3a ed. Rev., atual. e ampl. São Paulo: Editora Revista dos Tribunais, 2009, p. 84.

${ }^{453}$ Como explicitado pelo CEPAM (Centro de Estudos e Pesquisas de Administração Municipal) - a quem se deve, em parte, o destaque feito -, a Defensoria Pública é a instituição "própria para a garantia de acesso ao Judiciário para toda a população carente", consistindo, inclusive, no "instrumento apto a dar eficácia plena ao disposto no art. $5^{\circ}, \mathrm{XXXV}$, da Constituição, que veda previsão legal, obstando apreciação do Poder Judiciário em caso de lesão ou ameaça a direito". (TUCCI, Rogério Lauria. Direitos e Garantias Individuais no Processo Penal Brasileiro. 3a ed. Rev., atual. e ampl. São Paulo: Editora Revista dos Tribunais, 2009, p. 84)

${ }^{454}$ Como lembra Ada Pellegrini Grinover: "A ideia de acesso à justiça não mais se limita ao mero acesso aos tribunais. Nas palavras lapidares de Kazuo Watanabe, não se trata apenas de possibilitar o acesso à justiça enquanto instituição estatal e sim de viabilizar o acesso à ordem jurídica justa". (GRINOVER, Ada Pellegrini. O Processo em Evolução. Rio de Janeiro: Forense Universitária, 1996, p. 115). 
jurisdicional final justo e obtido em equidade de armas com a acusação. O fortalecimento da instituição é a única forma de afirmação da norma hipotética fundamental consistente no direito de defesa em sua plenitude no cenário jurídico brasileiro ${ }^{455}$, e inclui-se aqui também o cenário jurídico internacional.

Para Rogério Lauria Tucci, a Defensoria Pública é instituição tipicamente social, de “advocacia do povo", que servirá para "a necessária e prévia orientação jurídica, bem como para a defesa, pré-processual e processual, em todos os graus de jurisdição, das pessoas desprovidas de recursos financeiros para o respectivo custeio". ${ }^{456}$

Como já visto neste trabalho, a Constituição não garante apenas a isonomia, ou a igualdade perante a lei. Garante, sobretudo, a igualdade material e a assistência jurídica integral e gratuita, tal como prevista no art. $5^{\circ}$, inc. LXXIV, in verbis: “o Estado prestará assistência jurídica integral e gratuita aos que comprovarem insuficiência de recursos".

Sublinhe-se, uma vez mais, que a assistência foi qualificada como integral, o que significa que ela não está restrita à atuação junto ao Judiciário. Seus limites são mais amplos do que os reservados à fase de judicialização. Envolve a possibilidade de atuações em diferentes e diversificadas áreas, como, por exemplo, a educação em direitos, a orientação jurídica, a busca e a efetivação de soluções extrajudiciais de conflitos, além de ser possível, na temática proposta, a atuação na defesa penal pré-judicial. Tais funções podem ser ainda intensificadas pelo fato de a Defensoria Pública possuir grau significativo de plasticidade, tanto para a definição de sua agenda quanto para a delimitação dos potenciais assistidos e para a eleição das áreas de atuação. ${ }^{457}$

Essas características permitem afirmar que o processo de construção institucional da Defensoria Pública está estreitamente ligado às políticas aprovadas. A potencialidade de produção de efeitos no interior da própria Defensoria é acentuada, principalmente por se tratar de uma instituição relativamente recente e, portanto, menos sujeita a resistências a mudanças e mais aberta a inovações. ${ }^{458}$

Nesse norte, a Defensoria Pública da União já manifestou intenção favorável em

\footnotetext{
${ }^{455}$ A despeito das indiscutíveis dificuldades, levantar a bandeira pelo fortalecimento da Defensoria Pública é lutar pela inclusão, pela efetivação dos direitos, por uma sociedade composta por cidadãos, regida pela Lei, na qual prevaleçam os preceitos da igualdade. (SADEK, Maria Tereza Aina. Prefácio - Defensoria Pública: um agente de igualdade in: SOUSA, José Augusto Garcia de. Uma nova Defensoria Pública pede passagem Reflexões sobre a Lei Complementar 132/09. Rio de Janeiro: Lumen Juris, 2011. p. xvii).

${ }^{456}$ TUCCI, Rogério Lauria. Direitos e Garantias Individuais no Processo Penal Brasileiro. 3a ed. Rev., atual. e ampl. São Paulo: Editora Revista dos Tribunais, 2009, p. 104.

457 SADEK, Maria Tereza Aina. Prefácio - Defensoria Pública: um agente de igualdade in: SOUSA, José Augusto Garcia de. Uma nova Defensoria Pública pede passagem - Reflexões sobre a Lei Complementar 132/09. Rio de Janeiro: Lumen Juris, 2011. p. xv.

458 Ibidem.
} 
integrar o Projeto de Cooperação Jurídica Internacional proposto pelo DRCI/MJ, ${ }^{459}$ para, no âmbito de suas atribuições legais, prestar assistência jurídica gratuita aos brasileiros residentes no exterior que comprovarem insuficiência de recursos. Já há parecer favorável do CONJUR/MJ, ${ }^{460}$ no intuito de estabelecer acordos de reciprocidade, observada a iminência da entrada em vigor da Convenção de Haia sobre Acesso Internacional à Justiça, que permitirá a tramitação desses pedidos para outros países europeus. ${ }^{461}$

A dificuldade que se apresenta é como alcançar o conteúdo da igualdade material processual como mecanismo de superação aos óbices de acesso à justiça, em face das profundas desigualdades sociais, políticas e econômicas existentes em nossa sociedade, já que as normas jurídicas não são suficientes para promover modificações substanciais em contextos sociais permeados por intensas diferenças fáticas. Entretanto, é função do Direito fomentar e gerar o início e o desenvolvimento de mudanças em direção à construção de uma sociedade mais equilibrada.

Se o resultado do processo não decorrer do desenvolvimento de uma relação processual em que as partes estejam em equilíbrio de forças, com a mesma capacidade técnica, econômica e cultural, os escopos da jurisdição não serão atingidos. E, consequentemente, com a incapacidade de realizar esses escopos, o exercício da jurisdição não estará legitimado pela sociedade. ${ }^{462}$

\footnotetext{
${ }^{459}$ A Defensoria Pública da União, por meio do memorando n 31/2011/DPU/GTAI, de 15 de junho de 2011, manifestou anuência com o Projeto para assistência jurídica gratuita a estrangeiros no exterior.

${ }^{460}$ Parecer $n^{\circ}$ 94/2011/CEP/CGLEG/CONJUR/MJ, no processo $n^{\circ}$ 08099.005089/2011-21.

${ }^{461}$ Veículo: DRCI/MJ. Acesso em 17 jun. de 2011. "O Departamento de Recuperação de Ativos e Cooperação Jurídica Internacional (DRCI), da Secretaria Nacional de Justiça (SNJ), do Ministério da Justiça (MJ), tem atuado na operacionalização dos acordos internacionais para a cooperação jurídica internacional. Dentre os tipos de pedidos possíveis na cooperação jurídica internacional em matéria civil e comercial, destacamos o Pedido de Assistência Judiciária, previsto em diversos normativos. O tema é conhecimento como 'Acesso Internacional à Justiça'.

Apesar de pouco conhecido, o Pedido de Assistência Judiciária permite que um brasileiro residente no Brasil possa solicitar assistência jurídica gratuita para se defender em ação judicial que corre em um país estrangeiro ou iniciar uma ação judicial no exterior.

A regra internacional para esse tipo de pedido é a seguinte: "Os nacionais e os habitualmente residentes em qualquer Estado Contratante terão o direito de receber assistência judiciária para procedimentos judiciais referentes à matéria civil e comercial em outro Estado Contratante, nas mesmas condições que receberiam caso fossem nacionais ou residentes habituais daquele Estado". Dessa forma, quando o pedido chega ao exterior, ele é analisado para verificar se o solicitante preenche os requisitos no país estrangeiro para a assistência judiciária.

Para fazer uso dessa possibilidade, é preciso verificar a existência de acordo internacional entre o Brasil e o país estrangeiro, com previsão normativa para esse tipo de pedido. A lista de acordos que permitem a assistência judiciária gratuita encontra-se na página no Ministério da Justiça, no item 'cooperação internacional' do Menu. Resumindo podemos relacionar os seguintes países: Itália, Espanha, França, Argentina, Paraguai, Chile, Uruguai. Disponível

em: http://portal.mj.gov.br/data/Pages/MJ4824E353ITEMID13E05ECCA5154723893874BD5A537563PTBRIE. $\underline{\text { htm. }}$. Em breve, a "Convenção da Haia sobre Acesso Internacional à Justiça”" estará em vigor no Brasil.

${ }^{462}$ Nesse sentido, Tucci pondera que "se realística e lamentavelmente os postulados constitucionais da igualdade e da assistência judiciária gratuita passaram, especialmente em matéria criminal, da salutar intenção
} 
Quando o desenvolvimento do processo não tiver respeitado todas as finalidades da jurisdição, a decisão final será injusta e inconstitucional. ${ }^{463}$

Como lembra Ada Pellegrini Grinover, o critério do fair trial tem envolvido o controle da duração razoável do processo, da imparcialidade, do respeito aos direitos de defesa e ao princípio da igualdade das armas, reconhecendo-se, entre outros, o direito à defesa técnica e à autodefesa. ${ }^{464}$

Assim, com base nos objetivos e nas funções destacadas acima, bem como na preocupação já demonstrada pela Defensoria Pública da União quanto ao dever de acesso internacional à justiça, é que se defende a possibilidade de a Defensoria Pública da União atuar como autoridade central, em futuros acordos bilaterais que versem sobre matéria de defesa na cooperação penal. Desse modo, pondo fim à querela acerca da possibilidade de utilização dos acordos bilaterais atualmente existentes para a produção de prova pela defesa.

Ainda que se entendesse pela exceção que se poderia efetuar para os assistidos da Defensoria, quando o próprio Juízo, de plano, poderia chancelar a solicitação defensiva como questão do Juízo, tal solução revela-se simplista, não equalizando o sistema, pois, ainda, assim o Estado estaria, de certa forma, discriminando réus, sem cumprir o mandamento constitucional e internacional acerca da oportunização de iguais possibilidades à acusação e à defesa. ${ }^{465}$

do legislador constituinte à quimera dos menos afortunados de, em algum dia, contar com o efetivo patrocínio defensivo de seu direito subjetivo material, precipuamente do de liberdade, relegado ao utópico anseio de assemelhação com o assegurado aos economicamente poderosos... Só mesmo uma, tanto quanto possível, perfeita regulamentação da Defensoria Pública, com a conjugação de um quadro de profissionais habilitados e capazes e de elementos estruturais e materiais plenamente satisfatórios, é que poderá transformar esse acalentado sonho em alvissareira realidade. Vale recordar, a propósito, com CAPPELLETTI e GARTH, que esse enfoque do acesso à justiça reclama a 'operacionalização de reformas cuidadosas, atentas aos perigos envolvidos, com uma plena consciência dos limites e potencialidades dos tribunais regulares, do procedimento comum e dos procuradores', com a perseguição da finalidade, não de 'fazer uma justiça 'mais pobre', mas torná-la acessível a todos, inclusive aos pobres'-, e tudo com a certeza de que 'a igualdade de todos perante a lei, igualdade efetiva- não apenas formal-é o ideal básico de nossa época”. E continua: "Trata-se, por certo, de garantia que, assecuratória de efetiva paridade de armas entre as partes, adquire maior transcendência e importância no âmbito do processo penal, sendo objeto, inclusive, de regras de caráter universal, inseridas nos textos internacionais sobre direitos humanos, e infraconstitucionais". (TUCCI, Rogério Lauria. Direitos e Garantias Individuais no Processo Penal Brasileiro. 3a Ed. Rev., atual. e ampl. São Paulo: Editora Revista dos Tribunais, 2009, p. 87-9).

${ }^{463}$ BEDAQUE, José Roberto dos Santos. Poderes Instrutórios do Juiz. 2a ed. São Paulo: RT, 1994, p. 74. Ainda, nas palavras de Kazuo Watanabe: "Deve haver uma plena e total aderência do processo à realidade sociojurídica a que se destina, cumprindo sua primordial vocação, que é a de servir de instrumento à efetiva realização dos direitos”. (WATANABE, Kazuo. Da cognição no processo civil. 2a ed. Campinas: Bookseller, 2000, p. 21). ${ }^{464}$ GRINOVER, Ada Pellegrini. O Processo em Evolução. Rio de Janeiro: Forense Universitária, 1996, p. 193. $465 \mathrm{O}$ processo desenvolvido ferindo o princípio da igualdade material será inconstitucional, uma vez que, quando uma das partes encontrar-se em condições desfavoráveis em relação à outra, o critério que as diferencia será ter ou não capacidade econômica, o que não está em harmonia com os valores preceituados na Constituição Federal. O efetivo acesso à justiça é um direito fundamental e todos os cidadãos têm direito de beneficiar-se nas mesmas condições do exercício da jurisdição. Assim, a aplicação do princípio da igualdade deve dar audições iguais a todos na fruição dos direitos fundamentais, e quando isso não ocorrer, o Estado deve implantar 
Questão que se coloca como "pseudo" empecilho para a consecução desse objetivo é a da ausência na maioria dos países de um sistema de Defensoria Pública patrocinado pelo Estado, nos moldes do sistema brasileiro, quer sejam da tradição do common law quer adotem o modelo da civil law, entretanto, como já referido anteriormente, nada impede que haja outra instituição apta a firmar os acordos com as Defensorias.

Nesse sentido, estudo comparativo do que se passa na maioria dos países ocidentais auxilia a melhor avaliar as potencialidades de fortalecimento institucional da Defensoria Pública brasileira. Em geral, nos países europeus, quem define quem será assistido, concedendo a gratuidade, é um órgão não judicial ligado à assistência social. Na maior parte dos casos europeus, a assistência se dá apenas nas áreas criminal e de família.

Neste ponto, cumpre trazer a lume o pensamento de Luigi Ferrajoli no que pertine ao modelo de Defensoria adotado na Argentina, o qual também é adotado no Brasil e na América Latina em geral ${ }^{466}$ : obviamente, tal como contempla o modelo argentino e tantos países latino-americanos, a defesa pública não exclui de forma alguma a defesa privada, mas a substitui por eleição do imputado. O que é importante ressaltar é que ela não é minimamente comparável com o simulacro de defesa que, nos ordenamentos como o

políticas que restabeleçam, ou criem, a igualdade real das partes. (MORALLES, Luciana Camponez Pereira. Acesso à justiça e princípio da igualdade. Porto Alegre: Sergio Antonio Fabris Editor, 2006, p. 108).

466 No original: "Obviamente, tal como se contempla en el modelo argentino y en el de tantos países latinoamericanos, la defensa pública no excluye de manera alguna la defensa privada, pero sustituye a la misma por elección del imputado. Lo que importa subrayar es que ella no es minimamente parangonable a ese simulacro de defensa que, en los ordenamientos como el italiano, es la difesa d'ufficio o el "gratuito patrocinio”, donde se ejercita una defensa ritual y burocrática. [...] Claro que para un jurista europeo, el carácter más interesante, más relevante del modelo argentino, es que el defensor público no es, como el defensor "d'ufficio" italiano, un abogado cualquiera, designado por el poder judicial, falto de compromiso y normalmente dispuesto a una defensa sólo ritual y burocrática, y totalmente desinteresado del destino de su defendido. Es, al contrario, un magistrado dei Ministerio Público de la Defensa, que se encuentra de pie frente al Ministerio Público de la Acusación. Se trata en todo caso, y a pesar de que sus poderes de intervención no igualan a los del fiscal, de una figura dotada del mismo prestigio y autoridad que el Ministerio Público Fiscal. $Y$ esto es suficiente para asegurar una funcionalidad y una efectividad en la defensa de los derechos humanos, incomparablemente mayor de la que pueda ofrecer la "difesa d'ufficio", y a veces, hasta la misma defensa de confianza. Una prueba indirecta de lo anterior, son los altos porcentajes de imputados, incluso dotados de recursos económicos, que en Argentina y en otros países Latinoamericanos, prefieren la asistencia de la defensa pública. Son datos significativos que deben ser evaluados y, que al mismo tiempo, demuestran la credibilidad de la que goza la defensa pública en muchos sectores de la sociedad; y que como es natural, se reflejan también dentro de la administración de justicia; percibida no ya como una corporación de poder, sino como una institución de garantia, que en su conjunto, está articulada en tres diversas funciones: la acusación y la defensa, en una posición de paridad, y el juez como tercero e imparcial. [...] Si todo ello es así, debemos reconocer que Argentina y los otros países latinoamericanos que han introducido el instituto de la defensa pública han dado a Europa una importante lección de civilidad jurídica. [...] Más aún, pienso que la introducción de un Ministerio Público de la Defensa sobre algunas de las bases del modelo argentino, debe constituir en Italia y en Europa- el objetivo de una batalla cívica: una batalla institucional no fácil, a causa de las resistencias corporativas que está destinada a encontrar, y que sin embargo constituye un desafio determinante sobre el carácter garantista del proceso penal." (FERRAJOLI, Luigi. Garantismo y Defensa Penal - o sobre la defensa pública. In: REVISTA DAS DEFENSORIAS PÚBLICAS DO MERCOSUL (REDPO). Defensoria Pública da União. n. 1 (out./2010). Brasília: DPU, 2010, pp. 13-15). 
italiano, é a defesa de ofício ou o "patrocínio gratuito", em que se exercita uma defesa ritual e burocrática. Claro que, para um jurista europeu, o caráter mais interessante do modelo argentino é que o defensor público não é, como o defensor de ofício italiano, qualquer advogado nomeado pelo Poder Judiciário, sem compromisso e geralmente disposto a uma defesa apenas ritual e burocrática e totalmente desinteressado no destino do seu cliente. É, ao contrário, um magistrado do Ministério Público da Defesa, que está em pé de igualdade em face do Ministério Público da acusação. Se tudo isso é assim, é preciso reconhecer que a Argentina e outros países latino-americanos que introduziram o instituto de defesa pública deram à Europa uma importante lição de civilidade jurídica. Acima disso, Ferrajoli pensa que a introdução de uma Defensoria Pública sobre algumas das bases do modelo argentino deve configurar na Itália e na Europa o objetivo de uma batalha cívica: uma batalha institucional que não é fácil, tendo em vista as resistências corporativas que está fadada a encontrar e que, sem embargo, constitui um desafio determinante sobre o caráter garantista do processo penal.

Nos Estados Unidos, a seu turno, a assistência jurídica só é concedida pelo Estado para processos criminais. Há um limite orçamentário e o sistema se baseia em convênios e na advocacia pro-bono. ${ }^{467}$

467 SADEK, Maria Tereza Aina. Prefácio - Defensoria Pública: um agente de igualdade in: SOUSA, José Augusto Garcia de. Uma nova Defensoria Pública pede passagem - Reflexões sobre a Lei Complementar 132/09. Rio de Janeiro: Lumen Juris, 2011. p. xvi.

Interessante a matéria recente intitulada "Defensoria Pública nos Estados Unidos está quebrada", publicada por João Ozorio de Melo, no sítio Consultor Jurídico, disponível em: <www.conjur.com.br/2013-mar-18/50-anosdefensoria-publica-estados-unidos-quebrada?utm_source=twitterfeed\&utm_medium=twitter>, acesso em: 19 mar. 2013, que refere que "as promessas de Gideon" não foram cumpridas. Isso porque, em 18 de março de 1963, a Suprema Corte dos EUA tomou uma decisão histórica, que prometia mudar para sempre a configuração do sistema americano de Justiça. No caso "Gideon v. Wainwright", a Corte decidiu que todo cidadão tem direito a um advogado, mesmo que não tenha capacidade de pagar. "Advogado em um tribunal criminal é uma necessidade, não um luxo", declarou a Suprema Corte. E dessa decisão, nasceu a Defensoria Pública nos EUA. "Nesta segunda-feira (18/3/13), a promessa de justiça para todos completa 50 anos 'totalmente irrealizada', de acordo com uma série de artigos publicados pelo The National Law Journal, para comemorar uma data sobre a qual não há nada para celebrar. 'A Defensoria Pública dos Estados Unidos está quebrada', disse ao jornal o presidente da Associação Nacional dos Defensores Públicos, Steven Benjamin. 'Não se pode confiar na instituição para proteger as pessoas contra condenações indevidas', afirmou”. O texto prossegue: "Politicamente, é uma atitude popular prover recursos financeiros para a Polícia e para a Promotoria, mas não para a Defensoria Pública, que cuida da defesa de indigentes", disse o professor de Direito e Criminologia da Faculdade de Direito da Universidade da Pensilvânia, Stephanos Bibas. "A solução para o problema é simples: infusão de fundos. Mas ninguém tem vontade de fazer isso", afirmou. "A consequência é que os defensores públicos não têm tempo e recursos para investigar os casos, enquanto, do outro lado, os promotores fazem isso com a ajuda da Polícia. Em muitos casos eles sequer se encontram com os réus, antes dos julgamentos, e nunca protocolam qualquer pedido a favor deles ou colocam objeção a provas inadmissíveis". Por fim, esclarece: “A referência à criação da Defensoria Pública nos EUA como 'a promessa de Gideon', porque Clarence Earl Gideon foi o primeiro cidadão americano a ser beneficiado pela decisão da Suprema Corte dos EUA — uma decisão que prometeu mudar todo o sistema judicial do país. Mas, antes, o direito à defesa por advogado público lhe foi negado na Flórida.

Acusado de roubo, mas jurando inocência, Gideon pediu ao tribunal que nomeasse um advogado público para defendê-lo. Entretanto, uma decisão da Suprema Corte dos EUA de 1942 (Betts v. Brady) negava aos réus 
Interessante lembrar, contudo, que, em 1963, decidiu-se o caso Gideon vs. Wainwright, 372 US 335 (1963), em que se afirmou a incorporação aos Estados do princípio do direito à indicação de um advogado aos indigentes em caso de crime grave (felony case). O sistema de justiça criminal da Flórida considerava obrigatória a indicação de um advogado dativo para o réu indigente apenas em restritas hipóteses, entre elas as dos crimes que poderiam conduzir à pena de morte (capital cases). Nesse aspecto, era coerente com a jurisprudência da Suprema Corte nos casos Powell e Betts. A Suprema Corte, em Gideon, estendeu esse dever às felonias, crimes mais graves do ordenamento jurídico antes dos crimes capitais. ${ }^{468}$

Já no que se refere à constitucionalização entre os 31 países da América Latina, a Defensoria Pública é prevista na Lei Maior em apenas outros sete países, além de no Brasil. São eles: Honduras, Nicarágua, Paraguai, Venezuela, México, Panamá e Peru. ${ }^{469}$

Nesse contexto e do ponto de vista comparativo, o potencial de protagonismo da Defensoria Pública brasileira revela-se indubitável.

Ressalta-se a aprovação da Recomendação AG/RES. 2714 (XLII-O/12), ${ }^{470}$ seguida

julgados em tribunais estaduais o direito à assistência jurídica prevista na Sexta Emenda da Constituição, sem que fossem atendidas determinadas condições.

Os estados só eram obrigados 'a apontar um advogado para réus indigentes em circunstâncias especiais, em casos em que um advogado se encarregaria de assegurar a justiça fundamental'. As circunstâncias não ajudaram Gideon. Ele não seria condenado à pena de morte, não era analfabeto, nem tinha problemas mentais. E seu caso não era particularmente complexo.

Gideon protestou veementemente contra sua condenação à prisão, por se dizer inocente. Mas foi para a cadeia. No entanto, seu caso acabou na Suprema Corte dos EUA. Mesmo sem ele saber, a maioria dos ministros da Suprema Corte declarou que a lei, baseada em Betts, criou 'sistemas de justiça criminal nos estados que criaram desigualdades e injustiças desenfreadas'. Para os ministros, 'qualquer pessoa arrastada a um tribunal, que não pode contratar um advogado por ser pobre, não pode ter um julgamento justo, a não ser que um defensor lhe seja garantido'. E mudou o sistema.”

Interessante lembrar que os Estados Unidos foram o segundo país do mundo a correlacionar o instituto da Defensoria Pública à Constituição, justamente com a decisão da Suprema Corte de 1963, que estendeu o direito à assistência jurídica a todas as pessoas pobres, sem estabelecer condições. O Brasil foi o primeiro a garantir um defensor público às pessoas de baixa renda na Constituição. E também foi o único a fazê-lo diretamente. A Defensoria Pública foi inicialmente criada no Rio de Janeiro, em 1897, através de um decreto governamental que alocou fundos para a assistência jurídica. A Constituição de 1937 estendeu o sistema para todo o país. Mas a Constituição de 1988 foi a que deu maior eficácia à instituição.

Quanto ao tema dos 50 anos de aniversário do precedente que criou a necessidade de assistência jurídica na área criminal, a imprensa americana fez uma boa cobertura sobre a precariedade do modelo instituído no país e uma das melhores reportagens analisadas sobre o tema que mostra, inclusive, um fac-símile da petição que Gideon fez chegar à Suprema Corte encontra-se disponível em: <http://www.theatlantic.com/national/archive/2013/03/how-americans-lost-the-right-to-counsel-50-yearsafter-gideon/273433/>, acesso em 20 mar. 2013.

468 RAMOS, João Gualberto Garcez. Curso de Processo Penal Norte-americano. São Paulo: Revista dos Tribunais, 2006, p. 151.

${ }^{469}$ SADEK, Maria Tereza Aina. Prefácio - Defensoria Pública: um agente de igualdade in: SOUSA, José Augusto Garcia de. Uma nova Defensoria Pública pede passagem - Reflexões sobre a Lei Complementar 132/09. Rio de Janeiro: Lumen Juris, 2011. p. xvi.

470 DEFENSA PÚBLICA OFICIAL COMO GARANTÍA DE ACCESO A LA JUSTICIA DE LAS PERSONAS EN CONDICIONES DE VULNERABILIDAD. Aprobada en la segunda sesión plenaria de OEA, 
da recente AG/RES. 2821 (XLIV-O/14), aprovada em 04 de junho de 2014, no âmbito da OEA, que deu novo fôlego à causa da Defensoria, a qual preceitua, em síntese, que todos os Estados que ainda não contem com o trabalho da instituição devem considerar a possibilidade de criá-la. Na íntegra:

Afirmando o caráter universal, indivisível e interdependente dos direitos humanos;

Afirmando ainda que os Estados membros têm a obrigação de respeitar e garantir o exercício dos direitos reconhecidos em tratados internacionais de que são partes e em sua legislação interna, eliminando os obstáculos que afetam ou limitam o acesso à defesa pública, de modo que o livre e pleno acesso à justiça é assegurada;

Destacando que a Convenção Americana sobre Direitos Humanos, em seu artigo 8 estabelece com amplitude as garantias judiciais;

Considerando que o acesso à justiça como um direito fundamental do ser humano é também o meio pelo qual se restaura o exercício de direitos que haviam sido ignorados ou violados, sem deixar de sublinhar que o acesso à justiça não termina quando a pessoas ingressa em um tribunal, mas estende-se ao longo de todo o processo, que deverá ser fundamentada em conformidade com os princípios do Estado de direito;

1. Afirmar que o acesso à justiça como um direito humano fundamental é, por sua vez, o meio que restaura o exercício dos direitos que haviam sido ignorados ou violados.

2. Apoiar o trabalho que está sendo desenvolvido pelos Defensores Públicos Oficiais do Hemisfério, que é essencial para o fortalecimento do acesso à justiça e à consolidação da democracia.

3. Afirmar a importância fundamental de serviços de assistência jurídica prestados pelos Defensores Públicos oficiais para a promoção e proteção do direito de acesso à justiça para todas as pessoas, especialmente aqueles que estão em situação particularmente vulnerável.

4. Reiterar aos Estados-Membros que já têm o serviço de assistência jurídica gratuita a adoção de medidas para garantir que os defensores públicos oficiais gozem de independência e autonomia funcional.

5. Incenetivar que os Estados que ainda não possuem defesa pública instituída considerem a possibilidade de criá-las no âmbito dos seus ordenamentos jurídicos. ${ }^{471}$

celebrada el 04 de junio de 2012. AG/RES. 2714 (XLII-O/12).

${ }^{471}$ Tradução livre de: "AFIRMANDO el carácter universal, indivisible e interdependiente de los derechos humanos;

AFIRMANDO TAMBIÉN que los Estados Miembros tienen la obligación de respetar y garantizar el ejercicio de los derechos reconocidos en los tratados internacionales de los que son parte y en sus legislaciones internas, eliminando los obstáculos que afecten o limiten el acceso a la defensa pública, de manera tal que se asegure el libre y pleno acceso a la justicia;

DESTACANDO que la Convención Americana sobre Derechos Humanos en su artículo 8 establece con amplitud las garantías judiciales;

CONSIDERANDO que el acceso a la justicia, en tanto derecho humano fundamental es, asimismo, el medio que permite restablecer el ejercicio de aquellos derechos que hubiesen sido desconocidos o vulnerados, a la vez que subraya que el acceso a la justicia no se agota con el ingreso de las personas a la instancia judicial, sino que se extiende a lo largo de todo proceso, que debe sustanciarse de conformidad con los principios del estado de derecho;

1. Afirmar que el acceso a la justicia, en tanto derecho humano fundamental es, a la vez, el medio que permite restablecer el ejercicio de aquellos derechos que hubiesen sido desconocidos o vulnerados. 
Institucionalmente, contudo, os desafios são consideráveis, tanto no que se refere aos recursos materiais e humanos quanto nas dificuldades de eleição de políticas face ao grau de exclusão que marca a realidade do país. ${ }^{472}$

Segundo o III Diagnóstico da Defensoria Pública no Brasil, ${ }^{473}$ as Defensorias Públicas estão presentes em menos da metade das comarcas brasileiras. Nas cidades em que se fazem presentes, os serviços de assistência jurídica são, na maioria das vezes, extremamente precários, inviabilizando o direito fundamental de acesso à justiça. Diante disso, pode-se dizer que os pobres brasileiros são tratados como cidadãos de segunda classe.

Tal situação revela-se sobremodo temerária, como traz Laszloczy ${ }^{474}$ : quando o homem se sente oprimido pela tirania, deseja a liberdade; porém, quando esta se degenera em caos, suplica o retorno do Leviatã; e, entre esses dois polos, se volta ao pensamento político, em busca de um ponto de equilíbrio. Agora, o mundo está se tornando cada vez menor, a criminalidade aumentando em quantidade, eficácia e perfídia. A violência inconsciente que atinge cada vez mais pessoas inocentes torna mais oportuna e urgente a exigência de cooperação dos Estados na defesa dos seus cidadãos-súditos. Mas esse apelo às

2. Apoyar el trabajo que vienen desarrollando los Defensores Públicos Oficiales de los Estados del Hemisferio, el cual constituye un aspecto esencial para el fortalecimiento del acceso a la justicia y la consolidación de la democracia.

3. Afirmar la importancia fundamental que tiene el servicio de asistencia letrada gratuita prestada por los Defensores Públicos Oficiales para la promoción y protección del derecho de acceso a la justicia de todas las personas, en particular de aquellas que se encuentran en una situación especial de vulnerabilidad.

4. Reiterar a los Estados Miembros que ya cuentan con el servicio de asistencia letrada gratuita que adopten acciones tendientes a que los defensores públicos oficiales gocen de independencia y autonomía funcional.

5. Alentar a los Estados que aún no cuenten con la institución de la defensa pública, que consideren la posibilidad de crearla en el marco de sus ordenamientos jurídicos."

472 Ibidem.

473 III Diagnóstico da Defensoria Pública no Brasil. Brasília: Ministério da Justiça. 2009 www.mj.gov.br/reforma acessado em 21.10.2011.

${ }^{474}$ No original: "Quando l'uomo si sente oppresso dalla tirannide desidera la libertà, ma quando questa degenera in caos, auspica il ritorno di Leviathan; e fra questi due poli si svolge oscillando il pensiero politico, alla ricerca di un punto d'equilibrio. Ora il mondo sempre più piccolo, la criminalità crescente in quantità, efficacia e perfidia, la violenza incosciente che sempre più si abbatte su ignari individui che altro non chiedono che di vivere nel rispetto e sotto l'usbergo delle leggi delle distinte Comunità Sovrane, rendono sempre più attuale ed impellente l'esigenza della cooperazione degli Stati nella tutela dei propri (cittadini-sudditi). Ma tale appello alle comuni forze delle Nazioni non deve fare dimenticare che dietro ogni Stato può celarsi un tiranno; che ogni legge apparentemente limpida può essere distorta, quando l'organizzazione dei pubblici poteri non garantisca al l'individuo quelie libertà che, almeno dal tempo delle rivoluzioni americana e francese/costituiscono l'aspettativa o il miraggio dei popoli. La collaborazione internazionale non può dunque avvenire a discapito di quelle garanzie per gli individui che sforzi secolari hanno conquistato e consacrato negli ordinamenti giuridici di molte Nazioni: nel tendere a ciò, anche a prezzo di attriti, riluttanze, rifiuti, l'ordinamento nazionale non rinnega valori essenziali di quello internazionale, se fra questi, per diria con Charles de Visscher si vogliono pur sempre comprendere " $i$ diritti fondamentali dell'uomo, la dignità ed il valore della persona umana", nei quali la carta delle nazioni Unite proclama la propria fede." (LASZLOCZKY, Paolo. La cooperazione internazionale negli atti d'istruzione penale. Padova: CEDAM, 1980, pp. 19, 20 e 21). 
forças comuns das nações não deve fazer esquecer que, por trás de cada Estado, pode se esconder um tirano e que toda lei aparentemente clara pode ser distorcida, quando a organização dos poderes públicos não garante aquelas liberdades ao indivíduo que, pelo menos desde o tempo das revoluções americana e francesa, constituem a expectativa ou a miragem do povo. A colaboração internacional não pode, portanto, ocorrer às custas dessas salvaguardas para os indivíduos conquistadas com esforços seculares e consagrados nos sistemas jurídicos de muitas nações: na tendência de que, mesmo ao preço de atrito e relutância, a legislação nacional não nega os valores essenciais da internacional, dentre eles, diria Charles de Visscher, "os direitos humanos fundamentais, a dignidade e o valor da pessoa humana”, nos quais a Carta das Nações Unidas proclamou a própria fé.

Não por acaso, o legislador constituinte, a fim de dar efetividade ao direito fundamental de acesso à justiça, previu instituição essencial à justiça denominada Defensoria Pública, que deve ser dotada de condições materiais e humanas para cumprir a sua missão constitucional precípua, qual seja, a de viabilizar o acesso à justiça àqueles desprovidos de recursos econômicos.

O Estado deve se aparelhar institucionalmente para permitir questionamentos à sua própria atuação, o que também é um direito econômico e social a sustentar o justo processo, mediante, por exemplo, o aparelhamento das defensorias públicas para atender aos primados do princípio da paridade de armas ínsito ao processo acusatório, ${ }^{475}$ pois, sob um enfoque publicístico, a defesa é entendida como garantia, não só do acusado mas também de um justo processo. Nesse sentido, a garantia é satisfeita somente se o contraditório for efetivo, a igualdade das armas, real. ${ }^{476}$

Por tudo isso, é que o presente trabalho, não obstante todos os desafios, vislumbra um futuro promissor para a defesa na cooperação jurídica internacional penal.

\footnotetext{
475 GEMAQUE, Silvio César Arouck. A necessária influência do processo penal internacional no processo penal brasileiro. Tese de Doutorado. Universidade de São Paulo. São Paulo, 2010, p. 38.

${ }^{476}$ MOURA, Maria Thereza Rocha de Assis; BASTOS, Cleunice A. Valentim. Defesa Penal: Direito ou Garantia. Revista Brasileira de Ciências Criminais. Ano 1, n. 4, out.-dez. 1993, p. 120.
} 


\section{CONSIDERAÇÕES FINAIS: FUTURO E DESAFIOS DA COOPERAÇÃO JURÍDICA INTERNACIONAL PENAL EM MATÉRIA DE DEFESA}

O Deus Janus, na mitologia romana, era o porteiro celestial, sendo representado com duas faces, uma que olhava para trás e outra para frente, representando os términos e os começos, o passado e o futuro.

Desse modo, reputa-se o momento atual de evolução do instituto da cooperação internacional como uma fase de transição; de certo modo, se está em um portal, como Janus, olhando para o futuro.

Até agora, a cooperação jurídica internacional penal evoluiu, primordialmente, para a facilitação da persecução penal, para a colheita de provas para a acusação, no intuito de coibir o avanço da criminalidade que atinge os países como um todo, que não respeita fronteiras e limites territoriais.

Entretanto, em contraponto, o respeito aos direitos humanos, em nível nacional e internacional, também apresenta grandes avanços, precisando angariar efetividade real no comportamento das nações.

Diante de tais constatações, reputa-se que o futuro da cooperação jurídica penal internacional está na disponibilização dos mesmos mecanismos postos à disposição da acusação, no procedimento de cooperação jurídica internacional, também à defesa, em plena e devida igualdade, haja vista não existir valor maior a ser respeitado que a dignidade da pessoa humana, que o homem em si mesmo.

Assim, não se justifica que a acusação tenha todos os meios mais céleres e efetivos para constituir sua prova e a defesa seja relegada a plano inferior, sendo-lhe apenas disponibilizados os meios mais custosos e burocráticos, sob pena de se instituir um verdadeiro Direito Penal do inimigo na cooperação jurídica internacional.

Nesse cenário, no primeiro capítulo, foi apresentado em linhas gerais o instituto da cooperação jurídica internacional, seu panorama histórico e arcabouço conceitual. Foram explanados também os princípios aplicáveis à cooperação jurídica internacional, respectiva classificação e as modalidades atualmente utilizadas, com ênfase à modalidade denominada auxílio direto, tendo em vista ser a via mais moderna e menos burocrática. Concernente ao tema específico objeto do trabalho, foram abordadas as hipóteses de denegação da utilização do auxílio direto pela defesa na cooperação jurídica internacional em matéria penal, 
mediante a análise das convenções e dos tratados bilaterais de auxílio jurídico mútuo ratificados pelo Brasil.

No segundo capítulo, o tema apreciado foi a igualdade das partes e os princípios e garantias atinentes ao devido processo penal, com o aprofundamento da análise da atuação da defesa e da instrumentalização da paridade de armas, mediante o exercício do contraditório diferido quando há a decretação da confidencialidade da medida cooperacional.

Nesse ponto, se pôde verificar que a inobservância dos direitos fundamentais tutelados pela legislação dos Estados pode implicar a ineficiência e ineficácia da cooperação. A resposta dada pelas instituições criminais internacionais nesse tópico é um tanto quanto ambígua. Os estatutos e as regras expõem claramente a necessidade de respeitar os direitos fundamentais. No entanto, a prática mostra a frequência com que se reluta em abandonar o discurso ao endurecimento penal. ${ }^{477}$

No terceiro capítulo, foi feita referência à experiência dos Tribunais Internacionais Penais em relação ao princípio da paridade de armas e a interação entre os sistemas do common law e do civil law, à mitigação da regra do non-inquiry e às críticas à eventual impossibilidade de utilização do auxílio direto pela defesa. Além disso, foram abordados os direitos dos investigados e a paridade de armas na cooperação jurídica internacional penal na União Europeia, com a explanação das tentativas e propostas veiculadas no âmbito comunitário com o intuito de equalizar o sistema, mediante a análise da possibilidade de se transplantar as soluções apresentadas com base no princípio do reconhecimento mútuo das decisões judiciais ao regime da mútua assistência aplicado em nosso país.

Como referido no texto, em suma, as Convenções Europeias em matéria de cooperação interestatal estão se movendo para o estágio de segunda geração, enquanto que a OEA e a ONU ainda estão na fase de sistema operacional de primeira geração, sistema no qual o Brasil está inserido. No entanto, como referido por Bassiouni, "estamos agora em um

477 Para Díez Ripollés, opinião que compartilha o presente trabalho e que cuja proposta intenta abrandar, em suma, a imagem da academia jurídico-penal nos últimos tempos roça muitas vezes a irresponsabilidade. Relutamos em entrar em questões político-criminais candentes, para evitar sermos abrasados por elas e, assim, preferimos nos refugiar no mundo "morno" dos conceitos jurídicos. Com isso, renunciamos ao desempenho de tarefas sociais que nos competem, ausência de cumprimento que dissimulamos torpemente mediante o emprego desqualificante de um conjunto de lugares comuns. (No original: "En resumidas cuentas, la imagen de la academia jurídicopenal en los últimos tiempos roza en demasiadas ocasiones la irresponsabilidad. Nos resistimos a entrar en las cuestiones políticocriminales candentes, para evitar ser abrasados en ellas, y preferimos ref ugiarnos en el templado mundo de los conceptos jurídicos. Con ello renunciamos a desempeñar las tareas sociales que nos competen, incumplimiento que disimulamos torpemente mediante el empleo descalificante de un conjunto de lugares comunes"). DÍEZ RIPOLLÉS, José L. El nuevo modelo penal de la seguridad ciudadana. Revista Electrónica de Ciencia Penal y Criminología. Núm. 06-03, 2004, p. 23. 
momento em que precisamos de uma terceira geração de instrumentos internacionais". ${ }^{478} \mathrm{E}$, como recomendação, já referida no desenvolvimento do trabalho, o autor sugere o desenvolvimento de novas modalidades de cooperação inter-estatal, com a aplicação de mecanismos similares aos já existentes, sendo particularmente importante compreender que a proteção dos direitos humanos individuais não é e não deve ser colocada em uma relação conflituosa com a eficácia do processo.

Levando em consideração esse premissa, no contexto jurídico nacional, foram explanadas as perspectivas para a defesa, o acesso internacional à justiça e a atuação da Defensoria Pública, como mecanismo de defesa social e como protagonista da cooperação jurídica internacional penal em matéria de defesa, oportunidade em que as seguintes soluções foram apresentadas: a criação de redes de cooperação para a defesa ou, em princípio, a utilização das redes já existentes; a utilização da cooperação horizontal, por meio de tratados bilaterais em prol da defesa, com a utilização do mecanismo das autoridades centrais; a inclusão da Defensoria Pública nas normativas já existentes em relação ao tema, de modo a assegurar amplo e efetivo acesso à justiça.

Além disso, chegou-se à conclusão de que a Corte Interamericana de Direitos Humanos, assim como já ocorre no Tribunal de Justiça da União Europeia, deveria ser instrumentalizada para atuação inicial — já na fase policial — em casos de ofensa dos direitos humanos e processuais dos acusados no início do processo - casos de colheita de provas na cooperação jurídica internacional sem atenção a todos os direitos previstos na Convenção Americana de Direitos Humanos e regulamentos nacionais, por exemplo.

De todo modo, reconhece-se que a tarefa é árdua e que se está em fase bastante incipiente em relação ao tema, não obstante todo o respaldo teórico que já autorizaria a implementação das referidas medidas no âmbito jurídico, e reconhece-se que a questão também diz respeito a questões eminentemente políticas.

Não restam dúvidas acerca do fato de o tema ser ainda bastante novo e que, não obstante as suas premissas conceituais - a questão da paridade de armas e da aplicação do padrão normativo universal dos direitos humanos, por exemplo — já tenham sido objeto de alguma discussão no plano nacional e internacional, certo é que a temática da defesa na cooperação jurídica internacional obteve, até o momento, pouca dedicação por parte da doutrina, em especial da doutrina nacional.

A própria jurisprudência do Supremo Tribunal Federal ainda carece de definição

\footnotetext{
${ }^{478}$ BASSIOUNI, M. Cherif. Policy Considerations on Inter-State Cooperation in Criminal Matters. Pace Y.B. International Law. Vol. 4, Issue 123, 1992, p. 139.
} 
acerca da aplicação integral dos direitos fundamentais a todas as formas de cooperação internacional penal. ${ }^{479}$

A verdadeira democracia, segundo a lição de Alexis de Tocqueville, tem como pressuposto elementar um estágio de "igualdade de condições" entre os cidadãos, que conduz á ideia da necessidade de se reconhecer a importância da "igualdade de armas" entre as partes litigantes num processo judicial, igualdade essa que deve ser garantida pelo Poder Público.

Até mesmo porque o escopo primordial do processo penal é a avaliação da responsabilidade penal e não a mera punição ${ }^{480}$ : ser capaz de forma eficaz e eficiente de infligir a pena não é o único propósito da cooperação internacional em matéria penal, uma vez que não é a única finalidade do processo penal. Séculos de cultura jurídica nos ensinaram que, antes de punir, é preciso determinar se, quem e em que medida punir. A determinação da responsabilidade criminal, não a punição, é o principal escopo do processo.

Ademais, em qualquer sistema de justiça criminal, a observação das regras persecutórias, de busca de prova e do justo processo revelam a maturidade da estrutura do Estado de Direito. É desse modo que se pretende que a cooperação jurídica internacional penal também possa alcançar esse grau de amadurecimento, com o devido respeito aos princípios processuais penais.

Entretanto, uma coisa é certa: os Estados devem cercar seu próprio processo de todas as garantias processuais, colocando à disposição da pessoa objeto do pedido de cooperação,

\footnotetext{
${ }^{479}$ Como conclui Denise Neves Abade: “A grande lacuna (na jurisprudência do STF), contudo, está ainda na falta de detalhamento, por parte da maioria formada, sobre o norte da aplicação dos demais direitos fundamentais previstos na Constituição à extradição e, ainda, se esse princípio (aplicação de direitos fundamentais na extradição) não deveria também, por coerência, ser transposto para outras formas de cooperação internacional penal." (ABADE, Denise Neves. Direitos fundamentais na cooperação jurídica internacional: extradição, assistência jurídica, execução de sentença estrangeira e transferência de presos. São Paulo: Saraiva, 2013. p. 296). Pode-se pensar que a extradição, por configurar a modalidade mais antiga, abarca discussões mais arrojadas, as quais, entretanto, devem ser levadas a efeito em todas as modalidades cooperacionais em uso pelo país. Sobreleva sinalar, ainda, em relação à aplicação dos direitos fundamentais ao instituto do auxílio direto, especificamente, as considerações de Denise Neves Abade sobre a questão: "No que tange à aplicação dos direitos fundamentais na cooperação, vemos que a ressurreição do auxílio direto quando pensávamos que o instituto havia sido extinto pelas cortes nacionais - fez renascer uma via pela qual os direitos fundamentais previstos no Brasil incidirão diretamente ao pleito cooperacional, uma vez que o pedido estrangeiro é, neste caso, mero fundamento de ações internas promovidas pelas autoridades brasileiras competentes, submetidas, é claro, aos direitos fundamentais estatuídos na Constituição e tratados internacionais." (Ibidem, p. 321-2)

${ }^{480}$ No original: "Il poter effettivamente ed efficacemente infliggere la sanzione penal e non è il solo scopo dela collaborazione internazionale in materia penale, come non è il solo scopo del processo penale. Secoli di civiltà gíuridica ci hanno insegnato che prima di punire, bisogna accertare se, chi, ed in qual misura punire. L' accertamento della responsabilità penale, non la punizione, è lo scopo principale del processo". (LASZLOCZKY, Paolo. La cooperazione internazionale negli atti d'istruzione penale. Padova: CEDAM, 1980, p. 9).
} 
mas sujeito processual, todo o arsenal próprio do devido processo legal (direito de defesa, incluindo a autodefesa e a defesa técnica; contraditório, com o direito à prova; publicidade, motivação das decisões; duplo grau, exclusão das provas obtidas por meios ilícitos, direito a intérprete, dentre outros).

O Processo Penal e o Direito Internacional devem, portanto, tentar abarcar o movimento de meios e recursos destinados a combater a delinquência transnacional e superar as dificuldades fáticas de uma investigação dessa natureza e, inclusive, as dificuldades derivadas das diferenças específicas entre as legislações dos distintos países, em relação aos direitos de defesa.

Apenas para reflexão, finaliza-se com a seguinte passagem extraída da obra "Fundamentos do Direito Internacional Pós-Moderno" do Professor Paulo Borba Casella ${ }^{481}$.

Pode a utopia, às vezes, vir a ser alcançada pela realidade? A ideia de organização internacional, que coordena a convivência entre os Estados, foi utópica, até que se desse a instauração da Liga das Nações, depois da primeira guerra mundial, com a passagem do patamar da coexistência para ser encetado o da cooperação. Pode esta não ter conseguido evitar a eclosão de nova guerra, mas representou a instauração de patamar nunca antes experimentado e mutação qualitativa do direito internacional, depois de todos os séculos de coexistência para começar o patamar da cooperação. [...] Se não se puder fazer o mundo ir mais longe e mais adiante, parte-se para a terra do nunca, utopia sob a égide de São Tomas Morus.

Ainda que, no momento presente, a proposta do trabalho possa parecer utópica, pretende-se fazer avançar no cenário da cooperação jurídica internacional, como referido na epígrafe: "[...] que a sua hora misteriosa tenha chegado e que se difunda pela terra toda". Com a promoção do debate e suas repercussões, espera-se que novas ideias surjam, com propostas hábeis a incluir e empoderar a defesa nesta temática, e que essas ideias possibilitem concluir que o mundo realmente mudou desde que a seguinte sentença foi pronunciada: "Justice is open to all, like the Ritz Hotel". ${ }^{482}$.

${ }^{481}$ Casella, Paulo Borba. Fundamentos do direito internacional pós-moderno. São Paulo : Quartier Latin, 2008, p. 34.

${ }^{482}$ Tradução livre de: “A justiça é acessível a todos, assim como o Ritz Hotel.” Aforismo atribuído ao Magistrado inglês Sir Charles James Mathew, falecido em 1908. 


\section{REFERÊNCIAS}

ABA, Luz María Puente; BARBEITO, Mónica Zapico; MORO, Luís Rodríguez (Coords.). Criminalidad Organizada, Terrorismo e Inmigración: Retos contemporáneos de la política criminal. Granada: Comares S.L, 2008.

ABADE, Denise Neves. Direitos fundamentais na cooperação jurídica internacional: extradição, assistência jurídica, execução de sentença estrangeira e transferência de presos. São Paulo: Saraiva, 2013.

Garantias do Processo Penal Acusatório: o Novo Papel do Ministério Público no Processo Penal de Partes. Rio de Janeiro: Renovar, 2005.

ABELLÁN, Marina Gascón. Los Hechos en el Derecho - Bases argumentales de la prueba. 3ed. Madrid: Marcial Pons, 2010.

ACCIOLY, Hildebrando; NASCIMENTO E SILVA, Geraldo E. e CASELLA, Paulo Borba. Manual de Direito Internacional Público. 20ª ed., São Paulo: Saraiva, 2012.

ALBANESE, Jay; REICHEL, Philip. Handbook of Transnational Crime and Justice. 2th Edition. Washington, USA: SAGE, 2013.

ALEGRE, Susie; LEAF, Marisa. Mutual Recognition in European Judicial Cooperation: A Step Too Far Too Soon? Case Study - the European Arrest Warrant. European Law Journal, Vol. 10, No. 2, March 2004, pp. 200-217.

AGUILERA MORALES, Marian. El Exhorto Europeo de Investigación: A la Búsqueda de la Eficacia y la Protección de los Derechos Fundamentales en las Investigaciones Penales Transfonterizas. Boletín del Ministerio de Justicia. Año LXV, n. 2145. Agosto, 2012, pp. 127.

ALMEIDA, Ricardo; ARAÚJO, Nádia; Salles, Carlos Alberto. Cooperação Interjurisdicional no Mercosul. Cartas Rogatórias, Homologação de Sentenças Estrangeiras e Laudos Arbitrais e Informação do Direito Estrangeiro. In: BASSO, Maristela (org.) Mercosul, seus efeitos jurídicos, econômicos e políticos nos Estados Membros. Porto Alegre: Livraria do Advogado, 1997.

ALVES, Cleber Francisco. Justiça para Todos! Assistência Jurídica Gratuita nos Estados Unidos, na França e no Brasil. Rio de Janeiro: Lumen Juris, 2006.

AMANN, Diane Marie. The Rights of the accused in a Global Enforcement Area. ILSA Journal of International \& Comparative Law, Vol. 6, 2000. 
AMBOS, Kai. La parte general del derecho penal internacional: bases para una elaboración dogmática. Tradução de Ezequile Malarino. Montevideo: Fundacion KonradAdenaur, 2005.

; La Nueva Justicia Penal Internacional. Guatemala: Fundación Myrna Mack, 2000.

; MALARINO, Ezequiel; WOISCHNIK, Jan (Orgs.). Temas Actuales del Derecho Penal Internacional: contribuciones de América Latina, Alemania y España. Urugüai: Fundación Konrad-Adenauer, 2005.

Temas de Derecho Penal Internacional y Europeu. Barcelona: Marcial Pons, 2006.

AMODIO, Ennio. Giusto processo, Procès Équitable e Fair Trial: La Riscoperta del Giusnaturalismo Processuale in Europa. In: Rivista Italiana di Diritto e Procedura Penale. Nuova Serie - Anno XLVI, Fasc. 1-2 - Milano: Dott. A. Giuffrè Editore, Gennaio-Giugno, 2003.

; BASSIOUNI, M. Cherif (orgs.). Il Processo Penale negli Stati Uniti D’America. Milano: Giuffrè Editore, 1988.

AMSTERDAM, Robert R. KNOOPS, Geert-Jan Alexander. THE DUALITY OF STATE COOPERATION WITHIN INTERNATIONAL AND NATIONAL CRIMINAL CASES. In: Fordham University School of Law, Fordham International Law Journal, Jan. 2007.

ANNONI, Danielle. O Direito Humano de Acesso à Justiça no Brasil. Porto Alegre: Sergio Antonio Fabris Editor, 2008.

ANSELMO, Márcio Adriano. Cooperação Internacional em Matéria Penal no Âmbito do Mercosul - Anatomia do Protocolo de San Luis. In: BALTAZAR Jr. José Paulo e LIMA, Luciano Flores de Lima. Cooperação Jurídica Internacional em Matéria Penal. Porto Alegre, Verbo Jurídico, 2010.

Lavagem de dinheiro e cooperação jurídica internacional: de acordo com a Lei

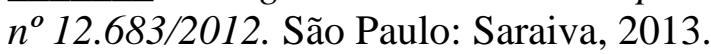

ARAS, Vladimir. O papel da autoridade central nos acordos de cooperação penal internacional. In: BALTAZAR Jr. José Paulo e LIMA, Luciano Flores de Lima. Porto Alegre, Verbo Juridico, 2010.

; LIMA, Luciano Flores de. Cooperação Internacional Direta pela Polícia ou Ministério Público. In: BALTAZAR Jr. José Paulo e LIMA, Luciano Flores de Lima. Porto Alegre, Verbo Juridico, 2010, p. 140. 
ARANGÜENA FANEGO, Coral. Nuevas Directivas Sobre Derechos Procesales de Sospechosos e Imputados en el Proceso Penal. In: ARANGÜENA FANEGO, Coral (Coord.). Cooperación Judicial Civil y Penal en el Nuevo Escenario de Lisboa. Granada: Editorial Comares, 2011, pp. 269-301.

(Coord.). Espacio Europeo de Libertad, Seguridad y Justicia: últimos avances em cooperación judicial penal. Valladolid: Lex Nova, 2010.

ARAUJO, Nadia. A importância da cooperação jurídica internacional para a atuação do Estado brasileiro no plano interno e internacional. In: CARVALHO RAMOS, André e CASELLA, Paulo Borba (orgs). Direito Internacional: homenagem a Adherbal Meira Mattos. São Paulo: Quartier Latin, 2009, pp. 98-114.

. Direito Internacional Privado: teoria e prática brasileira. 4 ed. Atualizada e ampliada. Rio de Janeiro: Renovar, 2008.

. Cooperação Jurídica Internacional no Superior Tribunal de Justiça. Rio de Janeiro: Renovar, 2010, pp. 01-17.

; SALLES, Carlos Alberto de; ALMEIDA, Ricardo Ramalho. Medidas de Cooperação interjurisdicional no MERCOSUL. Revista de Proceso, São Paulo: RT, v. 30, n. 123, p. 45, mai. 2005.

; CASELLA, Paulo Borba. Integração Jurídica Interamericana. São Paulo: LTR, 1998.

AYAGO, Antonia Durán. El Derecho a la Asistencia Jurídica Gratuita en los Litigios Transfonterizos. Vol. 22, Revista Electrónica de Estudios Internacionales, 2011.

AZEVEDO, Rodrigo Ghiringhelli de; CARVALHO, Salo de (orgs.). A Crise no Processo Penal e as Novas Formas de Administração da Justiça Criminal. Sapucaia do Sul: Notadez, 2006.

BACIGALUPO, Enrique. Justicia Penal y derechos fundamentales. Madrid: Marcial Pons Ediciones Jurídicas y Sociales, 2002.

BACIGAlUPO, Silvina; MELIÁ, Manuel Cancio (coords.). Derecho Penal y Política Transnacional. Barcelona: Atelier, 2005.

BADARÓ, Gustavo Henrique Righi Ivahy. Ônus da Prova no Processo Penal. São Paulo: Editora Revista dos Tribunais, 2003. 
BADARÓ, Gustavo; LOPES JR, Aury. Direito ao processo penal no prazo razoável. Rio de Janeiro: Lumen Juris, 2006.

BALBO, Paola. Il Terrorismo: Le Fattispecie di un Reato in Evoluzione Nelle Disposizioni Italiane ed Internazionale. Itália: Halley Editrice, 2007.

BALUTA, José Jairo; CUNHA, J. S. Fagundes. O Processo Penal à Luz do Pacto de São José da Costa Rica. Curitiba: Juruá, 2000.

BAPTISTA, Luiz Olavo; FONSECA, José Roberto Franco da (Coords.). O Direito Internacional no Terceiro Milênio: Estudos em homenagem ao Professor Vicente Marotta Rangel. São Paulo: Ltr, 1998.

BARCELLOS, Ana Paula de. A eficácia jurídica dos princípios constitucionais. O princípio da dignidade da pessoa humana. Rio de Janeiro: Renovar: 2002.

BARRADO, Cástor Miguel Díaz. La Lucha contra Delincuencia Organizada en el Espacio Iberoamericano. Revista Electrónica de Estudios Internacionales. Vol. 20, 2010.

BARRETO, Irineo Cabral: A Convenção Europeia dos Direitos do Homen Anotada, 3 ed. Coimbra Editora Coimbra, 2005

BARROS, Antonio Milton de. Da Prova no Processo Penal: Apontamentos Gerais. São Paulo: Editora Juarez de Oliveira, 2001.

BARROS, Marco Antonio de. A Busca da Verdade no Processo Penal. 2a. ed. rev., atual. e ampl. São Paulo: Editora Revista dos Tribunais, 2010.

BARROS, Sérgio Resende de. Direitos Humanos: paradoxo da civilização. Belo Horizonte: Del Rey, 2003.

BARROSO, Luís Roberto; TIBURCIO, Carmen (Org.). O Direito Internacional contemporâneo: estudos em homenagem ao Professor Jacob Dolinger. Rio de Janeiro: Renovar, 2006.

BASSIOUNI, M. Cherif. Derecho Penal Internacional: Proyecto de Código Penal Internacional. Madrid: Tecnos, 1984.

. Policy Considerations on Inter-State Cooperation in Criminal Matters. Pace Y.B. International Law. Vol. 4, Issue 123, 1992. 
BASSIOUNI, M. Cherif. A Comprehensive Strategic Approach on International Cooperation for the Prevention Control and Suppression of International and Transnational Criminality. Nova Law Review. Vol. 15, 1991.

BATES, Sanford. One World in Penology. Journal of Criminal Law and Criminology. Vol. 38, n. 6, mar-abr 1948.

BAZELAIRE, Jean-Paul; CRETIN, Thierry. A Justiça Penal Internacional: sua evolução, seu futuro - De Nuremberg a Haia. Tradução de Luciana Pinto Venâncio. Barueri, SP: Manole, 2004.

BECHARA, Fábio Ramazzini. Cooperação Jurídica Internacional em Matéria Penal: Eficácia da Prova Produzida no Exterior. São Paulo: Saraiva, 2011.

BEDAQUE, José roberto dos Santos. Poderes Instrutórios do Juiz. 2a ed. São Paulo: RT, 1994.

BELTRAME, Adriana. Cooperação Jurídica Internacional. In: Revista de Processo, vol. 162, Ago. 2008.

BERGMAN, Eduardo Tellechea. La Cooperación Jurisdiccional Internacional en el Ámbito Interamericano y del Mercosur, con Especial Referencia al Derecho Uruguayo. Boletín Mexicano de Derecho Comparado. Disponível em: <https://vpn.upf.edu/+CSCO+00756767633A2F2F6A6A6A2E776865767176706E662E68 616E7A2E7A6B++/publica/rev/boletin/cont/123.5/cnt/cnt39.htm>.

BEZERRA, Camila Colares. SAADI, Ricardo Andrade. Papel da Autoridade Central Brasileira para Cooperação Jurídica: DRCI. In: Revista Criminal - Ensaios sobre a atividade policial. Ano 04. Vol. 10. Jan./Abr. 2010.

BIRGIN, Haydée; KOHEN, Beatriz (compiladoras). Acceso a la justicia como garantía de igualdad - Instituciones, actores y experiencias comparadas. 1a Ed. Buenos Aires: Biblos, 2006.

BOBBIO, Norberto. Presente e futuro dos direitos do homem. In: A Era dos Direitos. Rio de Janeiro: Campus, 1992, p. 25-47.

BONDT, Wendy De; VERMEULEN, Gert. The Procedural Rights Debate. A Bridge Too Far or Still Not Far Enough? EUCRIM, vol. 4, 2010.

BORGES, Paulo César Corrêa (Coord.). O Princípio da Igualdade na Perspectiva Penal: Temais Atuais. São Paulo: UNESP, 2007. 
BRANTS, Chrisje; FIELD, Stewart; JÖRG, Nico. Are Inquisitorial and Adversarial Systems Converging? In: FENNELL, Phil; HARDING, Christopher; JÖRG, Nico; SWART, Bert. (Editores.). Criminal Justice in Europe - A comparative Study. New York: Clarendon Press and Oxford University Press, 2002.

BRAZ, Mário Sérgio A. Imunidade de jurisdição e negativa de exequatur a cartas rogatórias passivas. Revista Forense, v. 100, n. 376, p. 431, Nov/dez. 2004.

BULNES, Mar Jimeno. (Coord). La Cooperación Judicial Civil y Penal en el Ámbito de la Unión Europea: instrumentos procesales. Barcelona: Bosch Editor, 2007.

European Judicial Cooperation in Criminal Matters. European Law Journal, Vol. 9, No. 5, Dez. 2003, pp. 614-630.

CANOTILHO, José Joaquim Gomes. Constituição dirigente e vinculação do legislador: contributo para a compreensão das normas constitucionais programáticas. Coimbra: Coimbra Ed., 1994.

CAPE, Ed; HODGSON; Jacqueline; PRAKKEN, Ties; SPRONKEN, Taru. Suspects in Europe Procedural Rights at the Investigative Stage of the Criminal Process in the European Union. Antwerpen - Oxford: Intersentia, 2007.

CAPELLETI, Mauro; GARTH, Bryant. Access to Justice - A World Survey. Vol. 1. Book 1. Milão: Sijthoff - Giuffrè Editore, 1978.

CAPELLETI, Mauro; GARTH, Bryant. Access to Justice - A World Survey. Vol. 1. Book 2. Milão: Sijthoff - Giuffrè Editore, 1978.

Acesso à Justiça: Tradução Ellen Gracie Northfleet, Sergio Antonio Fabris Editor, Porto Alegre, 1998.

CARLSON, Scott; ZAGARIS, Bruce. International Cooperation in Criminal Matters: Western Europe's International Approach to International Crime. HeinOnline 15 Nova L. Rev. 551, 1991.

CARVALHO RAMOS, André de. A execução das sentenças da Corte Interamericana de Direitos Humanos no Brasil. In: CASELLA, Paulo Borba, MEIRELLES, Elisabeth de Almeida e POLIDO, Fabricio B. Pasquot (Orgs.). Direito Internacional, Humanismo e Globalidade - Guido Fernando Silva Soares Amicorum Discipulorum Liber. Rio de Janeiro: Renovar, 2008, pp. 461-468. 
CARVAlHO, Salo de. A Política Criminal de Drogas no Brasil (Estudo Criminológico e Dogmático). 4a ed. ampliada e atualizada. Rio de Janeiro: Lumen Juris, 2007.

CASELLA, Paulo B. e SANCHEZ, Rodrigo E. (org). Cooperação judiciária internacional. Rio de Janeiro: Ed. Renovar, 2002.

CASELLA, Paulo Borba. A ordem pública e a execução de cartas rogatórias no Brasil in: Revista da Faculdade de Direito da Universidade de São Paulo, v. 98, 2003. p. 563-571.

2008 .

Fundamentos do Direito Internacional Pós-Moderno. São Paulo: Quartier Latin,

CASSESE, Antonio; DELMAS-MARTY, Mireille (Coords.). Crimes Internationaux et Juridictions Internationales. Paris: Presses Universitaires de France, 2002.

International Criminal Law. $2^{\text {nd }}$ Ed. Oxford: Oxford University Press, 2008.

CATENA, Víctor Moreno. La Garantía de los Derechos Fundamentales durante la Investigación Penal. In: Cuadernos Penales José María Lidón, n. 7, Problemas Actuales del Proceso Penal y Derechos Fundamentales. Bilbao: Universidad de Deusto, 2010.

La Cooperación Jurídica Internacional. In: Problemas Actuales del Derecho Penal y de la Criminología - Estudios penales em memoria de la Profesora Dra. María del Mar Días Pita. CONDE, Francisco Muñoz (Dir.). Valencia: Tirant lo Blanch, 2008.

CERVINI, Raúl e TAVARES, Juarez. Princípios de cooperação judicial penal internacional no protocolo do Mercosul. São Paulo: Editora Revista dos Tribunais, 2000.

Os processos de descriminalização. 2a ed. São Paulo: RT, 1995.

. Princípios da Cooperação Judicial Internacional em Assuntos Penais. Doutrina Direito Comparado. Disponível em: <http://www.amprs.org.br/arquivos/revista_artigo/arquivo_1283279756.pdf >. Último acesso em: 18 fev. 2014.

Principio de Confidencialidad y Magisterio de la Defensa en la Cooperación Judicial Penal Internacional. Revista de la Facultad de Derecho, $\mathrm{n}^{\mathrm{o}} 31$, Montevideo, juliodiciembre 2011, pp. 103-115. 
CHOUKR, Fauzi Hassan. As Garantias Constitucionais na Investigação Criminal. Dissertação de Mestrado apresentada à Faculdade de Direito da Universidade de São Paulo, sob a orientação da Professora Doutora Ada Pellegrini Grinover. São Paulo, 1993.

Processo Penal à Luz da Constituição. 1. ed. São Paulo: Edipro, 1999.

CLEMENTINO, Marco Bruno Miranda. A Cooperação Jurídica Internacional em Matéria Penal e as Dificuldades Enfrentadas no Direito Brasileiro. In: Direito Federal - Revista da Associação dos Juízes Federais do Brasil, v. 25, n. 92, jan./jun, 2012. p. 221-240.

CÓDIGO de Cooperação Interjurisdicional para Ibero-américa. Revista da SJRJ, Rio de Janeiro, n. 25, 2009, p. 429-456.

COMPARATO, Fábio Konder. A afirmação histórica dos Direitos Humanos. 3. ed. São Paulo: Saraiva, 2004.

CONRADI, Faustino Gutiérrez-Alviz (Org.). La Criminalidad Organizada ante la Justicia. Sevilla: Universidad de Sevilla, 1996.

CORDANI, Dora Cavalcanti. Cooperação Jurídica Internacional em Matéria Penal no Brasil: as Cartas Rogatórias e o Auxílio Direto - Controle dos Atos pela Parte Atingida. In: VILARDI, Celso Sanchez; PEREIRA, Flávia Rahal Bresser; NETO, Theodomiro Dias. Direito Penal Econômico - Crimes Econômicos e Processo Penal. São Paulo: GVLaw e Ed. Saraiva, 2008.

COSTA, Jorge Albino Alves. La Creación de la Fiscalía Europea. In: FANEGO, Coral Arangüena (Coord.). Espacio Europeo de Libertad, Seguridad y Justicia: últimos avances em cooperación judicial penal. Valladolid: Lex Nova, 2010, pp. 98 y ss.

COSTA, Paula Bajer Fernandes Martins da. Igualdade no Direito Processual Penal Brasileiro. São Paulo: Editora Revista dos Tribunais, 2001.

CUADRADO, Maria Pia Calderón; DEU, Teresa Armenta; SANTOS, Andrés de La Oliva. (Coords.) Garantías Fundamentales del Proceso Penal en el Espacio Judicial Europeo. Madrid: Colex, 2007.

D’ANGELIS, Wagner Rocha. In: D’ANGELIS, Wagner Rocha (Org.). Direito Internacional do século XXI: Integração, Justiça e Paz. Curitiba: Juruá, 2005.

DAVIN, João. A criminalidade organizada Transnacional: a cooperação judiciária e policial na UE. 2a ed. Rev. e Ampl. Coimbra: Almedina, 2007. 
DEFLEM, Mathieu. Global Rule of law or global rule of Law Enforcement? International police cooperation and Counterterrorism. Annals of the American Academy of Political and Social Science. Vol. 603, Law, Society, and Democracy: Comaprative Perspectives. Jan 2006, pp. 240-251. Disponível em: <http://www.jstor.org/stable/25097769>. Acesso em: 29 set. 2012.

DEFENSA PÚBLICA OFICIAL COMO GARANTÍA DE ACCESO A LA JUSTICIA DE LAS PERSONAS EN CONDICIONES DE VULNERABILIDAD. Aprobada en la segunda sesión plenaria de OEA, celebrada el 4 de junio de 2012. AG/RES. 2714 (XLII-O/12).

DELGADO MARTÍN, Joaquín. La Orden de Detención Europea y los Procedimientos de Entrega entre los Estados Mimebros de La Unión Europea. In: PECO, Ángel Galgo (Director). Derecho Penal Supranancional y Cooperación Jurídica Internacional. Cuadernos de Derecho Judicial, XIII. Madrid: Consejo General del Poder Judicial - Centro de documentación Judicial, 2003.

DELMAS-MARTY, Mireille. A imprecisão do Direito: do Código Penal aos Direitos Humanos (tradução Denise Radanovic Vieira). Barueri,SP: Manole, 2005.

O direito penal como ética da mundialização. Revista Portuguesa de Ciência Criminal. Coimbra, v. 14, n. 3, p. 287-304, jul./set. 2004.

Os Grandes Sistemas de Política Criminal. Tradução de Denise Radanovic Vieira. Barueri, SP: Manole, 2004.

Trois défis pour un droit mondial. Paris: Éditions du Seuil, 1998.

DIAGO, Maria del Pilar Diago. La Obtención de Pruebas en la Unión Europea. Navarra: Thomson Aranzadi, 2003.

DIOS, José Maria de. La Asistencia Jurídica Gratuita en Derecho Internacional Privado Español. Madrid: Eurolex D.L., 1999.

DIPP, Gilson Langaro. Carta rogatória e cooperação internacional. In: MANUAL DE COOPERAÇÃO JURÍDICA INTERNACIONAL E RECUPERAÇÃO DE ATIVOS. Cooperação em Matéria Penal. Brasília: Secretaria Nacional de Justiça, 2008.

DIREITO, Carlos Alberto; PEREIRA, Antônio Celso; TRINDADE, Antônio Augusto Cançado (Orgs.). Novas perspectivas do Direito Internacional contemporâneo: estudos em homenagem ao Professor Celso D. Albuquerque Mello. Rio de Janeiro: Renovar, 2008. 
DOCUMENTO DE TRABAJO relativo a la asistencia jurídica gratuita provisional a los sospechosos o acusados privados de libertad y a la asistencia jurídica gratuita en el procedimiento de la orden de detención europea. Comisión de Libertades Civiles, Justicia y Asuntos de Interior Ponente: Cornelis de Jong. Disponível em: $<$ http://www.europarl.europa.eu/sides/getDoc.do?pubRef=\%2F\%2FEP\%2F\%2FNONSGM $\%$ 2BCOMPARL $\% 2 \mathrm{BPE}-530.085 \% 2 \mathrm{~B} 02 \% 2 \mathrm{BDOC} \% 2 \mathrm{BPDF} \% 2 \mathrm{BV} 0 \% 2 \mathrm{~F} \% 2 \mathrm{FES}>$. Acesso em 30 abr. 2014.

DOLINGER, Jacob. Direito internacional privado (parte geral). Rio de Janeiro: Renovar, 1997.

Os Estados Unidos perante o direito internacional. A decadência jurídica de uma grande nação in: Novas perspectivas do direito internacional contemporâneo - Estudos em homenagem ao Professor Celso D. De Albuquerque Mello. Carlos Alberto Menezes Direito, Antônio Augusto Cançado Trindade, Antônio Celso Alves Pereira (orgs.). Rio de Janeiro: Renovar, 2008.

DORNELAS, Luciano Ferreira. Tráfico de Pessoa: cooperação jurídica internacional no combate ao tráfico. Curitiba: Edição do Autor, 2012.

DREYZIN DE KLOR, Adriana Los Instrumentos De Cooperación Jurisdiccional Del Mercosur, ¿Útiles a la Asistencia? Revista de Derecho Privado y Comunitario, 2009, n.o 3, pp. 608 e seguintes.

ESTELLITA, Heloisa. Prerrogativas Processuais dos Acusados Estrangeiros: O Outro Lado da Moeda da "Luta Contra o Crime Transnacional". Boletim IBCCRIM. Ano 18, n. 214, set. 2010.

FANEGO, Coral Arangüena (Coord.). Cooperación Judicial Civil y Penal en el Nuevo Escenario de Lisboa. Granada: Editorial Comares, 2011.

(Coord.) Espacio Europeo de Libertad, Seguridad y Justicia: últimos avances em cooperación judicial penal. Valladolid: Lex Nova, 2010.

FARIA COSTA, J. A Globalização e o Direito Penal (ou o Tributo da Consonância ao Elogio da Incompletude). In: Globalização e Direito, STVDIA IVRIDICA, 73, coloquio 12, Coimbra Editora, pp. 182-186.

FERNANDES, Antonio Scarance. O Tempo e o Movimento no Processo Penal: A Eficiência e o Garantismo em uma Visão Equilibrada do Processo Penal. In LIMA, Marcellus Polastri; SANTIAGO, Nestor Eduardo Araruna (Coords.). A Renovação Processual Penal após a Constituição de 1988: Estudos em Homenagem ao Professor José Barcelos de Souza. Rio de Janeiro: Lumen Juris, 2009. 
FERNÁNDEZ, Begoña Vidal. Obtención de Pruebas. In: BULNES, Mar Jimeno. (Coord). La Cooperación Judicial Civil y Penal en el Ámbito de la Unión Europea: instrumentos procesales. Barcelona: Bosch Editor, 2007.

Reflexões sobre as noções de eficiência e de garantismo no processo penal. In: FERNANDES, Antonio Scarance; ALMEIDA, José Raul Gavião de; MORAES, Maurício Zanoide de. Sigilo no processo penal: eficiência e garantismo. São Paulo: Revista dos Tribunais, 2008.

; ALMEIDA, José Raul Gavião de; MORAES, Maurício Zanoide de (Coords.). Crime Organizado - aspectos processuais. São Paulo: Revista dos Tribunais, 2009.

Processo penal constitucional.4 $4^{\mathrm{a}}$ Ed. São Paulo: Revista dos Tribunais, 2005.

FERRAJOLI, Luigi. Derecho y razón - Teoría del garantismo penal. 10a ed., Madrid: Editorial Trotta, 2011.

. A Soberania no Mundo Moderno: nascimento e crise do Estado nacional. Traduzido por Carlo Coccioli e Márcio Lauria Filho. São Paulo: Martins Fontes, 2002.

Garantismo y Defensa Penal - o sobre la defensa pública. In: REVISTA DAS DEFENSORIAS PÚBLICAS DO MERCOSUL (REDPO). Defensoria Pública da União. n. 1 (out./2010). Brasília: DPU, 2010, 247 p.

FIJNAUT, Cyrille; OUWERKERK, Jannemieke. The Future of Police and Judicial Cooperation in the European Union. Martinus Nijhoff Publishers: Leiden/Boston, 2010.

FRÍAS, Ana Salinas de; GÓMEZ-URRUTIA, Marina Vargas (Coords.). Soberanía del Estado y Derecho Internacional - Homenaje al Profesor Juan Antonio Carrillo Salcedo. Sevilla: Servicio de Publicaciones Universidad de Córdoba, Secretariado de Publicaciones Universidad de Sevilla y Servicio de Publicaciones Universidad de Málaga, 2005.

G., Rodrigo P. Correa. Chile. I CON International Journal of Constitutional Law. Nova Iorque, n. 1, vol. 1, 2002, p. 130-5.

G., Daniel Zovatto. Los Derechos Humanos en el Sistema Interamericano: Recopilación de Instrumentos Básicos. San José, Costa Rica: Instituto Interamericano de Derechos.

GARCÍA, Enrique Vallines. Los Equipos Conjuntos de Investigación Penal: en el marco de la cooperación policial y judicial entre los estados de la Unión Europea. Madrid: Colex, 2006. 
GARCÍA, Nicolás Rodríguez. A Necessária Flexibilização do Conceito de Soberania em Prol do Controle Judicial da Corrupção. In: JÚNIOR, Paulo Gomes Pimentel (Trad.). A Corrupção em um Mundo Globalizado. Curitiba: Juruá (no prelo).

GARCÍA CANO, Sandra. Evolución de las Técnicas de Cooperación Internacional entre Autoridades en el Derecho Internacional Privado. Boletín Mexicano de Derecho Comparado, n. 112.

GARZÓN, Juan Antonio Robles; RAMOS, Manuel Ortells (Directores). Problemas Actuales del Proceso Iberoamericano. Vol. I, XX Jornadas Iberoamericanas de Derecho Procesal. Málaga: CEDMA, 2006.

GEMAQUE, Silvio César Arouck. A necessária influência do processo penal internacional no processo penal brasileiro. Tese de Doutorado. Universidade de São Paulo. São Paulo, 2010 .

GIACOMOLLI, Nereu José; SANTOS, Laura Rodrigues dos. Cooperação Jurídica Internacional em Matéria Criminal: autoridades centrais, das rogatórias ao auxílio direto. In: Revista de Estudos Criminais, ano X, n 46, jul./set. 2012.

GIL, Alicia Gil. Derecho Penal Internacional. Madrid: Edigrafos S.A., 1999.

GLESS, Sabine. Transnational Cooperation in Criminal Matters and the Guarantee of a Fair Trial: Approaches to a General Principle. Utrech Law Review. Vol. 9, Issue 4, Set. 2013.

GONZÁLEZ, Felix Valbuena. Derechos Procesales del Imputado. In: BULNES, Mar Jimeno. (Coord). La Cooperación Judicial Civil y Penal en el Ámbito de la Unión Europea: instrumentos procesales. Barcelona: Bosch Editor, 2007.

GRINOVER, Ada Pellegrini. Princípios e Garantias Constitucionais. In LIMA, Marcellus Polastri; SANTIAGO, Nestor Eduardo Araruna - Coords - A Renovação Processual Penal após a Constituição de 1988: Estudos em Homenagem ap Professor José Barcelos de Souza. Rio de Janeiro: Lumen Juris, 2009.

GRINOVER, Ada Pellegrini. Novas tendências do direito processual. Rio de Janeiro: Forense, 1990.

As Garantias Processuais na Cooperação Internacional em Matéria Penal. In: BAPTISTA, Luiz Olavo; FONSECA, José Roberto Franco da (Coords.). O Direito Internacional no Terceiro Milênio: Estudos em homenagem ao Professor Vicente Marotta Rangel. São Paulo: Ltr, 1998. pp. 834-855. 
GRINOVER, Ada Pellegrini. Processo Penal Transnacional: linhas evolutivas e garantias processuais. In Revista Brasileira de Ciências Criminais, São Paulo, v. 3, n. 9, jan./mar. 1995.

Lineamento gerais do novo processo penal América Latina: Argentina, Brasil e código modelo 1990. In Revista Vasca de Derecho Procesal y Arbitraje, Sao Sebastian, v. 2, n. 3, p. 439-456, jul. 1990.

. O Processo em Evolução. Rio de Janeiro: Forense Universitária, 1996.

As Garantias Constitucionais do Novo Processo Penal da América Latina. In: MARTINS, Ives Gandra da Silva; JOBIM, Eduardo (Coord.). O Processo na Constituição. São Paulo: Quartier Latin, 2008. p. 120-132.

O Princípio da Ampla Defesa. Revista da Procuradoria Geral do Estado de São Paulo, n. 19, dez./81-dez./82, 1982.

; FERNANDES, Antônio Scarance; GOMES FILHO, Antônio Magalhães. As Nulidades no Processo Penal. 3a ed. São Paulo: Malheiros, 1994.

GOMES FILHO, Antonio Magalhães. Direito à Prova no Processo Penal. São Paulo: Editora Revista dos Tribunais, 1997.

GONZÁLEZ, Félix Valbuena. La Propuesta de Decisión Marco del Consejo Relativa a Determinados Derechos Procesales en los Procesos Penales Celebrados en la Unión Europea. Diario La Ley, Año XXVII, n. 6564, out. 2006.

GONZÁLES, S. Álvarez; TEJADA, J. R. Remacha. Cooperación Jurídica Internacional Colección Escuela Diplomática n. 5. Madrid: Boletin Oficial del Estado, 2001.

GORDILLO, Agustín et al. Derechos Humanos. 4a ed. Fundación de Derecho Administrativo: Buenos Aires, 1999.

GUIMARÃES, Marcello Ovidio Lopes. Tratamento Penal do Terrorismo. São Paulo: Quartier Latin, 2007.

HÄBERLE, Peter. Estado constitucional cooperativo. Trad. de Marcos Maliska e Elisete Antoniuk. Rio de Janeiro: Renovar, 2007. 
HARDING, Christopher; SWART, Bert. Intergovernmental Co-operation in the Field of Criminal Law. In: FENNELL, Phil; HARDING, Christopher; JÖRG, Nico; SWART, Bert. (Editores.). Criminal Justice in Europe - A comparative Study. New York: Clarendon Press and Oxford University Press, 2002.

HERMIDA, Ágata M. Sanz; PRADILLO, Juan Carlos Ortiz (Coords.). Problemas Actuales de la Justicia Penal: Secreto Profesional, cooperación jurídica interancional, víctimas de delitos, criminalidad organizada, personas jurídicas, eficacia y licitud de la prueba, prueba y derechos fundamentales. Madrid: Colex, 2013.

HODGSON, Jacqueline S. Safeguarding Suspects' Rights in Europe: a Comparative Perspective. New Criminal Law Review, vol. 14, n. 04, 2011.

JÚNIOR, Alberto do Amaral. A proteção internacional dos direitos humanos. Revista de Informação Legislativa. Brasília, n. 155, ano 39, p.51-60, jul.-set. 2002.

JUNIOR, João Marcello de Araujo (org.). Sistema Penal para o Terceiro Milênio: atos do colóquio Marc Ancel. Rio de Janeiro: Revan, 1991.

JUNOY, I Joan Picó. Problemas Actuales de La Justicia Penal. Barcelona: José Maria Bosch Editor, 2001.

KLEEBANK, Susan. Cooperação judiciária por via diplomáticas: avaliação e propostas de atualização do quadro normativo. Brasília: Instituto Rio Branco - Fundação Alexandre de Gusmão, 2004.

KLEFFENS, E. N. Van. Sovereignty in International Law: Five Lectures. RCADI, t. 1, 1953. p. 108.

KELSEN, Hans; CAMPAGNOLO, Umberto. In: LOSANO, Mário G. (Org.). Direito Internacional e Estado Soberano. Traduzido por Marcela Varejão. São Paulo: Martins Fontes, 2002.

LARENZ, Karl. Derecho justo: fundamentos de ética jurídica, trad. Luis Díez-Picazo, Madrid: Civitas, 1990.

LASZLOCZKY, Paolo. La cooperazione internazionale negli atti d'istruzione penale. Padova: CEDAM, 1980.

LEÃO, André Carneiro. A Extradição no Brasil: Uma Releitura a Partir das Garantias do Devido Processo Transnacional. Monografia de Pós-Graduação. Recife, 2011. 
LEITE, Antonio José Maffezoli. A Atuação da Defensoria Pública na Promoção e Defesa dos Direitos Humanos, inclusive perante o Sistema Interamericano de Direitos Humanos. In: RÉ, Aluísio Lunes Monti Ruggeri; REIS, Gustavo Augusto Soares dos. Temas Aprofundados de Defensoria Pública. Vol. 2, Salvador: Ed. Juspodivm, 2014, pp. 581-83.

LINARES, Maria Ángeles Cano. Una Aproximación a la Cooperación Judicial Penal em el Espacio Iberoamericano: Aspectos Normativos e Institucionales. Revista Eletrónica Iberoamericana. V. 2, n. 2, 2008. Disponível em: <http://www.urjc.es/ceib/

LOULA, Maria Rosa Guimarães. Auxílio Direto - Novo Instrumento de Cooperação Jurídica Internacional Civil. Belo Horizonte: Forum, 2010.

MACHADO, André Augusto Mendes. A Investigação Criminal Defensiva. Dissertação de Mestrado apresentada na Faculdade de Direito da Universidade de São Paulo. São Paulo, 2009.

MACHADO, Maíra Rocha. Internacionalização do direito penal: a gestão de problemas internacionais por meio do crime e da pena. São Paulo: Ed. 34/Edesp, 2004.

; REFINETTI, Domingos Fernando. Cooperação Penal Internacional e o Intercâmbio de Informações Bancárias: as Decisões do STF sobre Quebra de Sigilo em Cartas Rogatórias. In: Lavagem de Dinheiro e Recuperação de Ativos: Brasil, Nigéria, Reino Unido e Suíça. São Paulo: Quartier Latin, 2006.

MADRUGA, Antenor. O Brasil e a jurisprudência do STF na idade média da cooperação jurídica internacional. In: Revista Brasileira de Ciências Criminais, fascículo 54, mai.jun. 2005.

MANUAL DE COOPERAÇÃO JURÍDICA INTERNACIONAL E RECUPERAÇÃO DE ATIVOS. Cooperação em Matéria Penal. Brasília: Secretaria Nacional de Justiça, 2008.

MANUAL DE COOPERAÇÃO JURÍDICA INTERNACIONAL E RECUPERAÇÃO DE ATIVOS. Cooperação em Matéria Penal. Brasília: Secretaria Nacional de Justiça, 2012.

MATIAS, Eduardo Felipe P. A Humanidade e suas fronteiras: do Estado soberano à sociedade global. São Paulo: Paz e Terra, 2005.

MCCLEAN, David. International Judicial Assistance. New York: Clarendon Press Oxford, 1992.

Transnational Organized Crime - A Commentary on the UN Convention and its Protocols. New York: Oxford University Press, 2007. 
MCCLEAN, David. International Co-operation in Civil and Criminal Matters. Oxford: Oxford University Press, 2002.

International Co-operation in Civil and Criminal Matters. 3a Ed. Oxford: Oxford University Press, 2012.

MELIÁ, Manuel Cancio; PÉREZ, Laura Pozuelo (Coords.). Política Criminal en Vanguardia: inmigración clandestina, terrorismo, criminalidad organizada. Navarra: Thomson Civitas, 2008.

MONNERAT, Carlos Fonseca. Inversão do ônus da Prova no Processo Penal Brasileiro. Santos, SP: Comunnicar, 2006

MOON JO, Hee; SOBRINO, Marcelo da Silva. Soberania no direito internacional: Evolução ou revolução? Revista de Informação Legislativa. Brasília, n. 163, ano 41, p. 7-29, jul.-set. 2004.

MORAES, Maurício Zanoide de. Política Criminal, Constituição e Processo Penal: Razões da Caminhada Brasileira para a Institucionalização do Caos. In: MARTINS, Ives Gandra da Silva; JOBIM, Eduardo (Coord.). O Processo na Constituição. São Paulo: Quartier Latin, 2008. p. 836-866.

MORAlES ROMERO, Marta M. La Propuesta de un Defensor del Pueblo Europeo en Materia Penal (ECLO). In: ROMERO, Marta Muñoz de Morales (Coord.). El Derecho Penal de la Unión Europea. Situación Actual y Perspectivas de Futuro. Cuenca: Ediciones de la Universidad de Castilla La-Mancha, 2007.

MORALLES, Luciana Camponez Pereira. Acesso à justiça e princípio da igualdade. Porto Alegre: Sergio Antonio Fabris Editor, 2006.

MORENO, José Miguel García. La cooperación judicial penal en el ámbito iberoamericano. Revista de Jurisprudencia, número 2, diciembre de 2013. Disponível em: http://www.elderecho.com/tribuna/penal/cooperacion_judicial_penal-

ambito_iberamericano_de_justicia_11_627430004.html. Acesso em: 14 ago. 2014.

MORO, Sérgio Fernando. Cooperação jurídica internacional em casos criminais: considerações gerais. In: BALTAZAR Jr. José Paulo e LIMA, Luciano Flores de. Cooperação Jurídica Internacional em Matéria Penal. Porto Alegre: Verbo Jurídico, 2010.

MOURA, Maria Thereza Rocha de Assis; BASTOS, Cleunice A. Valentim. Defesa Penal: Direito ou Garantia. Revista Brasileira de Ciências Criminais. Ano 1, n. 4, out.-dez. 1993. 
MUELLER, Gerhard O.W. "International Judicial Assistance in Criminal Matters" in MUELLER, Gerhard \& WISE, Edward (eds). International Criminal Law. New Jersey: Rothman Ed., 1965.

MURRAY, Christopher. Defense Requests for International Judicial Assistance: The UK Perspective. In: Fordham International Law Journal. Vol. 23, Issue 5, Article 4, 1999.

NEWBURN, Tim; SPARKS, Richard (Editores). Criminal Justice and Political Cultures National and International dimensions of Crime Control. Inglaterra: Willian Publishing, 2004.

NUCCI, Guilherme de Souza. Provas no Processo Penal. São Paulo: Editora Revista dos Tribunais, 2009.

NUNES, Radam Nakai. A Cooperação Jurídica Penal Internacional à Luz do Garantismo Penal. Dissertação apresentada ao Programa de Pós-Gradução em Direito da Faculdade Católica de Brasília, como requisito parcial para obtenção do grau de Mestre em Direito. Orientadora Profa. Dra. Arinda Fernandes. Brasília, 2006.

OLIVEIRA, Carlos Alberto Corrêa de Almeida; SILVA, Ronaldo Sérgio Moreira da. $A$ Criminalidade Moderna e as Garantias Constitucionais. A influência da Globalização no Direito Penal e Direito Processual Penal. In SILVA, Marco Antonio Marques da (Coord.). Processo Penal e Garantias Constitucionais. São Paulo: Quartier Latin, 2006.

OLIVEIRA, Eugênio Pacelli de. Processo e Hermenêutica na Tutela Penal dos Direitos Fundamentais. Belo Horizonte: Del Rey, 2004.

. Curso de Processo Penal. 17a ed. Rev., ampliada e atualizada. São Paulo: Editora Atlas, 2013.

PACKER, Herbert L. The Limits of the Criminal Sanction. California, USA: Stanford University Press, 1968.

PANIAGUA, Enrique Linde; SAGGESE, Mariano Bacigalupo; PASTOR, Jesús Ángel Fuentetaja. Principios de Derecho de La Unión Europea. 6a ed. Madrid: Colex, 2012.

PAZ, Isabel Sánchez García de. La Criminalidad Organizada: aspectos penales, procesales, administrativos y policiales. Madrid: Dykinson, S.L., 2005.

PECO, Ángel Galgo (Director). Derecho Penal Supranancional y Cooperación Jurídica Internacional. Cuadernos de Drecho Judicial, XIII. Madrid: Consejo General del Poder Judicial - Centro de documentación Judicial, 2003. 
PENÍN ALEGRE, Clara. Cooperación Jurídica Internacional. In: HERMIDA, Ágata M. Sanz; PRADILlO, Juan Carlos Ortiz (Coords.). Problemas Actuales de la Justicia Penal: Secreto Profesional, cooperación jurídica internacional, víctimas de delitos, criminalidad organizada, personas jurídicas, eficacia y licitud de la prueba, prueba y derechos fundamentales. Madrid: Colex, 2013.

PENTEADO, Jaques de Camargo (coord.). Justiça Penal 3: Críticas e Sugestões. São Paulo: Revista dos Tribunais, 1995.

PÉREZ GIL, Julio. El Convenio de Asistencia Judicial en Materia Penal Entre los Estados Miembros de la UE: ¿Un Instrumento Anclado en Coordenadas Superadas? Diario La Ley, Año XXVI. Número 6208, 2005.

PERUCHIN, Marcelo Caetano Guazzelli. Legitimação ativa e direito a ampla defesa e ao contraditório pelo cidadão envolvido na Cooperação Judicial Penal Internacional. Dissertação de mestrado. Pontifícia Universidade Católica Do Rio Grande Do Sul, Porto Alegre, agosto 2000.

Cooperação judicial internacional: a invalidade do art. $8^{o}$, parágrafo único, da Resolução $n^{\circ}$ 09, do Superior Tribunal de Justiça, de 2005. Tese Doutorado - Programa de Pós-Graduação em Direito - Faculdade de Direito, Pontifícia Universidade Católica do Rio Grande do Sul, 2012.

Direitos fundamentais e cooperação judicial internacional: Um diálogo necessário. Sistema Penal \& Violência. Porto Alegre, v. 5, n. 1, p. 36-59, jan./jun. 2013.

PETRUS, Christian Herrera. La obtención internacional de pruebas, asistencia jurisdiccional en Europa. Real Colegio de España: Bolonia, 2005.

PIOVESAN, Flávia Cristina. Direitos Humanos e a Jurisdição Constitucional Internacional. Revista Brasileira de Direito Constitucional. São Paulo, n. 1, p. 147-161, jan.-jun. 2003.

PISANI, Mario. Note Brevi su Temi Penalistici - Riflessioni sul "giusto processo" penale. In: Rivista Italiana di Diritto e Procedura Penale. Nuova Serie - Anno LI, Fasc. 3 - Milano: Dott. A. Giuffrè Editore, Luglio-Settembre, 2008.

POP, Oana Mihaela. The Principles and General Rules of the International judicial Cooperation in Criminal Matters. In: 2008 AGORA Int'1 J. Jurid. Sci. 209 2008. Disponível em: $<$ https://www.copyright.com/ccc/basicSearch.do\&operation=go\&searchType=0\&lastSe arch $=$ simple $\&$ all $=$ on \& titleOrStdNo=1843-570X $>$. Acesso em 03 set. 2012. 
PUYENBROECK, Laurens Van; VERMEULEN, Gert. Towards Minimum Procedural Guarantees for the Defence in Criminal Proceedings in the EU. International and Comparative Law Quarterly, vol. 60, 2011.

RAMOS, André de Carvalho. Teoria Geral dos direitos humanos na ordem internacional. 3a ed. São Paulo: Saraiva, 2013.

. Direitos Humanos em Juízo. São Paulo: Max Limonad, 2001.

RAMOS, João Gualberto Garcez. Curso de Processo Penal Norte-americano. São Paulo: Revista dos Tribunais, 2006.

REICHSTEINER, Beat Walter. Direito Internacional Privado, teoria e prática. 4a ed. São Paulo: Saraiva, 2000. p. 229.

REUTER, Paul. Principles de droit international public. In Recueil des Cours de L'Academie de Droit Internacional da la Haye, vol. 103, 1961-II, Paris, pp 425-656.

REVISTA DA DEFENSORIA PÚBLICA DA UNIÃO. Defensoria Pública da União. n. 3 (jul./dez. 2010). Brasília: DPU, 2010, 120 p. 268 p.)

Defensoria Pública da União. n. 4 (dez./2010 - ago. 2011). Brasília: DPU, 2010 -

REVISTA DAS DEFENSORIAS PÚBLICAS DO MERCOSUL (REDPO). Defensoria Pública da União. n. 2 (dez./2011). Brasília: DPU, 2011, 180 p.

RICO, Elena del Mar García. International Cooperation in Criminal Matters between Spain and Latin America. Spanish Yearbook of International Law. Vol. XII, 2008.

ROCHA, Alexandre Lobão. A Exclusão Legal da População Carente. Brasília: Thesaurus, 2009.

ROBERT, Cinthia; SÉGUIN, Elida. Direitos Humanos, acesso à justiça: um olhar da Defensoria Pública. Rio de Janeiro: Forense, 2000.

ROUX, Jean-André. L'entr'aide des Etats dans la lutte contre la criminalité. In Recueil des Cours de L'Academie de Droit Internacional da la Haye, Vol 36, 1931 - II, Paris, pp. 77181 . 
RUBIO, Carlos Ramos. Comisiones Rogatorias para la obtención de pruebas Problemas de validez de las pruebas obtenidas en el extranjero: análisis de la jurisprudencia del Tribunal Supremo Español. Estudios Jurídicos No. 3, Ministerio Fiscal, Madrid, 2003.

SADEK, Maria Tereza Aina. Prefácio - Defensoria Pública: um agente de igualdade in: SOUSA, José Augusto Garcia de. Uma nova Defensoria Pública pede passagem - Reflexões sobre a Lei Complementar 132/09. Rio de Janeiro: Lumen Juris, 2011.

SALDARRIAGA, Víctor Prado. Cooperación judicial internacional en materia penal: El Estatuto de Roma y la legislación nacional. Agenda Internacional. Año VII, N” 16, 2002, pp. 137-158.

SARAMAGO, José. Este mundo de la injusticia globalizada. Diario El País, 6 de fevereiro de 2002.

SAVIGNY, F. de. De La Vocación de Nuestro Siglo para la Legislación y para la Ciencia del Derecho. Madrid: La España Moderna, 1916.

SCHLOSSER, Peter. Jurisdiction and International Judicial and Administrative Cooperation. Recueil des Cours de l'Academie de Droit International de la Haye, t. 284, p. 9430, 2000.

SCHÜNEMANN, Bernd. As Bases do Processo Penal Transnacional. Traduzido por Heloisa Estellita Salomão. Revista Brasileira de Ciências Criminais. Ano 19, v. 90, mai-jun. 2011.

SERRANO, Nicolás Gonzáles-Cuellar; FERNÁNDEZ, Francisco Jiménez-Villarejo; AGUADO, Javier Alberto Zaragoza; VALIENTE, Luis Maria Uriarte; ESTRADA, Jesús J. Tirado. Mecanismos de Cooperación Judicial Internacional. Navarra: Thomson Aranzadi, 2006.

SOARES, Guido Fernando Silva. Common Law: introdução ao direito dos EUA. São Paulo: Editora Revista dos Tribunais, 1999.

SOUZA, Carolina Yumi de. A Defesa na Cooperação Jurídica Internacional - Reflexões Preliminares. Boletim IBCCRIM. Ano 18, n. 214, set. 2010.

SILVA, Ricardo Perlingeiro Mendes da. Anotações sobre o anteprojeto de lei de cooperação jurídica internacional In Revista de Processo, n 129 , ano 30, nov. 2005, p. 133-167.

Cooperação Jurídica Internacional e Auxílio Direto in BARROSO, Luis Roberto e TIBURCIO, Carmen (orgs.). O Direito Internacional Contemporâneo. Estudos em homenagem ao Professor Jacob Dolinger. Rio de Janeiro: Ed. Renovar, 2006, pp.797-809. 
SILVA, Ricardo Perlingeiro Mendes da. Cooperação Jurídica Internacional e Auxílio Direto. In: Revista CEJ, Brasília, n. 32, p. 75-79, jan./mar. 2006.

SILVA, Eduardo Araujo da. Crime Organizado: procedimento probatório. São Paulo: Atlas, 2003.

SILVA, Luciano Nascimento (Coord.). Estudos Jurídicos Criminais. Curitiba: Juruá, 2008.

SLAUGHTER, Anne-Marie. Sovereignty and Power in a Networked World Order In Stanford Journal of International Law 40:283, 2004.

$\frac{}{2000 .}$. Judicial Globalization. 40 Virginia Journal of International Law, p. 1103-1124, 1999 -

SOUSA, Alfredo José de. A Criminalidade Transnacional na União Europeia: um Ministério Público Europeu? Coimbra: Almedina, 2005.

SOUZA, Carolina Yumi de. A defesa na cooperação jurídica internacional - reflexões preliminares. In Boletim IBCCRIM. São Paulo : IBCCRIM, ano 18, n. 214, p. 14-15, set., 2001.

SOUZA, Fábio Luís Mariani de. A Defensoria Pública e o Acesso à Justiça Penal. Porto Alegre: Nuria Fabris, 2011.

SOUZA, Solange Mendes de. Cooperação Jurídica Penal no Mercosul: novas possibilidades. Rio de Janeiro: Renovar, 2001.

SPRONKEN, Taru; VOCHT, Dorris de. EU policy to guarantee procedural rights in criminal proceedings: "step by step". Paper to be presented at the conference "The Future of the Adversarial System", University of North Carolina at Chapel Hill School of Law, April, 2011.

SPRONKEN, Taru. An EU-Wide Letter of Rights - Toward Best Practice. Antwerp, Cambridge, Portland: Intersentia and Metro, 2010.

SPRONKEN, Taru, ATTINGER, Marelle. Procedural Rights in Criminal Proceedings: Existing Level of Safeguards in the European Union. Completed version 12th December 2005. European Comission. Disponível em: < http://arno.unimaas.nl/show.cgi?fid=3891>.

STEINER, Henry J.; DETLEV, F. Vagts; KOH, Harold Hongju. Transnational legal problems: materials and text. 4th ed.Westbury, NY: The Foundation Press, inc, 1994. 
SUPREMO TRIBUNAL FEDERAL. Extradição, Carta Rogatória, Sentença Estrangeira. Brasília: Supremo Tribunal Federal, Coordenadoria de Biblioteca, 1999.

TIBURCIO, Carmen. Temas de Direito Internacional. Rio de Janeiro: Renovar, 2006.

TRECHSEL, Stefan. The Scope of Application of the Right to a Fair Trial in Criminal Matters. In: TRECHSEL, Stefan; SUMMERS, Sarah. Human Rights in Criminal Proceedings. Oxford Scholarship Online: January 2010.

TRINDADE, Antônio Augusto Cançado. A proteção internacional dos Direitos Humanos Fundamentos jurídicos e instrumentos básicos. São Paulo: Saraiva, 1991.

. Princípios do Direito Internacional Contemporâneo. Brasília: Universidade de Brasília, 1981. 268p.

TODOROV, Tzvetan. In: CASSESE, Antônio; DELMAS-MARTY, Mireille. (Orgs.). Crimes Internacionais e Jurisdições Internacionais. Traduzido por Sílvio Antunha. São Paulo: Manole, 2004.

TOPIEL, Michael S. The Doctrine of Non-Inquiry and the Preservation of Human Rights: Is There Room for Reconciliation? Cardozo Journal of International and Comparative Law. Vol. 9, 2001.

TORRE, Ignacio Berdugo Gómez de la. Viejo y Nuevo Derecho Penal - Principios y desafíos del derecho penal de hoy. Madrid: Iustel, 2012.

TROTTA, Sandro Brescovit. Os limites da cooperação jurídica internacional em matéria penal. In: Sistema Penal \& Violência, Porto Alegre, v. 5, n. 1, p. 15-35, jan./jun. 2013.

TUCCI, Rogério Lauria. Direitos e Garantias Individuais no Processo Penal Brasileiro. 3a ed. Rev., atual. e ampl. São Paulo: Editora Revista dos Tribunais, 2009.

VADELL, Lorenzo Bujosa. La Cooperación Procesal de Los Estados con La Corte Penal Internacional. Barcelona: Atelier Livros Jurídicos, 2008.

VALENTE, Manuel Monteiro Guedes. La cooperación en materia procesal penal: los engaños y las ilusiones formales de los instrumentos jurídicos europeos e internacionales. Diario La Ley, Nº 6914, Sección Doctrina, Año XXIX, Ref. D-96, Editorial LA LEY, Mar. 2008. 
VALENTINI, Cristiana. L'Acquisizione della prova tra limiti territoriali e cooperazione com autorità straniere. Padova: CEDAM, 1998.

VALLADÃO, Haroldo. Da cooperação internacional nos processos criminais. São Paulo: Revista dos Tribunais, 1933.

III Diagnóstico da Defensoria Pública no Brasil. Brasília: Ministério da Justiça. 2009 www.mj.gov.br/reforma acessado em 21.10.2011.

VAN HOEK, Aukje A.H.; LUCHTMAN, Michiel J.J.P. Transnational cooperation in criminal mattters and the safeguarding of human rights. Utrecht Law Review, Volume 1, Issue, 2005.

VASCONCELLOS, Helena. Cooperação Jurídica Internacional em Matéria Penal: Uma Análise do Mutual Legal Assistance Treaty Brasil/Estados Unidos. Dissertação apresentada ao Programa de Pós-Gradução em Direito da Faculdade de Direito da Universidade Federal do Rio Grande do Sul como requisito parcial para obtenção do grau de mestre em Direito. Orientador Prof. Dr. Tupinambá Pinto de Azevedo. Porto Alegre, 2013.

VERGUEIRO, Luiz Fabrício Thaumaturgo. Implementação da Cooperação Jurídica Internacional Vertical. Tese de Doutorado apresentada à Faculdade de Direito da Universidade de São Paulo. São Paulo: 2012.

VOGEL, Joachim. Cooperación Penal: Cinco Tendencias. Cinco Propuestas Para Una Acción Futura. In: ROMERO, Marta Muñoz de Morales (Coord.). El Derecho Penal de la Unión Europea. Situación Actual y Perspectivas de Futuro. Cuenca: Ediciones de la Universidad de Castilla La-Mancha, 2007.

La prueba transnacional en el proceso penal: un marco para la teoría y práxis. In: FLUJA, Vicente C. Guzmán. La prueba en el espacio europeo de libertad, seguridad y justicia penal. Navarra: Thomson Aranzadi, 2006. Colección Centro de Estudios Jurídicos, p. 46.

WADE, Marianne L. General Principles of Transnationalised Criminal Justice? Exploratory Reflections. Utrecht Law Review. Vol. 9, Issue 4 (September) 2013.

WASEK-WIADEREK, Malgorzata. The principle of "equality of arms" in criminal procedure under Article 6 of the european Convention on Human Rights and its functions in criminal justice of selected European countries - A comparative view. Belgium: Leuven University Press, 2000.

WEBER, Patrícia Núñez. A Cooperação Jurídica Internacional em Medidas Processuais Penais. Porto Alegre: Verbo Jurídico, 2011. 
WINTER, Lorena Bachmaier. La Orden Europea de Investigaciones y el Principio de Proporcionalidad. In: Revista General de Derecho Europeo, 2011, (25), Universidad Complutense de Madrid.

Transnational Inquiries and the Protection of Fundamental Rights in Criminal Proceedings. A Study in Memory of Vittorio Grevi and Giovanni Tranchina. Londres: Springer, 2013.

BACHMAIER WINTER, Lorena. European investigation order for obtaining evidence in the criminal proceedings Study of the proposal for a European directive. In: Zeitschrift für Internationale Strafrechtsdogmatik. Set, 2010, pp. 580-589.

WISE, Edward M.; PODGOR, Ellen S.; CLARK, ROGER S. International Criminal Law Cases and Materials. $2^{\text {nd }}$ edition. São Francisco: LexisNexis, 2004.

WLADIMIROFF, Michail. Cooperation on Criminal Matters: a Defence Lawyer's Perspective. In: R. Yepes-Enríquez and L. Tabassi (eds.), Treaty Enforcement and International Cooperation in Criminal Matters, 2002.

WYNGAERT, Christine Van den. International Criminal Law: A Collection of International and European Instruments. $2^{\text {nd }}$ Revised Ed. The Hague: Kluwer Law International, 2001.

ZAGARIS, Bruce. U.S. - Brazil and International Evidence Gathering: The Need for Better Procedural Due Process. Revista Brasileira de Ciências Criminais. RBCCrim. Ano 20, vol. 99, nov.-dez./2012.

ZAPPALÀ, Salvatore. Human Rights in International Criminal Proceedings. Oxford Scholarship Online, 2003.

ZARAGOZA AGUADO, Javier-Alberto. La Cooperación Judicial Internacional en Materia Penal en el Ámbito de la Unión europea. Especial referencia a la materia de las drogas. Cuaderno del Instituto Vasco de Criminología. San Sebastián, n. 15, 2001. 


\begin{abstract}
ANEXOS
ANEXO I - Convenções internacionais

Convenção das Nações Unidas Contra o Crime Organizado Transnacional Convenção de Palermo

A presente Convenção foi promulgada pelo Decreto n ${ }^{\circ}$ 5.015/2004, de 12 de março de 2004, que explicita, em seu artigo 18, em que consiste a assistência judiciaria recíproca, in verbis:
\end{abstract}

Artigo 18

1. Os Estados-Partes prestarão reciprocamente toda a assistência judiciária possível nas investigações, nos processos e em outros atos judiciais relativos às infrações previstas pela presente Convenção, nos termos do artigo $3^{\circ}$, e prestarão reciprocamente uma assistência similar quando o Estado-Parte requerente tiver motivos razoáveis para suspeitar que a infração a que se referem as alíneas a) ou b) do parágrafo $1^{\circ}$ do artigo $3^{\circ}$ é de caráter transnacional, inclusive quando as vítimas, as testemunhas, o produto, os instrumentos ou os elementos de prova destas infrações se encontrem no Estado-Parte requerido e nelas esteja implicado um grupo criminoso organizado.

2. Será prestada toda a cooperação judiciária possível, tanto quanto o permitam as leis, tratados, acordos e protocolos pertinentes do Estado-Parte requerido, no âmbito de investigações, processos e outros atos judiciais relativos a infrações pelas quais possa ser considerada responsável uma pessoa coletiva no Estado-Parte requerente, em conformidade com o artigo 10 da presente Convenção.

3. A cooperação judiciária prestada em aplicação do presente artigo pode ser solicitada para os seguintes efeitos:

a) recolher testemunhos ou depoimentos;

b) notificar atos judiciais;

c) efetuar buscas, apreensões e embargos;

d) examinar objetos e locais;

e) fornecer informações, elementos de prova e pareceres de peritos;

f) fornecer originais ou cópias certificadas de documentos e processos pertinentes, incluindo documentos administrativos, bancários, financeiros ou comerciais e documentos de empresas;

g) identificar ou localizar os produtos do crime, bens, instrumentos ou outros elementos para fins probatórios;

h) facilitar o comparecimento voluntário de pessoas no Estado-Parte requerente;

i) prestar qualquer outro tipo de assistência compatível com o direito interno do Estado-Parte requerido.

4. Sem prejuízo do seu direito interno, as autoridades competentes de um Estado-Parte poderão, sem pedido prévio, comunicar informações relativas a questões penais a uma autoridade competente de outro Estado-Parte, se considerarem que estas informações poderão ajudar a empreender ou concluir com êxito investigações e processos penais ou conduzir este último Estado-Parte a formular um pedido ao abrigo da presente Convenção.

5. A comunicação de informações em conformidade com o parágrafo $4^{\circ}$ do presente Artigo será efetuada sem prejuízo das investigações e dos processos penais no Estado cujas autoridade competentes fornecem as informações. As autoridades competentes que recebam estas informações deverão satisfazer qualquer pedido no sentido de manter confidenciais as 
referidas informações, mesmo se apenas temporariamente, ou de restringir a sua utilização. Todavia, tal não impedirá o Estado Parte que receba as informações de revelar, no decurso do processo judicial, informações que inocentem um arguido. Neste último caso, o Estado Parte que recebeu as informações avisará o Estado Parte que as comunicou antes de as revelar e, se lhe for pedido, consultará este último. Se, num caso excepcional, não for possível uma comunicação prévia, o Estado Parte que recebeu as informações dará conhecimento da revelação, prontamente, ao Estado Parte que as tenha comunicado.

6. As disposições do presente artigo em nada prejudicam as obrigações decorrentes de qualquer outro tratado bilateral ou multilateral que regule, ou deva regular, inteiramente ou em parte, a cooperação judiciária.

$[\ldots]$

9. Os Estados-Partes poderão invocar a ausência de dupla criminalização para recusar prestar a assistência judiciária prevista no presente artigo. O Estado-Parte requerido poderá, não obstante, quando o considerar apropriado, prestar esta assistência, na medida em que o decida por si próprio, independentemente de o ato estar ou não tipificado como uma infração no direito interno do Estado-Parte requerido.

$[\ldots]$

13. Cada Estado-Parte designará uma Autoridade Central que terá a responsabilidade e o poder de receber pedidos de cooperação judiciária e, quer de os executar, quer de os transmitir às autoridades competentes para execução. Se um Estado-Parte possuir uma região ou um território especial dotado de um sistema de cooperação judiciária diferente, poderá designar uma autoridade central distinta, que terá a mesma função para a referida região ou território. As Autoridades Centrais deverão assegurar a execução ou a transmissão rápida e em boa e devida forma dos pedidos recebidos. Quando a Autoridade Central transmitir o pedido a uma autoridade competente para execução, instará pela execução rápida e em boa e devida forma do pedido por parte da autoridade competente. O Secretário-Geral da Organização das Nações Unidas será notificado da Autoridade Central designada para este efeito no momento em que cada Estado-Parte depositar os seus instrumentos de ratificação, aceitação, aprovação ou adesão à presente Convenção. Os pedidos de cooperação judiciária e qualquer comunicação com eles relacionada serão transmitidos às autoridades centrais designadas pelos Estados-Partes.

A presente disposição não afetará o direito de qualquer Estado-Parte a exigir que estes pedidos e comunicações lhe sejam remetidos por via diplomática e, em caso de urgência, e se os Estados-Partes nisso acordarem, por intermédio da Organização Internacional de Polícia Criminal, se tal for possível.

[...]

21. A cooperação judiciária poderá ser recusada:

a) se o pedido não for feito em conformidade com o disposto no presente artigo;

b) se o Estado-Parte requerido considerar que a execução do pedido pode afetar sua soberania, sua segurança, sua ordem pública ou outros interesses essenciais;

c) se o direito interno do Estado-Parte requerido proibir suas autoridades de executar as providências solicitadas com relação a uma infração análoga que tenha sido objeto de investigação ou de procedimento judicial no âmbito da sua própria competência;

d) se a aceitação do pedido contrariar o sistema jurídico do Estado-Parte requerido no que se refere à cooperação judiciária.

22. Os Estados-Partes não poderão recusar um pedido de cooperação judiciária unicamente por considerarem que a infração envolve também questões fiscais.

23. Qualquer recusa de cooperação judiciária deverá ser fundamentada. $[\ldots]$ 
26. Antes de recusar um pedido feito ao abrigo do parágrafo 21 do presente artigo ou de diferir a sua execução ao abrigo do parágrafo 25, o Estado-Parte requerido estudará com o Estado-Parte requerente a possibilidade de prestar a assistência sob reserva das condições que considere necessárias. Se o Estado-Parte requerente aceitar a assistência sob reserva destas condições, deverá respeitá-las.

[...]

30. Os Estados-Partes considerarão, se necessário, a possibilidade de celebrarem acordos ou protocolos bilaterais ou multilaterais que sirvam os objetivos e as disposições do presente artigo, reforçando-as ou dando-lhes maior eficácia.

Como se vê, não se verifica qualquer restrição explícita à possibilidade de a defesa se utilizar da presente Convenção para a produção de prova nos seus moldes, tampouco foram previstas restrições nos seus protocolos adicionais, quais sejam:

a) Protocolo Adicional à Convenção das Nações Unidas Contra o Crime Organizado Transnacional relativo ao Combate ao Tráfico de Migrantes por Via Terrestre, Marítima e Aérea, que foi promulgado pelo Decreto $\mathrm{n}^{\circ}$ 5.016, de 12 de março de 2004 e tem como objetivo prevenir e combater o tráfico de migrantes, bem como promover a cooperação entre os Estados Partes com esse fim, protegendo ao mesmo tempo os direitos dos migrantes objeto desse tráfico (artigo 2 do Protocolo);

b) Protocolo Adicional à Convenção das Nações Unidas Contra o Crime Organizado Transnacional relativo à Prevenção, Repressão e Punição do Tráfico de Pessoas, em Especial Mulheres e Crianças, o qual foi promulgado pelo Decreto $n^{\circ} 5.017$, de 12 de março de 2004, que objetiva prevenir e combater o tráfico de pessoas, prestando atenção especial às mulheres e crianças; proteger e ajudar as vítimas desse tráfico, respeitando plenamente os seus direitos humanos, com a promoção da cooperação entre os Estados Partes de forma a atingir esses objetivos (artigo 2 do Protocolo);

c) Protocolo Adicional à Convenção das Nações Unidas Contra o Crime Organizado Transnacional Contra a Fabricação e o Tráfico Ilícito de Armas de Fogo, suas Peças, Componentes e Munições, promulgado pelo Decreto $\mathrm{n}^{\circ}$ 5.941, de 26 de outubro de 2006, com a finalidade de promover, facilitar e fortalecer a cooperação entre os Estados Partes a fim de prevenir, combater e erradicar a fabricação e o tráfico ilícitos de armas de fogo, suas peças, componentes e munições (artigo 2 do Protocolo).

Não bastasse isso, verifica-se, inclusive, o direito à demonstração da inocência, como se pode observar no artigo 18 , item 5 , acima transcrito e grifado:

[...] As autoridades competentes que recebam estas informações deverão satisfazer qualquer pedido no sentido de manter confidenciais as referidas informações, mesmo se apenas temporariamente, ou de restringir a sua utilização. Todavia, tal não impedirá o Estado Parte que receba as informações de revelar, no decurso do processo judicial, informações que inocentem um arguido. [...]

Previsão semelhante consta também no artigo 46.5 da Convenção da ONU Contra a Corrupção, a qual será abordada na sequência.

\section{Convenção Contra o Tráfico Ilícito de Entorpecentes e Substâncias Psicotrópicas - Convenção de Viena}

Esta Convenção foi promulgada pelo Decreto ${ }^{\circ} 154$ de 26 de junho de 1991 e prevê no artigo $7^{\circ}$ os assuntos pertinentes à assistência jurídica recíproca:

Artigo 7 
1. As partes se prestarão, de acordo com o disposto no presente artigo, a mais ampla assistência jurídica recíproca nas investigações, julgamentos e processos jurídicos referentes a delitos estabelecidos no parágrafo $1^{\circ}$ do artigo $3^{\circ}$.

2. A assistência jurídica recíproca que deverá ser prestada, de acordo com este artigo, poderá ser solicitada para qualquer um dos seguintes fins:

a) receber testemunhas ou declarações de pessoas;

b) apresentar documentos jurídicos;

c) efetuar buscas e apreensões;

d) examinar objetos e locais;

e) facilitar acesso de informações e evidência;

f) entregar originais ou cópias autenticadas de documentos e expedientes relacionadas ao caso, inclusive documentação bancária, financeira, social ou comercial;

g) identificar ou detectar o produto, os bens, os instrumentos ou outros elementos comprobatórios.

3. As partes poderão prestar qualquer outra forma de assistência judicial recíproca autorizada pelo direito interno da parte requerida.

4. As partes, se assim lhes for solicitado e na medida compatível com seu direito e prática interna, facilitarão ou encorajarão a apresentação ou a disponibilidade das pessoas, incluindo a dos detentos, que consintam em colaborar com as investigações ou em intervir nos procedimentos.

5. As partes não declinarão a assistência jurídica recíproca prevista neste artigo sob alegação de sigilo bancário.

6. O disposto neste artigo não afetará as obrigações derivadas de outros tratados bilaterais ou multilaterais, vigentes ou futuros, que regem, total ou parcialmente, a assistência jurídica recíproca em assuntos penais.

$[\ldots]$

15. A assistência jurídica recíproca solicitada poderá será denegada:

a) quando a solicitação não se ajuste ao disposto no presente artigo;

b) quando a parte requerida considerar que o cumprimento da solicitação possa prejudicar sua soberania, sua segurança, sua ordem pública ou outros interesses fundamentais;

c) quando o direito interno da parte requerida proibir suas autoridades de atender à solicitação formulada com respeito a delito análogo, se este tiver sido objeto de investigação, processo ou procedimento no exercício da própria competência;

d) no caso de a assistência jurídica recíproca de atender à solicitação contrariar a ordem jurídica da parte requerida.

[...]

20. Quando for necessário, as partes considerarão a possibilidade de entrar em acordos ou ajustes bilaterais ou multilaterais que sirvam para os fins deste artigo e que, na prática, deem efeito às suas disposições ou as reforcem.

De igual modo, não se visualiza qualquer restrição à possibilidade de a defesa se utilizar da presente Convenção para a produção de prova.

\section{Convenção das Nações Unidas Contra a Corrupção - Convenção de Mérida}

Foi promulgada pelo Decreto $\mathrm{n}^{\circ} 5.687$ de 31 de janeiro de 2006 e prevê, em seu artigo 46, questões atinentes à assistência judicial recíproca, bem como aduz as hipóteses de denegação de cooperação, in verbis: 
1. Os Estados-Partes prestar-se-ão a mais ampla assistência judicial recíproca relativa a investigações, processos e ações judiciais relacionados com os delitos compreendidos na presente Convenção.

2. Prestar-se-á assistência judicial recíproca no maior grau possível conforme as leis, tratados, acordos e declarações pertinentes do Estado-Parte requerido com relação a investigações, processos e ações judiciais relacionados com os delitos dos quais uma pessoa jurídica pode ser considerada responsável em conformidade com o artigo 26 da presente Convenção no Estado-Parte requerente.

3. A assistência judicial recíproca que se preste em conformidade com o presente artigo poderá ser solicitada para quaisquer dos fins seguintes:

a) receber testemunhos ou tomar declaração de pessoas;

b) apresentar documentos judiciais;

c) efetuar inspeções, incautações e/ou embargos preventivos;

d) examinar objetos e lugares;

e) proporcionar informação, elementos de prova e avaliações de peritos;

f) entregar originais ou cópias certificadas dos documentos e expedientes pertinentes, incluída a documentação pública, bancária e financeira, assim como a documentação social ou comercial de sociedades mercantis;

g) identificar ou localizar o produto de delito, os bens, os instrumentos e outros elementos para fins probatórios;

h) facilitar o comparecimento voluntário de pessoas ao Estado-Parte requerente;

i) prestar qualquer outro tipo de assistência autorizada pela legislação interna do EstadoParte requerido;

j) identificar, embargar com caráter preventivo e localizar o produto de delito, em conformidade com as disposições do Capítulo V da presente Convenção;

1) recuperar ativos em conformidade com as disposições do Capítulo $\mathrm{V}$ da presente Convenção.

4. Sem menosprezo à legislação interna, as autoridades competentes de um EstadoParte poderão, sem que se lhes solicite previamente, transmitir informação relativa a questões penais a uma autoridade competente de outro Estado-Parte se creem que essa informação poderia ajudar a autoridade a empreender ou concluir com êxito indagações e processos penais ou poderia dar lugar a uma petição formulada por este último Estado-Parte de acordo com a presente Convenção.

5. A transmissão de informação de acordo com o parágrafo 4 do presente Artigo se fará sem prejuízo às indagações e processos penais que tenham lugar no Estado das autoridades competentes que facilitaram a informação. As autoridades competentes que recebem a informação deverão aquiescer a toda solicitação de que se respeite seu caráter confidencial, inclusive temporariamente, ou de que se imponham restrições a sua utilização. Sem embargo, ele não obstará para que o Estado Parte receptor revele, em suas ações, informação que seja fator de absolvição de uma pessoa acusada. Em tal caso, o Estado Parte receptor notificará o Estado Parte transmissor antes de revelar a mencionada informação e, se assim for solicitado, consultará o Estado Parte transmissor. Se, em um caso excepcional, não for possível notificar com antecipação, o Estado Parte receptor informará sem demora ao Estado Parte transmissor sobre a mencionada revelação.

9.a) ao atender a uma solicitação de assistência de acordo com o presente artigo, na ausência de dupla incriminação, o Estado-Parte requerido terá em conta a finalidade da presente Convenção, enunciada no artigo 1;

b) os Estados-Partes poderão negar-se a prestar assistência de acordo com o presente artigo invocando a ausência de dupla incriminação. Não obstante, o Estado-Parte requerido, quando esteja em conformidade com os conceitos básicos de seu ordenamento jurídico, 
prestará assistência que não envolva medidas coercitivas. Essa assistência poderá ser negada quando a solicitação envolva assuntos de minimis ou questões relativas às quais a cooperação ou a assistência solicitada estiver prevista em virtude de outras disposições da presente Convenção;

c) Na ausência da dupla incriminação, cada Estado-Parte poderá considerar a possibilidade de adotar as medidas necessárias que lhe permitam prestar uma assistência mais ampla de acordo com o presente artigo.

$[\ldots]$

21. A assistência judicial recíproca poderá ser negada:

a) quando a solicitação não esteja em conformidade com o disposto no presente artigo;

b) quando o Estado-Parte requerido considere que o cumprimento da solicitação poderia agredir sua soberania, sua segurança, sua ordem pública ou outros interesses fundamentais;

c) quando a legislação interna do Estado-Parte requerido proíba suas autoridades de atuarem na forma solicitada relativa a um delito análogo, se este tiver sido objeto de investigações, processos ou ações judiciais no exercício de sua própria competência;

d) quando aquiescer à solicitação seja contrário ao ordenamento jurídico do EstadoParte requerido no tocante à assistência judicial recíproca.

22. Os Estados-Partes não poderão negar uma solicitação de assistência judicial recíproca unicamente por considerarem que o delito também envolve questões tributárias.

23. Toda negação de assistência judicial recíproca deverá fundamentar-se devidamente. [...]

26. Antes de negar uma solicitação apresentada de acordo com o parágrafo 21 do presente artigo ou de modificar seu cumprimento de acordo com o parágrafo 25 do presente artigo, o Estado-Parte requerido consultará o Estado-Parte requerente para considerar se é possível prestar a assistência solicitada submetendo-a às condições que julgue necessárias. Se o Estado-Parte requerente aceita a assistência de acordo com essas condições, esse EstadoParte deverá cumprir as condições impostas.

[...]

30. Quando se fizer necessário, os Estados-Partes considerarão a possibilidade de celebrar acordos ou tratados bilaterais ou multilaterais que contribuam a lograr os fins do presente artigo e que levem à prática ou reforcem suas disposições.

Além disso, como anteriormente referido, há previsão expressa ao direito de demonstração da inocência no artigo 46, item 5, assim como ocorre na Convenção das Nações Unidas contra o Crime Organizado Transnacional. E mais, a revelação de dados aptos a ensejar a prolação de um Juízo absolutório impõe-se mesmo diante do princípio da especificidade.

Isto significa que, excepcionalmente, quando provas, documentos e determinadas medidas forem necessárias para prolação de juízo absolutório, eles poderão ser usados em relação a fatos e/ou procedimentos distintos daqueles que embasaram o pleito ao Estado requerido.

É o que se depreende do artigo 46, item 19, da presente Convenção:

O Estado Parte requerente não transmitirá nem utilizará, sem prévio consentimento do Estado Parte requerido, a informação ou as provas proporcionadas por este para investigações, processos ou ações judiciais distintas daquelas indicadas na solicitação. Nada do disposto no presente parágrafo impedirá que o Estado Parte requerente revele, em suas ações, informação ou provas que sejam fatores de absolvição de uma pessoa acusada. Neste último caso, o Estado Parte requerente notificará o Estado Parte requerido antes de revelar a informação ou as provas e, se assim solicitado, consultará o Estado Parte requerido. Se, em um caso excepcional, não for possível notificar este com antecipação, o 
Estado Parte requerente informará sem demora o Estado Parte requerido da mencionada revelação.

Nesse contexto, observa-se que a cooperação jurídica internacional, se devidamente instrumentalizada, é um fator decisivo de aprimoramento da justiça e do devido processo legal, no que se inclui o princípio da paridade de armas entre acusação e defesa, pois o modelo do devido processo exige procedimentos contraditórios de averiguação, tribunais imparciais, com a possibilidade real de o acusado desacreditar as provas produzidas contra ele. Este modelo, ao contrário do modelo de controle do crime ${ }^{483}$, defende a noção de igualdade a todos, segundo o qual ambas as partes devem ser colocadas na mesma posição com relação aos recursos à disposição para a coleta de provas no processo penal ${ }^{484}$.

\section{Convenção Interamericana sobre Assistência Mútua em Matéria Penal - Convenção de Nassau}

A presente Convenção foi promulgada pelo Decreto $\mathrm{n}^{\circ} 6.340$ de 03 de janeiro de 2008, com previsão das recusas de assistência, no artigo $9^{\circ}$ :

\section{Recusa de assistência}

O Estado requerido poderá recusar a assistência quando, em sua opinião:

a) o pedido de assistência for usado com o objetivo de julgar uma pessoa por um delito pelo qual essa pessoa já tiver sido previamente condenada ou absolvida num processo no Estado requerente ou requerido;

b) a investigação for iniciada com o objetivo de processar, punir ou discriminar de alguma maneira uma pessoa ou grupo de pessoas, por motivo de sexo, raça, condição social, nacionalidade, religião ou ideologia;

c) o pedido se referir a delito político ou relacionado com delito político, ou a delito comum que estiver sendo processado por motivos políticos;

d) se tratar de pedido de assistência emanado de um tribunal de exceção ou de um tribunal ad hoc;

e) for afetada a ordem pública, soberania, segurança ou interesses públicos fundamentais; $\mathrm{e}$

f) o pedido se referir a um delito fiscal. Não obstante, prestar-se-á a assistência se o delito for cometido por uma declaração intencionalmente falsa feita verbalmente ou por escrito, ou por uma omissão intencional de declaração, com o objetivo de ocultar receitas provenientes de qualquer outro delito previsto nesta Convenção.

De igual modo, sob a égide da presente Convenção, também não se verifica qualquer restrição à possibilidade de a defesa utilizá-la para a produção de prova nos seus termos, verificado que as recusas dizem respeito a outras questões procedimentais, em regra.

\footnotetext{
${ }^{483} \mathrm{O}$ referencial teórico mais conhecido para o processo criminal no sistema do common law foi desenvolvido por Herbert Packer na década de 1960. Na revisão de Packer, as tendências na justiça criminal poderão ser avaliadas no quadro normativo de dois modelos: o modelo de controle do crime e o modelo do devido processo. "Esse sistema de valores destaca que o modelo de Controle do Crime é baseado na proposição de que a repressão da conduta criminosa é de longe a mais importante função a ser realizada pelo processo penal". (PACKER, Herbert. The Limits of the Criminal Sanction. California, USA: Stanford University Press, 1968, p. 158-9).

${ }^{484}$ WASEK-WIADEREK, Malgorzata. The principle of "equality of arms" in criminal procedure under Article 6 of the european Convention on Human Rights and its functions in criminal justice of selected European countries - A comparative view. Belgium: Leuven University Press, 2000, p. 11.
} 
Protocolo de Assistência Jurídica Mútua em Assuntos Penais do Mercosul - Protocolo de São Luís

Foi promulgado pelo Decreto 3.468 de 17 de maio de 2000. Prevê, no artigo $5^{\circ}$, as hipóteses de denegação de assistência:

\section{Artigo 5}

Denegação de assistência

1. O Estado-Parte requerido poderá denegar a assistência quando:

a) a solicitação se refira a delito tipificado como tal na sua legislação militar mas não na legislação penal ordinária;

b) a solicitação se refira a delito que o Estado requerido considere como político ou como delito comum conexo com delito político ou realizado com finalidade política;

c) a solicitação se refira a delito tributário;

d) a pessoa em relação a qual se solicita a medida haja sido absolvida ou haja cumprido condenação no Estado requerido pelo mesmo delito mencionado na solicitação. Contudo, esta disposição não poderá ser invocada para negar assistência em relação a outras pessoas; ou

e) o cumprimento da solicitação seja contrário à segurança, à ordem pública ou a outros interesses essenciais do Estado requerido.

2. Se o Estado requerido denega a assistência, deverá informar ao Estado requerente, por intermédio da Autoridade Central, as razões em que se funda a denegatória, ressalvado o disposto no artigo 15 , alínea "b".

Igualmente, entende-se que não há qualquer restrição à possibilidade de a defesa utilizar o presente Protocolo para a produção de prova nos seus termos. 


\section{ANEXO II - Quadro comparativo dos acordos bilaterais firmados pelo Brasil}

\begin{tabular}{|c|c|c|}
\hline & Alcance do Acordo & $\begin{array}{c}\text { Denegação, adiamento ou restrições à } \\
\text { cooperação }\end{array}$ \\
\hline $\begin{array}{l}\text { Decreto n }^{\circ} \\
862 / 93\end{array}$ & $\begin{array}{l}\text { Artigo 1 } \\
\text { Objeto da cooperação } \\
\text { 1. Cada uma das partes, a pedido, prestará à } \\
\text { outra parte, na forma prevista no presente } \\
\text { Tratado, ampla cooperação em favor dos } \\
\text { procedimentos penais conduzidos pelas } \\
\text { autoridades judiciárias da parte requerente. } \\
\text { 2. Tal cooperação compreenderá, } \\
\text { especialmente, a comunicação de atos } \\
\text { judicial, o interrogatório de indiciados ou } \\
\text { acusados, a coleta de provas, a transferência } \\
\text { de presos para fins de prova, a informação } \\
\text { dos antecedentes aos cidadãos da outra } \\
\text { parte. } \\
\text { 3. A cooperação não compreenderá a execução } \\
\text { de medidas restritivas da liberdade pessoal nem } \\
\text { a execução de condenações. } \\
4 \text { Cada parte pode requerer a outra } \\
\text { informações referentes a legislação e } \\
\text { jurisprudência. } \\
\text { Artigo } 2 \text { q } \\
\text { Fatos que dão lugar à cooperação } \\
\text { 1. A Cooperação será prestada ainda que os } \\
\text { fatos que deram origem ao processo não } \\
\text { constituam crime perante a lei da parte } \\
\text { requerida. } \\
\text { 2. Para a execução de revistas pessoais, } \\
\text { apreensão e sequestro de bens, a cooperação } \\
\text { somente será prestada se o fato que originou o } \\
\text { processo na parte requerente for previsto como } \\
\text { crime também na lei da parte requerida ou, } \\
\text { ainda, se ficar comprovado que o acusado } \\
\text { manifestou expressamente seu consentimento. } \\
\text { Para a execução de interceptação de } \\
\text { telecomunicações, a cooperação somente será } \\
\text { prestada se, em relação ao crime tipificado no } \\
\text { processo e em circunstâncias análogas, tal } \\
\text { interceptação for admissível em procedimento } \\
\text { penais da parte requerida. }\end{array}$ & $\begin{array}{l}\text { Artigo } 3 \\
\text { Recusa da cooperação } \\
\text { 1. A cooperação será recusada: } \\
\text { a) se os atos solicitados forem vedados } \\
\text { pela lei da parte requerida, ou contrários } \\
\text { aos princípios fundamentais de seu } \\
\text { ordenamento jurídico; } \\
\text { b) se o fato tipificado no processo for } \\
\text { considerado, pela parte requerida, crime } \\
\text { político ou crime exclusivamente militar; } \\
\text { c) se a parte requerida tiver fundados } \\
\text { motivos para admitir que considerações } \\
\text { relativas a raça, religião, sexo, } \\
\text { nacionalidade, idioma, opiniões políticas } \\
\text { ou condições pessoais e sociais poderão } \\
\text { influir negativamente } \\
\text { desenvolvimento ou conclusão do } \\
\text { processo; pou } \\
\text { d) se o acusado já tiver sido julgado pelo } \\
\text { mesmo fato na parte requerida, e não } \\
\text { houver escapado à execução da pena; } \\
\text { e) se a parte requerida considerar que a } \\
\text { prestação da cooperação pode } \\
\text { comportar prejuízo à própria soberania, } \\
\text { segurança ou a outros interesses } \\
\text { nacionais essenciais. } \\
\text { 2. No entanto, nos casos previstos nas } \\
\text { letras b) c) e d) do parágrafo 1, a } \\
\text { cooperação será prestada se for } \\
\text { demonstrado que o acusado manifestou } \\
\text { livremente seu consentimento. } \\
\text { 3. A parte requerida deverá informar } \\
\text { prontamente à parte requerente a } \\
\text { decisão de não atender, no todo ou em } \\
\text { parte, o pedido de cooperação, indicando } \\
\text { seus motivos. }\end{array}$ \\
\hline $\begin{array}{c}\text { PORTUGAL } \\
\text { Decreto n }^{\circ} \\
1.320 / 94\end{array}$ & $\begin{array}{l}\text { Artigo } 1 \\
\text { Objeto e âmbito do auxílio } \\
\text { 1. As partes Contratantes obrigam-se a } \\
\text { prestar auxílio mútuo em matéria penal, } \\
\text { segundo as disposições deste Tratado, na } \\
\text { realização de diligências preparatórias e } \\
\text { necessárias em qualquer processo penal por } \\
\text { fatos cujo conhecimento caiba às entidades } \\
\text { para o efeito competente de acordo com a lei } \\
\text { de cada uma das partes. } \\
\text { 2. O auxílio compreende, nomeadamente: } \\
\text { a) a notificação de documentos; } \\
\text { b) a obtenção de meios de prova; } \\
\text { c) exames de pessoas, lugares ou coisas, }\end{array}$ & $\begin{array}{l}\text { Artigo } 3 \\
\text { Recusa de Auxílio } \\
\text { 1. O auxílio será recusado se a parte } \\
\text { requerida considerar que: } \\
\text { a) o pedido respeita a uma infração } \\
\text { política ou com ela conexa; } \\
\text { b) o cumprimento do pedido ofende a sua } \\
\text { soberania, segurança, ordem pública ou } \\
\text { qualquer outro seu interesse essencial; } \\
\text { c) existem fundadas razões para concluir } \\
\text { que o pedido de auxílio foi formulado } \\
\text { para facilitar a perseguição de uma } \\
\text { pessoa em virtude da sua raça, sexo, } \\
\text { religião, nacionalidade ou convicções }\end{array}$ \\
\hline
\end{tabular}




\begin{tabular}{|c|c|c|}
\hline & $\begin{array}{l}\text { revistas, buscas e apreensões de bens; } \\
\text { d) a notificação de suspeitos, arguidos ou } \\
\text { indiciados, testemunhas ou peritos e a } \\
\text { audição dos mesmos; } \\
\text { e) as informações sobre o direito respectivo } \\
\text { e as relativas aos antecedentes penais de } \\
\text { suspeitos, arguidos ou indiciados es } \\
\text { condenados. } \\
\text { 3. O auxílio não abrange os atos processuais } \\
\text { posteriores à decisão judicial de recebimento } \\
\text { da acusação ou de pronúncia do arguido. } \\
\text { 4. O auxílio é independente da extradição, } \\
\text { podendo mesmo ser concedido nos casos em } \\
\text { que aquela seria recusada. } \\
\text { 5. O presente Tratado não se aplica à execução } \\
\text { de decisões de detenção ou de condenação, } \\
\text { nem às infrações militares que não constituam } \\
\text { infrações de direito comum. } \\
\text { 6. O auxílio relativo a processos por infrações } \\
\text { em matéria de taxas, impostos, direitos } \\
\text { aduaneiro e cambial só pode ser prestado } \\
\text { mediante acordo das partes para cada categoria } \\
\text { de infração. }\end{array}$ & $\begin{array}{l}\text { políticas, ou que a situação dessa pessoa } \\
\text { possa ser prejudicada por qualquer } \\
\text { dessas razões; } \\
\text { d) o cumprimento do pedido ofende os } \\
\text { direitos e liberdades fundamentais da } \\
\text { pessoa humana. } \\
\text { 2. O auxílio pode ser recusado se a parte } \\
\text { requerida entender que se verificam } \\
\text { fundadas razões que tornariam } \\
\text { desproporcionada a concessão desse } \\
\text { auxílio. } \\
\text { 3. Antes de recusar um pedido de auxílio, a } \\
\text { parte requerida deve considerar a } \\
\text { possibilidade de subordinar a concessão } \\
\text { desse auxílio às condições que julgue } \\
\text { necessárias. Se a parte requerente aceitar o } \\
\text { auxílio sujeito a essas condições, deve } \\
\text { cumpri-las. } \\
\text { 4. A parte requerida deve informar } \\
\text { imediatamente a parte requerente da sua } \\
\text { decisão de não dar cumprimento, no todo } \\
\text { ou em parte, ao pedido de auxílio e das } \\
\text { razões dessa decisão. }\end{array}$ \\
\hline $\begin{array}{l}\text { FRANÇA } \\
\text { Decreto n }^{\circ} \\
3.324 / 99\end{array}$ & $\begin{array}{l}\text { Disposições Gerais } \\
\text { Artigo 1 } \\
\text { 1. Os dois Estados se comprometem a prestar- } \\
\text { se mutuamente, de acordo com as disposições } \\
\text { do presente Acordo, a cooperação judiciária } \\
\text { mais ampla possível em todo processo que } \\
\text { tenha por objeto infrações cuja repressão } \\
\text { seja, no momento em que a ajuda for pedida, } \\
\text { da competência das autoridades judiciárias } \\
\text { do Estado requerente. } \\
\text { 2. Cada um dos Estados poderá, no âmbito do } \\
\text { presente Acordo, pedir ao outro informações } \\
\text { sobre sua legislação e sua jurisprudência. } \\
\text { 3. O presente Acordo não se aplica à execução } \\
\text { de decisões que impliquem prisão, nem às } \\
\text { infrações militares que não constituam } \\
\text { infrações de direito comum. }\end{array}$ & $\begin{array}{l}\text { Artigo } 2 \\
\text { A cooperação judiciária poderá ser } \\
\text { recusada: } \\
\text { a) se o pedido referir-se a infração que } \\
\text { não seja punível, tanto pela legislação do } \\
\text { Estado requerente, como pela do Estado } \\
\text { requerido; } \\
\text { b) se o pedido referir-se a infrações } \\
\text { consideradas pelo Estado requerido } \\
\text { como infrações políticas, ou a elas } \\
\text { conexas; } \\
\text { c) se o Estado requerido considera que a } \\
\text { execução do pedido é de natureza que } \\
\text { atente contra a soberania, a segurança, a } \\
\text { ordem pública ou outros interesses } \\
\text { essenciais do seu país; } \\
\text { d) se houver sérios motivos para crer que } \\
\text { o pedido de cooperação foi apresentado } \\
\text { com a finalidade de perseguir ou de } \\
\text { punir uma pessoa em razão de sua raça, } \\
\text { de seu sexo, de sua religião, de sua } \\
\text { nacionalidade ou de suas opiniões } \\
\text { políticas, ou que a situação desta pessoa } \\
\text { corra o risco de ser agravada por uma ou } \\
\text { por outra destas razões. }\end{array}$ \\
\hline $\begin{array}{c}\text { EUA } \\
\text { Decreto }^{\circ} \\
\text { 3.810/2001 }\end{array}$ & $\begin{array}{l}\text { Artigo I } \\
\text { 1. As partes se obrigam a prestar assistência } \\
\text { mútua, nos termos do presente Acordo, em } \\
\text { matéria de investigação, inquérito, ação penal, } \\
\text { prevenção de crimes e processos relacionados } \\
\text { a delitos de natureza criminal. } \\
\text { 2. A assistência incluirá: } \\
\text { a) tomada de depoimentos ou declarações de } \\
\text { pessoas; } \\
\text { b) fornecimento de documentos, registros e }\end{array}$ & $\begin{array}{l}\text { Artigo III } \\
\text { Restrições à assistência } \\
1 \text { 1. A Autoridade Central do Estado } \\
\text { Requerido poderá negar assistência se: } \\
\text { a) a solicitação referir-se a delito previsto } \\
\text { na legislação militar, sem contudo } \\
\text { constituir crime comum; } \\
\text { b) o atendimento à solicitação prejudicar } \\
\text { a segurança ou interesses essenciais } \\
\text { semelhantes do Estado Requerido; ou }\end{array}$ \\
\hline
\end{tabular}




\begin{tabular}{|c|c|c|}
\hline & $\begin{array}{l}\text { bens; } \\
\text { c) localização ou identificação de pessoas } \\
\text { (físicas ou jurídicas) ou bens; } \\
\text { d) entrega de documentos; } \\
\text { e) transferência de pessoas sob custódia para } \\
\text { prestar depoimento ou outros fins; } \\
\text { f) execução de pedidos de busca e apreensão; } \\
\text { g) assistência em procedimentos } \\
\text { relacionados a imobilização e confisco de } \\
\text { bens, restituição, cobrança de multas; e } \\
\text { h) qualquer outra forma de assistência não } \\
\text { proibida pelas leis do Estado Requerido. } \\
\text { 3. A assistência será prestada ainda que o fato } \\
\text { sujeito a investigação, inquérito ou ação penal } \\
\text { não seja punível na legislação de ambos os } \\
\text { Estados. } \\
\text { 4. As partes reconhecem a especial importância } \\
\text { de combater graves atividades criminais, } \\
\text { incluindo lavagem de dinheiro e tráfico ilícito } \\
\text { de armas de fogo, munições e explosivos. Sem } \\
\text { limitar o alcance da assistência prevista neste } \\
\text { artigo, as partes devem prestar assistência } \\
\text { mútua sobre essas atividades, nos termos deste } \\
\text { Acordo. } \\
\text { 5. O presente Acordo destina-se tão-somente } \\
\text { à assistência judiciária mútua entre as } \\
\text { partes. Seus dispositivos não darão direito a } \\
\text { qualquer indivíduo de obter, suprimir ou } \\
\text { excluir qualquer prova ou impedir que uma } \\
\text { solicitação seja atendida. }\end{array}$ & $\begin{array}{l}\text { c) a solicitação não for feita de } \\
\text { conformidade com o Acordo. } \\
\text { 2. Antes de negar a assistência com base no } \\
\text { disposto neste artigo, a Autoridade Central } \\
\text { do Estado Requerido deverá consultar a } \\
\text { Autoridade Central do Estado Requerente } \\
\text { para avaliar se a assistência pode ser } \\
\text { prestada sob as condições consideradas } \\
\text { necessárias. } \\
\text { Caso o Estado Requerente aceite essa } \\
\text { assistência condicionada, tais condições } \\
\text { deverão ser respeitadas. } \\
\text { 3. Caso a Autoridade Central do Estado } \\
\text { Requerido negue a assistência, deverá } \\
\text { informar a Autoridade Central do Estado } \\
\text { Requerente das razões dessa denegação. }\end{array}$ \\
\hline $\begin{array}{l}\text { COLÔMBIA } \\
\text { Decreto n }^{\circ} \\
\mathbf{3 . 8 9 5 / 2 0 0 1}\end{array}$ & $\begin{array}{l}\text { Artigo I } \\
\text { Âmbito de aplicação } \\
\text { 1. O presente Acordo tem por finalidade a } \\
\text { assistência judiciária mútua em assuntos penais } \\
\text { entre as autoridades competentes das partes. } \\
\text { 2. As partes prestar-se-ão assistência mútua, } \\
\text { conforme as disposições do presente Acordo e } \\
\text { em estrito cumprimento de seus respectivos } \\
\text { ordenamentos jurídicos, para a investigação de } \\
\text { delitos e a cooperação em processos } \\
\text { relacionados a matéria penal. } \\
\text { 3. O presente Acordo não faculta às autoridades } \\
\text { ou a particulares da parte requerente a } \\
\text { realização, no território da parte requerida, de } \\
\text { funções que, segundo as leis internas, estejam } \\
\text { reservadas às suas autoridades, salvo no caso } \\
\text { previsto no artigo 13, parágrafo } 3 \text {. } \\
\text { 4. Este Acordo não se aplicará a: } \\
\text { a) detenção de pessoas com o fim de que sejam } \\
\text { extraditadas nem aos pedidos de extradição; } \\
\text { b) traslado de pessoas condenadas com o } \\
\text { objetivo de que cumpram sentença penal; } \\
\text { c) assistência a particulares ou a terceiros } \\
\text { Estados. } \\
\text { Artigo II } \\
\text { Alcance da assistência } \\
\text { A assistência compreenderá: } \\
\text { a) notificação de atos processuais; } \\
\text { b) recepção e produção ou prática de provas, }\end{array}$ & $\begin{array}{l}\text { Artigo V } \\
\text { Denegação de assistência } \\
\text { 1. A parte requerida poderá denegar a } \\
\text { assistência quando: } \\
\text { a) o pedido referir-se a um delito } \\
\text { tipificado como tal na legislação militar, } \\
\text { mas não na legislação penal ordinária; } \\
\text { b) o pedido referir-se a um delito que na } \\
\text { parte requerida seja de caráter político } \\
\text { ou conexo e realizado com fins políticos; } \\
\text { c) a pessoa com relação à qual se solicita } \\
\text { a medida haja sido absolvida ou haja } \\
\text { cumprido pena na parte requerida pelo } \\
\text { delito mencionado no pedido. Este } \\
\text { dispositivo não poderá, no entanto, ser } \\
\text { invocado para negar assistência em } \\
\text { relação a outras pessoas; } \\
\text { d) o cumprimento do pedido seja } \\
\text { contrário à segurança, à ordem pública } \\
\text { ou a outros interesses essenciais da parte } \\
\text { requerida; } \\
\text { e) o pedido de assistência seja contrário } \\
\text { ao ordenamento jurídico da parte } \\
\text { requerida ou não se ajuste aos } \\
\text { dispositivos deste Acordo. } \\
\text { 2. Se a parte requerida denegar assistência, } \\
\text { deverá, por intermédio de sua Autoridade } \\
\text { Central, informar esse fato à parte } \\
\text { requerida, aduzindo as razões da }\end{array}$ \\
\hline
\end{tabular}




\begin{tabular}{|c|c|c|}
\hline & $\begin{array}{l}\text { tais como testemunhos e declarações, perícia } \\
\text { e inspeção de pessoas, bens e lugares; } \\
\text { c) localização e identificação de pessoas; } \\
\text { d) notificação de pessoas e peritos para } \\
\text { comparecer voluntariamente a fi m de } \\
\text { prestar declaração ou testemunho no } \\
\text { território da parte requerente; } \\
\text { e) traslado de pessoas detidas para efeito de } \\
\text { comparecimento como testemunho no } \\
\text { território da parte requerente ou com outros } \\
\text { propósitos expressamente indicados no } \\
\text { pedido, conforme o presente Acordo; } \\
\text { f) medidas cautelares sobre bens; } \\
\text { g) cumprimento de outros pedidos relativos } \\
\text { a bens, inclusive a eventual transferência } \\
\text { definitiva do valor dos bens confiscados; } \\
\text { h) entrega de documentos e de outros objetos } \\
\text { de prova; } \\
\text { i) embargo e sequestro de bens para efeitos } \\
\text { de pagamento de indenizações e multas } \\
\text { impostas por sentença penal; } \\
\text { j) qualquer outra forma de assistência de } \\
\text { acordo com os fins deste Acordo sempre que } \\
\text { não for incompatível com as leis do Estado } \\
\text { Requerido }\end{array}$ & $\begin{array}{l}\text { denegação, sem prejuízo do disposto no } \\
\text { artigo 12, alínea "b". } \\
\text { 3. A Autoridade Competente da parte } \\
\text { requerida poderá denegar, condicionar ou } \\
\text { diferir o cumprimento do pedido, } \\
\text { quando considerar que constitui } \\
\text { obstáculo a um processo penal em curso } \\
\text { no seu território. Sobre essas condições a } \\
\text { parte requerida consultará a parte } \\
\text { requerente por intermédio das Autoridades } \\
\text { Centrais. Se a parte requerente aceita a } \\
\text { assistência condicionada, o pedido será } \\
\text { atendido de acordo com as condições } \\
\text { apresentadas. } \\
\text { Artigo XXIII } \\
\text { Compatibilidade com outros tratados, } \\
\text { acordos ou outras formas de cooperação } \\
\text { 1. A assistência estabelecida no presente } \\
\text { Acordo não impedirá que cada uma das } \\
\text { partes preste assistência à outra com } \\
\text { base em outros instrumentos } \\
\text { internacionais vigentes entre elas. } \\
\text { 2. Este Acordo não impedirá às partes a } \\
\text { possibilidade de desenvolver outras } \\
\text { formas de cooperação de acordo com } \\
\text { seus respectivos ordenamentos jurídicos. }\end{array}$ \\
\hline $\begin{array}{c}\text { PERU } \\
\text { Decreto n }^{\circ} \\
3.988 / 01\end{array}$ & $\begin{array}{l}\text { Artigo } 2 \\
\text { Obrigação de Assistência Mútua } \\
\text { 1. As Partes se obrigam a prestar assistência } \\
\text { mútua, conforme os dispositivos do presente } \\
\text { Acordo e de seus respectivos ordenamentos } \\
\text { jurídicos para a realização de investigações, } \\
\text { processos e procedimentos penais, } \\
\text { instaurados por fatos cujo conhecimento } \\
\text { corresponde às autoridades competentes da } \\
\text { Parte requerente. } \\
\text { 2. A assistência será prestada mesmo quando } \\
\text { o fato que lhe der motivo na Parte } \\
\text { requerente não constitua delito na Parte } \\
\text { requerida. } \\
\text { 3. Para a execução de mandados de busca de } \\
\text { pessoas e registros, confiscos, } \\
\text { indisponibilidade de bens, de sequestro com } \\
\text { fim de prova e interceptação telefônica por } \\
\text { ordem judicial devidamente motivada, } \\
\text { assim como para a execução de medidas que } \\
\text { envolvam algum tipo de coerção, a } \\
\text { assistência será prestada somente quando o } \\
\text { fato que lhe der motivo na Parte requerente } \\
\text { estiver previsto como delito também na } \\
\text { legislação da Parte requerida, ou quando a } \\
\text { pessoa envolvida no pedido de assistência } \\
\text { tiver manifestado livremente seu } \\
\text { consentimento de forma escrita. } \\
\text { Artigo } 3 \text { s a } \\
\text { Âmbito de Aplicação } \\
1 \text { 1. As Partes prestarão, de acordo com sua } \\
\text { legislação, assistência mútua em matéria de }\end{array}$ & $\begin{array}{l}\text { Artigo } 4 \\
\text { Limitações à Assistência } \\
\text { 1. A Parte requerente não usará qualquer } \\
\text { informação ou prova obtida nos termos } \\
\text { deste Acordo para fins diferentes dos } \\
\text { declarados na solicitação de assistência } \\
\text { jurídica, sem prévia autorização da Parte } \\
\text { requerida. } \\
\text { 2. Este Acordo não facultará às Partes } \\
\text { executar, no território da Parte onde se } \\
\text { realizam as diligências, as funções } \\
\text { reservadas exclusivamente às autoridades } \\
\text { desta Parte, nos termos de sua legislação } \\
\text { interna. } \\
\text { 3. Este Acordo não se aplicará a: } \\
\text { a) prisão de pessoas para extradição, nem a } \\
\text { solicitações de extradição; } \\
\text { b) a transferência de pessoas condenadas } \\
\text { para cumprimento de sentença penal; } \\
\text { c) assistência a particulares ou a } \\
\text { terceiros Estados. } \\
\text { Artigo 5 } \\
\text { Assistência Condicionada } \\
\text { 1. A autoridade competente da Parte } \\
\text { requerida, se considerar que o } \\
\text { atendimento a uma solicitação poderá } \\
\text { criar obstáculo a alguma investigação ou } \\
\text { procedimento penal que esteja em curso } \\
\text { em seu território, poderá adiar o seu } \\
\text { cumprimento ou condicioná-lo à forma } \\
\text { que considere necessária. } \\
\text { 2. A Autoridade Central da Parte requerida }\end{array}$ \\
\hline
\end{tabular}




\begin{tabular}{|c|c|c|}
\hline & $\begin{array}{l}\text { intercâmbio de informação, provas, } \\
\text { processamento e demais procedimentos penais. } \\
\text { A assistência compreenderá, entre outros: } \\
\text { a) localização e identificação de pessoas e } \\
\text { bens; } \\
\text { b) notificação de atos judiciais; } \\
\text { c) entrega de documentos e informações } \\
\text { judiciais; } \\
\text { d) mandados de busca e apreensão e } \\
\text { inspeções judiciais; } \\
\text { e) depoimentos de testemunhas e } \\
\text { interrogatório de acusados; } \\
\text { f) citação e comparecimento voluntário de } \\
\text { pessoas, na qualidade de acusados, } \\
\text { testemunhas ou peritos; } \\
\text { g) comparecimento voluntário de pessoas } \\
\text { presas para prestar depoimento no } \\
\text { território da Parte requerente; } \\
\text { h) indisponibilidade, sequestro, arresto ou } \\
\text { confisco de bens, inclusive o levantamento de } \\
\text { sigilo bancário; } \\
\text { i) qualquer outra forma de assistência, de } \\
\text { conformidade com a legislação da Parte } \\
\text { requerida. } \\
\text { 2. As Partes facilitarão o ingresso e a presença, } \\
\text { no território da Parte requerida, de autoridades } \\
\text { competentes da Parte requerente para assistir e } \\
\text { participar dos procedimentos solicitados, } \\
\text { sempre que isso não contrarie o disposto em } \\
\text { sua legislação. Os funcionários da Parte } \\
\text { requerente atuarão de acordo com o que for } \\
\text { autorizado pelas autoridades competentes da } \\
\text { Parte requerida. }\end{array}$ & $\begin{array}{l}\text { dará conhecimento à Autoridade Central da } \\
\text { Parte requerente do exposto no parágrafo } \\
\text { anterior, para que esta aceite a assistência } \\
\text { condicionada, caso em que respeitará as } \\
\text { condições estabelecidas. } \\
\text { 3. Quando uma solicitação de assistência } \\
\text { jurídica não puder ser cumprida, parcial ou } \\
\text { totalmente, a Parte requerida comunicará à } \\
\text { Parte requerente, com menção expressa dos } \\
\text { motivos ou causas da falta de cumprimento, } \\
\text { devendo a Parte requerida decidir se insiste } \\
\text { ou não na solicitação. } \\
\text { Artigo 6 } \\
\text { Denegação de Assistência } \\
\text { 1. A Parte requerida poderá negar a } \\
\text { assistência quando: } \\
\text { a) a solicitação de assistência jurídica } \\
\text { seja contrária ao seu ordenamento } \\
\text { jurídico, ou não esteja prevista nas } \\
\text { disposições do presente Acordo; } \\
\text { b) considere que o atendimento à } \\
\text { solicitação possa criar obstáculo a uma } \\
\text { investigação ou processo penal em curso } \\
\text { na Parte requerida, ressalvado o } \\
\text { disposto no Artigo } 5 \text { do presente Acordo; } \\
\text { c) a solicitação de assistência jurídica } \\
\text { esteja relacionada a um delito sob o qual } \\
\text { a pessoa tenha sido exonerada } \\
\text { definitivamente de responsabilidade } \\
\text { penal ou, caso tenha sido condenada, a } \\
\text { pena tenha sido cumprida ou declarada } \\
\text { extinta; } \\
\text { d) a investigação tenha sido iniciada } \\
\text { para processar ou discriminar, sob } \\
\text { qualquer forma, pessoa ou grupo, por } \\
\text { motivo de raça, sexo, condição social, } \\
\text { nacionalidade, religião, ideologia ou } \\
\text { qualquer outra forma de discriminação; } \\
\text { e) a concessão da assistência possa afetar } \\
\text { a ordem pública, a soberania, a } \\
\text { segurança nacional ou os interesses } \\
\text { públicos essenciais da Parte requerida; } \\
\text { f) a solicitação de assistência jurídica } \\
\text { refira-se a delito político, militar ou } \\
\text { conexo. } \\
\text { 2. A denegação da assistência será } \\
\text { fundamentada e informada por escrito à } \\
\text { Parte requerente. }\end{array}$ \\
\hline $\begin{array}{c}\text { COREIA DO } \\
\text { SUL } \\
\text { Decreto n }^{\circ} \\
5.721 / 06\end{array}$ & $\begin{array}{l}\text { Artigo 1 } \\
\text { Alcance da Assistência } \\
\text { 1. As Partes se obrigam a prestar assistência } \\
\text { mútua nos termos do presente Acordo, da } \\
\text { forma mais ampla possível, em matéria de } \\
\text { investigação, ação penal ou processos } \\
\text { relacionados a delitos de natureza criminal. } \\
\text { 2. Para efeito do presente Acordo, matéria } \\
\text { criminal significa investigação, ação penal ou } \\
\text { processos relativos a qualquer crime punível no } \\
\text { momento da solicitação de assistência, sob a }\end{array}$ & $\begin{array}{l}\text { Artigo } 4 \\
\text { Recusa ou Adiamento da Assistência } \\
\text { 1. A assistência poderá ser denegada se, } \\
\text { no entendimento da Parte Requerida: } \\
\text { a) a solicitação referir-se a delito político } \\
\text { ou crime previsto na legislação militar } \\
\text { sem, contudo, constituir crime comum; } \\
\text { b) o atendimento à solicitação prejudicar } \\
\text { a soberania, a segurança, a ordem } \\
\text { pública ou outro interesse público } \\
\text { essencial da Parte Requerida; }\end{array}$ \\
\hline
\end{tabular}




\begin{tabular}{|c|c|c|}
\hline & $\begin{array}{l}\text { competência de autoridade judicial da Parte } \\
\text { Requerente. } \\
\text { 3. A assistência incluirá: } \\
\text { a) tomada de depoimentos ou declarações de } \\
\text { pessoas; } \\
\text { b) fornecimento de informações, } \\
\text { documentos, registros e elementos de prova; } \\
\text { c) localização ou identificação de pessoas } \\
\text { (físicas e jurídicas) ou bens; } \\
\text { d) entrega de documentos; } \\
\text { e) execução de pedidos de busca e apreensão; } \\
\text { f) transferência de pessoas sob custódia para } \\
\text { prestar depoimento ou ajudar nas } \\
\text { investigações; } \\
\text { g) medidas de assistência em relação a } \\
\text { produtos de crimes, tais como bloqueio, } \\
\text { confisco e transferência; e } \\
\text { h) qualquer outra forma de assistência não } \\
\text { proibida pelas leis da Parte Requerida. } \\
\text { 4. O presente Acordo não se aplica a: } \\
\text { a) extradição de qualquer pessoa; } \\
\text { b) execução, na Parte Requerida, de um } \\
\text { julgamento criminal realizado na Parte } \\
\text { Requerente, exceto na medida em que seja } \\
\text { permitido pelas leis da Parte Requerida e neste } \\
\text { Acordo; } \\
\text { c) transferência de pessoas condenadas para } \\
\text { cumprimento de sentença; e } \\
\text { d) transferência de procedimentos em matéria } \\
\text { criminal. }\end{array}$ & $\begin{array}{l}\text { c) existirem substanciais motivos para } \\
\text { crer que o pedido de assistência foi } \\
\text { formulado para perseguir ou punir uma } \\
\text { pessoa em razão de sua raça, sexo, } \\
\text { religião, nacionalidade ou opinião } \\
\text { política ou quando a posição dessa } \\
\text { pessoa pode ser prejudicada por } \\
\text { qualquer uma dessas razões; ou } \\
\text { d) a conduta objeto da investigação, ação } \\
\text { ou processo penal na Parte Requerente } \\
\text { não constituir um delito nos termos da lei } \\
\text { da Parte Requerida. } \\
\text { 2. Aassistência poderá ser adiada pela Parte } \\
\text { Requerida se a execução do pedido (puder) } \\
\text { interferir em uma investigação ou } \\
\text { procedimento em curso na Parte Requerida. } \\
\text { 3. Antes de negar a assistência ou adiar a } \\
\text { execução, a Parte Requerida deverá } \\
\text { consultar a Parte Requerente para avaliar se } \\
\text { a assistência pode ser prestada sob as } \\
\text { condições consideradas necessárias. Caso a } \\
\text { Parte Requerente aceite essa assistência } \\
\text { condicionada, tais condições deverão ser } \\
\text { respeitadas. } \\
\text { 4. Se a Parte Requerida denegar ou adiar a } \\
\text { assistência, deverá informar à Parte } \\
\text { Requerente as razóes da recusa ou } \\
\text { adiamento. }\end{array}$ \\
\hline $\begin{array}{l}\text { UCRÂNIA } \\
\text { Decreto n }^{\circ} \\
5.984 / 06\end{array}$ & $\begin{array}{l}\text { Artigo I } \\
\text { Alcance da Assistência } \\
\text { 1. As Partes se obrigam a prestar assistência } \\
\text { mútua, nos termos do presente Acordo, em } \\
\text { matéria de investigação, inquérito, ação penal, } \\
\text { prevenção de crimes e processos relacionados } \\
\text { a delitos de natureza criminal. } \\
\text { 2. A assistência incluirá: } \\
\text { a) tomada de depoimentos ou declaraçães de } \\
\text { pessoas; } \\
\text { b) fornecimento de documentos, registros e } \\
\text { bens; } \\
\text { c) localização ou identificação de pessoas } \\
\text { físicas ou jurídicas ou bens; } \\
\text { d) entrega de documentos; } \\
\text { e) transferência de pessoas sob custódia para } \\
\text { prestar depoimento ou outros fins; } \\
\text { f) execução de pedidos de busca e apreensão; } \\
\text { g) assistência em procedimentos } \\
\text { relacionados a imobilização e confisco de } \\
\text { bens, restituição, cobrança de multas; e } \\
\text { h) qualquer outra forma de assistência não } \\
\text { proibida pelas leis da Parte Requerida. } \\
\text { 3. A assistência será prestada ainda que o } \\
\text { fato sujeito a investigação, inquérito ou ação } \\
\text { penal não seja punível na legislação de } \\
\text { ambas as Partes. } \\
\text { 4. O presente Acordo destina-se tão-somente } \\
\text { à assistência judiciária mútua entre as }\end{array}$ & $\begin{array}{l}\text { Artigo III } \\
\text { Restrições à Assistência } \\
\text { 1. A Autoridade Central da Parte } \\
\text { Requerida poderá negar assistência se: } \\
\text { a) a solicitação referir-se a delito previsto } \\
\text { na legislação militar, sem contudo } \\
\text { constituir crime comum; } \\
\text { b) o atendimento à solicitação prejudicar } \\
\text { a segurança ou interesses essenciais } \\
\text { semelhantes da Parte Requerida; ou } \\
\text { c) a solicitação não for feita de } \\
\text { conformidade com o Acordo. } \\
\text { 2. Antes de negar a assistência com base no } \\
\text { disposto neste Artigo, a Autoridade Central } \\
\text { da Parte Requerida deverá consultar a } \\
\text { Autoridade Central da Parte Requerente } \\
\text { para avaliar se a assistência pode ser } \\
\text { prestada sob as condições consideradas } \\
\text { necessárias. Caso a Parte Requerente aceite } \\
\text { essa assistência condicionada, tais } \\
\text { condições deverão ser respeitadas. } \\
\text { 3. Caso a Autoridade Central da Parte } \\
\text { Requerida negue a assistência, deverá } \\
\text { informar à Autoridade Central da Parte } \\
\text { Requerente das razões dessa denegação. } \\
\end{array}$ \\
\hline
\end{tabular}




\begin{tabular}{|c|c|c|}
\hline & $\begin{array}{l}\text { Partes. Seus dispositivos não darão direito a } \\
\text { qualquer indivíduo de obter, suprimir ou } \\
\text { excluir qualquer prova ou impedir que uma } \\
\text { solicitação seja atendida. }\end{array}$ & \\
\hline $\begin{array}{l}\text { CHINA } \\
\text { Decreto n }^{\circ} \\
6.282 / 07\end{array}$ & $\begin{array}{l}\text { Artigo } 1 \\
\text { 1. As partes se obrigam a prestar assistência } \\
\text { mútua, nos termos do presente Tratado, em } \\
\text { matéria de investigação, inquérito, ação } \\
\text { penal e processos relacionados a delitos de } \\
\text { natureza criminal. } \\
\text { 2. A assistência incluirá: } \\
\text { a) entrega de documentos; } \\
\text { b) tomada de depoimentos ou declarações de } \\
\text { pessoas; } \\
\text { c) obtenção e fornecimento de avaliação por } \\
\text { peritos; } \\
\text { d) fornecimento de documentos, registros, e } \\
\text { meios de prova, inclusive registros } \\
\text { bancários, financeiros, corporativos ou } \\
\text { empresariais; } \\
\text { e) localização ou identificação de pessoas, } \\
\text { ativos ou meios de prova; } \\
\text { f) condução de inspeção judicial ou exame de } \\
\text { locais ebjetos; } \\
\text { g) disponibilização de pessoas para } \\
\text { fornecimento de provas ou auxílio nas } \\
\text { investigaçães; } \\
\text { h) transferência de pessoas sob custódia } \\
\text { para prestar depoimento ou provas; } \\
\text { i) execução de pedidos de rastreamento, } \\
\text { busca, imobilização e apreensão; } \\
\text { j) disposição de produtos ou instrumentos de } \\
\text { crime; } \\
\text { k) notificação de resultados de } \\
\text { procedimentos criminais e fornecimento de } \\
\text { registros criminais e outros; } \\
\text { l) troca informações sobre a legislação; e } \\
\text { m) qualquer outra forma de assistência não } \\
\text { proibida pelas leis do Estado Requerido. } \\
\text { 3. As partes podem recusar-se a prestar } \\
\text { assistência judiciária mútua de acordo com este } \\
\text { artigo com base na ausência de dupla } \\
\text { incriminação. Entretanto, quando julgar } \\
\text { apropriado, a parte requerida pode decidir } \\
\text { fornecer assistência de forma discricionária } \\
\text { independentemente da conduta constituir-se ou } \\
\text { não em ofensa sob a lei interna do Estado } \\
\text { Requerido. }\end{array}$ & $\begin{array}{l}\text { Artigo } 3 \\
\text { Restrições à assistência } \\
\text { 1. O Estado Requerido poderá negar } \\
\text { assistência se: } \\
\text { a) a solicitação referir-se a delito militar; } \\
\text { b) o atendimento à solicitação prejudicar } \\
\text { sua soberania, segurança, ordem pública } \\
\text { ou outros interesses essenciais; } \\
\text { c) a parte requerida já tiver dado } \\
\text { julgamento ou decisão final sobre a } \\
\text { mesma pessoa pelo mesmo delito } \\
\text { relacionado na solicitação; } \\
\text { d) a solicitação referir-se a delito } \\
\text { político; } \\
\text { e) existir motivos substanciais para a } \\
\text { parte requerida acreditar que a } \\
\text { solicitação foi feita com intuito de } \\
\text { investigar, processar, punir ou proceder } \\
\text { de qualquer outra forma contra uma } \\
\text { pessoa por causa de sua raça, sexo, } \\
\text { religião, nacionalidade ou opinião } \\
\text { política, ou que a posição daquela pessoa } \\
\text { possa ser prejudicada por qualquer } \\
\text { daquelas razões; ou } \\
\text { f) a solicitação não for feita de } \\
\text { conformidade com este Tratado. } \\
\text { 2. A parte requerida pode adiar o } \\
\text { fornecimento da solicitação se o } \\
\text { atendimento da solicitação interferir em } \\
\text { uma investigação, processo ou qualquer } \\
\text { outro procedimento em curso na parte } \\
\text { requerida. } \\
\text { 3. Antes de negar a assistência com base no } \\
\text { disposto neste artigo, a Autoridade Central } \\
\text { do Estado Requerido deverá consultar a } \\
\text { Autoridade Central do Estado Requerente } \\
\text { para avaliar se a assistência pode ser } \\
\text { prestada sob as condições consideradas } \\
\text { necessárias. } \\
\text { Caso o Estado Requerente aceite essa } \\
\text { assistência condicionada, tais condições } \\
\text { deverão ser respeitadas. } \\
\text { 4. Caso a Autoridade Central do Estado } \\
\text { Requerido negue ou adie a assistência, } \\
\text { deverá informar a Autoridade Central do } \\
\text { Estado Requerente sobre as razões da } \\
\text { denegação ou adiamento. }\end{array}$ \\
\hline $\begin{array}{c}\text { Decreto } \mathrm{n}^{\circ} \\
\mathbf{6 . 4 6 2 / 0 8}\end{array}$ & $\begin{array}{l}\text { Artigo I } \\
\text { 1. As partes cooperarão entre si adotando todas } \\
\text { as medidas apropriadas de que dispõem, a fim } \\
\text { de prestar cooperação em matéria penal, nos } \\
\text { termos do presente Acordo e dentro dos limites } \\
\text { das disposições dos respectivos ordenamentos } \\
\text { jurídicos internos. }\end{array}$ & $\begin{array}{l}\text { Artigo II } \\
\text { Denegação da Cooperação } \\
\text { 1. A cooperação será denegada se, } \\
\text { conforme juízo da parte requerida: } \\
\text { a) a execução do pedido afetar sua } \\
\text { soberania, segurança, ordem pública ou } \\
\text { interesses públicos essenciais similares, }\end{array}$ \\
\hline
\end{tabular}




\begin{tabular}{|c|c|c|}
\hline & 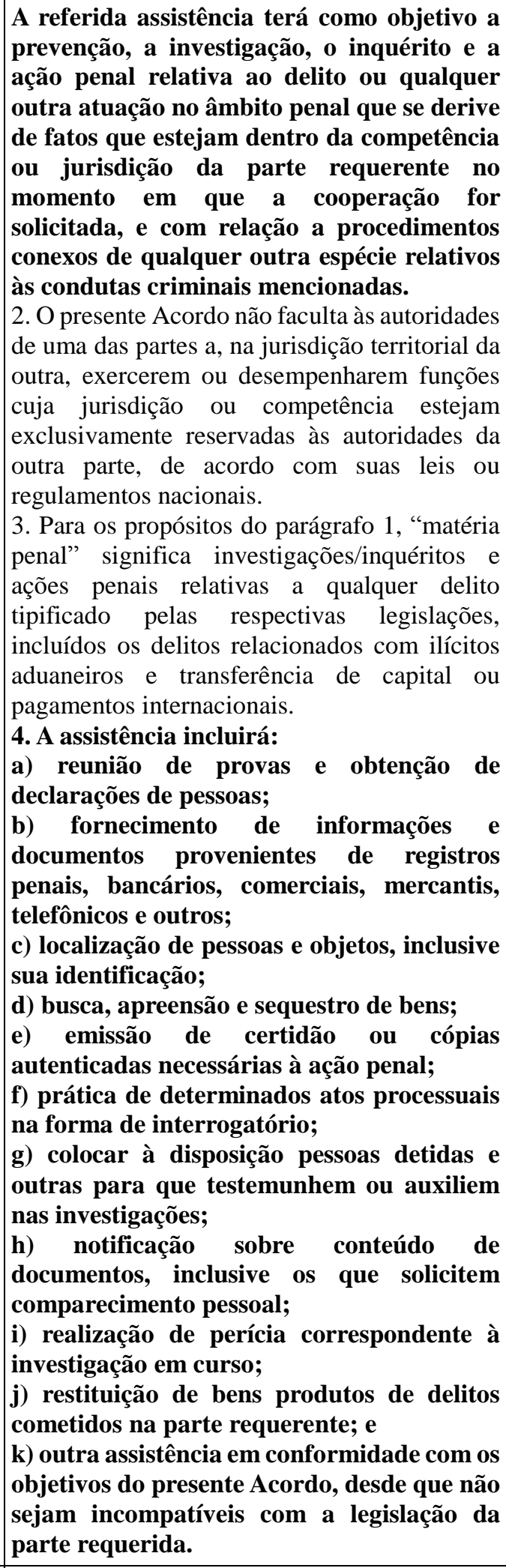 & $\begin{array}{l}\text { prejudicar a segurança de qualquer } \\
\text { pessoa ou não for razoável por outros } \\
\text { motivos; } \\
\text { b) a execução do pedido implicar que a } \\
\text { parte requerida exceda os limites de sua } \\
\text { autoridade ou contrarie as disposições } \\
\text { legais vigentes, em cujo caso as } \\
\text { Autoridades Centrais a que se refere o } \\
\text { artigo XII deste Acordo realizarão } \\
\text { consultas para identificar os meios legais } \\
\text { que garantam a cooperação; } \\
\text { c) houver a possibilidade de que a pena } \\
\text { de morte seja imposta ou executada em } \\
\text { virtude do pedido de cooperação; } \\
\text { d) o delito for de natureza estritamente } \\
\text { militar; } \\
\text { e) o delito for de índole política ou se a } \\
\text { situação da pessoa que esteja sendo } \\
\text { investigada ou processada puder } \\
\text { agravar-se por razões políticas; ou } \\
\text { f) A pessoa em relação a qual se requer a } \\
\text { medida tenha sido absolvida ou haja } \\
\text { cumprido pena no território da parte } \\
\text { requerida pelos mesmos fatos } \\
\text { mencionados no pedido. } \\
\text { 2. O pedido poderá ser adiado pela parte } \\
\text { requerida caso a concessão do mesmo de } \\
\text { maneira imediata possa interferir em } \\
\text { investigação ou procedimento em curso. } \\
\text { 3. Antes de recusar, conceder ou adiar a } \\
\text { assistência solicitada, a parte requerida } \\
\text { considerará se essa poderá ser outorgada } \\
\text { sujeita às condições que julgar necessárias. } \\
\text { Se a parte requerente aceitar a assistência } \\
\text { sujeita a estas condições, deverá cumpri- } \\
\text { las. } \\
\text { 4.A parte requerida informará rapidamente } \\
\text { a parte requerente sobre a decisão de não } \\
\text { outorgar, na totalidade ou em parte, um } \\
\text { pedido de cooperação, ou se sua execução } \\
\text { for adiada, e exporá as razões da referida } \\
\text { decisão. }\end{array}$ \\
\hline $\begin{array}{c}\text { ESPANHA } \\
\text { Decreto n }^{\circ} \\
6.681 / 08\end{array}$ & $\begin{array}{l}\text { Artigo } \mathbf{1}^{\mathbf{0}} \\
\text { Âmbito de Aplicação } \\
\text { 1. O presente Acordo tem por finalidade o } \\
\text { auxílio jurídico mútuo em matéria penal entre } \\
\text { as autoridades competentes das Partes. } \\
\text { 2. As Partes se comprometem a prestar } \\
\text { mutuamente, segundo as disposições do }\end{array}$ & $\begin{array}{l}\text { Artigo } 5^{\circ} \\
\text { Denegação de Auxílio } \\
\text { 1. A Parte requerida poderá denegar } \\
\text { auxílio caso: } \\
\text { a) o pedido se refira a delitos tipificados } \\
\text { na Parte requerida como exclusivamente } \\
\text { militares; }\end{array}$ \\
\hline
\end{tabular}




\begin{tabular}{|c|c|c|}
\hline & 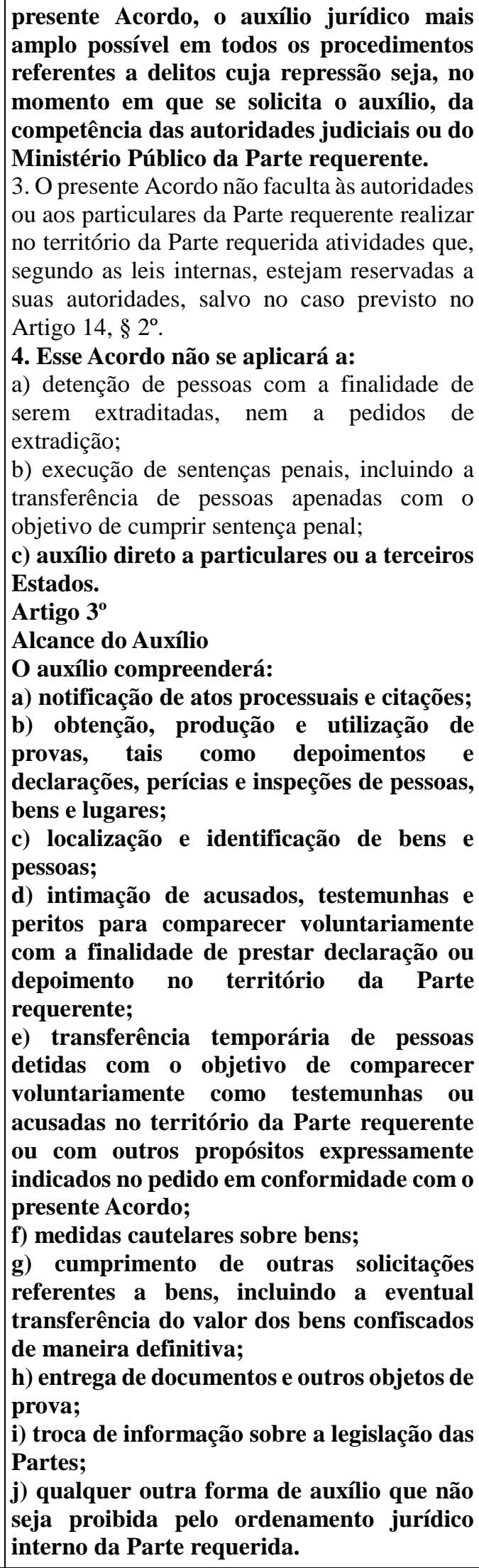 & 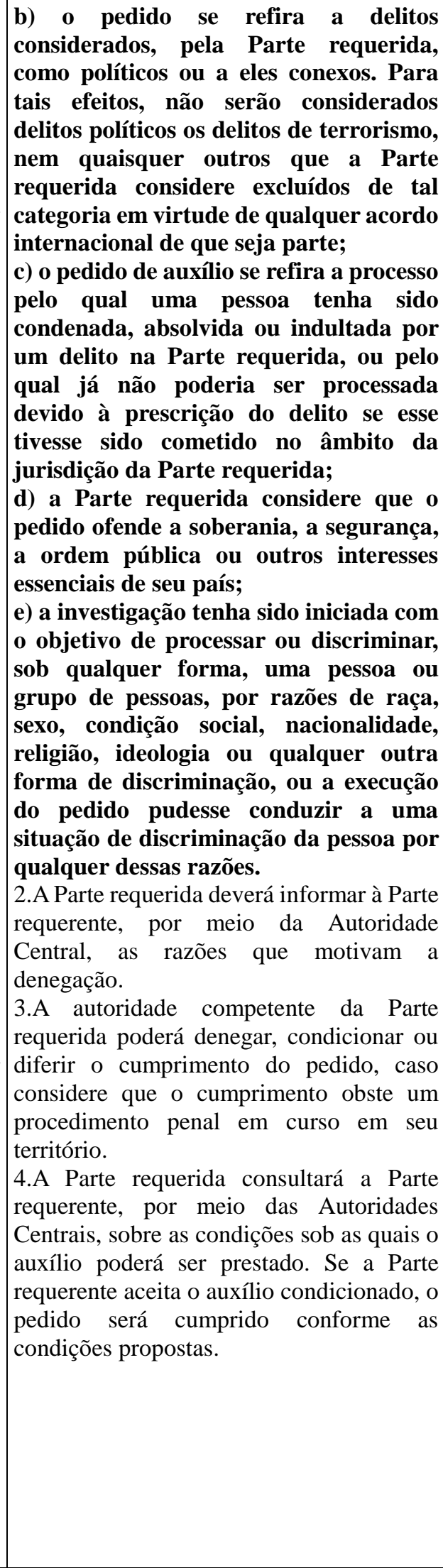 \\
\hline $\begin{array}{c}\text { Decreto }^{\circ} \\
6.747 / 09\end{array}$ & $\begin{array}{l}\text { Artigo } 1 \\
\text { Obrigação De Prestar Assistência Mútua } \\
\text { 1. Os Estados Contratantes deverão, no } \\
\text { âmbito do presente Tratado, prestar }\end{array}$ & $\begin{array}{l}\text { Artigo } 3 \\
\text { Recusa Ou Adiamento De Assistência } \\
\text { 1. A assistência poderá ser recusada se, } \\
\text { na opinião do Estado requerido, sua }\end{array}$ \\
\hline
\end{tabular}




\begin{tabular}{|c|c|c|}
\hline & 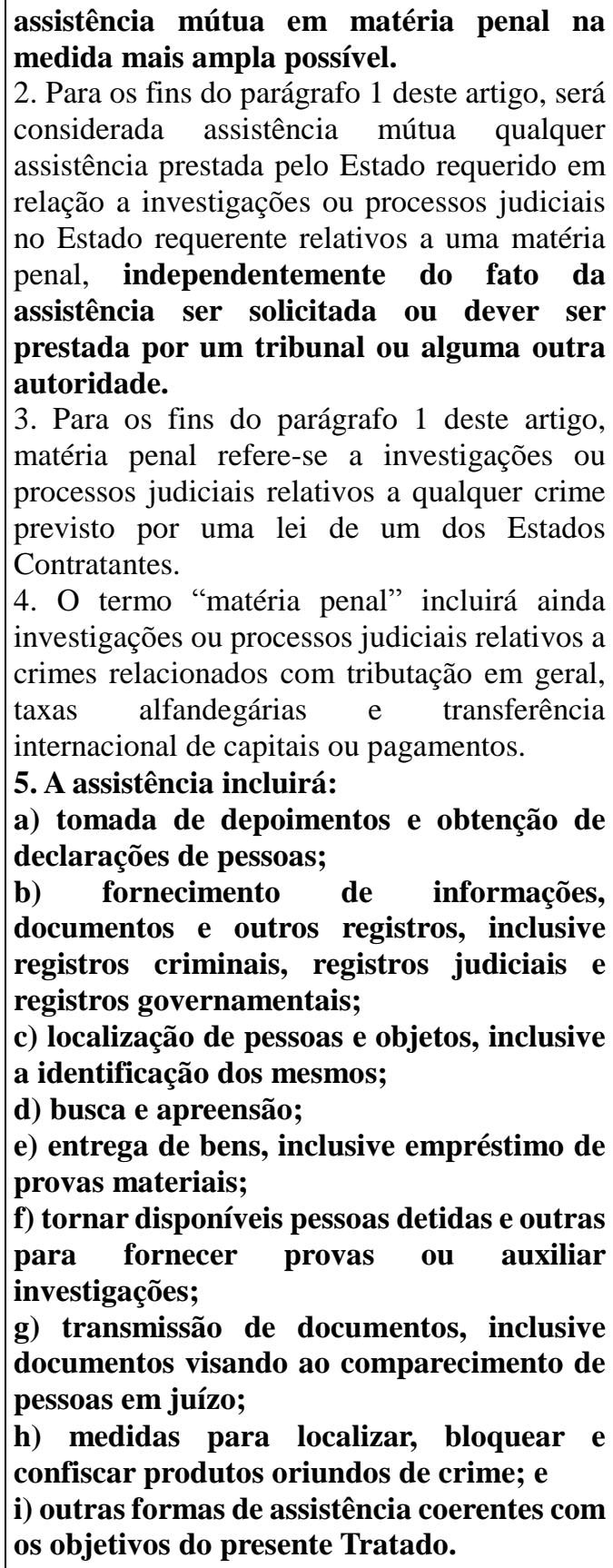 & 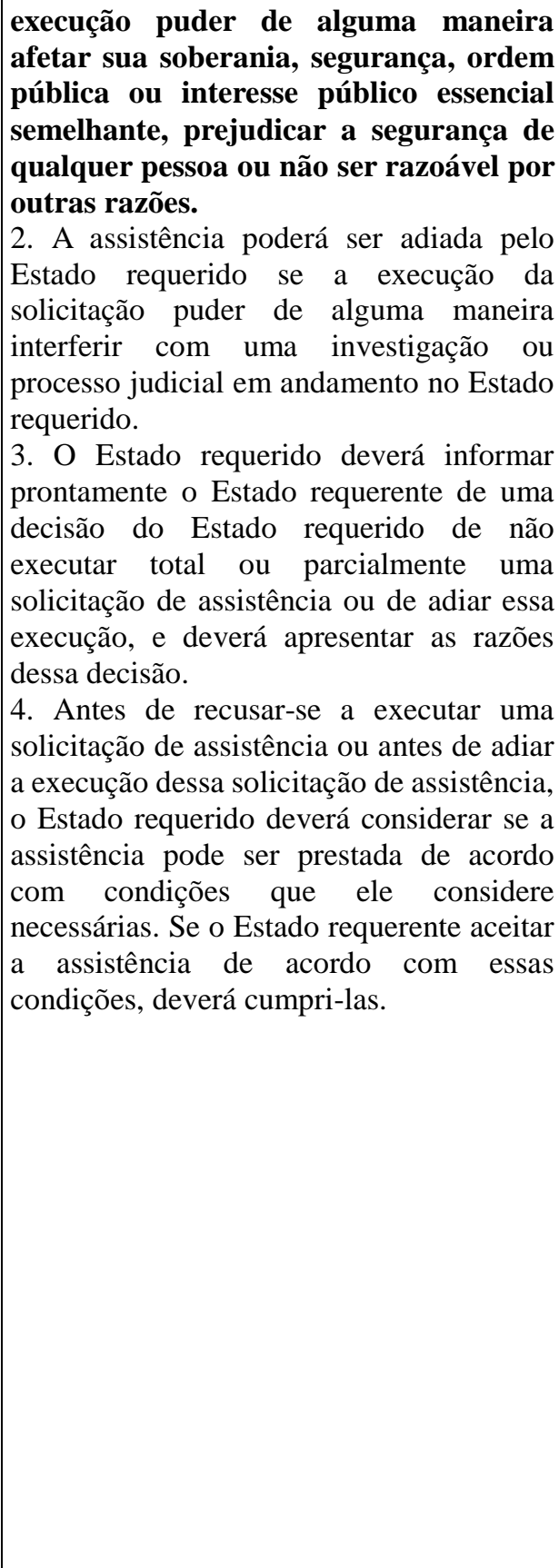 \\
\hline $\begin{array}{l}\text { SURINAME } \\
\text { Decreto }^{\circ} \\
6.832 / 09\end{array}$ & $\begin{array}{l}\text { Artigo 1 } \\
\text { Alcance da Assistência } \\
\text { 1. As Partes prestarão uma à outra assistência } \\
\text { jurídica mútua, nos dispositivos do presente } \\
\text { Tratado, em relação à investigação, inquérito e } \\
\text { prevenção de crimes e processos relacionados } \\
\text { à matéria penal, dentro dos limites de suas } \\
\text { legislações. } \\
\text { 2. As Partes trocarão, por meio de suas } \\
\text { Autoridades Centrais, uma lista de autoridades } \\
\text { competentes para solicitar assistência jurídica } \\
\text { mútua mediante o presente Tratado. } \\
\text { 3. A assistência incluirá: } \\
\text { a) tomada de depoimentos ou declarações de } \\
\text { pessoas, inclusive por meio de } \\
\text { teleconferência ou vídeo conferência, de }\end{array}$ & $\begin{array}{l}\text { Artigo 3 } \\
\text { Denegação de Assistência } \\
\text { O presente Tratado não se aplicará nos } \\
\text { seguintes casos: } \\
\text { a) busca, prisão ou encarceramento de } \\
\text { pessoa processada ou julgada } \\
\text { criminalmente com a intenção de obter-se a } \\
\text { extradição da pessoa; } \\
\text { b) execução de sentenças penais. } \\
\text { Artigo } 4 \\
\text { Restrições à Assistência } \\
\text { A Parte Requerida poderá negar } \\
\text { assistência se: } \\
\text { a) a solicitação referir-se a delito previsto } \\
\text { na legislação militar, sem, entretanto, } \\
\text { constituir crime comum; }\end{array}$ \\
\hline
\end{tabular}




\begin{tabular}{|c|c|c|}
\hline & $\begin{array}{l}\text { acordo com a legislação interna da Parte } \\
\text { Requerida; } \\
\text { b) fornecimento de documentos, registros e } \\
\text { outros materiais de prova; } \\
\text { c) entrega de documentos judiciais ou de } \\
\text { outra natureza; } \\
\text { d) localização ou identificação de pessoas ou } \\
\text { objetos, quando solicitado como parte de } \\
\text { uma solicitação mais abrangente de provas; } \\
\text { e) transferência de pessoas sob custódia, de } \\
\text { acordo com o artigo 12; } \\
\text { f) execução de pedidos de busca e apreensão; } \\
\text { g) identificação, rastreamento, } \\
\text { indisponibilidade, sequestro, confisco e } \\
\text { disposição de produtos do crime e } \\
\text { assistência em processos relacionados; } \\
\text { h) devolução de ativos, de acordo com a } \\
\text { legislação interna da Parte Requerida; } \\
\text { i) troca de informações sobre a legislação das } \\
\text { Partes; } \\
\text { j) qualquer outra forma de assistência que } \\
\text { não seja proibida pela legislação interna da } \\
\text { Parte Requerida. } \\
\text { 4. A assistência será prestada ainda que a } \\
\text { conduta sujeita a investigação, inquérito ou } \\
\text { ação penal não seja punível nos termos da } \\
\text { legislação de ambas as Partes. } \\
\text { 5. A assistência solicitada não será impedida } \\
\text { por sigilo bancário ou qualquer outro tipo de } \\
\text { sigilo legal desde que o sigilo tenha sido } \\
\text { quebrado por decisão judicial de uma } \\
\text { autoridade judicial competente de qualquer das } \\
\text { Partes. } \\
\text { 6. O presente Tratado destina-se tão- } \\
\text { somente à assistência jurídica mútua entre } \\
\text { as Partes. Seus dispositivos não darão direito } \\
\text { a qualquer indivíduo de obter, suprimir ou } \\
\text { excluir qualquer prova ou impedir que uma } \\
\text { solicitação seja atendida. }\end{array}$ & $\begin{array}{l}\text { b) o atendimento à solicitação prejudicar } \\
\text { sua soberania, segurança, ordem pública } \\
\text { ou outros interesses públicos essenciais; } \\
\text { c) a Parte Requerida já tiver proferido } \\
\text { julgamento ou decisão final sobre a } \\
\text { mesma pessoa pelo mesmo delito } \\
\text { referido na solicitação; } \\
\text { d) a solicitação referir-se a delito } \\
\text { político; } \\
\text { e) a Parte Requerida tiver motivos } \\
\text { substanciais para acreditar que a } \\
\text { solicitação foi feita com intuito de } \\
\text { investigar, processar, punir ou proceder } \\
\text { de qualquer outra forma contra uma } \\
\text { pessoa por causa de sua raça, sexo, } \\
\text { religião, nacionalidade ou opinião } \\
\text { política, ou que a posição daquela pessoa } \\
\text { possa ser prejudicada por qualquer } \\
\text { daquelas razões; ou } \\
\text { f) a solicitação não for feita de } \\
\text { conformidade com o presente Tratado. } \\
\end{array}$ \\
\hline $\begin{array}{c}\text { SUIÇA } \\
\text { Decreto n }^{\circ} \\
6.974 / 09\end{array}$ & $\begin{array}{l}\text { ARTIGO PRIMEIRO } \\
\text { Obrigação de Conceder a Cooperação } \\
\text { 1. Os Estados Contratantes comprometem- } \\
\text { se a conceder um ao outro, conforme as } \\
\text { disposições do presente Tratado, a mais } \\
\text { ampla cooperação jurídica em qualquer } \\
\text { investigação ou procedimento judiciário } \\
\text { relativos a delitos cuja repressão é da } \\
\text { jurisdição do Estado Requerente. } \\
\text { 2. Os Estados Contratantes trocarão, por suas } \\
\text { Autoridades Centrais, a lista das autoridades } \\
\text { competentes para apresentar pedidos de } \\
\text { cooperação jurídica para os fins do presente } \\
\text { Tratado. } \\
\text { 3. A cooperação jurídica abrange as } \\
\text { seguintes medidas, tomadas em favor de um } \\
\text { procedimento penal no Estado Requerente: } \\
\text { a) tomada de depoimentos ou outras } \\
\text { declaraçães; de documentos, registros e e } \\
\text { b) entrega de }\end{array}$ & $\begin{array}{l}\text { Artigo } 3 \\
\text { Motivos para Recusar ou Adiar a } \\
\text { Execução do Pedido } \\
\text { 1. A cooperação jurídica poderá ser } \\
\text { recusada: } \\
\text { a) se o pedido de cooperação se referir a } \\
\text { infrações consideradas pelo Estado } \\
\text { Requerido como delitos políticos ou } \\
\text { conexos a delitos políticos; } \\
\text { b) se o pedido referir-se a delitos } \\
\text { militares que não constituam delitos de } \\
\text { direito comum; } \\
\text { c) se o pedido referir-se a infrações } \\
\text { fiscais; no entanto o Estado Requerido } \\
\text { poderá atender a um pedido se a } \\
\text { investigação ou o procedimento visar } \\
\text { fraude em matéria fiscal. Se o pedido } \\
\text { referir-se somente em parte a infrações } \\
\text { fiscais, o Estado Requerido tem a } \\
\text { possibilidade de limitar, nesta parte, a }\end{array}$ \\
\hline
\end{tabular}




\begin{tabular}{|c|c|}
\hline $\begin{array}{l}\text { elementos de prova, inclusive os de natureza } \\
\text { administrativa, bancária, financeira, } \\
\text { comercial e societária; } \\
\text { c) restituição de bens e valores; } \\
\text { d) troca de informações; } \\
\text { e) busca pessoal e domiciliar; } \\
\text { f) busca, apreensão, sequestro e confisco de } \\
\text { produtos de delito; } \\
\text { g) intimação de atos processuais; } \\
\text { h) transferência temporária de pessoas } \\
\text { detidas para fins de audiência ou acareação; } \\
\text { i) quaisquer outras medidas de cooperação } \\
\text { compatíveis com os objetivos deste Tratado } \\
\text { e que sejam aceitáveis pelos Estados } \\
\text { Contratantes. } \\
\text { Artigo } 2 \\
\text { Inaplicabilidade } \\
\text { O presente Tratado não se aplica aos seguintes } \\
\text { casos: } \\
\text { a) busca, detenção ou prisão de uma pessoa } \\
\text { processada ou julgada penalmente com o } \\
\text { intuito de obter a sua extradição; } \\
\text { b)execução de sentenças penais. }\end{array}$ & 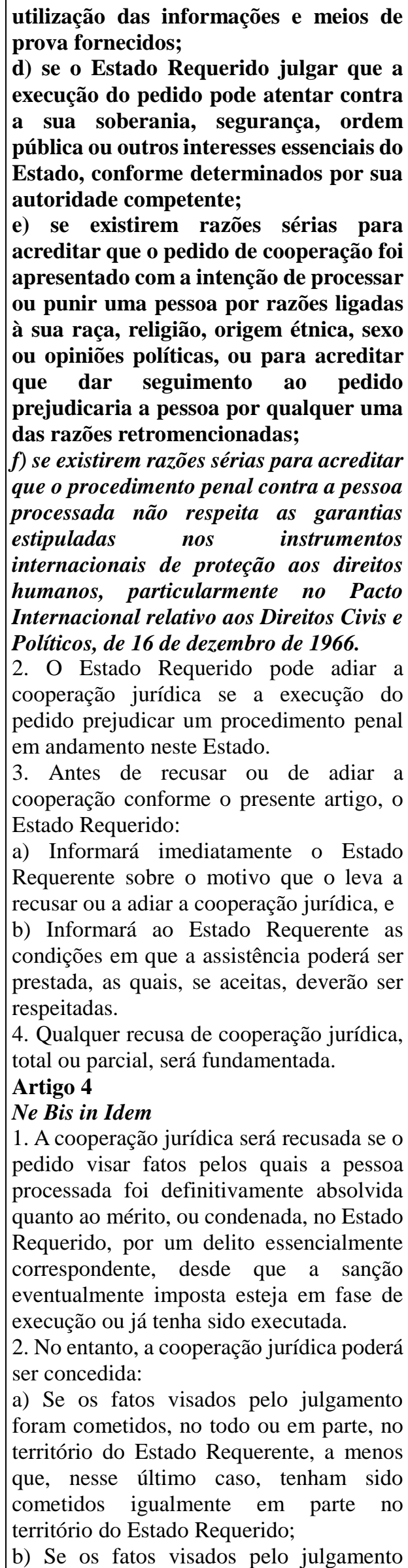 \\
\hline
\end{tabular}




\begin{tabular}{|c|c|c|}
\hline & & $\begin{array}{l}\text { constituam delito contra a segurança ou } \\
\text { contra outros interesses essenciais do } \\
\text { Estado Requerente; } \\
\text { c) Se os fatos visados pelo julgamento } \\
\text { foram cometidos por funcionário do Estado } \\
\text { Requerente com violação dos seus deveres } \\
\text { funcionais. } \\
\text { 3. De qualquer maneira, o parágrafo } 1 \\
\text { não se aplicará se: } \\
\text { a) o procedimento aberto no Estado } \\
\text { Requerente não for dirigido somente } \\
\text { contra a pessoa visada pelo parágrafo 1; } \\
\text { ou } \\
\text { b) a execução da demanda tiver o } \\
\text { objetivo de inocentá-la. }\end{array}$ \\
\hline $\begin{array}{l}\text { NIGÉRIA } \\
\text { Decreto n }^{\circ} \\
7.582 / 11\end{array}$ & $\begin{array}{l}\text { Disposições Gerais } \\
\text { Artigo } 1^{\circ} \\
\text { Escopo da Assistência } \\
\text { 1. As Partes prestarão assistência jurídica } \\
\text { mútua, conforme as disposições do presente } \\
\text { Tratado, para o propósito de procedimentos. } \\
\text { 2. Para os propósitos do presente Tratado, } \\
\text { "procedimentos" significam procedimentos } \\
\text { relacionados à matéria penal e incluem } \\
\text { quaisquer medidas ou atos relacionados às } \\
\text { investigações ou processos criminais, } \\
\text { incluindo bloqueio, apreensão ou perdimento } \\
\text { dos produtos do crime e, de acordo com a lei } \\
\text { interna da Parte Requerida, dos instrumentos } \\
\text { do crime. } \\
\text { 3. Para os propósitos deste Tratado, as } \\
\text { autoridades competentes para enviar } \\
\text { solicitação de auxílio jurídico mútuo a sua } \\
\text { Autoridade Central são aquelas } \\
\text { responsáveis por conduzir investigações, } \\
\text { ações penais ou processos judiciais, } \\
\text { conforme definido na lei interna da Parte } \\
\text { Requerente. } \\
\text { 4. Assistência incluirá: } \\
\text { a) realização de depoimentos ou outras } \\
\text { declaraçós de pessoas, inclusive por meio de } \\
\text { videoconferência ou televisão, conforme a lei } \\
\text { interna da Parte Requerida; } \\
\text { b) fornecimento de documentos, registros e } \\
\text { outros elementos probatórios; } \\
\text { c) entrega de documentos; } \\
\text { d) localização ou identificação de pessoas } \\
\text { quando solicitada como parte de solicitação } \\
\text { de prova mais ampla; } \\
\text { e) transferência de pessoas sob custódia de } \\
\text { acordo com o artigo 13; } \\
\text { f) cumprimento de solicitação de busca e } \\
\text { apreensão; } \\
\text { g) identificaçãa, rastreamento, bloqueio, } \\
\text { apreensão, perdimento e disposição de } \\
\text { produtos do crime e assistência em } \\
\text { procedimentos conexos; } \\
\text { h) devolução de ativos, de acordo com a lei } \\
\text { interna; }\end{array}$ & 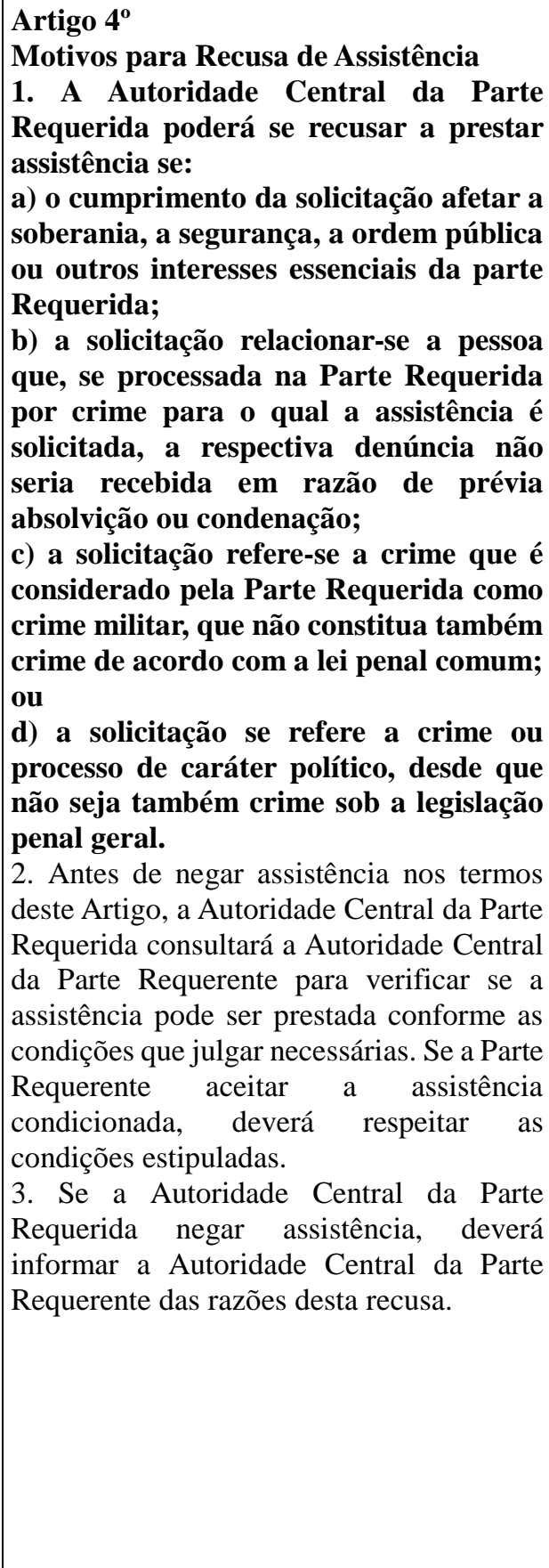 \\
\hline
\end{tabular}




\begin{tabular}{|c|c|c|}
\hline & $\begin{array}{l}\text { i) divisão de ativos, de acordo com o } \\
\text { Capítulo II; } \\
\text { j) qualquer outro tipo de assistência } \\
\text { acordada entre as Autoridades Centrais. } \\
\text { 5. Quando forem solicitados a busca e } \\
\text { apreensão de provas, o bloqueio ou } \\
\text { perdimento de produtos do crime, a Parte } \\
\text { Requerida pode, discricionariamente, } \\
\text { prestar a assistência, de acordo com sua lei } \\
\text { interna. }\end{array}$ & \\
\hline $\begin{array}{l}\text { MÉXICO } \\
\text { Decreto n }^{\circ} \\
7.595 / 11\end{array}$ & 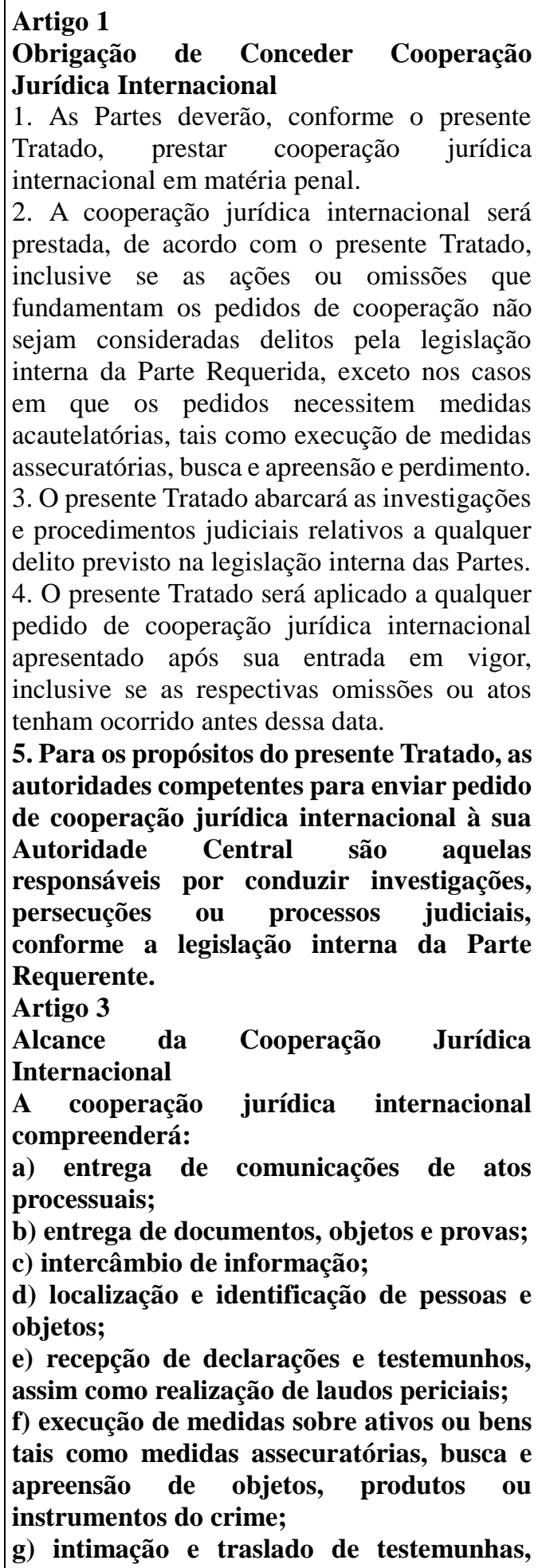 & $\begin{array}{l}\text { Artigo } 4 \\
\text { Limitações no Alcance da Cooperação } \\
\text { Jurídica Internacional } \\
\text { 1. O presente Tratado não faculta às } \\
\text { autoridades de uma das Partes exercer, no } \\
\text { território da outra Parte, funções cuja } \\
\text { competência esteja exclusivamente } \\
\text { reservada às autoridades desta outra Parte } \\
\text { por sua legislação interna. A presença e } \\
\text { participação de autoridades da Parte } \\
\text { Requerente a que se refere o Artigo } 12 \text { não } \\
\text { se consideram contrárias ao disposto neste } \\
\text { parágrafo. } \\
\text { 2. As disposições do presente Tratado } \\
\text { não outorgam direito algum a favor de } \\
\text { pessoas físicas ou jurídicas na obtenção, } \\
\text { eliminação ou exclusão de provas, ou } \\
\text { para impedir o cumprimento de pedido } \\
\text { de cooperação jurídica internacional. } \\
\text { 3. Do mesmo modo, o presente Tratado não } \\
\text { será aplicável a: } \\
\text { a) detenção de pessoas para extradição, } \\
\text { nem a pedidos de extradição; } \\
\text { b) execução de sentenças penais, incluído o } \\
\text { traslado de apenados; ou } \\
\text { c) prestação de cooperação jurídica } \\
\text { internacional a terceiros Estados. }\end{array}$ \\
\hline
\end{tabular}




\begin{tabular}{|c|c|c|}
\hline & $\begin{array}{l}\text { vítimas e peritos para comparecer } \\
\text { voluntariamente perante autoridade } \\
\text { competente na Parte Requerente; } \\
\text { h) traslado temporário de pessoas detidas } \\
\text { para comparecimento em processo penal } \\
\text { como testemunhas ou vítimas no território } \\
\text { da Parte Requerente ou para outros atos } \\
\text { processuais indicados no pedido; } \\
\text { i) devolução de ativos ou bens; } \\
\text { j) divisão de ativos ou bens; } \\
\text { k) autorização de presença ou participação, } \\
\text { durante a execução de pedido, de } \\
\text { representantes das autoridades competentes } \\
\text { da Parte Requerente; } \\
\text { l) qualquer outra forma de cooperação } \\
\text { jurídica internacional em conformidade } \\
\text { com os fins do presente Tratado, desde que } \\
\text { não seja incompatível com a legislação } \\
\text { interna da Parte Requerida. }\end{array}$ & \\
\hline $\begin{array}{l}\text { PANAMÁ } \\
{\text { Decreto }{ }^{\circ}}^{\circ} \\
7.596 / 11\end{array}$ & $\begin{array}{l}\text { Disposições Gerais } \\
\text { Artigo 1 } \\
\text { Alcance do Auxílio } \\
\text { 1. As Partes prestarão auxílio jurídico } \\
\text { mútuo, conforme as disposições do presente } \\
\text { Tratado, em procedimentos relacionados a } \\
\text { matéria penal, incluindo qualquer medida } \\
\text { tomada em relação a investigação ou } \\
\text { persecução de delitos e medidas } \\
\text { assecuratórias referentes a produtos e } \\
\text { instrumentos do crime, tais como bloqueio, } \\
\text { sequestro e apreensão, bem como o seu } \\
\text { perdimento e repatriação. } \\
\text { 2. O auxílio incluirá: } \\
\text { a) entrega da comunicação de atos } \\
\text { processuais; } \\
\text { b) tomada de depoimentos ou inquirição de } \\
\text { pessoas; } \\
\text { c) transferência provisória de pessoas sob } \\
\text { custódia com fins probatórios; } \\
\text { d) cumprimento de solicitações de busca e } \\
\text { apreensão; } \\
\text { e) fornecimento de documentos, registros e } \\
\text { outros elementos de prova; } \\
\text { f) perícia de pessoas, objetos e locais; } \\
\text { g) obtenção e fornecimento de avaliações de } \\
\text { peritos; } \\
\text { h) localização e identificação de pessoas; } \\
\text { i) identificaçãa, rastreamento, medidas } \\
\text { assecuratórias, tais como bloqueio, } \\
\text { apreensão, sequestro e o perdimento de } \\
\text { produtos e instrumentos do crime, es es } \\
\text { cooperação em procedimentos correlatos; } \\
\text { j) repatriação de ativos; } \\
\text { k) divisão de ativos; } \\
\text { l) troca de informações relacionadas com a } \\
\text { prevenção, investigação ou persecução do } \\
\text { crime; e } \\
\text { m) qualquer outro tipo de auxílio que seja } \\
\text { acordado pelas Autoridades Centrais. }\end{array}$ & $\begin{array}{l}\text { Artigo } 2 \\
\text { Denegação de Auxílio } \\
\text { 1. A Autoridade Central da Parte } \\
\text { requerida poderá se recusar a prestar } \\
\text { auxílio se: } \\
\text { a) o cumprimento da solicitação ofender } \\
\text { a soberania, a segurança, a ordem } \\
\text { pública ou outros interesses essenciais da } \\
\text { Parte requerida; } \\
\text { b) o delito for considerado de natureza } \\
\text { política; } \\
\text { c) houver razões fundadas para } \\
\text { acreditar que o auxílio foi solicitado com } \\
\text { o intuito de processar uma pessoa por } \\
\text { motivos de raça, sexo, crença, condição } \\
\text { social, religião, nacionalidade, opinião } \\
\text { política ou origem étnica; } \\
\text { d) a solicitação foi emitida por tribunal } \\
\text { especial ou ad hoc; } \\
\text { e) a solicitação referir-se a pessoa que } \\
\text { tenha sido julgada anteriormente na } \\
\text { Parte requerida ou na Parte requerente } \\
\text { pela mesma conduta que originou o } \\
\text { pedido de auxílio; } \\
\text { f) a solicitação referir-se a conduta } \\
\text { prevista como delito somente pela } \\
\text { legislação militar da Parte requerida e } \\
\text { não por sua legislação penal comum; } \\
\text { g) a solicitação de auxílio for contrária } \\
\text { ao ordenamento jurídico da Parte } \\
\text { requerida ou não se ajustar às } \\
\text { disposições deste Tratado; e } \\
\text { h) a informação requerida não guardar } \\
\text { relação com os fatos investigados. } \\
\text { 2. Antes de negar auxílio nos termos deste } \\
\text { Artigo, a Autoridade Central da Parte } \\
\text { requerida consultará a Autoridade Central } \\
\text { da Parte requerente para verificar se o } \\
\text { auxílio pode ser prestado conforme as } \\
\text { condições que julgar necessárias. Caso a }\end{array}$ \\
\hline
\end{tabular}




\begin{tabular}{|c|c|c|}
\hline & $\begin{array}{l}\text { 3. As Partes, por meio de suas Autoridades } \\
\text { Centrais, se comprometem a prestar-se } \\
\text { mutuamente, em conformidade com as } \\
\text { disposições do presente Tratado, bem como de } \\
\text { seus respectivos ordenamentos jurídicos, o } \\
\text { auxílio jurídico mútuo e a cooperação jurídica } \\
\text { mais ampla possível nos procedimentos } \\
\text { relativos a condutas puníveis da competência } \\
\text { das suas autoridades. } \\
\text { 4. Para os fins do disposto no parágrafo } 3 \text { deste } \\
\text { Artigo, poder-se-á prestar auxílio se a conduta } \\
\text { constitutiva do delito a respeito do qual se } \\
\text { solicita auxílio configura delito de acordo com } \\
\text { a legislação de ambas as Partes, } \\
\text { independentemente de que as leis da Parte } \\
\text { requerida incluam o delito na mesma categoria } \\
\text { ou o denominem com a mesma terminologia } \\
\text { que a Parte requerente. } \\
\text { 5. Não obstante o disposto nos parágrafos } 3 o \text { e } \\
\text { 4o deste Artigo, a Parte requerida poderá } \\
\text { prestar auxílio que não implique medidas } \\
\text { coercitivas, se isso estiver em consonância com } \\
\text { seu ordenamento jurídico. } \\
\text { 6. Para os propósitos deste Tratado, as } \\
\text { autoridades competentes para enviar } \\
\text { solicitaçôes de auxílio jurídico mútuo à sua } \\
\text { autoridade central são aquelas responsáveis } \\
\text { ou com poder para atuar em procedimentos } \\
\text { administrativos ou judiciais relacionados à } \\
\text { prática de um delito, conforme definido na } \\
\text { lei interna da Parte requerente. }\end{array}$ & $\begin{array}{l}\text { Parte requerente aceite o auxílio sujeito às } \\
\text { condições estipuladas, deverá respeitá-las. } \\
\text { 3. Caso a Autoridade Central da Parte } \\
\text { requerida negue auxílio, deverá informar a } \\
\text { Autoridade Central da Parte requerente das } \\
\text { razões dessa recusa. }\end{array}$ \\
\hline $\begin{array}{l}\text { HONDURAS } \\
\text { Decreto n }^{\circ} \\
8.046 / 13\end{array}$ & $\begin{array}{l}\text { ARTIGO 10 } \\
\text { Alcance da Assistência } \\
\text { 1. As Partes prestarão auxílio jurídico } \\
\text { mútuo, conforme as disposições do presente } \\
\text { Tratado, em procedimentos relacionados a } \\
\text { matéria penal, incluindo qualquer medida } \\
\text { tomada em relação a investigação ou } \\
\text { persecução de delito, assim como a bloqueio, } \\
\text { apreensão ou perdimento de produtos e } \\
\text { instrumentos do crime, conforme a } \\
\text { legislação doméstica da Parte Requerida. } \\
\text { 2. A assistência incluirá: a) entrega de } \\
\text { documentos; b) tomada de depoimentos ou } \\
\text { declarações de pessoas; c) transferência de } \\
\text { pessoas sob custódia; d) cumprimento de } \\
\text { solicitações de busca e apreensão; e) } \\
\text { fornecimento de documentos, registros e outros } \\
\text { elementos de prova; f) exame ou perícia de } \\
\text { objetos e locais; g) obtenção e fornecimento de } \\
\text { avaliações de peritos; h) localização ou } \\
\text { identificação de pessoas, quando necessária } \\
\text { como parte de solicitação de prova mais ampla; } \\
\text { i) identificação, rastreamento, bloqueio, } \\
\text { apreensão, perdimento e disposição de } \\
\text { produtos do crime e auxílio em procedimentos } \\
\text { relacionados; } \\
\text { j) devolução de ativos; k) divisão de ativos; l) } \\
\text { qualquer outro tipo de auxílio que seja }\end{array}$ & $\begin{array}{l}\text { ARTIGO 20 } \\
\text { Denegação de Auxílio } \\
\text { 1. A Autoridade Central da Parte } \\
\text { Requerida poderá se recusar a prestar } \\
\text { auxílio se: a) o cumprimento da } \\
\text { solicitação ofender a soberania, a } \\
\text { segurança, a ordem pública ou outros } \\
\text { interesses essenciais da Parte Requerida; } \\
\text { b) o delito for considerado de natureza } \\
\text { política; c) houver razões para acreditar- } \\
\text { se que o auxílio foi solicitado com o } \\
\text { intuito de processar uma pessoa por } \\
\text { causa de sua raça, sexo, crença, religião, } \\
\text { nacionalidade ou origem étnica; d) a } \\
\text { solicitação foi emitida por tribunal } \\
\text { especial ou ad hoc; e) a solicitação } \\
\text { referir-se a pessoa que já tenha sido } \\
\text { julgada na Parte Requerida pela mesma } \\
\text { conduta que originou o pedido de } \\
\text { assistência; f) a solicitação referir-se a } \\
\text { ação considerada, pela Parte Requerida, } \\
\text { como delito somente em legislação } \\
\text { militar e não sob legislação penal } \\
\text { comum. } \\
\text { 2. Antes de negar auxílio nos termos deste } \\
\text { artigo, a Autoridade Central da Parte } \\
\text { Requerida consultará a Autoridade Central } \\
\text { da Parte Requerente para verificar se o }\end{array}$ \\
\hline
\end{tabular}




\begin{tabular}{|c|c|c|}
\hline & $\begin{array}{l}\text { acordado pelas Autoridades Centrais. } \\
\text { 3. O auxílio será prestado independentemente } \\
\text { de a conduta que motivou a da solicitação ser } \\
\text { punível nos termos da legislação de ambas as } \\
\text { Partes. Caso seja solicitada busca e apreensão } \\
\text { de provas ou bloqueio ou perdimento de } \\
\text { produtos ou instrumentos do crime, a Parte } \\
\text { Requerida pode prestar auxílio, de acordo com } \\
\text { sua lei interna. } \\
\text { 4. Para os propósitos deste Tratado, as } \\
\text { autoridades competentes para enviar } \\
\text { solicitação de auxílio jurídico mútuo à sua } \\
\text { Autoridade Central são aquelas } \\
\text { responsáveis ou com poder para conduzir } \\
\text { investigações, persecuções ou procedimentos } \\
\text { judiciais, conforme definido na lei interna da } \\
\text { Parte Requerente. }\end{array}$ & $\begin{array}{l}\text { auxílio pode ser prestado conforme as } \\
\text { condições julgadas necessárias. Se a Parte } \\
\text { Requerente aceitar o auxílio sujeito às } \\
\text { condições estipuladas, deverá respeitá-las. } \\
\text { 3. Se a Autoridade Central da Parte } \\
\text { Requerida negar auxílio, deverá informar a } \\
\text { Autoridade Central da Parte Requerente } \\
\text { das razões dessa recusa. }\end{array}$ \\
\hline $\begin{array}{c}\text { REINO } \\
\text { UNIDO } \\
\text { Decreto n }^{\circ} \\
\mathbf{8 . 0 4 7 / 1 3}\end{array}$ & 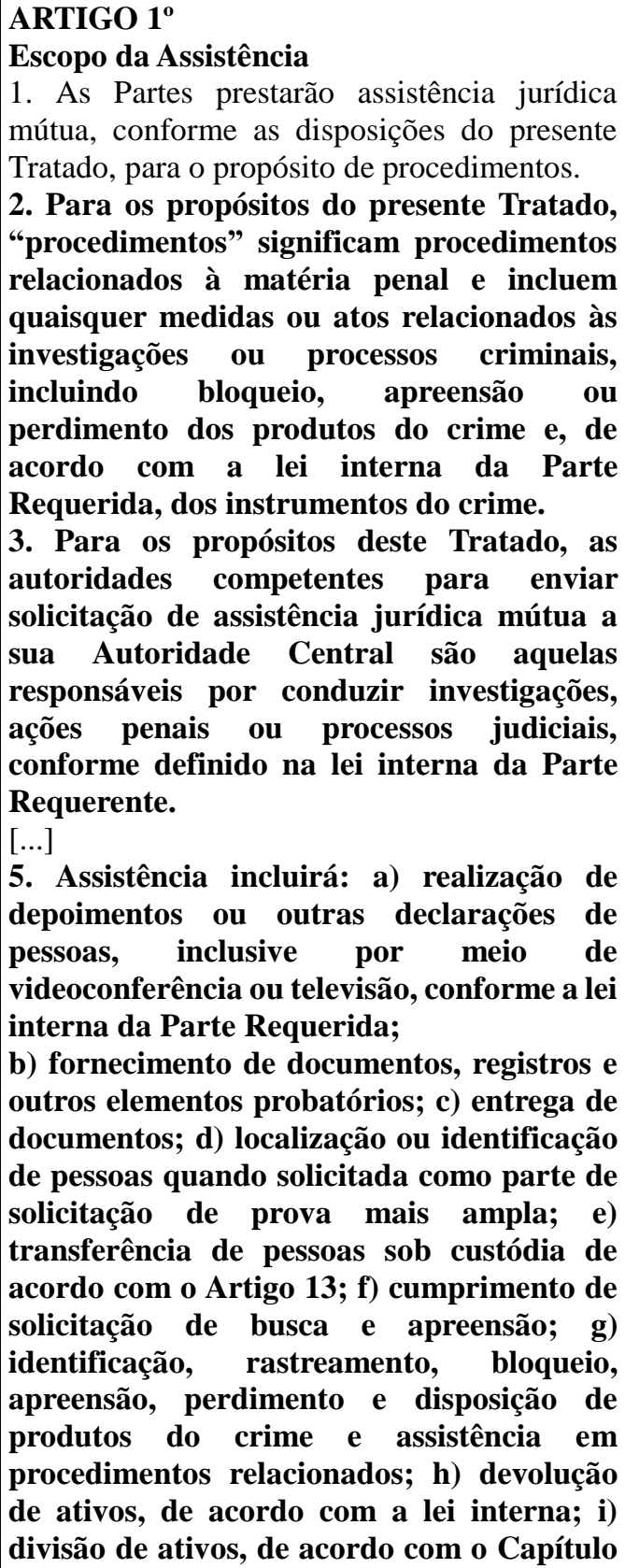 & 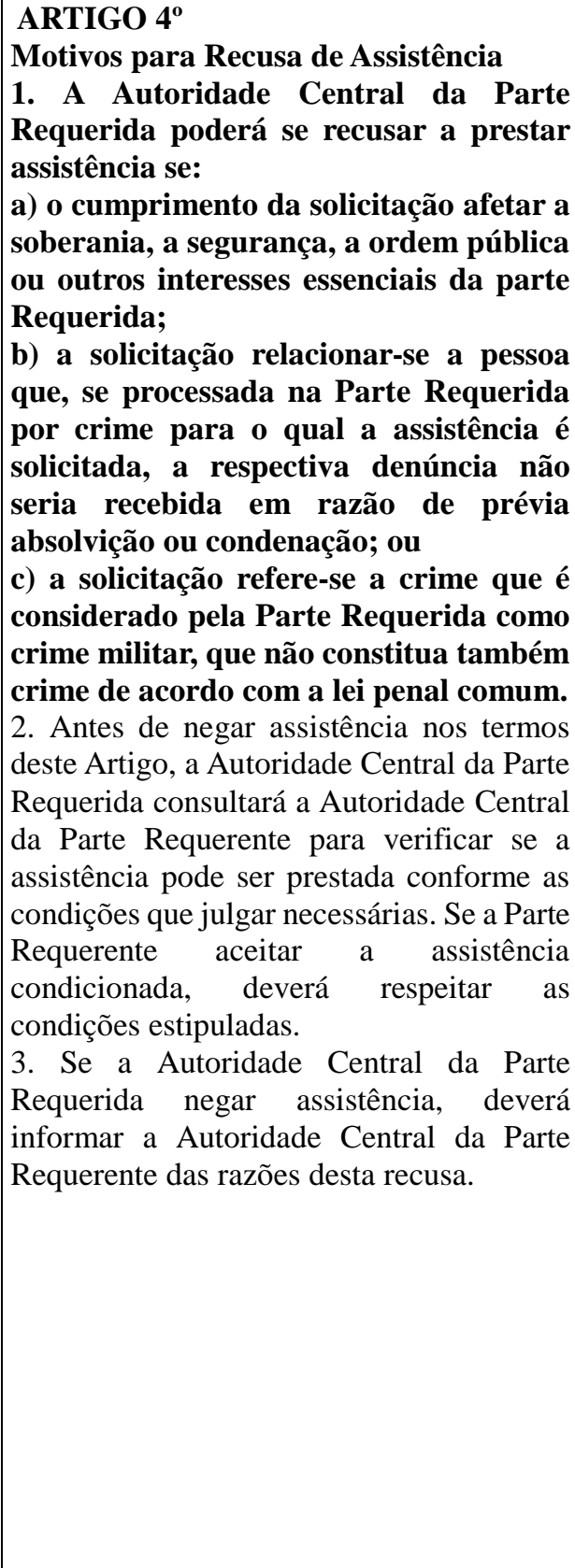 \\
\hline
\end{tabular}


II; j) qualquer outro tipo de assistência acordado entre as Autoridades Centrais.

6. Assistência será prestada

independentemente de a conduta objeto da solicitação ser punível nos termos da legislação de ambas as Partes. Quando forem solicitados a busca e apreensão de provas, o bloqueio ou perdimento de produtos do crime, a Parte Requerida pode, discricionariamente, prestar a assistência, de acordo com sua lei interna. 